Supplementary Materials

for

\title{
Hydrogen Atom Transfer Induced Boron Retaining Coupling of Organoboronic Esters and Organolithium Reagents
}

Dinghai Wang, Christian Mück-Lichtenfeld, Armido Studer*

Corresponding author. e-mail: studer@uni-muenster.de

Table of Contents

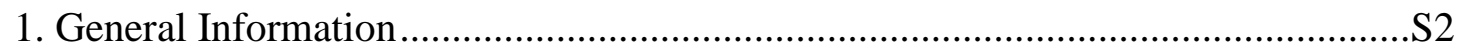

2. General Procedures for Coupling of Organoboronic Esters and Organolithium

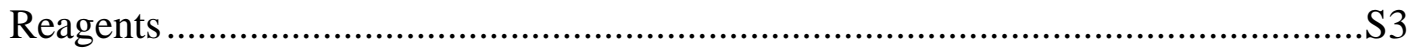

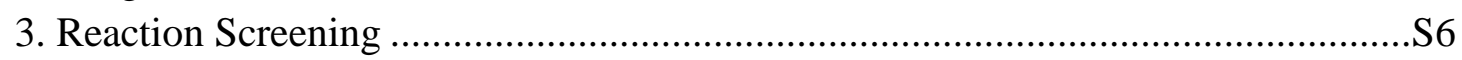

4. Preparation of Boronic Esters and Alkyllithium Reagents ...................................S7

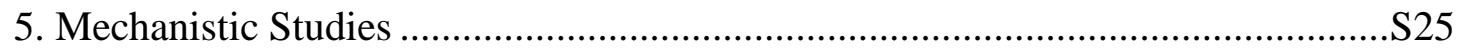

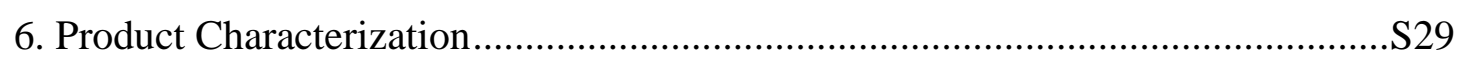

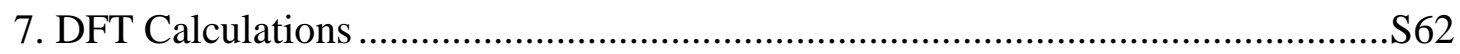

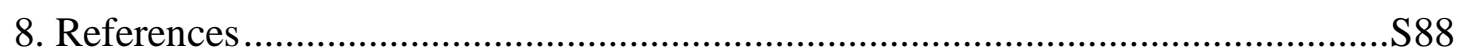

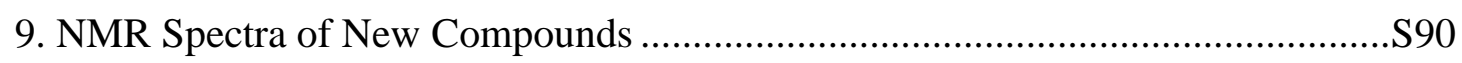




\section{General Information}

All reactions involving air or moisture sensitive reagents were carried out in flame-dried glassware under argon atmosphere using standard Schlenk techniques. Solvents used in reactions were either freshly distilled or obtained in extra-dry grade from commercial sources. Diethyl ether $\left(\mathrm{Et}_{2} \mathrm{O}\right)$ was refluxed over $\mathrm{K}$ and freshly distilled from K-Na-alloy (4:1) afterwards. Tetrahydrofuran (THF) was refluxed over $\mathrm{Na}$ and distilled from $\mathrm{K}$ afterwards. Acetonitrile $(\mathrm{MeCN}, 99.9 \%$, Extra Dry over Molecular Sieves) was purchased from Acros Organics. Dimethyl sulfoxide (DMSO, 99.9\%, Extra Dry over Molecular Sieves) was purchased from Acros Organics. Solvents for extraction and for flash chromatography were distilled. Otherwise noticed, commercially available arylboronic acid pinacol esters were purchased from ABCR, Acros Organics, Alfa Aesar, Fluka, Sigma Aldrich and TCI and were used as received. $n$-Butyllithium was purchased from Acros Organics. s-Butyllithium, isopropyllithium, phenyllithium and lithium were purchased from Sigma Aldrich. Trifluoromethyl iodide was purchased from ABCR and dissolved in DMSO. All other chemicals were purchased from ABCR, Acros Organics, Alfa Aesar, Fluka, Sigma Aldrich and TCI and were used as received. Flash chromatography (FC) was performed on Merck silica gel $60(40-63 \mu \mathrm{m})$. Merck silica gel 60 F254 plates were used for thin layer chromatography (TLC) using UV light $(254 / 366 \mathrm{~nm}$ ) or oxidation with $\mathrm{KMnO}_{4}\left(1.5 \mathrm{~g}\right.$ in $200 \mathrm{~mL} \mathrm{H} \mathrm{H}_{2} \mathrm{O}, 5 \mathrm{~g} \mathrm{NaHCO}$ ) for detection. Melting points (MP) were determined with a Stuart SMP10 and are uncorrected. Infrared spectra (IR) were measured on a Digilab 3100 FT-IR Excalibur Series spectrometer and the position of the absorption bands is given in wave numbers $v\left(\mathrm{~cm}^{-1}\right) .{ }^{\mathbf{1}} \mathbf{H}$ NMR $(300 \mathrm{MHz}, 400$ MHz and $600 \mathrm{MHz}),{ }^{13} \mathbf{C}$ NMR $(75 \mathrm{MHz}, 100 \mathrm{MHz}$ and $151 \mathrm{MHz}),{ }^{19}$ F NMR (282 MHz and $564 \mathrm{MHz}$ ) and ${ }^{11} \mathbf{B}$ NMR $(96 \mathrm{MHz}, 128 \mathrm{MHz}$ and $192 \mathrm{MHz})$ spectra were measured on a Bruker DPX 300, Bruker AV 300 or an Agilent DD2 600 spectrometer. The multiplicity of all signals were described as s (singlet), $d$ (doublet), $t$ (triplet), $q$ (quartet) and $\mathrm{m}$ (multiplet). Chemical shifts $(\delta$ in $\mathrm{ppm}$ ) were referenced on the residual peak of $\mathrm{CDCl}_{3}\left({ }^{1} \mathrm{HNMR}: \delta=7.26 ;{ }^{13} \mathrm{C} \mathrm{NMR}: \delta=77.0\right)$ or on an external standard $\left(\mathrm{CFCl}_{3}:{ }^{19} \mathrm{~F}\right.$ NMR: $\left.\delta=0.0\right)$. HRMS ESI $(\mathrm{m} / \mathrm{z})$ measurements were performed on a Bruker MicroTof and HRMS EI $(\mathrm{m} / \mathrm{z})$ on a Waters-Micromass QuattroMicro GC-MS. Chiral HPLC analysis was performed on a Hewlett Packard HP 1100 Series HPLC System using AD-H $\left(0.46 * 25 \mathrm{~cm}, 5 \mu \mathrm{m}\right.$ silica-gel, Daicel $\left.^{T M}\right)$ and IC $\left(0.46^{*} 25 \mathrm{~cm}, 5 \mu \mathrm{m}\right.$ silica-gel, Daice $\left.^{T M}\right)$ chiral columns eluting with a mixture of cyclohexane and isopropyl alcohol. Optical rotation $\left([\alpha]_{D}^{T}\right)$ was measured on a Bellingham and Stanley Ltd. ADP220 polarimeter and is quoted in $\left({ }^{\circ} \mathrm{ml}\right)(\mathrm{g} \mathrm{dm})^{-1}$. GCMS was performed on an Agilent 6890+ with an Agilent HP-5ms column (15.0 m $\times 250 \mu \mathrm{m} \times 0.30 \mu \mathrm{m}$ film thickness) and with an Agilent 5973 mass detector operating at $70 \mathrm{eV}$. The method used for GCMS was: start at $50{ }^{\circ} \mathrm{C}$ and $1 \mathrm{ml} / \mathrm{min}, 1.85 \mathrm{psi}$, increase to $300{ }^{\circ} \mathrm{C}$ at $10{ }^{\circ} \mathrm{C} / \mathrm{min}$, hold for $15 \mathrm{~min}$. Gas Chromatography (GC) was performed on an Hewlett Packard HP 6890 series GC system using an Agilent HP-1 column (30 m x $0.32 \mathrm{~mm} \times 0.25 \mu \mathrm{m}$ film thickness). The method used for GC was: start at $50{ }^{\circ} \mathrm{C}$ and $1.5 \mathrm{ml} / \mathrm{min}, 3.81 \mathrm{psi}$, increase to $300{ }^{\circ} \mathrm{C}$ at $10{ }^{\circ} \mathrm{C} / \mathrm{min}$, hold for $15 \mathrm{~min}$. 
Chiral GC analysis was performed on a Hewlett Packard HP 6890 Series GC System equipped with a SUPELCO Beta DexтM $120(30 \mathrm{~m} \times 0.25 \mathrm{~mm} \times 25 \mu \mathrm{L}$ film thickness $)$ column combined with a FID detector. The method used for chiral GC was: start at $50{ }^{\circ} \mathrm{C}$ and $1.5 \mathrm{ml} / \mathrm{min}, 8.86 \mathrm{psi}$, increase to $100{ }^{\circ} \mathrm{C}$ at $5{ }^{\circ} \mathrm{C} / \mathrm{min}$, hold for $0 \mathrm{~min}$, then increase to $150{ }^{\circ} \mathrm{C}$ at $1{ }^{\circ} \mathrm{C} / \mathrm{min}$, hold for $0 \mathrm{~min}$, then increase to $200{ }^{\circ} \mathrm{C}$ at $1{ }^{\circ} \mathrm{C} / \mathrm{min}$, hold for $20 \mathrm{~min}$. Emission spectra were recorded using Jasco FP-8300 spectrofluorometer, and UV/vis absorption spectra were recorded using Jasco $V-730$ spectrophotometer.

\section{General Procedures for Coupling of Organoboronic Esters and}

\section{Organolithium Reagents}

\subsection{Preparation of $\mathrm{CF}_{3} I$ solution in DMSO}

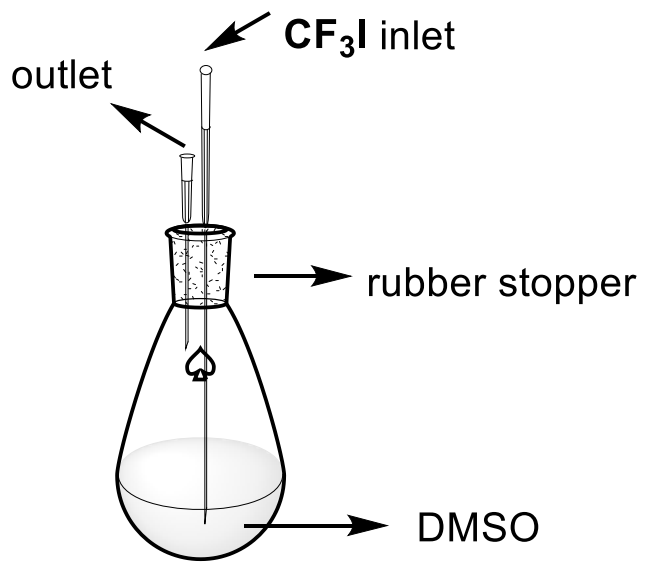

Apparatus for $\mathrm{CF}_{3} \mathrm{I}$ solution preparation

In a $10 \mathrm{~mL}$ flask was charged with $5 \mathrm{~mL}$ anhydrous DMSO under Argon flow. The flask was sealed with a rubber stopper and the mass of the flask was weighed to be m1. After bubbling $\mathrm{CF}_{3} \mathrm{I}$ gas into the DMSO in the flask, the mass of the vial was weighed to be $\mathrm{m} 2$ and the volume of the solution was determined to be $\mathrm{V}$ by a $10 \mathrm{~mL}$ syringe. The concentration of the prepared $\mathrm{CF}_{3} \mathrm{I}$ solution was calculated to be $\frac{\mathrm{m} 2-\mathrm{m} 1}{\mathrm{~V} * \mathrm{M}\left(C F_{3} \mathrm{I}\right)} .\left(\mathrm{M}\left(C F_{3} \mathrm{I}\right)\right.$ is the molecular weight of $\left.\mathrm{CF}_{3} \mathrm{I}\right)$

2.2 General Procedure for coupling of organoboronic esters and organolithium reagents (GP1) 


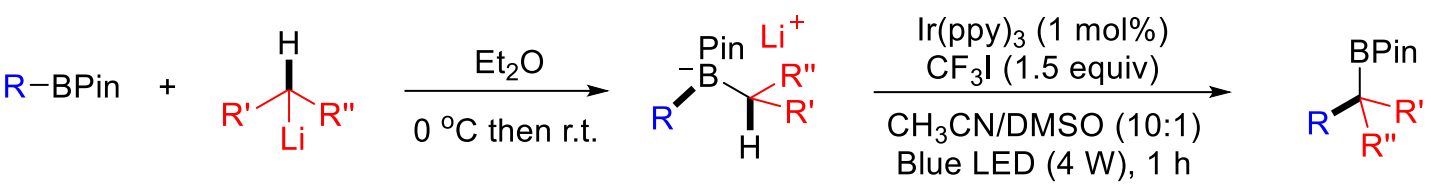

$$
\begin{aligned}
& \text { or }
\end{aligned}
$$

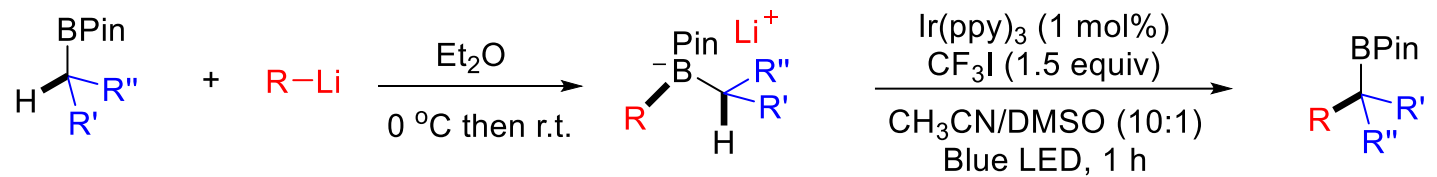

Organoboronic ester $(0.20 \mathrm{mmol}, 1.0$ equiv) was dissolved in diethyl ether $(2.0 \mathrm{~mL})$. The alkyllithium solution $(0.22 \mathrm{mmol}, 1.1$ equiv $)$ was added dropwise over $5 \mathrm{~min}$ at $0{ }^{\circ} \mathrm{C}$. The mixture was stirred at $0{ }^{\circ} \mathrm{C}$ for $30 \mathrm{~min}$ then room temperature for another $30 \mathrm{~min}$. The solvent was carefully removed in vacuo and further dried for $30 \mathrm{~min}$ under high vacuum. After subsequent addition of $\operatorname{Ir}(\mathrm{ppy})_{3}(1.3 \mathrm{mg}, 0.002 \mathrm{mmol}, 0.01$ equiv), acetonitrile $(2 \mathrm{~mL})$, DMSO $(0.1 \mathrm{~mL})$ under argon, the mixture was stirred for $1 \mathrm{~min}$ until all solid was dissolved. Then $\mathrm{CF}_{3} \mathrm{I}(3.0 \mathrm{M}$ in DMSO, $0.1 \mathrm{~mL}, 0.3 \mathrm{mmol}$, 1.5 equiv) was added to the reaction mixture and the reaction mixture was immediately irradiated by a $4 \mathrm{~W}$ blue LED $(465 \mathrm{~nm})$ and stirred for $1 \mathrm{~h}$. The reaction mixture was diluted with $20 \mathrm{~mL} \mathrm{CH}_{2} \mathrm{Cl}_{2}$ and quenched with saturated $\mathrm{NH}_{4} \mathrm{Cl}$ aqueous solution. The organic phase was separated and dried over $\mathrm{MgSO}_{4}$ and concentrated under reduced pressure. Flash column chromatography eluting with pentane and $\mathrm{CH}_{2} \mathrm{Cl}_{2}$ afforded the desired product.

2.3 General Procedure for coupling of organoboronic esters and organolithium reagents (GP2)

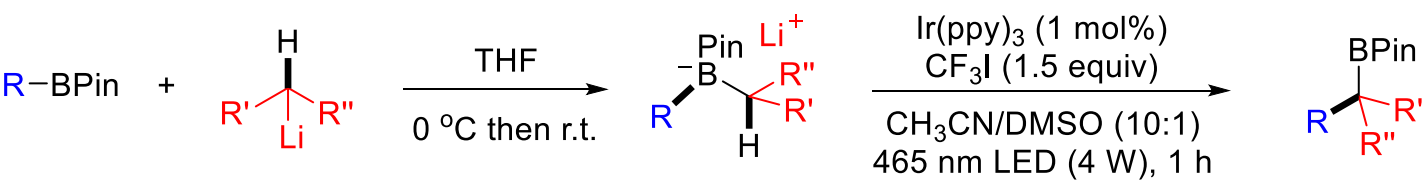

$$
\begin{aligned}
& \text { or }
\end{aligned}
$$

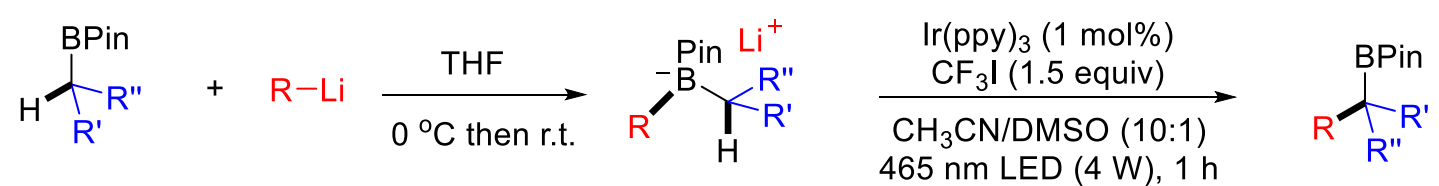

Organoboronic ester $(0.20 \mathrm{mmol}, 1.0$ equiv) was dissolved in tetrahydrofuran (2.0 $\mathrm{mL})$. The alkyllithium solution $(0.22 \mathrm{mmol}, 1.1$ equiv) was added dropwise over 5 $\min$ at $0{ }^{\circ} \mathrm{C}$. The mixture was stirred at $0{ }^{\circ} \mathrm{C}$ for $30 \mathrm{~min}$ then room temperature for another $30 \mathrm{~min}$. The solvent was carefully removed in vacuo and further dried for 30 min under high vacuum. After subsequent addition of $\operatorname{Ir}(\mathrm{ppy})_{3}(1.3 \mathrm{mg}, 0.002 \mathrm{mmol}$, 0.01 equiv), acetonitrile $(2 \mathrm{~mL})$, DMSO $(0.1 \mathrm{~mL})$ under argon, the mixture was stirred for $1 \mathrm{~min}$ until all solid was dissolved. Then $\mathrm{CF}_{3} \mathrm{I}$ (3.0 $\mathrm{M}$ in DMSO, $0.1 \mathrm{~mL}, 0.3$ mmol, 1.5 equiv) was added to the reaction mixture and the reaction mixture was immediately irradiated by a $4 \mathrm{~W}$ blue LED $(465 \mathrm{~nm})$ and stirred for $1 \mathrm{~h}$. The reaction mixture was diluted with $20 \mathrm{~mL} \mathrm{CH}_{2} \mathrm{Cl}_{2}$ and quenched with saturated $\mathrm{NH}_{4} \mathrm{Cl}$ aqueous solution. The organic phase was separated and dried over $\mathrm{MgSO}_{4}$ and concentrated 
under reduced pressure. Flash column chromatography eluting with pentane and $\mathrm{CH}_{2} \mathrm{Cl}_{2}$ afforded the desired product.

2.4 General Procedure for coupling of organoboronic esters and organolithium reagents (GP3)

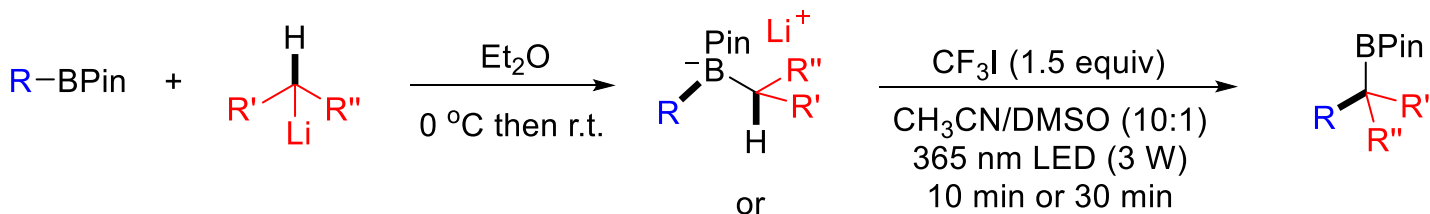

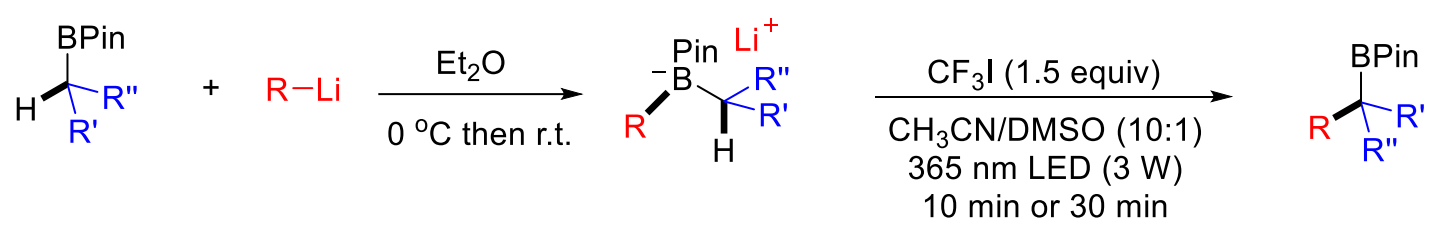

Organoboronic ester $(0.20 \mathrm{mmol}, 1.0$ equiv) was dissolved in diethyl ether $(2.0 \mathrm{~mL})$. The alkyllithium solution $(0.22 \mathrm{mmol}, 1.1$ equiv) was added dropwise over $5 \mathrm{~min}$ at $0{ }^{\circ} \mathrm{C}$. The mixture was stirred at $0{ }^{\circ} \mathrm{C}$ for $30 \mathrm{~min}$ then room temperature for another $30 \mathrm{~min}$. The solvent was carefully removed in vacuo and further dried for $30 \mathrm{~min}$ under high vacuum. After subsequent addition of acetonitrile $(2 \mathrm{~mL})$, DMSO $(0.1 \mathrm{~mL})$ under argon, the mixture was stirred for 1 min until all solid was dissolved. Then $\mathrm{CF}_{3} \mathrm{I}$ (3.0 $\mathrm{M}$ in DMSO, $0.1 \mathrm{~mL}, 0.3 \mathrm{mmol}, 1.5$ equiv) was added to the reaction mixture and the reaction mixture was immediately irradiated by a 3 W LED (365 nm) and stirred for 10 or $30 \mathrm{~min}$. (10 $\mathrm{min}$ for $\mathrm{C}\left(\mathrm{sp}^{2}\right)-\mathrm{C}\left(\mathrm{sp}^{3}\right)$ coupling and $30 \mathrm{~min}$ for $\mathrm{C}\left(\mathrm{sp}^{3}\right)-\mathrm{C}\left(\mathrm{sp}^{3}\right)$ coupling) The reaction mixture was diluted with $20 \mathrm{~mL} \mathrm{CH}_{2} \mathrm{Cl}_{2}$ and quenched with saturated $\mathrm{NH}_{4} \mathrm{Cl}$ aqueous solution. The organic phase was separated and dried over $\mathrm{MgSO}_{4}$ and concentrated under reduced pressure. Flash column chromatography eluting with pentane and $\mathrm{CH}_{2} \mathrm{Cl}_{2}$ afforded the desired product.

\subsection{General Procedure for coupling of organoboronic esters and organolithium reagents (GP4)}

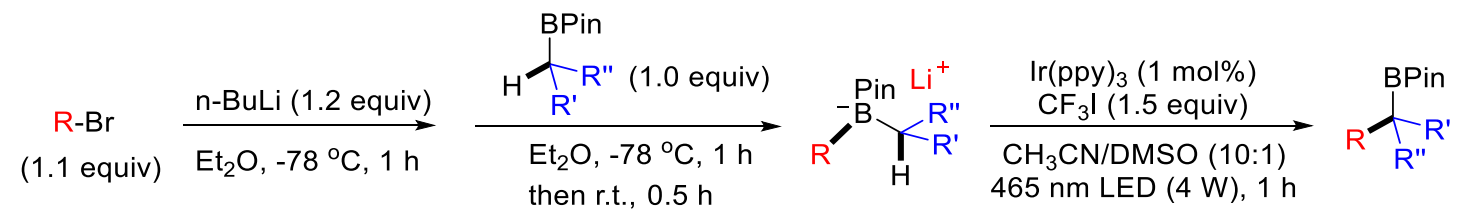

To a solution of arylbromide $(0.22 \mathrm{mmol}, 1.1$ equiv) in diethyl ether $(2 \mathrm{~mL})$ was added a solution of $n$-butyllithium $\left(1.6 \mathrm{M}, 0.24 \mathrm{mmol}, 1.2\right.$ equiv) under $-78{ }^{\circ} \mathrm{C}$ over a period of $5 \mathrm{~min}$. The mixture was stirred at that temperature for $1 \mathrm{~h}$. Alkylboronic pinacol esters was added to the reaction mixture and stirred under $-78{ }^{\circ} \mathrm{C}$ for $1 \mathrm{~h}$. The mixture was then stirred at room temperature for another $30 \mathrm{~min}$. The solvent was carefully removed in vacuo and further dried for $30 \mathrm{~min}$ under high vacuum. After subsequent addition of $\operatorname{Ir}(\text { ppy })_{3}(1.3 \mathrm{mg}, 0.002 \mathrm{mmol}, 0.01$ equiv), acetonitrile $(2 \mathrm{~mL})$, DMSO $(0.1 \mathrm{~mL})$ under argon, the mixture was stirred for 5 min until all solid was 
dissolved. Then $\mathrm{CF}_{3} \mathrm{I}$ (3.0 $\mathrm{M}$ in DMSO, $0.1 \mathrm{~mL}, 0.3 \mathrm{mmol}, 1.5$ equiv) was added to the reaction mixture and the reaction mixture was immediately irradiated by a $4 \mathrm{~W}$ blue LED and stirred for $1 \mathrm{~h}$. The reaction mixture was diluted with $20 \mathrm{~mL} \mathrm{CH}_{2} \mathrm{Cl}_{2}$ and quenched with saturated $\mathrm{NH}_{4} \mathrm{Cl}$ aqueous solution. The organic phase was separated and dried over $\mathrm{MgSO}_{4}$ and concentrated under reduced pressure. Flash column chromatography eluting with pentane and $\mathrm{CH}_{2} \mathrm{Cl}_{2}$ afforded the desired product.

\section{Reaction Screening}

\subsection{General Procedure for reaction condition optimization}

3,5-Bis(trifluoromethyl)phenylboronic acid pinacol ester $(68.0 \mathrm{mg}, 0.20 \mathrm{mmol}, 1.0$ equiv) was dissolved in diethyl ether $(2.0 \mathrm{~mL}) . s$-Butyllithium solution $(1.4 \mathrm{M}$ in cyclohexane, $0.16 \mathrm{~mL}, 0.22 \mathrm{mmol}, 1.1$ equiv) was added dropwise over $5 \mathrm{~min}$ at $0{ }^{\circ} \mathrm{C}$. The mixture was stirred at $0{ }^{\circ} \mathrm{C}$ for $30 \mathrm{~min}$ then room temperature for another $30 \mathrm{~min}$. The solvent was carefully removed in vacuo and further dried for $30 \mathrm{~min}$ under high vacuum. After subsequent addition of $\operatorname{Ir}(\mathrm{ppy})_{3}(1.3 \mathrm{mg}, 0.002 \mathrm{mmol}, 0.01$ equiv) and solvent under argon. The reaction mixture was stirred for 1 min until all solid was dissolved. Then perfluoroalkyl iodide was added to the reaction mixture and the reaction mixture was immediately irradiated by a $4 \mathrm{~W}$ blue LED and stirred for specified time. The reaction mixture was diluted with $20 \mathrm{~mL} \mathrm{CH} \mathrm{Cl}_{2}$ and quenched with saturated $\mathrm{NH}_{4} \mathrm{Cl}$ aqueous solution. The organic phase was separated and dried over $\mathrm{MgSO}_{4}$ and concentrated under reduced pressure. The yields were determined by crude $\mathrm{GC}$ analysis with $n-\mathrm{C}_{14} \mathrm{H}_{30}$ as internal standard.

Table S1. Influence of solvents, time and oxidants. 


\begin{tabular}{|c|c|c|c|c|c|}
\hline $\mathrm{CF}_{3}$ & $+\underbrace{\operatorname{Pin}}_{(1.1 \text { equiv })}$ & $\underset{0^{\circ} \mathrm{C} \text { then r.t. }}{\stackrel{\mathrm{Et}_{2} \mathrm{O}}{\longrightarrow}}$ & ${ }_{\mathrm{CF}_{3}}^{\mathrm{Pin}_{\mathrm{B}}^{\mathrm{Bi}}}$ & 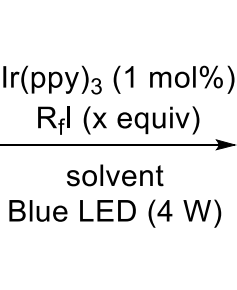 & $\left.\right|_{3 a} ^{C_{3}}$ \\
\hline Entry & solvent & & $\mathrm{R}_{\mathrm{f}} \mathrm{l}$ (x equiv) & time & Yield of $\mathbf{3} \mathbf{a}^{a}$ \\
\hline 1 & $\mathrm{CH}_{3} \mathrm{CN}$ & & $\mathrm{CF}_{3} \mathrm{l}(1.5$ equiv $)$ & $1 \mathrm{~h}$ & $50 \%$ \\
\hline 2 & DMSO & & $\mathrm{CF}_{3} \mathrm{I}(1.5$ equiv $)$ & $1 \mathrm{~h}$ & $62 \%$ \\
\hline 3 & $\mathrm{CH}_{3} \mathrm{CN} / \mathrm{DMS}$ & (10:1) & $\mathrm{CF}_{3} \mathrm{I}(1.5$ equiv $)$ & $1 \mathrm{~h}$ & $72 \%\left(67 \%^{b}\right)$ \\
\hline 4 & $\mathrm{CH}_{3} \mathrm{CN} / \mathrm{DMS}$ & o (10:1) & $\mathrm{CF}_{3} \mathrm{I}(5.0$ equiv $)$ & $1 \mathrm{~h}$ & $67 \%$ \\
\hline 5 & $\mathrm{CH}_{3} \mathrm{CN} / \mathrm{DMS}$ & o $(10: 1)$ & $\mathrm{CF}_{3} \mathrm{I}(1.5$ equiv $)$ & $0.5 \mathrm{~h}$ & $45 \%$ \\
\hline 6 & $\mathrm{CH}_{3} \mathrm{CN} / \mathrm{DMS}$ & O (10:1) & $\mathrm{CF}_{3} \mathrm{I}$ (1.5 equiv) & $1.5 \mathrm{~h}$ & $71 \%$ \\
\hline 7 & $\mathrm{CH}_{3} \mathrm{CN} / \mathrm{DMS}$ & (10:1) & $n-C_{3} F_{7} l(1.5$ equiv $)$ & $1 \mathrm{~h}$ & $21 \%$ \\
\hline 8 & $\mathrm{CH}_{3} \mathrm{CN} / \mathrm{DMS}$ & O (10:1) & $\mathrm{n}-\mathrm{C}_{4} \mathrm{~F}_{9} \mathrm{l}(1.5$ equiv) & $1 \mathrm{~h}$ & $37 \%$ \\
\hline
\end{tabular}

a $0.2 \mathrm{mmol}$ scale reaction, yields determinded by crude GC analysis with $n-\mathrm{C}_{14} \mathrm{H}_{30}$ as internal standard. ${ }^{\mathbf{b}}$ Isolated yield.

Table S2. Influence of photo catalysts.

\begin{tabular}{|c|c|c|c|c|c|}
\hline $\mathrm{CF}_{3}$ & $\overbrace{(1.1 \text { equiv })}^{\mathrm{Li}}$ & $\underset{\mathrm{O}^{\circ} \mathrm{C} \text { then r.t. }}{\stackrel{\mathrm{Et}_{2} \mathrm{O}}{\longrightarrow}}$ & ${ }_{\mathrm{CF}_{3}}^{\mathrm{Pin} \mathrm{Li}^{+}}$ & 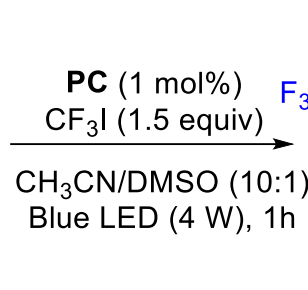 & $\left.\right|_{3 a}$ \\
\hline Entry & & & Photo Cataly & $t(P C)$ & Yield of $3 a^{a}$ \\
\hline 1 & & & $\operatorname{Ir}(\text { ppy })_{3}$ & & $72 \%$ \\
\hline 2 & & & $\mathrm{Ru}(\mathrm{bpy})_{3} \mathrm{Cl}_{2}$ & & $69 \%$ \\
\hline 3 & & & Eosin $Y$ & & $70 \%$ \\
\hline 4 & & & Eosin B & & $17 \%$ \\
\hline 5 & & & Rose Bengal & & $68 \%$ \\
\hline 6 & & & Rhodamine $\mathrm{B}$ & base & $69 \%$ \\
\hline $7^{\mathrm{b}}$ & & & $\operatorname{Ir}(p p y)_{3}$ & & $0 \%$ \\
\hline 8 & & & - & & $0 \%$ \\
\hline
\end{tabular}

a $0.2 \mathrm{mmol}$ scale reaction, yields determinded by crude $\mathrm{GC}$ analysis with $n-\mathrm{C}_{14} \mathrm{H}_{30}$ as internal standard. ${ }^{b}$ No light.

\section{Preparation of Boronic Esters and Alkyllithium Reagents}




\subsection{General procedure for preparation of organoboronic acid pinacol esters}

(GP5)

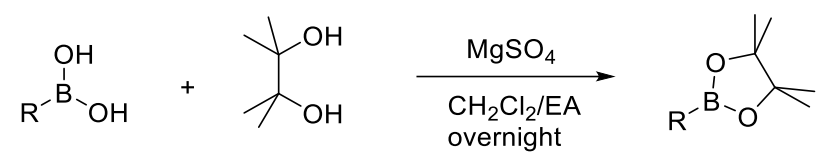

A mixture of boronic acid (1.0 equiv), pinacol (1.1 equiv) and anhydrous $\mathrm{MgSO}_{4}$ (4.0 equiv) in $\mathrm{CH}_{2} \mathrm{Cl}_{2}$ /Ethyl Acetate (5:1) was stirred at room temperature overnight. The reaction mixture was filtered and the solvent removed in vacuo. The crude material was purified by Kugelrohr distillation or flash column chromatography to give the pure boronic ester. Attention: Sometimes a rapid Kugelrohr distillation could not afford a pure enough product, further purification by flash column chromatography was needed.

\subsection{General procedure for preparation of organoboronic acid pinacol esters} (GP6)

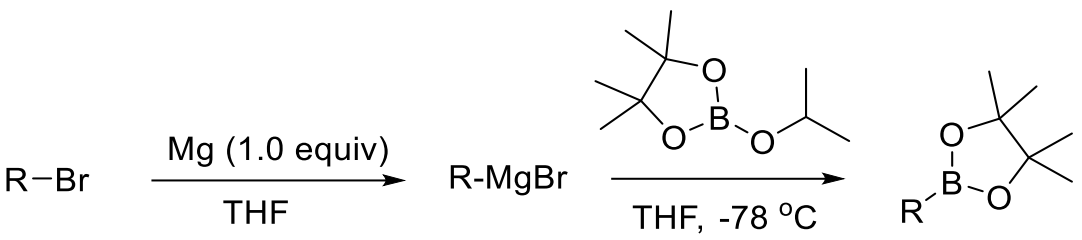

Magnesium chippings (1.0 equiv) were added to a dried flask under argon atmosphere and suspended with dry THF. A small amount of a solution of alkyl bromide (1.0 equiv) in dry THF was added to the magnesium and the activation of the Grignard formation was accelerated by addition of an iodine crystal and heating. Afterwards, the rest of the solution of alkyl bromide in THF was added dropwise. The reaction mixture was stirred until magnesium chippings disappeared. The reaction mixture was cooled to $-78{ }^{\circ} \mathrm{C}$, 2-isopropoxy-4,4,5,5-tetramethyl-1,3,2-dioxaborolane (1.0 equiv) was added in one portion. The reaction mixture was stirred overnight, quenched with saturated $\mathrm{NH}_{4} \mathrm{Cl}$ aqueous solution, and extracted with $\mathrm{Et}_{2} \mathrm{O}$. The combined organic layer was dried over $\mathrm{MgSO}_{4}$ and filtered. The filtrate was concentrated under reduced pressure and purified by flash column chromatography to afford the pure alkylboronic ester. Attention: Sometimes a rapid Kugelrohr distillation could not afford a pure enough product, further purification by flash column chromatography was needed.

\subsection{Preparation of organoboronic acid pinacol esters}

2-(3,5-Bis(trifluoromethyl)phenyl)-4,4,5,5-tetramethyl-1,3,2-dioxaborolane (1a)<smiles>C=C1OB(c2cc(C(F)(F)F)cc(C(F)(F)F)c2)OC1(C)C</smiles>

Following GP5, using 3,5-bis(trifluoromethyl)phenylboronic acid (5.16 g, $20 \mathrm{mmol}$ ) and pinacol (2.6 g, $22 \mathrm{mmol})$, purifying the crude material by passing through a short 
( $\sim \mathrm{cm}$ ) silica plug eluting with $\mathrm{CH}_{2} \mathrm{Cl}_{2}$ and then Kugelrohr distillation (0.1 mbar, 150 ${ }^{\circ} \mathrm{C}$, dry ice cooling) afforded $1 \mathrm{a}$ as white solid (6.7 g, 98\% yield). ${ }^{1} \mathrm{H}$ NMR (300 MHz, $\left.\mathrm{CDCl}_{3}\right) \delta 8.24(\mathrm{~s}, 2 \mathrm{H}), 7.94(\mathrm{~s}, 1 \mathrm{H}), 1.37$ (s, 12H). ${ }^{11} \mathrm{~B} \mathrm{NMR}\left(96 \mathrm{MHz}, \mathrm{CDCl}_{3}\right) \delta 30.0$. ${ }^{19} \mathrm{~F}$ NMR $\left(282 \mathrm{MHz}, \mathrm{CDCl}_{3}\right) \delta-62.9$ (s). Spectral data were in accordance with the literature. ${ }^{\mathrm{S} 1}$

4,4,5,5-Tetramethyl-2-(1-phenylpentan-3-yl)-1,3,2-dioxaborolane (1e)<smiles>CCC(CCc1ccccc1)B1OC(C)(C)C(C)(C)O1</smiles>

1e was prepared according to the reported procedure. ${ }^{\mathrm{S} 2}$

Trimethyl(4-(4,4,5,5-tetramethyl-1,3,2-dioxaborolan-2-yl)phenyl)silane (1f)<smiles>C=C1OB(c2ccc([Si]C)cc2)OC1(C)C</smiles>

1f was prepared according to the reported procedure. ${ }^{\mathrm{S} 3}$

4-(4,4,5,5-Tetramethyl-1,3,2-dioxaborolan-2-yl)phenyl trifluoromethanesulfonate (1k)<smiles>CC1(C)OB(c2ccc(O)cc2)OC1(C)C</smiles>

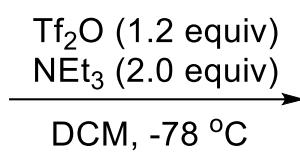<smiles>CC1(C)OB(c2ccc(O)cc2)OC1(C)C</smiles>

To a solution of 4-(4,4,5,5-tetramethyl-1,3,2-dioxaborolan-2-yl)phenol (1.0 g, 4.54 mmol) in $\mathrm{CH}_{2} \mathrm{Cl}_{2}$, was added triethylamine $(0.92 \mathrm{~g}, 1.3 \mathrm{~mL}, 9.1 \mathrm{mmol}, 2.0$ equiv) at $-78{ }^{\circ} \mathrm{C}$. The mixture was allowed to stir at $-78{ }^{\circ} \mathrm{C}$ for $5 \mathrm{~min}$ followed by dropwise addition of $\mathrm{Tf}_{2} \mathrm{O}$ (1.54 g, $0.9 \mathrm{~mL}, 5.46 \mathrm{mmol}, 1.2$ equiv). The reaction mixture was allowed to stir over night. The resulting mixture was quenched with water (approx. 20 $\mathrm{mL})$, and extracted with $\mathrm{CH}_{2} \mathrm{Cl}_{2}(3 \times 20 \mathrm{~mL})$. The combined organic layer was dried over $\mathrm{MgSO}_{4}$ and filtered. The filtrate was concentrated under reduced pressure and purified by Kugelrohr distillation $\left(0.1 \mathrm{mbar}, 150{ }^{\circ} \mathrm{C}\right.$, dry ice cooling) to afford $1 \mathbf{k}$ as white solid (1.3 g, $81 \%$ yield). 1k was further purified by flash column chromatography $($ PENTANE/Et $2 \mathrm{O}=10: 1), \mathrm{R}_{\mathrm{f}} 0.4($ Pentane/Et2O $=10: 1) .{ }^{1} \mathrm{H}$ NMR $\left(300 \mathrm{MHz}, \mathrm{CDCl}_{3}\right) \delta$ 7.92-7.86 (m, 2H), 7.29-7.24 (m, 2H), $1.35(\mathrm{~s}, 12 \mathrm{H}) .{ }^{11} \mathrm{~B}$ NMR $\left(96 \mathrm{MHz}, \mathrm{CDCl}_{3}\right) \delta 29.8 .{ }^{19} \mathrm{~F} \mathrm{NMR}\left(282 \mathrm{MHz}, \mathrm{CDCl}_{3}\right) \delta-72.9$ (s). Spectral data were in accordance with the literature. ${ }^{\mathrm{S} 4}$ 
3-(4,4,5,5-Tetramethyl-1,3,2-dioxaborolan-2-yl)phenyl trifluoromethanesulfonate (1s)<smiles>CC1(C)OB(c2cccc(O)c2)OC1(C)C</smiles>

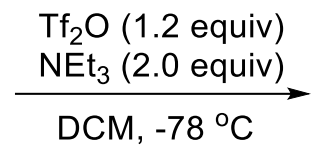<smiles>C=C1OB(c2cccc(O)c2)OC1(C)C</smiles>

To a solution of 3-(4,4,5,5-tetramethyl-1,3,2-dioxaborolan-2-yl)phenol (2.2 g, 10 mmol) in $\mathrm{CH}_{2} \mathrm{Cl}_{2}$, was added triethylamine $\left(2.8 \mathrm{~mL}, 20 \mathrm{mmol}, 2.0\right.$ equiv) at $-78{ }^{\circ} \mathrm{C}$. The mixture was allowed to stir at $-78{ }^{\circ} \mathrm{C}$ for $5 \mathrm{~min}$ followed by dropwise addition of $\mathrm{Tf}_{2} \mathrm{O}(2.0 \mathrm{~mL}, 12 \mathrm{mmol}, 1.2$ equiv). The reaction mixture was allowed to stir over night. The resulting mixture was quenched with water (approx. $40 \mathrm{~mL}$ ), and extracted with $\mathrm{CH}_{2} \mathrm{Cl}_{2}(3 \times 40 \mathrm{~mL})$. The combined organic layer was dried over $\mathrm{MgSO}_{4}$ and filtered. The filtrate was concentrated under reduced pressure and purified by Kugelrohr distillation $\left(0.1 \mathrm{mbar}, 150{ }^{\circ} \mathrm{C}\right.$, dry ice cooling) to afford 1s as sticky oil (2.0 $\mathrm{g}, 57 \%$ yield). 1s was further purified by flash column chromatography (Pentane/Et $\mathrm{E}_{2} \mathrm{O}$ $=10: 1), \mathrm{R}_{\mathrm{f}} 0.4($ Pentane/Et $2 \mathrm{O}=10: 1) .{ }^{1} \mathrm{H}$ NMR $\left(300 \mathrm{MHz}, \mathrm{CDCl}_{3}\right) \delta 7.81(\mathrm{~d}, J=7.3$ $\mathrm{Hz}, 1 \mathrm{H}), 7.67(\mathrm{~d}, J=2.5 \mathrm{~Hz}, 1 \mathrm{H}), 7.49-7.41(\mathrm{~m}, 1 \mathrm{H}), 7.37-7.31(\mathrm{~m}, 1 \mathrm{H}), 1.35$ (s, $12 \mathrm{H}) .{ }^{13} \mathrm{C} \mathrm{NMR}\left(75 \mathrm{MHz}, \mathrm{CDCl}_{3}\right) \delta 149.4,134.6,129.7,127.0,123.8,118.8$ (q, $J=$ $320.5 \mathrm{~Hz}), 84.4,24.9$, carbon attached to boron not observed. ${ }^{11} \mathrm{~B}$ NMR $(96 \mathrm{MHz}$, $\left.\mathrm{CDCl}_{3}\right) \delta 30.2 .{ }^{19} \mathrm{~F} \mathrm{NMR}\left(282 \mathrm{MHz}, \mathrm{CDCl}_{3}\right) \delta-73.0$ (s). HRMS (ESI) $\mathrm{m} / \mathrm{z}=375.0656$ calcd. for $\mathrm{C}_{13} \mathrm{H}_{16} \mathrm{BF}_{3} \mathrm{O}_{5} \mathrm{SNa}^{+}[\mathrm{M}+\mathrm{Na}]^{+}$, found: 375.0659. FTIR (neat): $v$ ( $\left.\mathrm{cm}^{-1}\right) 2984$, 2936, 1572, 1490, 1422, 1354, 1331, 1247, 1205, 1167, 1136, 1095, 1071, 1004, 964 , $911,857,830,799,748,702,670,606$.

2-(3-Chloro-4-fluorophenyl)-4,4,5,5-tetramethyl-1,3,2-dioxaborolane (1n)<smiles>CC1(C)OB(c2ccc(F)c(Cl)c2)OC1(C)C</smiles>

Following GP5, using (3-chloro-4-fluorophenyl)boronic acid (1.74 g, $10 \mathrm{mmol}$ ) and pinacol ( $1.30 \mathrm{~g}, 11 \mathrm{mmol}, 1.1$ equiv), purifying the crude material by passing through a short $(\sim 4 \mathrm{~cm})$ silica plug eluting with $\mathrm{CH}_{2} \mathrm{Cl}_{2}$ and then Kugelrohr distillation $(0.1$ mbar, $150{ }^{\circ} \mathrm{C}$, dry ice cooling) afforded $\mathbf{1 n}$ as white solid $\left(2.1 \mathrm{~g}, 82 \%\right.$ yield). ${ }^{1} \mathrm{H}$ NMR $\left(300 \mathrm{MHz}, \mathrm{CDCl}_{3}\right) \delta 7.84(\mathrm{dd}, J=7.9,1.3 \mathrm{~Hz}, 1 \mathrm{H}), 7.72-7.61(\mathrm{~m}, 1 \mathrm{H}), 7.18-7.06$ $(\mathrm{m}, 1 \mathrm{H}), 1.34(\mathrm{~s}, 12 \mathrm{H}) .{ }^{11} \mathrm{~B} \mathrm{NMR}\left(96 \mathrm{MHz}, \mathrm{CDCl}_{3}\right) \delta 30.2 .{ }^{19} \mathrm{~F}$ NMR $(282 \mathrm{MHz}$, $\left.\mathrm{CDCl}_{3}\right) \delta-111.2(\mathrm{~s})$. Spectral data were in accordance with the literature. ${ }^{\mathrm{S} 5}$

\section{4,4,5,5-Tetramethyl-2-(4-(2-methyl-1,3-dioxolan-2-yl)phenyl)-1,3,2-dioxaborolane} (1y) 
<smiles>CC1(c2ccc(B3OC(C)(C)C(C)(C)O3)cc2)OCCO1</smiles>

To a mixture of 1-(4-(4,4,5,5-tetramethyl-1,3,2-dioxaborolan-2-yl)phenyl)ethan-1-one $(1.0 \mathrm{~g}, 4.06 \mathrm{mmol})$ and ethylene glycol $(2.54 \mathrm{~g}, 2.3 \mathrm{~mL}, 41 \mathrm{mmol}, 10$ equiv) in toluene $(40 \mathrm{~mL})$ was added p-tolylsulfonic acid trihydrate $(38.0 \mathrm{mg}, 0.2 \mathrm{mmol}, 0.05$ equiv). The mixture was refluxed for 16 hours over a Dean-Stark apparatus to remove generated water. Solvent was removed under reduced pressure. The residue was purified by silica chromatography eluting with (pentane/ethyl acetate $=4: 1$ ) to afford $1 \mathbf{y}$ as white solid (1.0 g, 85\% yield), $\mathrm{R}_{\mathrm{f}} 0.4$ (Pentane/ ethyl acetate $\left.=3: 1\right) .{ }^{1} \mathrm{H}$ NMR $\left(300 \mathrm{MHz}, \mathrm{CDCl}_{3}\right) \delta 7.80(\mathrm{~d}, J=8.2 \mathrm{~Hz}, 2 \mathrm{H}), 7.49(\mathrm{~d}, J=8.2 \mathrm{~Hz}, 2 \mathrm{H}), 4.10-3.95(\mathrm{~m}$, $2 \mathrm{H}), 3.85-3.63(\mathrm{~m}, 2 \mathrm{H}), 1.65(\mathrm{~s}, 3 \mathrm{H}), 1.34(\mathrm{~s}, 12 \mathrm{H}) .{ }^{13} \mathrm{C} \mathrm{NMR}\left(75 \mathrm{MHz}, \mathrm{CDCl}_{3}\right) \delta$ 146.3, 134.7, 124.6, 108.8, 83.8, 64.4, 27.5, 24.9, carbon attached to boron not observed. ${ }^{11} \mathrm{~B} \mathrm{NMR}\left(96 \mathrm{MHz}, \mathrm{CDCl}_{3}\right) \delta 30.8$. Spectral data were in accordance with the literature. ${ }^{\mathrm{S} 6}$

4,4,5,5-Tetramethyl-2-((8R,9S,13S,14S)-13-methyl-6,7,8,9,11,12,13,14,15,16-decahy drospiro[cyclopenta[a]phenanthrene-17,2'-[1,3]dioxolan]-3-yl)-1,3,2-dioxaborolane (1z)
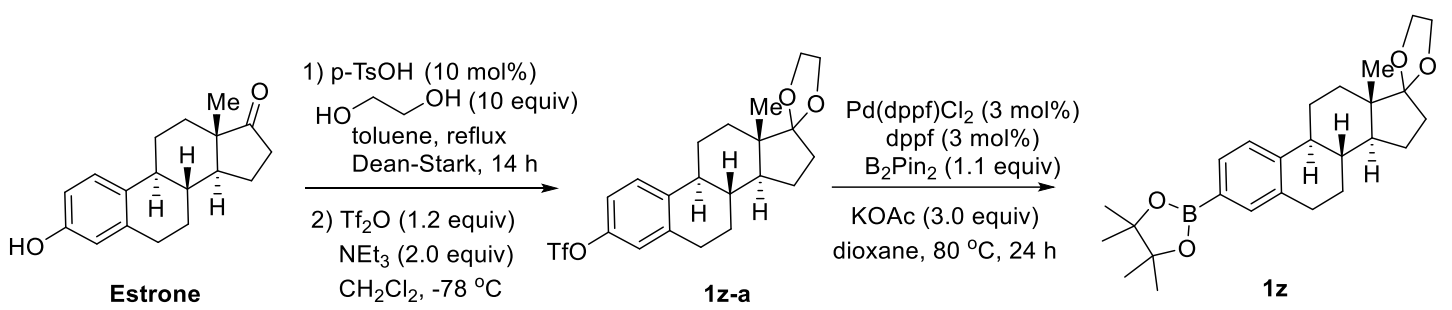

1z-a was synthesized from estrone according to the reported procedure. ${ }^{\mathrm{S} 7}$

To a $50 \mathrm{~mL}$ Schlenk tube equipped with a stirring bar was added $\mathrm{Pd}(\mathrm{dppf}) \mathrm{Cl}_{2}(124 \mathrm{mg}$, $0.17 \mathrm{mmol}, 0.03$ equiv), 1,1'-bis(diphenylphosphino)ferrocene (dppf, $98 \mathrm{mg}, 0.17$ mmol, 0.03 equiv), $\mathrm{B}_{2} \mathrm{Pin}_{2}$ (1.6 g, $6.3 \mathrm{mmol}, 1.1$ equiv), KOAc (1.67 g, $17 \mathrm{mmol}, 3.0$ equiv), 1z-a (2.55 g, $5.7 \mathrm{mmol}, 1.0$ equiv) and then sealed. The Schlenk tube was evacuated and backfilled with Ar for 3 times. Dioxane $(30 \mathrm{~mL})$ was added under $\mathrm{Ar}$ atmosphere and the mixture was stirred at $80{ }^{\circ} \mathrm{C}$ for $24 \mathrm{~h}$. After cooling to room temperature, the reaction mixture was diluted with $\mathrm{Et}_{2} \mathrm{O}(200 \mathrm{~mL})$. The organic layer was washed with water $(3 \times 100 \mathrm{~mL})$ and dried over anhydrous $\mathrm{MgSO}_{4}$. After filtration and concentration, the residue was purified by silica gel chromatography with pentane and ethyl acetate (Pentane/EA = 10:1) to afford $\mathbf{1 z}$ as white solid (1.96 $\mathrm{g}$, $81 \%$ yield). $\mathrm{R}_{\mathrm{f}} 0.4$ (pentane/EA = 20:3). M.p.: $179-181{ }^{\circ} \mathrm{C} . \quad[\alpha]{ }_{D}^{24}+20(c 0.8$, $\left.\mathrm{CHCl}_{3}\right) .{ }^{1} \mathrm{H}$ NMR $\left(300 \mathrm{MHz}, \mathrm{CDCl}_{3}\right) \delta 7.64-7.50(\mathrm{~m}, 2 \mathrm{H}), 7.32(\mathrm{~d}, J=7.8 \mathrm{~Hz}, 1 \mathrm{H})$, $4.08-3.83(\mathrm{~m}, 4 \mathrm{H}), 3.01-2.82(\mathrm{~m}, 2 \mathrm{H}), 2.52-2.21(\mathrm{~m}, 2 \mathrm{H}), 2.15-1.73(\mathrm{~m}, 5 \mathrm{H})$, $1.72-1.37(\mathrm{~m}, 6 \mathrm{H}), 1.34$ (s, 12H), 0.89 (s, 3H). ${ }^{13} \mathrm{C} \mathrm{NMR}\left(75 \mathrm{MHz}, \mathrm{CDCl}_{3}\right) \delta 143.9$, 
136.1, 135.5, 132.0, 124.7, 119.4, 83.6, 65.2, 64.5, 49.5, 46.1, 44.4, 38.7, 34.2, 30.7, $29.3,26.9,25.8,24.8,24.8,22.4,14.3$, carbon attached to boron not observed. ${ }^{11} \mathrm{~B}$ NMR $\left(96 \mathrm{MHz}, \mathrm{CDCl}_{3}\right) \delta$ 30.2. HRMS (ESI) $\mathrm{m} / z=447.2677$ calcd. for $\mathrm{C}_{26} \mathrm{H}_{37} \mathrm{BO}_{4} \mathrm{Na}^{+}[\mathrm{M}+\mathrm{Na}]^{+}$, found: 447.2678. FTIR (neat): $v\left(\mathrm{~cm}^{-1}\right)$ 2975, 2937, 2874, 1611, 1408, 1363, 1352, 1309, 1273, 1289, 1213, 1180, 1143, 1108, 1045, 964, 854, $725,676$.

2-((R)-2,8-Dimethyl-2-((4R,8R)-4,8,12-trimethyltridecyl)chroman-6-yl)-4,4,5,5-tetra methyl-1,3,2-dioxaborolane (1aa)

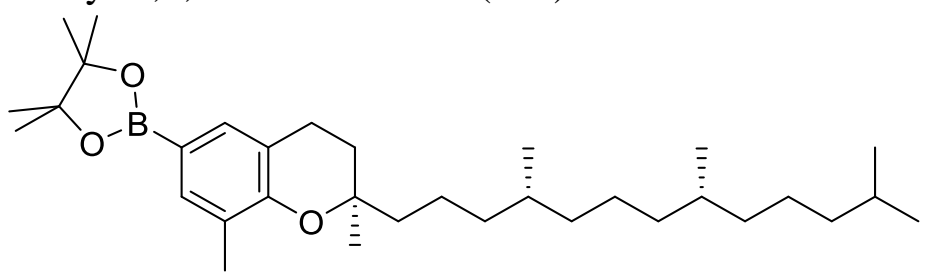

1aa was prepared according to the reported procedure. ${ }^{\mathrm{S} 8}$

2-(Sec-butyl)-4,4,5,5-tetramethyl-1,3,2-dioxaborolane (4c)

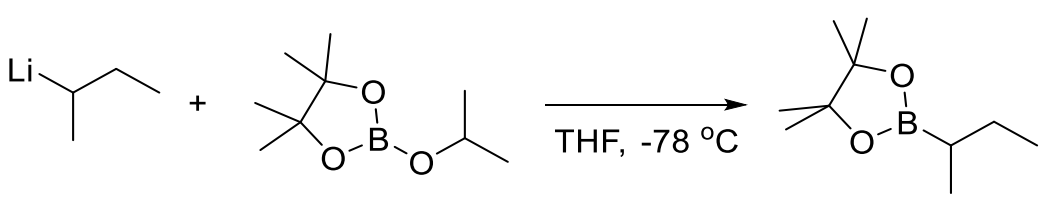

To a solution of 2-isopropoxy-4,4,5,5-tetramethyl-1,3,2-dioxaborolane (3.72 g, 4.1 $\mathrm{mL}, 20 \mathrm{mmol})$ in THF $(50 \mathrm{~mL})$ was added s-butyl lithium solution $(1.4 \mathrm{M}$ in cyclohexane, $14.2 \mathrm{~mL}, 20 \mathrm{mmol}$ ) dropwise at $-78{ }^{\circ} \mathrm{C}$. The mixture was stirred overnight and quenched with saturated $\mathrm{NH}_{4} \mathrm{Cl}$ aqueous solution. The mixture was extracted with $\mathrm{Et}_{2} \mathrm{O}(50 \mathrm{~mL} \times 3)$. The organic phase was combined and dried over $\mathrm{MgSO}_{4}$. After filtration and evaporation of solvent, the residue was purified by Kugelrohr distillation (10 mbar, $100{ }^{\circ} \mathrm{C}$, dry ice cooling) to afford $\mathbf{4 c}$ as colorless liquid (2.0 g, 54\% yield). 4c was further purified by flash column chromatography (pentane $\left./ \mathrm{Et}_{2} \mathrm{O}=20: 1\right), \mathrm{R}_{\mathrm{f}} 0.5$ (pentane/Et $\left.2 \mathrm{O}=20: 1\right) .{ }^{1} \mathrm{H}$ NMR $\left(300 \mathrm{MHz}, \mathrm{CDCl}_{3}\right) \delta$ $1.55-1.40(\mathrm{~m}, 1 \mathrm{H}), 1.40-1.29(\mathrm{~m}, 1 \mathrm{H}), 1.24(\mathrm{~s}, 12 \mathrm{H}), 0.99-0.92(\mathrm{~m}, 4 \mathrm{H}), 0.90(\mathrm{t}, J$ $=7.4 \mathrm{~Hz}, 3 \mathrm{H})$. The NMR spectra were in accordance with the literature. ${ }^{\mathrm{S} 9}$

2-Cyclopropyl-4,4,5,5-tetramethyl-1,3,2-dioxaborolane (4d)<smiles>CC1(C)OB(C2CC2)OC1(C)C</smiles>

Following GP5, using cyclopropylboronic acid (2.58 g, $30 \mathrm{mmol})$ and pinacol (3.54 g, $30 \mathrm{mmol})$, purifying the crude material by passing through a short $(\sim 4 \mathrm{~cm})$ silica plug eluting with $\mathrm{CH}_{2} \mathrm{Cl}_{2}$ and then Kugelrohr distillation (10 mbar, $80{ }^{\circ} \mathrm{C}$, dry ice cooling) afforded $\mathbf{4 d}$ as colorless liquid (4.24 g, 84\% yield). 4d was further purified by flash column chromatography (Pentane $/ \mathrm{Et}_{2} \mathrm{O}=20: 1$ ), $\mathrm{R}_{\mathrm{f}} 0.5$ (pentane/Et ${ }_{2} \mathrm{O}=20: 1$ ). ${ }^{1} \mathrm{H}$ NMR $\left(300 \mathrm{MHz}, \mathrm{CDCl}_{3}\right) \delta 1.22(\mathrm{~s}, 12 \mathrm{H}), 0.65-0.57(\mathrm{~m}, 2 \mathrm{H}), 0.55-0.44(\mathrm{~m}, 2 \mathrm{H})$, 
$-0.20(\mathrm{tt}, J=9.2,6.1 \mathrm{~Hz}, 1 \mathrm{H}) .{ }^{11} \mathrm{~B} \mathrm{NMR}\left(96 \mathrm{MHz}, \mathrm{CDCl}_{3}\right) \delta 33.5$. The NMR spectra were in accordance with the literature. ${ }^{\mathrm{S} 9}$

2-Cyclopentyl-4,4,5,5-tetramethyl-1,3,2-dioxaborolane (4e)<smiles>CC1(C)OB(C2CCCC2)OC1(C)C</smiles>

Following GP6, using cyclopentyl bromide (2.98 g, $2.14 \mathrm{~mL}, 20 \mathrm{mmol})$, magnesium (0.48 g, $20 \mathrm{mmol})$ and 2-isopropoxy-4,4,5,5-tetramethyl-1,3,2-dioxaborolane (3.7 g, $4.1 \mathrm{~mL}, 20 \mathrm{mmol}$ ), purifying the crude material by Kugelrohr distillation (10 mbar, $100{ }^{\circ} \mathrm{C}$, dry ice cooling) afforded $4 \mathbf{e}$ as colorless liquid $(2.7 \mathrm{~g}, 69 \%$ yield). 4e was further purified by flash column chromatography (Pentane/Et $\mathrm{t}_{2} \mathrm{O}=20: 1$ ), $\mathrm{R}_{\mathrm{f}} 0.5$ (pentane/Et $2 \mathrm{O}=20: 1) .{ }^{1} \mathrm{H}$ NMR $\left(300 \mathrm{MHz}, \mathrm{CDCl}_{3}\right) \delta 1.82-1.66(\mathrm{~m}, 2 \mathrm{H}), 1.66-$ $1.35(\mathrm{~m}, 6 \mathrm{H}), 1.23(\mathrm{~s}, 12 \mathrm{H}), 1.21-1.05(\mathrm{~m}, 1 \mathrm{H}) .{ }^{11} \mathrm{~B} \mathrm{NMR}\left(96 \mathrm{MHz}, \mathrm{CDCl}_{3}\right) \delta 34.5$. The NMR spectra were in accordance with the literature. ${ }^{\mathrm{S} 9}$

2-Cyclohexyl-4,4,5,5-tetramethyl-1,3,2-dioxaborolane (4f)<smiles>CC1(C)OB(C2CCCCC2)OC1(C)C</smiles>

Following GP6, using cyclohexyl bromide (3.26 g, $2.46 \mathrm{~mL}, 20 \mathrm{mmol}$ ), magnesium $(0.48 \mathrm{~g}, 20 \mathrm{mmol})$ and 2-isopropoxy-4,4,5,5-tetramethyl-1,3,2-dioxaborolane $(3.7 \mathrm{~g}$, $4.1 \mathrm{~mL}, 20 \mathrm{mmol}$ ), purifying the crude material by Kugelrohr distillation (10 mbar, $120^{\circ} \mathrm{C}$, dry ice cooling) afforded $\mathbf{4 f}$ as colorless liquid (2.45 g, $58 \%$ yield). $4 \mathbf{f}$ was further purified by flash column chromatography (Pentane/Et $\left.\mathrm{E}_{2} \mathrm{O}=20: 1\right), \mathrm{R}_{\mathrm{f}} 0.5$ (pentane/Et $2 \mathrm{O}=20: 1) .{ }^{1} \mathrm{H} \mathrm{NMR}\left(300 \mathrm{MHz}, \mathrm{CDCl}_{3}\right) \delta 1.78-1.46(\mathrm{~m}, 5 \mathrm{H}), 1.42-$ $1.26(\mathrm{~m}, 5 \mathrm{H}), 1.23(\mathrm{~s}, 12 \mathrm{H}), 1.01-0.92(\mathrm{~m}, 1 \mathrm{H}) .{ }^{11} \mathrm{~B} \mathrm{NMR}\left(96 \mathrm{MHz}, \mathrm{CDCl}_{3}\right) \delta 33.8$. The NMR spectra were in accordance with the literature. ${ }^{\mathrm{S} 9}$

4,4,5,5-Tetramethyl-2-neopentyl-1,3,2-dioxaborolane (4g)<smiles>CC(C)(C)CB1OC(C)(C)C(C)(C)O1</smiles>

Following GP6, using neopentyl bromide (3.02 g, $2.5 \mathrm{~mL}, 20 \mathrm{mmol})$, magnesium (0.48 g, $20 \mathrm{mmol})$ and 2-isopropoxy-4,4,5,5-tetramethyl-1,3,2-dioxaborolane $(3.7 \mathrm{~g}$, $4.1 \mathrm{~mL}, 20 \mathrm{mmol}$ ), purifying the crude material by Kugelrohr distillation (10 mbar, $110^{\circ} \mathrm{C}$, dry ice cooling) afforded $4 \mathrm{~g}$ as colorless liquid $\left(2.13 \mathrm{~g}, 54 \%\right.$ yield). ${ }^{1} \mathrm{H}$ NMR $\left(300 \mathrm{MHz}, \mathrm{CDCl}_{3}\right) \delta 1.24(\mathrm{~s}, 12 \mathrm{H}), 0.99(\mathrm{~s}, 9 \mathrm{H}), 0.80(\mathrm{~s}, 2 \mathrm{H}) .{ }^{13} \mathrm{C} \mathrm{NMR}(75 \mathrm{MHz}$, $\left.\mathrm{CDCl}_{3}\right) \delta 82.7,32.0,29.7,24.9$, carbon attached to boron not observed. ${ }^{11} \mathrm{~B} \mathrm{NMR}(96$ $\left.\mathrm{MHz}, \mathrm{CDCl}_{3}\right) \delta$ 33.6. HRMS (EI) $\mathrm{m} / z=183.1551$ calcd. for $\mathrm{C}_{10} \mathrm{H}_{20} \mathrm{BO}_{2}{ }^{+}\left[\mathrm{M}-\mathrm{CH}_{3}\right]^{+}$, found: 183.1551. FTIR (neat): $v\left(\mathrm{~cm}^{-1}\right)$ 2979, 2952, 2870, 1466, 1354, 1318, 1269, 
2-Cyclobutyl-4,4,5,5-tetramethyl-1,3,2-dioxaborolane (4k)<smiles>CC1(C)OB(C2CCC2)OC1(C)C</smiles>

Following GP6, using cyclobutyl bromide ( $2.70 \mathrm{~g}, 20 \mathrm{mmol})$, magnesium (0.48 g, 20 mmol) and 2-isopropoxy-4,4,5,5-tetramethyl-1,3,2-dioxaborolane (3.7 g, $4.1 \mathrm{~mL}, 20$ mmol), purifying the crude material by Kugelrohr distillation $\left(10 \mathrm{mbar}, 100^{\circ} \mathrm{C}\right.$, dry ice cooling) afforded $4 \mathbf{k}$ as colorless liquid (1.2 g, 33\% yield). 4k was further purified by flash column chromatography (Pentane $/ \mathrm{Et}_{2} \mathrm{O}=20: 1$ ), $\mathrm{R}_{\mathrm{f}} 0.5$ (pentane/Et ${ }_{2} \mathrm{O}=20: 1$ ). ${ }^{1} \mathrm{H}$ NMR $\left(300 \mathrm{MHz}, \mathrm{CDCl}_{3}\right) \delta 2.15-1.79(\mathrm{~m}, 7 \mathrm{H}), 1.23(\mathrm{~s}, 12 \mathrm{H}) .{ }^{11} \mathrm{~B} \mathrm{NMR}(96 \mathrm{MHz}$, $\left.\mathrm{CDCl}_{3}\right) \delta 33.8$. The NMR spectra were in accordance with the literature ${ }^{\mathrm{S} 9}$

2-Cycloheptyl-4,4,5,5-tetramethyl-1,3,2-dioxaborolane (4n)<smiles>CC1(C)OB(C2CCCCCC2)OC1(C)C</smiles>

Following GP6, using cyclobutyl bromide (1.77 g, $10 \mathrm{mmol})$, magnesium (0.24 g, 10 $\mathrm{mmol})$ and 2-isopropoxy-4,4,5,5-tetramethyl-1,3,2-dioxaborolane $(1.85 \mathrm{~g}, 2.05 \mathrm{~mL}$, $10 \mathrm{mmol})$, purifying the crude material by Kugelrohr distillation $\left(1 \mathrm{mbar}, 120^{\circ} \mathrm{C}\right.$, dry ice cooling) afforded $4 \mathrm{n}$ as colorless liquid (1.0 g, 45\% yield). 4n was further purified by flash column chromatography (Pentane/Et ${ }_{2} \mathrm{O}=20: 1$ ), $\mathrm{R}_{\mathrm{f}} 0.5$ (pentane $/ \mathrm{Et}_{2} \mathrm{O}=20: 1$ ). ${ }^{1} \mathrm{H}$ NMR $\left(300 \mathrm{MHz}, \mathrm{CDCl}_{3}\right) \delta 1.80-1.32(\mathrm{~m}, 12 \mathrm{H}), 1.22(\mathrm{~s}, 12 \mathrm{H}), 1.12-1.00(\mathrm{~m}, 1 \mathrm{H})$. ${ }^{11} \mathrm{~B}$ NMR $\left(96 \mathrm{MHz}, \mathrm{CDCl}_{3}\right) \delta 34.3$. The NMR spectra were in accordance with the literature. $^{\mathrm{S} 9}$

2-(Adamantan-2-yl)-4,4,5,5-tetramethyl-1,3,2-dioxaborolane (4o)<smiles>CC1(C)OB(C2CC3CCC2CC3)OC1(C)C</smiles>

Following GP6, using 2-bromoadamantane (2.15g, $10 \mathrm{mmol})$, magnesium (0.24 g, 10 $\mathrm{mmol}$ ) and 2-isopropoxy-4,4,5,5-tetramethyl-1,3,2-dioxaborolane (1.85 g, $2.05 \mathrm{~mL}$, $10 \mathrm{mmol}$ ), purifying the crude material by flash chromatography (Pentane/Et $2 \mathrm{O}=$ 20:1) afforded 40 as white solid $\left(0.35 \mathrm{~g}, 13 \%\right.$ yield), $\mathrm{R}_{\mathrm{f}} 0.5$ (pentane/ $\left.\mathrm{Et}_{2} \mathrm{O}=20: 1\right) .{ }^{1} \mathrm{H}$ NMR (300 MHz, $\left.\mathrm{CDCl}_{3}\right) \delta$ 2.07-2.02 (br, 2H), 1.93 - $1.62(\mathrm{~m}, 12 \mathrm{H}), 1.38$ - 1.34 (br, $1 \mathrm{H}), 1.25(\mathrm{~s}, 12 \mathrm{H}) .{ }^{13} \mathrm{C} \mathrm{NMR}\left(75 \mathrm{MHz}, \mathrm{CDCl}_{3}\right) \delta 82.8,39.4,37.8,36.3,29.4,28.3$, 28.2, 24.8, carbon attached to boron not observed. ${ }^{11} \mathrm{~B} \mathrm{NMR}\left(96 \mathrm{MHz}, \mathrm{CDCl}_{3}\right) \delta 33.6$. FTIR (neat): v (cm $\left.{ }^{-1}\right)$ 2977, 2901, 2846, 1450, 1407, 1380, 1363, 1351, 1306, 1286, 1272, 1145, 1098, 1044, 980, 850, 737. The NMR spectra were in accordance with the 
literature. $^{\mathrm{S} 9}$

2-(1-Methoxypentyl)-4,4,5,5-tetramethyl-1,3,2-dioxaborolane (4p)
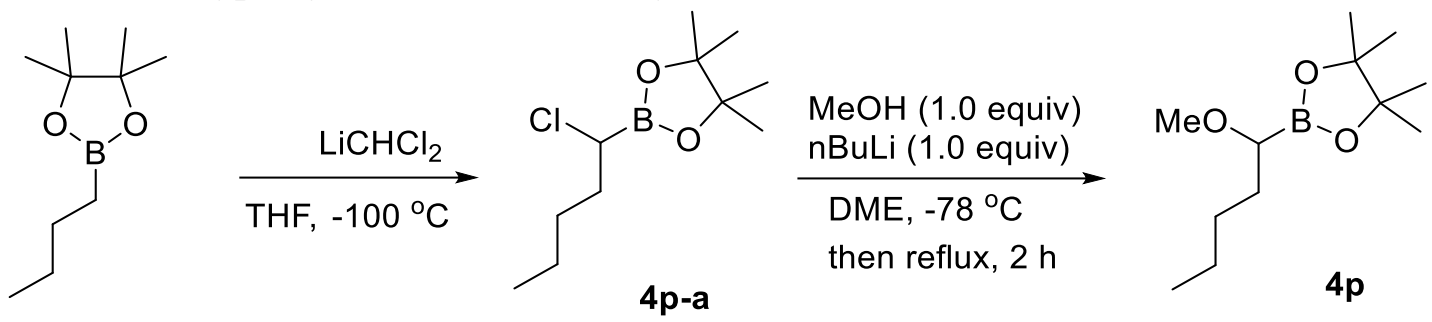

A solution of dichloromethane ( $2 \mathrm{~mL}, 31 \mathrm{mmol}, 1.55$ equiv) in $50 \mathrm{~mL}$ of THF was cooled to $-100{ }^{\circ} \mathrm{C}$ in a $95 \%$ ethanol/liquid nitrogen slush bath and stirred magnetically during the dropwise addition of n-butyllithium $(1.6 \mathrm{M}$ in hexane, $13.1 \mathrm{~mL}, 21 \mathrm{mmol}$, 1.05 equiv) by a syringe over a period of $10 \mathrm{~min}$. The butyllithium must be chilled before contacting the dichloromethane solution, by running the butyllithium solution down the cold wall of the reaction flask. After about half of the butyllithium had been added, a white precipitate of (dichloromethyl)lithium formed. The solution should remain colorless or pale yellow. Darkening is a sign of overheating and decomposition. After $30 \mathrm{~min}$, a solution of n-butylboronic acid pinacol ester (3.68 g, $20 \mathrm{mmol}, 1.0$ equiv) in $10 \mathrm{~mL}$ of diethyl ether was injected in one portion, resulting in dissolution of the precipitate of (dichloromethyl)lithium. The solution was allowed to warm slowly to $20-25{ }^{\circ} \mathrm{C}$ and was kept this temperature overnight. $100 \mathrm{~mL}$ of dichloromethane were added to precipitate the lithium chloride, the solution was filtered and concentrated under vacuum, and 2-(1-chloropentyl)-4,4,5,5-tetramethyl-1,3,2-dioxaborolane (4p-a) was purified by Kugelrohr distillation (10 mbar, $100^{\circ} \mathrm{C}$, dry ice cooling) to afford a colorless liquid (3.56 g, 77\% yield). ${ }^{1} \mathrm{H}$ NMR (300 MHz, $\left.\mathrm{CDCl}_{3}\right) \delta 3.46-3.32(\mathrm{~m}, 1 \mathrm{H}), 1.90-1.70$ $(\mathrm{m}, 2 \mathrm{H}), 1.52-1.29(\mathrm{~m}, 4 \mathrm{H}), 1.27(\mathrm{~s}, 12 \mathrm{H}), 0.89(\mathrm{t}, J=7.1 \mathrm{~Hz}, 3 \mathrm{H}) .{ }^{13} \mathrm{C}$ NMR $(75$ $\left.\mathrm{MHz}, \mathrm{CDCl}_{3}\right) \delta 84.3,33.8,29.5,24.6,24.6,22.2,13.9$, carbon attached to boron not observed. ${ }^{11} \mathrm{~B}$ NMR $\left(96 \mathrm{MHz}, \mathrm{CDCl}_{3}\right) \delta 31.5$. HRMS (ESI) $\mathrm{m} / \mathrm{z}=255.1294$ calcd. for $\mathrm{C}_{11} \mathrm{H}_{22} \mathrm{BO}_{2} \mathrm{ClNa}^{+}[\mathrm{M}+\mathrm{Na}]^{+}$, found: 255.1294. FTIR (neat): $v\left(\mathrm{~cm}^{-1}\right)$ 2979, 2961, 2934, 2872, 1468, 1416, 1381, 1342, 1269, 1240, 1215, 1167, 1141, 1113, 967, 873, 846, 675, 652.

To anhydrous $\mathrm{MeOH}(64 \mathrm{mg}, 2 \mathrm{mmol}, 1.0$ equiv) in DME $(15 \mathrm{~mL})$ was added n-butyllithium (1.6 M in hexane, $1.25 \mathrm{~mL}, 1.0$ equiv) at $-78^{\circ} \mathrm{C} . \mathbf{4 p - a}(0.46 \mathrm{~g}, 2 \mathrm{mmol}$, 1.0 equiv) was added from a syringe to the cold, stirred solution. When the mixture was warmed to room temperature, the mixture was refluxed $2 \mathrm{~h}$. Filtration and evaporation of the solvent under reduced pressure gave the crude product. Kugelrohr distillation ( $1 \mathrm{mbar}, 150^{\circ} \mathrm{C}$, dry ice cooling) afforded $4 p$ as colorless liquid $(0.2 \mathrm{~g}, 44 \%$ yield). ${ }^{1} \mathrm{H}$ NMR $\left(300 \mathrm{MHz}, \mathrm{CDCl}_{3}\right) \delta 3.32(\mathrm{~s}, 3 \mathrm{H}), 3.16(\mathrm{t}, J=6.0 \mathrm{~Hz}, 1 \mathrm{H}), 1.80-$ $1.50(\mathrm{~m}, 2 \mathrm{H}), 1.40-1.15(\mathrm{~m}, 4 \mathrm{H}), 1.27(\mathrm{~s}, 12 \mathrm{H}), 0.97-0.83(\mathrm{~m}, 3 \mathrm{H}) .{ }^{13} \mathrm{C}$ NMR $(75$ $\left.\mathrm{MHz}, \mathrm{CDCl}_{3}\right) \delta 83.8,57.8,30.1,28.3,24.9,24.7,22.9,14.0$, carbon attached to boron not observed. ${ }^{11} \mathrm{~B}$ NMR $\left(96 \mathrm{MHz}, \mathrm{CDCl}_{3}\right) \delta 32.5$. HRMS (ESI) $\mathrm{m} / \mathrm{z}=$ 251.1789 calcd. for $\mathrm{C}_{12} \mathrm{H}_{25} \mathrm{BO}_{3} \mathrm{Na}^{+}[\mathrm{M}+\mathrm{Na}]^{+}$, found: 251.1803 . FTIR (neat): $v\left(\mathrm{~cm}^{-1}\right)$ 2979, 2958, 2930, 2814, 1467, 1407, 1380, 1372, 1332, 1255, 1215, 1144, 1110, 968, 855, 
670.

2-(1-(Ethylthio)pentyl)-4,4,5,5-tetramethyl-1,3,2-dioxaborolane (4q)

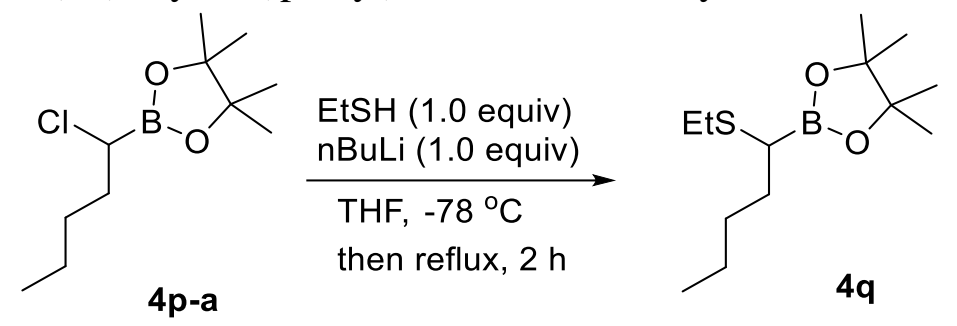

To ethanethiol (186 mg, $3 \mathrm{mmol}, 1.0$ equiv) in THF (15 mL) was added n-butyllithium ( $1.6 \mathrm{M}$ in hexane, $2.0 \mathrm{~mL}, 1.05$ equiv) at $-78{ }^{\circ} \mathrm{C} .4 \mathrm{p}-\mathbf{a}(0.70 \mathrm{~g}, 3 \mathrm{mmol}$, 1.0 equiv) was added by a syringe to the cold, stirred solution. The mixture was allowed to warm to room temperature, then the mixture was refluxed for $2 \mathrm{~h}$. Filtration and evaporation of the solvent under reduced pressure gave the crude product. Flash chromatography (Pentane/Et $2 \mathrm{O}=10: 1$ ) afforded $\mathbf{4 q}$ as colorless liquid $\left(0.55 \mathrm{~g}, 71 \%\right.$ yield). $\mathrm{R}_{\mathrm{f}} 0.3$ (pentane/EtOAc $\left.=20: 1\right) .{ }^{1} \mathrm{H} \mathrm{NMR}\left(300 \mathrm{MHz}, \mathrm{CDCl}_{3}\right) \delta$ $2.68-2.49(\mathrm{~m}, 2 \mathrm{H}), 2.10(\mathrm{dd}, J=8.4,6.9 \mathrm{~Hz}, 1 \mathrm{H}), 1.76-1.53(\mathrm{~m}, 2 \mathrm{H}), 1.41-1.29$ $(\mathrm{m}, 4 \mathrm{H}), 1.28-1.19(\mathrm{~m}, 15 \mathrm{H}), 0.93-0.85(\mathrm{~m}, 3 \mathrm{H}) .{ }^{13} \mathrm{C} \mathrm{NMR}\left(75 \mathrm{MHz}, \mathrm{CDCl}_{3}\right) \delta$ 83.5, 31.1, 30.8, 25.5, 24.8, 24.6, 22.6, 14.8, 14.0, carbon attached to boron not observed. ${ }^{11} \mathrm{~B}$ NMR $\left(96 \mathrm{MHz}, \mathrm{CDCl}_{3}\right) \delta 32.2$. HRMS (ESI) $\mathrm{m} / \mathrm{z}=281.1717 \mathrm{calcd}$. for $\mathrm{C}_{13} \mathrm{H}_{27} \mathrm{BO}_{2} \mathrm{SNa}^{+}[\mathrm{M}+\mathrm{Na}]^{+}$, found: 281.1736. FTIR (neat): $v\left(\mathrm{~cm}^{-1}\right)$ 2976, 2960, 2930, 2863, 1457, 1402, 1370, 1324, 1264, 1141, 968, 875, 847.

Tert-butyl 2-(4,4,5,5-tetramethyl-1,3,2-dioxaborolan-2-yl)pyrrolidine-1-carboxylate $(4 \mathbf{r})$<smiles>CC(C)(C)OC(=O)N1CCCC1B1OC(C)(C)C(C)(C)O1</smiles>

$4 \mathbf{r}$ was prepared according to the reported procedure. ${ }^{\mathrm{S} 10}$

2-(5-(2,5-Dimethylphenoxy)-2-methylpentan-2-yl)-4,4,5,5-tetramethyl-1,3,2-dioxabor olane $(\mathbf{4 u})$
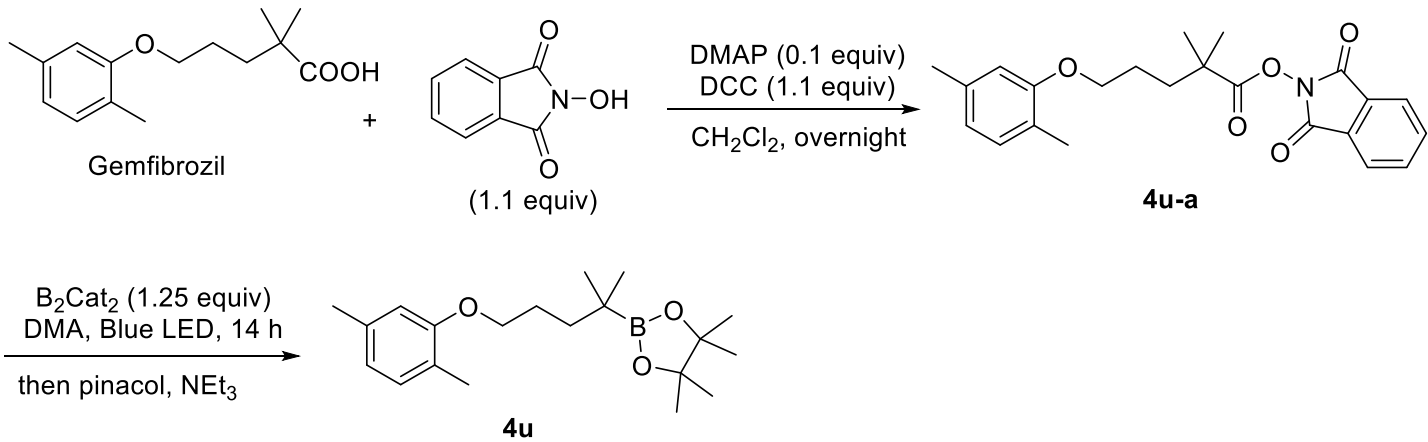

To a mixture of gemfibrozil ( $1.25 \mathrm{~g}, 5 \mathrm{mmol}, 1.0$ equiv), $N$-hydroxyphthalimide ( 0.89 g, $5.5 \mathrm{mmol}, 1.1$ equiv), 4-( $N, N$-dimethylamino)pyridine (61 mg, $0.5 \mathrm{mmol}, 0.1$ equiv) 
in $\mathrm{CH}_{2} \mathrm{Cl}_{2}(40 \mathrm{~mL})$ was added $N, N^{\prime}$-dicyclohexylcarbodiimide $(1.13 \mathrm{~g}, 5.5 \mathrm{mmol}, 1.1$ equiv). The reaction mixture was stirred overnight and filtered through a pad of silica gel, rinsed with $\mathrm{CH}_{2} \mathrm{Cl}_{2}(100 \mathrm{~mL})$. Solvent amount was reduced under reduced pressure and the residue was purified by flash chromatography $(\mathrm{PENTANE} / \mathrm{EtOAc}=$ $5: 1)$ to afford $4 \mathbf{u}-\mathbf{a}$ as light yellow sticky oil (1.94 g, $98 \%$ yield). ${ }^{1} \mathrm{H}$ NMR (300 MHz, $\left.\mathrm{CDCl}_{3}\right) \delta 7.92-7.84(\mathrm{~m}, 2 \mathrm{H}), 7.83-7.74(\mathrm{~m}, 2 \mathrm{H}), 7.01(\mathrm{~d}, J=7.8 \mathrm{~Hz}, 1 \mathrm{H})$, 6.69-6.64 (m, 2H), 4.06-3.96 (m, 2H), $2.32(\mathrm{~s}, 3 \mathrm{H}), 2.19$ (s, 3H), 1.99-1.93 (m, 4H), 1.46 (s, 6H). FTIR (neat): $v\left(\mathrm{~cm}^{-1}\right)$ 2975, 2930, 2871, 1807, 1783, 1743, 1615, 1585, $1509,1468,1371,1265,1187,1157,1131,1044,878,696$. The NMR spectra were identical to the literature. ${ }^{\mathrm{S} 11}$

4u was synthesized in $4 \times 0.5 \mathrm{mmol}$ scale according to the method reported by Aggarwal's group. ${ }^{\mathrm{S} 12}$ To four Schlenk tubes were added $\mathbf{4 u}-\mathbf{a}(0.188 \mathrm{~g}, 0.5 \mathrm{mmol}, 1$ equiv), $\mathrm{B}_{2} \mathrm{cat}_{2}$ (149 mg, $0.625 \mathrm{mmol}, 1.25$ equiv), DMAc $(5 \mathrm{~mL}, 0.1 \mathrm{M})$ and magnetic stirrer bar, respectively. The Schlenk tubes were tightly sealed and stirred under blue LED irradiation for $14 \mathrm{~h}$. The reaction solution of the four Schlenk tubes was combined and pinacol $\left(3.0 \mathrm{~g}, 16 \mathrm{mmol}, 8\right.$ equiv) was added by $\mathrm{NEt}_{3}(5 \mathrm{~mL})$ at $0{ }^{\circ} \mathrm{C}$. The mixture was stirred for $1 \mathrm{~h}$, then quenched by water $(40 \mathrm{~mL})$. After extraction with EtOAc $(30 \times 4 \mathrm{~mL})$, the organic layers were combined and dried over $\mathrm{MgSO}_{4}$. After filtration and evaporation of solvent under reduced pressure, the residue was purified by flash chromatography (Pentane/Et $2 \mathrm{O}=10: 1$ ) to afford $\mathbf{4} \mathbf{u}$ as white solid (0.49 g, 74\% yield). ${ }^{1} \mathrm{H}$ NMR $\left(300 \mathrm{MHz}, \mathrm{CDCl}_{3}\right) \delta 7.01(\mathrm{~d}, J=7.3 \mathrm{~Hz}, 1 \mathrm{H}), 6.69-6.62$ $(\mathrm{m}, 2 \mathrm{H}), 3.93(\mathrm{t}, J=6.6 \mathrm{~Hz}, 2 \mathrm{H}), 2.32(\mathrm{~s}, 3 \mathrm{H}), 2.20(\mathrm{~s}, 3 \mathrm{H}), 1.83-1.70(\mathrm{~m}, 2 \mathrm{H}), 1.51$ $-1.38(\mathrm{~m}, 2 \mathrm{H}), 1.24(\mathrm{~s}, 12 \mathrm{H}), 0.99(\mathrm{~s}, 6 \mathrm{H}) .{ }^{13} \mathrm{C} \mathrm{NMR}\left(75 \mathrm{MHz}, \mathrm{CDCl}_{3}\right) \delta 157.2$, 136.3, 130.2, 123.7, 120.5, 112.1, 82.9, 68.7, 37.3, 26.5, 24.8, 24.7, 21.4, 15.8, carbon attached to boron not observed. ${ }^{11} \mathrm{~B} \mathrm{NMR}\left(96 \mathrm{MHz}, \mathrm{CDCl}_{3}\right) \delta 35.2$. FTIR (neat): v $\left(\mathrm{cm}^{-1}\right)$ 2977, 2939, 2864, 1615, 1586, 1509, 1475, 1389, 1370, 1308, 1265, 1210, 1139, $1130,1038,967,851,802,693$. The NMR spectra were identical to the literature. ${ }^{\mathrm{S} 13}$

2-(((1R,4aS, 10aS)-6-Isopropyl-1,4a-dimethyl-1,2,3,4,4a,9,10,10a-octahydrophenanthr en-1-yl)methyl)-4,4,5,5-tetramethyl-1,3,2-dioxaborolane (4v)

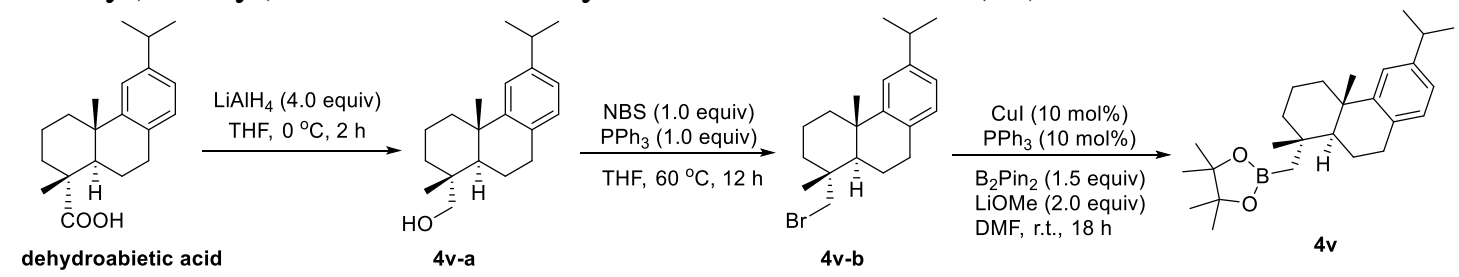

$\mathbf{4 v - a}$ was synthesized according to a reported procedure. ${ }^{\text {S14 }}$

To a $50 \mathrm{~mL}$ sealed tube was added $4 \mathbf{v}-\mathbf{a}(0.57 \mathrm{~g}, 2.0 \mathrm{mmol}, 1$ equiv), N-bromosuccinimide (NBS, $0.36 \mathrm{~g}, 2.0 \mathrm{mmol}, 1.0$ equiv), triphenylphosphine $\left(\mathrm{PPh}_{3}\right.$, $0.52 \mathrm{~g}, 2.0 \mathrm{mmol}, 1.0$ equiv), dry THF $(10 \mathrm{~mL})$ and magnetic stir bar. The tube was sealed and stirred at $60{ }^{\circ} \mathrm{C}$ for $12 \mathrm{~h}$. The reaction mixture was diluted with $\mathrm{Et}_{2} \mathrm{O}$ (50 $\mathrm{mL})$ and washed with water $(30 \mathrm{~mL} \times 4)$. The organic layer was dried over $\mathrm{MgSO}_{4}$. After filtration and evaporation of solvent under reduced pressure, the residue was purified by flash chromatography (Pentane) to afford $\mathbf{4 v - b}$ as colorless sticky liquid 
(0.46 g, 65\% yield). $\mathrm{R}_{\mathrm{f}} 0.5$ (pentane/DCM $\left.=10: 1\right) . \quad[\alpha]{ }_{D}^{24}+2\left(c 0.9, \mathrm{CHCl}_{3}\right) .{ }^{1} \mathrm{H}$ NMR $\left(300 \mathrm{MHz}, \mathrm{CDCl}_{3}\right) \delta 7.09(\mathrm{~d}, J=8.0 \mathrm{~Hz}, 1 \mathrm{H}), 6.91(\mathrm{~d}, J=8.2 \mathrm{~Hz}, 1 \mathrm{H}), 6.81(\mathrm{~s}$, $1 \mathrm{H}), 3.39$ (d, $J=10.2 \mathrm{~Hz}, 1 \mathrm{H}), 3.20(\mathrm{~d}, J=10.2 \mathrm{~Hz}, 1 \mathrm{H}), 2.89-2.65(\mathrm{~m}, 3 \mathrm{H}), 2.26-$ $2.11(\mathrm{~m}, 1 \mathrm{H}), 1.77-1.53(\mathrm{~m}, 5 \mathrm{H}), 1.52-1.26(\mathrm{~m}, 3 \mathrm{H}), 1.15(\mathrm{~s}, 3 \mathrm{H}), 1.14-1.10(\mathrm{~m}$, $6 \mathrm{H}), 0.97(\mathrm{~s}, 3 \mathrm{H}) .{ }^{13} \mathrm{C} \mathrm{NMR}\left(75 \mathrm{MHz}, \mathrm{CDCl}_{3}\right) \delta 147.0,145.6,134.6,126.8,124.3$, 123.9, 48.6, 45.5, 38.2, 37.5, 37.1, 36.4, 33.4, 30.0, 24.9, 24.0, 18.8, 18.7, 18.7. HRMS (EI) $m / z=348.1447$ calcd. for $\mathrm{C}_{20} \mathrm{H}_{29} \mathrm{Br}^{+}[\mathrm{M}]^{+}$, found: 348.1450 . FTIR (neat): v $\left(\mathrm{cm}^{-1}\right) 3001,2958,2931,2868,1497,1458,1381,1363,1345,1248,1172,1074,1058$, 970, 1035, 909, 885, 821, 731, 665, 651, 627.

4v was synthesized according to Liu's procedure. ${ }^{\mathrm{S} 15}$ To a $10 \mathrm{~mL}$ Schlenk tube was added 4v-b ( $0.19 \mathrm{~g}, 0.54 \mathrm{mmol}, 1$ equiv), $\mathrm{CuI}$ (10.3 mg, $0.054 \mathrm{mmol}, 0.1$ equiv), triphenylphosphine $\left(\mathrm{PPh}_{3}, 14.1 \mathrm{mg}, 0.054 \mathrm{mmol}, 0.1\right.$ equiv), $\mathrm{B}_{2} \mathrm{Pin}_{2}(0.21 \mathrm{~g}, 0.81$ mmol, 1.5 equiv), LiOMe (41.0 mg, $1.08 \mathrm{mmol}, 2.0$ equiv) and a magnetic stir bar. The Schlenk tube was evacuated and backfilled with Ar for 3 times. DMF (1.1 mL) was added under Ar flow. The reaction mixture was stirred at room temperature for $18 \mathrm{~h}$. The reaction mixture was diluted with $\mathrm{Et}_{2} \mathrm{O}(50 \mathrm{~mL})$ and washed with water (30 $\mathrm{mL} \times 4$ ). The organic layer was dried over $\mathrm{MgSO}_{4}$. After filtration and evaporation of solvent under reduced pressure, the residue was purified by flash chromatography (Pentane/Et $2 \mathrm{O}=20: 1$ ) to afford $\mathbf{4 v}$ as white solid (101 $\mathrm{mg}, 47 \%$ yield). $\mathrm{R}_{\mathrm{f}} 0.3$ (pentane/DCM = 2:1). M. p. $=133-134{ }^{\circ} \mathrm{C} . \quad[\alpha]{ }_{D}^{24}+3\left(c 0.4, \mathrm{CHCl}_{3}\right) .{ }^{1} \mathrm{H} \mathrm{NMR}(300$ $\left.\mathrm{MHz} \mathrm{CDCl}_{3}\right) \delta 7.16(\mathrm{~d}, J=8.2 \mathrm{~Hz}, 1 \mathrm{H}), 6.98(\mathrm{~d}, J=8.2 \mathrm{~Hz}, 1 \mathrm{H}), 6.88(\mathrm{~s}, 1 \mathrm{H}), 3.00-$ $2.73(\mathrm{~m}, 3 \mathrm{H}), 2.26(\mathrm{~d}, J=12.4 \mathrm{~Hz}, 1 \mathrm{H}), 2.00-1.86(\mathrm{~m}, 1 \mathrm{H}), 1.84-1.51(\mathrm{~m}, 4 \mathrm{H})$, $1.49-1.31(\mathrm{~m}, 3 \mathrm{H}), 1.25-1.20(\mathrm{~m}, 18 \mathrm{H}), 1.19(\mathrm{~s}, 3 \mathrm{H}), 1.10(\mathrm{~d}, J=14.3 \mathrm{~Hz}, 1 \mathrm{H})$, $1.02(\mathrm{~s}, 3 \mathrm{H}), 0.74(\mathrm{~d}, J=14.3 \mathrm{~Hz}, 1 \mathrm{H}) .{ }^{13} \mathrm{C} \mathrm{NMR}\left(75 \mathrm{MHz}, \mathrm{CDCl}_{3}\right) \delta 147.7,145.2$, 135.0, 126.8, 124.3, 123.7, 82.7, 51.6, 40.4, 38.8, 37.9, 35.9, 33.4, 30.6, 25.2, 25.0, $24.8,24.0,24.0,21.8,19.4,19.1$, carbon attached to boron not observed. ${ }^{11} \mathrm{~B} \mathrm{NMR}$ $\left(96 \mathrm{MHz}, \mathrm{CDCl}_{3}\right) \delta$ 32.3. HRMS (ESI) $\mathrm{m} / z=419.3092$ calcd. for $\mathrm{C}_{26} \mathrm{H}_{41} \mathrm{BO}_{2} \mathrm{Na}^{+}$ $[\mathrm{M}+\mathrm{Na}]^{+}$, found: 419.3090. FTIR (neat): $v\left(\mathrm{~cm}^{-1}\right)$ 2958, 2926, 2869, 1498, 1458, 1419, 1378, 1351, 1319, 1213, 1146, 971, 882, 849, 821.

(S)-4,4,5,5-Tetramethyl-2-(3-methyl-1-phenylheptan-3-yl)-1,3,2-dioxaborolane (4w)

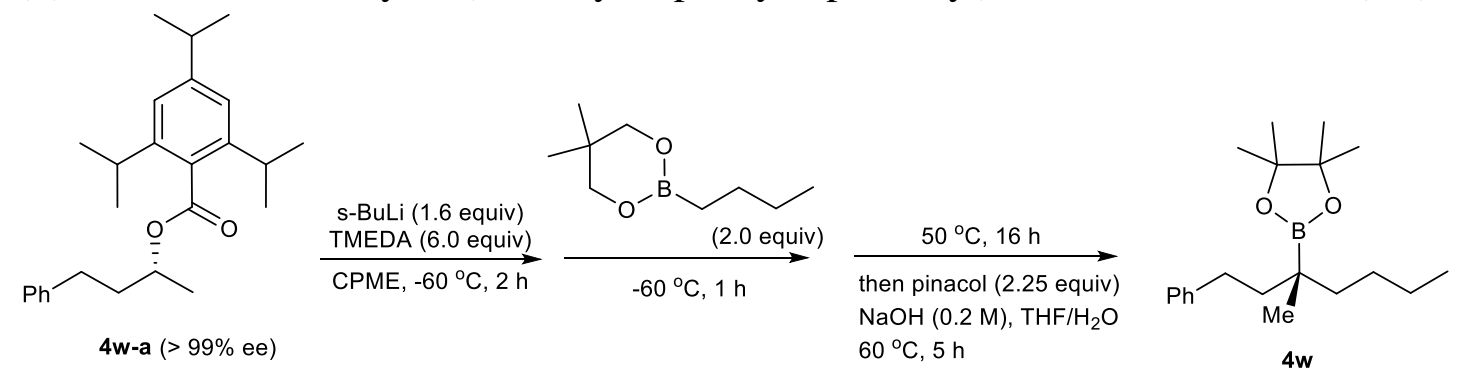

4w was synthesized according to Aggarwal's method. ${ }^{\text {S16 }}$ To a vigorously stirred solution (without splashing) of benzoate $\mathbf{4 w - a}(0.38 \mathrm{~g}, 1.0 \mathrm{mmol}, 1.0$ equiv, synthesized according to the reported procedure $\left.{ }^{\mathrm{S} 16}\right)$ and TMEDA $(0.92 \mathrm{ml}, 6.0 \mathrm{mmol}$, 6.0 equiv) in anhydrous cyclopentyl methyl ether (CPME, $6 \mathrm{ml}$ ) at $-60{ }^{\circ} \mathrm{C}$ (internal temperature) under a argon atmosphere, was added $s$-BuLi (1.4 $\mathrm{M}$ in cyclohexane, $1.14 \mathrm{ml}, 1.6 \mathrm{mmol}, 1.6$ equiv) dropwise over $10 \mathrm{~min}$. After $2 \mathrm{~h}$, a solution of the 
borylating agent ( $0.34 \mathrm{~g}, 2.0 \mathrm{mmol}, 2.0$ equiv) in CPME $(2 \mathrm{ml})$ was added dropwise over $10 \mathrm{~min}$. The reaction mixture was stirred at $-60{ }^{\circ} \mathrm{C}$ for $1 \mathrm{~h}$ and then the cooling bath was removed and the reaction mixture was stirred at $50{ }^{\circ} \mathrm{C}$ (migration temperature) overnight $(\sim 16 \mathrm{~h})$. The volatiles were removed from the reaction mixture in vacuo and the residue dissolved in THF $(12 \mathrm{ml})$. To the stirred solution was added pinacol ( $0.26 \mathrm{~g}, 2.25 \mathrm{mmol}, 2.25$ equiv) and $0.2 \mathrm{M} \mathrm{NaOH}$ (aq) $(1 \mathrm{ml})$. The reaction mixture was stirred for $5 \mathrm{~h}$ at $60{ }^{\circ} \mathrm{C}$ at which point GC/MS showed $95 \%$ conversion of the tertiary neopentyl boronic ester to the corresponding pinacol boronic ester. The reaction mixture was cooled to ambient temperature and $\mathrm{Et}_{2} \mathrm{O}(20 \mathrm{ml})$ and water $(5 \mathrm{ml})$ was added. The phases were separated and the aqueous phase extracted with $\mathrm{Et}_{2} \mathrm{O}$ (3 $\times 20 \mathrm{ml}$ ). The combined organic phases were washed with brine, dried over $\mathrm{MgSO}_{4}$ and the solvent removed in vacuo. The crude material was purified by flash column chromatography eluting with pentane/DCM (4:1) to afford $\mathbf{4 w}$ as colorless liquid $\left(0.20 \mathrm{~g}, 63 \%\right.$ yield, $99 \%$ ee). $\mathrm{R}_{\mathrm{f}} 0.4$ (pentane/DCM = 2:1). Ee value was determined by chiral HPLC after oxidation $\left(\mathrm{NaOH} / \mathrm{H}_{2} \mathrm{O}_{2}\right) .{ }^{\mathrm{S} 17}{ }^{1} \mathrm{H} \mathrm{NMR}\left(300 \mathrm{MHz}, \mathrm{CDCl}_{3}\right) \delta 7.24$ - $7.14(\mathrm{~m}, 2 \mathrm{H}), 7.14-7.04(\mathrm{~m}, 3 \mathrm{H}), 2.59-2.35(\mathrm{~m}, 2 \mathrm{H}), 1.72-1.56(\mathrm{~m}, 1 \mathrm{H}), 1.52-$ $1.32(\mathrm{~m}, 2 \mathrm{H}), 1.27-1.12(\mathrm{~m}, 5 \mathrm{H}), 1.18(\mathrm{~s}, 12 \mathrm{H}), 0.92(\mathrm{~s}, 3 \mathrm{H}), 0.82(\mathrm{t}, J=6.8 \mathrm{~Hz}, 3 \mathrm{H})$. ${ }^{13} \mathrm{C} \mathrm{NMR}\left(75 \mathrm{MHz}, \mathrm{CDCl}_{3}\right) \delta 143.8,128.3,128.2,125.4,83.0,41.6,38.8,32.4,28.0$, $24.924 .9,23.6,21.4,14.1$, carbon attached to boron not observed. ${ }^{11} \mathrm{~B} \mathrm{NMR}(96$ $\mathrm{MHz}, \mathrm{CDCl}_{3}$ ) $\delta$ 34.6. HRMS (ESI) $\mathrm{m} / \mathrm{z}=339.2466$ calcd. for $\mathrm{C}_{20} \mathrm{H}_{33} \mathrm{BO}_{2} \mathrm{Na}^{+}$ $[\mathrm{M}+\mathrm{Na}]^{+}$, found: 339.2466. FTIR (neat): $v\left(\mathrm{~cm}^{-1}\right)$ 2978, 2956, 2928, 2859, 1497, 1468, 1371, 1306, 1216, 1138, 967, 855, 746, 697. Chiral HPLC (IC, 0.5\% $i \mathrm{PrOH} /$ cyclohexane, $1.0 \mathrm{ml} / \mathrm{min}$ ) $\mathrm{T}_{R} 17.84 \mathrm{~min}$ (minor), $18.95 \mathrm{~min}$ (major). $[\alpha]_{D}^{26}$ $-12\left(c 0.46, \mathrm{CHCl}_{3}\right)$.

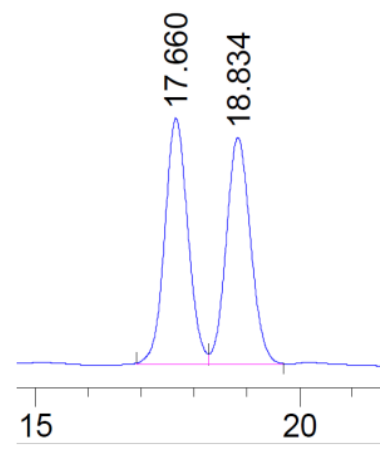

\begin{tabular}{|c|c|c|c|c|c|c|}
\hline $\begin{array}{c}\text { Peak } \\
\text { \# }\end{array}$ & $\begin{array}{c}\text { RetTime } \\
\text { [min] }\end{array}$ & Type & $\begin{array}{l}\text { Width } \\
\text { [min] }\end{array}$ & $\begin{array}{c}\text { Area } \\
{\left[\mathrm{mAU}{ }^{\star} \mathrm{S}\right]}\end{array}$ & $\begin{array}{l}\text { Height } \\
{[\mathrm{mAU}]}\end{array}$ & $\begin{array}{c}\text { Area } \\
\frac{\circ}{\circ}\end{array}$ \\
\hline & & & & ---------- & --- & . \\
\hline 1 & 17.6 & BV & & 3140.21973 & 88875 & 251 \\
\hline 2 & 18.834 & VB & 0.5013 & 3038.26709 & 94.95518 & 49.1749 \\
\hline
\end{tabular}



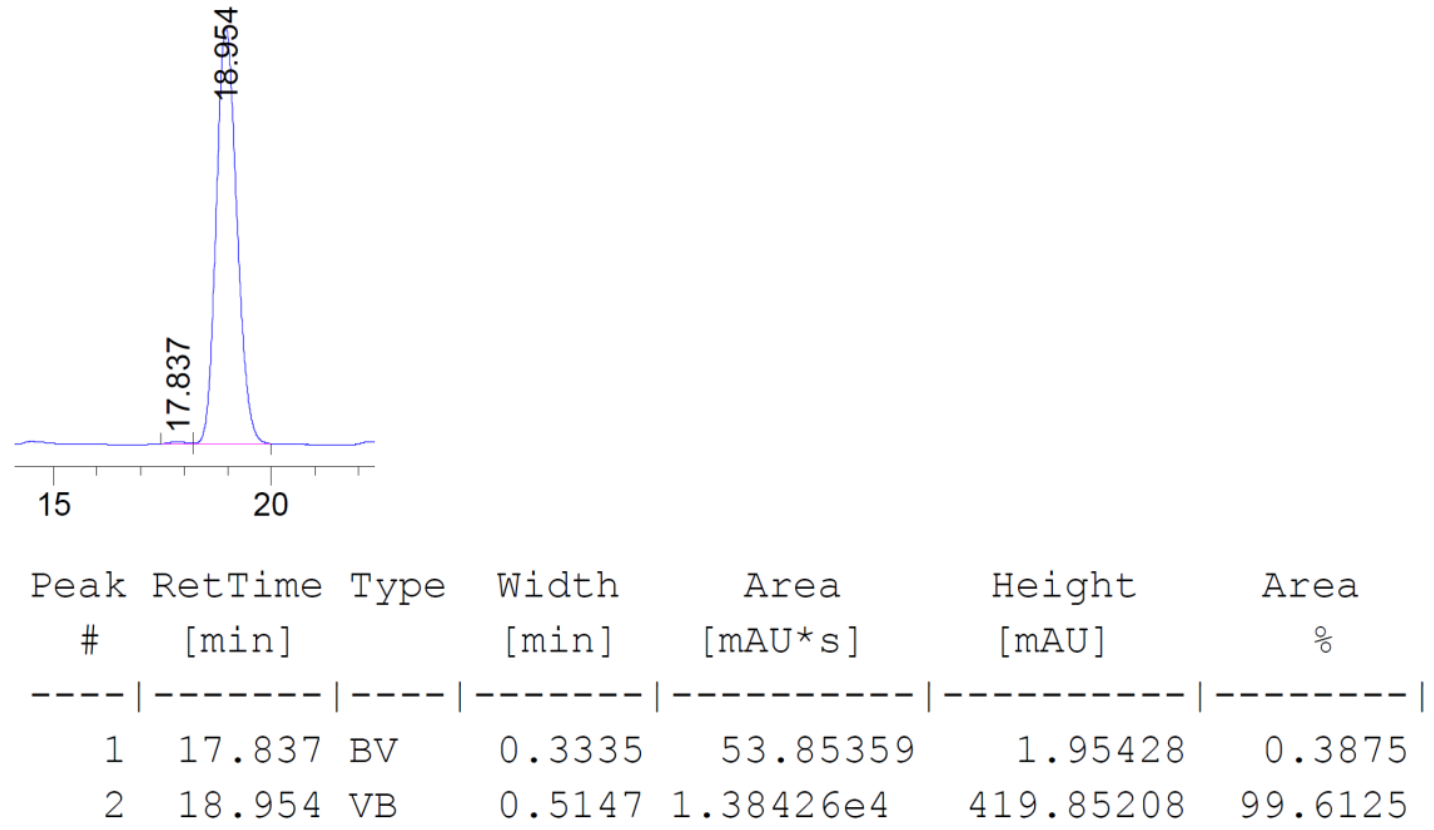

(S)-Tert-butyl

2-(4,4,5,5-tetramethyl-1,3,2-dioxaborolan-2-yl)piperidine-1-carboxylate (4x)<smiles>CC(C)(C)OC(=O)N1CCCC[C@H]1B1OC(C)(C)C(C)(C)O1</smiles>

$\mathbf{4 x}$ was prepared according to the reported procedure. ${ }^{\mathrm{S} 10}$

$N$-Boc-piperidine (1.85 g, $10.0 \mathrm{mmol}, 1.00$ equiv) and (-)-sparteine (2.81 g, $2.75 \mathrm{~mL}$, $12.0 \mathrm{mmol}, 1.20$ equiv) were dissolved in $\mathrm{Et}_{2} \mathrm{O}(40 \mathrm{~mL})$. The solution was cooled to $-78{ }^{\circ} \mathrm{C}$ and $s$-BuLi (1.4 M in cyclohexane, $8.6 \mathrm{~mL}, 12.0 \mathrm{mmol}, 1.20$ equiv) was added dropwise. The solution was stirred for $3 \mathrm{~h}$ at $-78{ }^{\circ} \mathrm{C}$, then $i$-PrOB(pin) $(2.42 \mathrm{~g}, 13.0$ mmol, 1.30 equiv) was added dropwise. The solution was stirred for $1 \mathrm{~h}$ at $-78{ }^{\circ} \mathrm{C}$, then allowed to warm up to room temperature slowly. Aqueous $1 \mathrm{M} \mathrm{HCl}(150 \mathrm{~mL})$ was added and the layers were separated. The organic layers were washed with brine $(3 \times 50 \mathrm{~mL})$ and the combined aqueous layers were extracted with $\mathrm{Et}_{2} \mathrm{O}(3 \times 100 \mathrm{~mL})$. The organic layers were combined, dried over $\mathrm{MgSO}_{4}$ and concentrated under vacuum. The crude product was purified by fast column chromatography on silica gel, eluting with pentane:EA $4: 1$, to give $(S)-\mathbf{4 x}$ as a colorless oil $(0.1 \mathrm{~g}, 3 \%$ yield, $73 \%$ ee). $\mathrm{R}_{\mathrm{f}} 0.3$ (pentane/EA = 3:1). ${ }^{1} \mathrm{H} \mathrm{NMR}\left(300 \mathrm{MHz}, \mathrm{CDCl}_{3}\right) \delta 3.73(\mathrm{~d}, J=12.8 \mathrm{~Hz}$, $1 \mathrm{H}), 2.81-2.60(\mathrm{~m}, 1 \mathrm{H}), 2.34(\mathrm{dd}, J=12.2,3.3 \mathrm{~Hz}, 1 \mathrm{H}), 1.90-1.74(\mathrm{~m}, 1 \mathrm{H}), 1.69-$ $1.55(\mathrm{~m}, 2 \mathrm{H}), 1.49$ (s, 9H), $1.46-1.24(\mathrm{~m}, 3 \mathrm{H}), 1.18(\mathrm{~s}, 12 \mathrm{H}) .{ }^{13} \mathrm{C}$ NMR $(75 \mathrm{MHz}$, $\left.\mathrm{CDCl}_{3}\right) \delta 139.8,85.6,80.0,42.5,28.5,26.5,25.2,25.1,24.9,24.5$, carbon attached to boron not observed. ${ }^{11} \mathrm{~B} \mathrm{NMR}\left(96 \mathrm{MHz}, \mathrm{CDCl}_{3}\right) \delta$ 14.9. The NMR spectra were identical to the literature. ${ }^{\mathrm{S} 10}$ Chiral HPLC (IC, $1.5 \%$ PrOH$/$ cyclohexane, $1.0 \mathrm{ml} / \mathrm{min}$ ) $\mathrm{T}_{R} 6.32 \mathrm{~min}$ (major), $6.92 \mathrm{~min}$ (minor). $[\alpha]_{D}^{24}+3\left(c 0.7, \mathrm{CHCl}_{3}\right)$. 

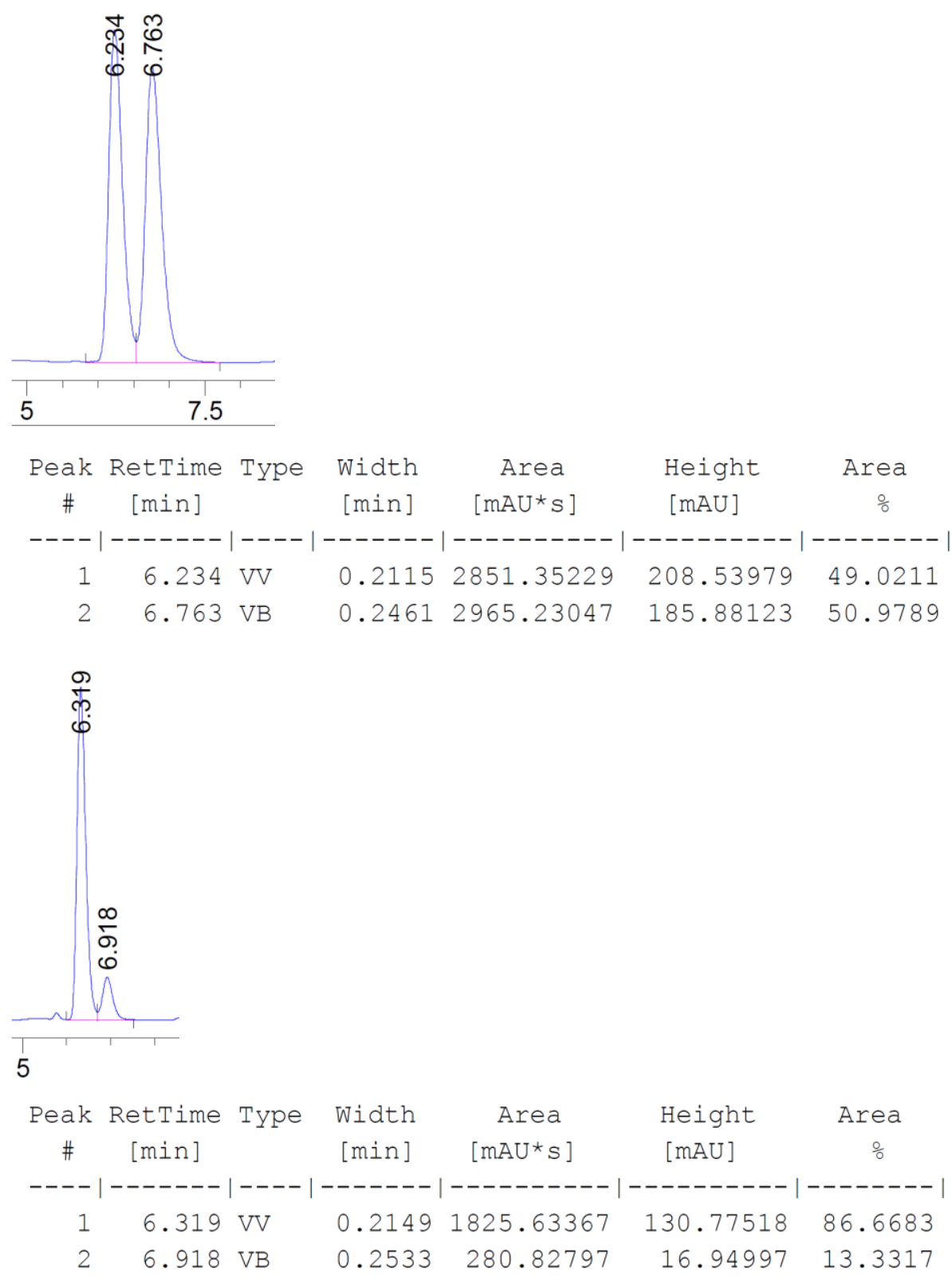

4,4,5,5-Tetramethyl-2-((1S,2R,3S,5S)-2,6,6-trimethylbicyclo[3.1.1]heptan-3-yl)-1,3,2 -dioxaborolane $(\mathbf{4 y})$
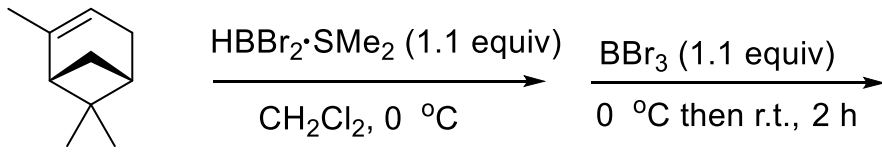

$$
\begin{aligned}
& \underset{\mathrm{NEt}_{3} \text { (8.0 equiv) }}{\stackrel{\text { pinacol (3.0 equiv) }}{\longrightarrow}} \\
& \mathrm{CH}_{2} \mathrm{Cl}_{2}, 0^{\circ} \mathrm{C} \\
& \text { then r.t., } 16 \mathrm{~h}
\end{aligned}
$$

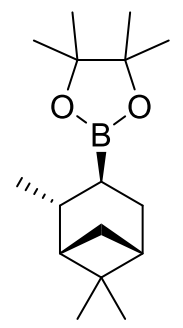

4y was synthesized according to the literature. ${ }^{\mathrm{S} 2}$ Dibromoborane dimethyl sulfide complex ( $1 \mathrm{M}$ in $\mathrm{CH}_{2} \mathrm{Cl}_{2}, 11 \mathrm{~mL}, 11.0 \mathrm{mmol}, 1.1$ equiv) was added dropwise to a solution of (-)- $\alpha$-pinene (1.36 g, $1.59 \mathrm{~mL}, 10.0 \mathrm{mmol}, 1.0$ equiv) in $\mathrm{CH}_{2} \mathrm{Cl}_{2}(20 \mathrm{~mL}$ ) at $0{ }^{\circ} \mathrm{C}$. After dropwise addition of tribromoborane $\left(1 \mathrm{M}\right.$ in $\mathrm{CH}_{2} \mathrm{Cl}_{2}, 11 \mathrm{~mL}, 11.0 \mathrm{mmol}$, 1.1 equiv), the mixture was allowed to warm up to room temperature and stirred for 2 
h. This mixture was then added dropwise to a solution of pinacol $(3.6 \mathrm{~g}, 30.0 \mathrm{mmol}$, 3.0 equiv) and triethylamine (11.2 mL, $80 \mathrm{mmol}, 8.0$ equiv) in $\mathrm{CH}_{2} \mathrm{Cl}_{2}$ (40 mL) at $0{ }^{\circ} \mathrm{C}$. The mixture was then allowed to warm up to room temperature and stirred for $16 \mathrm{~h}$. The mixture was diluted with $\mathrm{CH}_{2} \mathrm{Cl}_{2}(100 \mathrm{~mL})$ and washed with $\mathrm{H}_{2} \mathrm{O}(2 \times 100$ $\mathrm{mL}$ ). The organic phase was dried over $\mathrm{Na}_{2} \mathrm{SO}_{4}$ and concentrated in vacuo. Flash column chromatography (pentane:DCM = 5:1) afforded compound 4y (2.09 g, 79\%) as a colorless oil. Diastereomeric ratio was determined to be $92: 8$ by chiral GC. $\mathrm{R}_{\mathrm{f}} 0.3$ (pentane/DCM = 4:1). $[\alpha] \underset{D}{26}+12\left(c 1.0, \mathrm{CHCl}_{3}\right) .\left([\alpha]_{D}^{25}-10.5\left(c 1.0, \mathrm{CHCl}_{3}\right)\right.$ for product from (+)- $\alpha$-pinene $\left.{ }^{\mathrm{S} 2}\right) .{ }^{1} \mathrm{H}$ NMR $\left(300 \mathrm{MHz}, \mathrm{CDCl}_{3}\right) \delta 2.36-2.23(\mathrm{~m}, 1 \mathrm{H})$, $2.20-1.96(\mathrm{~m}, 2 \mathrm{H}), 1.94-1.79(\mathrm{~m}, 2 \mathrm{H}), 1.79-1.71(\mathrm{~m}, 1 \mathrm{H}), 1.30-1.20(\mathrm{~m}, 13 \mathrm{H})$, $1.17(\mathrm{~s}, 3 \mathrm{H}), 1.07-0.99(\mathrm{~m}, 6 \mathrm{H}), 0.82(\mathrm{~d}, J=9.4 \mathrm{~Hz}, 1 \mathrm{H}) .{ }^{13} \mathrm{C}$ NMR $(75 \mathrm{MHz}$, $\left.\mathrm{CDCl}_{3}\right) \delta 82.8,48.0,41.3,38.6,38.2,34.1,28.6,28.4,24.7,24.7,23.2,22.7$, carbon attached to boron not observed. ${ }^{11} \mathrm{~B} \mathrm{NMR}\left(96 \mathrm{MHz}^{\mathrm{CDCl}} \mathrm{CDC}_{3}\right) \delta 34.4$. Spectroscopic data are in accordance with those described in the literature. ${ }^{\mathrm{S} 2}$

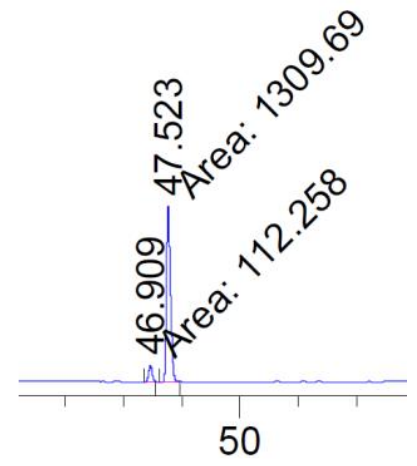

2-((1R,2R,5R)-2-Isopropyl-5-methylcyclohexyl)-4,4,5,5-tetramethyl-1,3,2-dioxaborolane $(\mathbf{4 z})$<smiles>C[C@H]1CCC[C@H](Cl)C1</smiles>

$\mathrm{CuCl}(3 \mathrm{~mol} \%)$ Xantphos (3 mol\%)

B2Pin2 (1.2 equiv) $\mathrm{KOtBu}(0.5$ equiv) THF, r.t., $24 \mathrm{~h}$<smiles>CC(C)[C@H]1CC[C@@H](C)C[C@H]1B1OC(C)(C)C(C)(C)O1</smiles>

$\mathbf{4 z}$ was synthesized according to a reported procedure. ${ }^{\mathrm{S} 2}$

2-((3S,6S,8R,9S, 10S, 13R,14S, 17R)-3-Methoxy-10,13-dimethyl-17-((R)-6-methylheptan-2 -yl)hexadecahydro-1H-cyclopenta[a]phenanthren-6-yl)-4,4,5,5-tetramethyl-1,3,2-dioxabo rolane (4aa) 


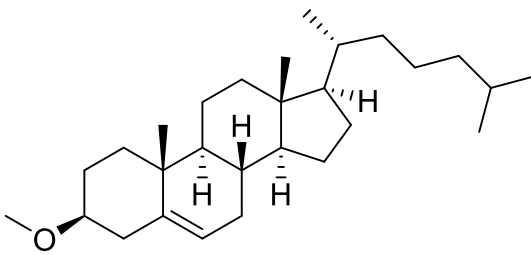

4aa-a
1) H-BCat (8 equiv) $100^{\circ} \mathrm{C}, 16 \mathrm{~h}$

2) 0.2 mbar, r.t., $2 \mathrm{~h}$

3) pinacol (3 equiv) $\mathrm{NEt}_{3}$ (8 equiv) $\mathrm{CH}_{2} \mathrm{Cl}_{2}, 0^{\circ} \mathrm{C}, 4 \mathrm{~h}$

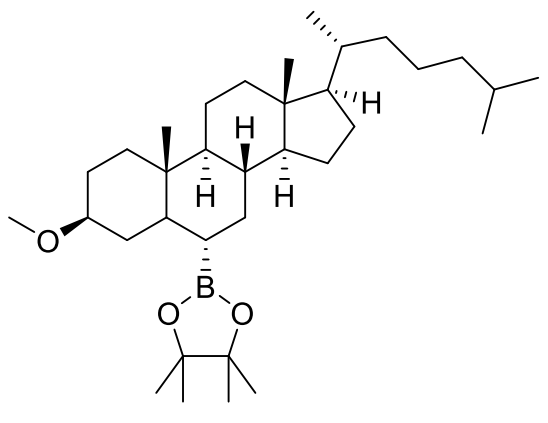

$4 a a$

4aa-a was synthesized from cholesterol by a reported procedure. ${ }^{\text {S18 }}$

4aa was synthesized according to Aggarwal's procedure. ${ }^{\text {S19 }}$ Freshly distilled catecholborane ( $0.48 \mathrm{~g}, 4.0 \mathrm{mmol}, 8.0$ equiv) was added to a Schlenk flask containing 4aa-a $\left(0.4 \mathrm{~g}, 0.5 \mathrm{mmol}, 1.0\right.$ equiv). The resulting mixture was heated to $100{ }^{\circ} \mathrm{C}$ at which point it turned into a solution. After $16 \mathrm{~h}$ at the same temperature, the mixture was cooled to room temperature and TLC analysis (pentane:EtOAc 3:1) revealed complete consumption of 4aa-a. Excess catecholborane was removed under high vacuum (0.2 mbar, $2 \mathrm{~h}$, room temperature). The crude material was diluted with $\mathrm{CH}_{2} \mathrm{Cl}_{2}(5 \mathrm{~mL})$ and $\mathrm{Et}_{3} \mathrm{~N}(0.4 \mathrm{~g}, 0.56 \mathrm{~mL}, 8.0$ equiv) and pinacol (177 mg, $1.5 \mathrm{mmol}$, 3.0 equiv) were added. After $1 \mathrm{~h}$ the mixture was diluted with $\mathrm{CH}_{2} \mathrm{Cl}_{2}(20 \mathrm{~mL})$ and water $(20 \mathrm{~mL})$. The layers were separated and the aqueous layer was extracted with $\mathrm{CH}_{2} \mathrm{Cl}_{2}(3 \times 20 \mathrm{~mL})$. The combined organic layers were dried $\left(\mathrm{MgSO}_{4}\right)$, filtered, and concentrated under vacuum. Purification by column chromatography on silica gel, eluting with pentane:EtOAc $(95: 5 \rightarrow 75: 25)$ gave 4 aa as white solid $(165 \mathrm{mg}, 63 \%$ yield). M.p.: $138-140{ }^{\circ} \mathrm{C} . \quad[\alpha] \stackrel{24}{24}+23\left(c 1.2, \mathrm{CHCl}_{3}\right) .{ }^{1} \mathrm{H} \mathrm{NMR}\left(300 \mathrm{MHz}, \mathrm{CDCl}_{3}\right)$ $\delta 3.31(\mathrm{~s}, 3 \mathrm{H}), 3.24-3.05(\mathrm{~m}, 1 \mathrm{H}), 2.01-1.67(\mathrm{~m}, 5 \mathrm{H}), 1.65-1.44(\mathrm{~m}, 4 \mathrm{H}), 1.39-$ $1.27(\mathrm{~m}, 6 \mathrm{H}), 1.24(\mathrm{~s}, 6 \mathrm{H}), 1.24(\mathrm{~s}, 6 \mathrm{H}), 1.22-0.92(\mathrm{~m}, 14 \mathrm{H}), 0.91-0.84(\mathrm{~m}, 9 \mathrm{H})$, $0.78(\mathrm{~s}, 3 \mathrm{H}), 0.73-0.66(\mathrm{~m}, 1 \mathrm{H}), 0.63(\mathrm{~s}, 3 \mathrm{H}) .{ }^{13} \mathrm{C} \mathrm{NMR}\left(75 \mathrm{MHz}, \mathrm{CDCl}_{3}\right) \delta 82.9$, 79.8, 56.3, 55.4, 54.1, 45.3, 42.6, 40.1, 39.5, 36.7, 36.2, 35.8, 35.6, 35.6, 33.7, 33.5, 28.3, 28.0, 27.9, 24.9, 24.6, 24.2, 23.9, 22.8, 22.6, 21.2, 18.7, 12.4, 12.1, carbon attached to boron not observed. ${ }^{11} \mathrm{~B}$ NMR $\left(96 \mathrm{MHz}, \mathrm{CDCl}_{3}\right) \delta 32.8$. HRMS (ESI) $\mathrm{m} / z$ $=551.4606$ calcd. for $\mathrm{C}_{34} \mathrm{H}_{61} \mathrm{BO}_{3} \mathrm{Na}^{+}[\mathrm{M}+\mathrm{Na}]^{+}$, found: 551.4625 . FTIR (neat): $v\left(\mathrm{~cm}^{-1}\right)$ 2930, 2912, 2868, 2850, 1468, 1379, 1319, 1273, 1215, 1165, 1146, 1105, 972, 931, 851.

2-((3S,6S,8R,9S,10S,13R,14S,17R)-3-chloro-10,13-dimethyl-17-((R)-6-methylheptan-2yl)hexadecahydro-1H-cyclopenta[a]phenanthren-6-yl)-4,4,5,5-tetramethyl-1,3,2-dioxabor olane (4ab)

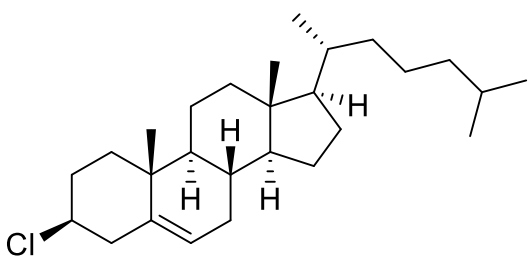

Cholesteryl chloride
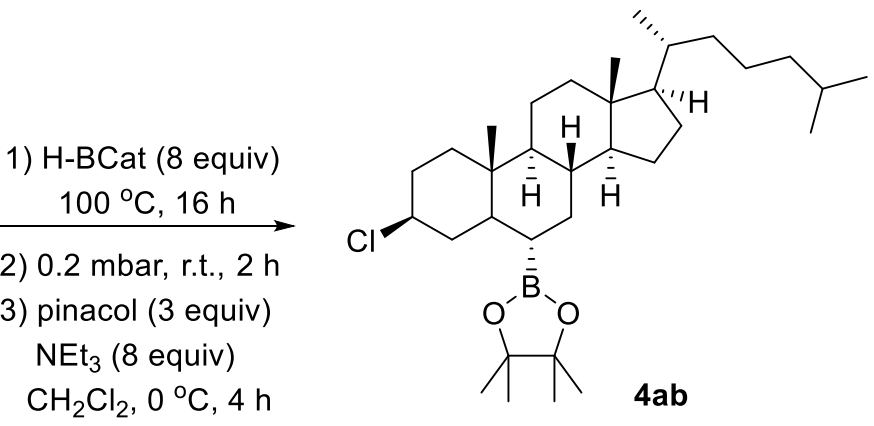
4ab was synthesized according to Aggarwal's procedure. ${ }^{S 19}$ Freshly distilled catecholborane (1.44 g, $12.0 \mathrm{mmol}, 6.0$ equiv) was added to a Schlenk flask containing cholesteryl chloride $(0.81 \mathrm{~g}, 2.0 \mathrm{mmol}, 1.0$ equiv). The resulting mixture was heated to $100{ }^{\circ} \mathrm{C}$ at which point it turned into a solution. After $16 \mathrm{~h}$ at the same temperature, the mixture was cooled to room temperature and TLC analysis (pentane:DCM 2:1) revealed complete consumption of cholesteryl chloride. Excess catecholborane was removed under high vacuum ( 0.2 mbar, $2 \mathrm{~h}$, room temperature). The crude material was diluted with $\mathrm{CH}_{2} \mathrm{Cl}_{2}(5 \mathrm{~mL})$ and $\mathrm{Et}_{3} \mathrm{~N}(1.62 \mathrm{~g}, 2.2 \mathrm{~mL}, 16$ mmol, 8.0 equiv) and pinacol ( $0.72 \mathrm{~g}, 6.0 \mathrm{mmol}, 3.0$ equiv) were added. After $1 \mathrm{~h}$ the mixture was diluted with $\mathrm{CH}_{2} \mathrm{Cl}_{2}(20 \mathrm{~mL})$ and water $(20 \mathrm{~mL})$. The layers were separated and the aqueous layer was extracted with $\mathrm{CH}_{2} \mathrm{Cl}_{2}(3 \times 20 \mathrm{~mL})$. The combined organic layers were dried $\left(\mathrm{MgSO}_{4}\right)$, filtered, and concentrated under vacuum. Purification by column chromatography on silica gel, eluting with pentane:DCM $(5: 1 \rightarrow 3: 1)$ gave $\mathbf{4 a b}$ as white solid $(0.87 \mathrm{~g}, 86 \%$ yield $)$. $\mathrm{R}_{\mathrm{f}} 0.4$ (pentane/DCM = 2:1). M.p.: 171-172 ${ }^{\circ} \mathrm{C} . \quad[\alpha]{ }_{D}^{24}+47\left(c 0.8, \mathrm{CHCl}_{3}\right) .{ }^{1} \mathrm{H}$ NMR $(300$ $\left.\mathrm{MHz}_{,} \mathrm{CDCl}_{3}\right) \delta 4.04-3.75(\mathrm{~m}, 1 \mathrm{H}), 2.09-1.90(\mathrm{~m}, 2 \mathrm{H}), 1.88-1.69(\mathrm{~m}, 4 \mathrm{H}), 1.67-$ $1.41(\mathrm{~m}, 6 \mathrm{H}), 1.39-1.27(\mathrm{~m}, 6 \mathrm{H}), 1.24(\mathrm{~s}, 12 \mathrm{H}), 1.15-0.95(\mathrm{~m}, 10 \mathrm{H}), 0.93-0.80$ $(\mathrm{m}, 13 \mathrm{H}), 0.74-0.67(\mathrm{~m}, 1 \mathrm{H}), 0.63(\mathrm{~s}, 3 \mathrm{H}) .{ }^{13} \mathrm{C} \mathrm{NMR}\left(75 \mathrm{MHz}, \mathrm{CDCl}_{3}\right) \delta 83.0,60.3$, 56.3, 56.2, 53.8, 47.3, 42.6, 40.0, 39.5, 39.1, 38.5, 36.2, 35.8, 35.6, 35.1, 33.5, 33.1, $28.2,28.0,24.8,24.7,24.2,23.9,22.8,22.6,21.1,18.7,12.4,12.1$, carbon attached to boron not observed. ${ }^{11} \mathrm{~B} \mathrm{NMR}\left(96 \mathrm{MHz}, \mathrm{CDCl}_{3}\right) \delta 34.4$. HRMS (ESI) $\mathrm{m} / \mathrm{z}=$ 555.4111 calcd. for $\mathrm{C}_{33} \mathrm{H}_{58} \mathrm{BClO}_{2} \mathrm{Na}^{+}[\mathrm{M}+\mathrm{Na}]^{+}$, found: 555.4121 . FTIR (neat): $v\left(\mathrm{~cm}^{-1}\right)$ 2937, 2868, 2848, 1468, 1444, 1378, 1320, 1273, 1229, 1214, 1167, 1145, 969, 850, 896, $850,756$.

\subsection{Preparation of organolithium reagents}

Cyclohexyllithium solution in hexane<smiles>ClC1CCCCC1</smiles>

$$
\underset{\text { hexane }(20 \mathrm{~mL})}{\stackrel{\mathrm{Li}(2.0 \text { equiv })}{\longrightarrow}}
$$<smiles>ClC1CCCCC1</smiles>

A Schlenk flask was flushed with dry Argon gas. After charging the flask with dry hexane $(20 \mathrm{ml})$ and lithium sand $(280 \mathrm{mg}, 40 \mathrm{mmol}, 2.0$ equiv), cyclohexyl chloride ( $2.36 \mathrm{~g}, 20 \mathrm{mmol}, 1.0$ equiv) was added slowly. The reaction mixture was stirred at high speed (1000 rpm) for 2 days. The upper clear solution was transferred to a dry Schlenk tube flushed with Argon via syringe. The concentration of cyclohexyllithium was titrated to be $0.53 \mathrm{~mol} / \mathrm{L}$ by menthol/2,2'-bipyridine.

Titration procedure: An oven dried $25 \mathrm{~mL}$ three neck flask equipped with an Argon inlet adapter, a stirring bar and two rubber septa, was cooled under a stream of Argon. Upon cooling the flask was charged with menthol $(99.7 \mathrm{mg}, 0.639 \mathrm{mmol}), 3 \mathrm{mg}$ of

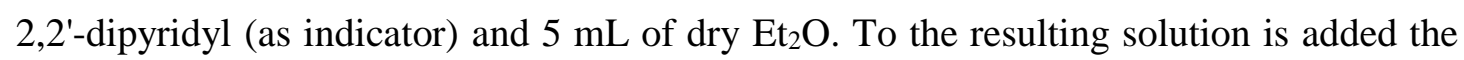
organometallic reagent solution at $0{ }^{\circ} \mathrm{C}$ via a $1.0 \mathrm{~mL}$ syringe (graduated in $0.01 \mathrm{~mL}$ increments) in a dropwise fashion. $1.21 \mathrm{~mL}$ of the cyclohexyllithium solution was used. 
The calculated concentration was $0.639 \mathrm{mmol} / 1.21 \mathrm{~mL}=0.53 \mathrm{~mol} / \mathrm{L}$.

Caution: During addition, it will be observed that periodic quantities of a red colored substance will appear in solution. This is the charge transfer complex between the alkyl lithium and 2,2'-dipyridyl, and it will be noted that in the early stages of this titration this red color will disperse rapidly. As one nears the endpoint, the red coloration will require longer periods of time to disperse. At this point, it is necessary to slow the rate of addition of the alkyl lithium reagent as the endpoint is approaching. Eventually, the addition of a single drop of alkyl lithium will cause a persistent red coloration of the solution. This is the endpoint of the titration.

Cyclopentyllithium solution in hexane

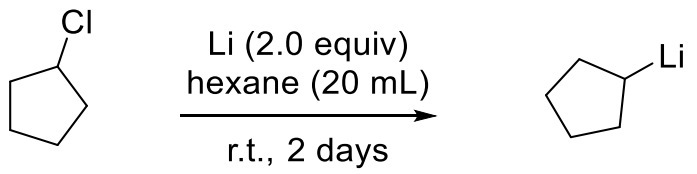

A Schlenk flask was flushed with dry Argon gas. After charging the flask with dry hexane $(20 \mathrm{ml})$ and lithium sand $(280 \mathrm{mg}, 40 \mathrm{mmol}, 2.0$ equiv), cyclopentyl chloride ( $2.08 \mathrm{~g}, 20 \mathrm{mmol}, 1.0$ equiv) was added slowly. The reaction mixture was stirred at high speed (1000 rpm) for 1 day. The upper clear solution was transferred to a dry Schlenk tube flushed with Argon. The concentration of cyclopentyllithium was determined to be $0.62 \mathrm{~mol} / \mathrm{L}$ by menthol/2,2'-bipyridine with the titration procedure presented above.

Cyclopropanyllithium lithium bromide complex solution in $\mathrm{Et}_{2} \mathrm{O}$

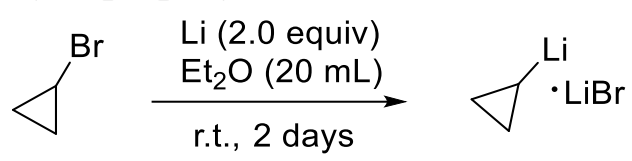

A Schlenk flask was flushed with dry Argon gas. After charging the flask with dry $\mathrm{Et}_{2} \mathrm{O}(20 \mathrm{ml})$ and lithium sand $(280 \mathrm{mg}, 40 \mathrm{mmol}, 2.0$ equiv), cyclopropanyl bromide (2.42 g, $1.6 \mathrm{~mL}, 20 \mathrm{mmol}, 1.0$ equiv) was added slowly. The reaction mixture was stirred at high speed (1000 rpm) for 1 day. The upper clear solution was transferred to a dry Schlenk tube flushed with Argon. The concentration of cyclopropanyllithium lithium bromide complex solution was determined to be $1.17 \mathrm{~mol} / \mathrm{L}$ by menthol/2,2'-bipyridine with the titration procedure presented above.

\section{Mechanistic Studies}

\subsection{Stern-Volmer Fluorescence Quenching Experiments}

All $f a c-\operatorname{Ir}(\text { ppy })_{3}$ solutions were excited at $420 \mathrm{~nm}$ and the emission intensity was collected at $528 \mathrm{~nm}$. In a typical experiment, the solution of $f a c-\operatorname{Ir}(\mathrm{ppy})_{3}$ in a mixture solvent of $\mathrm{CH}_{3} \mathrm{CN} / \mathrm{DMSO}(10: 1)(178 \mu \mathrm{M})$ was added the appropriate amount of quencher (solution in $\mathrm{CH}_{3} \mathrm{CN} / \mathrm{DMSO}(10: 1)$ ) in a screw-top $1.0 \mathrm{~cm}$ quartz cuvette. After degassing with Argon for $3 \mathrm{~min}$, the emission spectra of the samples were collected (Figure S1). 


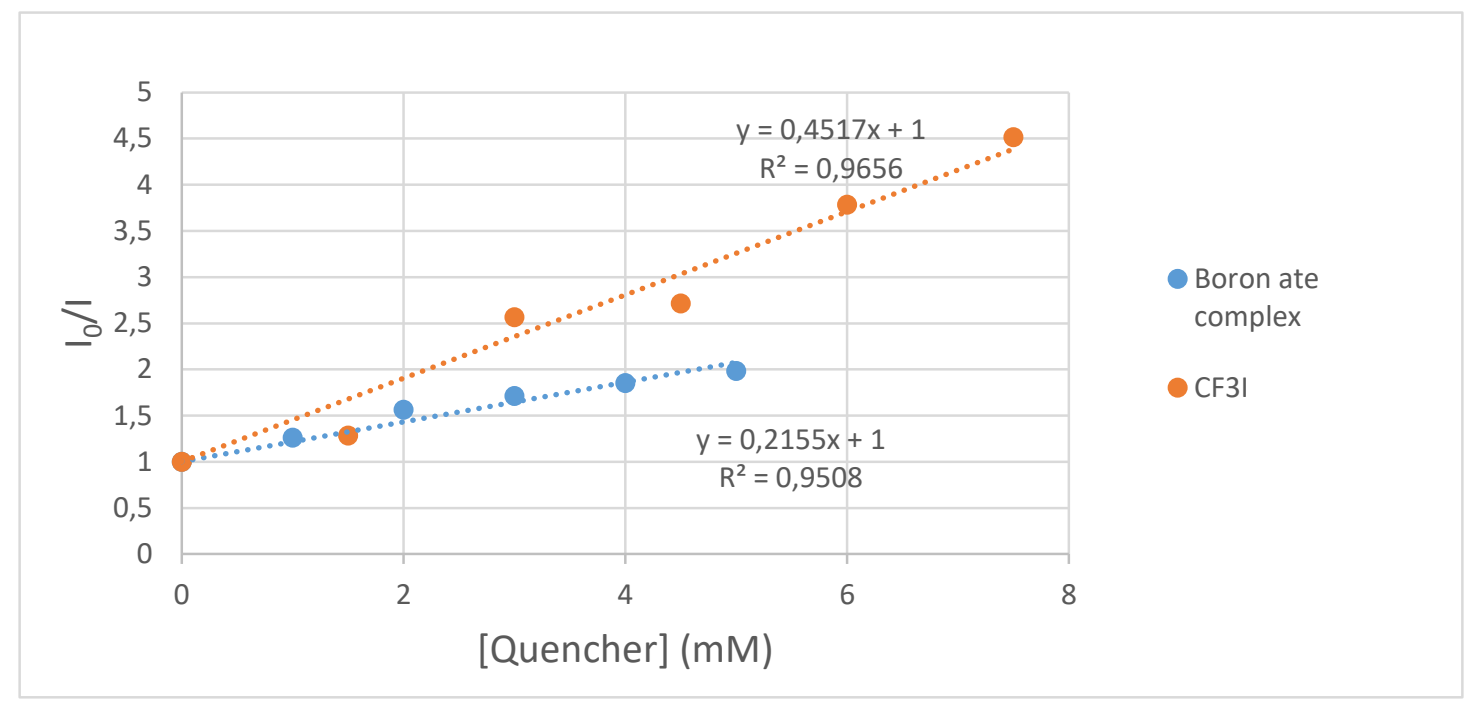

Figure S1. Fac-Ir(ppy) ${ }_{3}$ Solutions Quenched by Boron Ate Complex and $\mathrm{CF}_{3} \mathrm{I}$.

\subsection{Quantum Yield Analysis}

The quantum yield of this reaction was determined by chemical actinometry. Following a similar procedure reported by Melchiorre ${ }^{\mathrm{S} 20}$ and Glorius ${ }^{\mathrm{S} 21}$, an aqueous solution of potassium ferrioxalate was prepared and stored in the dark. This actinometer solution measures the photodecomposition of ferric oxalate anions to ferrous oxalate anions, which are then reacted with 1,10-phenanthroline to form $\left[\mathrm{Fe}(\text { phen })_{3}\right]^{2+}$. The concentration of this complex is then estimated by UV/Vis absorbance at $510 \mathrm{~nm}$. The number of moles of $\left[\mathrm{Fe}(\mathrm{phen})_{3}\right]^{2+}$ complex formed is related to the numbers of photons absorbed by the actinometer solution.

Preparation of the solutions used for the quantum yield measurements:

1. Potassium ferrioxalate solution: Potassium ferrioxalate trihydrate $(294 \mathrm{mg})$ and $95-98 \% \mathrm{H}_{2} \mathrm{SO}_{4}(140 \mu \mathrm{L})$ were added to a $50 \mathrm{~mL}$ volumetric flask and filled to the mark with distilled water.

2. Buffer solution: Sodium acetate $(4.94 \mathrm{~g})$ and $95-98 \% \mathrm{H}_{2} \mathrm{SO}_{4}(1.0 \mathrm{~mL})$ were added to a $100 \mathrm{~mL}$ volumetric flask and filled to the mark with distilled water.

The actinometry measurements:

a) $1 \mathrm{~mL}$ of the actinometer solution was taken in a quartz cuvette $(1=1 \mathrm{~cm})$. This solution was placed $5 \mathrm{~cm}$ away from a $4 \mathrm{~W}$ blue $\operatorname{LED}\left(\lambda_{\max }=455 \mathrm{~nm}\right)$ and irradiated for $15 \mathrm{~s}$. The same process was repeated for different time intervals: 30, 45, $60 \mathrm{~s}$.

b) After irradiation, the actinometer solution was transferred to a $10 \mathrm{~mL}$ volumetric flask containing $1.0 \mathrm{mg}$ of 1,10-phenanthroline in $2 \mathrm{~mL}$ of buffer solution. The flask was filled to the mark with distilled water. In a similar manner, a blank solution was also prepared using the actinometer solution stored in dark.

c) The absorbance of the actinometer solution after complexation with 1,10-phenanthroline at $\lambda=510 \mathrm{~nm}$ was measured by UV/Vis spectrophotometry.

d) According to Beer's law, the number of moles of $\mathrm{Fe}^{2+}$ formed (x) for each sample was determined by: 


$$
F e^{2+}=\frac{v_{1} v_{3} \Delta A(510 \mathrm{~nm})}{10^{3} v_{2} l \varepsilon(510 \mathrm{~nm})}
$$

Where:

$\mathrm{v}_{1}=$ Irradiated volume $(1 \mathrm{~mL})$.

$\mathrm{v}_{2}=$ The aliquot of the irradiated solution taken for the estimation of $\mathrm{Fe}^{2+}$ ions (1 $\mathrm{mL})$.

$\mathrm{v}_{3}=$ Final volume of the solution after complexation with 1,10-phenanthroline $(10 \mathrm{~mL})$.

$\varepsilon(510 \mathrm{~nm})=$ Molar extinction coefficient of $\left[\mathrm{Fe}(\mathrm{Phen})_{3}\right]^{2+}$ complex $(11100 \mathrm{~L}$ $\left.\mathrm{mol}^{-1} \mathrm{~cm}^{-1}\right)$.

$1=$ Optical path-length of the cuvette $(1 \mathrm{~cm})$

$\Delta \mathrm{A}(510 \mathrm{~nm})=$ Difference in absorbance between the irradiated solution and the solution stored in dark (blank)

e) The number of moles of $\mathrm{Fe}^{2+}$ formed (x) was plotted as a function of time (t) (Figure S2). The slope $(\mathrm{dx} / \mathrm{dt})$ of the line is equal to the number of moles of $\mathrm{Fe}^{2+}$ formed per unit time.

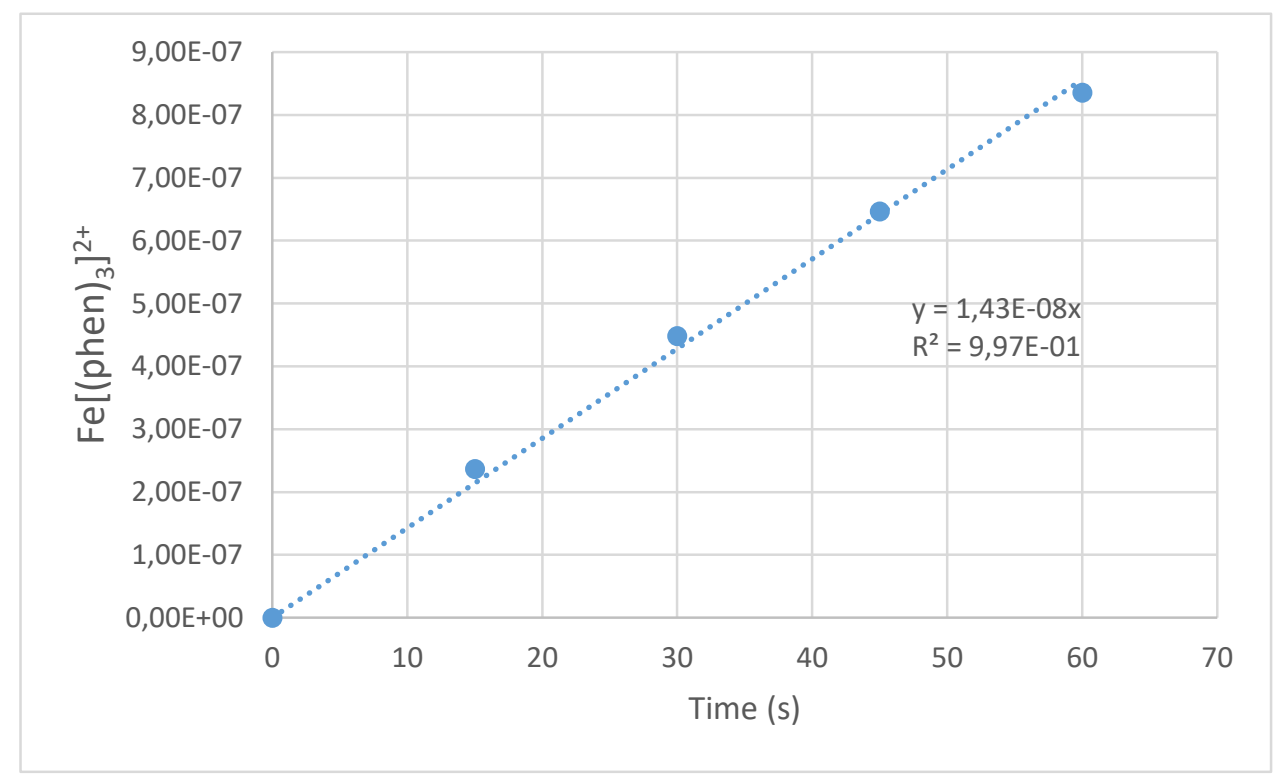

Figure S2. Moles of $\left[\mathrm{Fe}(\mathrm{phen})_{3}\right]^{2+}$ per unit of time formed due to decomposition of the actinometer solution at $4 \mathrm{~W}$ blue $\operatorname{LED}\left(\lambda_{\max }=455 \mathrm{~nm}\right)$ irradiation.

f) This slope $(\mathrm{dx} / \mathrm{dt})$ was correlated to the number of moles of incident photons per unit time ( $\mathrm{F}=$ photon flux) by using following equation:

$$
\Phi(\lambda)=\frac{d x / d t}{F\left(1-10^{-A(\lambda)}\right)}
$$

$\Phi(\lambda)=$ The quantum yield for $\mathrm{Fe}^{2+}$ formation at $450 \mathrm{~nm}$ is $0.9 .{ }^{\mathrm{S} 22}$

g) $\mathrm{A}(\lambda)=$ Absorbance of the ferrioxalate actinometer solution at a wavelength of $455 \mathrm{~nm}$, which was measured placing $1 \mathrm{~mL}$ of the solution in a cuvette of pathlength $1 \mathrm{~cm}$ by UV/Vis spectrophotometry. We obtained an absorbance value of 0.246 .

h) The determined incident photons per unit time $(\mathbf{F})$ is $3.68 \times 10^{-8}$ einsteins/s. 


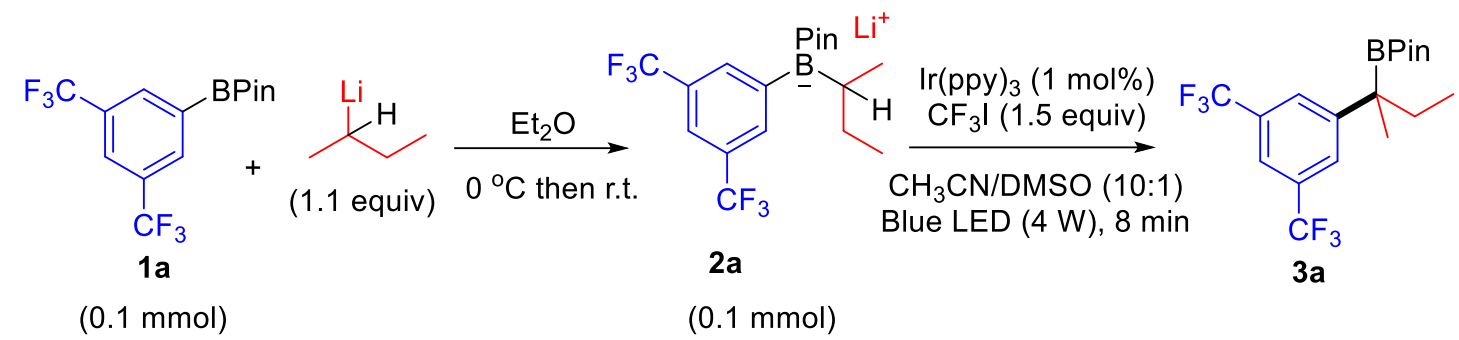

i) The number of moles of product formed upon irradiation of a reaction on 0.1 mmol scale of $\mathbf{2 a}$ in $1 \mathrm{~mL}$ solvent $\left(\mathrm{CH}_{3} \mathrm{CN} / \mathrm{DMSO} 10: 1\right)$ using the same reaction setup used before for the actinometer was determined by crude GC analysis using $n-\mathrm{C}_{14} \mathrm{H}_{30}$ as internal standard after $1 \mathrm{~min}$ of light irradiation. $19 \%$ of product was generated. Before irradiation, the measured absorbance of the reaction solution at 455 $\mathrm{nm}$ by UV/Vis spectrophotometry was 1.700 . Using the following equation, the quantum yield of the reaction was determined to be 8.8:

$$
\begin{aligned}
\Phi(455 \mathrm{~nm}) & =\frac{\text { moles of product }}{F\left(1-10^{-A(\lambda)}\right) t} \\
& =\frac{0.1 \times 10^{-3} \times 0.19 \mathrm{~mol}}{3.68 \times 10^{-8} \frac{\text { einsteins }}{\mathrm{s}}\left(1-10^{-1.7}\right) \times 60 \mathrm{~s}}=8.8
\end{aligned}
$$

\subsection{Proposed Mechanisms}

\subsubsection{Smart initiation by oxidative quenching}

According to the results of Stern-Volmer fluorescence quenching experiments, the excited photo catalyst $(\mathbf{P C} *)$ was mainly quenched by $\mathrm{CF}_{3} \mathrm{I}$. A quantum yield of 8.8 indicated a radical chain process (Figure $\mathbf{S 3}$ ).

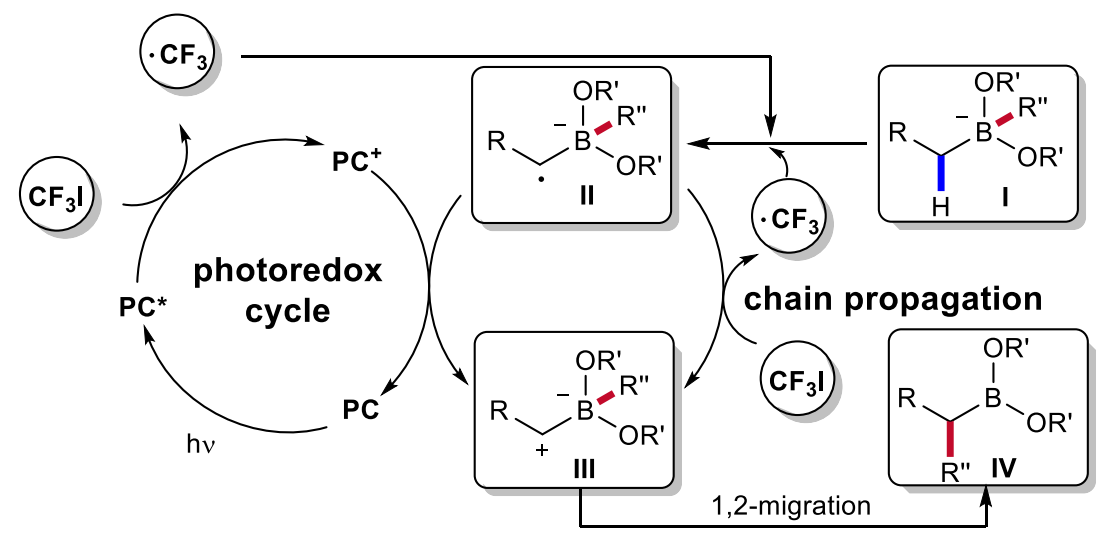

Figure S3. Possible reaction pathway initiated by oxidative quenching.

The radical chain process was initiated by a photoredox process. For the photoredox cycle, the photo catalyst $\operatorname{Ir}(\mathrm{ppy})_{3}$ was excited by blue LED light to $\operatorname{Ir}(\mathrm{ppy})_{3}$ * $\left\{\mathrm{E}_{1 / 2}{ }^{\mathrm{red}}\left[\mathrm{Ir}^{\mathrm{IV}} / \mathrm{Ir}^{\mathrm{III}}\right]=-1.73 \mathrm{~V} \text { vs SCE in } \mathrm{MeCN}\right\}^{\mathrm{S} 23}$, which would reduce $\mathrm{CF}_{3} \mathrm{I}\left\{\mathrm{E}_{\mathrm{p}}=\right.$ $-1.52 \mathrm{~V}$ vs $\mathrm{SCE}$ in $\mathrm{DMF}\}^{\mathrm{S} 24}$ to release $\mathrm{CF}_{3}$ radical. $\mathrm{CF}_{3}$ radical would abstract the $\alpha-\mathrm{H}$ of the boron ate complex I to afford the radical anion intermediate II. II could be further oxidized to zwitterion III by the oxidized photo catalyst $\operatorname{Ir}(\text { ppy })_{3}{ }^{+}$ $\left\{\mathrm{E}_{1 / 2}{ }^{\mathrm{red}}\left[\mathrm{Ir}^{\mathrm{IV}} / \mathrm{Ir}^{\mathrm{III}}\right]=+0.77 \mathrm{~V} \text { vs SCE in MeCN }\right\}^{\mathrm{S} 23}$, regenerating $\operatorname{Ir}(\mathrm{ppy})$ 3. $_{3}$ 1,2-Migration 
of $\mathrm{R}^{\prime \prime}$ group from III would give the final product IV.

For the radical chain propagation process, another equivalent of hydrogen atom abstractor, $\mathrm{CF}_{3}$ radical, was released when radical anion II was oxidized to zwitterion III by $\mathrm{CF}_{3} \mathrm{I}^{\mathrm{S} 17,25,26}$

\subsubsection{Smart initiation by reductive quenching}

According to the results of Stern-Volmer fluorescence quenching experiments, the excited photo catalyst (PC*) was also quenched by the boronate complex I (minor pathway). The possibility of smart initiation by reductive quenching could not be excluded (Figure S4). The excited photo catalyst $\operatorname{Ir}(\mathrm{ppy}) 3^{*}\left\{\mathrm{E}_{1 / 2}{ }^{\mathrm{red}}\left[\mathrm{Ir}^{\mathrm{III}} / \mathrm{Ir}^{\mathrm{II}}\right]=+0.31\right.$ $\mathrm{V}$ vs SCE in $\mathrm{MeCN}\}^{\mathrm{S} 23}$ could oxidize the boronate complex $\mathrm{I}\left(\mathrm{E}_{\mathrm{p} / 2}=+0.31 \mathrm{~V}\right.$ vs SCE in $\left.\mathrm{CH}_{3} \mathrm{CN}\right)^{\mathrm{S} 27}$, releasing an alkyl radical $\cdot \mathrm{R}^{\prime \prime}$. Then the reduced photo catalyst $\operatorname{Ir}(\text { ppy })_{3}{ }^{-}\left\{\mathrm{E}_{1 / 2}{ }^{\text {red }}\left[\mathrm{Ir}^{\mathrm{III}} / \mathrm{Ir}^{\mathrm{II}}\right]=-2.19 \mathrm{~V} \text { vs SCE in } \mathrm{MeCN}\right\}^{\mathrm{S} 23}$ reduce $\mathrm{CF}_{3} \mathrm{I}$ to $\mathrm{CF}_{3}$ radical to initiate the chain reaction. $\mathrm{CF}_{3}$ radical could also be generated by iodine atom transfer from $\mathrm{CF}_{3} \mathrm{I}$ to radical $\cdot \mathrm{R}^{\prime \prime}$.

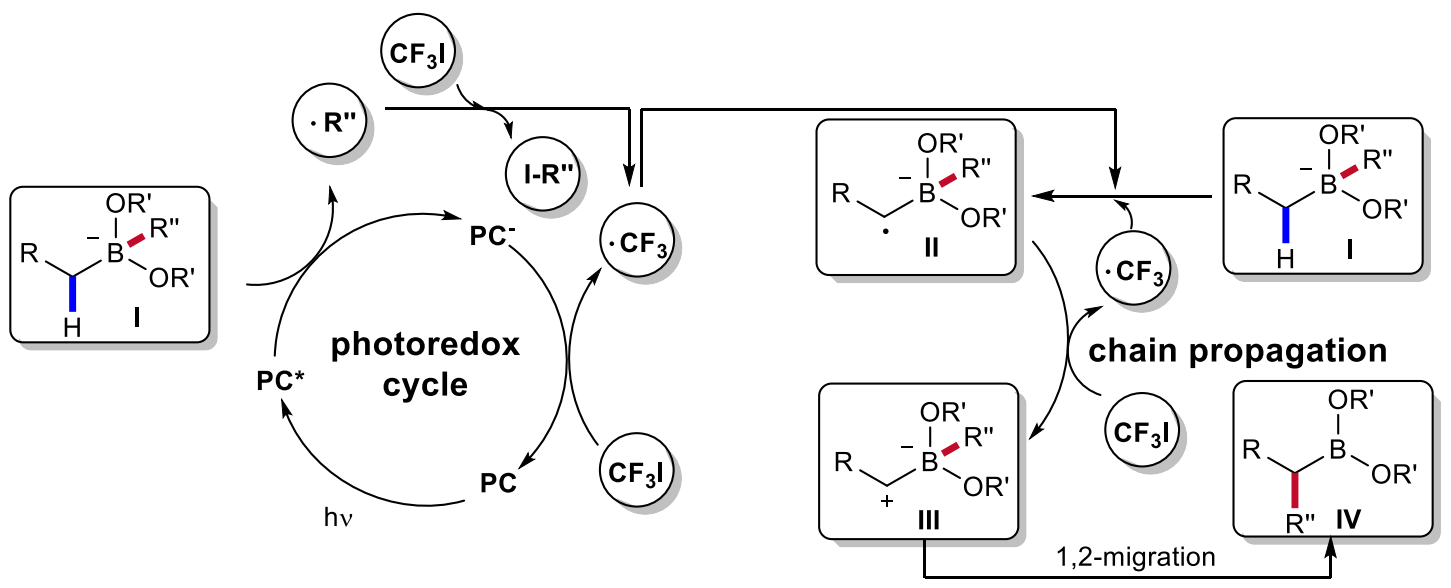

Figure S4. Possible reaction pathway initiated by reductive quenching.

\section{Product Characterization}

2-(2-(3,5-Bis(trifluoromethyl)phenyl)butan-2-yl)-4,4,5,5-tetramethyl-1,3,2-dioxaborol ane (3a)<smiles>CCC(C)(B1OC(C)(C)C(C)(C)O1)c1cc(C(F)(F)F)cc(C(F)(F)F)c1</smiles>

Following GP1, using 1a $(68.0 \mathrm{mg}, 0.2 \mathrm{mmol})$ and $s$-butyllithium $(1.4 \mathrm{M}$ in cyclohexane, $0.16 \mathrm{~mL}, 0.22 \mathrm{mmol}$ ), flash chromatography eluting with pentane/DCM (5:1) afforded 3a as colorless liquid $\left(53.1 \mathrm{mg}, 67 \%\right.$ yield). $\mathrm{R}_{\mathrm{f}} 0.5$ (pentane/DCM = 4:1). ${ }^{1} \mathrm{H}$ NMR $\left(300 \mathrm{MHz}, \mathrm{CDCl}_{3}\right) \delta 7.78(\mathrm{~s}, 2 \mathrm{H}), 7.66(\mathrm{~s}, 1 \mathrm{H}), 1.96-1.84(\mathrm{~m}, 1 \mathrm{H})$, 1.79-1.67 (m, 1H), $1.37(\mathrm{~s}, 3 \mathrm{H}), 1.22(\mathrm{~s}, 12 \mathrm{H}), 0.84(\mathrm{t}, J=7.4 \mathrm{~Hz}, 3 \mathrm{H}) .{ }^{13} \mathrm{C} \mathrm{NMR}(75$ 
$\left.\mathrm{MHz}, \mathrm{CDCl}_{3}\right) \delta 150.3,131.1(\mathrm{q}, J=32.7 \mathrm{~Hz}), 127.5-127.2(\mathrm{~m}), 123.7(\mathrm{q}, J=272.5$ $\mathrm{Hz}), 119.89-118.71(\mathrm{~m}), 83.9,32.0,24.6,24.5,20.8$, 9.9, carbon attached to boron not observed. ${ }^{19} \mathrm{~F}$ NMR $\left(282 \mathrm{MHz}, \mathrm{CDCl}_{3}\right) \delta-62.8 .{ }^{11} \mathrm{~B} \mathrm{NMR}\left(96 \mathrm{MHz}, \mathrm{CDCl}_{3}\right) \delta$ 33.6. HRMS (EI) $m / z=396.1690$ calcd. for $\mathrm{C}_{18} \mathrm{H}_{23} \mathrm{BF}_{6} \mathrm{O}_{2}{ }^{+}[\mathrm{M}]^{+}$, found: 396.1688 . FTIR (neat): $v\left(\mathrm{~cm}^{-1}\right)$ 2981, 1463, 1369, 1320, 1274, 1169, 1126, 965, 895, 851, 708, 682.

According to crude GC analysis with $n-\mathrm{C}_{14} \mathrm{H}_{30}$ as internal standard, GC yield of 3a was $72 \%$ and recovered yield of $\mathbf{1 a}$ was $18 \%$.

2-(2-(3,5-Bis(trifluoromethyl)phenyl)propan-2-yl)-4,4,5,5-tetramethyl-1,3,2-dioxabor olane (3b)

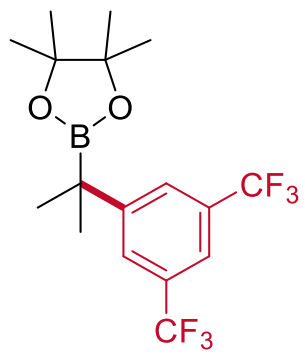

Following GP1, using 1a $(68.0 \mathrm{mg}, 0.2 \mathrm{mmol})$ and isopropyllithium $(0.7 \mathrm{M}$ in pentane, $0.31 \mathrm{~mL}, 0.22 \mathrm{mmol})$, flash chromatography eluting with pentane/DCM (5:1) afforded $3 \mathrm{~b}$ as colorless liquid $\left(50.8 \mathrm{mg}, 66 \%\right.$ yield). $\mathrm{R}_{\mathrm{f}} 0.6$ (pentane/DCM $\left.=4: 1\right) .{ }^{1} \mathrm{H}$ NMR (300 MHz, CDCl 3 ) $\delta 7.76(\mathrm{~s}, 2 \mathrm{H}), 7.66(\mathrm{~s}, 1 \mathrm{H}), 1.39(\mathrm{~s}, 6 \mathrm{H}), 1.21(\mathrm{~s}, 12 \mathrm{H}) .{ }^{13} \mathrm{C}$ NMR $\left(75 \mathrm{MHz}, \mathrm{CDCl}_{3}\right) \delta 151.5,131.1(\mathrm{q}, J=32.7 \mathrm{~Hz}), 126.9-126.5(\mathrm{~m}), 123.7(\mathrm{q}$, $J=272.6 \mathrm{~Hz}), 119.1(\mathrm{dd}, J=7.7,3.9 \mathrm{~Hz}), 83.9,25.3,24.4$, carbon attached to boron not observed. ${ }^{19} \mathrm{~F} \mathrm{NMR}\left(282 \mathrm{MHz}, \mathrm{CDCl}_{3}\right) \delta-62.8 .{ }^{11} \mathrm{~B} \mathrm{NMR}\left(96 \mathrm{MHz}, \mathrm{CDCl}_{3}\right) \delta$ 33.7. HRMS (EI) $\mathrm{m} / z=382.1533$ calcd. for $\mathrm{C}_{17} \mathrm{H}_{21} \mathrm{BF}_{6} \mathrm{O}_{2}{ }^{+}[\mathrm{M}]^{+}$, found: 382.1538 . FTIR (neat): $v\left(\mathrm{~cm}^{-1}\right)$ 2980, 2937, 2880, 1462, 1369, 1319, 1274, 1169, 1125, 965, $895,878,851,708,682$. According to crude $\mathrm{GC}$ analysis with $n-\mathrm{C}_{14} \mathrm{H}_{30}$ as internal standard, GC yield of $\mathbf{3 b}$ was $82 \%$ and recovered yield of $\mathbf{1 a}$ was $8 \%$.

Following GP3, using 1a $(68.0 \mathrm{mg}, 0.2 \mathrm{mmol})$ and isopropyllithium $(0.7 \mathrm{M}$ in pentane, $0.31 \mathrm{~mL}, 0.22 \mathrm{mmol})$, flash chromatography eluting with pentane/DCM (5:1) afforded $3 \mathrm{~b}$ as colorless liquid (42.0 $\mathrm{mg}, 55 \%$ yield). $\mathrm{R}_{\mathrm{f}} 0.6$ (pentane/DCM $=4: 1$ ). ${ }^{1} \mathrm{H}$ NMR $\left(300 \mathrm{MHz}, \mathrm{CDCl}_{3}\right) \delta 7.76(\mathrm{~s}, 2 \mathrm{H}), 7.66(\mathrm{~s}, 1 \mathrm{H}), 1.39(\mathrm{~s}, 6 \mathrm{H}), 1.21(\mathrm{~s}, 12 \mathrm{H}) .{ }^{13} \mathrm{C}$ NMR $\left(75 \mathrm{MHz}, \mathrm{CDCl}_{3}\right) \delta 151.5,131.1(\mathrm{q}, J=32.7 \mathrm{~Hz}), 126.9-126.5(\mathrm{~m}), 123.7(\mathrm{q}$, $J=272.6 \mathrm{~Hz}), 119.1(\mathrm{dd}, J=7.7,3.9 \mathrm{~Hz}), 83.9,25.3,24.4$, carbon attached to boron not observed. ${ }^{19} \mathrm{~F} \mathrm{NMR}\left(282 \mathrm{MHz}, \mathrm{CDCl}_{3}\right) \delta-62.8 .{ }^{11} \mathrm{~B} \mathrm{NMR}\left(96 \mathrm{MHz}, \mathrm{CDCl}_{3}\right) \delta$ 33.7. HRMS (EI) $\mathrm{m} / z=382.1533$ calcd. for $\mathrm{C}_{17} \mathrm{H}_{21} \mathrm{BF}_{6} \mathrm{O}_{2}{ }^{+}[\mathrm{M}]^{+}$, found: 382.1538 . FTIR (neat): $v\left(\mathrm{~cm}^{-1}\right)$ 2980, 2937, 2880, 1462, 1369, 1319, 1274, 1169, 1125, 965, $895,878,851,708,682$. According to crude $\mathrm{GC}$ analysis with $n-\mathrm{C}_{14} \mathrm{H}_{30}$ as internal standard, GC yield of $\mathbf{3 b}$ was $76 \%$ and recovered yield of $\mathbf{1 a}$ was $11 \%$.

2-(1-(3,5-Bis(trifluoromethyl)phenyl)cyclopentyl)-4,4,5,5-tetramethyl-1,3,2-dioxabor olane $(3 \mathbf{c})$ 


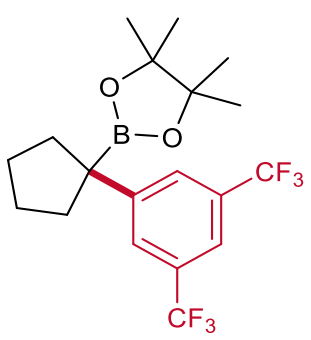

Following GP1, using 1a $(68.0 \mathrm{mg}, 0.2 \mathrm{mmol})$ and cyclopentyllithium $(0.62 \mathrm{M}$ in hexane, $0.355 \mathrm{~mL}, 0.22 \mathrm{mmol})$, flash chromatography eluting with pentane/DCM (4:1) afforded $3 \mathbf{c}$ as colorless sticky oil $\left(51.7 \mathrm{mg}, 63 \%\right.$ yield). $\mathrm{R}_{\mathrm{f}} 0.5$ (pentane/DCM $=4: 1$ ). ${ }^{1} \mathrm{H}$ NMR $\left(300 \mathrm{MHz}, \mathrm{CDCl}_{3}\right) \delta 7.71(\mathrm{~s}, 2 \mathrm{H}), 7.63(\mathrm{~s}, 1 \mathrm{H}), 2.46-2.27(\mathrm{~m}, 2 \mathrm{H})$, 1.78-1.63 (m, 7H), $1.37-1.18(\mathrm{~m}, 2 \mathrm{H}), 1.15(\mathrm{~s}, 12 \mathrm{H}) .{ }^{13} \mathrm{C} \mathrm{NMR}\left(75 \mathrm{MHz}, \mathrm{CDCl}_{3}\right) \delta$ $150.0,130.7(\mathrm{t}, J=32.7 \mathrm{~Hz}), 127.3-127.1(\mathrm{~m}), 123.6(\mathrm{q}, J=272.6 \mathrm{~Hz}), 119.5-118.4$ $(\mathrm{m}), 83.9,35.2,24.4,24.3$, carbon attached to boron not observed. ${ }^{19} \mathrm{~F}$ NMR (282 $\left.\mathrm{MHz}, \mathrm{CDCl}_{3}\right) \delta-62.8 .{ }^{11} \mathrm{~B}$ NMR $\left(96 \mathrm{MHz}, \mathrm{CDCl}_{3}\right) \delta 33.4$. HRMS (ESI) $\mathrm{m} / \mathrm{z}=$ 431.1588 calcd. for $\mathrm{C}_{19} \mathrm{H}_{23} \mathrm{BF}_{6} \mathrm{O}_{2} \mathrm{Na}$ [M+Na] ${ }^{+}$, found: 431.1583 . FTIR (neat): $v\left(\mathrm{~cm}^{-1}\right)$ 2978, 2960, 2873, 1456, 1372, 1320, 1275, 1167, 1130, 982, 893, 854, 708, 682. According to crude GC analysis with $n-\mathrm{C}_{14} \mathrm{H}_{30}$ as internal standard, GC yield of $\mathbf{3 c}$ was $72 \%$ and recovered yield of $\mathbf{1 a}$ was $18 \%$.

Following GP3, using 1a $(68.0 \mathrm{mg}, 0.2 \mathrm{mmol})$ and cyclopentyllithium $(0.62 \mathrm{M}$ in hexane, $0.355 \mathrm{~mL}, 0.22 \mathrm{mmol})$, flash chromatography eluting with pentane/DCM (4:1) afforded $\mathbf{3 c}$ as colorless sticky oil $\left(49.8 \mathrm{mg}, 61 \%\right.$ yield). $\mathrm{R}_{\mathrm{f}} 0.5$ (pentane/DCM $=4: 1$ ). ${ }^{1} \mathrm{H}$ NMR $\left(300 \mathrm{MHz}, \mathrm{CDCl}_{3}\right) \delta 7.71(\mathrm{~s}, 2 \mathrm{H}), 7.63(\mathrm{~s}, 1 \mathrm{H}), 2.46-2.27(\mathrm{~m}, 2 \mathrm{H})$, 1.78-1.63 (m, 7H), $1.37-1.18(\mathrm{~m}, 2 \mathrm{H}), 1.15(\mathrm{~s}, 12 \mathrm{H}) .{ }^{13} \mathrm{C} \mathrm{NMR}\left(75 \mathrm{MHz}, \mathrm{CDCl}_{3}\right) \delta$ $150.0,130.7(\mathrm{t}, J=32.7 \mathrm{~Hz}), 127.3-127.1(\mathrm{~m}), 123.6(\mathrm{q}, J=272.6 \mathrm{~Hz}), 119.5-118.4$ (m), 83.9, 35.2, 24.4, 24.3, carbon attached to boron not observed. ${ }^{19} \mathrm{~F}$ NMR (282 $\left.\mathrm{MHz}, \mathrm{CDCl}_{3}\right) \delta-62.8 .{ }^{11} \mathrm{~B}$ NMR $\left(96 \mathrm{MHz}, \mathrm{CDCl}_{3}\right) \delta 33.4$. HRMS (ESI) $\mathrm{m} / \mathrm{z}=$ 431.1588 calcd. for $\mathrm{C}_{19} \mathrm{H}_{23} \mathrm{BF}_{6} \mathrm{O}_{2} \mathrm{Na}$ [M+Na] ${ }^{+}$, found: 431.1583. FTIR (neat): $v\left(\mathrm{~cm}^{-1}\right)$ 2978, 2960, 2873, 1456, 1372, 1320, 1275, 1167, 1130, 982, 893, 854, 708, 682. According to crude GC analysis with $n-\mathrm{C}_{14} \mathrm{H}_{30}$ as internal standard, GC yield of $\mathbf{3 c}$ was $66 \%$ and recovered yield of $1 \mathbf{a}$ was $17 \%$.

2-(1-(3,5-Bis(trifluoromethyl)phenyl)butyl)-4,4,5,5-tetramethyl-1,3,2-dioxaborolane (3d)<smiles>CCCC(B1OC(C)(C)C(C)(C)O1)c1cc(C(F)(F)F)cc(C(F)(F)F)c1</smiles>

Following GP1, using 1a $(68.0 \mathrm{mg}, 0.2 \mathrm{mmol})$ and n-butyllithium (1.6 $\mathrm{M}$ in hexane, $0.14 \mathrm{~mL}, 0.22 \mathrm{mmol})$, flash chromatography eluting with pentane/DCM (5:1) afforded 
3d as colorless liquid (27.0 mg, 34\% yield). $\mathrm{R}_{\mathrm{f}} 0.6$ (pentane/DCM $\left.=4: 1\right) .{ }^{1} \mathrm{H}$ NMR $\left(300 \mathrm{MHz}, \mathrm{CDCl}_{3}\right) \delta 7.69-7.60(\mathrm{~m}, 3 \mathrm{H}), 2.46(\mathrm{t}, J=7.9 \mathrm{~Hz}, 1 \mathrm{H}), 1.95-1.80(\mathrm{~m}$, $1 \mathrm{H}), 1.73-1.57(\mathrm{~m}, 1 \mathrm{H}), 1.33-1.24(\mathrm{~m}, 2 \mathrm{H}), 1.20(\mathrm{~s}, 12 \mathrm{H}), 0.91(\mathrm{t}, J=7.3 \mathrm{~Hz}, 3 \mathrm{H})$. ${ }^{13} \mathrm{C} \mathrm{NMR}\left(75 \mathrm{MHz}, \mathrm{CDCl}_{3}\right) \delta 146.3,131.3(\mathrm{q}, J=32.8 \mathrm{~Hz}), 128.5,123.6(\mathrm{q}, J=$ $272.6 \mathrm{~Hz}), 120.0-118.8(\mathrm{~m}), 83.8,34.7,24.6,24.5,22.3$, 14.0, carbon attached to boron not observed. ${ }^{19} \mathrm{~F} \mathrm{NMR}\left(282 \mathrm{MHz}, \mathrm{CDCl}_{3}\right) \delta$-62.9. ${ }^{11} \mathrm{~B} \mathrm{NMR}\left(96 \mathrm{MHz}, \mathrm{CDCl}_{3}\right)$ $\delta$ 33.5. HRMS (EI) $\mathrm{m} / \mathrm{z}=396.1690$ calcd. for $\mathrm{C}_{18} \mathrm{H}_{23} \mathrm{BF}_{6} \mathrm{O}_{2}{ }^{+}[\mathrm{M}]^{+}$, found: 396.1691 . FTIR (neat): $v\left(\mathrm{~cm}^{-1}\right)$ 2979, 2935, 2875, 1467, 1433, 1373, 1332, 1276, 1167, 1128 , 967, 896, 707, 682. According to crude GC analysis with $n-\mathrm{C}_{14} \mathrm{H}_{30}$ as internal standard, GC yield of 3d was 34\% and recovered yield of 1a was 39\%.

2-(3-(3,5-Bis(trifluoromethyl)phenyl)-1-phenylpentan-3-yl)-4,4,5,5-tetramethyl-1,3,2dioxaborolane $(\mathbf{3 e})$<smiles>CCC(CCc1ccccc1)(B1OC(C)(C)C(C)(C)O1)c1cc(C(F)(F)F)cc(C(F)(F)F)c1</smiles>

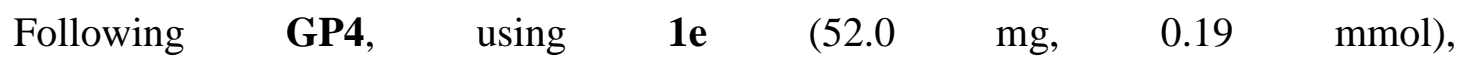
1-bromo-3,5-bis(trifluoromethyl)benzene $(64.5 \mathrm{mg}, 0.22 \mathrm{mmol})$ and n-butyllithium (1.6 $\mathrm{M}$ in hexane, $0.15 \mathrm{~mL}, 0.24 \mathrm{mmol}$ ), flash chromatography eluting with pentane/DCM (1:1) afforded 3e as light yellow oil (26.6 mg, 29\% yield). $R_{f} 0.4$ (pentane/DCM = 1:1). ${ }^{1} \mathrm{H}$ NMR $\left(300 \mathrm{MHz}, \mathrm{CDCl}_{3}\right) \delta 7.74$ (s, 2H), $7.61(\mathrm{~s}, 1 \mathrm{H}), 7.23$ $-7.01(\mathrm{~m}, 5 \mathrm{H}), 2.39-2.22(\mathrm{~m}, 2 \mathrm{H}), 2.12-2.00(\mathrm{~m}, 2 \mathrm{H}), 1.90(\mathrm{q}, J=7.4 \mathrm{~Hz}, 2 \mathrm{H})$, $1.18(\mathrm{~s}, 12 \mathrm{H}), 0.76(\mathrm{t}, J=7.4 \mathrm{~Hz}, 3 \mathrm{H}) .{ }^{13} \mathrm{C} \mathrm{NMR}\left(75 \mathrm{MHz}, \mathrm{CDCl}_{3}\right) \delta 148.4,142.5$, $131.1(\mathrm{q}, J=32.8 \mathrm{~Hz}), 128.4,128.3,128.0-127.8(\mathrm{~m}), 125.9,123.7(\mathrm{q}, J=272.7 \mathrm{~Hz})$, $119.3,83.9,37.1,31.7,27.7,24.7,9.4$, carbon attached to boron not observed. ${ }^{19} \mathrm{~F}$ NMR (282 MHz, $\left.\mathrm{CDCl}_{3}\right) \delta-62.8 .{ }^{11} \mathrm{~B} \mathrm{NMR}\left(96 \mathrm{MHz}, \mathrm{CDCl}_{3}\right) \delta 33.2$. HRMS (ESI) $m / z=509.2057$ calcd. for $\mathrm{C}_{25} \mathrm{H}_{29} \mathrm{BF}_{6} \mathrm{NaO}_{2}{ }^{+}[\mathrm{M}+\mathrm{Na}]^{+}$, found: 509.2060 . FTIR (neat): $v\left(\mathrm{~cm}^{-1}\right)$ 2981, 2936, 2879, 1455, 1371, 1323, 1274, 1167, 1126, 966, 889, 853, 798, $750,724,709,699,682$. According to crude GC analysis with $n-\mathrm{C}_{14} \mathrm{H}_{30}$ as internal standard, the crude yield of 3,5-bis(trifluoromethyl)phenylboronic acid pinacol ester was $35 \%$.

Trimethyl(4-(2-(4,4,5,5-tetramethyl-1,3,2-dioxaborolan-2-yl)butan-2-yl)phenyl)silane (3f)

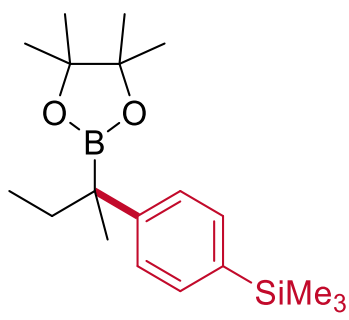


Following GP1, using 1f $(55.2 \mathrm{mg}, 0.2 \mathrm{mmol})$ and $s$-butyllithium (1.4 $\mathrm{M}$ in hexane, $0.16 \mathrm{~mL}, 0.22 \mathrm{mmol})$, flash chromatography eluting with pentane/DCM (5:1) afforded 3f as yellow oil (34.8 $\mathrm{mg}, 52 \%$ yield). $\mathrm{R}_{\mathrm{f}} 0.4$ (pentane/DCM $\left.=4: 1\right) .{ }^{1} \mathrm{H}$ NMR (300 $\left.\mathrm{MHz}, \mathrm{CDCl}_{3}\right) \delta 7.48-7.39(\mathrm{~m}, 2 \mathrm{H}), 7.34-7.27(\mathrm{~m}, 2 \mathrm{H}), 1.94-1.82(\mathrm{~m}, 1 \mathrm{H}), 1.76-$ $1.66(\mathrm{~m}, 1 \mathrm{H}), 1.33(\mathrm{~s}, 1 \mathrm{H}), 1.23(\mathrm{~s}, 6 \mathrm{H}), 1.23(\mathrm{~s}, 6 \mathrm{H}), 0.85(\mathrm{t}, J=7.4 \mathrm{~Hz}, 2 \mathrm{H}), 0.25$ (s, 9H). ${ }^{13} \mathrm{C} \mathrm{NMR}\left(75 \mathrm{MHz}, \mathrm{CDCl}_{3}\right) \delta 148.1,136.1,133.1,126.3,83.3,32.0,24.7,24.6$, $21.2,10.2,-1.0$, carbon attached to boron not observed. ${ }^{11} \mathrm{~B} \mathrm{NMR}\left(96 \mathrm{MHz}, \mathrm{CDCl}_{3}\right)$ $\delta$ 33.9. HRMS (ESI) $m / z=355.2235$ calcd. for $\mathrm{C}_{19} \mathrm{H}_{33} \mathrm{BO}_{2} \mathrm{SiNa}^{+}[\mathrm{M}+\mathrm{Na}]^{+}$, found:355.2250. FTIR (neat): $v\left(\mathrm{~cm}^{-1}\right)$ 2978, 2958, 1598, 1458, 1372, 1345, 1315, 1248, 1139, 1087, 1043, 982, 835, 817, 753, 726, 691, 673.

2-(2-(4-(Tert-butyl)phenyl)butan-2-yl)-4,4,5,5-tetramethyl-1,3,2-dioxaborolane (3g)<smiles>CCC(C)(B1OC(C)(C)C(C)(C)O1)c1ccc(C(C)C)cc1</smiles>

Following GP1, using $1 \mathrm{~g}(52.0 \mathrm{mg}, 0.2 \mathrm{mmol})$ and $s$-butyllithium $(1.4 \mathrm{M}$ in hexane, $0.16 \mathrm{~mL}, 0.22 \mathrm{mmol})$, flash chromatography eluting with pentane/DCM (5:1) afforded $3 \mathrm{~g}$ as yellow oil $\left(38.3 \mathrm{mg}, 61 \%\right.$ yield). $\mathrm{R}_{\mathrm{f}} 0.5$ (pentane/DCM $\left.=3: 1\right) .{ }^{1} \mathrm{H}$ NMR $(300$ $\left.\mathrm{MHz}, \mathrm{CDCl}_{3}\right) \delta 7.24-7.09(\mathrm{~m}, 4 \mathrm{H}), 1.76-1.72(\mathrm{~m}, 1 \mathrm{H}), 1.64-1.52(\mathrm{~m}, 1 \mathrm{H}), 1.23-$ $1.21(\mathrm{~m}, 12 \mathrm{H}), 1.14(\mathrm{~s}, 6 \mathrm{H}), 1.14(\mathrm{~s}, 6 \mathrm{H}), 0.76(\mathrm{t}, J=7.4 \mathrm{~Hz}, 3 \mathrm{H}) .{ }^{13} \mathrm{C}$ NMR $(75 \mathrm{MHz}$, $\left.\mathrm{CDCl}_{3}\right) \delta 147.5,144.2,126.4,124.8,83.2,34.2,32.1,31.4,24.6,24.6,21.4,10.3$, carbon attached to boron not observed. ${ }^{11} \mathrm{~B} \mathrm{NMR}\left(96 \mathrm{MHz}, \mathrm{CDCl}_{3}\right) \delta 33.7 . \mathbf{H R M S}$ (ESI) $m / z=339.2466$ calcd. for $\mathrm{C}_{20} \mathrm{H}_{33} \mathrm{O}_{2} \mathrm{BNa}^{+}[\mathrm{M}+\mathrm{Na}]^{+}$, found: 339.2491. FTIR (neat): $v\left(\mathrm{~cm}^{-1}\right)$ 2965, 2939, 2871, 1512, 1461, 1380, 1364, 1351, 1308, 1269, 1140 , $1114,1017,965,851,827,794$.

4,4,5,5-Tetramethyl-2-(2-(p-tolyl)butan-2-yl)-1,3,2-dioxaborolane (3h)

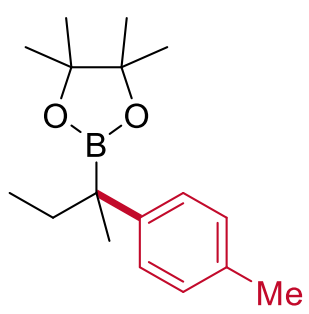

Following GP2, using $\mathbf{1 h}(43.6 \mathrm{mg}, 0.2 \mathrm{mmol})$ and $s$-butyllithium (1.4 M in hexane, $0.16 \mathrm{~mL}, 0.22 \mathrm{mmol})$, flash chromatography eluting with pentane/DCM (4:1) afforded $\mathbf{3 h}$ as yellow oil (18.2 $\mathrm{mg}, 33 \%$ yield). $\mathrm{R}_{\mathrm{f}} 0.4$ (pentane/DCM $\left.=3: 1\right) .{ }^{1} \mathrm{H}$ NMR (300 $\left.\mathrm{MHz}, \mathrm{CDCl}_{3}\right) \delta 7.21(\mathrm{~d}, J=8.2 \mathrm{~Hz}, 2 \mathrm{H}), 7.09(\mathrm{~d}, J=8.2 \mathrm{~Hz}, 2 \mathrm{H}), 2.31(\mathrm{~s}, 3 \mathrm{H}), 1.92-$ $1.80(\mathrm{~m}, 1 \mathrm{H}), 1.74-1.60(\mathrm{~m}, 1 \mathrm{H}), 1.31(\mathrm{~s}, 3 \mathrm{H}), 1.22(\mathrm{~s}, 6 \mathrm{H}), 1.21(\mathrm{~s}, 6 \mathrm{H}), 0.83(\mathrm{t}, J=$ $7.4 \mathrm{~Hz}, 3 \mathrm{H}) .{ }^{13} \mathrm{C} \mathrm{NMR}\left(75 \mathrm{MHz}, \mathrm{CDCl}_{3}\right) \delta 144.3,134.2,128.7,126.7,83.2,32.0$, 24.6, 24.6, 21.1, 20.9, 10.1, carbon attached to boron not observed. ${ }^{11} \mathrm{~B} \mathrm{NMR}(96$ $\left.\mathrm{MHz}, \mathrm{CDCl}_{3}\right) \delta$ 34.4. HRMS (ESI) $\mathrm{m} / z=297.1996$ calcd. for $\mathrm{C}_{17} \mathrm{H}_{27} \mathrm{BO}_{2} \mathrm{Na}^{+}$ 
$[\mathrm{M}+\mathrm{Na}]^{+}$, found: 297.2009. FTIR (neat): $v\left(\mathrm{~cm}^{-1}\right)$ 2976, 2930, 2877, 1512, 1457, 1379, 1377, 1347, 1307, 1264, 1214, 1138, 1096, 1043, 1020, 965, 849, 815, 723, 673, 576. According to GC analysis with $n-\mathrm{C}_{14} \mathrm{H}_{30}$ as internal standard, GC yield of $\mathbf{3 h}$ was $34 \%$ and recovered yield of $\mathbf{1 h}$ was $33 \%$.

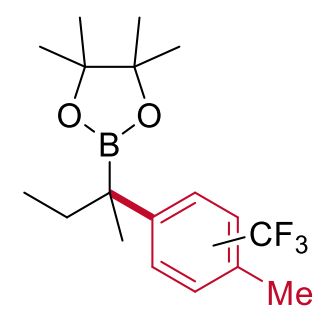

About $10 \%$ trifluoromethylated $\mathbf{3 h}$ was also detected $(\mathrm{o} / \mathrm{m}=1: 1.2)$ by crude $\mathrm{GC}$ and GC/MS.

4,4,5,5-Tetramethyl-2-(2-phenylbutan-2-yl)-1,3,2-dioxaborolane (3i)<smiles>CCC(C)(B1OC(C)(C)C(C)(C)O1)c1ccccc1</smiles>

Following GP1, using 1i (40.8 mg, $0.2 \mathrm{mmol})$ and $s$-butyllithium (1.4 $\mathrm{M}$ in hexane, $0.16 \mathrm{~mL}, 0.22 \mathrm{mmol})$, flash chromatography eluting with pentane/DCM (4:1) afforded $3 \mathbf{i}$ as yellow oil $\left(31.1 \mathrm{mg}, 60 \%\right.$ yield). $\mathrm{R}_{\mathrm{f}} 0.4$ (pentane/DCM $\left.=3: 1\right) .{ }^{1} \mathrm{H}$ NMR (300 $\left.\mathrm{MHz}, \mathrm{CDCl}_{3}\right) \delta 7.28-7.14(\mathrm{~m}, 4 \mathrm{H}), 7.08-7.02(\mathrm{~m}, 1 \mathrm{H}), 1.88-1.72(\mathrm{~m}, 1 \mathrm{H}), 1.70-$ $1.55(\mathrm{~m}, 1 \mathrm{H}), 1.25(\mathrm{~s}, 3 \mathrm{H}), 1.14(\mathrm{~s}, 6 \mathrm{H}), 1.13(\mathrm{~s}, 6 \mathrm{H}), 0.75(\mathrm{t}, J=7.4 \mathrm{~Hz}, 3 \mathrm{H}),{ }^{13} \mathrm{C}$ NMR $\left(75 \mathrm{MHz}, \mathrm{CDCl}_{3}\right) \delta 147.3,128.0,126.9,124.9,83.2,31.9,24.6,21.0,10.0$, carbon attached to boron not observed. ${ }^{11} \mathrm{~B}$ NMR $\left(96 \mathrm{MHz}, \mathrm{CDCl}_{3}\right) \delta 33.8$. HRMS (ESI) $\mathrm{m} / z=283.1840$ calcd. for $\mathrm{C}_{16} \mathrm{H}_{25} \mathrm{BO}_{2} \mathrm{Na}^{+}[\mathrm{M}+\mathrm{Na}]^{+}$, found: 283.1851. FTIR (neat): $v\left(\mathrm{~cm}^{-1}\right)$ 2976, 2931, 2876, 1600, 1495, 1458, 1371, 1348, 1309, 1264, 1215, 1139, 1099, 1031, 965, 856, 763, 699.

2-(2-(4-Chlorophenyl)butan-2-yl)-4,4,5,5-tetramethyl-1,3,2-dioxaborolane (3j)<smiles>CCC(C)(B1OC(C)(C)C(C)(C)O1)c1ccc(Cl)cc1</smiles>

Following GP1, using $\mathbf{1 j}$ (47.6 mg, $0.2 \mathrm{mmol})$ and $s$-butyllithium (1.4 $\mathrm{M}$ in hexane, $0.16 \mathrm{~mL}, 0.22 \mathrm{mmol})$, flash chromatography eluting with pentane/DCM (4:1) afforded 3j as yellow sticky oil $\left(34.5 \mathrm{mg}, 59 \%\right.$ yield). $\mathrm{R}_{\mathrm{f}} 0.4$ (pentane/DCM $\left.=3: 1\right) .{ }^{1} \mathrm{H}$ NMR $\left(300 \mathrm{MHz}, \mathrm{CDCl}_{3}\right) \delta 7.18-7.15(\mathrm{~m}, 4 \mathrm{H}), 1.82-1.70(\mathrm{~m}, 1 \mathrm{H}), 1.66-1.54(\mathrm{~m}, 1 \mathrm{H})$, $1.22(\mathrm{~s}, 3 \mathrm{H}), 1.13(\mathrm{~s}, 6 \mathrm{H}), 1.12(\mathrm{~s}, 6 \mathrm{H}), 0.73(\mathrm{t}, J=7.4 \mathrm{~Hz}, 3 \mathrm{H}) .{ }^{13} \mathrm{C} \mathrm{NMR}(75 \mathrm{MHz}$, 
$\left.\mathrm{CDCl}_{3}\right) \delta 145.8,130.7,128.3,128.0,83.4,31.9,24.6,24.7,20.9,9.8$, carbon attached to boron not observed. ${ }^{11} \mathrm{~B} \mathrm{NMR}\left(96 \mathrm{MHz}, \mathrm{CDCl}_{3}\right) \delta 34.2$. HRMS (ESI) $\mathrm{m} / \mathrm{z}=$ 317.1450 calcd. for $\mathrm{C}_{16} \mathrm{H}_{24} \mathrm{BClO}_{2} \mathrm{Na}^{+}[\mathrm{M}+\mathrm{Na}]^{+}$, found: 317.1459. FTIR (neat): $v$ $\left(\mathrm{cm}^{-1}\right)$ 2976, 2936, 2877, 1491, 1460, 1372, 1346, 1313, 1264, 1214, 1166, 1138, $1098,1043,1013,965,858,823,757,704,672,580$.

4-(2-(4,4,5,5-Tetramethyl-1,3,2-dioxaborolan-2-yl)butan-2-yl)phenyl trifluoromethanesulfonate $(\mathbf{3 k})$

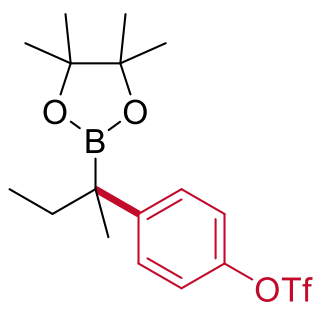

Following GP1, using 1k (70.4 mg, $0.2 \mathrm{mmol})$ and $s$-butyllithium $(1.4 \mathrm{M}$ in hexane, $0.16 \mathrm{~mL}, 0.22 \mathrm{mmol})$, flash chromatography eluting with pentane/DCM (3:1) afforded 3k as yellow sticky oil $\left(44.7 \mathrm{mg}, 55 \%\right.$ yield). $\mathrm{R}_{\mathrm{f}} 0.4$ (pentane $\left./ \mathrm{DCM}=5: 2\right) .{ }^{1} \mathrm{H}$ NMR $\left(300 \mathrm{MHz}, \mathrm{CDCl}_{3}\right) \delta 7.43-7.34(\mathrm{~m}, 2 \mathrm{H}), 7.22-7.12(\mathrm{~m}, 2 \mathrm{H}), 1.92-1.77(\mathrm{~m}, 1 \mathrm{H})$, $1.77-1.63(\mathrm{~m}, 1 \mathrm{H}), 1.32(\mathrm{~s}, 3 \mathrm{H}), 1.20(\mathrm{~s}, 12 \mathrm{H}), 0.81(\mathrm{t}, J=7.4 \mathrm{~Hz}, 3 \mathrm{H}) .{ }^{13} \mathrm{C} \mathrm{NMR}$ $\left(75 \mathrm{MHz}, \mathrm{CDCl}_{3}\right) \delta 148.0,147.2,128.7,120.6,118.7$ (q, $\left.J=320.7 \mathrm{~Hz}\right), 83.5,32.0$, 24.5, 24.5, 21.0, 9.9, carbon attached to boron not observed. ${ }^{19} \mathrm{~F}$ NMR $(282 \mathrm{MHz}$, $\left.\mathrm{CDCl}_{3}\right) \delta$-73.0. ${ }^{11} \mathrm{~B}$ NMR $\left(96 \mathrm{MHz}, \mathrm{CDCl}_{3}\right.$ ) $\delta$ 34.3. HRMS (ESI) $\mathrm{m} / z=431.1282$ calcd. for $\mathrm{C}_{17} \mathrm{H}_{24} \mathrm{O}_{5} \mathrm{SBF}_{3} \mathrm{Na}^{+}[\mathrm{M}+\mathrm{Na}]^{+}$, found: 431.1291. FTIR (neat): $v\left(\mathrm{~cm}^{-1}\right)$ 2979, $2935,1501,1424,1381,1350,1319,1250,1210,1140,1016,889,607$. According to GC analysis with $n-\mathrm{C}_{14} \mathrm{H}_{30}$ as internal standard, GC yield of $\mathbf{3 k}$ was $56 \%$ and recovered yield of $1 \mathbf{k}$ was $24 \%$.

4,4,5,5-Tetramethyl-2-(2-(4-(trifluoromethoxy)phenyl)butan-2-yl)-1,3,2-dioxaborolan e (31)

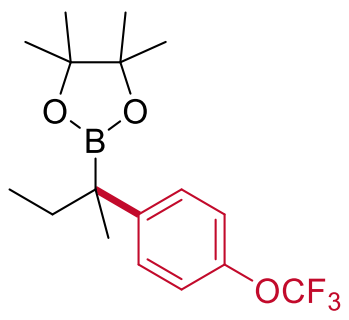

Following GP1, using 11 (57.6 mg, $0.2 \mathrm{mmol})$ and $s$-butyllithium (1.4 M in hexane, $0.16 \mathrm{~mL}, 0.22 \mathrm{mmol})$, flash chromatography eluting with pentane/DCM (4:1) afforded $3 \mathrm{l}$ as yellow sticky oil $\left(45.3 \mathrm{mg}, 66 \%\right.$ yield). $\mathrm{R}_{\mathrm{f}} 0.4$ (pentane/DCM $\left.=3: 1\right) .{ }^{1} \mathrm{H}$ NMR $\left(300 \mathrm{MHz}, \mathrm{CDCl}_{3}\right) \delta 7.37-7.29(\mathrm{~m}, 2 \mathrm{H}), 7.16-7.06(\mathrm{~m}, 2 \mathrm{H}), 1.94-1.77(\mathrm{~m}, 1 \mathrm{H})$, $1.77-1.61(\mathrm{~m}, 1 \mathrm{H}), 1.32(\mathrm{~s}, 3 \mathrm{H}), 1.21(\mathrm{~s}, 6 \mathrm{H}), 1.21(\mathrm{~s}, 6 \mathrm{H}), 0.82(\mathrm{t}, J=7.4 \mathrm{~Hz}, 3 \mathrm{H})$. ${ }^{13} \mathrm{C}$ NMR $\left(75 \mathrm{MHz}, \mathrm{CDCl}_{3}\right) \delta 146.8(\mathrm{q}, J=1.7 \mathrm{~Hz}), 146.1,128.2,120.6(\mathrm{q}, J=256.3$ $\mathrm{Hz}), 120.3,83.5,32.0,24.6,24.6,21.1,9.9$, carbon attached to boron not observed. ${ }^{19} \mathrm{~F}$ NMR $\left(282 \mathrm{MHz}, \mathrm{CDCl}_{3}\right) \delta-57.9 .{ }^{11} \mathrm{~B} \mathrm{NMR}\left(96 \mathrm{MHz}, \mathrm{CDCl}_{3}\right) \delta 34.3$. HRMS (ESI) $m / z=367.1663$ calcd. for $\mathrm{C}_{17} \mathrm{H}_{24} \mathrm{BF}_{3} \mathrm{O}_{3} \mathrm{Na}^{+}[\mathrm{M}+\mathrm{Na}]^{+}$, found: 367.1696 . FTIR 
(neat): $v\left(\mathrm{~cm}^{-1}\right) 2979,2937,1510,1350,1318,1260,1222,1168,1142,1020,965$, 860,662 .

4,4,5,5-Tetramethyl-2-(2-(4-(trifluoromethyl)phenyl)butan-2-yl)-1,3,2-dioxaborolane $(3 \mathrm{~m})$

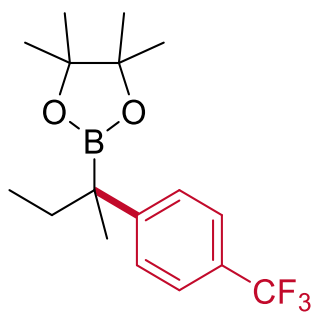

Following GP1, using 1m (54.4 mg, $0.2 \mathrm{mmol})$ and $s$-butyllithium (1.4 M in hexane, $0.16 \mathrm{~mL}, 0.22 \mathrm{mmol})$, flash chromatography eluting with pentane/DCM (4:1) afforded $3 \mathbf{m}$ as yellow sticky oil $\left(43.2 \mathrm{mg}, 66 \%\right.$ yield). $\mathrm{R}_{\mathrm{f}} 0.4$ (pentane/DCM $\left.=3: 1\right) .{ }^{1} \mathrm{H}$ NMR $\left(300 \mathrm{MHz}, \mathrm{CDCl}_{3}\right) \delta 7.53(\mathrm{~d}, J=8.4 \mathrm{~Hz}, 2 \mathrm{H}), 7.42(\mathrm{~d}, J=8.4 \mathrm{~Hz}, 2 \mathrm{H}), 1.95-1.81(\mathrm{~m}$, $1 \mathrm{H}), 1.80-1.66(\mathrm{~m}, 1 \mathrm{H}), 1.34(\mathrm{~s}, 3 \mathrm{H}), 1.21(\mathrm{~s}, 6 \mathrm{H}), 1.21(\mathrm{~s}, 6 \mathrm{H}), 0.82(\mathrm{t}, J=7.4 \mathrm{~Hz}$, $3 \mathrm{H}) .{ }^{13} \mathrm{C} \mathrm{NMR}\left(75 \mathrm{MHz}, \mathrm{CDCl}_{3}\right) \delta 151.7,127.3,127.2(\mathrm{q}, J=32.2 \mathrm{~Hz}), 124.8(\mathrm{q}, J=$ $3.8 \mathrm{~Hz}), 124.6(\mathrm{q}, J=271.5 \mathrm{~Hz}), 83.5,31.8,24.6,24.6,20.8,9.8$, carbon attached to boron not observed. ${ }^{19} \mathrm{~F}$ NMR $\left(282 \mathrm{MHz}, \mathrm{CDCl}_{3}\right) \delta$-62.2. ${ }^{11} \mathrm{~B} \mathrm{NMR}\left(96 \mathrm{MHz}, \mathrm{CDCl}_{3}\right)$ $\delta$ 34.1. HRMS (ESI) $\mathrm{m} / z=351.1714$ calcd. for $\mathrm{C}_{17} \mathrm{H}_{24} \mathrm{O}_{2} \mathrm{BF}_{3} \mathrm{Na}^{+}[\mathrm{M}+\mathrm{Na}]^{+}$, found: 351.1729. FTIR (neat): $v\left(\mathrm{~cm}^{-1}\right)$ 2978, 2938, 2878, 1618, 1460, 1373, 1349, 1324, 1265, 1164, 1139, 1121, 1099, 1069, 1016, 965, 860, 835, 687.

2-(2-(3-Chloro-4-fluorophenyl)butan-2-yl)-4,4,5,5-tetramethyl-1,3,2-dioxaborolane (3n)<smiles>CCC(C)(B1OC(C)(C)C(C)(C)O1)c1ccc(F)c(Cl)c1</smiles>

Following GP1, using 1n $(51.2 \mathrm{mg}, 0.2 \mathrm{mmol})$ and $s$-butyllithium $(1.4 \mathrm{M}$ in hexane, $0.16 \mathrm{~mL}, 0.22 \mathrm{mmol})$, flash chromatography eluting with pentane/DCM (4:1) afforded 3n as yellow sticky oil (35.6 mg, 57\% yield). $\mathrm{R}_{\mathrm{f}} 0.4$ (pentane/DCM $=3: 1$ ). ${ }^{1} \mathrm{H}$ NMR $\left(300 \mathrm{MHz}, \mathrm{CDCl}_{3}\right) \delta 7.25(\mathrm{dd}, J=7.2,2.3 \mathrm{~Hz}, 1 \mathrm{H}), 7.13-7.05(\mathrm{~m}, 1 \mathrm{H}), 6.96(\mathrm{t}, J=$ $8.8 \mathrm{~Hz}, 1 \mathrm{H}), 1.83-1.66(\mathrm{~m}, 1 \mathrm{H}), 1.66-1.51(\mathrm{~m}, 1 \mathrm{H}), 1.21(\mathrm{~s}, 3 \mathrm{H}), 1.13(\mathrm{~s}, 12 \mathrm{H})$, $0.73(\mathrm{t}, J=7.4 \mathrm{~Hz}, 3 \mathrm{H}) .{ }^{13} \mathrm{C} \mathrm{NMR}\left(75 \mathrm{MHz}, \mathrm{CDCl}_{3}\right) \delta 155.9(\mathrm{~d}, J=245.7 \mathrm{~Hz}), 144.4$ $(\mathrm{d}, J=3.7 \mathrm{~Hz}), 128.9,126.7(\mathrm{~d}, J=6.7 \mathrm{~Hz}), 120.1(\mathrm{~d}, J=17.2 \mathrm{~Hz}), 115.8(\mathrm{~d}, J=20.5$ $\mathrm{Hz}), 83.5,32.0,24.6,24.5,20.9,9.8$, carbon attached to boron not observed. ${ }^{19} \mathrm{~F}$ NMR (282 MHz, $\left.\mathrm{CDCl}_{3}\right) \delta-121.4(\mathrm{~s}) .{ }^{11} \mathrm{~B}$ NMR (96 MHz, $\left.\mathrm{CDCl}_{3}\right) \delta 33.8 . \mathbf{H R M S}$ (ESI) $m / z=335.1356$ calcd. for $\mathrm{C}_{16} \mathrm{H}_{23} \mathrm{BClFO}_{2} \mathrm{Na}^{+}[\mathrm{M}+\mathrm{Na}]^{+}$, found: 335.1353 . FTIR (neat): $v\left(\mathrm{~cm}^{-1}\right) 2976,2935,2878,1499,1460,1348,1315,1265,1246,1214,1138$, 1099, 1059, 965, 871, 852, 820, 743, 713, 674, 609, 580 . 
2-(2-(3-methoxyphenyl)butan-2-yl)-4,4,5,5-tetramethyl-1,3,2-dioxaborolane (3o)<smiles>CCC(C)(B1OC(C)(C)C(C)(C)O1)c1cccc(OC)c1</smiles>

Following GP1, using $10(46.8 \mathrm{mg}, 0.2 \mathrm{mmol})$ and $s$-butyllithium $(1.4 \mathrm{M}$ in hexane, $0.16 \mathrm{~mL}, 0.22 \mathrm{mmol})$, flash chromatography eluting with pentane/DCM (1:1) afforded 3o as yellow sticky oil $\left(27.6 \mathrm{mg}, 48 \%\right.$ yield). $\mathrm{R}_{\mathrm{f}} 0.3$ (pentane/DCM $\left.=1: 1\right) .{ }^{1} \mathrm{H} \mathrm{NMR}$ $\left(300 \mathrm{MHz}, \mathrm{CDCl}_{3}\right) \delta 7.19(\mathrm{t}, J=7.9 \mathrm{~Hz}, 1 \mathrm{H}), 6.94-6.86(\mathrm{~m}, 2 \mathrm{H}), 6.68(\mathrm{dd}, J=7.9$, $2.0 \mathrm{~Hz}, 1 \mathrm{H}), 3.79(\mathrm{~s}, 3 \mathrm{H}) 1.95-1.78(\mathrm{~m}, 1 \mathrm{H}), 1.77-1.62(\mathrm{~m}, 1 \mathrm{H}), 1.31(\mathrm{~s}, 3 \mathrm{H}), 1.22$ $(\mathrm{s}, 6 \mathrm{H}), 1.21(\mathrm{~s}, 6 \mathrm{H}), 0.83(\mathrm{t}, J=7.4 \mathrm{~Hz}, 3 \mathrm{H}) .{ }^{13} \mathrm{C} \mathrm{NMR}\left(75 \mathrm{MHz}, \mathrm{CDCl}_{3}\right) \delta 159.4$, 149.2, 128.8, 119.5, 113.1, 110.1, 83.3, 55.0, 31.9, 24.6, 24.6, 21.0, 10.0, carbon attached to boron not observed. ${ }^{11} \mathrm{~B} \mathrm{NMR}\left(96 \mathrm{MHz}, \mathrm{CDCl}_{3}\right) \delta 34.2$. HRMS (ESI) $\mathrm{m} / \mathrm{z}$ $=313.1945$ calcd. for $\mathrm{C}_{17} \mathrm{H}_{27} \mathrm{O}_{3} \mathrm{BNa}^{+}[\mathrm{M}+\mathrm{Na}]^{+}$, found: 313.1960. FTIR (neat): $v$ $\left(\mathrm{cm}^{-1}\right)$ 2977, 2935, 2877, 2836, 1599, 1581, 1486, 1461, 1372, 1347, 1311, 1289, $1253,1215,1166,1139,1041,965,852,776,704,681$.

2-(2-(3-Fluorophenyl)butan-2-yl)-4,4,5,5-tetramethyl-1,3,2-dioxaborolane (3p)<smiles>CCC(C)(B1OC(C)(C)C(C)(C)O1)c1cccc(F)c1</smiles>

Following GP1, using 1p (44.4 mg, $0.2 \mathrm{mmol})$ and $s$-butyllithium (1.4 $\mathrm{M}$ in hexane, $0.16 \mathrm{~mL}, 0.22 \mathrm{mmol})$, flash chromatography eluting with pentane/DCM (5:1) afforded $3 p$ as yellow sticky oil $\left(25.5 \mathrm{mg}, 46 \%\right.$ yield). $\mathrm{R}_{\mathrm{f}} 0.3$ (pentane/DCM $\left.=4: 1\right) .{ }^{1} \mathrm{H}$ NMR $\left(300 \mathrm{MHz}, \mathrm{CDCl}_{3}\right) \delta 7.20-7.09(\mathrm{~m}, 1 \mathrm{H}), 7.04-6.91(\mathrm{~m}, 2 \mathrm{H}), 6.79-6.69(\mathrm{~m}, 1 \mathrm{H})$, $1.84-1.70(\mathrm{~m}, 1 \mathrm{H}), 1.70-1.55(\mathrm{~m}, 1 \mathrm{H}), 1.23(\mathrm{~s}, 3 \mathrm{H}), 1.14(\mathrm{~s}, 6 \mathrm{H}), 1.13(\mathrm{~s}, 6 \mathrm{H}), 0.74$ $(\mathrm{t}, J=7.4 \mathrm{~Hz}, 3 \mathrm{H}) .{ }^{13} \mathrm{C} \mathrm{NMR}\left(75 \mathrm{MHz}, \mathrm{CDCl}_{3}\right) \delta 163.0(\mathrm{~d}, J=243.7 \mathrm{~Hz}), 150.3(\mathrm{~d}, J$ $=6.7 \mathrm{~Hz}), 129.1(\mathrm{~d}, J=8.4 \mathrm{~Hz}), 122.7(\mathrm{~d}, J=2.6 \mathrm{~Hz}), 113.9(\mathrm{~d}, J=21.5 \mathrm{~Hz}), 111.7$ $(\mathrm{d}, J=21.1 \mathrm{~Hz}), 83.4,31.8,24.6,24.6,20.8,9.8$, carbon attached to boron not observed. ${ }^{19} \mathrm{~F}$ NMR $\left(282 \mathrm{MHz}, \mathrm{CDCl}_{3}\right) \delta-114.1(\mathrm{~s}) .{ }^{11} \mathrm{~B} \mathrm{NMR}\left(96 \mathrm{MHz}, \mathrm{CDCl}_{3}\right) \delta$ 33.8. HRMS (ESI) $\mathrm{m} / z=301.1746$ calcd. for $\mathrm{C}_{16} \mathrm{H}_{24} \mathrm{BFO}_{2} \mathrm{Na}^{+}[\mathrm{M}+\mathrm{Na}]^{+}$, found: 301.1755. FTIR (neat): $v\left(\mathrm{~cm}^{-1}\right)$ 2978, 2933, 2878, 1612, 1583, 1486, 1460, 1372, 1349, 1314, 1266, 1242, 1215, 1164, 1139, 1120, 1100, 1042, 965, 914, 865, 851, 780, $702,677,586$.

2-(2-(3-Chlorophenyl)butan-2-yl)-4,4,5,5-tetramethyl-1,3,2-dioxaborolane (3q) 


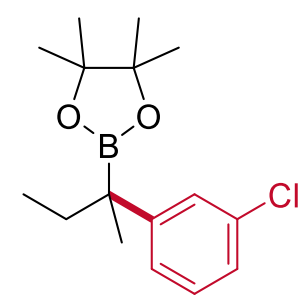

Following GP1, using 1q (47.6 mg, $0.2 \mathrm{mmol})$ and $s$-butyllithium $(1.4 \mathrm{M}$ in hexane, $0.16 \mathrm{~mL}, 0.22 \mathrm{mmol})$, flash chromatography eluting with pentane/DCM (5:1) afforded 3q as light yellow sticky oil (31.2 $\mathrm{mg}, 53 \%$ yield). $\mathrm{R}_{\mathrm{f}} 0.4$ (pentane/DCM $\left.=4: 1\right) .{ }^{1} \mathrm{H}$ NMR (300 MHz, $\left.\mathrm{CDCl}_{3}\right) \delta 7.25-7.20(\mathrm{~m}, 1 \mathrm{H}), 7.15-7.09(\mathrm{~m}, 2 \mathrm{H}), 7.07-6.99(\mathrm{~m}$, $1 \mathrm{H}), 1.84-1.69(\mathrm{~m}, 1 \mathrm{H}), 1.69-1.54(\mathrm{~m}, 1 \mathrm{H}), 1.23(\mathrm{~s}, 3 \mathrm{H}), 1.14(\mathrm{~s}, 6 \mathrm{H}), 1.14(\mathrm{~s}, 6 \mathrm{H})$, $0.74(\mathrm{t}, J=7.4 \mathrm{~Hz}, 3 \mathrm{H}) .{ }^{13} \mathrm{C} \mathrm{NMR}\left(75 \mathrm{MHz}, \mathrm{CDCl}_{3}\right) \delta 149.6,133.9,129.1,127.1$, 125.3, 125.1, 83.4, 31.8, 24.6, 24.5, 20.8, 9.9, carbon attached to boron not observed. ${ }^{11} \mathrm{~B}$ NMR $\left(96 \mathrm{MHz}, \mathrm{CDCl}_{3}\right) \delta$ 33.7. HRMS (ESI) $\mathrm{m} / \mathrm{z}=317.1450$ calcd. for $\mathrm{C}_{16} \mathrm{H}_{24} \mathrm{BClO}_{2} \mathrm{Na}^{+}[\mathrm{M}+\mathrm{Na}]^{+}$, found: 317.1454. FTIR (neat): $v\left(\mathrm{~cm}^{-1}\right)$ 2976, 2935, 2876, 1593, 1567, 1460, 1372, 1348, 1314, 1263, 1214, 1167, 1138, 1107, 1043, 965, 874, $849,781,700,668$.

4,4,5,5-Tetramethyl-2-(2-(3-(trifluoromethyl)phenyl)butan-2-yl)-1,3,2-dioxaborolane (3r)<smiles>CCC(C)(B1OC(C)(C)C(C)(C)O1)c1cccc(C(F)(F)F)c1</smiles>

Following GP1, using 1r (54.4 mg, $0.2 \mathrm{mmol})$ and $s$-butyllithium (1.4 $\mathrm{M}$ in hexane, $0.16 \mathrm{~mL}, 0.22 \mathrm{mmol})$, flash chromatography eluting with pentane/DCM (4:1) afforded $3 \mathbf{r}$ as light yellow sticky oil (41.9 $\mathrm{mg}, 64 \%$ yield). $\mathrm{R}_{\mathrm{f}} 0.5$ (pentane/DCM $\left.=3: 1\right) .{ }^{1} \mathrm{H}$ NMR $\left(300 \mathrm{MHz}, \mathrm{CDCl}_{3}\right) \delta 7.59(\mathrm{~s}, 1 \mathrm{H}), 7.54-7.46(\mathrm{~m}, 1 \mathrm{H}), 7.43-7.35(\mathrm{~m}, 2 \mathrm{H})$, $1.96-1.81(\mathrm{~m}, 1 \mathrm{H}), 1.80-1.64(\mathrm{~m}, 1 \mathrm{H}), 1.35(\mathrm{~s}, 3 \mathrm{H}), 1.22(\mathrm{~s}, 12 \mathrm{H}), 0.83(\mathrm{t}, J=7.4$ $\mathrm{Hz}, 3 \mathrm{H}) .{ }^{13} \mathrm{C}$ NMR $\left(75 \mathrm{MHz}, \mathrm{CDCl}_{3}\right) \delta 148.4,130.4-130.2(\mathrm{~m}), 130.2(\mathrm{q}, J=31.6$ $\mathrm{Hz}), 128.3,124.5$ (d, $J=272.3 \mathrm{~Hz}), 123.9$ (q, $J=3.8 \mathrm{~Hz}), 121.9$ (q, $J=3.8 \mathrm{~Hz}), 83.5$, $31.9,24.6,24.5,20.9,9.9$, carbon attached to boron not observed. ${ }^{19} \mathrm{~F}$ NMR (282 $\left.\mathrm{MHz}, \mathrm{CDCl}_{3}\right) \delta-62.5$ (s). ${ }^{11} \mathrm{~B}$ NMR $\left(96 \mathrm{MHz}, \mathrm{CDCl}_{3}\right) \delta 34.1$. HRMS (ESI) $m / z=$ 351.1714 calcd. for $\mathrm{C}_{17} \mathrm{H}_{24} \mathrm{BF}_{3} \mathrm{O}_{2} \mathrm{Na}^{+}[\mathrm{M}+\mathrm{Na}]^{+}$, found: 351.1727. FTIR (neat): $v$ $\left(\mathrm{cm}^{-1}\right)$ 2978, 2937, 2877, 1461, 1350, 1326, 1265, 1164, 1123, 1076, 965, 851, 803, 704.

3-(2-(4,4,5,5-Tetramethyl-1,3,2-dioxaborolan-2-yl)butan-2-yl)phenyl trifluoromethanesulfonate $(3 \mathbf{s})$ 


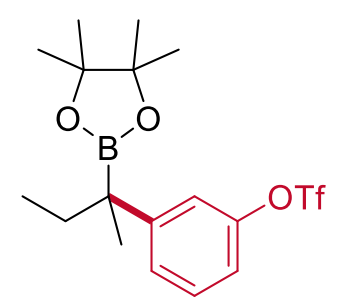

Following GP1, using 1s (70.4 mg, $0.2 \mathrm{mmol})$ and $s$-butyllithium (1.4 M in hexane, $0.16 \mathrm{~mL}, 0.22 \mathrm{mmol})$, flash chromatography eluting with pentane/DCM (3:1) afforded $3 \mathrm{~s}$ as yellow sticky oil $\left(48.1 \mathrm{mg}, 59 \%\right.$ yield). $\mathrm{R}_{\mathrm{f}} 0.4$ (pentane/DCM $\left.=2: 1\right) .{ }^{1} \mathrm{H}$ NMR $\left(300 \mathrm{MHz}, \mathrm{CDCl}_{3}\right) \delta 7.29-7.23(\mathrm{~m}, 2 \mathrm{H}), 7.18(\mathrm{~s}, 1 \mathrm{H}), 7.02-6.92(\mathrm{~m}, 1 \mathrm{H}), 1.84-$ $1.70(\mathrm{~m}, 1 \mathrm{H}), 1.70-1.55(\mathrm{~m}, 1 \mathrm{H}), 1.25(\mathrm{~s}, 3 \mathrm{H}), 1.14(\mathrm{~s}, 6 \mathrm{H}), 1.13(\mathrm{~s}, 6 \mathrm{H}), 0.73(\mathrm{t}, J=$ $7.4 \mathrm{~Hz}, 3 \mathrm{H}) .{ }^{13} \mathrm{C} \mathrm{NMR}\left(75 \mathrm{MHz}, \mathrm{CDCl}_{3}\right) \delta 150.8,149.7,129.5,126.8,120.2,118.8(\mathrm{q}$, $J=320.8 \mathrm{~Hz}), 117.7,83.6,32.0,24.6,24.5,20.8,9.8$, carbon attached to boron not observed. ${ }^{19} \mathrm{~F}$ NMR $\left(282 \mathrm{MHz}, \mathrm{CDCl}_{3}\right) \delta-73.0(\mathrm{~s}) .{ }^{11} \mathrm{~B} \mathrm{NMR}\left(96 \mathrm{MHz}, \mathrm{CDCl}_{3}\right) \delta 33.8$. HRMS (ESI) $m / z=431.1282$ calcd. for $\mathrm{C}_{17} \mathrm{H}_{24} \mathrm{BF}_{3} \mathrm{O}_{5} \mathrm{SNa}^{+}[\mathrm{M}+\mathrm{Na}]^{+}$, found: 431.1299 . FTIR (neat): $v\left(\mathrm{~cm}^{-1}\right)$ 2978, 2936, 2878, 1611, 1575, 1423, 1381, 1351, 1319, 1250 , $1212,1141,926,848,799,607$. According to $\mathrm{GC}$ analysis with $n-\mathrm{C}_{14} \mathrm{H}_{30}$ as internal standard, GC yield of $3 \mathrm{~s}$ was $60 \%$ and recovered yield of $1 \mathrm{~s}$ was $24 \%$.

2-(2-(2-Fluorophenyl)butan-2-yl)-4,4,5,5-tetramethyl-1,3,2-dioxaborolane (3t)<smiles>CCC(C)(B1OC(C)(C)C(C)(C)O1)c1ccccc1F</smiles>

Following GP1, using 1t (44.4 mg, $0.2 \mathrm{mmol})$ and $s$-butyllithium (1.4 $\mathrm{M}$ in hexane, $0.16 \mathrm{~mL}, 0.22 \mathrm{mmol})$, flash chromatography eluting with pentane/DCM (5:1) afforded 3t as yellow sticky oil $\left(21.0 \mathrm{mg}, 38 \%\right.$ yield). $\mathrm{R}_{\mathrm{f}} 0.3$ (pentane/DCM $\left.=3: 1\right) .{ }^{1} \mathrm{H}$ NMR $\left(300 \mathrm{MHz}, \mathrm{CDCl}_{3}\right) \delta 7.22-7.12(\mathrm{~m}, 1 \mathrm{H}), 7.11-6.96(\mathrm{~m}, 2 \mathrm{H}), 6.94-6.84(\mathrm{~m}, 1 \mathrm{H})$, $1.84-1.57(\mathrm{~m}, 2 \mathrm{H}), 1.21(\mathrm{~s}, 3 \mathrm{H}), 1.18(\mathrm{~s}, 12 \mathrm{H}), 0.70(\mathrm{t}, J=7.5 \mathrm{~Hz}, 3 \mathrm{H}) .{ }^{13} \mathrm{C} \mathrm{NMR}$ $\left(75 \mathrm{MHz}, \mathrm{CDCl}_{3}\right) \delta 161.1(\mathrm{~d}, J=242.9 \mathrm{~Hz}), 134.6(\mathrm{~d}, J=14.4 \mathrm{~Hz}), 127.5(\mathrm{~d}, J=5.5$ $\mathrm{Hz}), 126.7$ (d, $J=8.6 \mathrm{~Hz}), 123.9$ (d, $J=3.2 \mathrm{~Hz}), 114.8$ (d, $J=23.2 \mathrm{~Hz}), 83.3,29.7$, 24.6, 20.7, 9.2, carbon attached to boron not observed. ${ }^{19} \mathrm{~F} \mathrm{NMR}\left(282 \mathrm{MHz}, \mathrm{CDCl}_{3}\right)$ $\delta-112.4$ (s). ${ }^{11} \mathrm{~B}$ NMR $\left(96 \mathrm{MHz}, \mathrm{CDCl}_{3}\right) \delta 34.1$. HRMS (ESI) $\mathrm{m} / z=301.1746 \mathrm{calcd}$. for $\mathrm{C}_{16} \mathrm{H}_{24} \mathrm{BFO}_{2} \mathrm{Na}^{+}[\mathrm{M}+\mathrm{Na}]^{+}$, found: 301.1755 . FTIR (neat): $v\left(\mathrm{~cm}^{-1}\right)$ 2977, 2929, 2876, 1487, 1462, 1447, 1380, 1351, 1317, 1266, 1218, 1198, 1142, 1114, 1101, 1032, $965,870,848,808,753,684$. According to $\mathrm{GC}$ analysis with $n-\mathrm{C}_{14} \mathrm{H}_{30}$ as internal standard, GC yield of $\mathbf{3 t}$ was $39 \%$ and recovered yield of $\mathbf{1 t}$ was $23 \%$.

2-(2-(trifluoromethyl)phenyl)propan-2-ol (3u-1) 
<smiles>CC(O)(c1ccccc1)c1ccccc1C(F)(F)F</smiles>

Following GP1, using 1u (54.4 mg, $0.2 \mathrm{mmol})$ and isopropyllithium (0.7 $\mathrm{M}$ in hexane, $0.31 \mathrm{~mL}, 0.22 \mathrm{mmol}$ ) afford the crude alkylboronic ester $3 \mathbf{u}$. According to crude GC analysis with $n-\mathrm{C}_{14} \mathrm{H}_{30}$ as internal standard, recovered yield of $\mathbf{1 u}$ was $12 \%$. After oxidation workup with $\mathrm{H}_{2} \mathrm{O}_{2} / \mathrm{NaOH},{ }^{\mathrm{S} 17}$ flash chromatography eluting with pentane/diethylether (3:1) afforded 3u-1 as light yellow liquid (22.2 mg, 54\% yield). $\mathrm{R}_{\mathrm{f}} 0.4$ (pentane/Et $\left.2 \mathrm{O}=3: 1\right) .{ }^{1} \mathrm{H}$ NMR $\left(300 \mathrm{MHz}, \mathrm{CDCl}_{3}\right) \delta 7.68(\mathrm{~m}, 1 \mathrm{H}), 7.59-7.51$ $(\mathrm{m}, 1 \mathrm{H}), 7.47-7.37(\mathrm{~m}, 1 \mathrm{H}), 7.27(\mathrm{~m}, 1 \mathrm{H}), 1.87(\mathrm{~s}, 1 \mathrm{H}), 1.62(\mathrm{~s}, 6 \mathrm{H}) .{ }^{13} \mathrm{C}$ NMR $(75$ $\left.\mathrm{MHz}, \mathrm{CDCl}_{3}\right) \delta 148.1,131.6,128.0,127.9(\mathrm{q}, J=7.2 \mathrm{~Hz}), 127.0(\mathrm{q}, J=30.8 \mathrm{~Hz})$, 126.9, 124.9 (q, $J=271.4 \mathrm{~Hz}), 73.6,32.5(\mathrm{q}, J=2.4 \mathrm{~Hz}) .{ }^{19} \mathrm{~F}$ NMR $\left(282 \mathrm{MHz}, \mathrm{CDCl}_{3}\right)$ $\delta-54.2$.

Following GP3, using $1 \mathbf{u}(54.4 \mathrm{mg}, 0.2 \mathrm{mmol})$ and isopropyllithium (0.7 M in hexane, $0.31 \mathrm{~mL}, 0.22 \mathrm{mmol}$ ) afford the crude alkylboronic ester $3 \mathbf{u}$. According to crude GC analysis with $n-\mathrm{C}_{14} \mathrm{H}_{30}$ as internal standard, recovered yield of $\mathbf{1} \mathbf{u}$ was $8 \%$. After oxidation workup with $\mathrm{H}_{2} \mathrm{O}_{2} / \mathrm{NaOH},{ }^{\mathrm{S} 17}$ flash chromatography eluting with pentane/diethylether (3:1) afforded $\mathbf{3 u - 1}$ as colorless liquid $\left(20.5 \mathrm{mg}, 50 \%\right.$ yield). $\mathrm{R}_{\mathrm{f}}$ 0.4 (pentane/Et $2 \mathrm{O}=3: 1) .{ }^{1} \mathrm{H}$ NMR $\left(300 \mathrm{MHz}, \mathrm{CDCl}_{3}\right) \delta 7.68(\mathrm{~m}, 1 \mathrm{H}), 7.59-7.51(\mathrm{~m}$, 1H), $7.47-7.37(\mathrm{~m}, 1 \mathrm{H}), 7.27(\mathrm{~m}, 1 \mathrm{H}), 1.87(\mathrm{~s}, 1 \mathrm{H}), 1.62(\mathrm{~s}, 6 \mathrm{H}) .{ }^{13} \mathrm{C} \mathrm{NMR}(75 \mathrm{MHz}$, $\left.\mathrm{CDCl}_{3}\right) \delta 148.1,131.6,128.0,127.9(\mathrm{q}, J=7.2 \mathrm{~Hz}), 127.0(\mathrm{q}, J=30.8 \mathrm{~Hz}), 126.9$, $124.9(\mathrm{q}, J=271.4 \mathrm{~Hz}), 73.6,32.5(\mathrm{q}, J=2.4 \mathrm{~Hz}) .{ }^{19} \mathrm{~F}$ NMR $\left(282 \mathrm{MHz}, \mathrm{CDCl}_{3}\right) \delta$ -54.2 .

2-(2-(3,5-Dichlorophenyl)butan-2-yl)-4,4,5,5-tetramethyl-1,3,2-dioxaborolane (3v)

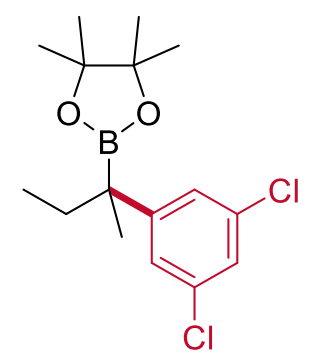

Following GP1, using 1v (54.6 mg, $0.2 \mathrm{mmol})$ and $s$-butyllithium (1.4 M in hexane, $0.16 \mathrm{~mL}, 0.22 \mathrm{mmol})$, flash chromatography eluting with pentane/DCM (5:1) afforded $3 \mathrm{v}$ as light yellow sticky oil $\left(31.8 \mathrm{mg}, 48 \%\right.$ yield). $\mathrm{R}_{\mathrm{f}} 0.5$ (pentane/DCM $\left.=4: 1\right) .{ }^{1} \mathrm{H}$ NMR $\left(300 \mathrm{MHz}, \mathrm{CDCl}_{3}\right) \delta 7.19(\mathrm{~d}, J=1.8 \mathrm{~Hz}, 2 \mathrm{H}), 7.13(\mathrm{t}, J=1.8 \mathrm{~Hz}, 1 \mathrm{H}), 1.91-$ $1.74(\mathrm{~m}, 1 \mathrm{H}), 1.75-1.61(\mathrm{~m}, 1 \mathrm{H}), 1.28(\mathrm{~s}, 3 \mathrm{H}), 1.21(\mathrm{~s}, 12 \mathrm{H}), 0.81(\mathrm{t}, J=7.4 \mathrm{~Hz}, 3 \mathrm{H})$. ${ }^{13} \mathrm{C} \mathrm{NMR}\left(75 \mathrm{MHz}, \mathrm{CDCl}_{3}\right) \delta 151.2,134.5,125.7,125.2,83.7,31.7,24.6,24.5,20.6$, 9.8 , carbon attached to boron not observed. ${ }^{11} \mathrm{~B} \mathrm{NMR}\left(96 \mathrm{MHz}, \mathrm{CDCl}_{3}\right) \delta 33.5$. HRMS (EI) $m / z=328.1163$ calcd. for $\mathrm{C}_{16} \mathrm{H}_{23} \mathrm{BCl}_{2} \mathrm{O}_{2}{ }^{+}[\mathrm{M}]^{+}$, found: 328.1162. FTIR (neat): v ( $\left.\mathrm{cm}^{-1}\right)$ 2977, 2938, 2883, 1586, 1561, 1459, 1415, 1381, 1347, 1319, 1139, $852,798,692$. 
Following GP3, using 1v (54.6 mg, $0.2 \mathrm{mmol})$ and $s$-butyllithium (1.4 M in hexane, $0.16 \mathrm{~mL}, 0.22 \mathrm{mmol})$, flash chromatography eluting with pentane/DCM (5:1) afforded $3 \mathrm{v}$ as colorless sticky oil (33.7 $\mathrm{mg}, 51 \%$ yield). $\mathrm{R}_{\mathrm{f}} 0.5$ (pentane/DCM $=4: 1$ ). ${ }^{1} \mathrm{H}$ NMR $\left(300 \mathrm{MHz}, \mathrm{CDCl}_{3}\right) \delta 7.19(\mathrm{~d}, J=1.8 \mathrm{~Hz}, 2 \mathrm{H}), 7.13(\mathrm{t}, J=1.8 \mathrm{~Hz}, 1 \mathrm{H}), 1.91-1.74(\mathrm{~m}$, $1 \mathrm{H}), 1.75-1.61(\mathrm{~m}, 1 \mathrm{H}), 1.28(\mathrm{~s}, 3 \mathrm{H}), 1.21(\mathrm{~s}, 12 \mathrm{H}), 0.81(\mathrm{t}, J=7.4 \mathrm{~Hz}, 3 \mathrm{H}),{ }^{13} \mathrm{C}$ NMR $\left(75 \mathrm{MHz}, \mathrm{CDCl}_{3}\right) \delta 151.2,134.5,125.7,125.2,83.7,31.7,24.6,24.5,20.6,9.8$, carbon attached to boron not observed. ${ }^{11} \mathrm{~B} \mathrm{NMR}\left(96 \mathrm{MHz}, \mathrm{CDCl}_{3}\right) \delta 33.5$. HRMS (EI) $m / z=328.1163$ calcd. for $\mathrm{C}_{16} \mathrm{H}_{23} \mathrm{BCl}_{2} \mathrm{O}_{2}{ }^{+}[\mathrm{M}]^{+}$, found: 328.1162. FTIR (neat): $v$ $\left(\mathrm{cm}^{-1}\right)$ 2977, 2938, 2883, 1586, 1561, 1459, 1415, 1381, 1347, 1319, 1139, 852, 798, 692. According to crude GC analysis with $n-\mathrm{C}_{14} \mathrm{H}_{30}$ as internal standard, crude yield of $\mathbf{3 v}$ was $51 \%$ and recovered yield of $\mathbf{1 v}$ was $16 \%$.

4,4,5,5-Tetramethyl-2-(1-phenylcyclobutyl)-1,3,2-dioxaborolane (3w)<smiles>CC1(C)OB(C2(c3ccccc3)CCC2)OC1(C)C</smiles>

Following GP1, using cyclobutylboronic acid pinacol ester $(36.4 \mathrm{mg}, 0.2 \mathrm{mmol})$ and phenyllithium (1.9 $\mathrm{M}$ in dibutylether, $0.12 \mathrm{~mL}, 0.22 \mathrm{mmol})$, flash chromatography eluting with pentane/DCM (5:1) afforded $3 \mathbf{w}$ as yellow sticky oil $(22.0 \mathrm{mg}, 43 \%$ yield). $\mathrm{R}_{\mathrm{f}} 0.4$ (pentane/DCM = 3:1). ${ }^{1} \mathrm{H}$ NMR $\left(300 \mathrm{MHz}, \mathrm{CDCl}_{3}\right) \delta 7.23-7.13(\mathrm{~m}$, $2 \mathrm{H}), 7.10-6.96(\mathrm{~m}, 3 \mathrm{H}), 2.55-2.39(\mathrm{~m}, 2 \mathrm{H}), 2.29-2.12(\mathrm{~m}, 2 \mathrm{H}), 2.06-1.86(\mathrm{~m}$, $1 \mathrm{H}), 1.84-1.68(\mathrm{~m}, 1 \mathrm{H}), 1.11(\mathrm{~s}, 12 \mathrm{H}) .{ }^{13} \mathrm{C} \mathrm{NMR}\left(75 \mathrm{MHz}, \mathrm{CDCl}_{3}\right) \delta 148.9,127.9$, $125.5,124.4,83.4,32.0,24.5,18.8$, carbon attached to boron not observed. ${ }^{11} \mathrm{~B} \mathrm{NMR}$ $\left(96 \mathrm{MHz}, \mathrm{CDCl}_{3}\right) \delta$ 34.1. HRMS (ESI) $\mathrm{m} / z=281.1683$ calcd. for $\mathrm{C}_{16} \mathrm{H}_{23} \mathrm{BO}_{2} \mathrm{Na}^{+}$ [M+Na $]^{+}$, found: 281.1680. FTIR (neat): $v\left(\mathrm{~cm}^{-1}\right)$ 2976, 2938, 2868, 1599, 1493, 1468, 1445, 1371, 1352, 1311, 1273, 1165, 1147, 1120, 965, 867, 842, 769, 736, 699.

4,4,5,5-Tetramethyl-2-(1-phenylcyclopentyl)-1,3,2-dioxaborolane (3x)

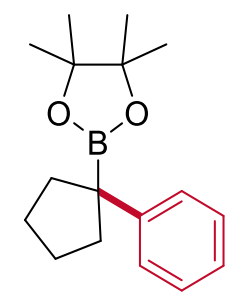

Following GP1, using cyclopentylboronic acid pinacol ester (39.2 mg, $0.2 \mathrm{mmol})$ and phenyllithium (1.9 $\mathrm{M}$ in dibutylether, $0.12 \mathrm{~mL}, 0.22 \mathrm{mmol})$, flash chromatography eluting with pentane/DCM (4:1) afforded 3x as yellow sticky oil ( $22.0 \mathrm{mg}, 40 \%$ yield). $\mathrm{R}_{\mathrm{f}} 0.3$ (pentane/DCM = 3:1). ${ }^{1} \mathrm{H}$ NMR $\left(300 \mathrm{MHz}, \mathrm{CDCl}_{3}\right) \delta 7.25-7.11(\mathrm{~m}, 4 \mathrm{H}), 7.10$ - $6.97(\mathrm{~m}, 1 \mathrm{H}), 2.38-2.06(\mathrm{~m}, 2 \mathrm{H}), 1.75-1.42(\mathrm{~m}, 6 \mathrm{H}), 1.06(\mathrm{~s}, 12 \mathrm{H}) .{ }^{13} \mathrm{C}$ NMR $(75$ $\left.\mathrm{MHz}, \mathrm{CDCl}_{3}\right) \delta 147.2,127.9,127.0,124.7,83.3,35.2,24.6,24.4$, carbon attached to 
boron not observed. ${ }^{11} \mathrm{~B}$ NMR $\left(96 \mathrm{MHz}, \mathrm{CDCl}_{3}\right) \delta$ 34.2. HRMS (ESI) $\mathrm{m} / z=$ 295.1840 calcd. for $\mathrm{C}_{17} \mathrm{H}_{25} \mathrm{BO}_{2} \mathrm{Na}^{+}[\mathrm{M}+\mathrm{Na}]^{+}$, found: 295.1853 . FTIR (neat): $v\left(\mathrm{~cm}^{-1}\right)$ 2979, 2960, 2870, 1351, 1309, 1265, 1141, 853, 735, 700, 617. According to crude GC analysis with $n-\mathrm{C}_{14} \mathrm{H}_{30}$ as internal standard, crude yield of $\mathbf{3 x}$ was $43 \%$ and recovered yield of phenylboronic acid pinacol ester was $16 \%$.

Following GP3, using cyclopentylboronic acid pinacol ester (39.2 mg, $0.2 \mathrm{mmol})$ and phenyllithium (1.9 $\mathrm{M}$ in dibutylether, $0.12 \mathrm{~mL}, 0.22 \mathrm{mmol})$, flash chromatography eluting with pentane/DCM (4:1) afforded 3x as yellow sticky oil (25.0 $\mathrm{mg}, 46 \%$ yield). $\mathrm{R}_{\mathrm{f}} 0.3$ (pentane/DCM = 3:1). ${ }^{1} \mathrm{H} \mathrm{NMR}\left(300 \mathrm{MHz}, \mathrm{CDCl}_{3}\right) \delta 7.25-7.11(\mathrm{~m}, 4 \mathrm{H}), 7.10$ $-6.97(\mathrm{~m}, 1 \mathrm{H}), 2.38-2.06(\mathrm{~m}, 2 \mathrm{H}), 1.75-1.42(\mathrm{~m}, 6 \mathrm{H}), 1.06(\mathrm{~s}, 12 \mathrm{H}) .{ }^{13} \mathrm{C}$ NMR $(75$ $\left.\mathrm{MHz}_{2} \mathrm{CDCl}_{3}\right) \delta 147.2,127.9,127.0,124.7,83.3,35.2,24.6,24.4$, carbon attached to boron not observed. ${ }^{11} \mathrm{~B} \mathrm{NMR}\left(96 \mathrm{MHz}, \mathrm{CDCl}_{3}\right) \delta 34.2$. HRMS (ESI) $\mathrm{m} / \mathrm{z}=$ 295.1840 calcd. for $\mathrm{C}_{17} \mathrm{H}_{25} \mathrm{BO}_{2} \mathrm{Na}^{+}[\mathrm{M}+\mathrm{Na}]^{+}$, found: 295.1853. FTIR (neat): $v\left(\mathrm{~cm}^{-1}\right)$ 2979, 2960, 2870, 1351, 1309, 1265, 1141, 853, 735, 700, 617. According to crude GC analysis with $n-\mathrm{C}_{14} \mathrm{H}_{30}$ as internal standard, crude yield of $\mathbf{3 x}$ was $47 \%$ and recovered yield of phenylboronic acid pinacol ester was $10 \%$.

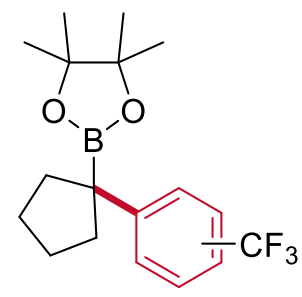

trifluoromethylated $\mathbf{3 x}$

About $10 \%$ trifluoromethylated $\mathbf{3 x}(\mathrm{o} / \mathrm{p}=1: 1.2)$ was also detected by crude GC and GC/MS.

4,4,5,5-Tetramethyl-2-(1-(4-(2-methyl-1,3-dioxolan-2-yl)phenyl)cyclopentyl)-1,3,2-di oxaborolane $(\mathbf{3 y})$

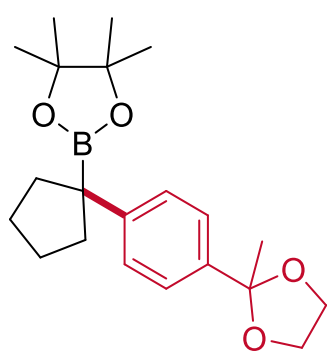

Following GP1, using 1y (58.0 mg, $0.2 \mathrm{mmol})$ and cyclopentyllithium $(0.55 \mathrm{M}$ in hexane, $0.40 \mathrm{~mL}, 0.22 \mathrm{mmol}$ ), flash chromatography eluting with DCM (4:1) afforded 3y as light yellow solid (30.0 mg, $42 \%$ yield). $\mathrm{R}_{\mathrm{f}} 0.2(\mathrm{DCM}) . \mathrm{m} . \mathrm{p}=87-89{ }^{\circ} \mathrm{C} .{ }^{1} \mathrm{H}$ NMR (300 MHz, $\left.\mathrm{CDCl}_{3}\right) \delta 7.27-7.19(\mathrm{~m}, 2 \mathrm{H}), 7.17-7.08(\mathrm{~m}, 2 \mathrm{H}), 3.98-3.82(\mathrm{~m}$, $2 \mathrm{H}), 3.75-3.58(\mathrm{~m}, 2 \mathrm{H}), 2.35-2.05(\mathrm{~m}, 2 \mathrm{H}), 1.67-1.46(\mathrm{~m}, 9 \mathrm{H}), 1.03(\mathrm{~s}, 12 \mathrm{H}) .{ }^{13} \mathrm{C}$ NMR $\left(75 \mathrm{MHz}, \mathrm{CDCl}_{3}\right) \delta 146.8,139.5,126.7,124.8,109.0,83.3,64.4,35.3,27.5$, 24.6, 24.4, carbon attached to boron not observed. ${ }^{11} \mathrm{~B} \mathrm{NMR}\left(96 \mathrm{MHz}, \mathrm{CDCl}_{3}\right) \delta 34.2$. HRMS (ESI) $m / z=381.2208$ calcd. for $\mathrm{C}_{21} \mathrm{H}_{31} \mathrm{BO}_{2} \mathrm{Na}^{+}[\mathrm{M}+\mathrm{Na}]^{+}$, found: 381.2217. 
FTIR (neat): v $\left(\mathrm{cm}^{-1}\right)$ 2978, 2952, 2868, 1610, 1508, 1372, 1353, 1314, 1258, 1198, 1167, 1142, 1041, 1019, 949, 870, 856, 833.

4,4,5,5-Tetramethyl-2-(2-((8R,9S,13S,14S)-13-methyl-6,7,8,9,11,12,13,14,15,16-deca hydrospiro[cyclopenta[a]phenanthrene-17,2'-[1,3]dioxolan]-3-yl)propan-2-yl)-1,3,2-d ioxaborolane (3z)

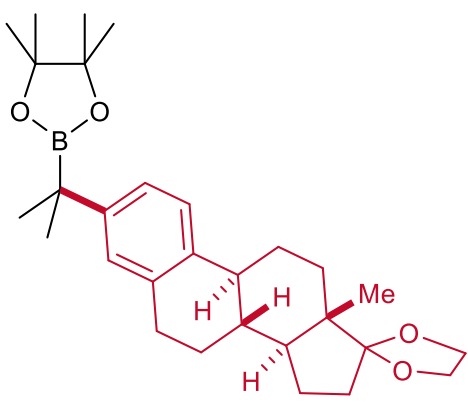

Following GP1, using $\mathbf{1 z}(84.8 \mathrm{mg}, 0.2 \mathrm{mmol})$ and isopropyllithium $(0.7 \mathrm{M}$ in pentane, $0.31 \mathrm{~mL}, 0.22 \mathrm{mmol}$ ), flash chromatography eluting with DCM afforded $\mathbf{3 z}$ as light yellow solid (38.2 mg, 41\% yield). $\mathrm{R}_{\mathrm{f}} 0.1$ (DCM). M.p.: 66-68 ${ }^{\circ} \mathrm{C} . \quad[\alpha]{ }_{D}^{24}$ $+27\left(c 0.5 \mathrm{CHCl}_{3}\right) .{ }^{1} \mathrm{H} \mathrm{NMR}\left(300 \mathrm{MHz}, \mathrm{CDCl}_{3}\right) \delta 7.20(\mathrm{~d}, J=8.2 \mathrm{~Hz}, 1 \mathrm{H}), 7.07(\mathrm{dd}$, $J=8.2,1.8 \mathrm{~Hz}, 1 \mathrm{H}), 7.01(\mathrm{~s}, 1 \mathrm{H}), 4.04-3.82(\mathrm{~m}, 4 \mathrm{H}), 2.97-2.77(\mathrm{~m}, 2 \mathrm{H}), 2.43-$ $2.19(\mathrm{~m}, 2 \mathrm{H}), 2.14-1.96(\mathrm{~m}, 1 \mathrm{H}), 1.95-1.70(\mathrm{~m}, 4 \mathrm{H}), 1.69-1.35(\mathrm{~m}, 6 \mathrm{H}), 1.31(\mathrm{~s}$, $6 \mathrm{H}), 1.22$ (s, 12H), 0.88 (s, 3H). ${ }^{13} \mathrm{C}$ NMR $\left(75 \mathrm{MHz}, \mathrm{CDCl}_{3}\right) \delta$ 145.7, 136.9, 136.1, 126.6, 125.0, 123.8, 119.5, 83.2, 65.2, 64.6, 49.5, 46.2, 43.9, 38.9, 34.3, 30.8, 29.8, $27.1,25.9,25.8,25.8,24.5,22.4,14.4$, carbon attached to boron not observed. ${ }^{11} \mathrm{~B}$ NMR $\left(96 \mathrm{MHz}, \mathrm{CDCl}_{3}\right.$ ) $\delta 34.2$. HRMS (EI) $\mathrm{m} / z=466.3249$ calcd. for $\mathrm{C}_{29} \mathrm{H}_{43} \mathrm{BO}_{4}{ }^{+}$ $[\mathrm{M}]^{+}$, found: 466.3250. FTIR (neat): $v\left(\mathrm{~cm}^{-1}\right)$ 2974, 2936, 2866, 1500, 1470, 1371, 1342, 1308, 1215, 1180, 1162, 1136, 1106, 1045, 965, 950, 885, 856, 835, 736.

2-(2-((R)-2,8-Dimethyl-2-((4R,8R)-4,8,12-trimethyltridecyl)chroman-6-yl)propan-2-y 1)-4,4,5,5-tetramethyl-1,3,2-dioxaborolane (3aa)

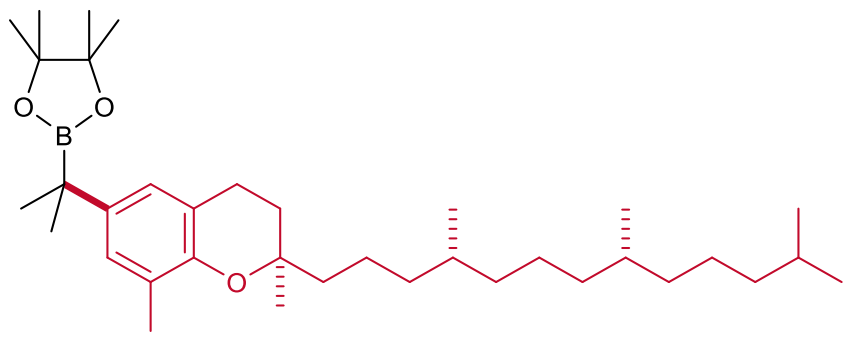

Following GP1, using 1aa (102.4 mg, $0.2 \mathrm{mmol})$ and isobutyllithium $(0.7 \mathrm{M}$ in pentane, $0.31 \mathrm{~mL}, 0.22 \mathrm{mmol}$ ), flash chromatography eluting with pentane/DCM (3:1) afforded 3aa as light yellow sticky oil $\left(67.5 \mathrm{mg}, 61 \%\right.$ yield). $\mathrm{R}_{\mathrm{f}} 0.4$ (pentane/DCM = 2:1). $[\alpha]{ }_{D}^{26}+10\left(c 0.46, \mathrm{CHCl}_{3}\right) .{ }^{1} \mathrm{H}$ NMR $\left(300 \mathrm{MHz}, \mathrm{CDCl}_{3}\right) \delta 6.88(\mathrm{~d}, J=1.8 \mathrm{~Hz}$, $1 \mathrm{H}), 6.80(\mathrm{~d}, J=1.8 \mathrm{~Hz}, 1 \mathrm{H}), 2.82-2.63(\mathrm{~m}, 2 \mathrm{H}), 2.14(\mathrm{~s}, 3 \mathrm{H}), 1.87-1.64(\mathrm{~m}, 2 \mathrm{H})$, $1.63-1.32(\mathrm{~m}, 9 \mathrm{H}), 1.32-1.26(\mathrm{~m}, 11 \mathrm{H}), 1.25(\mathrm{~s}, 3 \mathrm{H}), 1.22(\mathrm{~s}, 12 \mathrm{H}), 1.20-0.99(\mathrm{~m}$, $7 \mathrm{H}), 0.93-0.83(\mathrm{~m}, 12 \mathrm{H}) .{ }^{13} \mathrm{C} \mathrm{NMR}\left(75 \mathrm{MHz}, \mathrm{CDCl}_{3}\right) \delta 149.7,138.5,126.5,125.4$, 124.3, 119.7, 83.1, 40.4, 39.4, 37.5, 37.5, 37.3, 32.8, 32.7, 31.4, 28.0, 26.0, 24.8, 24.5, 
24.5, 24.3, 22.7, 22.6, 22.6, 21.0, 19.8, 19.7, 16.2, carbon attached to boron not observed. ${ }^{11} \mathrm{~B}$ NMR $\left(96 \mathrm{MHz}, \mathrm{CDCl}_{3}\right) \delta 33.6$. HRMS (EI) $\mathrm{m} / z=554.4865$ calcd. for $\mathrm{C}_{36} \mathrm{H}_{63} \mathrm{BO}_{3}{ }^{+}[\mathrm{Ma}]^{+}$, found: 554.4878. FTIR (neat): $v\left(\mathrm{~cm}^{-1}\right)$ 2926, 2868, 1470, 1371 , 1340, 1307, 1226, 1134, 1111, 966, 929, 856, 735, 697, 675 .

4,4,5,5-Tetramethyl-2-(octan-4-yl)-1,3,2-dioxaborolane (6a)

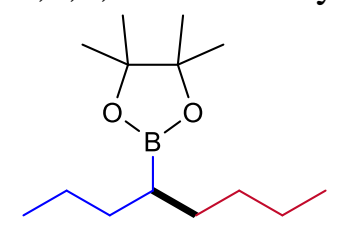

Following GP1, using $n$-butylboronic acid pinacol ester $4 \mathbf{a}(36.8 \mathrm{mg}, 0.2 \mathrm{mmol})$ and $n$-butyllithium (1.6 M in hexane, $0.14 \mathrm{~mL}, 0.22 \mathrm{mmol}$ ), flash chromatography eluting with pentane/DCM (5:1) afforded $\mathbf{6 a}$ as light yellow liquid $\left(23.3 \mathrm{mg}, 49 \%\right.$ yield). $\mathrm{R}_{\mathrm{f}}$ 0.4 (pentane/DCM = 3:1). ${ }^{1} \mathrm{H}$ NMR $\left(300 \mathrm{MHz}, \mathrm{CDCl}_{3}\right) \delta 1.46-1.26(\mathrm{~m}, 10 \mathrm{H}), 1.23$ $(\mathrm{s}, 12 \mathrm{H}), 1.01-0.91(\mathrm{~m}, 1 \mathrm{H}), 0.91-0.81(\mathrm{~m}, 6 \mathrm{H}) .{ }^{13} \mathrm{C} \mathrm{NMR}\left(75 \mathrm{MHz}, \mathrm{CDCl}_{3}\right) \delta 82.7$, 33.8, 31.6, 31.1, 24.8, 23.0, 22.4, 14.4, 14.1, carbon attached to boron not observed. ${ }^{11} \mathrm{~B}$ NMR (96 MHz, $\left.\mathrm{CDCl}_{3}\right) \delta$ 34.3. HRMS (ESI) $\mathrm{m} / \mathrm{z}=263.2153$ calcd. for $\mathrm{C}_{14} \mathrm{H}_{29} \mathrm{BO}_{2} \mathrm{Na}^{+}[\mathrm{M}+\mathrm{Na}]^{+}$, found: 263.2161. FTIR (neat): v $\left(\mathrm{cm}^{-1}\right) 2979,2956,2925$, 2859, 1467, 1412, 1388, 1353, 1315, 1247, 1215, 1145, 967, 862, 687.

Following GP3, using $n$-butylboronic acid pinacol ester $\mathbf{4 a}(36.8 \mathrm{mg}, 0.2 \mathrm{mmol})$ and $n$-butyllithium (1.6 M in hexane, $0.14 \mathrm{~mL}, 0.22 \mathrm{mmol}$ ), flash chromatography eluting with pentane/DCM (5:1) afforded $6 \mathbf{a}$ as colorless liquid (20.9 mg, $44 \%$ yield). $\mathrm{R}_{\mathrm{f}} 0.4$ (pentane/DCM = 3:1). ${ }^{1} \mathrm{H}$ NMR $\left(300 \mathrm{MHz}, \mathrm{CDCl}_{3}\right) \delta 1.46-1.26(\mathrm{~m}, 10 \mathrm{H}), 1.23(\mathrm{~s}$, $12 \mathrm{H}), 1.01-0.91(\mathrm{~m}, 1 \mathrm{H}), 0.91-0.81(\mathrm{~m}, 6 \mathrm{H}) .{ }^{13} \mathrm{C} \mathrm{NMR}\left(75 \mathrm{MHz}, \mathrm{CDCl}_{3}\right) \delta 82.7$, 33.8, 31.6, 31.1, 24.8, 23.0, 22.4, 14.4, 14.1, carbon attached to boron not observed. ${ }^{11} \mathrm{~B}$ NMR $\left(96 \mathrm{MHz}, \mathrm{CDCl}_{3}\right) \delta 34.3$. HRMS (ESI) $\mathrm{m} / \mathrm{z}=263.2153$ calcd. for $\mathrm{C}_{14} \mathrm{H}_{29} \mathrm{BO}_{2} \mathrm{Na}^{+}[\mathrm{M}+\mathrm{Na}]^{+}$, found: 263.2161. FTIR (neat): $v\left(\mathrm{~cm}^{-1}\right)$ 2979, 2956, 2925, 2859, 1467, 1412, 1388, 1353, 1315, 1247, 1215, 1145, 967, 862, 687. According to crude GC analysis with $n-\mathrm{C}_{14} \mathrm{H}_{30}$ as internal standard, crude yield of $6 \mathbf{a}$ was $47 \%$ and recovered yield of $n$-butylboronic acid pinacol ester $\mathbf{4 a}$ was $36 \%$.

2-(2,3-Dimethylbutan-2-yl)-4,4,5,5-tetramethyl-1,3,2-dioxaborolane (6b)

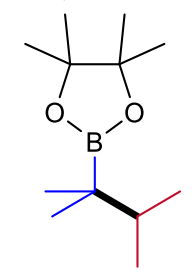

Following GP1, using isopropylboronic acid pinacol ester $4 \mathbf{b}(34.0 \mathrm{mg}, 0.2 \mathrm{mmol})$ and isopropyllithium $(0.7 \mathrm{M}$ in pentane, $0.31 \mathrm{~mL}, 0.22 \mathrm{mmol})$, flash chromatography eluting with pentane/DCM (5:1) afforded $\mathbf{6 b}$ as light yellow liquid (30.5 mg, $72 \%$ yield). $\mathrm{R}_{\mathrm{f}} 0.5$ (pentane/DCM = 4:1). ${ }^{1} \mathrm{H} \mathrm{NMR}\left(300 \mathrm{MHz}, \mathrm{CDCl}_{3}\right) \delta 1.72-1.50(\mathrm{~m}$, $1 \mathrm{H}), 1.22(\mathrm{~s}, 12 \mathrm{H}), 0.86(\mathrm{~s}, 6 \mathrm{H}), 0.84(\mathrm{~d}, J=6.9 \mathrm{~Hz}, 6 \mathrm{H}) .{ }^{13} \mathrm{C} \mathrm{NMR}\left(75 \mathrm{MHz}, \mathrm{CDCl}_{3}\right)$ $\delta 82.7,34.6,24.7,21.4,18.4$, carbon attached to boron not observed. ${ }^{11} \mathrm{~B} \mathrm{NMR}(96$ 
$\mathrm{MHz}, \mathrm{CDCl}_{3}$ ) $\delta$ 34.8. HRMS (EI) $\mathrm{m} / z=212.1942$ calcd. for $\mathrm{C}_{12} \mathrm{H}_{25} \mathrm{BO}_{2}{ }^{+}[\mathrm{M}]^{+}$, found: 212.1944. FTIR (neat): $v\left(\mathrm{~cm}^{-1}\right)$ 2977, 2959, 2872, 1467, 1390, 1378, 1371, 1356, 1303, 1214, 1144, 1125, 1092, 1054, 967, 861, 838, 805, 689, 669. According to crude GC analysis with $n-\mathrm{C}_{14} \mathrm{H}_{30}$ as internal standard, recovered yield of isopropylboronic acid pinacol ester $\mathbf{4 b}$ was $13 \%$.

Following GP3, using isopropylboronic acid pinacol ester $4 \mathbf{b}(34.0 \mathrm{mg}, 0.2 \mathrm{mmol})$ and isopropyllithium $(0.7 \mathrm{M}$ in pentane, $0.31 \mathrm{~mL}, 0.22 \mathrm{mmol})$, flash chromatography eluting with pentane/DCM (5:1) afforded $\mathbf{6 b}$ as light yellow liquid $(32.7 \mathrm{mg}, 77 \%$ yield). $\mathrm{R}_{\mathrm{f}} 0.5$ (pentane/DCM = 4:1). ${ }^{1} \mathrm{H} \mathrm{NMR}\left(300 \mathrm{MHz}, \mathrm{CDCl}_{3}\right) \delta 1.72-1.50(\mathrm{~m}$, $1 \mathrm{H}), 1.22(\mathrm{~s}, 12 \mathrm{H}), 0.86(\mathrm{~s}, 6 \mathrm{H}), 0.84(\mathrm{~d}, J=6.9 \mathrm{~Hz}, 6 \mathrm{H}) .{ }^{13} \mathrm{C} \mathrm{NMR}\left(75 \mathrm{MHz}, \mathrm{CDCl}_{3}\right)$ $\delta 82.7,34.6,24.7,21.4,18.4$, carbon attached to boron not observed. ${ }^{11} \mathrm{~B}$ NMR (96 $\mathrm{MHz}, \mathrm{CDCl}_{3}$ ) $\delta 34.8$. HRMS (EI) $\mathrm{m} / z=212.1942$ calcd. for $\mathrm{C}_{12} \mathrm{H}_{25} \mathrm{BO}_{2}{ }^{+}[\mathrm{M}]^{+}$, found: 212.1944. FTIR (neat): $v\left(\mathrm{~cm}^{-1}\right)$ 2977, 2959, 2872, 1467, 1390, 1378, 1371, 1356, 1303, 1214, 1144, 1125, 1092, 1054, 967, 861, 838, 805, 689, 669. According to crude GC analysis with $n-\mathrm{C}_{14} \mathrm{H}_{30}$ as internal standard, recovered yield of isopropylboronic acid pinacol ester $\mathbf{4 b}$ was $15 \%$.

2-(3,4-Dimethylhexan-3-yl)-4,4,5,5-tetramethyl-1,3,2-dioxaborolane (6c)

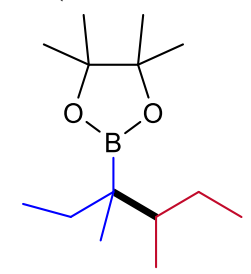

Following GP1, using 4c $(36.8 \mathrm{mg}, 0.2 \mathrm{mmol})$ and isobutyllithium $(1.4 \mathrm{M}$ in cyclohexane, $0.16 \mathrm{~mL}, 0.22 \mathrm{mmol}$ ), flash chromatography eluting with pentane/DCM (4:1) afforded 6c as light yellow liquid (26.0 mg, 54\% yield, $d r=1: 1)$. $\mathrm{R}_{\mathrm{f}} 0.4$ (pentane/DCM = 3:1). Dr was determined by crude GCMS and GC. ${ }^{1} \mathrm{H}$ NMR (300 $\left.\mathrm{MHz}, \mathrm{CDCl}_{3}\right) \delta 1.62-1.26(\mathrm{~m}, 5 \mathrm{H}), 1.24-1.22(\mathrm{~m}, 12 \mathrm{H}), 0.93-0.71(\mathrm{~m}, 12) .{ }^{13} \mathrm{C}$ NMR $\left(75 \mathrm{MHz}, \mathrm{CDCl}_{3}\right) \delta 82.8,40.8,40.6,30.0,29.1,27.5,25.0,25.0,24.9,24.9$, $23.7,16.9,16.1,15.7,13.1,13.0,12.5,10.4,10.4$, carbon attached to boron not observed. ${ }^{11} \mathrm{~B}$ NMR $\left(96 \mathrm{MHz}, \mathrm{CDCl}_{3}\right) \delta 34.8$. HRMS (ESI) $\mathrm{m} / z=263.2153$ calcd. for $\mathrm{C}_{14} \mathrm{H}_{29} \mathrm{BO}_{2} \mathrm{Na}^{+}[\mathrm{M}+\mathrm{Na}]^{+}$, found: 263.2155. FTIR (neat): $v\left(\mathrm{~cm}^{-1}\right)$ 2962, 2934, 2875, 1459, 1371, 1341, 1301, 1261, 1213, 1143, 1118, 966, 855, 684.

2-([1,1'-Bi(cyclopropan)]-1-yl)-4,4,5,5-tetramethyl-1,3,2-dioxaborolane (6d)

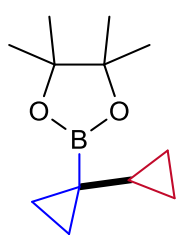

Following GP1, using 4d (33.6 mg, $0.2 \mathrm{mmol})$ and cyclopropyllithium (0.85 $\mathrm{M}$ in $\left.\mathrm{Et}_{2} \mathrm{O}, 0.26 \mathrm{~mL}, 0.22 \mathrm{mmol}\right)$, flash chromatography eluting with pentane/DCM (2:1) afforded $\mathbf{6 d}$ as light yellow liquid $\left(12.1 \mathrm{mg}, 29 \%\right.$ yield). $\mathrm{R}_{\mathrm{f}} 0.5$ (pentane/DCM = 10:7). 
${ }^{1} \mathrm{H}$ NMR $\left(300 \mathrm{MHz}, \mathrm{CDCl}_{3}\right) \delta 1.21(\mathrm{~s}, 12 \mathrm{H}), 1.10-0.96(\mathrm{~m}, 1 \mathrm{H}), 0.56-0.47(\mathrm{~m}, 2 \mathrm{H})$, $0.33-0.18(\mathrm{~m}, 4 \mathrm{H}), 0.02--0.09(\mathrm{~m}, 2 \mathrm{H}) .{ }^{13} \mathrm{C} \mathrm{NMR}\left(75 \mathrm{MHz}, \mathrm{CDCl}_{3}\right) \delta 82.9,24.7$, 13.0, 8.7, 1.9, carbon attached to boron not observed. ${ }^{11} \mathrm{~B} \mathrm{NMR}\left(96 \mathrm{MHz}, \mathrm{CDCl}_{3}\right) \delta$ 33.8. HRMS (ESI) $\mathrm{m} / z=231.1527$ calcd. for $\mathrm{C}_{12} \mathrm{H}_{21} \mathrm{BO}_{2} \mathrm{Na}^{+}[\mathrm{M}+\mathrm{Na}]^{+}$, found: 231.1540. FTIR (neat): $v\left(\mathrm{~cm}^{-1}\right)$ 3080, 2979, 1468, 1442, 1414, 1371, 1356, 1309, 1262, 1216, 1194, 1165, 1135, 1099, 1015, 967, 866, 845, 813, 706, 683, 667, 581.

Following GP3, using 4d (33.6 mg, $0.2 \mathrm{mmol})$ and cyclopropyllithium $(0.85 \mathrm{M}$ in $\left.\mathrm{Et}_{2} \mathrm{O}, 0.26 \mathrm{~mL}, 0.22 \mathrm{mmol}\right)$, flash chromatography eluting with pentane/DCM (2:1) afforded $\mathbf{6 d}$ as light yellow liquid (14.8 $\mathrm{mg}, 35 \%$ yield). $\mathrm{R}_{\mathrm{f}} 0.5$ (pentane/DCM = 10:7). ${ }^{1} \mathrm{H}$ NMR $\left(300 \mathrm{MHz}, \mathrm{CDCl}_{3}\right) \delta 1.21(\mathrm{~s}, 12 \mathrm{H}), 1.10-0.96(\mathrm{~m}, 1 \mathrm{H}), 0.56-0.47(\mathrm{~m}, 2 \mathrm{H})$, $0.33-0.18(\mathrm{~m}, 4 \mathrm{H}), 0.02--0.09(\mathrm{~m}, 2 \mathrm{H}) .{ }^{13} \mathrm{C} \mathrm{NMR}\left(75 \mathrm{MHz}, \mathrm{CDCl}_{3}\right) \delta 82.9,24.7$, $13.0,8.7,1.9$, carbon attached to boron not observed. ${ }^{11} \mathrm{~B} \mathrm{NMR}\left(96 \mathrm{MHz}, \mathrm{CDCl}_{3}\right) \delta$ 33.8. HRMS (ESI) $\mathrm{m} / z=231.1527$ calcd. for $\mathrm{C}_{12} \mathrm{H}_{21} \mathrm{BO}_{2} \mathrm{Na}^{+}[\mathrm{M}+\mathrm{Na}]^{+}$, found: 231.1540. FTIR (neat): $v\left(\mathrm{~cm}^{-1}\right)$ 3080, 2979, 1468, 1442, 1414, 1371, 1356, 1309, 1262, 1216, 1194, 1165, 1135, 1099, 1015, 967, 866, 845, 813, 706, 683, 667, 581. According to crude GC analysis with $n-\mathrm{C}_{14} \mathrm{H}_{30}$ as internal standard, recovered yield of cyclopropylboronic acid pinacol ester $\mathbf{4 d}$ was $16 \%$.

2-([1,1'-Bi(cyclopentan)]-1-yl)-4,4,5,5-tetramethyl-1,3,2-dioxaborolane (6e)

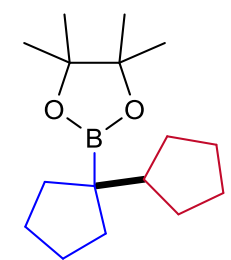

Following GP1, using cyclopentylboronic acid pinacol ester 4 e $(39.2 \mathrm{mg}, 0.2 \mathrm{mmol})$ and cyclopentyllithium $(0.62 \mathrm{M}$ in hexane, $0.355 \mathrm{~mL}, 0.22 \mathrm{mmol})$, flash chromatography eluting with pentane/DCM (5:1) afforded $6 \mathbf{6}$ as colorless liquid (37.1 mg, 70\% yield). $\mathrm{R}_{\mathrm{f}} 0.4$ (pentane/DCM = 4:1). ${ }^{1} \mathrm{H} \mathrm{NMR}\left(300 \mathrm{MHz}, \mathrm{CDCl}_{3}\right) \delta 1.89-$ $1.73(\mathrm{~m}, 3 \mathrm{H}), 1.72-1.39(\mathrm{~m}, 10 \mathrm{H}), 1.36-1.24(\mathrm{~m}, 4 \mathrm{H}), 1.21(\mathrm{~s}, 12 \mathrm{H}) .{ }^{13} \mathrm{C}$ NMR $(75$ $\left.\mathrm{MHz}, \mathrm{CDCl}_{3}\right) \delta 82.7,47.7,33.9,29.6,25.7,25.7,24.7$, carbon attached to boron not observed. ${ }^{11} \mathrm{~B}$ NMR $\left(96 \mathrm{MHz}, \mathrm{CDCl}_{3}\right) \delta 35.1$. HRMS (ESI) $\mathrm{m} / \mathrm{z}=287.2153$ calcd. for $\mathrm{C}_{16} \mathrm{H}_{29} \mathrm{BO}_{2} \mathrm{Na}^{+}[\mathrm{M}+\mathrm{Na}]^{+}$, found: 287.2163. FTIR (neat): $v\left(\mathrm{~cm}^{-1}\right)$ 2977, 2948, 2866, 1452, 1370, 1337, 1299, 1268, 1196, 1141, 984, 962, 859, 671. According to crude GC analysis with $n-\mathrm{C}_{14} \mathrm{H}_{30}$ as internal standard, crude yield of $6 \mathbf{e}$ was $76 \%$ and recovered yield of $4 \mathbf{e}$ was $20 \%$.

Following GP1, using cyclopentylboronic acid pinacol ester $4 \mathbf{e}(39.2 \mathrm{mg}, 0.2 \mathrm{mmol})$ and cyclopentyllithium $(0.62 \mathrm{M}$ in hexane, $0.355 \mathrm{~mL}, 0.22 \mathrm{mmol})$, flash chromatography eluting with pentane/DCM (5:1) afforded $6 \mathbf{e}$ as colorless liquid (34.4 $\mathrm{mg}, 65 \%$ yield). $\mathrm{R}_{\mathrm{f}} 0.4$ (pentane/DCM $\left.=4: 1\right) .{ }^{1} \mathrm{H} \mathrm{NMR}\left(300 \mathrm{MHz}, \mathrm{CDCl}_{3}\right) \delta 1.89-$ $1.73(\mathrm{~m}, 3 \mathrm{H}), 1.72-1.39(\mathrm{~m}, 10 \mathrm{H}), 1.36-1.24(\mathrm{~m}, 4 \mathrm{H}), 1.21(\mathrm{~s}, 12 \mathrm{H}) .{ }^{13} \mathrm{C}$ NMR (75 $\left.\mathrm{MHz}, \mathrm{CDCl}_{3}\right) \delta 82.7,47.7,33.9,29.6,25.7,25.7,24.7$, carbon attached to boron not observed. ${ }^{11} \mathrm{~B}$ NMR $\left(96 \mathrm{MHz}, \mathrm{CDCl}_{3}\right.$ ) $\delta 35.1$. HRMS (ESI) $m / z=287.2153$ calcd. for 
$\mathrm{C}_{16} \mathrm{H}_{29} \mathrm{BO}_{2} \mathrm{Na}^{+}[\mathrm{M}+\mathrm{Na}]^{+}$, found: 287.2163. FTIR (neat): $v\left(\mathrm{~cm}^{-1}\right)$ 2977, 2948, 2866, 1452, 1370, 1337, 1299, 1268, 1196, 1141, 984, 962, 859, 671. According to crude GC analysis with $n-\mathrm{C}_{14} \mathrm{H}_{30}$ as internal standard, crude yield of $6 \mathbf{e}$ was $72 \%$ and recovered yield of $\mathbf{4 e}$ was $19 \%$.

2-([1,1'-Bi(cyclohexan)]-1-yl)-4,4,5,5-tetramethyl-1,3,2-dioxaborolane (6f)

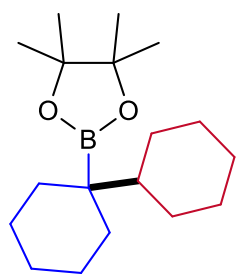

Following GP1, using $4 \mathbf{f}(42.0 \mathrm{mg}, 0.2 \mathrm{mmol})$ and cyclohexyllithium $(0.53 \mathrm{M}$ in hexane, $0.42 \mathrm{~mL}, 0.22 \mathrm{mmol})$, flash chromatography eluting with pentane/DCM $(5: 1)$ afforded $6 \mathbf{f}$ as light yellow solid $\left(22.3 \mathrm{mg}, 38 \%\right.$ yield). $\mathrm{R}_{\mathrm{f}} 0.5$ (pentane/DCM = 3:1). M.p.: $72-73{ }^{\circ} \mathrm{C} .{ }^{1} \mathrm{H}$ NMR $\left(300 \mathrm{MHz}, \mathrm{CDCl}_{3}\right) \delta 2.01-1.88(\mathrm{~m}, 2 \mathrm{H}), 1.88-1.77(\mathrm{~m}$, $2 \mathrm{H}), 1.75-1.52(\mathrm{~m}, 6 \mathrm{H}), 1.26(\mathrm{~s}, 12 \mathrm{H}), 1.36-0.83(\mathrm{~m}, 11 \mathrm{H}) .{ }^{13} \mathrm{C}$ NMR $(75 \mathrm{MHz}$, $\left.\mathrm{CDCl}_{3}\right) \delta 82.9,47.5,32.9,29.0,27.4,27.1,26.7,25.7,25.0$, carbon attached to boron not observed. ${ }^{11} \mathrm{~B} \mathrm{NMR}\left(96 \mathrm{MHz}, \mathrm{CDCl}_{3}\right) \delta 34.5$. HRMS (ESI) $\mathrm{m} / \mathrm{z}=315.2466$ calcd. for $\mathrm{C}_{18} \mathrm{H}_{33} \mathrm{BO}_{2} \mathrm{Na}^{+}[\mathrm{M}+\mathrm{Na}]^{+}$, found: 315.2470. FTIR (neat): $v\left(\mathrm{~cm}^{-1}\right)$ 2978, 2918, 2849, 1447, 1409, 1388, 1370, 1334, 1301, 1263, 1232, 1213, 1162, 1141, 1110, 969, $860,832,710,671,600$. According to crude $\mathrm{GC}$ analysis with $n-\mathrm{C}_{14} \mathrm{H}_{30}$ as internal standard, crude yield of $6 \mathbf{e}$ was $40 \%$ and recovered yield of $\mathbf{4 f}$ was $39 \%$.

2-(2,2-Dimethylheptan-4-yl)-4,4,5,5-tetramethyl-1,3,2-dioxaborolane (6g)

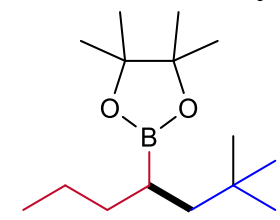

Following GP1, using 4g (39.6 mg, $0.2 \mathrm{mmol})$ and $n$-butyllithium (1.6 M in hexane, $0.14 \mathrm{~mL}, 0.22 \mathrm{mmol})$, flash chromatography eluting with pentane/DCM (5:1) afforded $\mathbf{6 g}$ as light yellow liquid ( $24.8 \mathrm{mg}, 49 \%$ yield, a mixture of two regioisomers). $\mathrm{R}_{\mathrm{f}} 0.3$ (pentane/DCM $=3: 1$ ). Regioisomeric ratio was determined to be $1.3: 1$ by crude GCMS and GC. ${ }^{1} \mathrm{H}$ NMR (300 MHz, $\left.\mathrm{CDCl}_{3}\right) \delta 1.58-1.07(\mathrm{~m}, 44 \mathrm{H}), 0.92(\mathrm{~s}, 9 \mathrm{H})$, $0.90-0.75(\mathrm{~m}, 7 \mathrm{H}), 0.86(\mathrm{~s}, 11.6 \mathrm{H}) .{ }^{13} \mathrm{C} \mathrm{NMR}\left(75 \mathrm{MHz}, \mathrm{CDCl}_{3}\right) \delta 82.7,82.7,45.8$, 35.9, 32.6, 32.0, 32.0, 31.0, 29.7, 29.6, 26.6, 25.0, 25.0, 24.9, 24.9, 23.0, 22.1, 14.4, 14.1, carbon attached to boron not observed. ${ }^{11} \mathrm{~B} \mathrm{NMR}\left(96 \mathrm{MHz}, \mathrm{CDCl}_{3}\right) \delta 34.3$. HRMS (ESI) $m / z=277.2309$ calcd. for $\mathrm{C}_{15} \mathrm{H}_{31} \mathrm{BO}_{2} \mathrm{Na}^{+}[\mathrm{M}+\mathrm{Na}]^{+}$, found: 277.2319. FTIR (neat): $v\left(\mathrm{~cm}^{-1}\right)$ 2955, 2928, 2869, 1467, 1371, 1314, 1235, 1143, 1113, 864,

2-(1-Butylcyclopentyl)-4,4,5,5-tetramethyl-1,3,2-dioxaborolane (6h) 


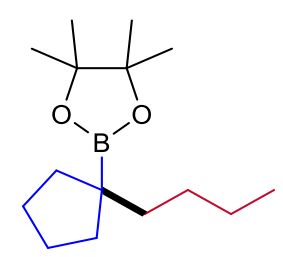

Following GP1, using cyclopentylboronic acid pinacol ester $\mathbf{4 h}$ (39.2 $\mathrm{mg}, 0.2 \mathrm{mmol})$ and $n$-butyllithium $(1.6 \mathrm{M}$ in hexane, $0.14 \mathrm{~mL}, 0.22 \mathrm{mmol})$, flash chromatography eluting with pentane/DCM (5:1) afforded $\mathbf{6 h}$ as light yellow liquid $(33.3 \mathrm{mg}, 66 \%$ yield, a mixture of two regioisomers). $\mathrm{R}_{\mathrm{f}} 0.5$ (pentane/DCM $=3: 1$ ). Regioisomeric ratio was determined to be $9: 1$ by crude GCMS and GC. ${ }^{1} \mathrm{H} \mathrm{NMR}\left(300 \mathrm{MHz}, \mathrm{CDCl}_{3}\right)$ $\delta 1.86-1.71(\mathrm{~m}, 2.2 \mathrm{H}), 1.65-1.42(\mathrm{~m}, 4.4 \mathrm{H}), 1.40-1.30(\mathrm{~m}, 2.2 \mathrm{H}), 1.24(\mathrm{~s}, 1.2 \mathrm{H})$ (minor isomer), $1.30-1.14(\mathrm{~m}, 6.6 \mathrm{H}), 1.22(\mathrm{~s}, 12 \mathrm{H}), 0.92-0.82(\mathrm{~m}, 3.3 \mathrm{H})$. Major isomer: ${ }^{13} \mathrm{C} \mathrm{NMR}\left(75 \mathrm{MHz}, \mathrm{CDCl}_{3}\right) \delta 82.8,38.7,35.4,30.3,25.3,24.7,23.6,14.1$, carbon attached to boron not observed. Minor isomer: ${ }^{13} \mathrm{C} \mathrm{NMR}\left(75 \mathrm{MHz}, \mathrm{CDCl}_{3}\right) \delta$ 82.7, 42.0, 33.2, 32.6, 32.1, 24.9, 22.2, 14.5, carbon attached to boron not observed. ${ }^{11} \mathrm{~B}$ NMR (96 MHz, $\left.\mathrm{CDCl}_{3}\right) \delta$ 34.9. HRMS (ESI) $\mathrm{m} / \mathrm{z}=275.2153$ calcd. for $\mathrm{C}_{15} \mathrm{H}_{29} \mathrm{BO}_{2} \mathrm{Na}^{+}[\mathrm{M}+\mathrm{Na}]^{+}$, found: 275.2160. FTIR (neat): $v\left(\mathrm{~cm}^{-1}\right) 2979,2954,2930$, 2858, 1457, 1408, 1379, 1341, 1303, 1216, 1144, 979, 856.

Following GP3, using cyclopentylboronic acid pinacol ester $\mathbf{4 h}$ (39.2 $\mathrm{mg}, 0.2 \mathrm{mmol})$ and $n$-butyllithium (1.6 M in hexane, $0.14 \mathrm{~mL}, 0.22 \mathrm{mmol}$ ), flash chromatography eluting with pentane/DCM (5:1) afforded $\mathbf{6 h}$ as colorless liquid (33.0 $\mathrm{mg}, 65 \%$ yield, a mixture of two regioisomers). $\mathrm{R}_{\mathrm{f}} 0.5$ (pentane/DCM $=3: 1$ ). Regioisomeric ratio was determined to be $7: 1$ by crude GC. According to crude GC analysis with $n-\mathrm{C}_{14} \mathrm{H}_{30}$ as internal standard, recovered yield of $\mathbf{4 h}$ was $7 \%$ and the yield of $\mathrm{n}$-butylboronic acid pinacol ester was $12 \%$.

4,4,5,5-Tetramethyl-2-(2,4,4-trimethylpentan-2-yl)-1,3,2-dioxaborolane (6i)

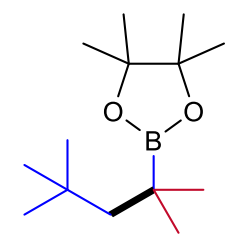

Following GP1, using 4i (39.6 mg, $0.2 \mathrm{mmol})$ and isopropyllithium $(0.7 \mathrm{M}$ in pentane, $0.31 \mathrm{~mL}, 0.22 \mathrm{mmol})$, flash chromatography eluting with pentane/DCM (5:1) afforded 6i as light yellow liquid ( $35.5 \mathrm{mg}, 74 \%$ yield, a mixture of two regioisomers). $\mathrm{R}_{\mathrm{f}} 0.4$ (pentane/DCM = 3:1). Regioisomeric ratio was determined to be $11.5: 1$ by crude GCMS and GC. ${ }^{1} \mathrm{H}$ NMR (300 MHz, $\left.\mathrm{CDCl}_{3}\right) \delta 1.35$ (s, 2H), 1.25 (s, 1.1H) (minor), $1.22(\mathrm{~s}, 12 \mathrm{H}), 1.02-0.89(\mathrm{~m}, 16.6 \mathrm{H})$. Major isomer: ${ }^{13} \mathrm{C} \mathrm{NMR}\left(75 \mathrm{MHz}, \mathrm{CDCl}_{3}\right) \delta$ $82.9,54.5,31.6,31.3,27.4,24.8$, carbon attached to boron not observed. Minor isomer: ${ }^{13} \mathrm{C} \mathrm{NMR}\left(75 \mathrm{MHz}, \mathrm{CDCl}_{3}\right) \delta 82.6,30.1,26.7,26.4,25.3,25.0,22.6$, carbon attached to boron not observed. ${ }^{11} \mathrm{~B} \mathrm{NMR}\left(96 \mathrm{MHz}, \mathrm{CDCl}_{3}\right) \delta 34.9$. HRMS (ESI) $\mathrm{m} / z$ $=263.2153$ calcd. for $\mathrm{C}_{14} \mathrm{H}_{29} \mathrm{BO}_{2} \mathrm{Na}^{+}[\mathrm{M}+\mathrm{Na}]^{+}$, found: 263.2158. FTIR (neat): $v$ $\left(\mathrm{cm}^{-1}\right)$ 2979, 2953, 2905, 2869, 2837, 1480, 1388, 1369, 1339, 1305, 1271, 1197, 
$1146,1130,1102,967,867,845,714,691,669,580$.

2-(1-Isopropylcyclopentyl)-4,4,5,5-tetramethyl-1,3,2-dioxaborolane (6j)

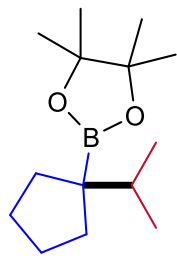

Following GP2, using 4j (39.2 mg, $0.2 \mathrm{mmol})$ and isopropyllithium $(0.7 \mathrm{M}$ in pentane, $0.31 \mathrm{~mL}, 0.22 \mathrm{mmol})$, flash chromatography eluting with pentane/DCM (5:1) afforded 6j as light yellow liquid $\left(29.7 \mathrm{mg}, 62 \%\right.$ yield, a mixture of two regioisomers). $\mathrm{R}_{\mathrm{f}} 0.5$ (pentane/DCM = 3:1). Regioisomeric ratio was determined to be $2.2: 1$ by crude GCMS and GC. ${ }^{1} \mathrm{H}$ NMR (300 MHz, $\left.\mathrm{CDCl}_{3}\right) \delta 1.95-1.37(\mathrm{~m}, 7 \mathrm{H}), 1.32-1.11(\mathrm{~m}$, $14 \mathrm{H}), 0.94-0.86(\mathrm{~m}, 6 \mathrm{H}) .{ }^{13} \mathrm{C} \mathrm{NMR}\left(75 \mathrm{MHz}, \mathrm{CDCl}_{3}\right) \delta 82.8,82.7,48.5,36.4,34.0$, 28.1, 25.9, 25.7, 24.8, 24.7, 22.9, 20.6, carbon attached to boron not observed. ${ }^{11} \mathrm{~B}$ NMR $\left(96 \mathrm{MHz}, \mathrm{CDCl}_{3}\right.$ ) $\delta$ 34.9. HRMS (ESI) $\mathrm{m} / z=261.1996$ calcd. for $\mathrm{C}_{14} \mathrm{H}_{27} \mathrm{BO}_{2} \mathrm{Na}^{+}[\mathrm{M}+\mathrm{Na}]^{+}$, found: 261.1990. FTIR (neat): $v\left(\mathrm{~cm}^{-1}\right) 2977,2951,2867$, 1473, 1371, 1338, 1302, 1271, 1214, 1196, 1141, 967, 863, 697, 670.

2-(1-Cyclopropylcyclobutyl)-4,4,5,5-tetramethyl-1,3,2-dioxaborolane (6k)

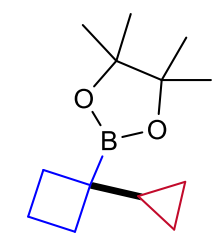

Following GP1, using cyclobutylboronic acid pinacol ester 4k (36.4 mg, $0.2 \mathrm{mmol})$ and cyclopropyllithium (1.17 $\mathrm{M}$ in $\left.\mathrm{Et}_{2} \mathrm{O}, 0.19 \mathrm{~mL}, 0.22 \mathrm{mmol}\right)$, flash chromatography eluting with pentane/DCM (5:1) afforded 6k as light yellow liquid (23.7 mg, 53\% yield). $\mathrm{R}_{\mathrm{f}} 0.5$ (pentane/DCM = 3:1). Regioisomeric ratio was determined to be 11:1 by crude GCMS and GC. ${ }^{1} \mathrm{H}$ NMR $\left(300 \mathrm{MHz}, \mathrm{CDCl}_{3}\right) \delta 2.05-1.89(\mathrm{~m}, 2 \mathrm{H}), 1.87-$ $1.52(\mathrm{~m}, 4 \mathrm{H}), 1.26(\mathrm{~s}, 12 \mathrm{H}), 0.98-0.83(\mathrm{~m}, 1 \mathrm{H}), 0.39-0.25(\mathrm{~m}, 2 \mathrm{H}), 0.25-0.14(\mathrm{~m}$, $2 \mathrm{H}) .{ }^{13} \mathrm{C} \mathrm{NMR}\left(75 \mathrm{MHz}, \mathrm{CDCl}_{3}\right) \delta 83.0,27.6,24.7,18.1,16.8,1.0$, carbon attached to boron not observed. ${ }^{11} \mathrm{~B} \mathrm{NMR}\left(96 \mathrm{MHz}, \mathrm{CDCl}_{3}\right) \delta 34.5$. HRMS (ESI) $\mathrm{m} / z=$ 245.1683 calcd. for $\mathrm{C}_{13} \mathrm{H}_{23} \mathrm{BO}_{2} \mathrm{Na}^{+}[\mathrm{M}+\mathrm{Na}]^{+}$, found: 245.1697 . FTIR (neat): $v\left(\mathrm{~cm}^{-1}\right)$ 3075, 2976, 2936, 2866, 1467, 1411, 1379, 1343, 1303, 1275, 1250, 1215, 1146, 1124 , $1013,967,866,840,818,684,671,579$. According to crude GC analysis with $n-\mathrm{C}_{14} \mathrm{H}_{30}$ as internal standard, recovered yield of $\mathbf{4 k}$ was $3 \%$ and the yield of cyclopropylboronic acid pinacol ester was $17 \%$.

Following GP3, using cyclobutylboronic acid pinacol ester 4k (36.4 mg, $0.2 \mathrm{mmol}$ ) and cyclopropyllithium (1.17 $\mathrm{M}$ in $\mathrm{Et}_{2} \mathrm{O}, 0.19 \mathrm{~mL}, 0.22 \mathrm{mmol}$ ), flash chromatography eluting with pentane/DCM (5:1) afforded 6k as light yellow liquid (21.6 mg, 49\% yield). $\mathrm{R}_{\mathrm{f}} 0.5$ (pentane/DCM = 3:1). Regioisomeric ratio was determined to be 10:1 by crude GCMS and GC. ${ }^{1} \mathrm{H}$ NMR $\left(300 \mathrm{MHz}, \mathrm{CDCl}_{3}\right) \delta 2.05-1.89(\mathrm{~m}, 2 \mathrm{H}), 1.87-$ 
$1.52(\mathrm{~m}, 4 \mathrm{H}), 1.26(\mathrm{~s}, 12 \mathrm{H}), 0.98-0.83(\mathrm{~m}, 1 \mathrm{H}), 0.39-0.25(\mathrm{~m}, 2 \mathrm{H}), 0.25-0.14(\mathrm{~m}$, $2 \mathrm{H}) .{ }^{13} \mathrm{C} \mathrm{NMR}\left(75 \mathrm{MHz}, \mathrm{CDCl}_{3}\right) \delta 83.0,27.6,24.7,18.1,16.8,1.0$, carbon attached to boron not observed. ${ }^{11} \mathrm{~B} \mathrm{NMR}\left(96 \mathrm{MHz}, \mathrm{CDCl}_{3}\right) \delta 34.5$. HRMS (ESI) $\mathrm{m} / z=$ 245.1683 calcd. for $\mathrm{C}_{13} \mathrm{H}_{23} \mathrm{BO}_{2} \mathrm{Na}^{+}[\mathrm{M}+\mathrm{Na}]^{+}$, found: 245.1697 . FTIR (neat): $v\left(\mathrm{~cm}^{-1}\right)$ 3075, 2976, 2936, 2866, 1467, 1411, 1379, 1343, 1303, 1275, 1250, 1215, 1146, 1124 , $1013,967,866,840,818,684,671,579$. According to crude GC analysis with $n-\mathrm{C}_{14} \mathrm{H}_{30}$ as internal standard, recovered yield of $\mathbf{4 k}$ was $3 \%$ and the yield of cyclopropylboronic acid pinacol ester was $14 \%$.

2-(1-Cyclopropylcyclopentyl)-4,4,5,5-tetramethyl-1,3,2-dioxaborolane (61)

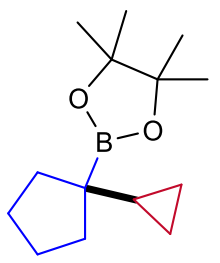

Following GP1, using $4 \mathbf{l}(39.2 \mathrm{mg}, 0.2 \mathrm{mmol})$ and cyclopropyllithium $(0.85 \mathrm{M}$ in $\left.\mathrm{Et}_{2} \mathrm{O}, 0.26 \mathrm{~mL}, 0.22 \mathrm{mmol}\right)$, flash chromatography eluting with pentane/DCM (5:1) afforded $\mathbf{6 1}$ as light yellow liquid (22.9 mg, $48 \%$ yield, single isomer). $\mathrm{R}_{\mathrm{f}} 0.5$ (pentane/DCM = 3:1). Regioisomeric ratio was determined to be $13: 1$ by crude GCMS and GC. The other isomer was not collected. ${ }^{1} \mathrm{H}$ NMR $\left(300 \mathrm{MHz}, \mathrm{CDCl}_{3}\right) \delta$ $1.82-1.66(\mathrm{~m}, 2 \mathrm{H}), 1.66-1.40(\mathrm{~m}, 4 \mathrm{H}), 1.32-1.14(\mathrm{~m}, 14 \mathrm{H}), 0.82-0.67(\mathrm{~m}, 1 \mathrm{H})$, $0.34-0.23(\mathrm{~m}, 2 \mathrm{H}), 0.23-0.14(\mathrm{~m}, 2 \mathrm{H}) .{ }^{13} \mathrm{C} \mathrm{NMR}\left(75 \mathrm{MHz}, \mathrm{CDCl}_{3}\right) \delta 82.9,33.6$, $25.4,24.6,17.3,1.6$, carbon attached to boron not observed. ${ }^{11} \mathrm{~B} \mathrm{NMR}(96 \mathrm{MHz}$, $\left.\mathrm{CDCl}_{3}\right) \delta$ 34.6. HRMS (ESI) $m / z=259.1840$ calcd. for $\mathrm{C}_{14} \mathrm{H}_{25} \mathrm{BO}_{2} \mathrm{Na}^{+}[\mathrm{M}+\mathrm{Na}]^{+}$, found: 259.1856. FTIR (neat): $v\left(\mathrm{~cm}^{-1}\right)$ 3079, 2978, 2952, 2867, 1454, 1371, 1346, 1303, 1273, 1214, 1197, 1143, 1112, 1013, 977, 863, 819, 670.

2-(2-Cyclohexylpropan-2-yl)-4,4,5,5-tetramethyl-1,3,2-dioxaborolane (6m)<smiles>CC(C)(B1OC(C)(C)C(C)(C)O1)C1CCCCC1</smiles>

Following GP1, using $\mathbf{4 m}(42.0 \mathrm{mg}, 0.2 \mathrm{mmol})$ and isopropyllithium $(0.70 \mathrm{M}$ in pentane, $0.31 \mathrm{~mL}, 0.22 \mathrm{mmol}$ ), flash chromatography eluting with pentane/DCM (5:1) afforded $\mathbf{6 m}$ as light yellow liquid $\left(32.7 \mathrm{mg}, 65 \%\right.$ yield, a mixture of two isomers). $\mathrm{R}_{\mathrm{f}}$ 0.3 (pentane/DCM = 5:1). Regioisomeric ratio was determined to be 29:1 by crude GCMS and GC. ${ }^{1} \mathrm{H}$ NMR (300 MHz, $\left.\mathrm{CDCl}_{3}\right) \delta 1.80-1.53(\mathrm{~m}, 5 \mathrm{H}), 1.22(\mathrm{~s}, 12 \mathrm{H})$, $1.32-0.90(\mathrm{~m}, 6 \mathrm{H}), 0.87(\mathrm{~s}, 6 \mathrm{H})$. Major isomer: ${ }^{13} \mathrm{C} \mathrm{NMR}\left(75 \mathrm{MHz}, \mathrm{CDCl}_{3}\right) \delta 82.7$, $45.5,28.7,27.1,27.0,24.7,21.7$, carbon attached to boron not observed. Minor isomer: ${ }^{13} \mathrm{C} \mathrm{NMR}\left(75 \mathrm{MHz}, \mathrm{CDCl}_{3}\right) \delta 36.7,32.9,26.6,25.6,25.0$, 18.9, carbon attached to boron not observed. ${ }^{11} \mathrm{~B} \mathrm{NMR}\left(96 \mathrm{MHz}, \mathrm{CDCl}_{3}\right) \delta 34.8$. HRMS (ESI) $\mathrm{m} / \mathrm{z}$ $=275.2153$ calcd. for $\mathrm{C}_{15} \mathrm{H}_{29} \mathrm{BO}_{2} \mathrm{Na}^{+}[\mathrm{M}+\mathrm{Na}]^{+}$, found: 275.2146 . FTIR (neat): $v\left(\mathrm{~cm}^{-1}\right)$ 
2978, 2925, 2853, 1472, 1449, 1388, 1371, 1354, 1302, 1145, 1134, 967, 855, 807. According to crude GC analysis with $n-\mathrm{C}_{14} \mathrm{H}_{30}$ as internal standard, recovered yield of $\mathbf{4 m}$ was $9 \%$ and the yield of isopropylboronic acid pinacol ester was 5\%.

Following GP1, using $4 \mathbf{m}(42.0 \mathrm{mg}, 0.2 \mathrm{mmol})$ and isopropyllithium $(0.70 \mathrm{M}$ in pentane, $0.31 \mathrm{~mL}, 0.22 \mathrm{mmol})$, flash chromatography eluting with pentane/DCM (5:1) afforded $\mathbf{6 m}$ as light yellow liquid $\left(26.7 \mathrm{mg}, 53 \%\right.$ yield, a mixture of two isomers). $\mathrm{R}_{\mathrm{f}}$ 0.3 (pentane/DCM = 5:1). Regioisomeric ratio was determined to be $24: 1$ by crude GCMS and GC. ${ }^{1} \mathrm{H}$ NMR (300 MHz, $\left.\mathrm{CDCl}_{3}\right) \delta 1.80-1.53(\mathrm{~m}, 5 \mathrm{H}), 1.22(\mathrm{~s}, 12 \mathrm{H})$, $1.32-0.90(\mathrm{~m}, 6 \mathrm{H}), 0.87(\mathrm{~s}, 6 \mathrm{H})$. Major isomer: ${ }^{13} \mathrm{C} \mathrm{NMR}\left(75 \mathrm{MHz}, \mathrm{CDCl}_{3}\right) \delta 82.7$, $45.5,28.7,27.1,27.0,24.7,21.7$, carbon attached to boron not observed. Minor isomer: ${ }^{13} \mathrm{C} \mathrm{NMR}\left(75 \mathrm{MHz}, \mathrm{CDCl}_{3}\right) \delta 36.7,32.9,26.6,25.6,25.0,18.9$, carbon attached to boron not observed. ${ }^{11} \mathrm{~B}$ NMR $\left(96 \mathrm{MHz}, \mathrm{CDCl}_{3}\right) \delta 34.8$. HRMS (ESI) $\mathrm{m} / \mathrm{z}$ $=275.2153$ calcd. for $\mathrm{C}_{15} \mathrm{H}_{29} \mathrm{BO}_{2} \mathrm{Na}^{+}[\mathrm{M}+\mathrm{Na}]^{+}$, found: 275.2146. FTIR (neat): $v\left(\mathrm{~cm}^{-1}\right)$ 2978, 2925, 2853, 1472, 1449, 1388, 1371, 1354, 1302, 1145, 1134, 967, 855, 807. According to crude $\mathrm{GC}$ analysis with $n-\mathrm{C}_{14} \mathrm{H}_{30}$ as internal standard, recovered yield of $\mathbf{4 m}$ was $18 \%$ and the yield of isopropylboronic acid pinacol ester was $7 \%$.

2-(2-Cycloheptylpropan-2-yl)-4,4,5,5-tetramethyl-1,3,2-dioxaborolane (6n)

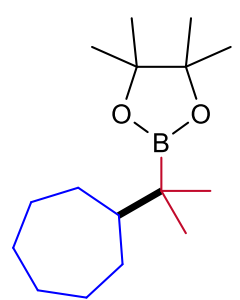

Following GP1, using cycloheptylboronic acid pinacol ester $4 \mathbf{n}(44.8 \mathrm{mg}, 0.2 \mathrm{mmol})$ and isopropyllithium $(0.70 \mathrm{M}$ in pentane, $0.31 \mathrm{~mL}, 0.22 \mathrm{mmol})$, flash chromatography eluting with pentane/DCM (5:1) afforded 6n as light yellow liquid (37.1 mg, 70\% yield, a mixture of two isomers). $\mathrm{R}_{\mathrm{f}} 0.3$ (pentane/DCM $=3: 1$ ). Regioisomeric ratio was determined to be 31:1 by crude GCMS and GC. ${ }^{1} \mathrm{H}$ NMR $\left(300 \mathrm{MHz}, \mathrm{CDCl}_{3}\right) \delta$ $1.77-1.31(\mathrm{~m}, 11 \mathrm{H}), 1.22(\mathrm{~s}, 12 \mathrm{H}), 1.29-1.12(\mathrm{~m}, 2 \mathrm{H}), 0.86(\mathrm{~s}, 6 \mathrm{H}) .{ }^{13} \mathrm{C}$ NMR $(75$ $\left.\mathrm{MHz}_{\mathrm{CDCl}}\right) \delta 82.7,45.6,30.3,28.1,28.1,21.1$, carbon attached to boron not observed. ${ }^{11} \mathrm{~B}$ NMR $\left(96 \mathrm{MHz}, \mathrm{CDCl}_{3}\right) \delta 34.7$. HRMS (ESI) $\mathrm{m} / z=289.2309$ calcd. for $\mathrm{C}_{16} \mathrm{H}_{31} \mathrm{BO}_{2} \mathrm{Na}^{+}[\mathrm{M}+\mathrm{Na}]^{+}$, found: 289.2334. FTIR (neat): $v\left(\mathrm{~cm}^{-1}\right) 2979,2924,2857$, $1471,1387,1371,1355,1303,1270,1214,1142,968,858,691,671$. According to crude GC analysis with $n-\mathrm{C}_{14} \mathrm{H}_{30}$ as internal standard, the yield of $6 \mathbf{n}$ was $76 \%$, recovered yield of $\mathbf{4 n}$ was $7 \%$ and the yield of isopropylboronic acid pinacol ester was $13 \%$.

Following GP3, using cycloheptylboronic acid pinacol ester 4n (44.8 mg, $0.2 \mathrm{mmol})$ and isopropyllithium $(0.70 \mathrm{M}$ in pentane, $0.31 \mathrm{~mL}, 0.22 \mathrm{mmol})$, flash chromatography eluting with pentane/DCM (5:1) afforded 6n as colorless liquid (34.0 mg, 64\% yield, a mixture of two isomers). $\mathrm{R}_{\mathrm{f}} 0.3$ (pentane/DCM $=3: 1$ ). Regioisomeric ratio was 
determined to be $31: 1$ by crude GCMS and GC. ${ }^{1} \mathrm{H}$ NMR $\left(300 \mathrm{MHz}, \mathrm{CDCl}_{3}\right) \delta 1.77-$ $1.31(\mathrm{~m}, 11 \mathrm{H}), 1.22(\mathrm{~s}, 12 \mathrm{H}), 1.29-1.12(\mathrm{~m}, 2 \mathrm{H}), 0.86(\mathrm{~s}, 6 \mathrm{H}) .{ }^{13} \mathrm{C} \mathrm{NMR}(75 \mathrm{MHz}$, $\left.\mathrm{CDCl}_{3}\right) \delta 82.7,45.6,30.3,28.1,28.1,21.1$, carbon attached to boron not observed. ${ }^{11} \mathrm{~B}$ NMR (96 MHz, $\mathrm{CDCl}_{3}$ ) $\delta$ 34.7. HRMS (ESI) $\mathrm{m} / \mathrm{z}=289.2309$ calcd. for $\mathrm{C}_{16} \mathrm{H}_{31} \mathrm{BO}_{2} \mathrm{Na}^{+}[\mathrm{M}+\mathrm{Na}]^{+}$, found: 289.2334. FTIR (neat): $v\left(\mathrm{~cm}^{-1}\right) 2979,2924,2857$, $1471,1387,1371,1355,1303,1270,1214,1142,968,858,691,671$. According to crude GC analysis with $n-\mathrm{C}_{14} \mathrm{H}_{30}$ as internal standard, crude yield of $\mathbf{6 n}$ was $69 \%$, recovered yield of $4 \mathbf{n}$ was $9 \%$ and the yield of isopropylboronic acid pinacol ester was $14 \%$.

2-(2-Adamantan-2-yl)propan-2-yl)-4,4,5,5-tetramethyl-1,3,2-dioxaborolane (6o)

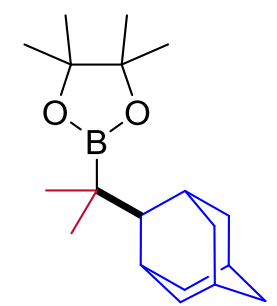

Following GP1, using $40(52.4 \mathrm{mg}, 0.2 \mathrm{mmol})$ and isopropyllithium $(0.70 \mathrm{M}$ in pentane, $0.31 \mathrm{~mL}, 0.22 \mathrm{mmol})$, flash chromatography eluting with pentane/DCM (5:1) afforded $\mathbf{6 0}$ as white solid ( $33.8 \mathrm{mg}, 56 \%$ yield, a mixture of two isomers). $\mathrm{R}_{\mathrm{f}} 0.4$ (pentane/DCM = 5:1). M.p. $=61-62{ }^{\circ} \mathrm{C}$. Regioisomeric ratio was determined to be 25:1 by crude GCMS and GC. ${ }^{1} \mathrm{H}$ NMR $\left(300 \mathrm{MHz}, \mathrm{CDCl}_{3}\right) \delta 2.16-1.94(\mathrm{~m}, 4 \mathrm{H})$, $1.90-1.64(\mathrm{~m}, 8 \mathrm{H}), 1.57-1.43(\mathrm{~m}, 3 \mathrm{H}), 1.23(\mathrm{~s}, 12 \mathrm{H}), 0.99(\mathrm{~s}, 6 \mathrm{H}) .{ }^{13} \mathrm{C}$ NMR $(75$ $\left.\mathrm{MHz}, \mathrm{CDCl}_{3}\right) \delta 82.8,56.0,41.0,38.6,32.9,30.0,28.7,27.5,26.3,24.8$, carbon attached to boron not observed. ${ }^{11} \mathrm{~B} \mathrm{NMR}\left(96 \mathrm{MHz}, \mathrm{CDCl}_{3}\right) \delta 35.1$. HRMS (ESI) $\mathrm{m} / \mathrm{z}$ $=327.2466$ calcd. for $\mathrm{C}_{19} \mathrm{H}_{33} \mathrm{BO}_{2} \mathrm{Na}^{+}[\mathrm{M}+\mathrm{Na}]^{+}$, found: 327.2455 . FTIR (neat): $v\left(\mathrm{~cm}^{-1}\right)$ 2976, 2903, 2850, 1476, 1455, 1389, 1371, 1315, 1296, 1257, 1137, 967, 859, 702.

2-(3-Methoxy-2-methylheptan-2-yl)-4,4,5,5-tetramethyl-1,3,2-dioxaborolane (6p)

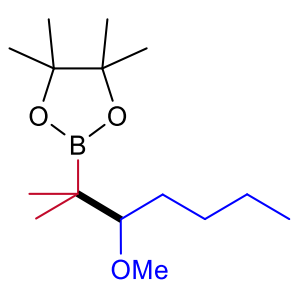

Following GP1, using $4 \mathbf{p}(45.6 \mathrm{mg}, 0.2 \mathrm{mmol})$ and isopropyllithium $(0.70 \mathrm{M}$ in pentane, $0.31 \mathrm{~mL}, 0.22 \mathrm{mmol}$ ), flash chromatography eluting with pentane/ethyl acetate (15:1) afforded $\mathbf{6 p}$ as light yellow liquid (39.0 mg, 72\% yield). $\mathrm{R}_{\mathrm{f}} 0.5$ (pentane/ethyl acetate $=10: 1) .{ }^{1} \mathrm{H}$ NMR $\left(300 \mathrm{MHz}, \mathrm{CDCl}_{3}\right) \delta 3.42(\mathrm{~s}, 3 \mathrm{H}), 3.09(\mathrm{dd}, J$ $=8.2,2.9 \mathrm{~Hz}, 1 \mathrm{H}), 1.56-1.26(\mathrm{~m}, 6 \mathrm{H}), 1.22(\mathrm{~s}, 6 \mathrm{H}), 1.21(\mathrm{~s}, 6 \mathrm{H}), 1.00-0.82(\mathrm{~m}$, 9H). ${ }^{13} \mathrm{C} \mathrm{NMR}\left(75 \mathrm{MHz}, \mathrm{CDCl}_{3}\right) \delta 87.7,82.9,60.4,32.3,29.8,24.7,24.5,23.1,20.7$, 19.5, 14.1, carbon attached to boron not observed. ${ }^{11} \mathrm{~B} \mathrm{NMR}\left(96 \mathrm{MHz}, \mathrm{CDCl}_{3}\right) \delta 34.2$. HRMS (ESI) $m / z=293.2258$ calcd. for $\mathrm{C}_{19} \mathrm{H}_{33} \mathrm{BO}_{3} \mathrm{Na}^{+}[\mathrm{M}+\mathrm{Na}]^{+}$, found: 293.2275. FTIR (neat): $v\left(\mathrm{~cm}^{-1}\right)$ 2975, 2957, 2934, 2873, 2825, 1470, 1371, 1343, 1307, 1274, 1215, 1136, 1095, 967, 849, 691, 674, 579. 
4,4,5,5-Tetramethyl-2-(2-methyl-3-(ethylthio)heptan-2-yl)-1,3,2-dioxaborolane (6q)

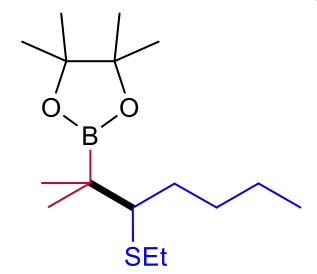

Following GP1, using 4q (51.6 mg, $0.2 \mathrm{mmol})$ and isopropyllithium $(0.70 \mathrm{M}$ in pentane, $0.31 \mathrm{~mL}, 0.22 \mathrm{mmol}$ ), flash chromatography eluting with pentane/ethyl acetate (20:1) afforded $\mathbf{6 q}$ as light yellow liquid (37.7 $\mathrm{mg}, 63 \%$ yield). $\mathrm{R}_{\mathrm{f}} 0.7$ (pentane/ethyl acetate $=10: 1) .{ }^{1} \mathrm{H} \mathrm{NMR}\left(300 \mathrm{MHz}, \mathrm{CDCl}_{3}\right) \delta 2.60(\mathrm{q}, J=7.4 \mathrm{~Hz}, 2 \mathrm{H})$, $2.49(\mathrm{dd}, J=10.4,2.6 \mathrm{~Hz}, 1 \mathrm{H}), 1.80-1.28(\mathrm{~m}, 6 \mathrm{H}), 1.26-1.17(\mathrm{~m}, 15 \mathrm{H}), 1.00(\mathrm{~s}$, $3 \mathrm{H}), 0.96-0.84(\mathrm{~m}, 6 \mathrm{H}) .{ }^{13} \mathrm{C}$ NMR $\left(75 \mathrm{MHz}, \mathrm{CDCl}_{3}\right) \delta 83.0,56.3,33.8,30.6,28.8$, $24.8,24.5,22.8,22.1,20.8,15.1,14.1$, carbon attached to boron not observed. ${ }^{11} \mathrm{~B}$ NMR (96 MHz, $\mathrm{CDCl}_{3}$ ) $\delta$ 34.4. HRMS (ESI) $\mathrm{m} / \mathrm{z}=323.2187$ calcd. for $\mathrm{C}_{16} \mathrm{H}_{33} \mathrm{BO}_{2} \mathrm{SNa}^{+}[\mathrm{M}+\mathrm{Na}]^{+}$, found: 323.2192. FTIR (neat): $v\left(\mathrm{~cm}^{-1}\right)$ 2958, 2928, 2869, 1468, 1371, 1343, 1307, 1138, 1118, 967, 850, 671.

Tert-butyl

2-isopropyl-2-(4,4,5,5-tetramethyl-1,3,2-dioxaborolan-2-yl)pyrrolidine-1-carboxylate (6r-1)

Tert-butyl

2-(2-(4,4,5,5-tetramethyl-1,3,2-dioxaborolan-2-yl)propan-2-yl)pyrrolidine-1-carboxyl ate $(\mathbf{6 r}-2)$

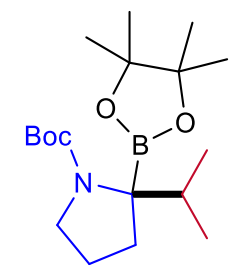

$6 r-1$

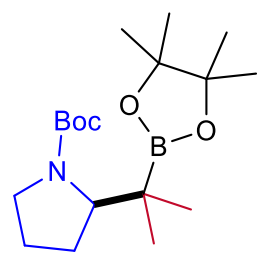

$6 r-2$

Following GP1, using $4 \mathbf{r}(59.4 \mathrm{mg}, 0.2 \mathrm{mmol})$ and isopropyllithium $(0.70 \mathrm{M}$ in pentane, $0.31 \mathrm{~mL}, 0.22 \mathrm{mmol}$ ), flash chromatography eluting with pentane/ethyl acetate (20:1) afforded $\mathbf{6 r - 1}$ as colorless sticky oil (40.5 mg, 60\% yield), $\mathrm{R}_{\mathrm{f}} 0.6$ (pentane/ethyl acetate $=10: 1)$; $\mathbf{6 r}-\mathbf{2}$ as colorless sticky oil $(10.9 \mathrm{mg}, 16 \%$ yield $), \mathrm{R}_{\mathrm{f}}$ 0.5 (pentane/ethyl acetate $=10: 1)$. Regioisomeric ratio was determined to be $4: 1$ by crude GCMS and GC.

6r-1: ${ }^{1} \mathrm{H}$ NMR (600 MHz, DMSO-d $\left.{ }^{6}, 363 \mathrm{~K}\right) \delta 3.58-3.47(\mathrm{~m}, 1 \mathrm{H}), 3.20-3.08(\mathrm{~m}$, $1 \mathrm{H}), 2.35-2.18(\mathrm{~m}, 1 \mathrm{H}), 1.94-1.63(\mathrm{~m}, 4 \mathrm{H}), 1.45(\mathrm{~d}, J=1.2 \mathrm{~Hz}, 9 \mathrm{H}), 1.25(\mathrm{~s}, 6 \mathrm{H})$, $1.23(\mathrm{~s}, 6 \mathrm{H}), 0.96(\mathrm{~d}, J=6.9 \mathrm{~Hz}, 3 \mathrm{H}), 0.80(\mathrm{br}, 3 \mathrm{H}) .{ }^{13} \mathrm{C}$ NMR $\left(151 \mathrm{MHz}, \mathrm{DMSO}-\mathrm{d}^{6}\right.$, $363 \mathrm{~K}) \delta 82.1,77.7,46.6,30.1,28.5,27.8,24.3,24.0,18.1,16.5$, carbonyl and carbon attached to boron not observed. ${ }^{11} \mathrm{~B}$ NMR $\left(96 \mathrm{MHz} \mathrm{CDCl}_{3}, 297 \mathrm{~K}\right) \delta 32.5$. HRMS (ESI) $m / z=362.2473$ calcd. for $\mathrm{C}_{18} \mathrm{H}_{34} \mathrm{BNO}_{4} \mathrm{Na}^{+}[\mathrm{M}+\mathrm{Na}]^{+}$, found: 362.2491 . FTIR (neat): $v\left(\mathrm{~cm}^{-1}\right)$ 2975, 2934, 1681, 1479, 1403, 1366, 1311, 1243, 1215, 1167, 1143, 1097, 
$987,972,862,771$.

6r-2: ${ }^{1} \mathrm{H}$ NMR (600 MHz, DMSO-d $\left.{ }^{6}, 363 \mathrm{~K}\right) \delta 3.88-3.82(\mathrm{~m}, 1 \mathrm{H}), 3.61-3.51(\mathrm{~m}$, $1 \mathrm{H}), 3.16-3.09(\mathrm{~m}, 1 \mathrm{H}), 1.92-1.80(\mathrm{~m}, 2 \mathrm{H}), 1.74-1.61(\mathrm{~m}, 2 \mathrm{H}), 1.45(\mathrm{~s}, 9 \mathrm{H}), 1.23$ $(\mathrm{s}, 12 \mathrm{H}), 0.85$ (s, 3H), 0.82 (s, 3H). ${ }^{13} \mathrm{C}$ NMR (151 MHz, DMSO-d 6 , $\left.363 \mathrm{~K}\right) \delta 154.3$, 81.7, 78.2, 62.5, 46.9, 27.8, 24.4, 24.3, 23.2, 20.9, carbon attached to boron not observed. ${ }^{11} \mathrm{~B}$ NMR $\left(96 \mathrm{MHz}, \mathrm{CDCl}_{3}, 297 \mathrm{~K}\right) \delta 26.5$. HRMS (ESI) $m / z=362.2473$ calcd. for $\mathrm{C}_{18} \mathrm{H}_{34} \mathrm{BNO}_{4} \mathrm{Na}^{+}[\mathrm{M}+\mathrm{Na}]^{+}$, found: 362.2493. FTIR (neat): $v\left(\mathrm{~cm}^{-1}\right)$ 2974, 2871, 1685, 1473, 1419, 1385, 1366, 1324, 1308, 1167, 1143, 1124, 969, 861, 772.

Tert-butyl

2-butyl-2-(4,4,5,5-tetramethyl-1,3,2-dioxaborolan-2-yl)pyrrolidine-1-carboxylate (6s)

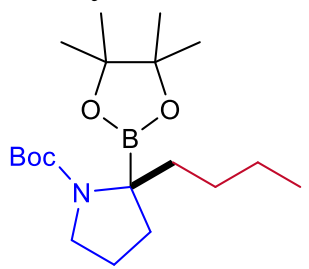

Following GP1, using $4 \mathbf{s}(59.4 \mathrm{mg}, 0.2 \mathrm{mmol})$ and isopropyllithium $(0.70 \mathrm{M}$ in pentane, $0.31 \mathrm{~mL}, 0.22 \mathrm{mmol})$, flash chromatography eluting with pentane/ethyl acetate (10:1) afforded $\mathbf{6 s}$ as colorless sticky oil (41.2 $\mathrm{mg}, 58 \%$ yield, single isomer), $\mathrm{R}_{\mathrm{f}} 0.6$ (pentane/ethyl acetate $=10: 1$ ). Regioisomeric ratio was determined to be 32:1 by crude GCMS and GC. The other isomer was not collected. ${ }^{1} \mathrm{H}$ NMR (300 MHz, $\left.\mathrm{CDCl}_{3}\right) \delta 3.67-3.34(\mathrm{~m}, 1 \mathrm{H}), 3.35-3.13(\mathrm{~m}, 1 \mathrm{H}), 2.01-1.47(\mathrm{~m}, 7 \mathrm{H}), 1.43(\mathrm{~s}, 9 \mathrm{H})$, $1.38-1.26(\mathrm{~m}, 3 \mathrm{H}), 1.24(\mathrm{~s}, 6 \mathrm{H}), 1.21(\mathrm{~s}, 6 \mathrm{H}), 0.88(\mathrm{t}, J=7.1 \mathrm{~Hz}, 3 \mathrm{H}) .{ }^{13} \mathrm{C} \mathrm{NMR}(75$ $\left.\mathrm{MHz}, \mathrm{CDCl}_{3}\right) \delta 83.1,78.9,46.7,34.6,32.8,28.6,26.7,25.1,24.5,23.4,14.3$, carbonyl and carbon attached to boron not observed. ${ }^{11} \mathrm{~B} \mathrm{NMR}\left(96 \mathrm{MHz}, \mathrm{CDCl}_{3}\right) \delta$ 32.1. HRMS (ESI) $\mathrm{m} / z=376.2630$ calcd. for $\mathrm{C}_{19} \mathrm{H}_{36} \mathrm{BNO}_{4} \mathrm{Na}^{+}[\mathrm{M}+\mathrm{Na}]^{+}$, found: 376.2633. FTIR (neat): $v\left(\mathrm{~cm}^{-1}\right)$ 2978, 2934, 1677, 1402, 1380, 1367, 1166, 1143, $1052,1025,1006,822,760,732,700$.

4,4,5,5-Tetramethyl-2-(2,3,3-trimethylbutan-2-yl)-1,3,2-dioxaborolane (6t)<smiles>C=C(C)C(C)B1OC(C)(C)C(C)(C)O1</smiles>

Following GP1, using 4t $(36.8 \mathrm{mg}, 0.2 \mathrm{mmol})$ and isopropyllithium $(0.70 \mathrm{M}$ in pentane, $0.31 \mathrm{~mL}, 0.22 \mathrm{mmol})$, flash chromatography eluting with pentane/DCM $(5: 1)$ afforded $6 \mathrm{t}$ as light yellow liquid (22.2 $\mathrm{mg}, 50 \%$ yield). $\mathrm{R}_{\mathrm{f}} 0.5$ (pentane/DCM = 5:1). ${ }^{1} \mathrm{H} \mathrm{NMR}\left(300 \mathrm{MHz}, \mathrm{CDCl}_{3}\right) \delta 1.22$ (s, 12H), 0.90 (s, 9H), 0.88 (s, 6H). ${ }^{13} \mathrm{C}$ NMR $(75$ $\left.\mathrm{MHz}, \mathrm{CDCl}_{3}\right) \delta 82.7,33.9,26.7,24.7,20.7$, carbon attached to boron not observed. ${ }^{11} \mathrm{~B}$ NMR $\left(96 \mathrm{MHz}, \mathrm{CDCl}_{3}\right) \delta$ 34.8. HRMS (ESI) $\mathrm{m} / \mathrm{z}=249.1996$ calcd. for $\mathrm{C}_{19} \mathrm{H}_{33} \mathrm{BO}_{2} \mathrm{Na}^{+}[\mathrm{M}+\mathrm{Na}]^{+}$, found: 249.2005. FTIR (neat): $v\left(\mathrm{~cm}^{-1}\right)$ 2971, 2872, 1464, 1401, 1379, 1371, 1339, 1298, 1261, 1214, 1150, 1121, 1022, 967, 877, 852, 805, 718, 682. 
2-(6-(2,5-Dimethylphenoxy)-2,3,3-trimethylhexan-2-yl)-4,4,5,5-tetramethyl-1,3,2-dio xaborolane (6u)

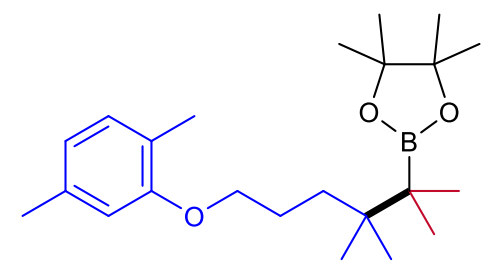

Following GP1, using $4 \mathbf{u}(66.4 \mathrm{mg}, 0.2 \mathrm{mmol})$ and isopropyllithium $(0.70 \mathrm{M}$ in pentane, $0.31 \mathrm{~mL}, 0.22 \mathrm{mmol})$, flash chromatography eluting with pentane/DCM (3:1) afforded 6u as light yellow sticky oil $\left(23.8 \mathrm{mg}, 32 \%\right.$ yield), $\mathrm{R}_{\mathrm{f}} 0.6$ (pentane/DCM = 2:1). ${ }^{1} \mathrm{H}$ NMR $\left(300 \mathrm{MHz}, \mathrm{CDCl}_{3}\right) \delta 7.00(\mathrm{~d}, J=7.3 \mathrm{~Hz}, 1 \mathrm{H}), 6.70-6.60(\mathrm{~m}, 2 \mathrm{H})$, $3.92(\mathrm{t}, J=6.6 \mathrm{~Hz}, 2 \mathrm{H}), 2.32(\mathrm{~s}, 3 \mathrm{H}), 2.19(\mathrm{~s}, 3 \mathrm{H}), 1.85-1.68(\mathrm{~m}, 2 \mathrm{H}), 1.53-1.42$ $(\mathrm{m}, 2 \mathrm{H}), 1.22(\mathrm{~s}, 12 \mathrm{H}), 0.93-0.89(\mathrm{~m}, 12 \mathrm{H}) .{ }^{13} \mathrm{C} \mathrm{NMR}\left(75 \mathrm{MHz}, \mathrm{CDCl}_{3}\right) \delta 157.2$, 136.4, 130.2, 123.6, 120.5, 112.0, 82.7, 69.0, 36.1, 34.5, 24.8, 24.7, 22.5, 21.4, 20.4, 15.8 , carbon attached to boron not observed. ${ }^{11} \mathrm{~B} \mathrm{NMR}\left(96 \mathrm{MHz}, \mathrm{CDCl}_{3}\right) \delta 34.8$. HRMS (ESI) $m / z=397.2884$ calcd. for $\mathrm{C}_{23} \mathrm{H}_{39} \mathrm{BO}_{3} \mathrm{Na}^{+}[\mathrm{M}+\mathrm{Na}]^{+}$, found: 397.2897. FTIR (neat): $v\left(\mathrm{~cm}^{-1}\right)$ 2973, 2959, 2872, 1617, 1586, 1509, 1466, 1379, 1371, 1338 , 1297, 1266, 1147, 1120, 1037, 967, 850, 802.

2-(1-((1S,4aS,10aS)-7-Isopropyl-1,4a-dimethyl-1,2,3,4,4a,9,10,10a-octahydrophenant hren-1-yl)-2-methylpropan-2-yl)-4,4,5,5-tetramethyl-1,3,2-dioxaborolane (6v)

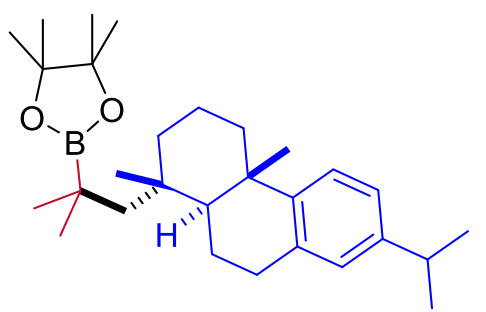

Following GP1, using 4v (74.1 $\mathrm{mg}, 0.187 \mathrm{mmol})$ and isopropyllithium $(0.70 \mathrm{M}$ in pentane, $0.29 \mathrm{~mL}, 0.22 \mathrm{mmol}$ ), flash chromatography eluting with pentane/DCM (3:1) afforded $6 \mathbf{v}$ as light yellow sticky oil $\left(43.4 \mathrm{mg}, 50 \%\right.$ yield), $\mathrm{R}_{\mathrm{f}} 0.5$ (pentane/DCM = 2:1). $[\alpha]_{D}^{24}+4\left(c 0.4, \mathrm{CHCl}_{3}\right)$. The other regioisomer was not detected by crude GCMS. ${ }^{1} \mathrm{H}$ NMR $\left(300 \mathrm{MHz}, \mathrm{CDCl}_{3}\right) \delta 7.16(\mathrm{~d}, J=8.2 \mathrm{~Hz}, 1 \mathrm{H}), 6.98(\mathrm{dd}, J=8.2,1.6$ $\mathrm{Hz}, 1 \mathrm{H}), 6.90$ (s, 1H), $3.00-2.72(\mathrm{~m}, 3 \mathrm{H}), 2.33-2.19(\mathrm{~m}, 1 \mathrm{H}), 2.10-1.89(\mathrm{~m}, 1 \mathrm{H})$, $1.80-1.52(\mathrm{~m}, 5 \mathrm{H}), 1.51-1.29(\mathrm{~m}, 4 \mathrm{H}), 1.25(\mathrm{~s}, 3 \mathrm{H}), 1.24-1.19(\mathrm{~m}, 18 \mathrm{H}), 0.99(\mathrm{~s}$, $6 \mathrm{H}), 0.96(\mathrm{~s}, 3 \mathrm{H}) .{ }^{13} \mathrm{C} \mathrm{NMR}\left(75 \mathrm{MHz}, \mathrm{CDCl}_{3}\right) \delta 148.1,145.3,135.0,126.8,124.0$, 123.6, 82.9, 55.5, 51.0, 38.7, 37.9, 37.0, 33.5, 30.6, 28.1, 27.7, 25.5, 24.8, 24.7, 24.0, $20.1,19.0,1.0$, carbon attached to boron not observed. ${ }^{11} \mathrm{~B} \mathrm{NMR}\left(96 \mathrm{MHz}, \mathrm{CDCl}_{3}\right) \delta$ 34.7. HRMS (ESI) $\mathrm{m} / \mathrm{z}=461.3561$ calcd. for $\mathrm{C}_{29} \mathrm{H}_{47} \mathrm{BNaO}_{2}{ }^{+}[\mathrm{M}+\mathrm{Na}]^{+}$, found: 461.3553. FTIR (neat): $v\left(\mathrm{~cm}^{-1}\right)$ 2957, 2926, 2867, 1477, 1456, 1389, 1371, 1340, 1303, 1264, 1212, 1165, 1141, 1108, 1094, 1020, 967, 863, 847, 821, 802, 738, 704, 691,670 .

(R)-2-(2,3-Dimethyl-3-phenethylheptan-2-yl)-4,4,5,5-tetramethyl-1,3,2-dioxaborolane 
$(6 \mathbf{w})$<smiles>CC(C)(C)C(CCc1ccccc1)C(C)(C)B1OC(C)(C)C(C)(C)O1</smiles>

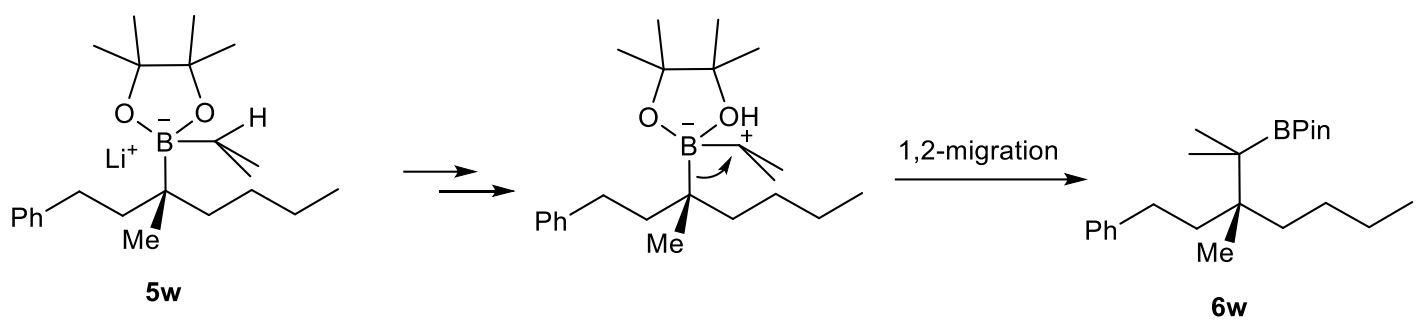

Following GP1, using 4w (73.2 mg, $0.2 \mathrm{mmol}$, 99\% ee) and isopropyllithium (0.70 M in pentane, $0.31 \mathrm{~mL}, 0.22 \mathrm{mmol})$, flash chromatography eluting with pentane/DCM (5:1) afforded $6 \mathrm{w}$ as colorless sticky oil (21.4 $\mathrm{mg}, 30 \%$ yield, 97\% ee), $\mathrm{R}_{\mathrm{f}} 0.5$ (pentane/DCM = 3:1). Ee determined by chiral HPLC after oxidation $\left(\mathrm{NaOH} / \mathrm{H}_{2} \mathrm{O}_{2}\right)$. ${ }^{\mathrm{S} 17}{ }^{1} \mathrm{H}$ NMR $\left(300 \mathrm{MHz}, \mathrm{CDCl}_{3}\right) \delta 7.23-7.15(\mathrm{~m}, 2 \mathrm{H}), 7.15-7.04(\mathrm{~m}, 3 \mathrm{H}), 2.62-$ $2.33(\mathrm{~m}, 2 \mathrm{H}), 1.74-1.17(\mathrm{~m}, 8 \mathrm{H}), 1.14(\mathrm{~s}, 12 \mathrm{H}), 0.94-0.75(\mathrm{~m}, 12 \mathrm{H}) .{ }^{13} \mathrm{C}$ NMR $(75$ $\left.\mathrm{MHz}, \mathrm{CDCl}_{3}\right) \delta 144.2,128.3,128.2,125.4,82.6,39.3,39.0,36.7,31.8,27.4,24.7$, 24.1, 21.2, 21.1, 14.3, carbon attached to boron not observed. ${ }^{11} \mathrm{~B} \mathrm{NMR}(96 \mathrm{MHz}$, $\left.\mathrm{CDCl}_{3}\right) \delta$ 34.1. HRMS (ESI) $m / z=381.2935$ calcd. for $\mathrm{C}_{23} \mathrm{H}_{39} \mathrm{BO}_{2} \mathrm{Na}^{+}[\mathrm{M}+\mathrm{Na}]^{+}$, found: 381.2937. FTIR (neat): $v\left(\mathrm{~cm}^{-1}\right)$ 2956, 2933, 2870, 1603, 1497, 1468, 1389, 1371, 1331, 1295, 1214, 1143, 1118, 1031, 966, 855, 750, 720, 698, 687, 670, 583. Chiral HPLC (IC, $1 \%$ iPrOH/cyclohexane, $1.0 \mathrm{ml} / \mathrm{min}$ ) $\mathrm{T}_{R} 7.06 \mathrm{~min}$ (major), 8.15 $\min$ (minor). $\quad[\alpha]_{D}^{25}+2\left(c 1.0, \mathrm{CHCl}_{3}\right)$.
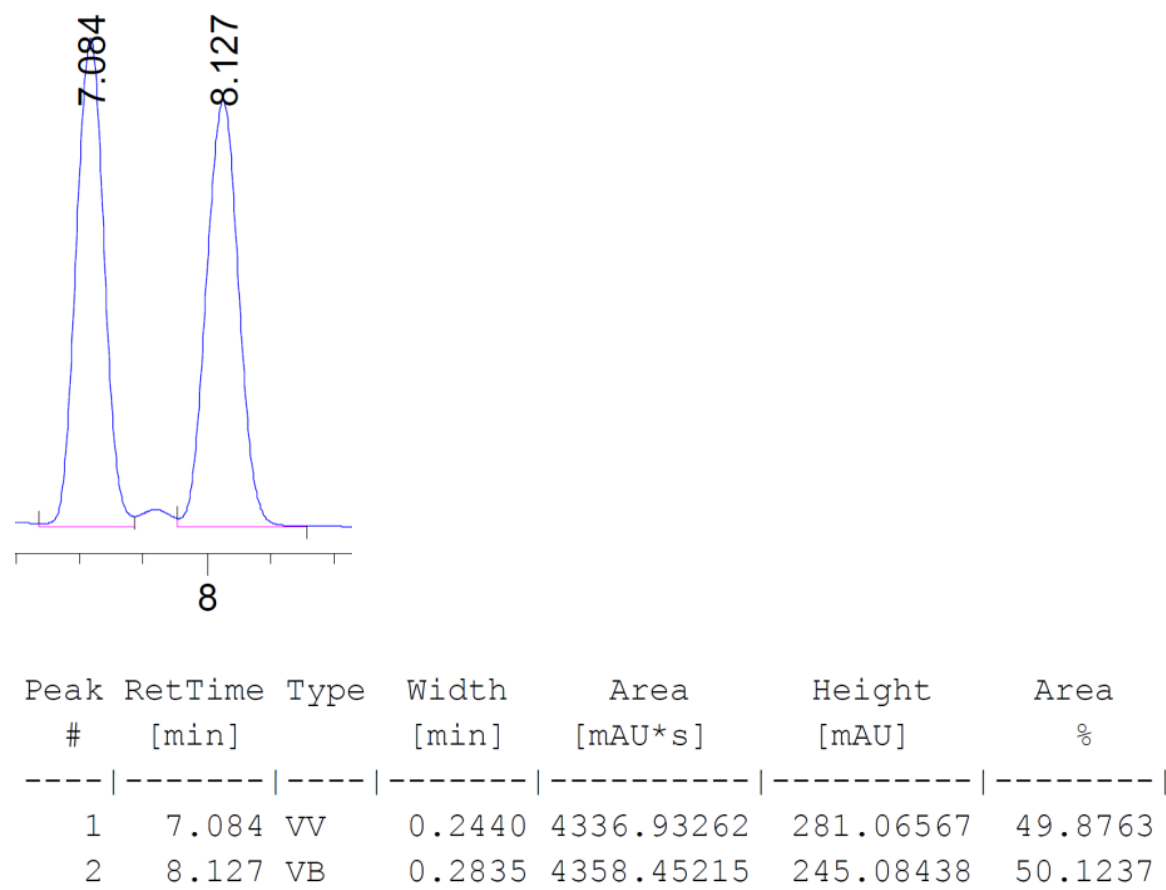

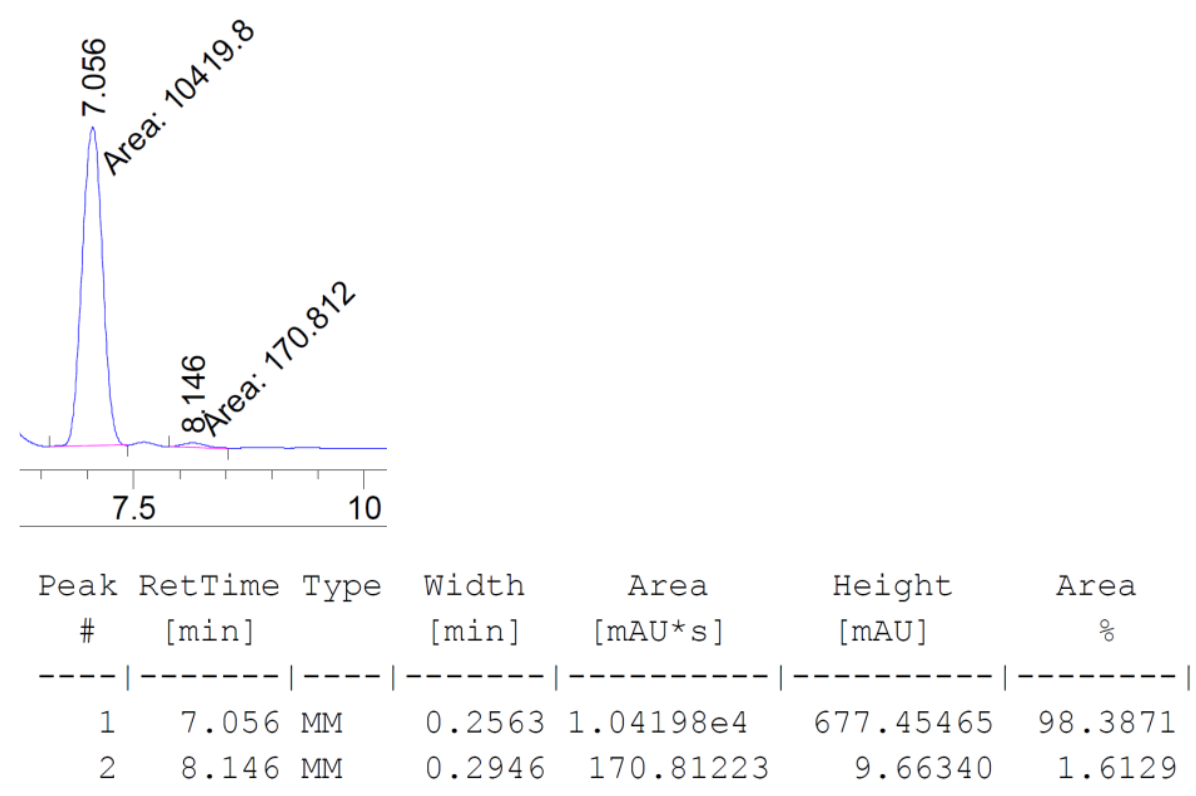

(R)-Tert-butyl

2-(2-(4,4,5,5-tetramethyl-1,3,2-dioxaborolan-2-yl)propan-2-yl)piperidine-1-carboxyla te $(\mathbf{6} \mathbf{x})$<smiles>CN1CCCCC1C(C)(C)C1OC(C)(C)C(C)(C)O1</smiles>

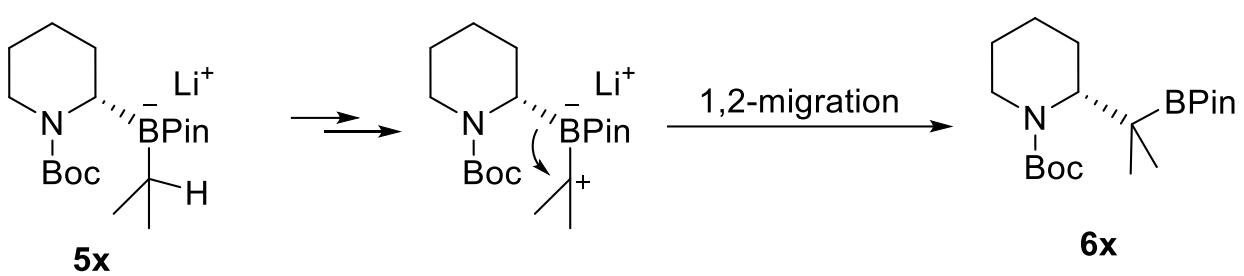

Following GP1, using $S \mathbf{- 4 x}(62.2 \mathrm{mg}, 0.2 \mathrm{mmol}, 73 \%$ ee) and isopropyllithium (0.70 $\mathrm{M}$ in pentane, $0.31 \mathrm{~mL}, 0.22 \mathrm{mmol}$ ), flash chromatography eluting with pentane/ ethyl acetate (10:1) afforded $R$-6u as colorless sticky oil (31.4 mg, 44\% yield, 73\% ee). Regioisomeric ratio was determined to be $10: 1$ by crude GC and GCMS. The other regioisomer was not collected. $R_{\mathrm{f}} 0.6$ (pentane/ethyl acetate $\left.=20: 3\right) .{ }^{1} \mathrm{H}$ NMR $(600$ MHz, DMSO-d ${ }^{6}, 363$ K) $\delta 3.79-3.57(\mathrm{~m}, 2 \mathrm{H}), 3.29-3.10(\mathrm{~m}, 1 \mathrm{H}), 1.83-1.72(\mathrm{~m}$, $1 \mathrm{H}), 1.71-1.59(\mathrm{~m}, 2 \mathrm{H}), 1.52-1.47(\mathrm{~m}, 2 \mathrm{H}), 1.46(\mathrm{~s}, 9 \mathrm{H}), 1.43-1.36(\mathrm{~m}, 1 \mathrm{H}), 1.24$ (s, 12H), 0.94 (s, 6H). ${ }^{13} \mathrm{C}$ NMR (151 MHz, DMSO-d 6 , $\left.363 \mathrm{~K}\right) \delta 154.9,81.8,78.3$, 27.7, 24.8, 24.3, 24.3, 23.6, 23.5, 22.6, 20.2, carbon attached to boron and two carbons attached to nitrogen not observed. ${ }^{11} \mathrm{~B}$ NMR $\left(192 \mathrm{MHz}, \mathrm{DMSO}-\mathrm{d}^{6}, 363 \mathrm{~K}\right) \delta$ 31.3. HRMS (ESI) $m / z=376.2630$ calcd. for $\mathrm{C}_{19} \mathrm{H}_{36} \mathrm{BNO}_{4} \mathrm{Na}^{+}[\mathrm{M}+\mathrm{Na}]^{+}$, found: 376.2643. FTIR (neat): $v\left(\mathrm{~cm}^{-1}\right)$ 2975, 2937, 1680, 1653, 1573, 1476, 1390, 1365, 1269, 1139, 1051, 1024, 1004, 822, 762, 733, 699, 632. Chiral HPLC (IC, 0.25\% 
$i \mathrm{PrOH} /$ cyclohexane, $1.0 \mathrm{ml} / \mathrm{min}$ ) $\mathrm{T}_{R} 8.97 \mathrm{~min}$ (minor), $9.66 \mathrm{~min}$ (major). $[\alpha]_{D}^{25}+27$ (c $0.5, \mathrm{CHCl}_{3}$ ).
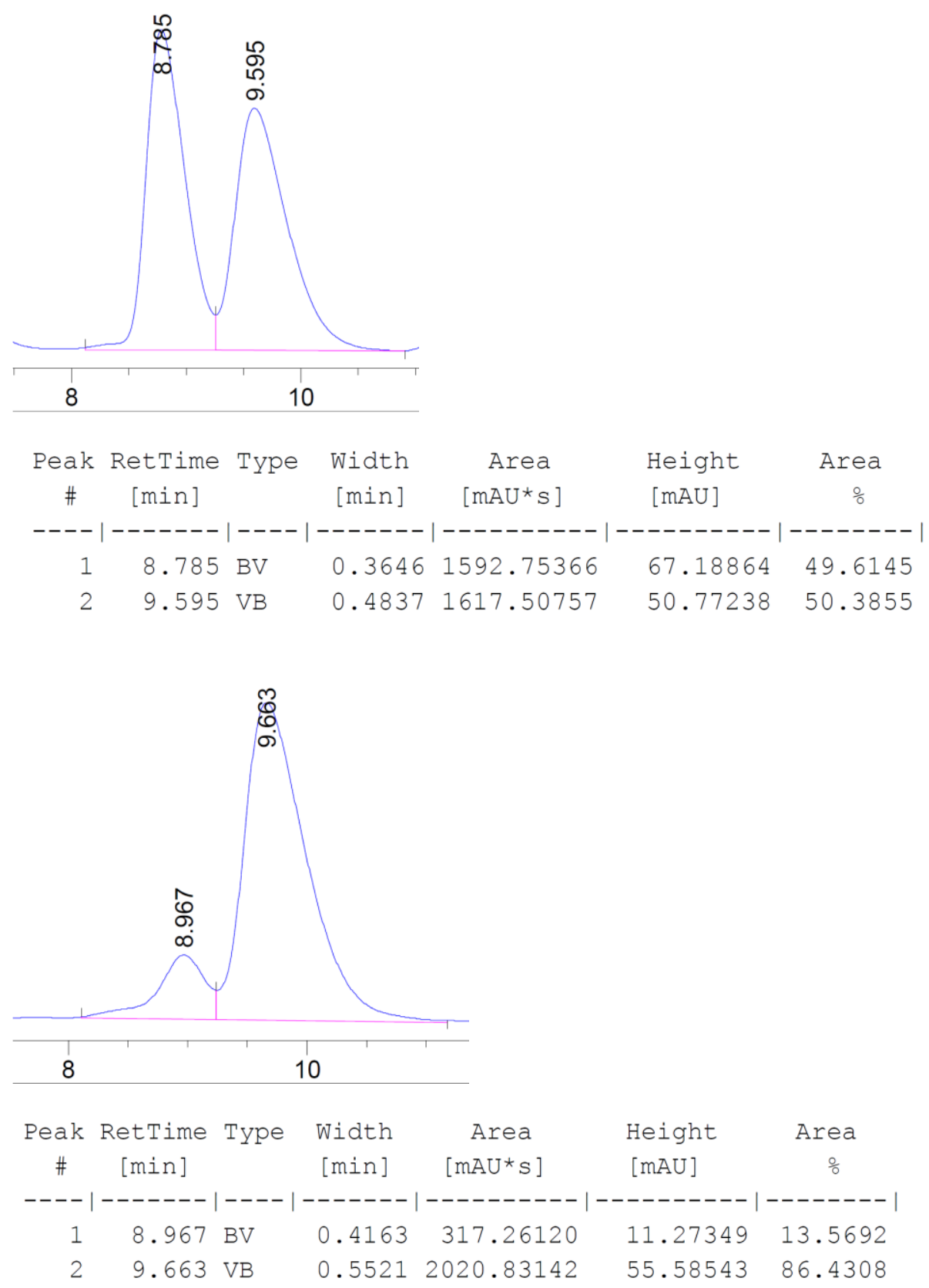

4,4,5,5-Tetramethyl-2-(2-((1S,2R,3S,5S)-2,6,6-trimethylbicyclo[3.1.1]heptan-3-yl)pro pan-2-yl)-1,3,2-dioxaborolane (6y)

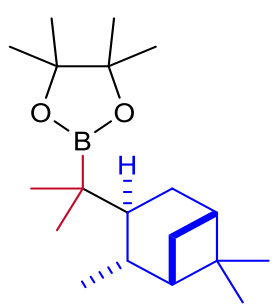




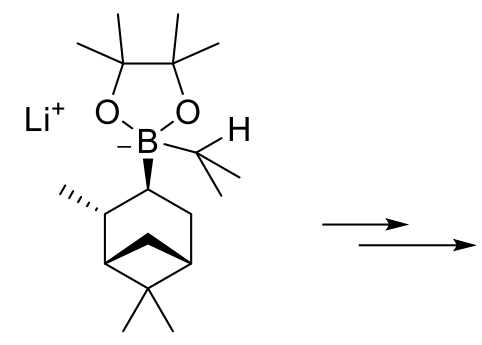

$5 y$

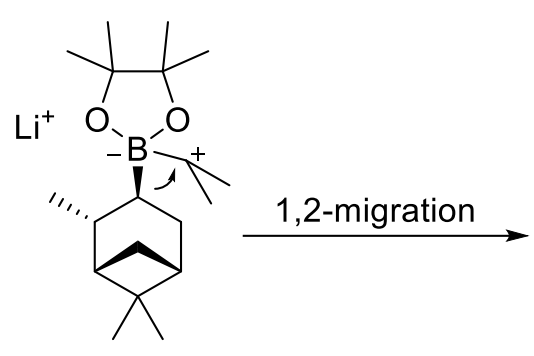

$6 y$

Following GP1, using $4 \mathbf{y}(52.8 \mathrm{mg}, 0.2 \mathrm{mmol}, \mathrm{dr}=92: 8)$ and isopropyllithium $(0.70$ $\mathrm{M}$ in pentane, $0.31 \mathrm{~mL}, 0.22 \mathrm{mmol})$, flash chromatography eluting with pentane/DCM (5:1) afforded 6y as colorless sticky oil (42.6 mg, 70\% yield, $\mathrm{dr}=93: 7), \mathrm{R}_{\mathrm{f}} 0.5$ (pentane/DCM = 3:1). $\quad[\alpha]{ }_{D}^{26}+9\left(c 0.46, \mathrm{CHCl}_{3}\right) .{ }^{1} \mathrm{H} \mathrm{NMR}\left(300 \mathrm{MHz}, \mathrm{CDCl}_{3}\right) \delta$ $2.17-1.78(\mathrm{~m}, 6 \mathrm{H}), 1.74-1.66(\mathrm{~m}, 1 \mathrm{H}), 1.56-1.45(\mathrm{~m}, 1 \mathrm{H}), 1.22(\mathrm{~s}, 6 \mathrm{H}), 1.22$ (s, $6 \mathrm{H}), 1.06(\mathrm{~d}, J=7.0 \mathrm{~Hz}, 3 \mathrm{H}), 1.03(\mathrm{~s}, 3 \mathrm{H}), 0.98(\mathrm{~s}, 3 \mathrm{H}), 0.95(\mathrm{~s}, 3 \mathrm{H}), 0.94(\mathrm{~s}, 3 \mathrm{H}) .{ }^{13} \mathrm{C}$ NMR $\left(75 \mathrm{MHz}, \mathrm{CDCl}_{3}\right) \delta 82.8,49.1,43.0,41.7,39.0,36.4,32.0,31.8,31.2,27.8$, 24.9, 24.6, 24.2, 23.4, 21.0, carbon attached to boron not observed. ${ }^{11} \mathrm{~B} \mathrm{NMR}(96$ $\left.\mathrm{MHz}, \mathrm{CDCl}_{3}\right) \delta$ 33.7. HRMS (ESI) $\mathrm{m} / z=329.2622$ calcd. for $\mathrm{C}_{19} \mathrm{H}_{35} \mathrm{BO}_{2} \mathrm{Na}^{+}$ $[\mathrm{M}+\mathrm{Na}]^{+}$, found: 329.2629. FTIR (neat): $v\left(\mathrm{~cm}^{-1}\right)$ 2978, 2896, 2868, 1471, 1388, 1347, 1302, 1262, 1229, 1214, 1140, 1124, 1078, 1022, 967, 863, 839, 692, 672. Diastereomeric ratio was determined by chiral GC.

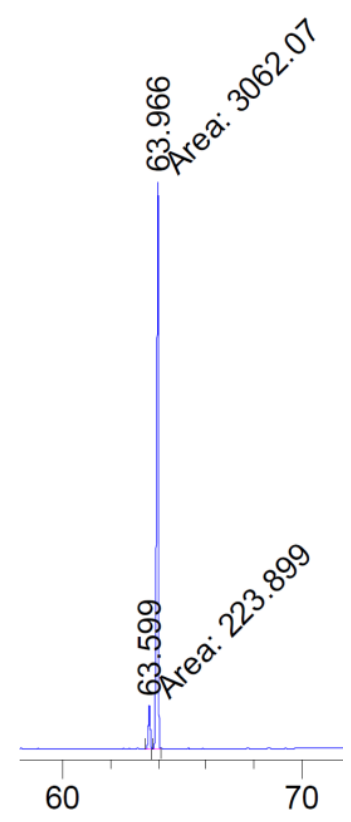

2-(2-((1R,2S,5R)-2-Isopropyl-5-methylcyclohexyl)propan-2-yl)-4,4,5,5-tetramethyl-1, 3,2-dioxaborolane $(\mathbf{6 z})$ 


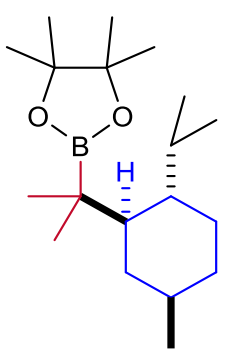

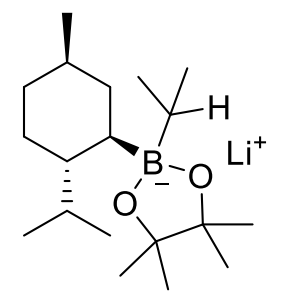

$5 z$

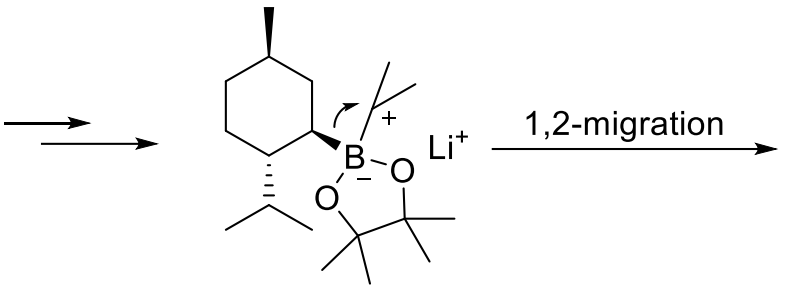

$\overbrace{(1}^{B \text { Bin }}$

$6 z$

Following GP1, using $\mathbf{4 z}(41.8 \mathrm{mg}, 0.157 \mathrm{mmol}$, dr > 99:1) and isopropyllithium ( $0.70 \mathrm{M}$ in pentane, $0.25 \mathrm{~mL}, 0.35 \mathrm{mmol}, 1.1$ equiv), flash chromatography eluting with pentane/DCM (5:1) afforded $\mathbf{6 z}$ as colorless sticky oil $(23.5 \mathrm{mg}, 49 \%$ yield, dr >

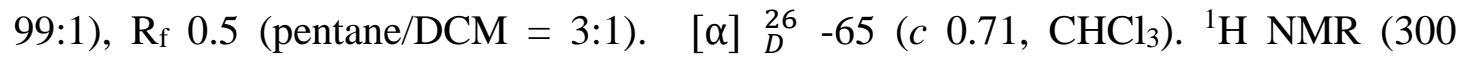
$\left.\mathrm{MHz}, \mathrm{CDCl}_{3}\right) \delta 1.73-1.46(\mathrm{~m}, 5 \mathrm{H}), 1.25(\mathrm{~s}, 6 \mathrm{H}), 1.19(\mathrm{~s}, 6 \mathrm{H}), 1.04-0.93(\mathrm{~m}, 2 \mathrm{H})$, $0.92-0.73(\mathrm{~m}, 17 \mathrm{H}), 0.71-0.55(\mathrm{~m}, 1 \mathrm{H}) .{ }^{13} \mathrm{C} \mathrm{NMR}\left(75 \mathrm{MHz}, \mathrm{CDCl}_{3}\right) \delta 82.7,45.4$, $42.9,35.3,34.6,33.0,27.2,25.4,24.5,24.0,23.1,22.4,17.4,16.8$, carbon attached to boron not observed. ${ }^{11} \mathrm{~B}$ NMR $\left(96 \mathrm{MHz}, \mathrm{CDCl}_{3}\right) \delta 34.2$. HRMS (ESI) $\mathrm{m} / z=$ 331.2779 calcd. for $\mathrm{C}_{19} \mathrm{H}_{37} \mathrm{BO}_{2} \mathrm{Na}^{+}[\mathrm{M}+\mathrm{Na}]^{+}$, found: 331.2788. FTIR (neat): $v\left(\mathrm{~cm}^{-1}\right)$ 2952, 2925, 2869, 1468, 1387, 1370, 1349, 1301, 1266, 1164, 1143, 1127, 1089, 966, 876, $853,842,710,686$. Diastereomer ratio was determined by chiral GC.

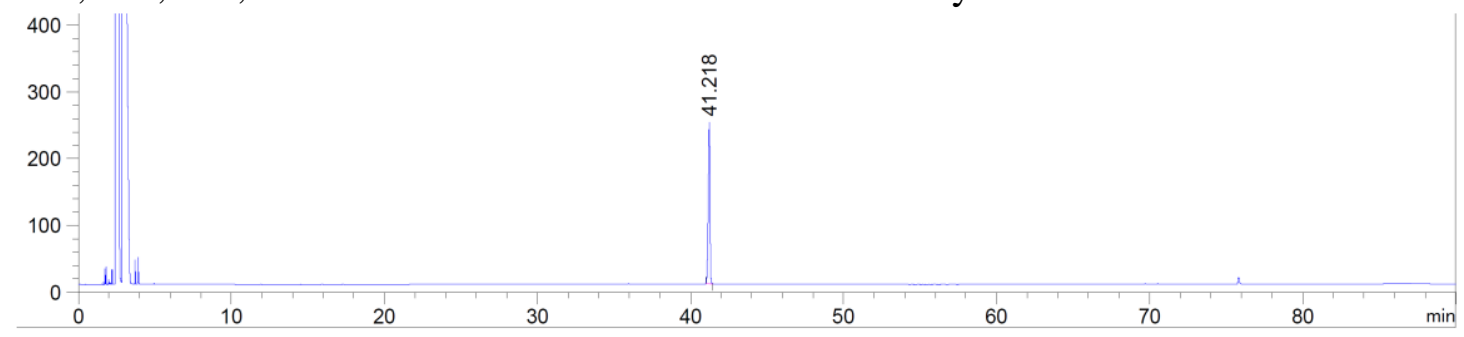

2-(2-((3S,5R,6S,8S,9S,10R,13R,14S,17R)-3-Methoxy-10,13-dimethyl-17-((R)-6-meth ylheptan-2-yl)hexadecahydro-1H-cyclopenta[a]phenanthren-6-yl)propan-2-yl)-4,4,5,5 -tetramethyl-1,3,2-dioxaborolane (6aa)

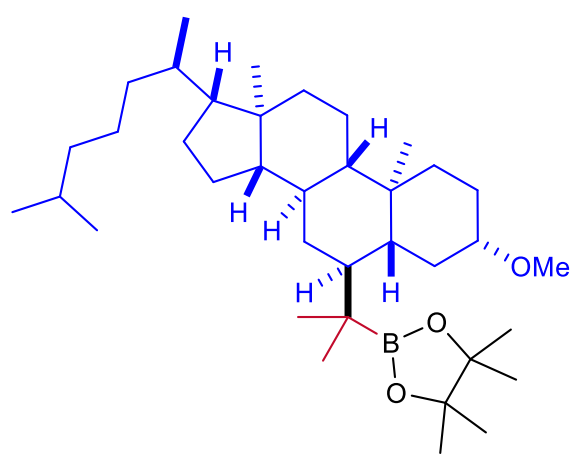




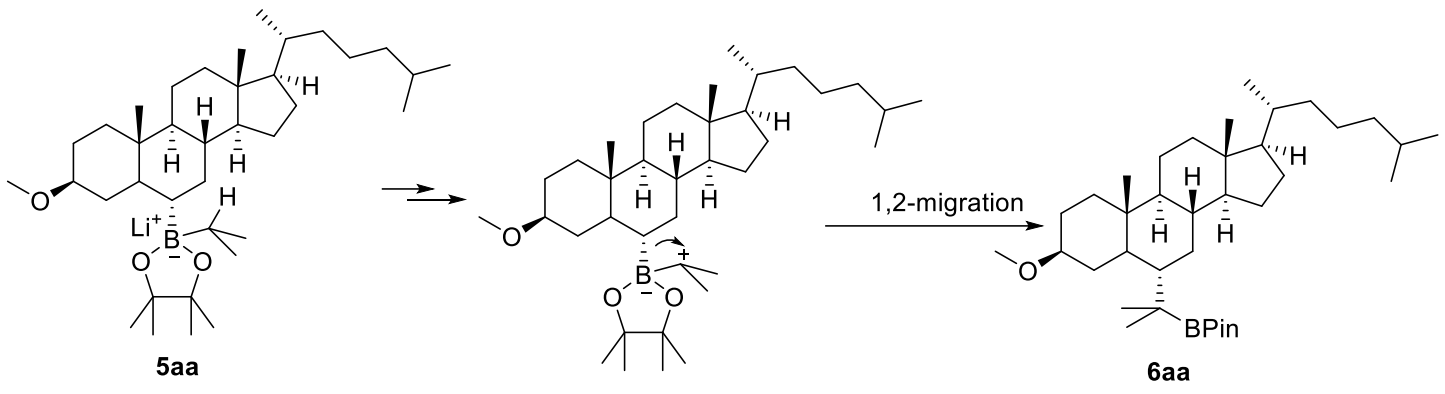

Following GP1, using 4aa $(62.6 \mathrm{mg}, 0.119 \mathrm{mmol})$ and isopropyllithium $(0.70 \mathrm{M}$ in pentane, $0.19 \mathrm{~mL}, 0.13 \mathrm{mmol}, 1.1$ equiv), flash chromatography eluting with DCM afforded 6aa as light yellow sticky oil $\left(46.4 \mathrm{mg}, 69 \%\right.$ yield), $\mathrm{R}_{\mathrm{f}} 0.2(\mathrm{DCM}) . \quad[\alpha]_{D}^{26}$ $+25\left(c\right.$ 0.57, $\left.\mathrm{CHCl}_{3}\right) .{ }^{1} \mathrm{H}$ NMR $\left(300 \mathrm{MHz}, \mathrm{CDCl}_{3}\right) \delta 3.32(\mathrm{~s}, 3 \mathrm{H}), 3.05-2.87(\mathrm{~m}, 1 \mathrm{H})$, $2.02-1.89(\mathrm{~m}, 1 \mathrm{H}), 1.88-1.69(\mathrm{~m}, 4 \mathrm{H}), 1.69-1.42(\mathrm{~m}, 5 \mathrm{H}), 1.40-1.26(\mathrm{~m}, 6 \mathrm{H})$, $1.23(\mathrm{~s}, 12 \mathrm{H}), 1.17-0.94(\mathrm{~m}, 10 \mathrm{H}), 0.92-0.81(\mathrm{~m}, 19 \mathrm{H}), 0.76(\mathrm{~s}, 3 \mathrm{H}), 0.63(\mathrm{~s}, 3 \mathrm{H})$. ${ }^{13} \mathrm{C}$ NMR $\left(75 \mathrm{MHz}, \mathrm{CDCl}_{3}\right) \delta 82.9,81.1,56.7,56.4,55.9,54.5,47.5,42.7,40.1,40.0$, $39.5,37.6,36.4,36.2,35.8,35.1,31.2$, 30.6, 28.3, 28.0, 27.9, 24.8, 24.8, 24.4, 24.3, 23.9, 22.8, 22.6, 21.4, 18.7, 16.7, 13.7, 12.0, carbon attached to boron not observed. ${ }^{11} \mathrm{~B}$ NMR (96 MHz, $\left.\mathrm{CDCl}_{3}\right) \delta$ 33.9. HRMS (ESI) $\mathrm{m} / z=593.5075$ calcd. for $\mathrm{C}_{37} \mathrm{H}_{67} \mathrm{BO}_{2} \mathrm{Na}^{+}[\mathrm{M}+\mathrm{Na}]^{+}$, found: 593.5082. FTIR (neat): v $\left(\mathrm{cm}^{-1}\right)$ 2935, 2902, 2868, 2849, 1469, 1444, 1378, 1347, 1304, 1267, 1210, 1140, 1104, 966, 850, 710, 687, 577.

$\mathrm{Dr}$ and $r r$ were determined by GCMS analysis after protondeboronation of 6aa. The minor isomers were not detected by GCMS.

2-(2-((3S,5R,6S,8S,9S,10R,13R,14S,17R)-3-Chloro-10,13-dimethyl-17-((R)-6-methylh eptan-2-yl)hexadecahydro-1H-cyclopenta[a]phenanthren-6-yl)propan-2-yl)-4,4,5,5-tet ramethyl-1,3,2-dioxaborolane (6ab)

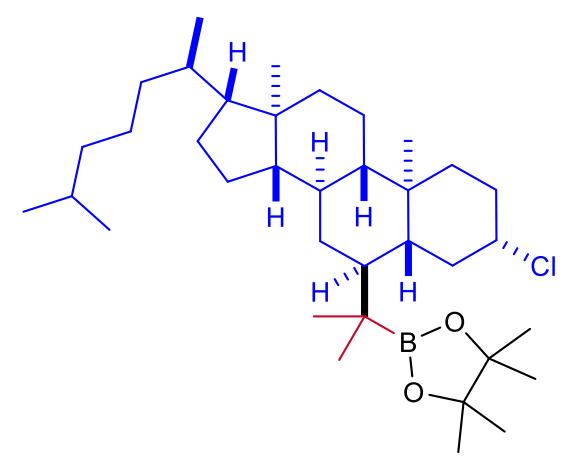

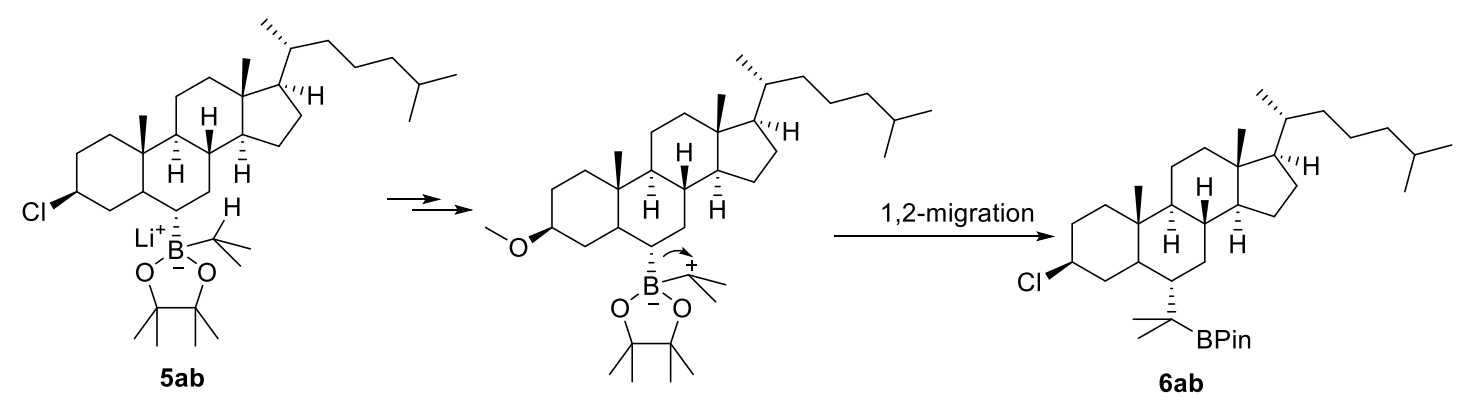

Following GP1, using 4ab (106.6 mg, $0.2 \mathrm{mmol})$ and isopropyllithium (0.70 M in 
pentane, $0.31 \mathrm{~mL}, 0.22 \mathrm{mmol}, 1.1$ equiv), flash chromatography eluting with pentane/DCM (4:1) afforded 6ab as white solid (55.2 $\mathrm{mg}, 48 \%$ yield), $\mathrm{R}_{\mathrm{f}} 0.4$ (pentane/DCM = 3:1). M.p.: $71-73{ }^{\circ} \mathrm{C} . \quad[\alpha]{ }_{D}^{25}+35\left(c 0.2, \mathrm{CHCl}_{3}\right) .{ }^{1} \mathrm{H}$ NMR (300 $\left.\mathrm{MHz}, \mathrm{CDCl}_{3}\right) \delta 3.89-3.67(\mathrm{~m}, 1 \mathrm{H}), 2.04-1.91(\mathrm{~m}, 2 \mathrm{H}), 1.91-1.70(\mathrm{~m}, 4 \mathrm{H}), 1.70-$ $1.41(\mathrm{~m}, 7 \mathrm{H}), 1.40-1.30(\mathrm{~m}, 5 \mathrm{H}), 1.25(\mathrm{~s}, 6 \mathrm{H}), 1.24(\mathrm{~s}, 6 \mathrm{H}), 1.17-0.94(\mathrm{~m}, 10 \mathrm{H})$, $0.88(\mathrm{t}, J=7.8 \mathrm{~Hz}, 16 \mathrm{H}), 0.76(\mathrm{~s}, 3 \mathrm{H}), 0.63(\mathrm{~s}, 3 \mathrm{H}), 0.60-0.44(\mathrm{~m}, 1 \mathrm{H}) .{ }^{13} \mathrm{C} \mathrm{NMR}$ $\left(75 \mathrm{MHz}, \mathrm{CDCl}_{3}\right) \delta 83.0,61.4,56.6,56.3,54.2,49.3,42.6,40.0,39.9,39.5,39.3$, 36.6, 36.2, 35.9, 35.8, 35.0, 33.0, 30.3, 28.3, 28.0, 25.0, 24.8, 24.5, 24.3, 23.9, 22.8, $22.7,21.3,18.7,16.4,13.7,12.0$, carbon attached to boron not observed. ${ }^{11} \mathrm{~B} \mathrm{NMR}$ $\left(96 \mathrm{MHz}, \mathrm{CDCl}_{3}\right) \delta 34.2$. HRMS (ESI) $\mathrm{m} / z=597.4580$ calcd. for $\mathrm{C}_{36} \mathrm{H}_{64} \mathrm{BClO}_{2} \mathrm{Na}^{+}$ [M+Na $]^{+}$, found: 597.4571. FTIR (neat): $v\left(\mathrm{~cm}^{-1}\right)$ 2948, 2869, 1468, 1444, 1372, 1347, 1306, 1167, 1139, 966, 908, 850, 732, 688.

$\mathrm{Dr}$ and $r r$ were determined by GCMS analysis after protondeboronation of 6ab. The minor isomers were not detected by GCMS.

\section{DFT Calculations}

\subsection{General information for computation}

All structures were optimized without geometry constraints using the BH-LYP hybrid functional ${ }^{\mathrm{S} 28-29}$ and an atom-pairwise dispersion correction (D3) ${ }^{S 30-31}$. A flexible triple zeta basis set $(\text { def2-TZVP })^{S 32}$ and the COSMO implicit solvation model ${ }^{S 33}$ with a dielectric constant of $\varepsilon=37.5\left(\mathrm{CH}_{3} \mathrm{CN}\right)$ were used in all calculations. For the calculation of zero point vibrational energies and free enthalpy contributions $\left(\mathrm{G}_{298}\right)$ with BH-LYP-D3, a rotor approximation was applied for the harmonic vibrational modes with wave numbers below $100 \mathrm{~cm}^{-1} .334$ Electronic energies were recalculated with the double hybrid functional PWPB95(-D3) ${ }^{\mathrm{S} 35}$ with the structures obtained with BH-LYP-D3, including a solvation energy obtained with the $\mathrm{C}-\mathrm{PCM}^{\mathrm{S} 36}$ solvent model for acetonitrile. PWPB95 includes a component of the correlation energy which is computed by perturbation theory and performs more accurately in the determination of energies, even for open shell molecules.

All geometry optimizations and vibrational frequency calculations were performed with the TURBOMOLE program ${ }^{\mathrm{S} 37}$. PWPB95-D3 calculations were performed with the ORCA program ${ }^{\mathrm{S} 38}$.

\subsection{Results}

\section{Transition Structures and HAT products}

The electronic energies and thermodynamic corrections for the Gibbs free energy $\mathrm{G}(298 \mathrm{~K})$ are summarized in Table S3, the optimized structures are depicted in Figure S5 and S6.

Table S3: Electronic energies (E) and thermodynamic correction to the Gibbs Free Energy at $\mathrm{T}=298.15 \mathrm{~K}(\mathrm{G} 298)$ for the structures involved in the reaction with $\mathrm{CF}_{3}$ radical. 


\begin{tabular}{|c|c|c|c|}
\hline Structure & $\begin{array}{c}\mathrm{E}(\mathrm{BH}-\mathrm{LYP}-\mathrm{D} 3)^{[\mathrm{a}][\mathrm{b}]} \\
{\left[\mathrm{E}_{\mathrm{h}}\right]}\end{array}$ & $\begin{array}{l}\mathrm{G}(298)^{[\mathrm{a}][\mathrm{b}]} \\
{[\mathrm{kcal} / \mathrm{mol}]}\end{array}$ & $\begin{array}{c}\mathrm{E}(\mathrm{PWPB} 95-\mathrm{D} 3)^{[\mathrm{a}][\mathrm{c}} \\
{ }^{]}\left[\mathrm{E}_{\mathrm{h}}\right]\end{array}$ \\
\hline$\cdot \mathrm{CF}_{3}$ & -337.5903708 & -8.447 & -337.5717281 \\
\hline $\mathrm{CF}_{3} \mathrm{H}$ & -338.26902979 & -0.001 & -338.2508622 \\
\hline $\mathrm{H}_{3} \mathrm{CCH}_{2}-\mathrm{Ph}(\mathrm{EtPh})$ & -338.2508622 & 81.517 & -310.7712210 \\
\hline $\begin{array}{l}{\left[\mathrm{F}_{3} \mathrm{C} \cdots \mathrm{H} \cdots \mathrm{CH}\left(\mathrm{CH}_{3}\right) \mathrm{Ph}\right]^{\ddagger}} \\
(\mathrm{EtPh}-\mathrm{TS})\end{array}$ & -648.3958687 & 83.228 & -648.3316871 \\
\hline${ }^{\circ} \mathrm{CH}\left(\mathrm{CH}_{3}\right) \mathrm{Ph}(\mathrm{EtPh}-\mathrm{Rad})$ & -310.1760955 & 72.322 & -310.1244915 \\
\hline $\begin{array}{l}{\left[\mathrm{H}\left(\mathrm{CH}_{3}\right)_{2} \mathrm{C}(\mathrm{Ph}) \mathrm{B}(\mathrm{Pin})\right]^{\ominus}} \\
\text { (Pinacolate) }\end{array}$ & -761.4423831 & 207.925 & -761.3378077 \\
\hline \multicolumn{4}{|c|}{$\left[\mathrm{F}_{3} \mathrm{C} \cdots \mathrm{H} \cdots \mathrm{C}\left(\mathrm{CH}_{3}\right)_{2} \mathrm{CB}(\mathrm{Ph})(\mathrm{P}\right.$} \\
\hline in) $]^{\bullet} \ominus^{\ddagger}($ Pinacolate-TS $)$ & -1099.0253656 & 209.142 & -1098.9038920 \\
\hline $\begin{array}{l}{\left[^{\circ} \mathrm{C}\left(\mathrm{CH}_{3}\right)_{2} \mathrm{~B}(\mathrm{Ph})(\mathrm{Pin})\right]^{\ominus}} \\
(\text { Pinacolate-Rad })\end{array}$ & -760.7868038 & 197.751 & -760.6802061 \\
\hline 5j-Anion & -725.7302176 & 233.631 & -725.6198361 \\
\hline 5m-Anion & -765.0404387 & 252.563 & -764.9204867 \\
\hline $5 \mathrm{j}-\mathrm{TS}_{\mathrm{iPr}}$ & -1063.3154861 & 234.913 & -1063.1881145 \\
\hline $5 \mathrm{j}-\mathrm{TS}_{\mathrm{cPent}}$ & -1063.3164816 & 235.643 & -1063.1897087 \\
\hline $5 \mathrm{~m}-\mathrm{TS}_{\mathrm{iPr}}$ & -1102.6292394 & 253.569 & -1102.4924885 \\
\hline $5 \mathrm{~m}-\mathrm{TS}_{\mathrm{cHex}}$ & -1102.6257927 & 254.123 & -1102.4886454 \\
\hline
\end{tabular}

[a] All energies have been calculated with the def2-TZVP basis set

[b] using the COSMO solvation model, implemented in Turbomole $(\varepsilon=37.5)$

[c] Energy calculation for the structure optimized with BH-LYP-D3/def2-TZVP and with the C-PCM implicit solvation model (Solvent: acetonitrile).

We have performed a conformational search for all conformers of boron-ate complexes $\mathbf{5 j}$ and $\mathbf{5 m}$ (anion only). The conformers were subjected to reaction with a $\mathrm{CF}_{3}$ radical in HAT reactions of the isopropyl and the cycloalkyl group. Only the most

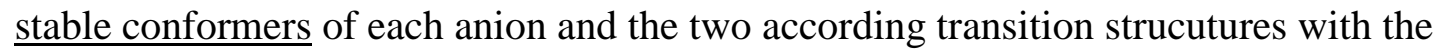
lowest free energy are reported here (Figure S2). The relative barrier heights correctly predict the preferred products, namely $\mathbf{6 j}$ with a ratio of $1.58: 1$ (exp: $2.2: 1$ ) and $\mathbf{6 m}$ with a ratio of 150.6:1 (exp.: 29:1). 


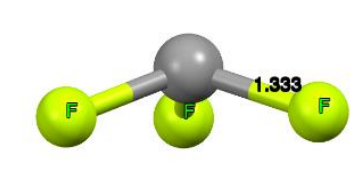

$\cdot \mathrm{CF}_{3}$

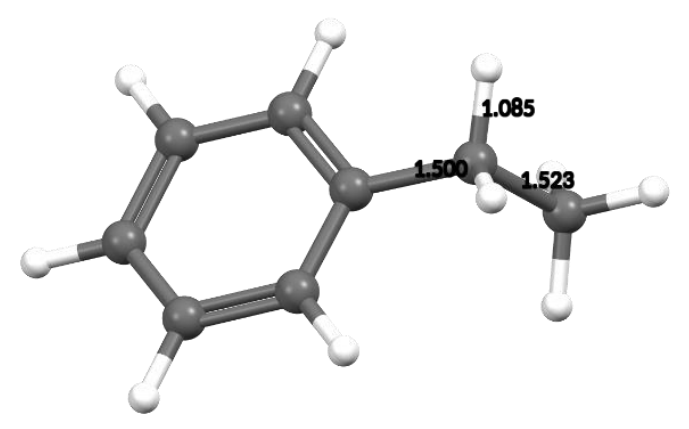

$\mathrm{H}_{3} \mathrm{CCH}_{2}-\mathrm{Ph}$

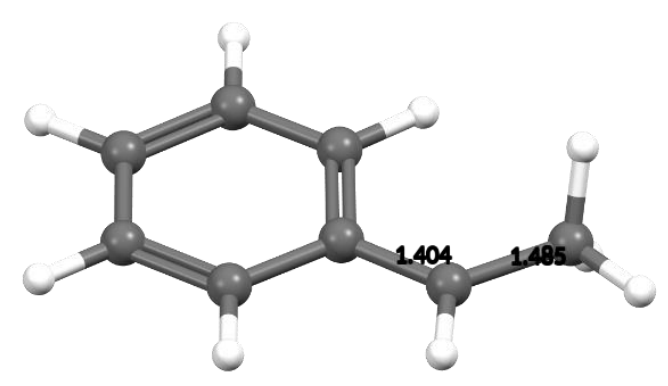

- $\mathrm{CH}\left(\mathrm{CH}_{3}\right) \mathrm{Ph}$

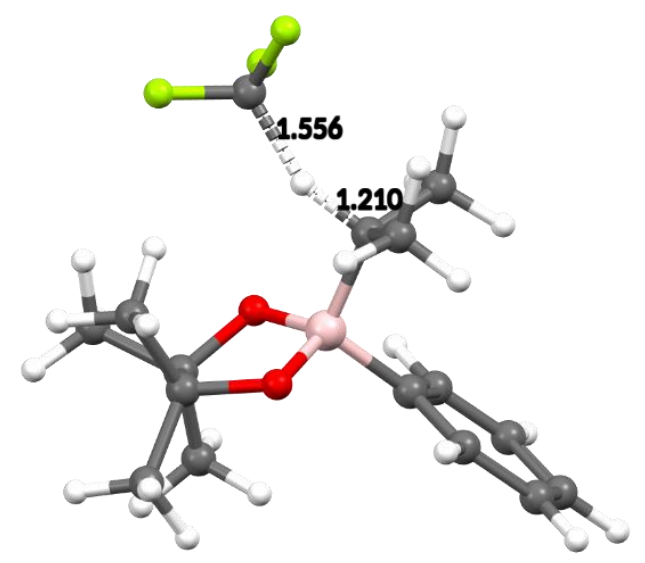

$\left[\mathrm{F}_{3} \mathrm{C} \cdots \mathrm{H} \cdots \mathrm{C}\left(\mathrm{CH}_{3}\right)_{2} \mathrm{~B}(\mathrm{Ph})(\mathrm{Pin})\right]^{\ominus \ddagger}$

(pinacolate TS)

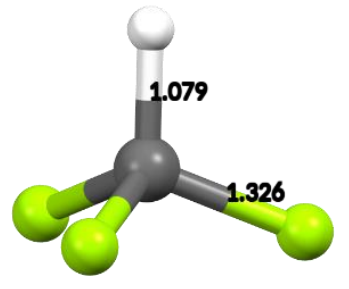

$\mathrm{CF}_{3} \mathrm{H}$

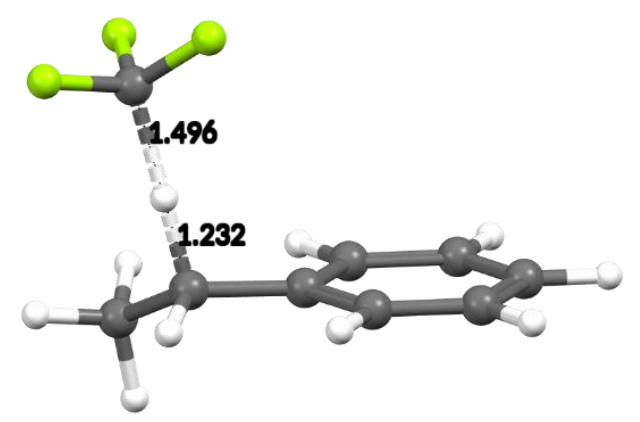

$\left[\mathrm{F}_{3} \mathrm{C} \cdots \mathrm{H} \cdots \mathrm{CH}\left(\mathrm{CH}_{3}\right) \mathrm{Ph}\right]^{\ddagger}(\mathrm{TS})$

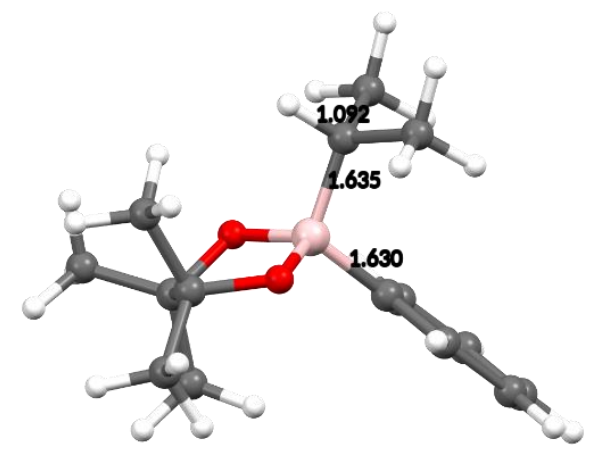

$\left[\mathrm{H}\left(\mathrm{CH}_{3}\right)_{2} \mathrm{CB}(\mathrm{Ph})(\mathrm{Pin})\right]^{\ominus}$ (pinacolate)

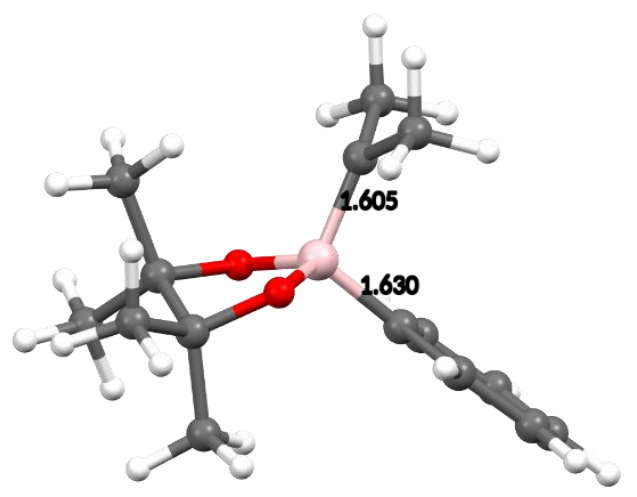

$\left[\cdot \mathrm{C}\left(\mathrm{CH}_{3}\right)_{2}(\mathrm{Ph}) \mathrm{B}(\mathrm{pin})\right]^{\ominus}$

(pinacolate radical)

Figure S5. Optimized Structures in the reaction of radical ${ }^{\circ} \mathrm{CF}_{3}$ with ethyl benzene and the phenyl isopropyl boron-ate complex. (BH-LYP-D3/def2-TZVP $+\mathrm{COSMO}(\varepsilon=$ 37.5)). Distances are given in $\AA$. 


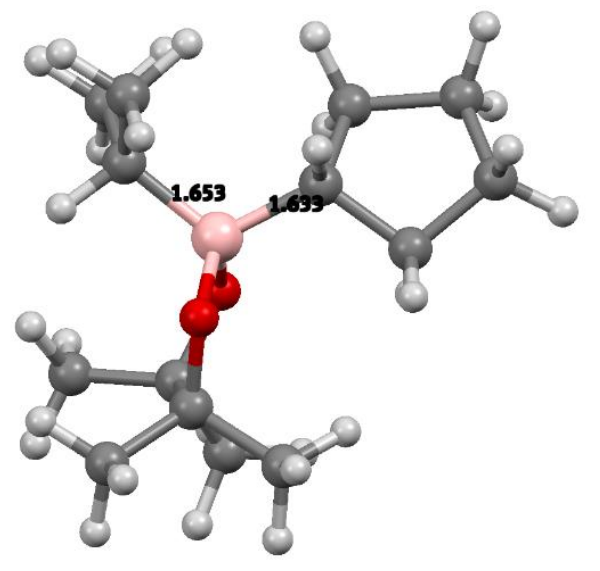

5j (Anion)

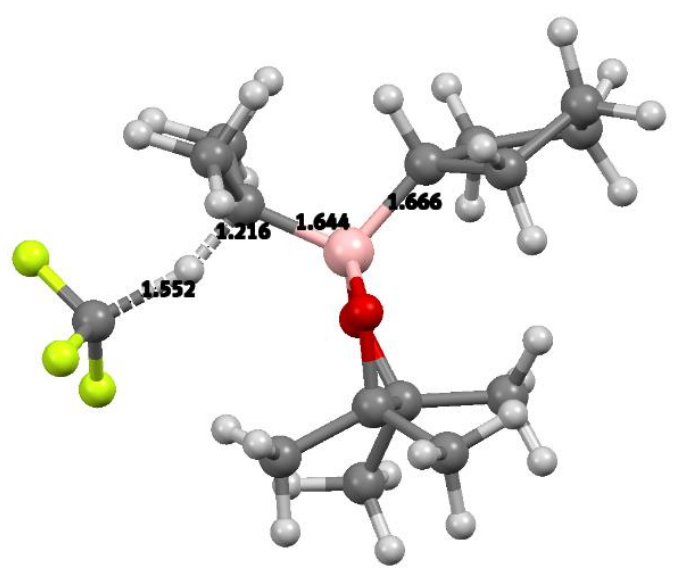

$5 \mathbf{j}-\mathrm{TS}_{\mathrm{iPr}}$

[11.89]

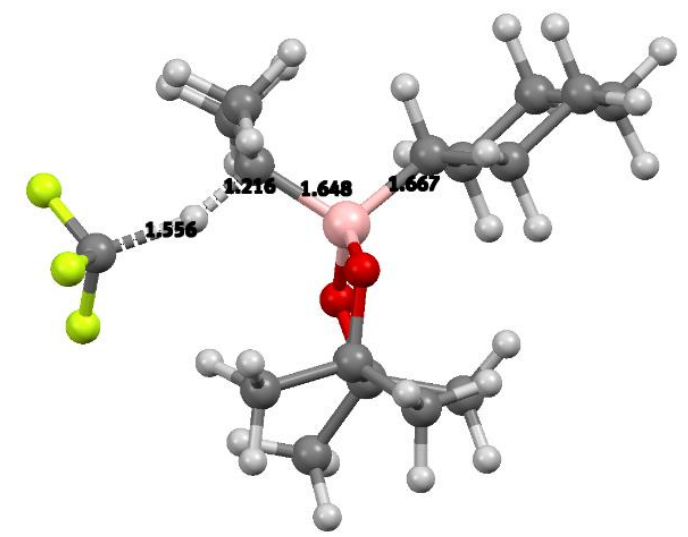

5m-TS

[11.90]

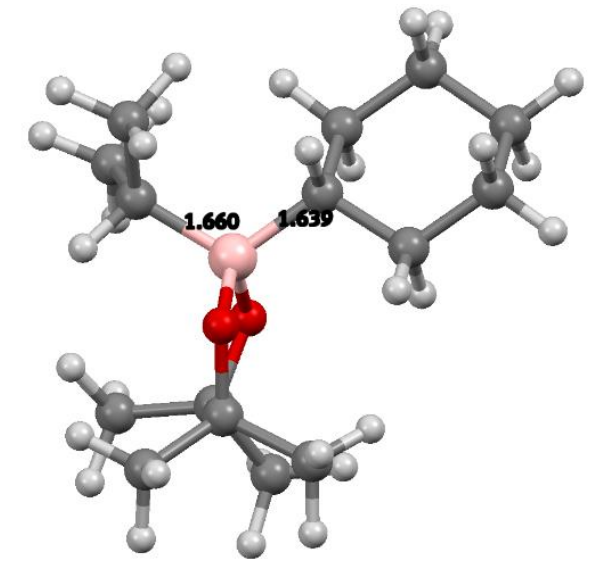

5m (Anion)

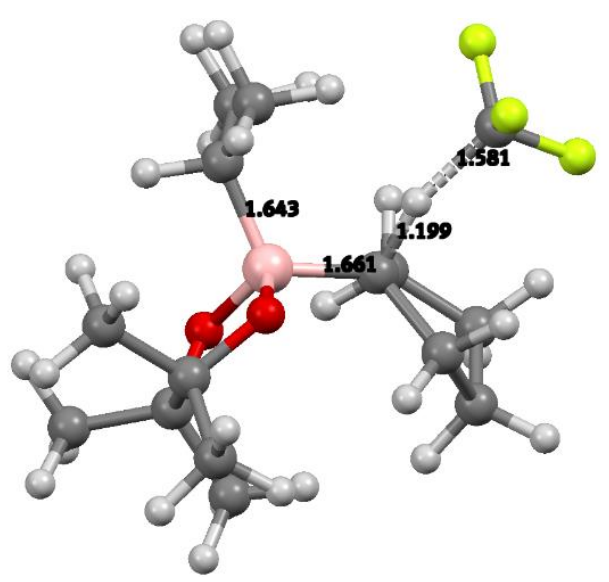

$5 \mathrm{j}-\mathrm{TS}_{\mathrm{cPent}}$

[11.62]

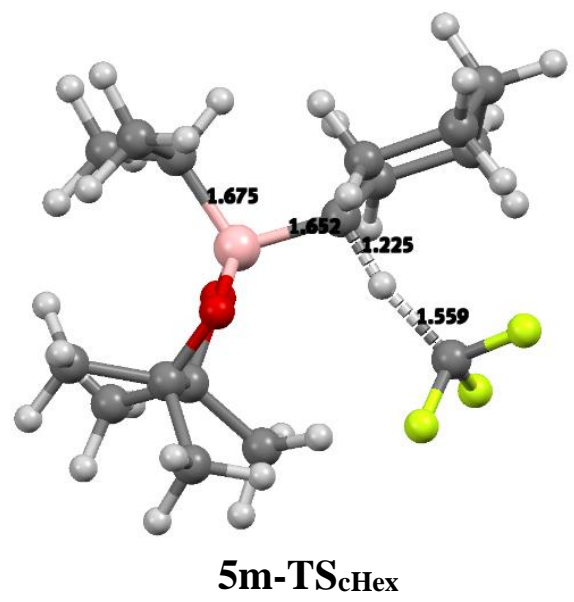

[14.87]

Figure S6. Optimized Structures of the most stable conformations of boron-ate complexes 5j ( $i \mathrm{Pr} / c y$ Pentyl) and $\mathbf{5 m}(i \mathrm{Pr} / c y \mathrm{Hexyl})$ and the favored transition structures in the HAT reaction with radical ${ }^{\circ} \mathrm{CF}_{3}$. (BH-LYP-D3/def2-TZVP $+\operatorname{COSMO}(\varepsilon=37.5))$. Distances are given in $\AA$. Free energies $\left(\Delta \mathrm{G}_{298}\right)$ relative to the boron-ate complex in $\mathrm{kcal} / \mathrm{mol}$ are given in square brackets. 
Cartesian Coordinates (in $\AA$ ) of all optimized structures reported in Table S1. Lowest harmonic vibrational frequencies in $\mathrm{cm}^{-1}$.

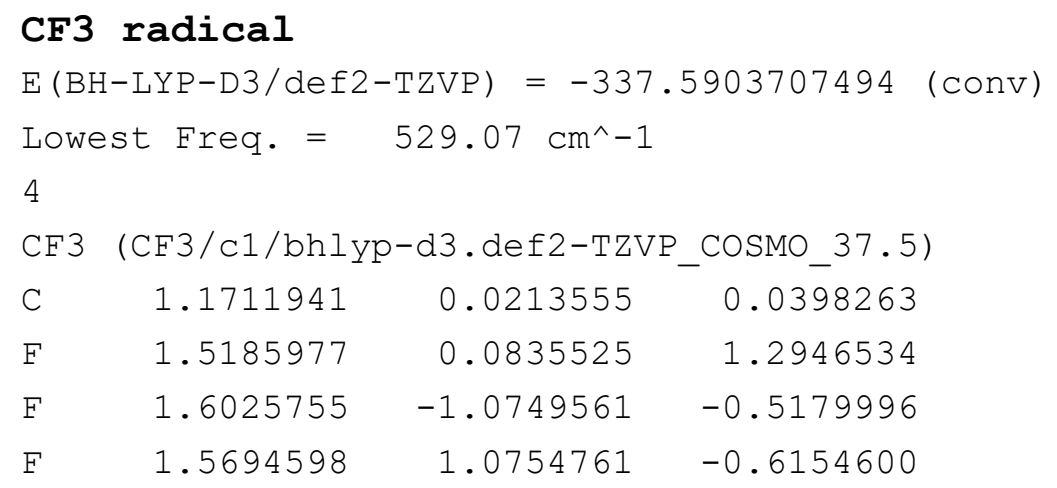

\section{CF $3 \mathrm{H}$}

$\mathrm{E}(\mathrm{BH}-\mathrm{LYP}-\mathrm{D} 3 / \operatorname{def} 2-\mathrm{TZVP})=-338.2690297933$ (conv) Lowest Freq. = $527.12 \mathrm{~cm}^{\wedge}-1$

5

CF3H (CF3H/c1/bhlyp-d3.def2-TZVP_COSMO_37.5)

$\begin{array}{llll}\mathrm{H} & 0.0249365 & 0.0011027 & 0.0000588\end{array}$

$\begin{array}{llll}\text { C } & 1.1026042 & 0.0198655 & 0.0377755\end{array}$

$\begin{array}{llll}\text { F } & 1.5339586 & 0.0834396 & 1.2897903\end{array}$

F $\quad 1.6171219 \quad-1.0699074 \quad-0.5147688$

F $\quad 1.5832061 \quad 1.0709276 \quad-0.6118356$

\section{EtPh}

\begin{tabular}{|c|c|c|c|}
\hline \multicolumn{4}{|c|}{$\begin{array}{l}\text { Lowest Freq. }=32.89 \mathrm{~cm}^{\wedge}-1 \\
18\end{array}$} \\
\hline EtPh & $(031 / \mathrm{cl} / \mathrm{bhl}$ & $p-d 3 \cdot d e f 2-T z$ & P_COSMO_37.5) \\
\hline C & -0.7791974 & 0.0606751 & -0.0873873 \\
\hline C & -1.5273013 & 1.1458984 & -0.5179717 \\
\hline C & -1.4511714 & -1.0807023 & 0.3223917 \\
\hline C & -2.8319116 & -1.1376789 & 0.3053681 \\
\hline C & -2.9080338 & 1.0949244 & -0.5371538 \\
\hline C & -3.5662110 & -0.0484144 & -0.1242856 \\
\hline $\mathrm{H}$ & -0.8872496 & -1.9346510 & 0.6558053 \\
\hline $\mathrm{H}$ & -1.0229309 & 2.0390262 & -0.8441448 \\
\hline $\mathrm{H}$ & -3.3338227 & -2.0335513 & 0.6242203 \\
\hline $\mathrm{H}$ & -3.4697714 & 1.9462124 & -0.8776435 \\
\hline $\mathrm{H}$ & -4.6400939 & -0.0913515 & -0.1411353 \\
\hline C & 0.7171980 & 0.1361423 & -0.0245040 \\
\hline $\mathrm{H}$ & 1.0801247 & 0.7718098 & -0.8252722 \\
\hline
\end{tabular}




$\begin{array}{lrrr}\mathrm{H} & 1.1350905 & -0.8513711 & -0.1890938 \\ \mathrm{C} & 1.2130100 & 0.6766010 & 1.3107675 \\ \mathrm{H} & 0.8295645 & 1.6756038 & 1.4879830 \\ \mathrm{H} & 2.2962755 & 0.7212381 & 1.3308437 \\ \mathrm{H} & 0.8848724 & 0.0434457 & 2.1280079\end{array}$




\section{EtPh-TS}

\begin{tabular}{|c|c|c|c|}
\hline \multicolumn{4}{|c|}{ Lowest Freq. $=60.45 \mathrm{~cm}^{\wedge}-1$} \\
\hline & -TS $(032 / \mathrm{c} 1)$ & hlyp-d3.def2 & TZVP_COSMO_37.5) \\
\hline C & -0.8341424 & 0.0605821 & 0.2174012 \\
\hline C & -1.6027231 & 1.2046308 & -0.0849443 \\
\hline C & -1.5105747 & -1.1776416 & 0.2721073 \\
\hline C & -2.8605419 & -1.2623802 & 0.0399584 \\
\hline C & -2.9548278 & 1.1077768 & -0.3153025 \\
\hline $\mathrm{C}$ & -3.5967201 & -0.1212122 & -0.2558673 \\
\hline $\mathrm{H}$ & -0.9473158 & -2.0653651 & 0.5002629 \\
\hline $\mathrm{H}$ & -1.1252400 & 2.1653928 & -0.1362322 \\
\hline $\mathrm{H}$ & -3.3509551 & -2.2181059 & 0.0873057 \\
\hline $\mathrm{H}$ & -3.5192653 & 1.9941429 & -0.5435399 \\
\hline $\mathrm{H}$ & -4.6536363 & -0.1897392 & -0.4365607 \\
\hline C & 0.5473842 & 0.1258728 & 0.4563611 \\
\hline H & 1.0549071 & -0.7954426 & 0.6813735 \\
\hline C & 1.3428334 & 1.3791307 & 0.4198858 \\
\hline H & 1.2789051 & 1.8688281 & -0.5496138 \\
\hline $\mathrm{H}$ & 2.3865997 & 1.1811250 & 0.6234276 \\
\hline $\mathrm{H}$ & 0.9912496 & 2.1009972 & 1.1543843 \\
\hline
\end{tabular}

\section{EtPh-Rad}

\begin{tabular}{|c|c|c|c|}
\hline \multicolumn{4}{|c|}{$\begin{array}{l}\text { E (BH-LYP-D3/def2-TZVP })=-648 \\
\text { Lowest Freq. }=-1562.98 \mathrm{~cm}^{\wedge}-1 \\
22\end{array}$} \\
\hline \multicolumn{4}{|c|}{ EtPh-Rad (031TS/c1/bhlyp-d3.def2-TZVP_COSMO_37.5) } \\
\hline & -0.6399212 & 0.6680476 & -0.4698628 \\
\hline C & -1.4438882 & 1.7928487 & -0.3265682 \\
\hline$C$ & -1.2436374 & -0.5309542 & -0.8332796 \\
\hline 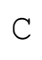 & -2.6051221 & -0.6074231 & -1.0409691 \\
\hline & -2.8067084 & 1.7182931 & -0.5347967 \\
\hline r & -3.3936814 & 0.5190339 & -0.8927157 \\
\hline $\mathrm{I}$ & -0.6360737 & -1.4113051 & -0.9484841 \\
\hline H & -1.0075856 & 2.7342223 & -0.0491164 \\
\hline $\mathrm{H}$ & -3.0518662 & -1.5457282 & -1.3159903 \\
\hline 11 & -3.4118099 & 2.5989412 & -0.4165435 \\
\hline & -4.4549124 & 0.4622111 & -1.0527269 \\
\hline ᄃ & 0.8265199 & 0.7240694 & -0.2952258 \\
\hline 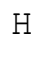 & 1.2830216 & 1.0412742 & -1.3951342 \\
\hline & 1.2466957 & -0.2644806 & -0.1627840 \\
\hline & 1.4005993 & 1.7257868 & 0.6730040 \\
\hline
\end{tabular}




$\begin{array}{llll}\mathrm{H} & 1.1276304 & 2.7423308 & 0.4178595 \\ \mathrm{H} & 2.4820011 & 1.6644723 & 0.6819897 \\ \mathrm{H} & 1.0444730 & 1.5288917 & 1.6797275 \\ \mathrm{C} & 1.8293786 & 1.5229362 & -2.7021639 \\ \mathrm{~F} & 3.0794100 & 1.1365024 & -2.8589836 \\ \mathrm{~F} & 1.7759832 & 2.8400858 & -2.7359422 \\ \mathrm{~F} & 1.0982930 & 1.0357825 & -3.6840613\end{array}$




\section{Pinacolate}

$\mathrm{E}(\mathrm{BH}-\mathrm{LYP}-\mathrm{D} 3 /$ def2-TZVP $)=-761.4423831268$ (conv)

\begin{tabular}{|c|c|c|c|}
\hline \multicolumn{4}{|c|}{ Pinacolate (022/c1/bhlyp-d3.def2-TZVP_COSMO_37.5) } \\
\hline C & 0.7714482 & -2.8591935 & -1.0231189 \\
\hline $\mathrm{C}$ & 0.0894699 & -2.2406647 & 0.1869886 \\
\hline $\mathrm{C}$ & 0.8055470 & -2.6555972 & 1.4634131 \\
\hline H & 0.8411429 & -3.7381919 & 1.5842570 \\
\hline $\mathrm{H}$ & 0.3190026 & -2.2392274 & 2.3402783 \\
\hline $\mathrm{H}$ & 1.8317339 & -2.2972019 & 1.4639879 \\
\hline $\mathrm{H}$ & -0.9244623 & -2.6430362 & 0.2324241 \\
\hline B & -0.0927269 & -0.6215695 & 0.0521016 \\
\hline 0 & -0.9089911 & -0.2527778 & -1.1395168 \\
\hline $\mathrm{C}$ & -2.1437330 & 0.2610953 & -0.7248728 \\
\hline C & -3.1714527 & -0.8657820 & -0.6826717 \\
\hline $\mathrm{H}$ & -2.9053232 & -1.6007770 & 0.0648833 \\
\hline $\mathrm{H}$ & -3.1850409 & -1.3557429 & -1.6499713 \\
\hline $\mathrm{H}$ & -4.1709194 & -0.5004189 & -0.4718995 \\
\hline $\mathrm{C}$ & -2.6114860 & 1.3102081 & -1.7151552 \\
\hline $\mathrm{H}$ & -3.5176575 & 1.8006268 & -1.3733851 \\
\hline $\mathrm{H}$ & -1.8497116 & 2.0612980 & -1.8737335 \\
\hline $\mathrm{H}$ & -2.8260811 & 0.8402433 & -2.6696222 \\
\hline $\mathrm{C}$ & -1.8332566 & 0.8129777 & 0.6945124 \\
\hline C & -1.1866294 & 2.1939357 & 0.6365110 \\
\hline $\mathrm{H}$ & -0.3636740 & 2.2053702 & -0.0646964 \\
\hline $\mathrm{H}$ & -0.7939974 & 2.4332395 & 1.6185277 \\
\hline $\mathrm{H}$ & -1.8993480 & 2.9619557 & 0.3563076 \\
\hline C & -3.0301725 & 0.8724961 & 1.6227288 \\
\hline $\mathrm{H}$ & -3.4392394 & -0.1135653 & 1.7976575 \\
\hline $\mathrm{H}$ & -2.7289679 & 1.2874988 & 2.5791576 \\
\hline $\mathrm{H}$ & -3.8129891 & 1.5048048 & 1.2160478 \\
\hline O & -0.9110094 & -0.1198628 & 1.1876204 \\
\hline C & 1.3517130 & 0.1283890 & -0.0298844 \\
\hline C & 1.9816210 & 0.3749830 & -1.2453163 \\
\hline C & 3.2171597 & 0.9931744 & -1.3261158 \\
\hline C & 3.8704465 & 1.3897346 & -0.1727818 \\
\hline C & 3.2686032 & 1.1587742 & 1.0515335 \\
\hline $\mathrm{C}$ & 2.0338370 & 0.5374550 & 1.1112847 \\
\hline $\mathrm{H}$ & 1.5745756 & 0.3776077 & 2.0715665 \\
\hline $\mathrm{H}$ & 3.7625610 & 1.4673609 & 1.9574772 \\
\hline $\mathrm{H}$ & 4.8299517 & 1.8733574 & -0.2273052 \\
\hline $\mathrm{H}$ & 3.6713678 & 1.1698344 & -2.2865560 \\
\hline $\mathrm{H}$ & 1.4803393 & 0.0851987 & -2.1526225 \\
\hline
\end{tabular}




$\begin{array}{llll}\mathrm{H} & 0.2546061 & -2.5913101 & -1.9391982 \\ \mathrm{H} & 1.7946581 & -2.5033469 & -1.1139225 \\ \mathrm{H} & 0.8106405 & -3.9467948 & -0.9655449\end{array}$




\section{Pinacolate-TS}

$\mathrm{E}(\mathrm{BH}-\mathrm{LYP}-\mathrm{D} 3 /$ def2-TZVP) $=-1099.025365575$ (conv)

Lowest Freq. $=-896.03 \mathrm{~cm}^{\wedge}-1$

46

Pinacolate-TS (022TS/c2/bhlyp-d3.def2-TZVP_COSMO_37.5)

C $\quad-0.7794705$

$-3.0005433-0.8747872$

C $\quad 0.2676163$

$-2.2424978 \quad 0.4234856$

$\mathrm{H} \quad 0.2293719$

$-2.6818946 \quad 1.4230925$

$\mathrm{H} \quad 0.1538775$

$-3.7537263$

1.6085124

$\mathrm{H} \quad 1.2617200$

$-2.1712806$

2.3729072

$\mathrm{H}-1.8215241$

$-2.4515226$

1.0498467

$-2.5950082$

0.9265420

B $\quad-1.0046554$

$-0.6167409$

0.2796865

O -1.7671748

$-0.2444239$

$-0.9322710$

C $\quad-3.0003646$

0.3164247

$-0.5728653$

C $\quad-4.0725036$

$-0.7633035$

$-0.6457595$

$\mathrm{H} \quad-3.8771354$

$-1.5493886$

0.0671373

H $\quad-4.0576709$

$-1.1945223$

$-1.6407281$

$\mathrm{H} \quad-5.0658644$

$-0.3681922$

$-0.4617781$

C $\quad-3.3561306$

1.4183745

$-1.5527225$

$\mathrm{H} \quad-4.2609721$

1.9369084

$-1.2516255$

$\mathrm{H} \quad-2.5551755$

2.1399112

$-1.6375385$

$\mathrm{H} \quad-3.5286681$

0.9889355

$-2.5342455$

C $\quad-2.7539076$

0.8131611

0.8829525

C $\quad-2.1114378$

2.1964234

0.9140146

$\mathrm{H} \quad-1.2451943$

2.2350589

0.2676867

$\mathrm{H} \quad-1.7827110$

2.4009765

1.9267918

$\mathrm{H} \quad-2.8072455$

2. 9731859

0.6166724

C $\quad-3.9929413$

0.8263567

1.7555572

$\mathrm{H} \quad-4.3956207$

$-0.1706094$

1.8713854

$\mathrm{H} \quad-3.7399559$

1.2052307

2.7403941

$\mathrm{H} \quad-4.7623756$

1.4677723

1.3378373

$-1.8488532$

$-0.1322561$

1.3872946

0.0949521

0.2327009

0.2070172

$-0.9568696$

0.7720531

$-1.0098887$

1.2486680

0.1445627

1.1526387

1. 3421648

C $\quad 2.3432378$

0.5830531

1.3759857

0.5242894

2. 3141780

$\mathrm{H} \quad 0.5588946$

1.5253975

2.2475068

H $\quad 4.0096719$

1.6909393

0.1109766

$\mathrm{H} \quad 2.9550157$

0.8448794

$-1.9499683$

$\mathrm{H} \quad 0.7202337$

$-0.1476899$

$-1.8673465$ 


$\begin{array}{lrrr}\mathrm{H} & -1.4722926 & -2.7625331 & -1.5461320 \\ \mathrm{H} & 0.2698198 & -2.7272552 & -1.3783222 \\ \mathrm{H} & -0.6315926 & -4.0780032 & -0.7221966 \\ \mathrm{C} & -2.7742676 & -3.4386354 & 1.8222499 \\ \mathrm{~F} & -2.5907931 & -4.7193948 & 1.5144821 \\ \mathrm{~F} & -2.4014337 & -3.2683775 & 3.0828485 \\ \mathrm{~F} & -4.0773051 & -3.1912900 & 1.7490687\end{array}$




\section{Pinacolate-Rad}

$\mathrm{E}(\mathrm{BH}-\mathrm{LYP}-\mathrm{D} 3 /$ def2-TZVP $)=-760.7868038024$ (conv) Lowest Freq. = $10.05 \mathrm{~cm}^{\wedge}-1$

41

Pinacolate-Rad (023/c1/bhlyp-d3.def2-TZVP_COSMO_37.5)

C $\quad-1.1280064$

1.7090216

2.1023087

C $\quad-0.4187744$

0.4089065

1.9599634

B $\quad 0.6467509$

0.1929762

0.7790708

O $\quad 1.5003552$

1.3962061

0.6060386

C $\quad 2.8343763$

0.9865040

0.4957260

O $\quad 1.6257265$

$-0.8953427$

1.0512418

C $\quad 2.8606408$

$-0.3074745$

1.3535463

C $\quad-0.1998303$

$-0.1570202$

$-0.5688200$

C $\quad-0.6339282$

0.8405576

$-1.4364517$

C $\quad-1.4182322$

0.5654237

$-2.5426441$

C $\quad-1.7998946$

$-0.7361165$

$-2.8174022$

C $\quad-1.3840944$

$-1.7491996$

$-1.9710762$

C $\quad-0.6012052$

$-1.4556410$

$-0.8685698$

$\mathrm{H} \quad-2.0289493$

1.7464928

1.4780052

H $\quad-1.4627798$

1.8932492

3.1242584

$\mathrm{H} \quad-0.4962301$

2.5355210

1.7954967

$\mathrm{H} \quad-0.3369189$

1.8568848

$-1.2416014$

$\mathrm{H} \quad-1.7308577$

1.3635032

$-3.1949573$

$\mathrm{H} \quad-2.4086004$

$-0.9573298$

$-3.6764358$

$\mathrm{H} \quad-1.6704113$

$-2.7674465$

$-2.1743105$

$\mathrm{H} \quad-0.2841723$

$-2.2586723$

$-0.2245723$

$-1.2707789$

1.0061273

$-1.6193538$

$-0.0140266$

3. 8875158

$-2.1337421$

1.6628779

3.9335220

$-0.8066930$

1.1294424

$\mathrm{H} \quad 4.9508286$

0.0085850

2.8448225

$\mathrm{H} \quad 2.1539720$

0.7317759

3.1025513

3.8863386

0.3897162

3.1469988

$\mathrm{H} \quad 2.7209212$

$-0.9031971$

3.3984730

2.0910982

0.9965212

C $\quad 3.7429658$

2. 4154129

1. 9854741

$\mathrm{H} \quad 3.6820500$

2.9450242

0.3293097

$\mathrm{H} \quad 4.7783383$

1.7667298

1.0297086

C $\quad 3.1553300$

0.6983943

$-0.9677328$

$\mathrm{H} \quad 2.9148422$

1.5787266

$-1.5535166$

$\mathrm{H} \quad 2.5537604$

$-0.1233796$

$-1.3333730$

$\mathrm{H} \quad 4.2036436$

0.4636731

$-1.1184582$

C $\quad-1.0932567$

$-0.7612945$

2.5844997

$\mathrm{H} \quad-0.4490303$

$-1.6342118$

2.5851137 


$\begin{array}{llll}\mathrm{H} & -2.0050357 & -1.0385470 & 2.0421770 \\ \mathrm{H} & -1.4024346 & -0.5640896 & 3.6120305\end{array}$




\section{5j-Anion}

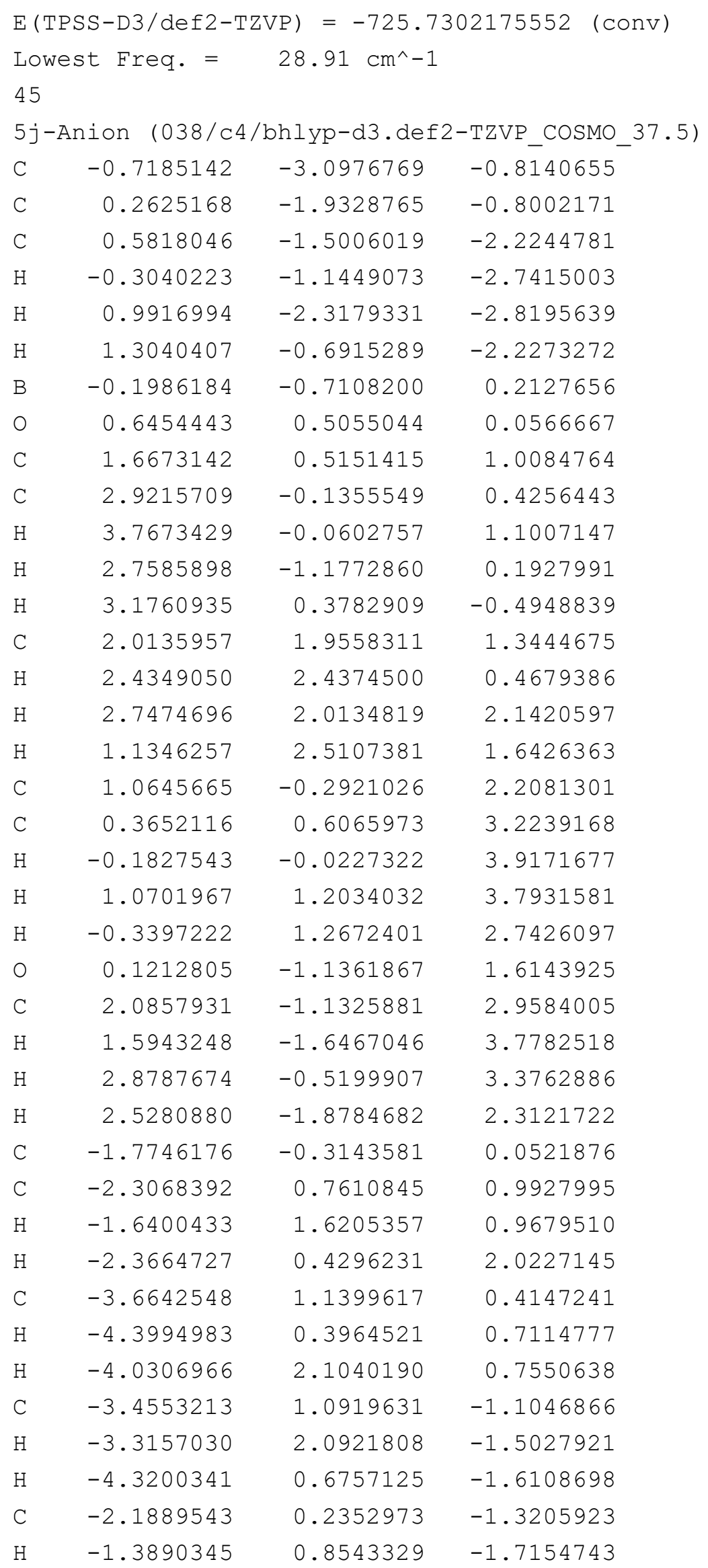




$\begin{array}{lrrr}\mathrm{H} & -2.3559157 & -0.5530103 & -2.0456206 \\ \mathrm{H} & -2.3731875 & -1.2093753 & 0.2396248 \\ \mathrm{H} & 1.1884471 & -2.3204726 & -0.3746705 \\ \mathrm{H} & -0.3348751 & -3.9557863 & -1.3670276 \\ \mathrm{H} & -0.9450370 & -3.4321828 & 0.1946357 \\ \mathrm{H} & -1.6594392 & -2.8141486 & -1.2785081\end{array}$




\section{5m-Anion}

\begin{tabular}{|c|c|c|c|}
\hline \multicolumn{4}{|c|}{ E (TPSS-D3/def2-TZVP) } \\
\hline \multicolumn{2}{|c|}{$\begin{array}{l}\text { Low } \\
48\end{array}$} & \multicolumn{2}{|l|}{$46.88 \mathrm{~cm}^{\wedge}-1$} \\
\hline & nion $(037 / \mathrm{c}$ & hlyp-d3.de & -TZVP_COSMO_37.5) \\
\hline r & -0.4632337 & 2.8595416 & -1.4501206 \\
\hline & 0.3434057 & 2.2069817 & -0.3344786 \\
\hline & 0.1775917 & 2.9955618 & 0.9585290 \\
\hline & 0.7582202 & 2.5515926 & 1.7590093 \\
\hline & -0.8561584 & 3.0214827 & 1.2884754 \\
\hline & 0.4993577 & 4.0320667 & 0.8467954 \\
\hline & 0.1059910 & 0.5683444 & -0.2187394 \\
\hline & 0.6482982 & 0.0058846 & 1.0475151 \\
\hline & 1.9515144 & -0.4588264 & 0.8575839 \\
\hline & 2.9528434 & 0.6440544 & 1.2011146 \\
\hline & 2.8504366 & 1.4966840 & 0.5466490 \\
\hline & 2.7617786 & 0.9754238 & 2.2158515 \\
\hline & 3.9765427 & 0.2893864 & 1.1487947 \\
\hline & 2.2034325 & -1.6134607 & 1.8128104 \\
\hline & 1.4482093 & -2.3803067 & 1.7089624 \\
\hline & 2.1725353 & -1.2463333 & 2.8335389 \\
\hline & 3.1782244 & -2.0614692 & 1.6487663 \\
\hline & 1.9853457 & -0.8643823 & -0.6568617 \\
\hline & 1.6691489 & -2.3415308 & -0.8740733 \\
\hline & 0.7634580 & -2.6312301 & -0.3636267 \\
\hline & 1.5248228 & -2.5085925 & -1.9362269 \\
\hline & 2.4781676 & -2.9813322 & -0.5377209 \\
\hline & 0.9838368 & -0.0845184 & -1.2467567 \\
\hline & 3.3129186 & -0.5753264 & -1.3404099 \\
\hline & 3.5399110 & 0.4820880 & -1.3253454 \\
\hline & 3.2581847 & -0.8926922 & -2.3768545 \\
\hline & 4.1307927 & -1.1122099 & -0.8699667 \\
\hline & -1.4601188 & 0.1203558 & -0.4042201 \\
\hline & -1.6418197 & -1.3900045 & -0.4973229 \\
\hline & -1.0513471 & -1.7726802 & -1.3212755 \\
\hline & -3.0910923 & -1.8237900 & -0.6587896 \\
\hline & -3.9623389 & -1.2700369 & 0.4550489 \\
\hline & -3.8304401 & 0.2403153 & 0.5378706 \\
\hline & -2.3775305 & 0.6703726 & 0.6855015 \\
\hline & -2.3324863 & 1.7527102 & 0.7028734 \\
\hline & -2.0066957 & 0.3351053 & 1.6542174 \\
\hline & -4.4276345 & 0.6245545 & 1.3621366 \\
\hline & -4.2380918 & 0.6788765 & -0.3725196 \\
\hline & -5.0009104 & -1.5557131 & 0.3086371 \\
\hline
\end{tabular}




$\begin{array}{lrrr}\mathrm{H} & -3.6482153 & -1.7071776 & 1.4022720 \\ \mathrm{H} & -3.1648904 & -2.9090718 & -0.6874389 \\ \mathrm{H} & -3.4691745 & -1.4611466 & -1.6143956 \\ \mathrm{H} & -1.2372830 & -1.8463914 & 0.4052048 \\ \mathrm{H} & -1.8126099 & 0.5342228 & -1.3536448 \\ \mathrm{H} & 1.3905621 & 2.3099161 & -0.6214705 \\ \mathrm{H} & -1.5268931 & 2.8489311 & -1.2277857 \\ \mathrm{H} & -0.1799042 & 3.9004723 & -1.6094072 \\ \mathrm{H} & -0.3283727 & 2.3361981 & -2.3929235\end{array}$




\section{5j-TS_iPr}

$\mathrm{E}(\mathrm{TPSS}-\mathrm{D} 3 / \operatorname{def} 2-\mathrm{TZVP})=-1063.315486138$ (conv)

Lowest Freq. $=-903.16 \mathrm{~cm}^{\wedge}-1$

49

5j-TS_iPr (038TS1/c1a/bhlyp-d3.def2-TZVP_COSMO_37.5)

$\begin{array}{llll}\text { C } & -0.4884846 & -3.2530355 & -0.6032375\end{array}$

$\begin{array}{llll}\text { C } & -0.8318207 & -2.3988750 & 0.5931306\end{array}$

$\begin{array}{llll}\text { C } & -0.0067270 & -2.7617822 & 1.8072793\end{array}$

$\begin{array}{llll}\mathrm{H} & -0.0749746 & -3.8188375 & 2.0542093\end{array}$

$\begin{array}{llll}\mathrm{H} & -0.3164411 & -2.1888577 & 2.6748804\end{array}$

$\mathrm{H} \quad 1.0431117 \quad-2.5410590 \quad 1.6301964$

$\mathrm{H} \quad-1.9582936 \quad-2.7400045 \quad 0.8977551$

$\begin{array}{llll}\text { B } & -0.9266945 & -0.7838365 & 0.3029377\end{array}$

$\begin{array}{llll}0 & -1.7616184 & -0.4458657 & -0.8717037\end{array}$

$\begin{array}{llll}\text { C } & -2.9273983 & 0.2275956 & -0.4873939\end{array}$

C $\quad-4.0846001 \quad-0.7621543 \quad-0.4489327$

$\begin{array}{llll}\mathrm{H} & -3.9321344 & -1.5021938 & 0.3196609\end{array}$

$\mathrm{H} \quad-4.1347944-1.2721050 \quad-1.4042783$

$\mathrm{H} \quad-5.0364073 \quad-0.2729995 \quad-0.2713269$

C $\quad-3.2482679 \quad 1.2966466 \quad-1.5166125$

$\mathrm{H} \quad-4.0996115 \quad 1.8970008 \quad-1.2115791$

$\begin{array}{llll}\mathrm{H} & -2.4030967 & 1.9515935 & -1.6781297\end{array}$

$\begin{array}{llll}\mathrm{H} & -3.4943273 & 0.8246929 & -2.4623781\end{array}$

$\begin{array}{llll}\text { C } & -2.5797122 & 0.7879232 & 0.9282630\end{array}$

$\begin{array}{llll}\text { C } & -1.9395427 & 2.1722557 & 0.8727090\end{array}$

$\begin{array}{llll}\mathrm{H} & -1.1003583 & 2.1918194 & 0.1936153\end{array}$

$\begin{array}{llll}\mathrm{H} & -1.5733442 & 2.4224292 & 1.8621068\end{array}$

$\begin{array}{llll}\mathrm{H} & -2.6482585 & 2.9352320 & 0.5697764\end{array}$

$\begin{array}{llll}\text { C } & -3.7633572 & 0.8552412 & 1.8768552\end{array}$

$\begin{array}{llll}\mathrm{H} & -4.1729291 & -0.1283616 & 2.0607275\end{array}$

$\begin{array}{llll}\mathrm{H} & -3.4405738 & 1.2689254 & 2.8267142\end{array}$

$\mathrm{H} \quad-4.5494272 \quad 1.4929003 \quad 1.4850193$

$\begin{array}{llll}0 & -1.6524805 & -0.1357867 & 1.4208931\end{array}$

$\begin{array}{llll}\text { C } & 0.6320674 & -0.2390301 & 0.0806108\end{array}$

$\mathrm{H} \quad-1.1451270 \quad-3.0321633 \quad-1.4371765$

$\mathrm{H} \quad \begin{array}{llll}\mathrm{H} & 0.5317630 & -3.0581778 & -0.9282444\end{array}$

$\mathrm{H} \quad-0.5544913 \quad-4.3179554 \quad-0.3860652$

$\begin{array}{llll}\text { C } & -3.0980246 & -3.6785213 & 1.3770679\end{array}$

F $\quad \begin{array}{llll}-2.5446092 & -4.7619973 & 1.9131987\end{array}$

F $\quad-3.8889805 \quad-3.1365536 \quad 2.2984999$

$\begin{array}{llll}F & -3.8665461 & -4.0834031 & 0.3703721\end{array}$

$\begin{array}{llll}\text { C } & 1.2469813 & 0.5419859 & 1.2661678\end{array}$

$\mathrm{H} \quad 1.9296713 \quad-0.0873425 \quad 1.8296271$

$\begin{array}{llll}\mathrm{H} & 0.4782814 & 0.8648295 & 1.9556697\end{array}$ 


$\begin{array}{lrrr}\mathrm{C} & 0.8690320 & 0.6666521 & -1.1314024 \\ \mathrm{H} & 0.0552953 & 1.3735012 & -1.2543283 \\ \mathrm{H} & 0.9260161 & 0.1016940 & -2.0565644 \\ \mathrm{C} & 2.1557328 & 1.4128888 & -0.8091968 \\ \mathrm{H} & 2.3228801 & 2.2903811 & -1.4275840 \\ \mathrm{H} & 3.0083474 & 0.7505270 & -0.9446061 \\ \mathrm{C} & 1.9895526 & 1.7494940 & 0.6680467 \\ \mathrm{H} & 2.9318296 & 1.9585100 & 1.1642669 \\ \mathrm{H} & 1.3770927 & 2.6423029 & 0.7616554 \\ \mathrm{H} & 1.2750164 & -1.1024931 & -0.0833126\end{array}$




\section{5j-TS_cPent}

\begin{tabular}{|c|c|c|c|}
\hline \multicolumn{4}{|c|}{ 5j-TS_cPent (038TS2/c4a/bhlyp-d3.def2-TZVP_COSMO_37.5) } \\
\hline $\mathrm{C}$ & -0.6928212 & -3.1815739 & -0.2637927 \\
\hline C & -1.1107778 & -2.2257121 & 0.8441411 \\
\hline C & -0.3845426 & -2.5707516 & 2.1370460 \\
\hline $\mathrm{H}$ & -0.5891831 & -3.5923413 & 2.4575218 \\
\hline $\mathrm{H}$ & -0.6773278 & -1.9073983 & 2.9454547 \\
\hline $\mathrm{H}$ & 0.6912336 & -2.4852184 & 2.0233012 \\
\hline $\mathrm{H}$ & -2.1695023 & -2.4065959 & 1.0309804 \\
\hline B & -1.0277579 & -0.6420680 & 0.4137881 \\
\hline O & -1.5727833 & -0.4051897 & -0.9445308 \\
\hline C & -2.8808929 & 0.0854616 & -0.8685553 \\
\hline C & -3.8677082 & -1.0778440 & -0.9401490 \\
\hline $\mathrm{H}$ & -3.7542518 & -1.7447330 & -0.0977168 \\
\hline $\mathrm{H}$ & -3.6672339 & -1.6412258 & -1.8448066 \\
\hline $\mathrm{H}$ & -4.8962592 & -0.7355799 & -0.9742725 \\
\hline C & -3.1396361 & 0.9911390 & -2.0592821 \\
\hline $\mathrm{H}$ & -4.1178871 & 1.4570740 & -1.9969907 \\
\hline $\mathrm{H}$ & -2.3912675 & 1.7683966 & -2.1319577 \\
\hline $\mathrm{H}$ & -3.1062579 & 0.4049200 & -2.9718043 \\
\hline C & -2.9142644 & 0.8197911 & 0.5103839 \\
\hline $\mathrm{C}$ & -2.5070969 & 2.2859574 & 0.4068038 \\
\hline $\mathrm{H}$ & -1.5712834 & 2.3971310 & -0.1196745 \\
\hline $\mathrm{H}$ & -2.3753139 & 2.6756368 & 1.4100528 \\
\hline $\mathrm{H}$ & -3.2598869 & 2.8846172 & -0.0947366 \\
\hline C & -4.2610633 & 0.7566212 & 1.2107222 \\
\hline $\mathrm{H}$ & -4.5427257 & -0.2650462 & 1.4258743 \\
\hline $\mathrm{H}$ & -4.2037040 & 1.2957416 & 2.1507708 \\
\hline $\mathrm{H}$ & -5.0423171 & 1.2133311 & 0.6111912 \\
\hline O & -1.9662935 & 0.1333797 & 1.2773307 \\
\hline $\mathrm{H}$ & -1.2694247 & -3.0019117 & -1.1639960 \\
\hline $\mathrm{H}$ & 0.3538915 & -3.0617712 & -0.5244664 \\
\hline $\mathrm{H}$ & -0.8289297 & -4.2249480 & 0.0217228 \\
\hline C & 2.5875345 & -1.6133839 & -0.2291815 \\
\hline F & 2.8639592 & -2.6473664 & 0.5538318 \\
\hline F & 2.5153392 & -2.0501055 & -1.4799300 \\
\hline F & 3.6022265 & -0.7631440 & -0.1533517 \\
\hline C & 0.4999177 & 0.0028309 & 0.5116401 \\
\hline $\mathrm{H}$ & 1.2566203 & -0.8653391 & 0.1796165 \\
\hline C & 0.9750069 & 0.4262523 & 1.9041256 \\
\hline $\mathrm{H}$ & 1.4322579 & -0.3839490 & 2.4598480 \\
\hline
\end{tabular}




$\begin{array}{lllr}\mathrm{C} & 0.8500456 & 1.1816106 & -0.4090096 \\ \mathrm{H} & 1.6560259 & 0.9103830 & -1.0873836 \\ \mathrm{H} & 0.0105742 & 1.4557758 & -1.0328948 \\ \mathrm{H} & 0.1078978 & 0.7503116 & 2.4725486 \\ \mathrm{C} & 1.9228344 & 1.6020461 & 1.6949925 \\ \mathrm{H} & 2.9159226 & 1.2412825 & 1.4420679 \\ \mathrm{H} & 2.0177348 & 2.2360758 & 2.5709160 \\ \mathrm{C} & 1.3169026 & 2.3195953 & 0.4987581 \\ \mathrm{H} & 0.4625898 & 2.9044555 & 0.8268202 \\ \mathrm{H} & 2.0077233 & 2.9979822 & 0.0088797\end{array}$




\section{5m-TS_iPr}

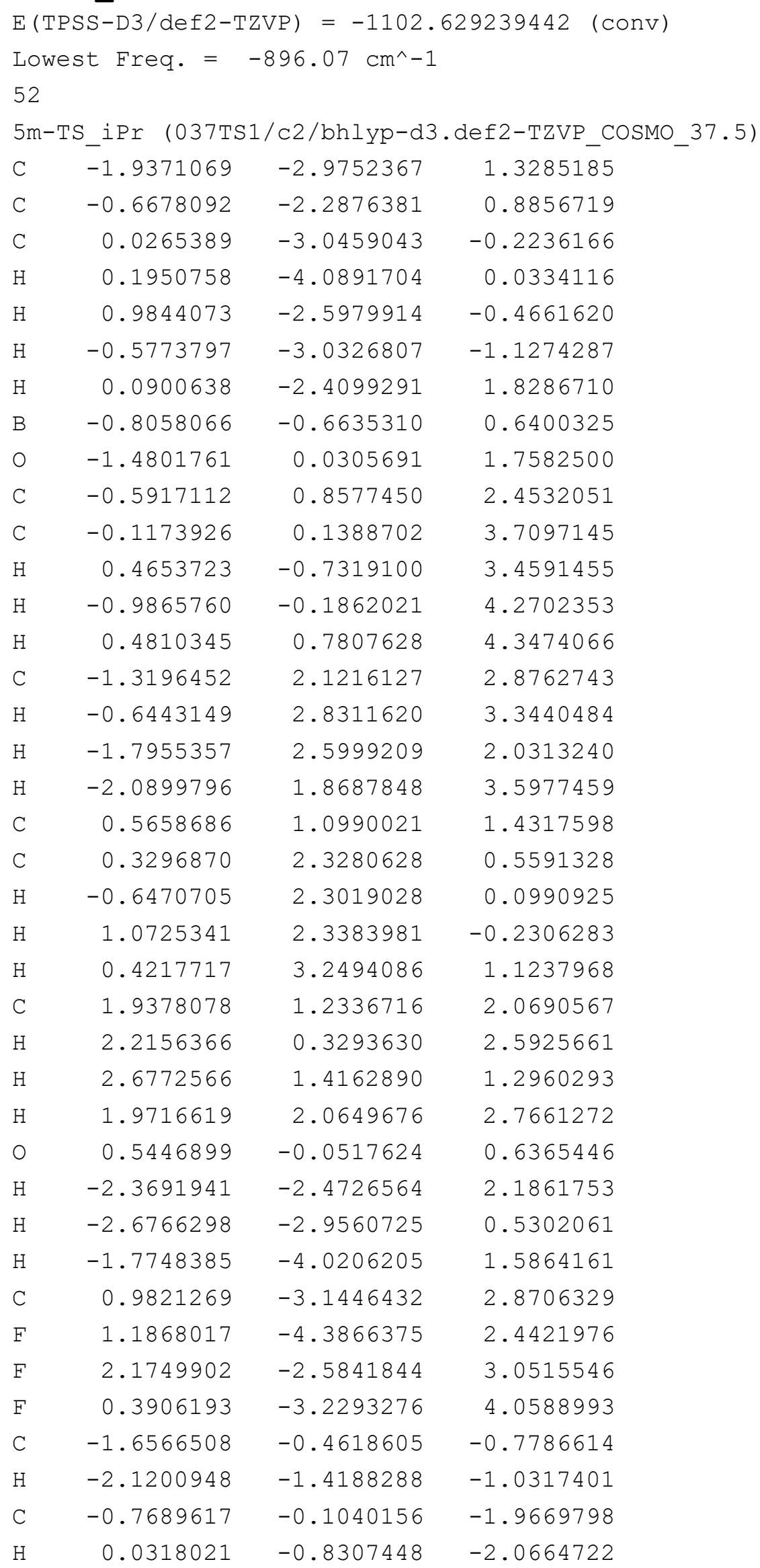




$\begin{array}{lrrr}\mathrm{C} & -2.8153906 & 0.5262318 & -0.6888544 \\ \mathrm{H} & -3.4749288 & 0.2398897 & 0.1234159 \\ \mathrm{H} & -2.4418246 & 1.5135848 & -0.4275624 \\ \mathrm{H} & -0.2827797 & 0.8485392 & -1.7742349 \\ \mathrm{C} & -1.5435312 & -0.0072811 & -3.2735350 \\ \mathrm{H} & -1.9417447 & -0.9893035 & -3.5270359 \\ \mathrm{H} & -0.8854117 & 0.2821444 & -4.0901335 \\ \mathrm{C} & -3.6005393 & 0.6282719 & -1.9889031 \\ \mathrm{H} & -4.3963896 & 1.3649181 & -1.9002387 \\ \mathrm{H} & -4.0823482 & -0.3281599 & -2.1895846 \\ \mathrm{C} & -2.6956872 & 0.9776110 & -3.1592818 \\ \mathrm{H} & -2.2917095 & 1.9779756 & -3.0081407 \\ \mathrm{H} & -3.2647220 & 1.0081535 & -4.0849470\end{array}$




\section{5m-TS cHex}

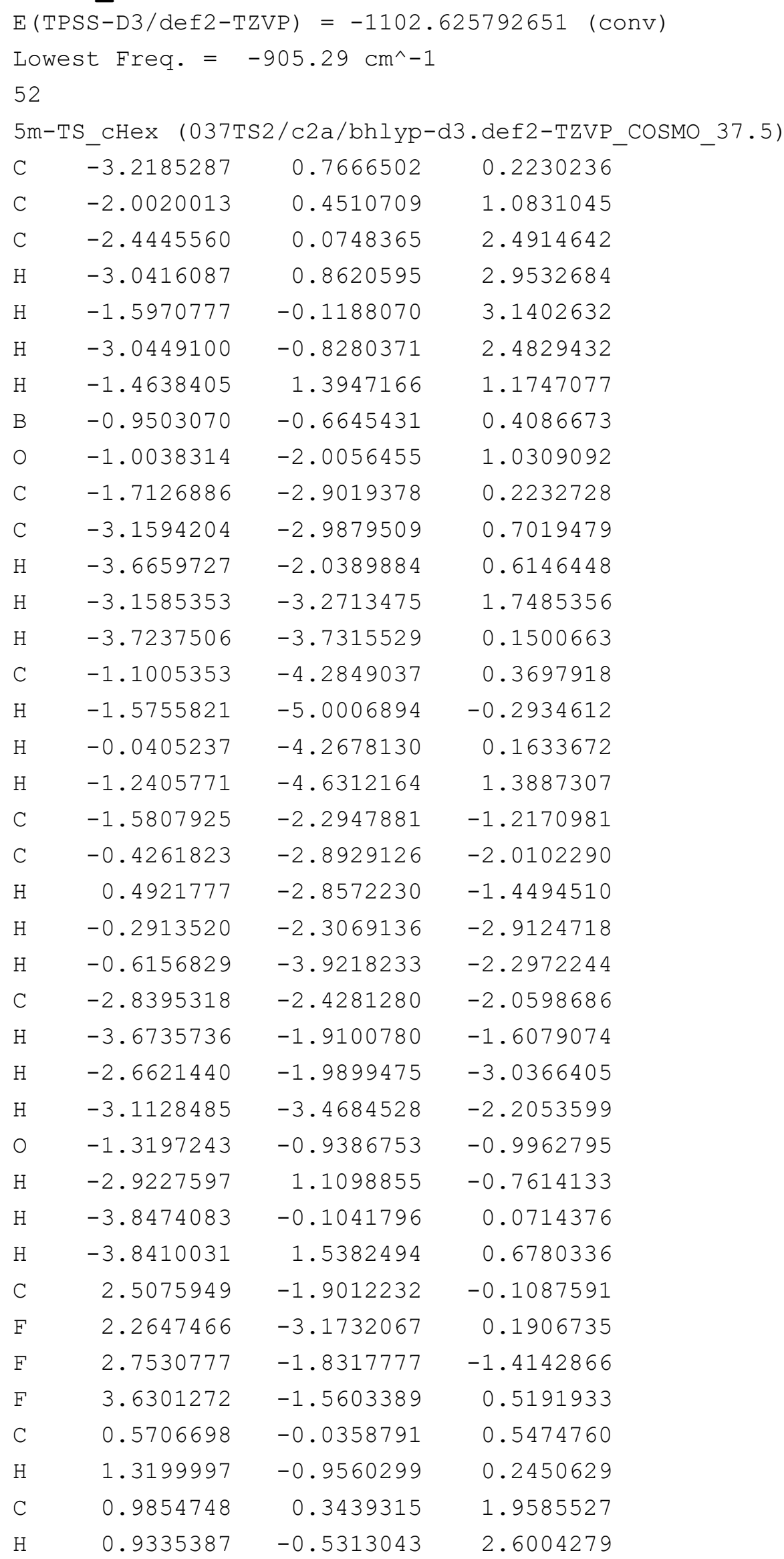




$\begin{array}{lllr}\text { C } & 0.8658639 & 1.0626655 & -0.4531350 \\ \text { H } & 0.7166209 & 0.6768804 & -1.4559721 \\ \text { H } & 0.1207440 & 1.8488773 & -0.3193672 \\ \text { H } & 0.2469100 & 1.0427380 & 2.3462986 \\ \text { C } & 2.3527385 & 1.0051202 & 2.0819591 \\ \text { H } & 3.1352497 & 0.2784740 & 1.8919615 \\ \text { H } & 2.4971343 & 1.3586194 & 3.0997430 \\ \text { C } & 2.2462991 & 1.6890151 & -0.3201208 \\ \text { H } & 2.3478281 & 2.5196392 & -1.0137881 \\ \text { H } & 3.0062583 & 0.9609696 & -0.5961149 \\ \text { C } & 2.5029978 & 2.1562212 & 1.1021454 \\ \text { H } & 1.7886119 & 2.9392174 & 1.3535690 \\ \text { H } & 3.4926246 & 2.5966573 & 1.1854222\end{array}$

\section{References}

S1 Tan, P. W.; Haughey, M.; Dixon, D. J. Chem. Commun. 2015, 51, 4406.

S2 Gerleve, C.; Kischkewitz, M.; Studer, A. Angew. Chem. Int. Ed. 2018, 57, 2441.

S3 Sakamoto, Y.; Suzuki, T. J. Am. Chem. Soc. 2013, 135, 14074.

S4 Zhang, K.-F.; Christoffel, F.; Baudoin, O. Angew. Chem. Int. Ed. 2018, 57, 1982.

S5 Newby, J. A.; Huck, L.; Blaylock, D. W.; Witt, P. M.; Ley, S. V.; Browne, D. L. Chem. Eur. J. 2014, 20, 263.

S6 Zhu, W.; Ma, D. Org. Lett. 2006, 8, 261.

S7 Vinogradova, E. V.; Park, N. H.; Fors, B. P.; Buchwald, S. L. Org. Lett. 2013, 15, 1394.

S8 Miller, D. K. Tetrahedron Lett. 2013, 54, 811.

S9 Bose, S. K.; Brand, S.; Omoregie, H. O.; Haehnel, M.; Maier, J.; Bringmann, G.; Marder, T. B. ACS Cat. 2016, 6, 8332.

S10 Varela, A.; Garve, L. K.; Leonori, D.; Aggarwal, V. K. Angew. Chem. Int. Ed. 2017, 56, 2127.

S11 Pratsch, G.; Lackner, G. L.; Overman, L. E. J. Org. Chem. 2015, 80, 6025.

S12 Fawcett, A.; Pradeilles, J.; Wang, Y.; Mutsuga, T.; Myers, E. L.; Aggarwal, V. K. Science 2017, 357, 283.

S13 Li, C.; Wang, J.; Barton, L. M.; Yu, S.; Tian, M.; Peters, D. S.; Kumar, M.; Yu, A. W.; Johnson, K. A.; Chatterjee, A. K.; Yan, M.; Baran, P. S. Science 2017, 356, eaam7355.

S14 Thommen, C.; Jana, C. K.; Neuburger, M.; Gademann, K. Org. Lett. 2013, 15, 1390.

S15 Yang, C. T.; Zhang, Z. Q.; Tajuddin, H.; Wu, C. C.; Liang, J.; Liu, J. H.; Fu, Y.; Czyzewska, M.; Steel, P. G.; Marder, T. B.; Liu, L. Angew. Chem. Int. Ed. 2012, 51,528 . 
S16 Pulis, A. P.; Blair, D. J.; Torres, E.; Aggarwal, V. K. J. Am. Chem. Soc. 2013, 135, 16054.

S17 Kischkewitz, M.; Okamoto, K.; Mück-Lichtenfeld, C.; Studer, A. Science 2017, $355,936$.

S18 Wang, B.; Du, H.; Zhang, J. Steroids 2011, 76, 204.

S19 Bonet, A.; Odachowski, M.; Leonori, D.; Essafi, S.; Aggarwal, V. K. Nat. Chem. 2014, 6, 584.

S20 Woźniak, Ł.; Murphy, J. J.; Melchiorre, P. J. Am. Chem. Soc. 2015, 137, 5678.

S21 Schwarz, J. L.; Schafers, F.; Tlahuext-Aca, A.; Luckemeier, L.; Glorius, F. J. Am. Chem. Soc. 2018, 140, 12705.

S22 Kandukuri, S. R.; Bahamonde, A.; Chatterjee, I.; Jurberg, I. D.; Escudero-Adán, E. C.; Melchiorre, P. Angew. Chem. Int. Ed. 2015, 54, 1485.

S23 Prier, C. K.; Rankic, D. A.; MacMillan, D. W. Chem. Rev. 2013, 113, 5322.

S24 Andrieux, C. P.; Gelis, L.; Medebielle, M.; Pinson, J.; Saveant, J. M. J. Am. Chem. Soc. 1990, 112, 3509.

S25 Silvi, M.; Sandford, C.; Aggarwal, V. K. J. Am. Chem. Soc. 2017, 139, 5736.

S26 Lovinger, G. J.; Morken, J. P. J. Am. Chem. Soc. 2017, 139, 17293.

S27 Shu, C.; Noble, A.; Aggarwal, V. K. Angew. Chem. Int. Ed. 2019, 58, 3870-3874.

S28 Becke, A. D. J. Chem. Phys. 1993, 98, 1372.

S29 Lee, C.; Yang, W.; Parr, R.G. Phys. Rev. B 1988, 37, 785.

S30 Grimme, S.; Antony, J.; Ehrlich, S.; Krieg, H. J. Chem. Phys. 2010, 132, 154104.

S31 Grimme, S.; Ehrlich, S.; Goerigk, L. J. Comput. Chem. 2011, 32, 1456.

S32 Weigend, F.; Ahlrichs, R.; Phys. Chem. Chem. Phys. 2005, 7, 3297.

S33 Klamt, A.; Schüürmann, G. J. Chem. Soc. Perkin Trans. 1993, 2, 799.

S34 Grimme, S. Chem. Eur. J. 2012, 18, 9955.

S35 Goerigk, L.; Grimme, S. J. Chem. Theory Comput. 2011, 7, 291.

S36 Barone, V.; Cozzi, M. J. Phys. Chem. A 1998, 102, 1995.

S37 TURBOMOLE V7.2 2018, a Development of University of Karlsruhe and

Forschungszentrum Karlsruhe GmbH, 1989-2007, TURBOMOLE GmbH, since 2007; available from http://www.turbomole.com.

S38 Neese, F. WIREs Comput. Mol. Sci. 2012, 2, 73. 


\section{NMR Spectra of New Compounds}
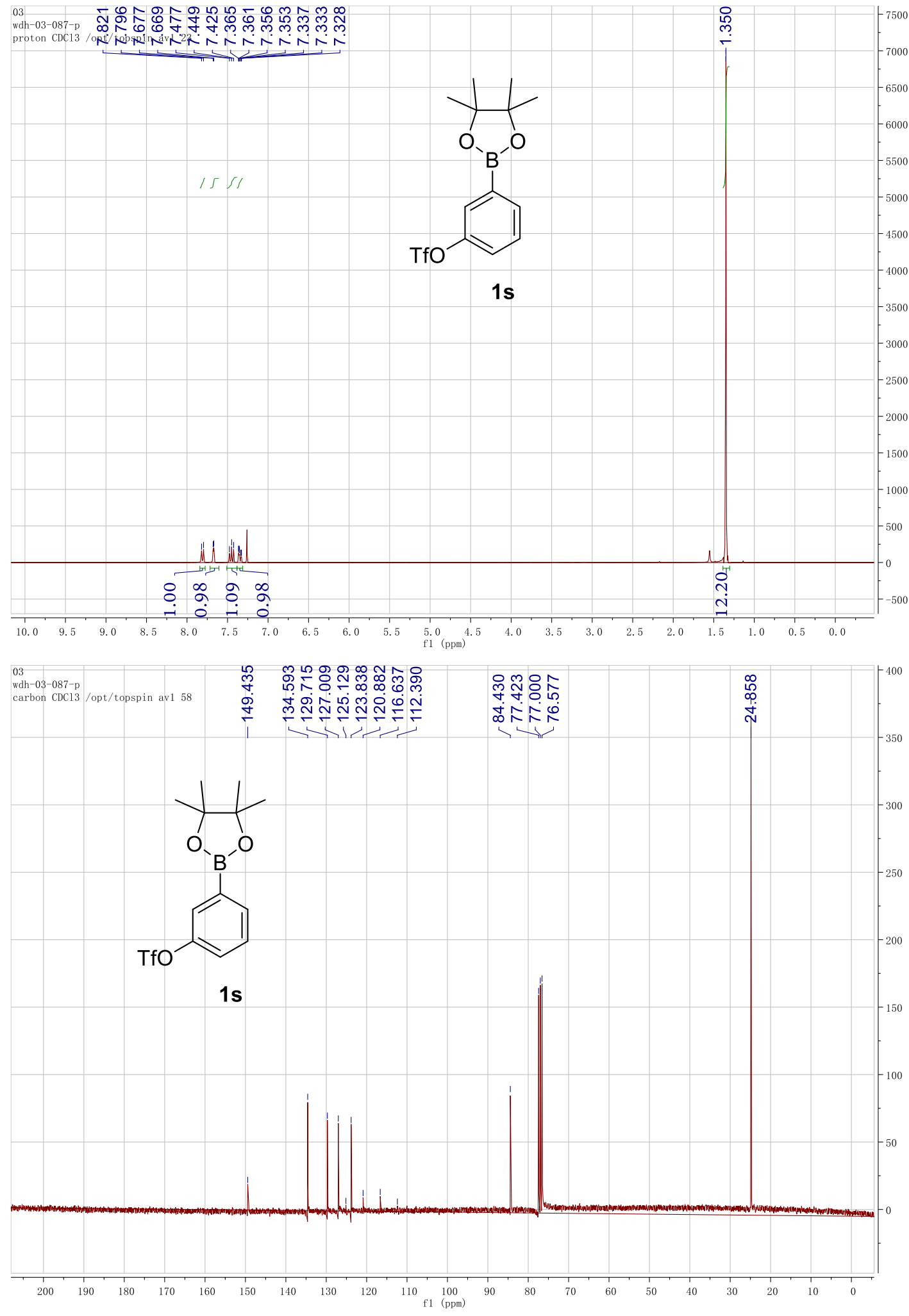


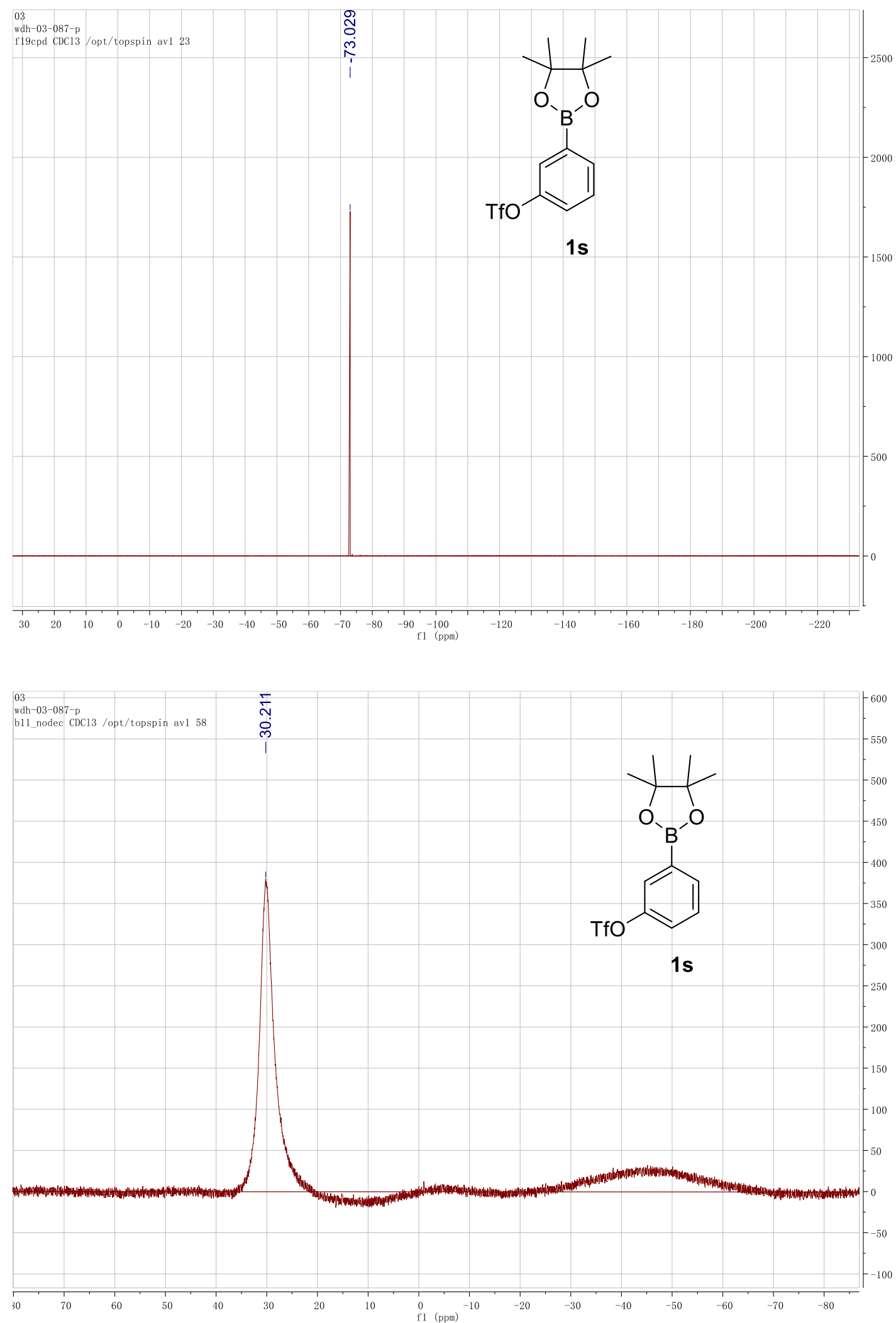



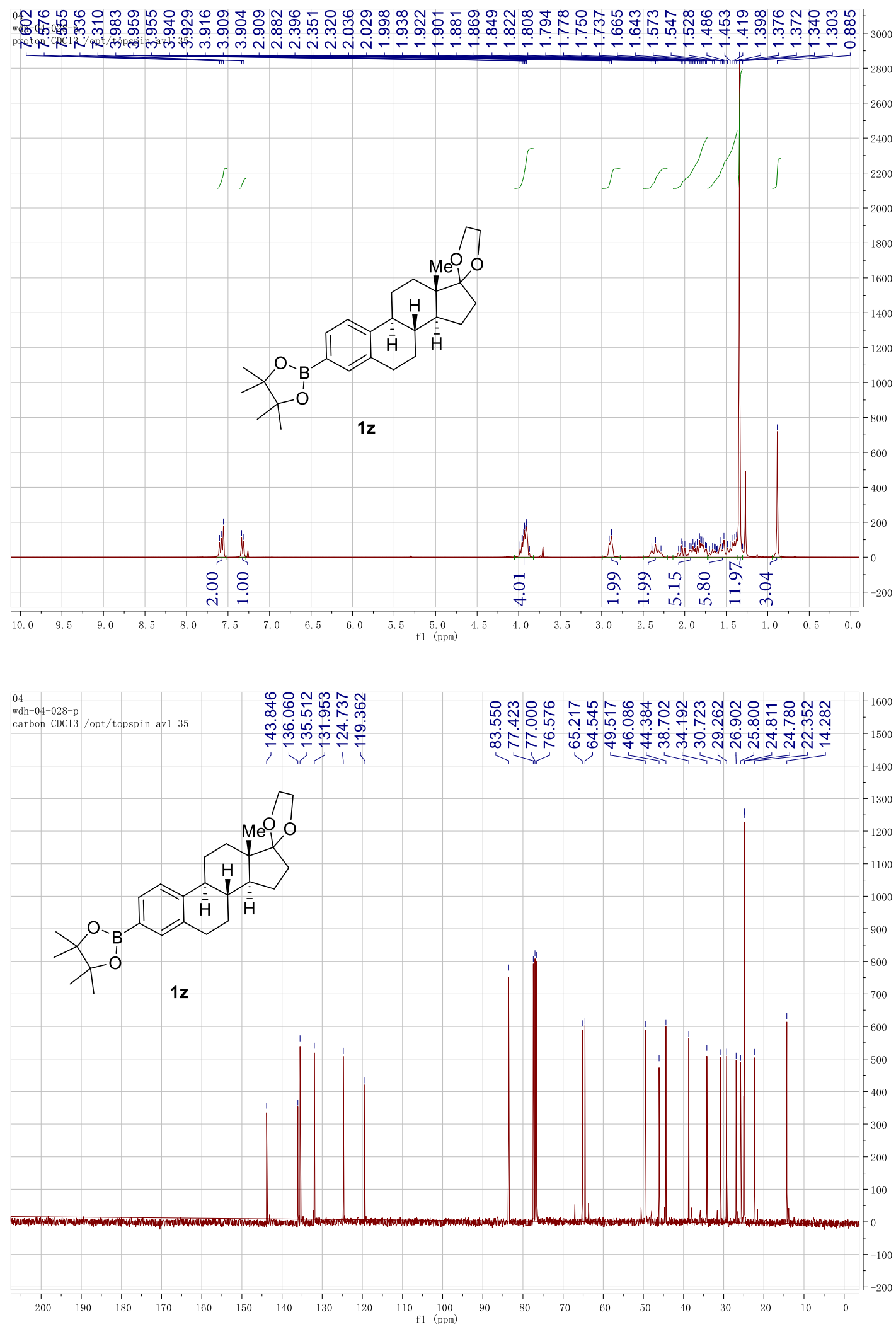

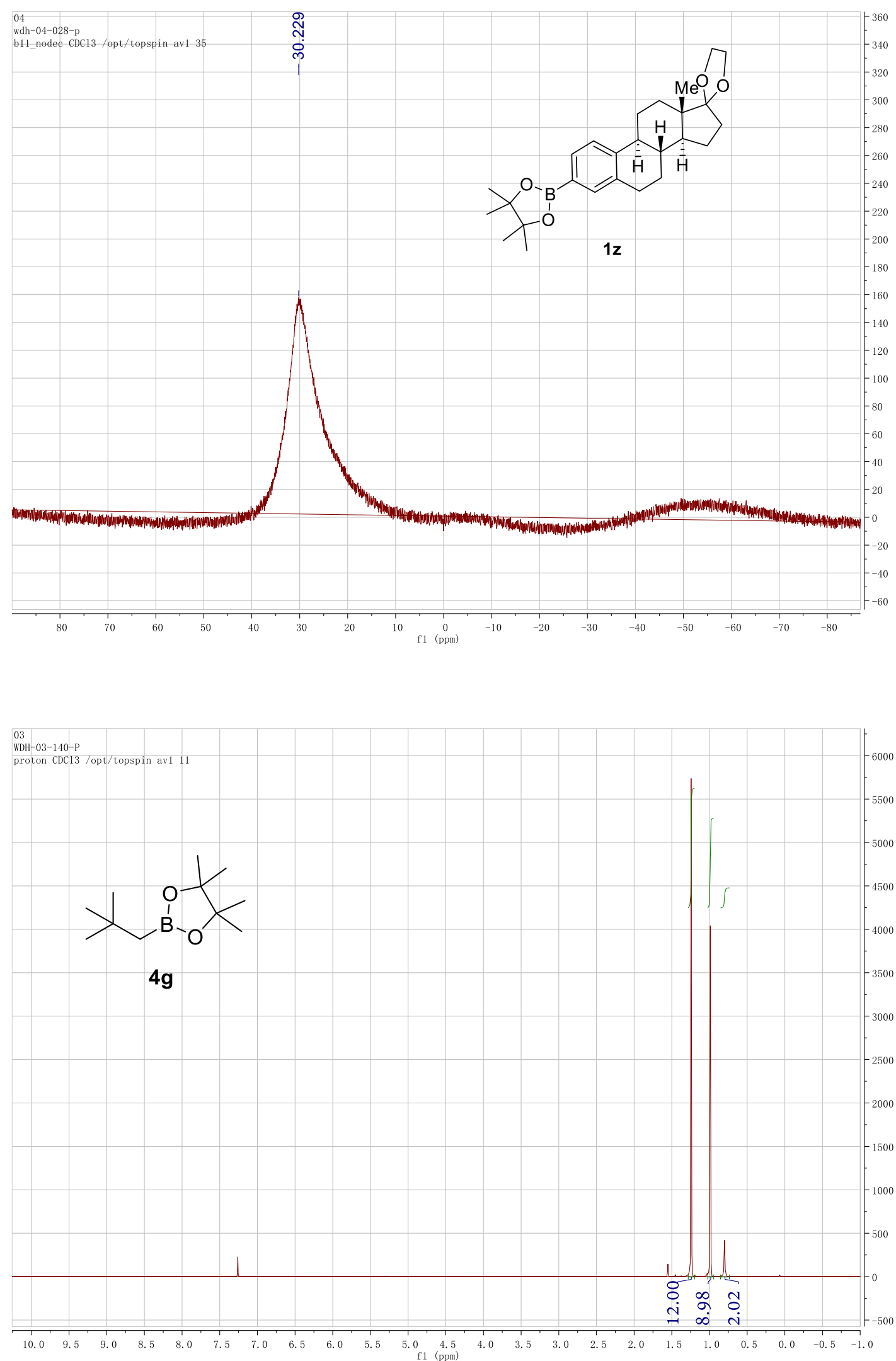


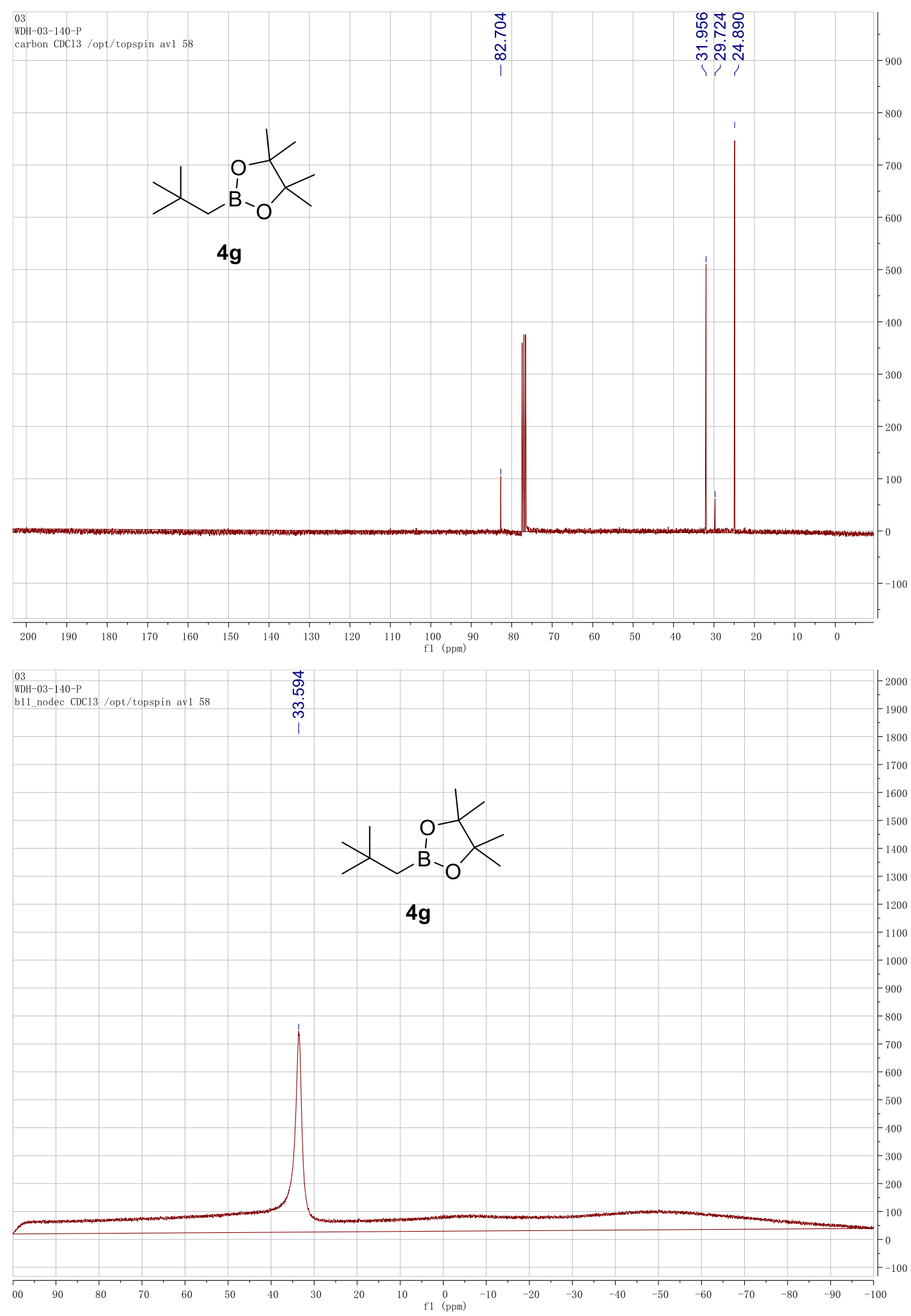



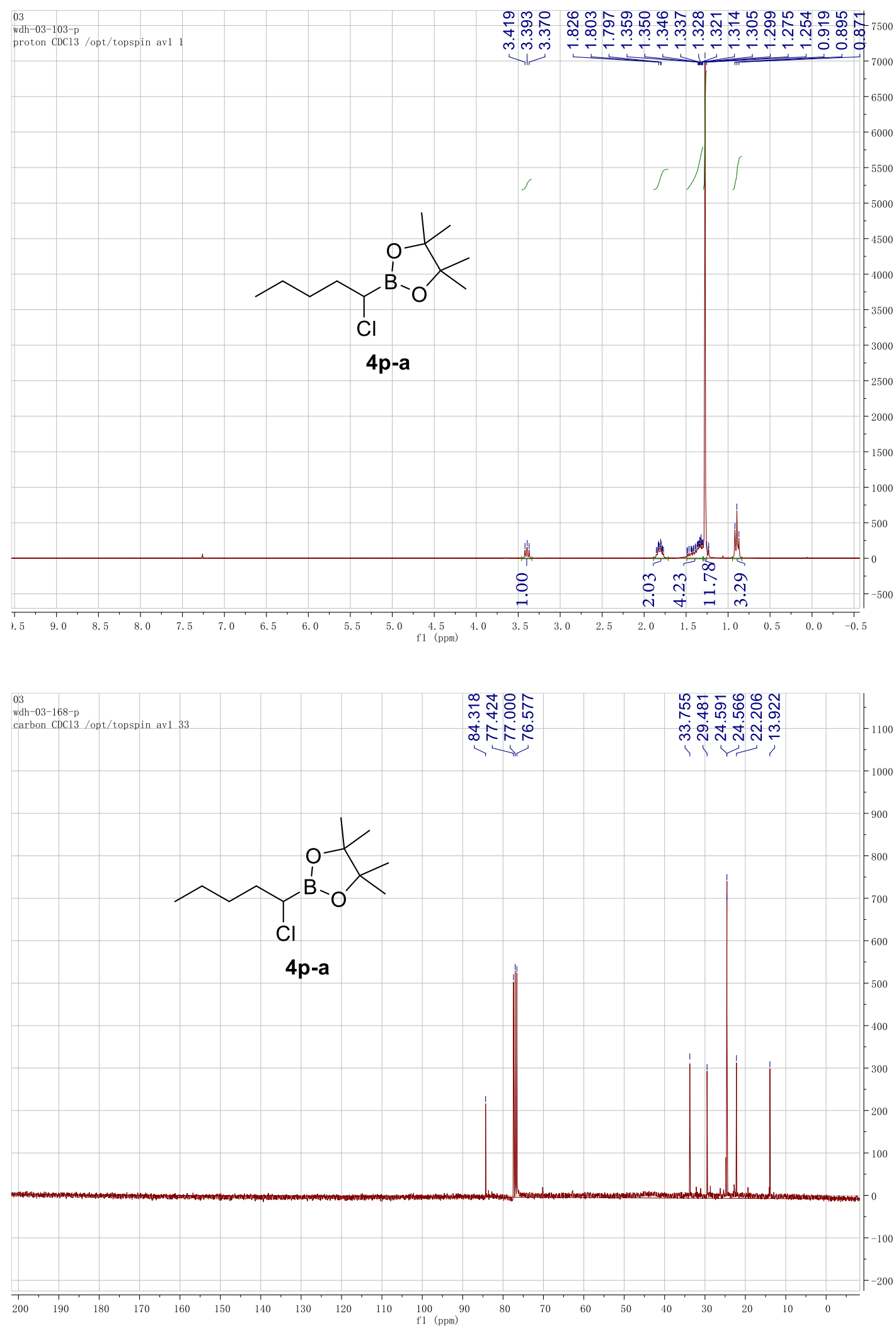

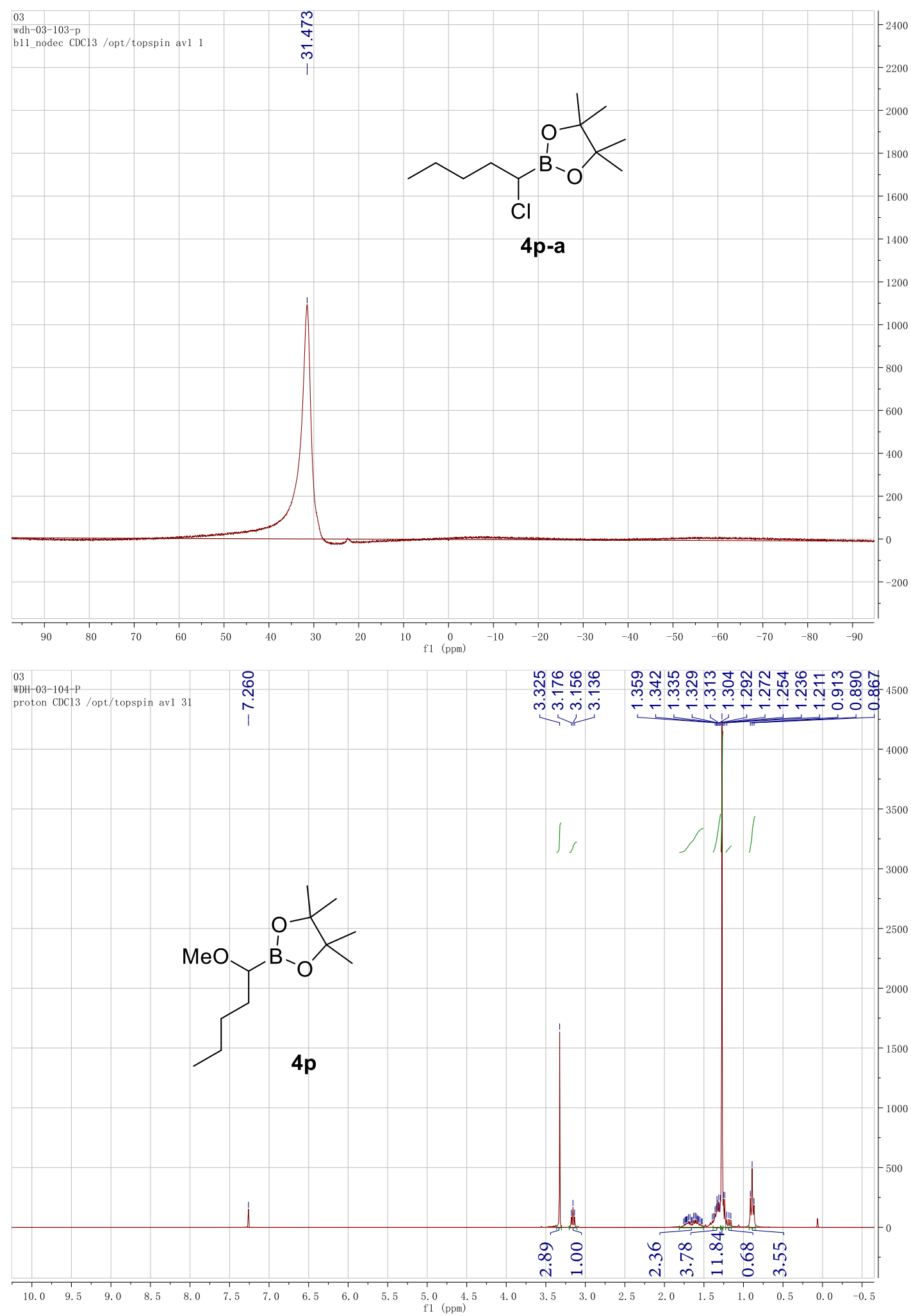

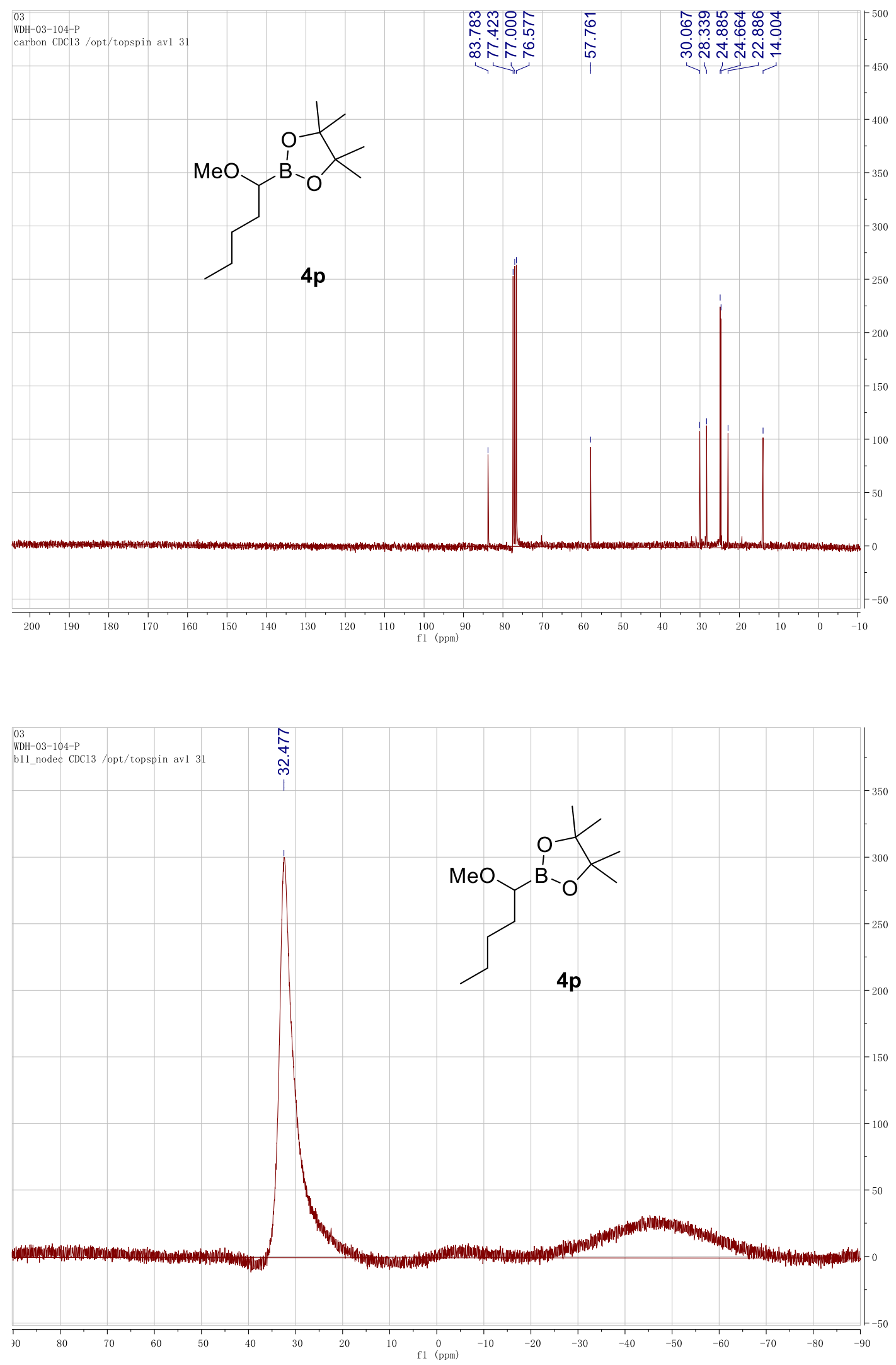

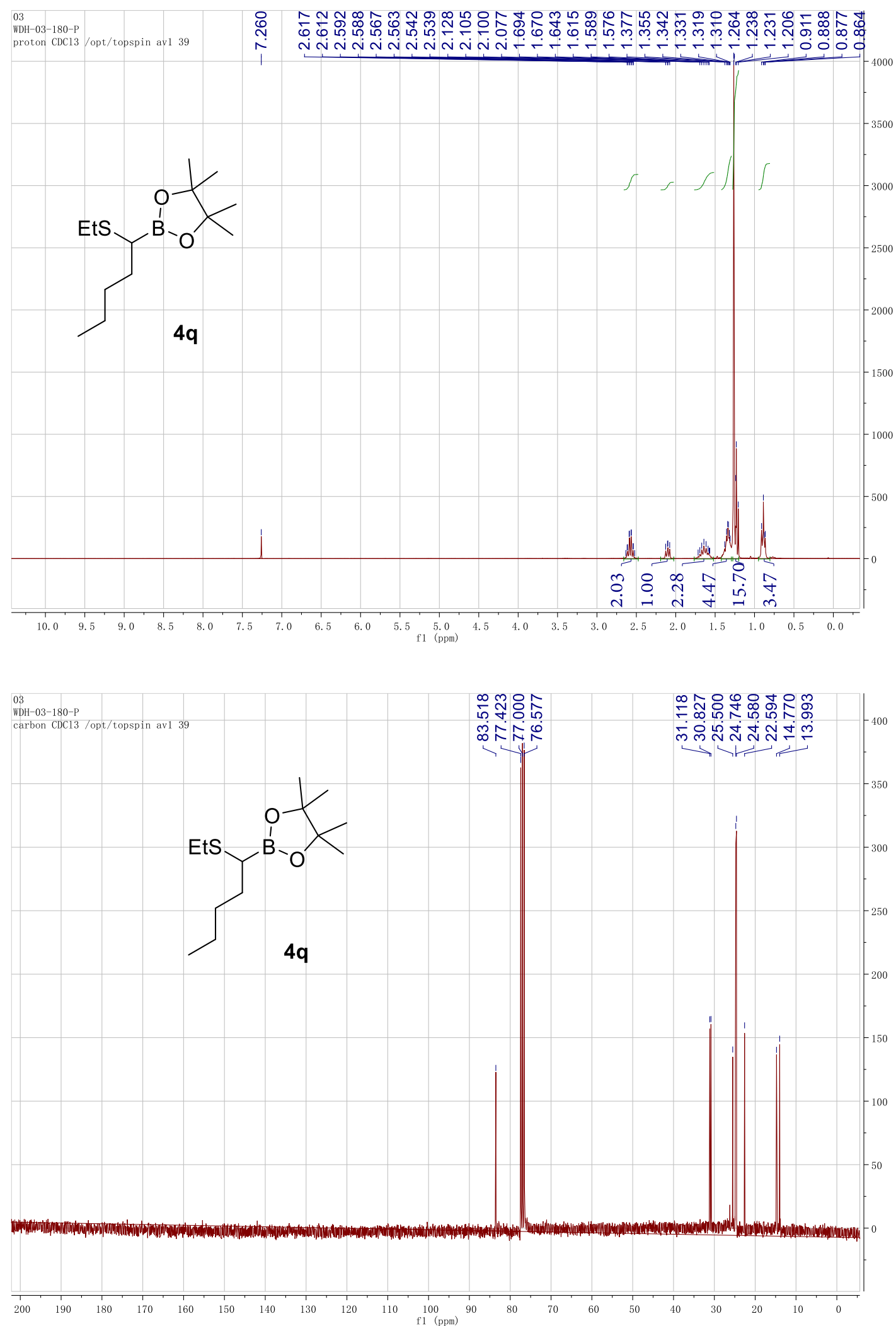

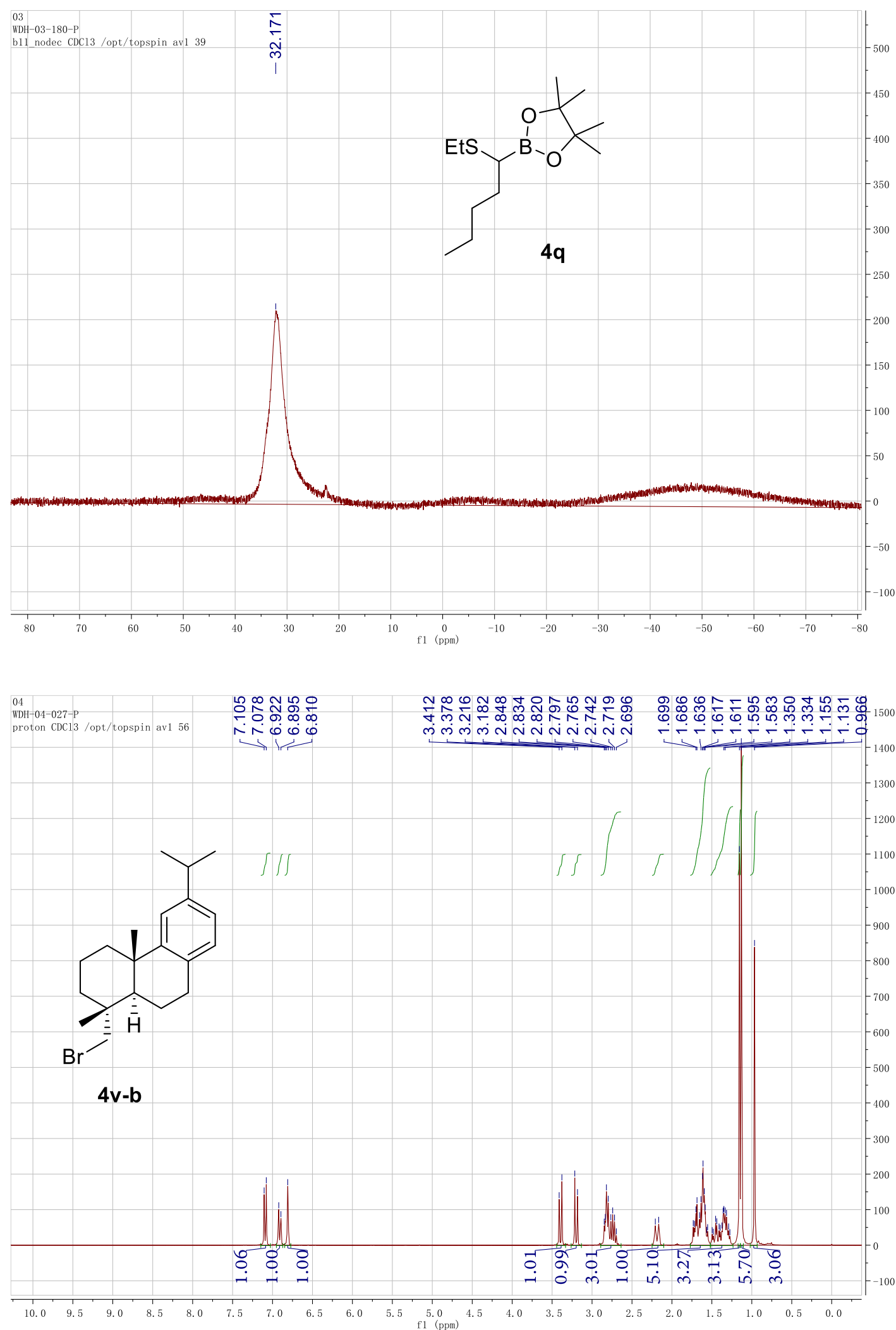


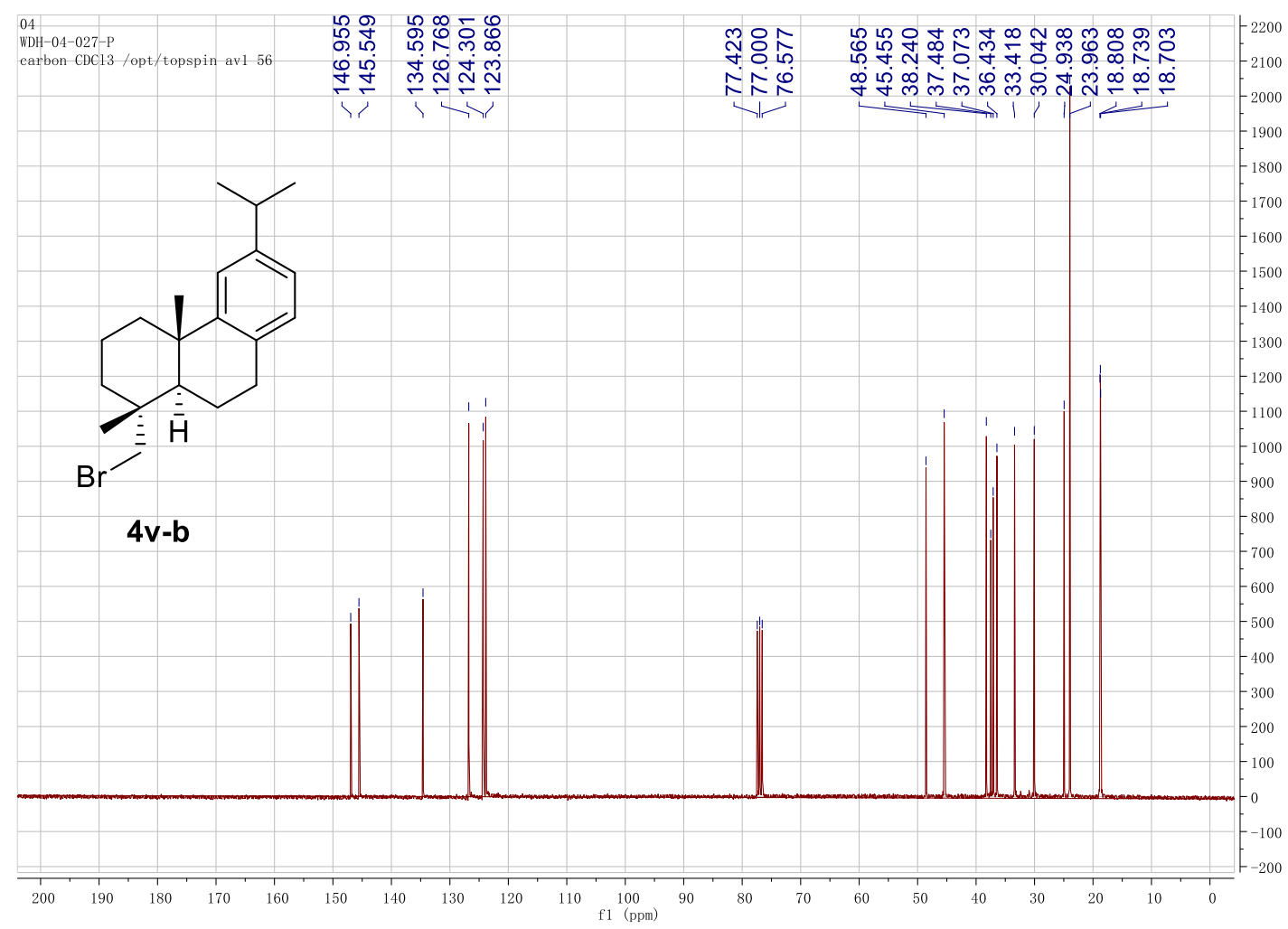

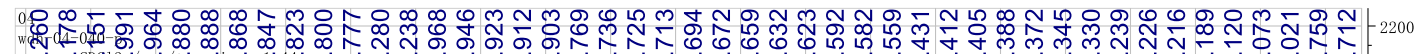

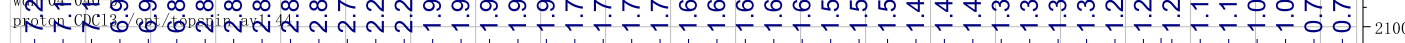

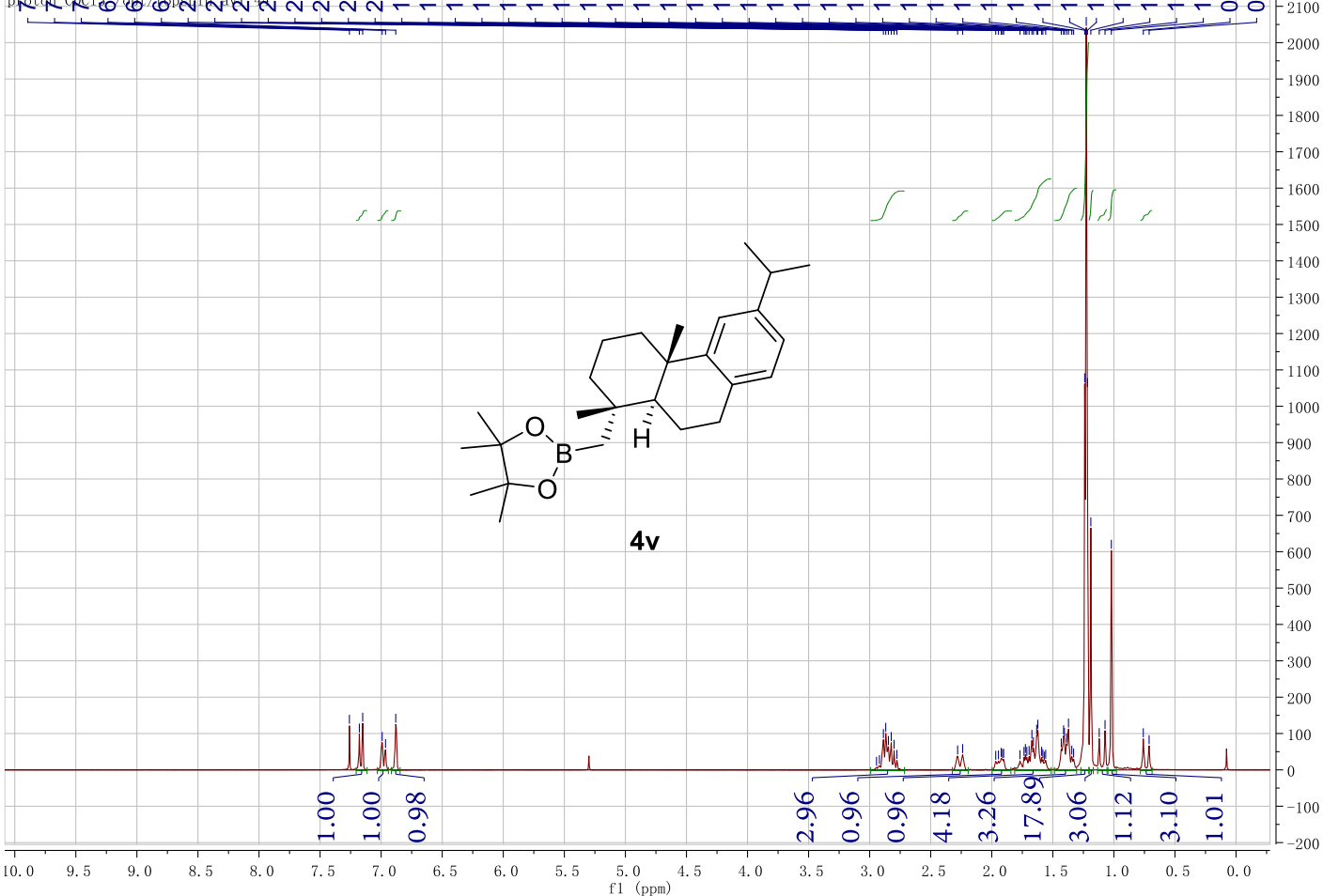



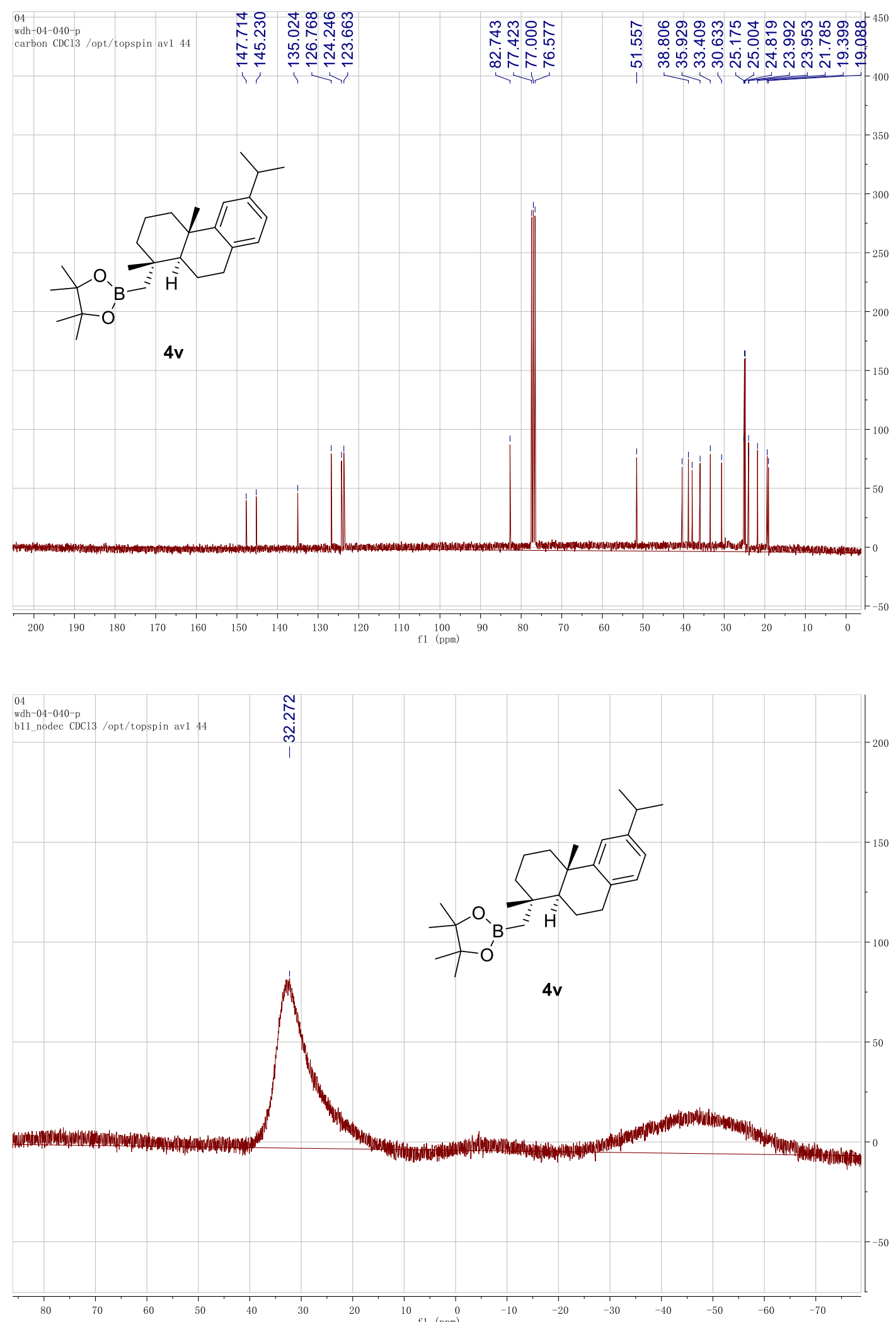

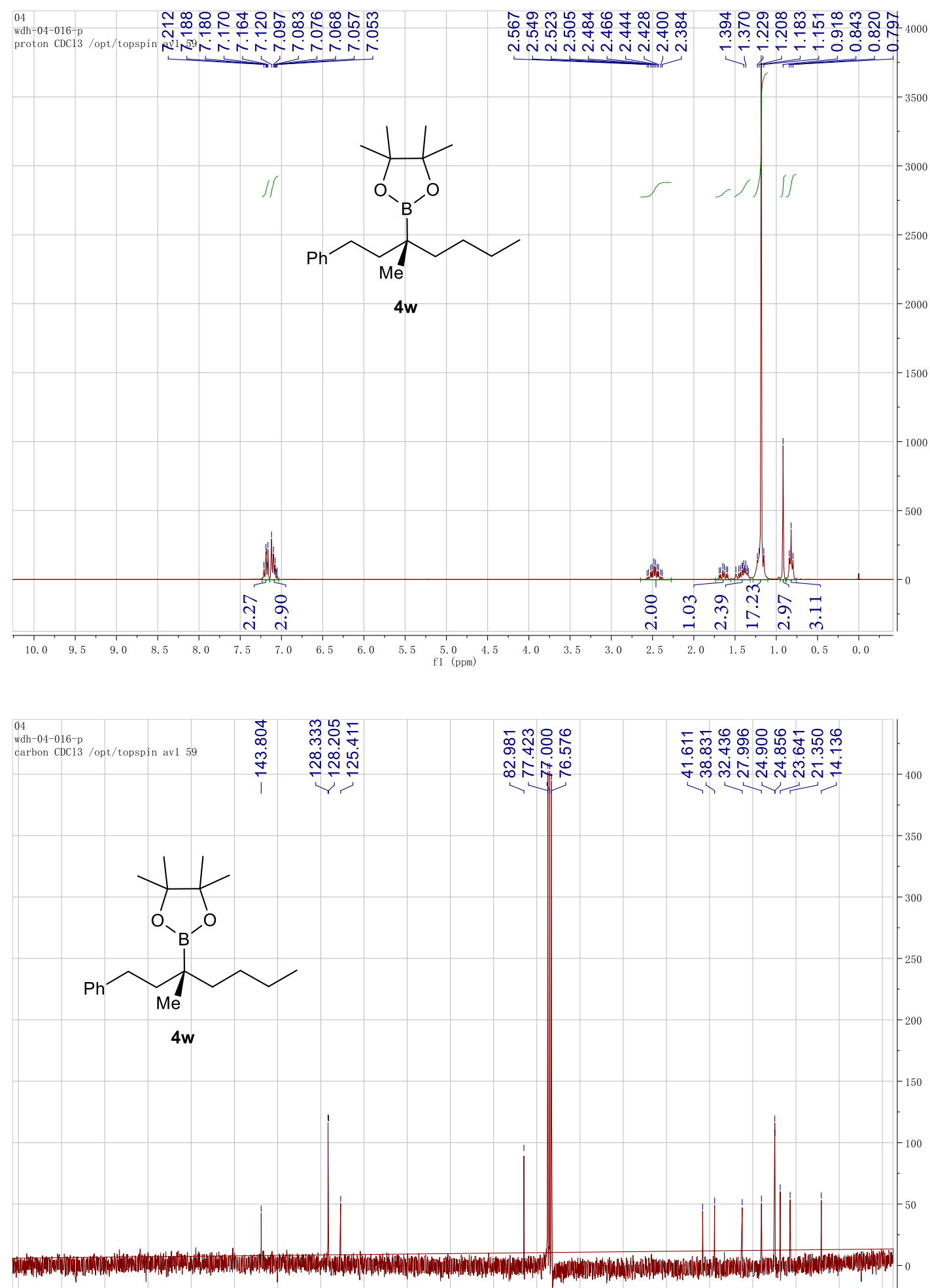


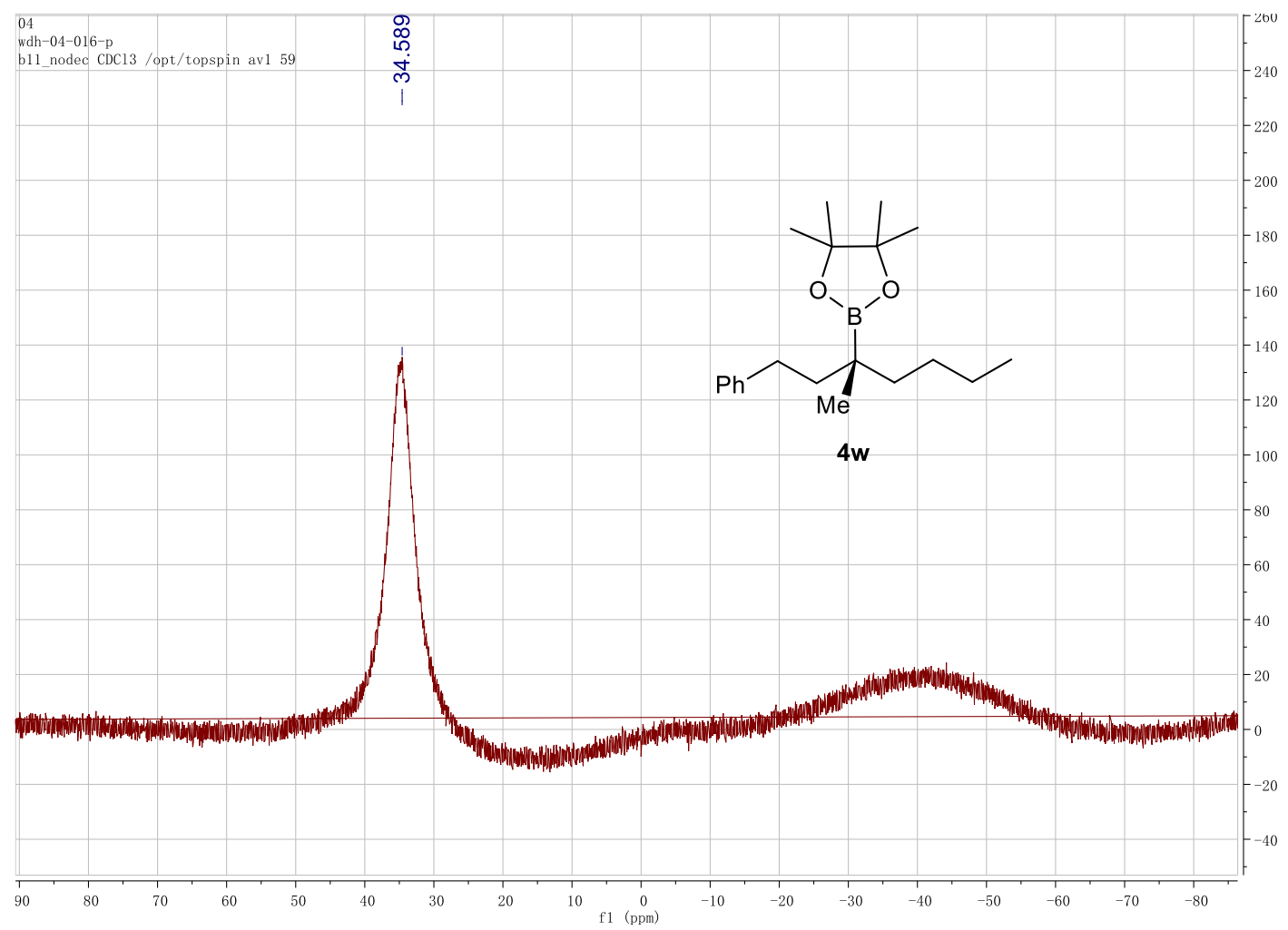

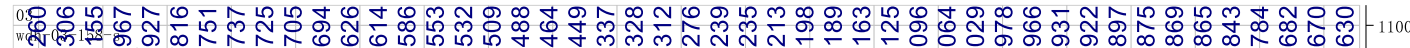
pret

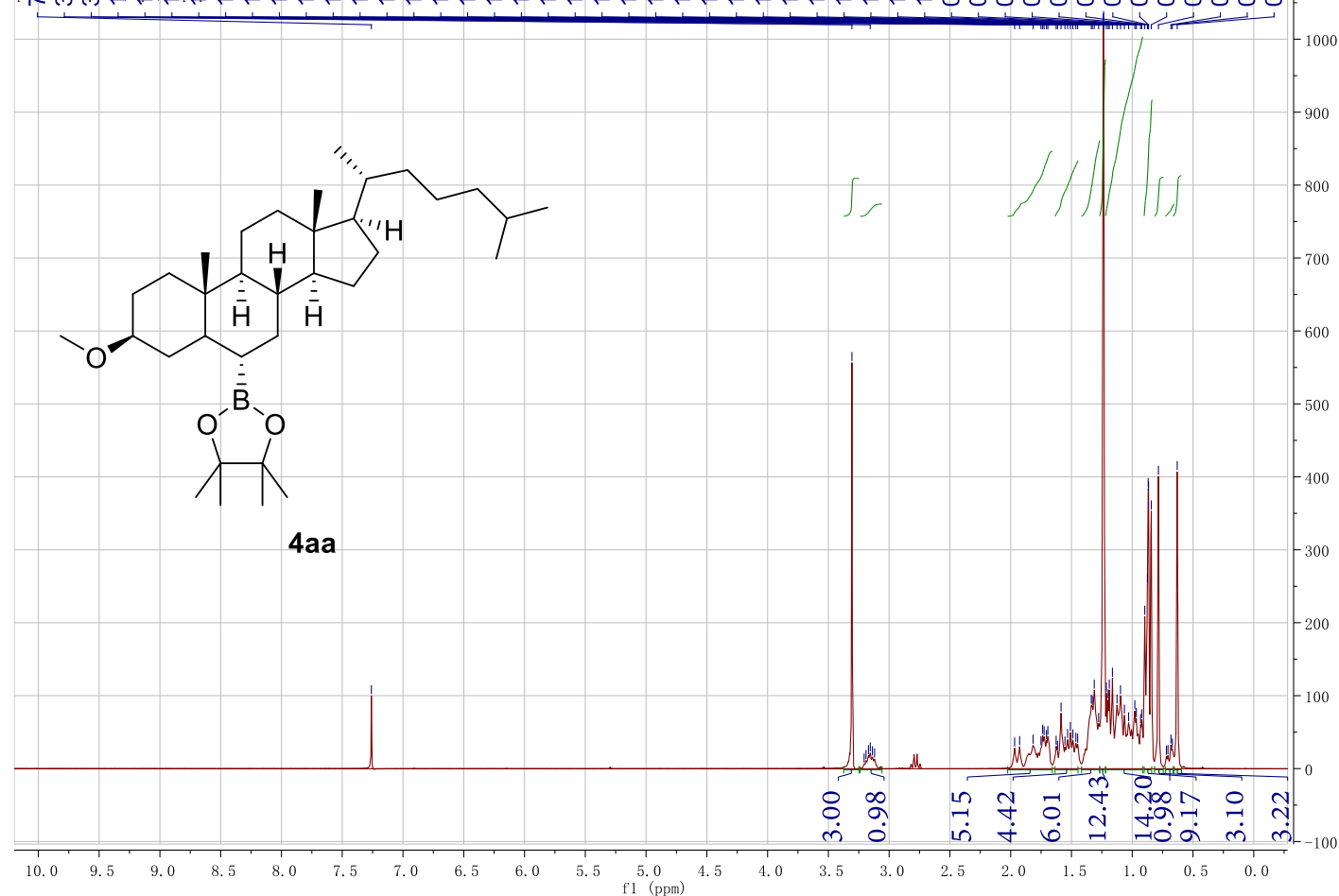




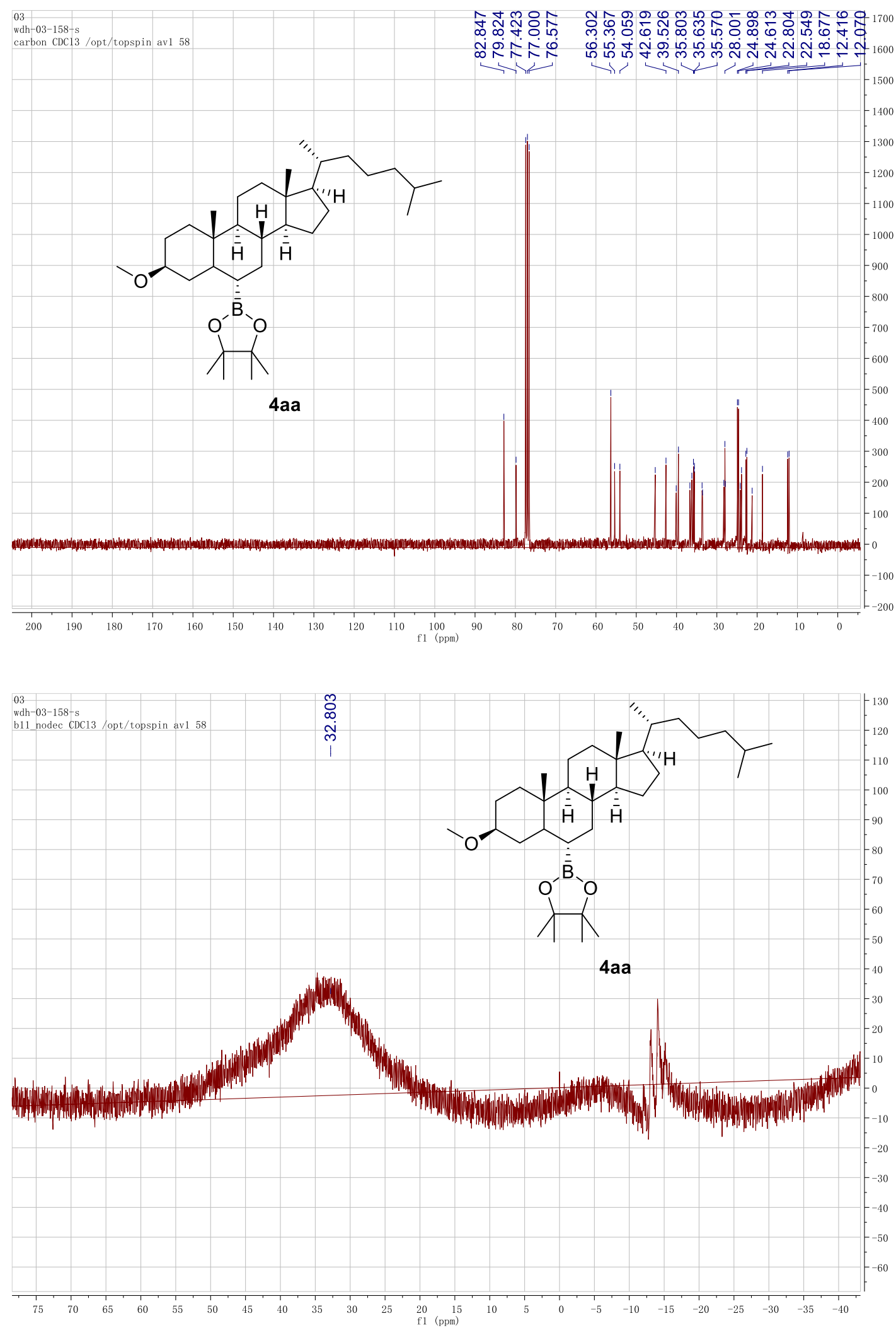




\begin{tabular}{l|l|l}
03 \\
WDH- $03-154-\mathrm{P}$
\end{tabular}

\begin{tabular}{l} 
I topt/topspin av1 57 \\
\hline
\end{tabular}

\begin{tabular}{l|l|l|l|l|l|l|l|l|} 
岕 & & & & & \\
\hline
\end{tabular}

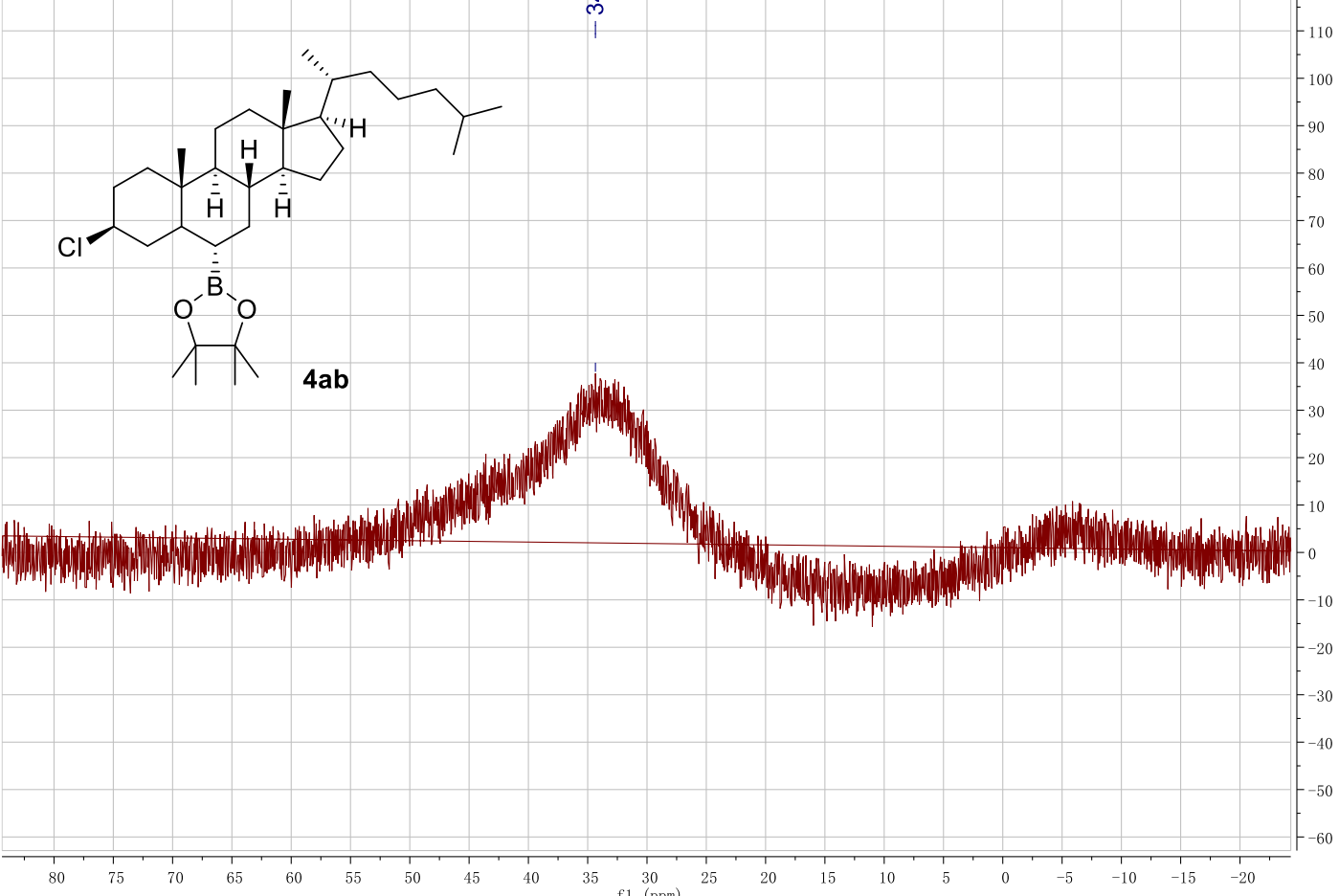

Ju123-2018
wdh-02-152-4-

용요

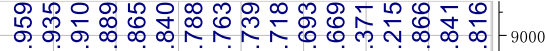

proton $\operatorname{CDC} 13$ /opt/topspin av1 6

rivi

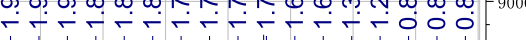

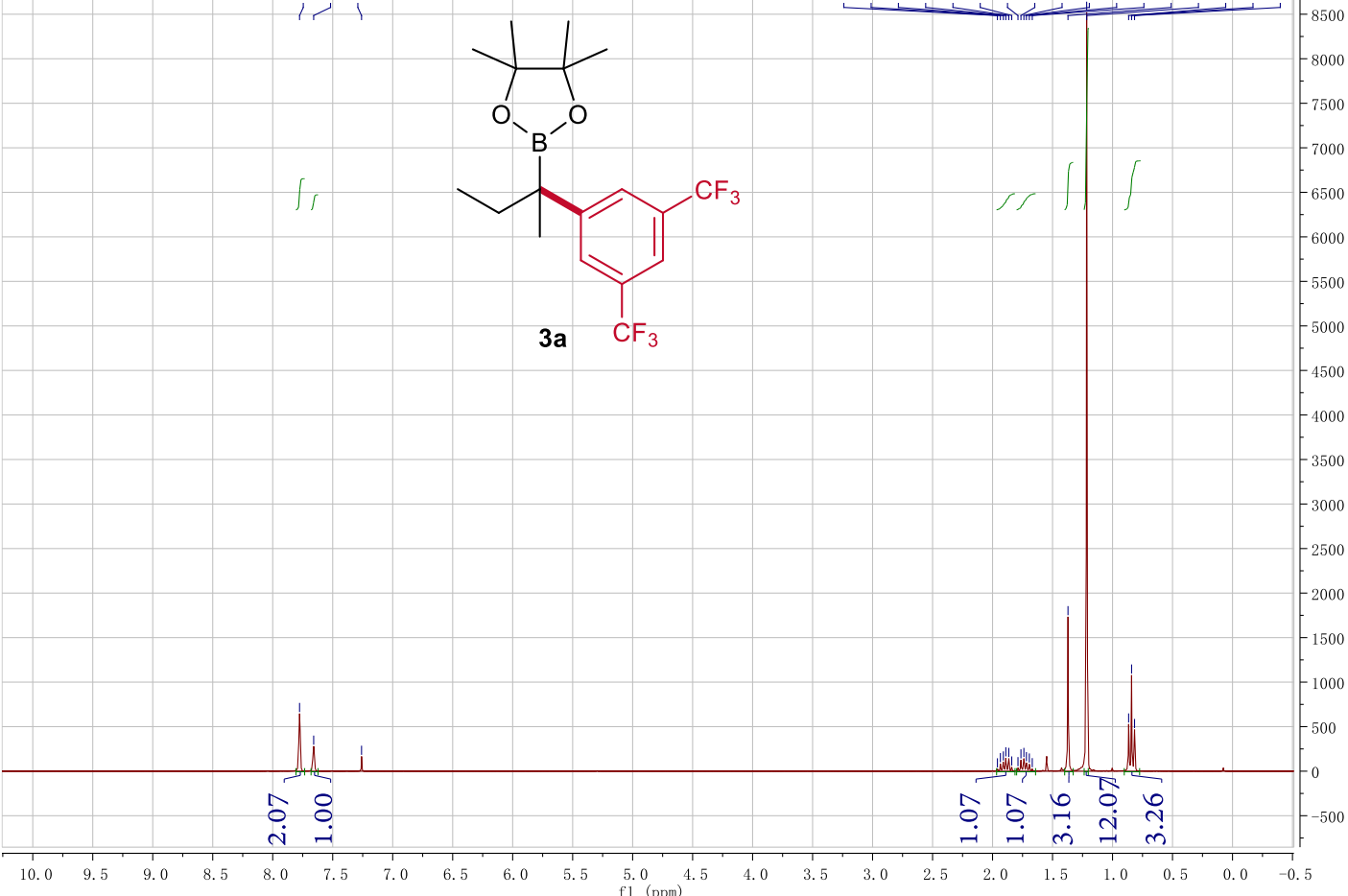




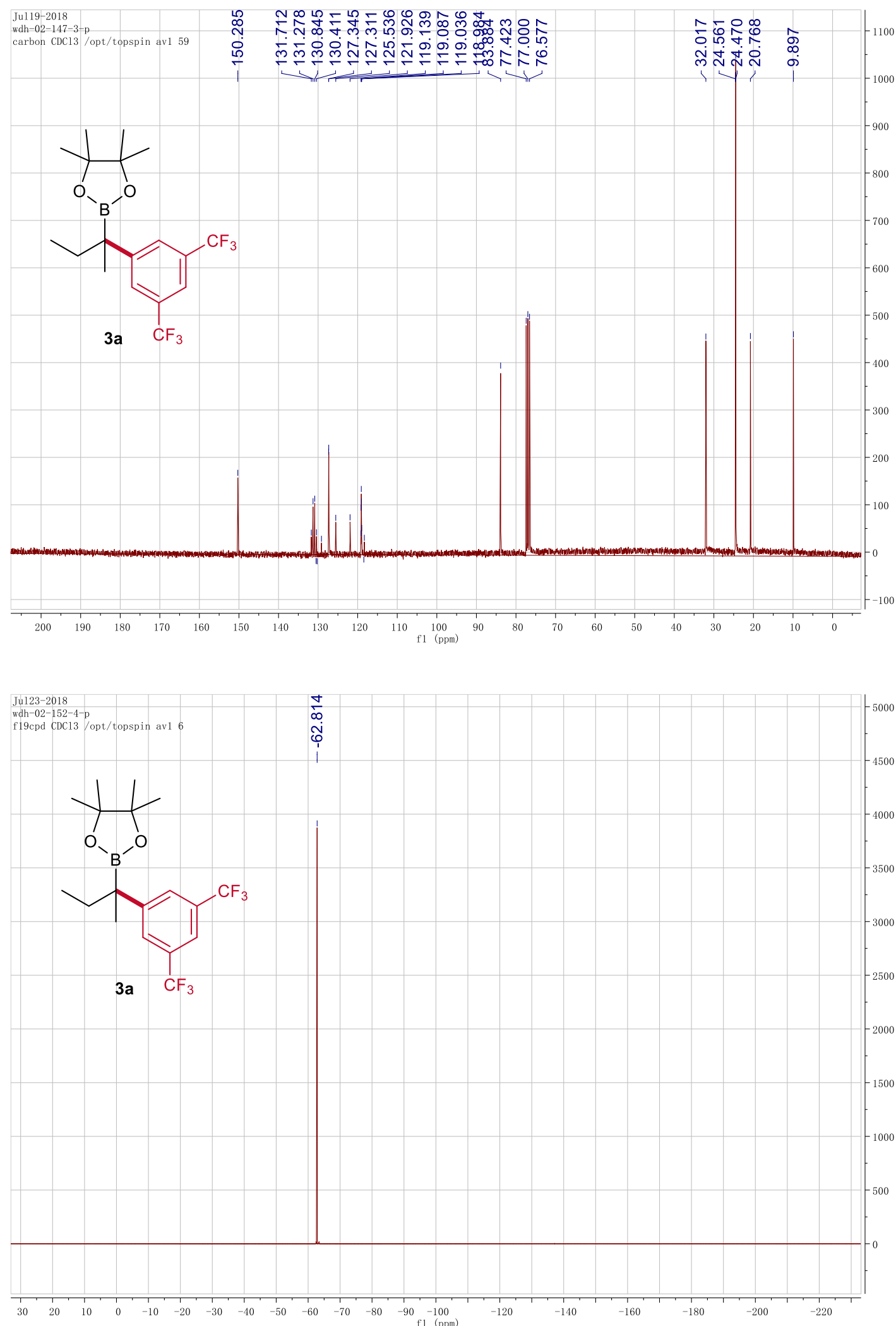





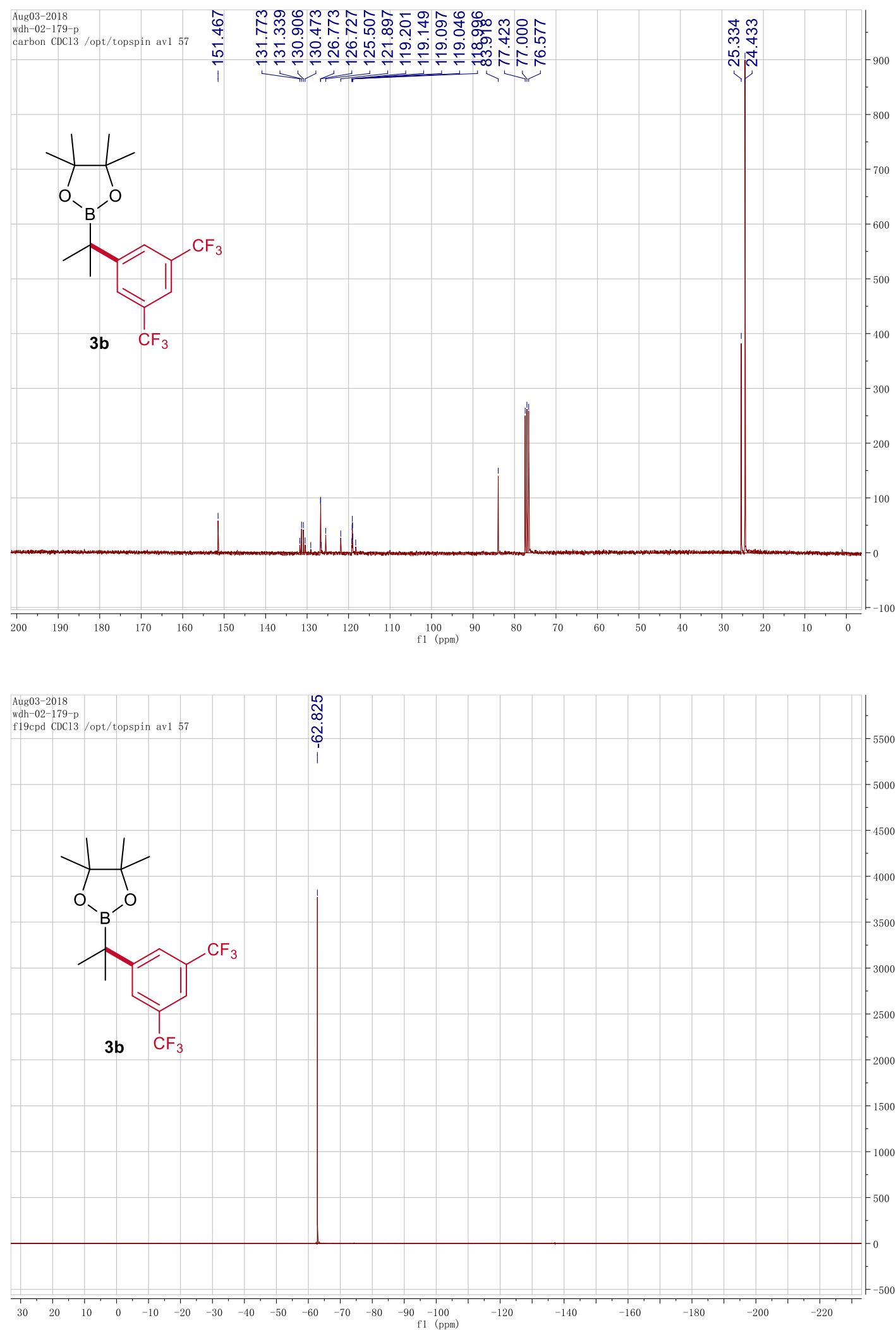

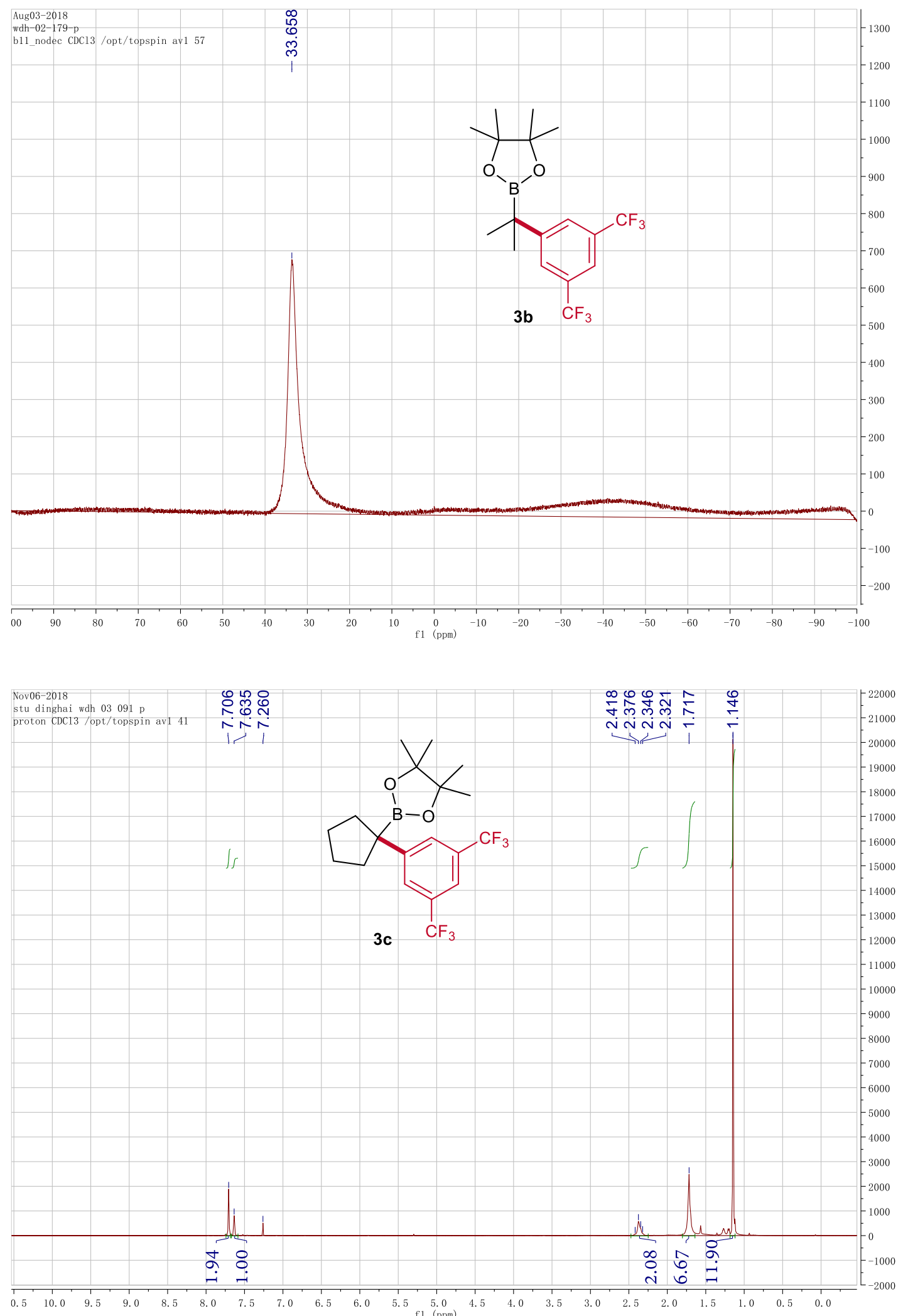

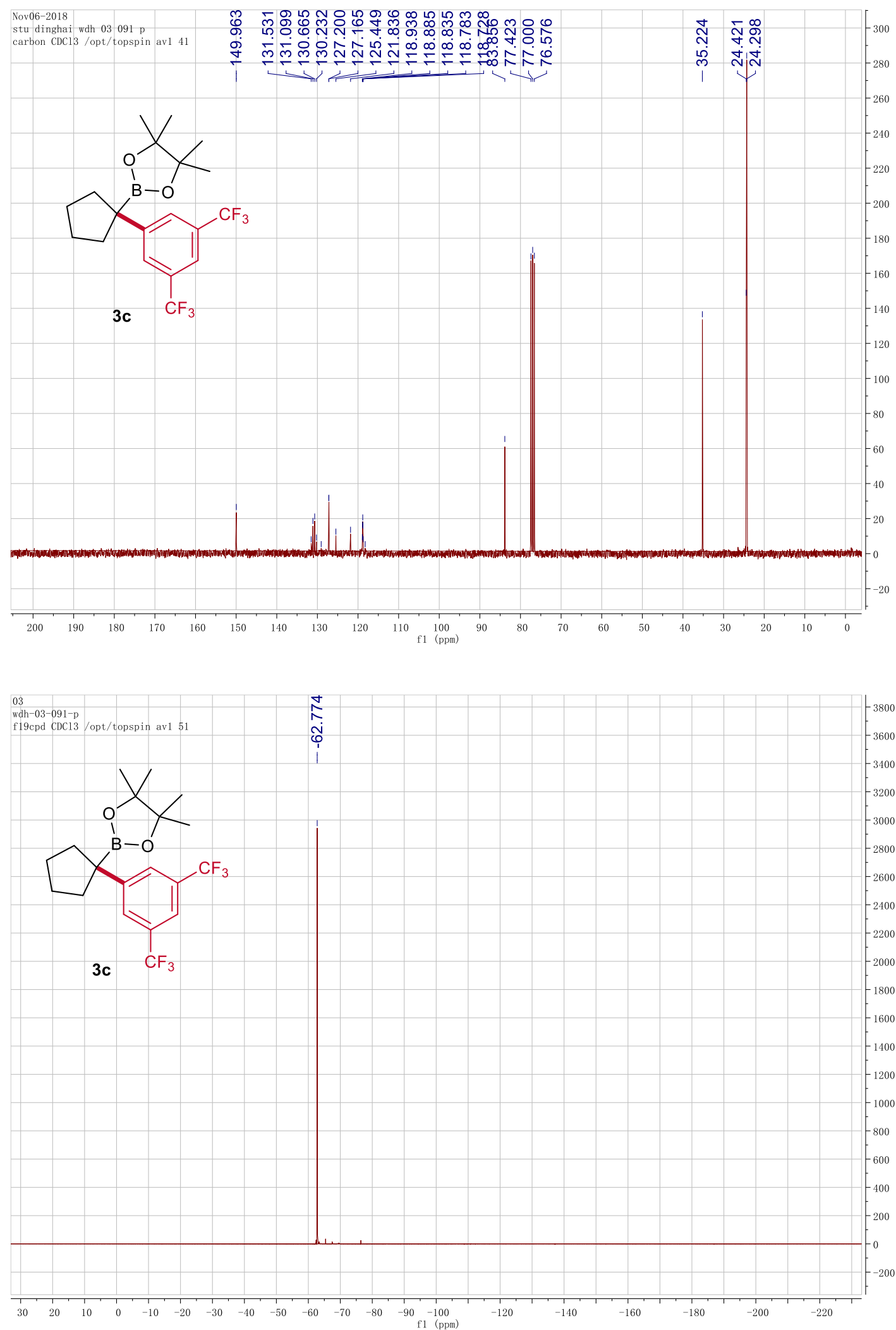

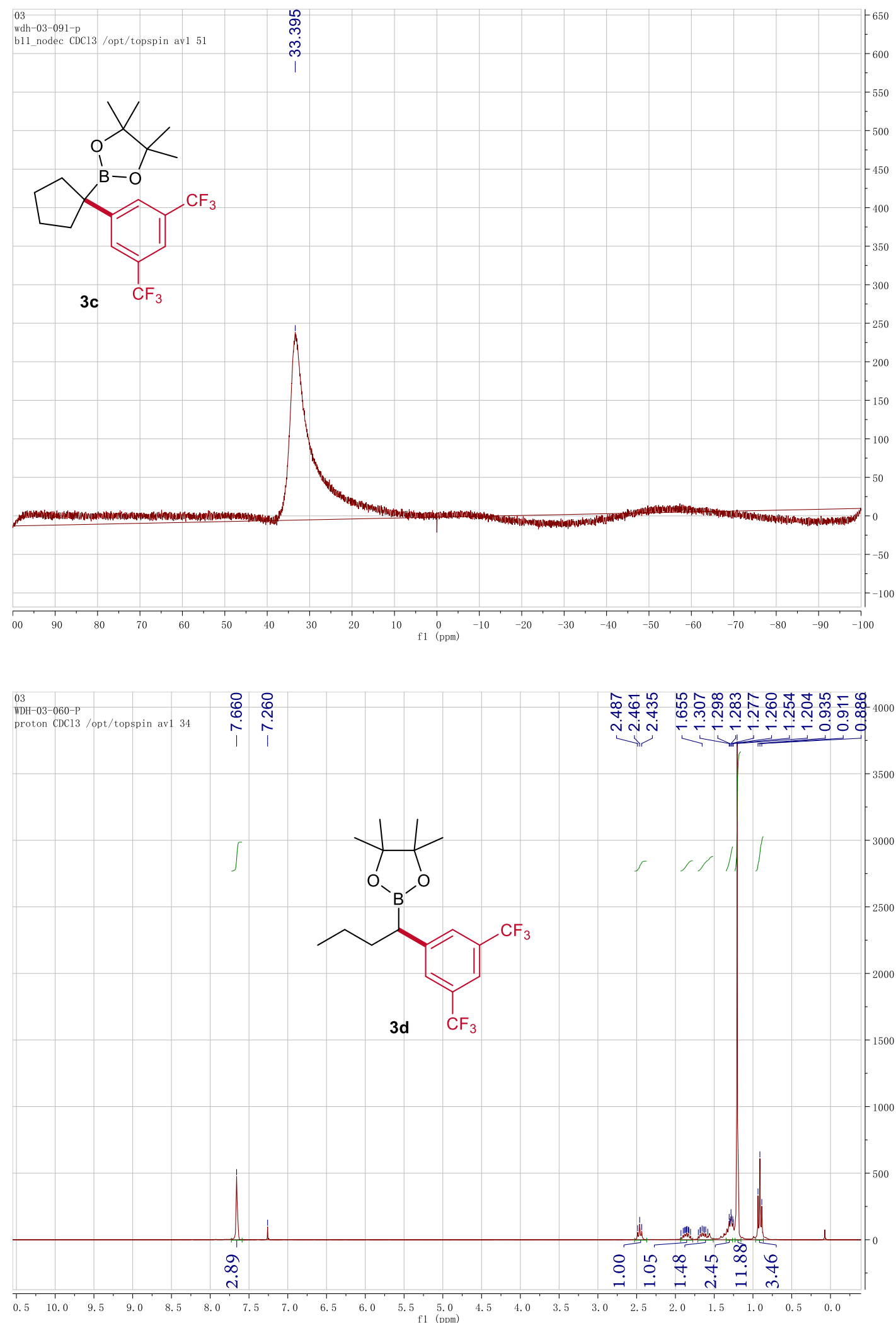

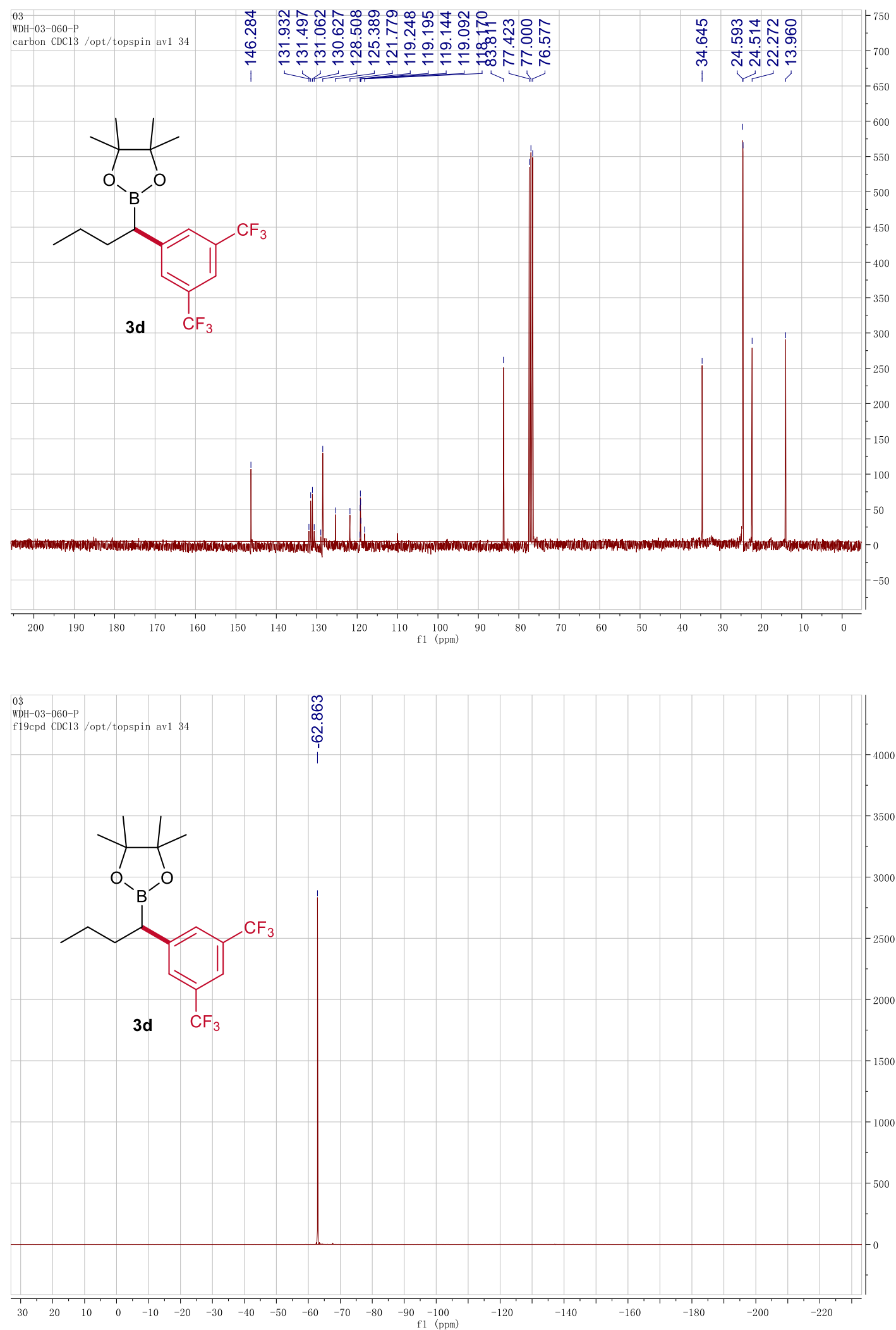

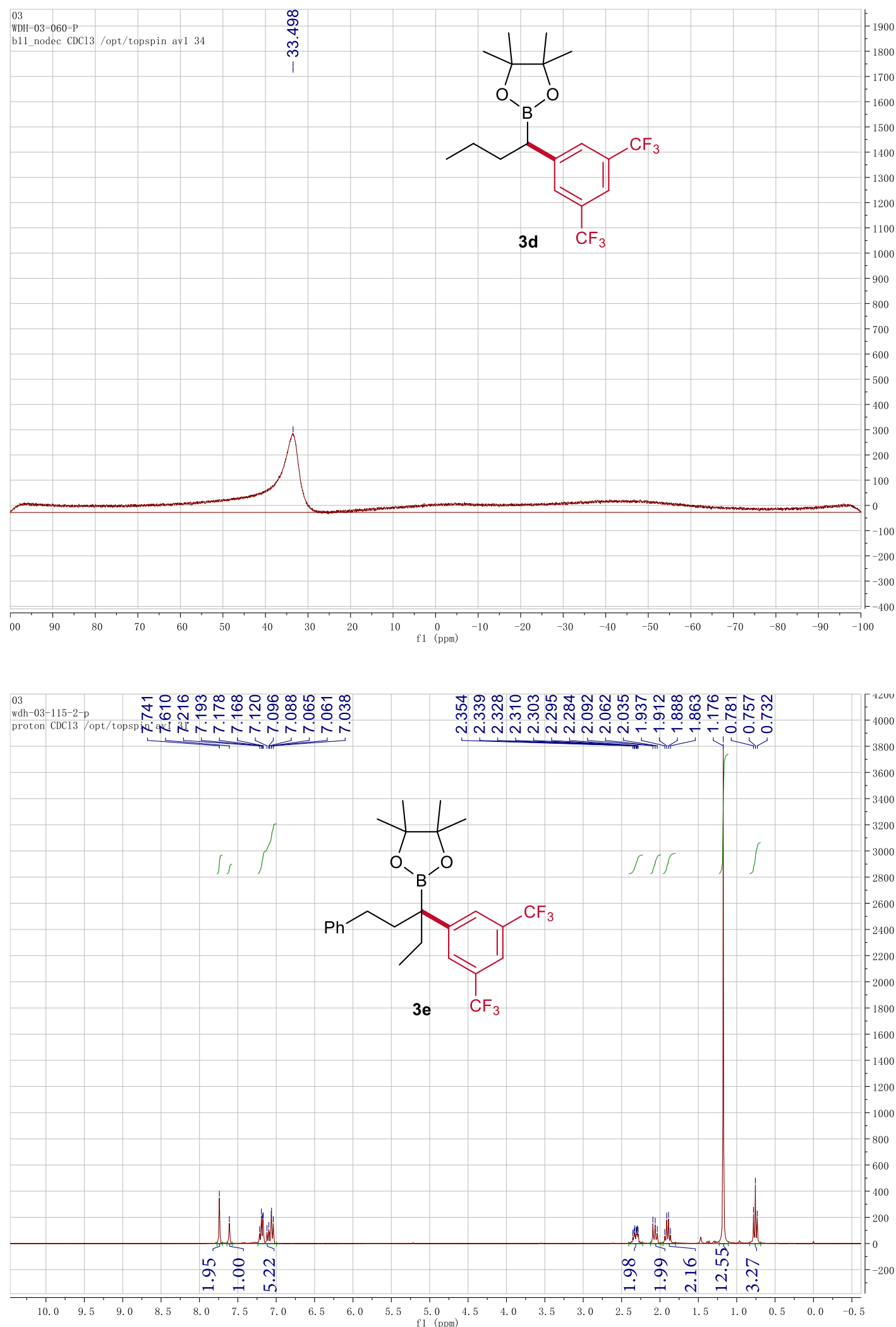

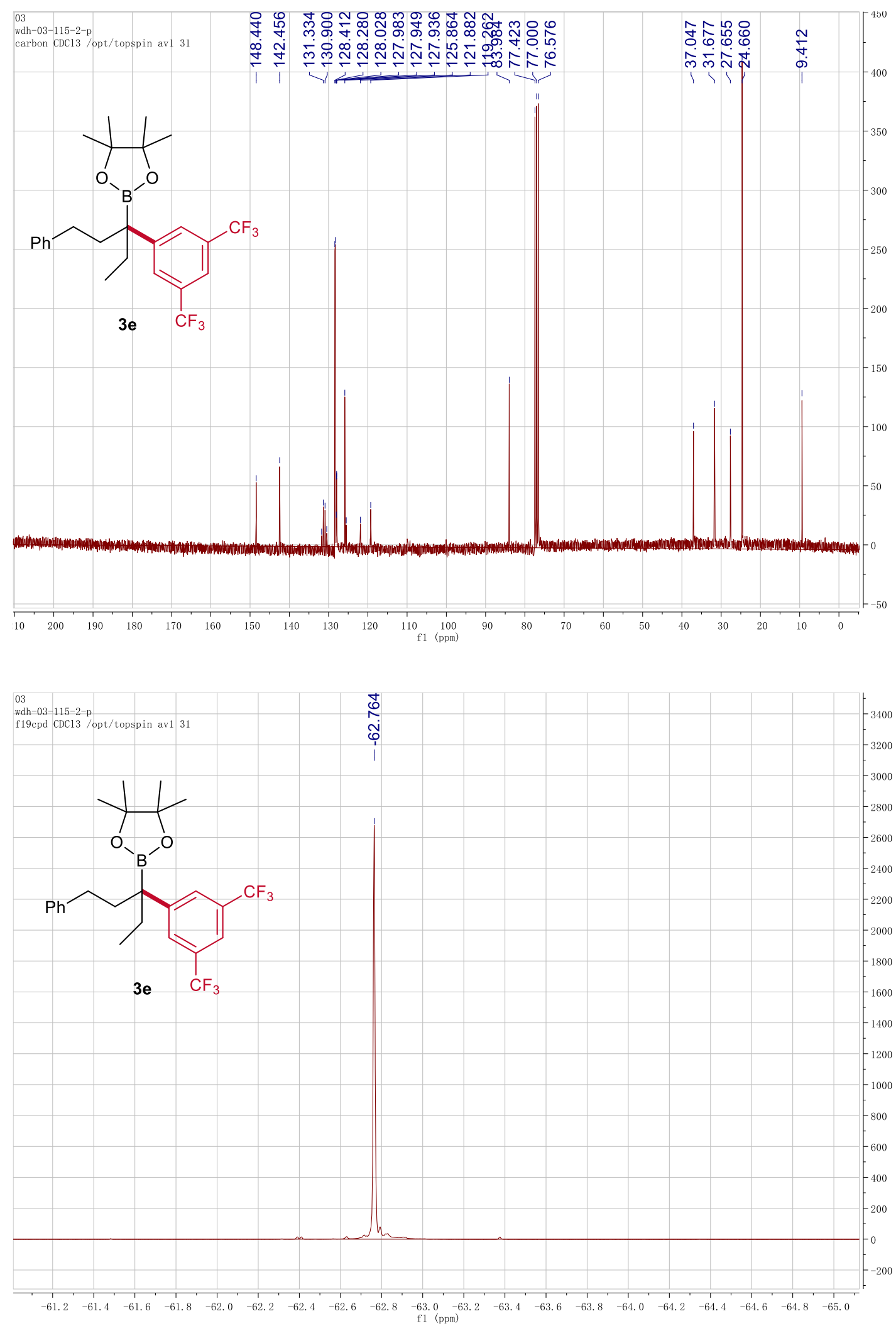

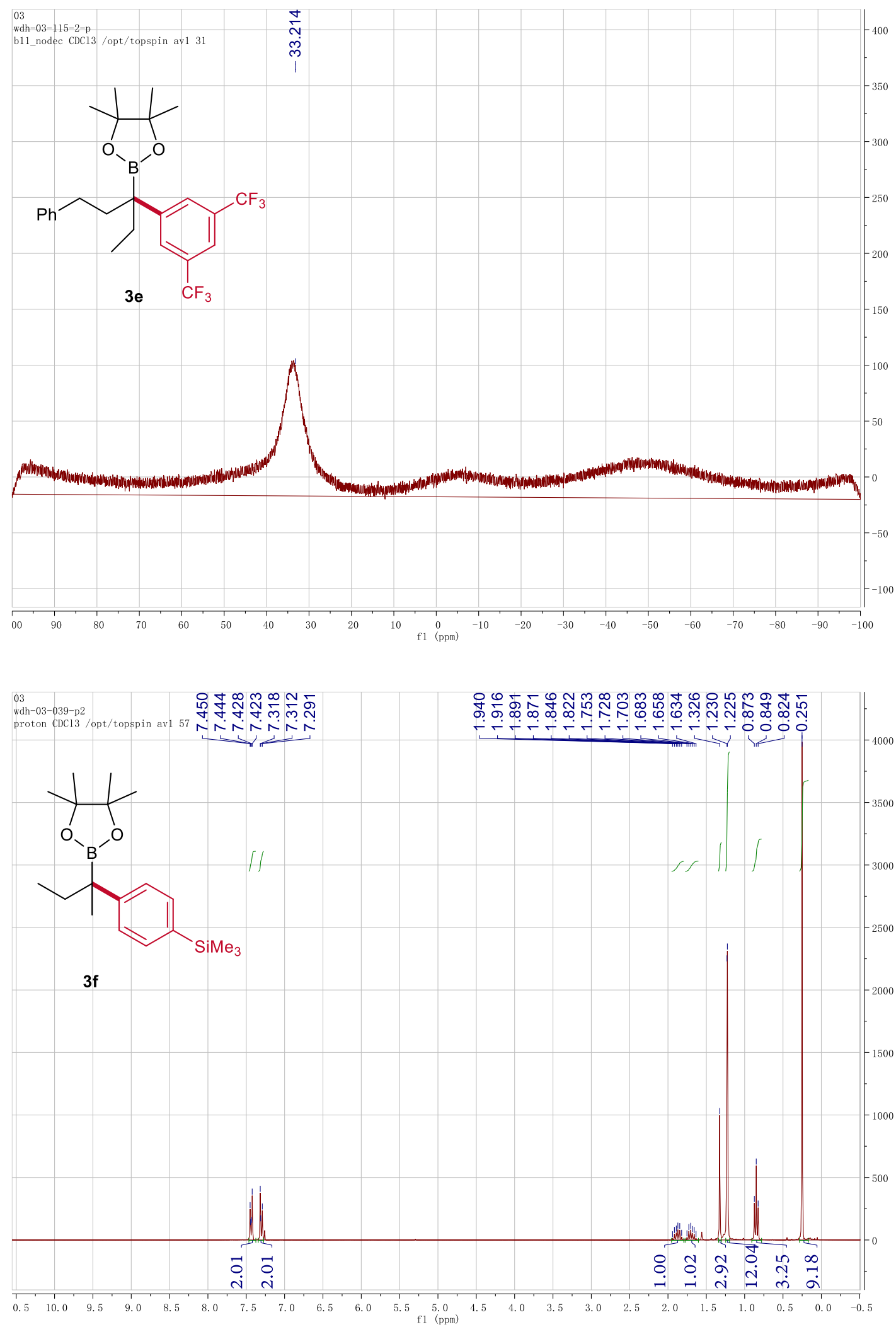

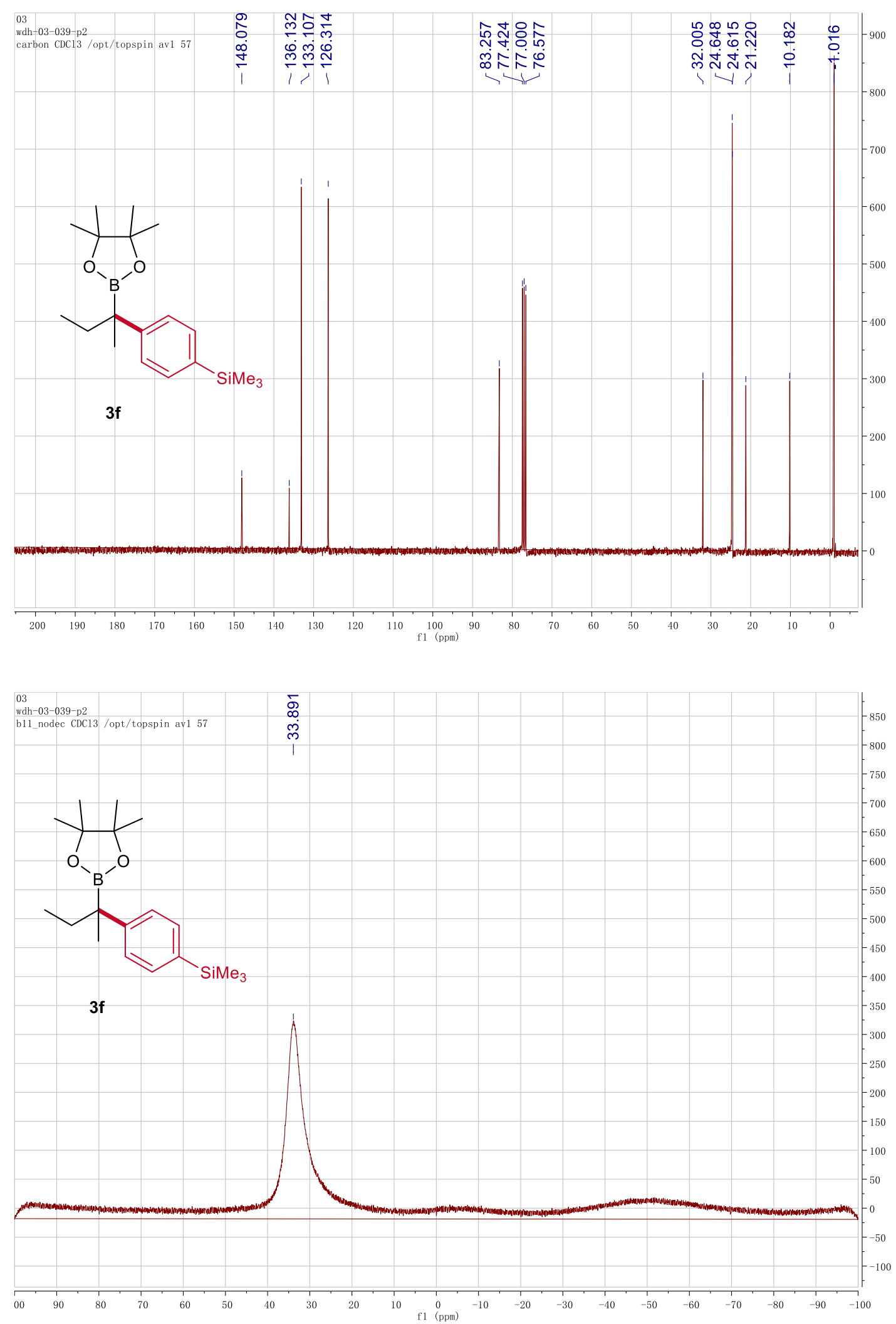

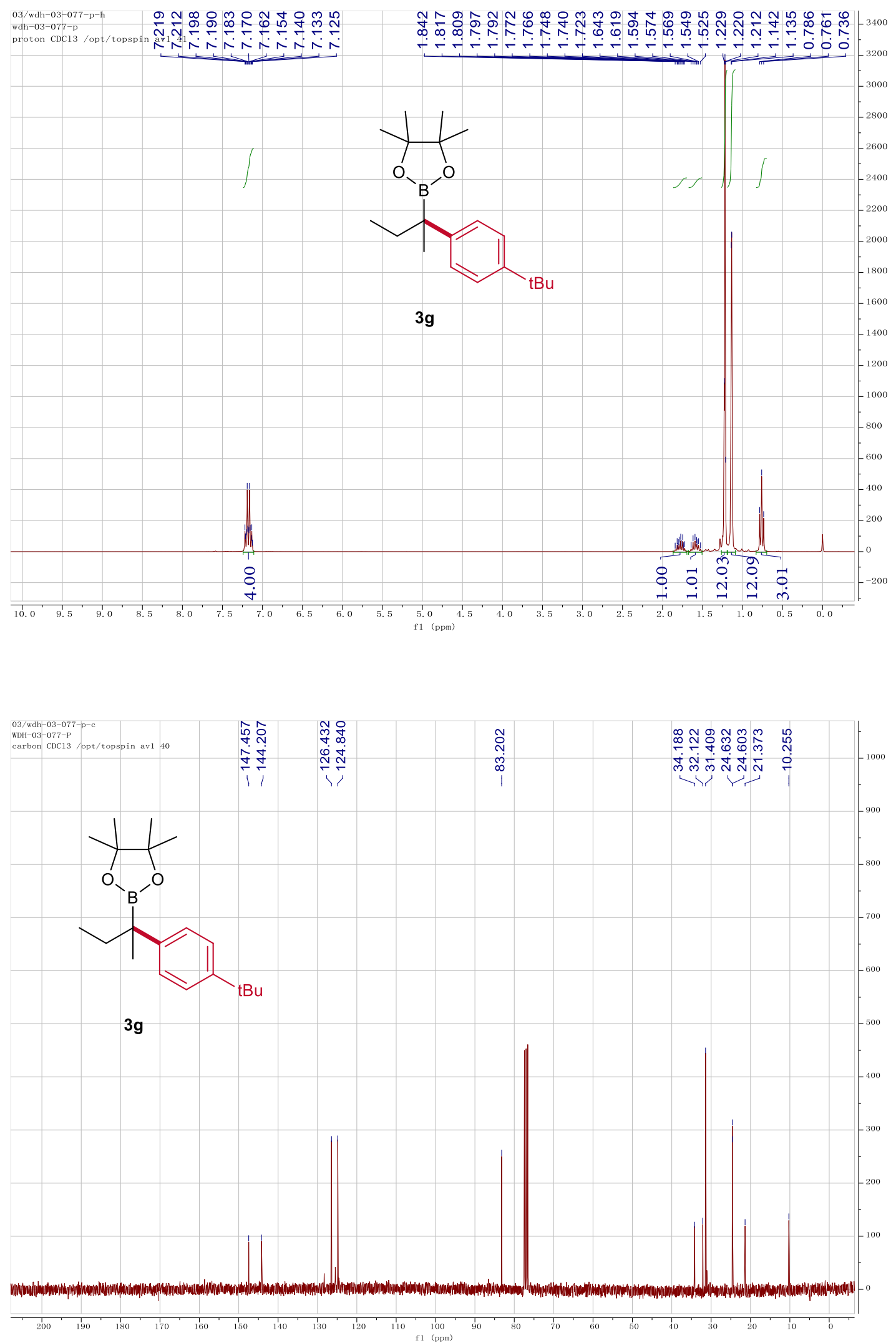

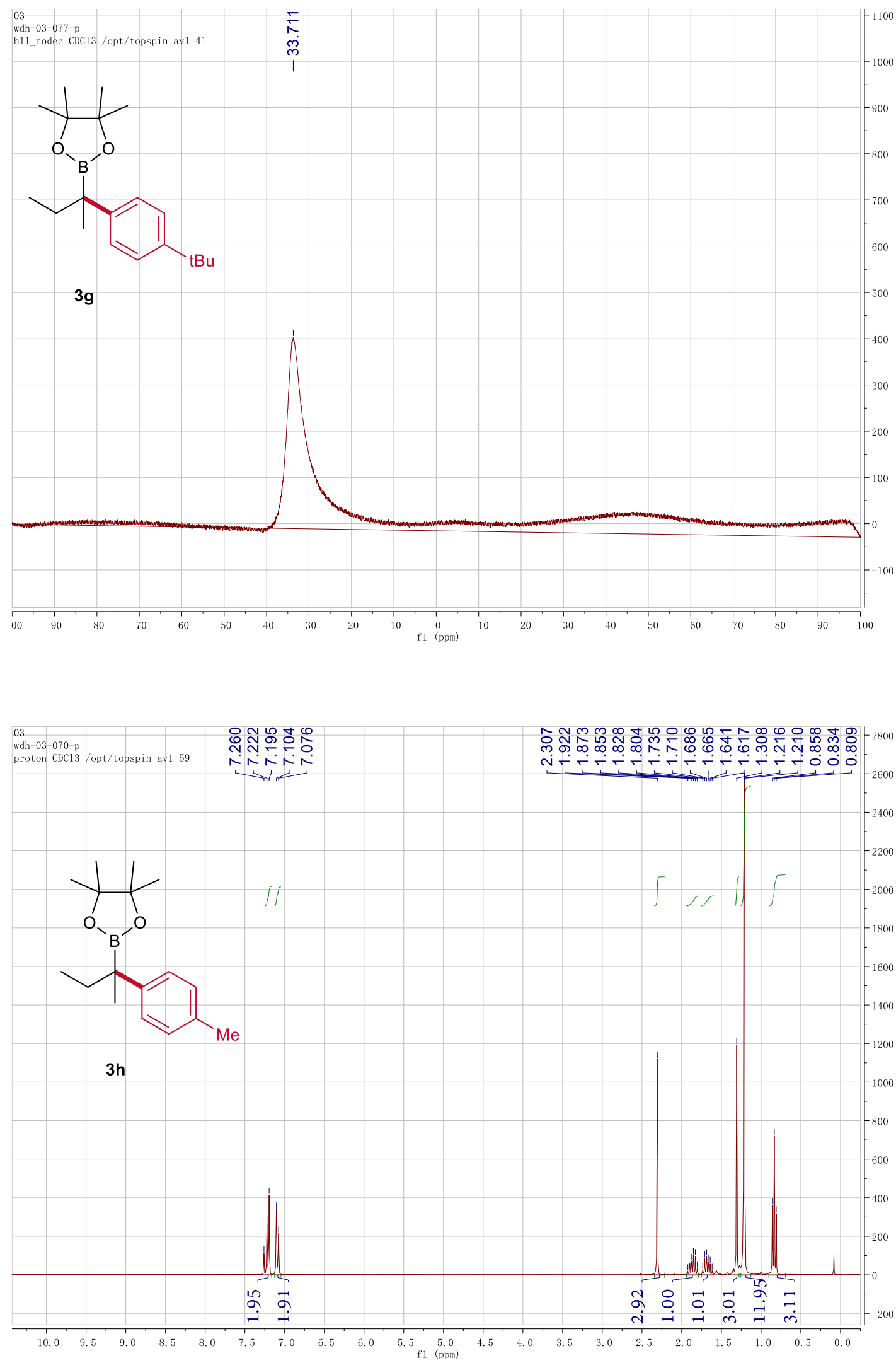

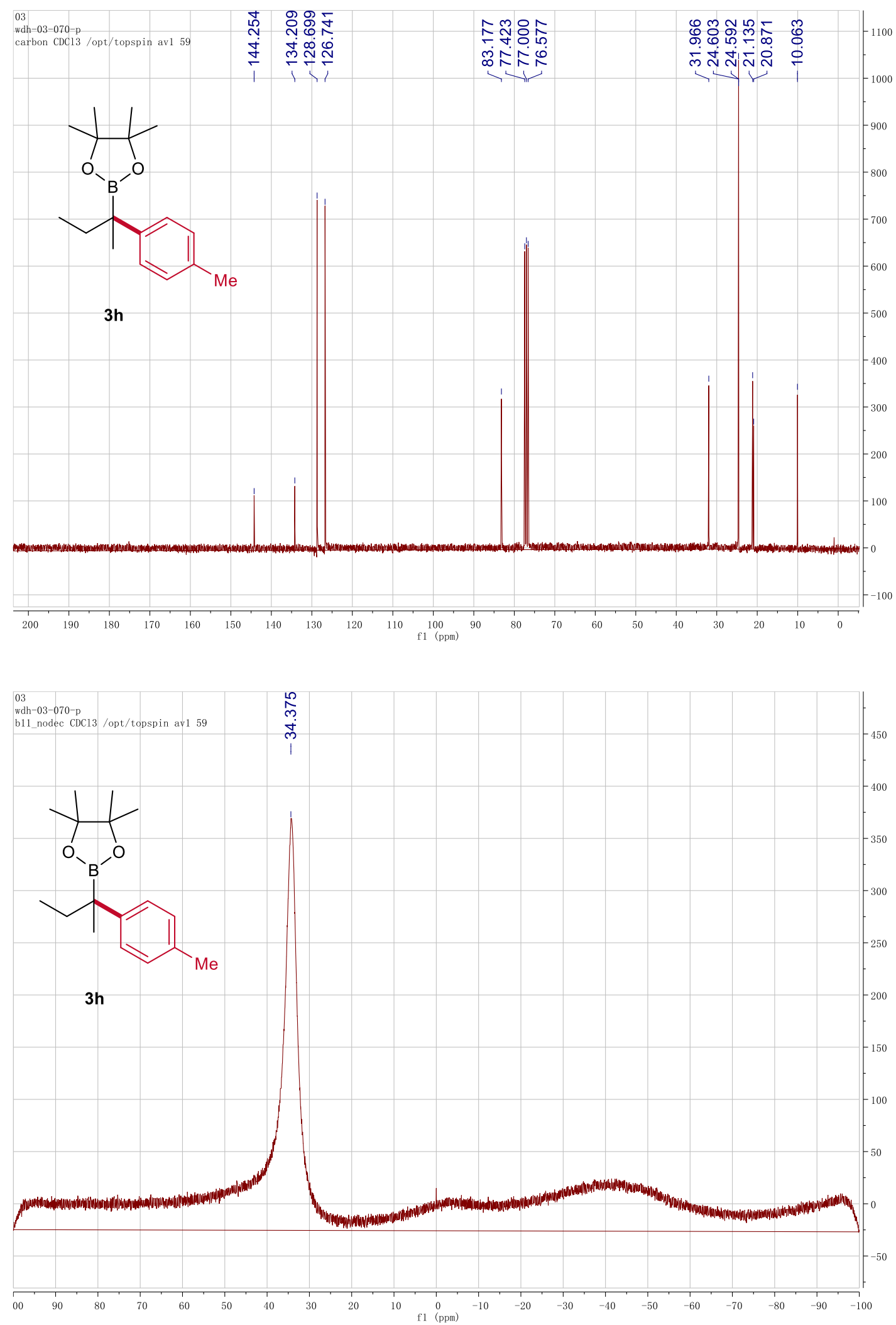


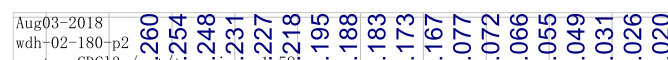

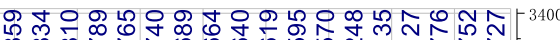

.

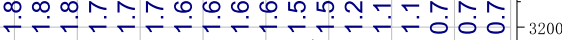
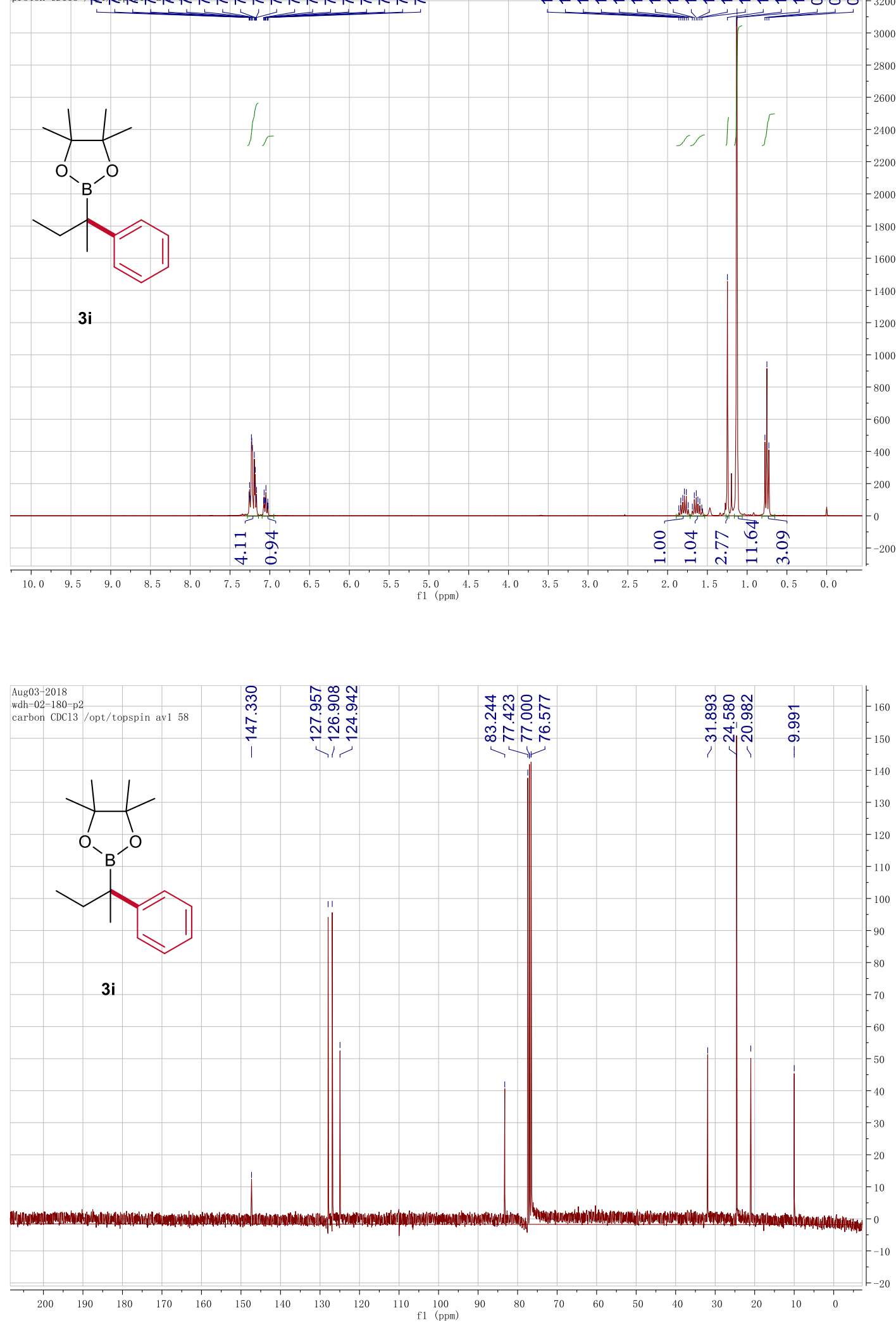

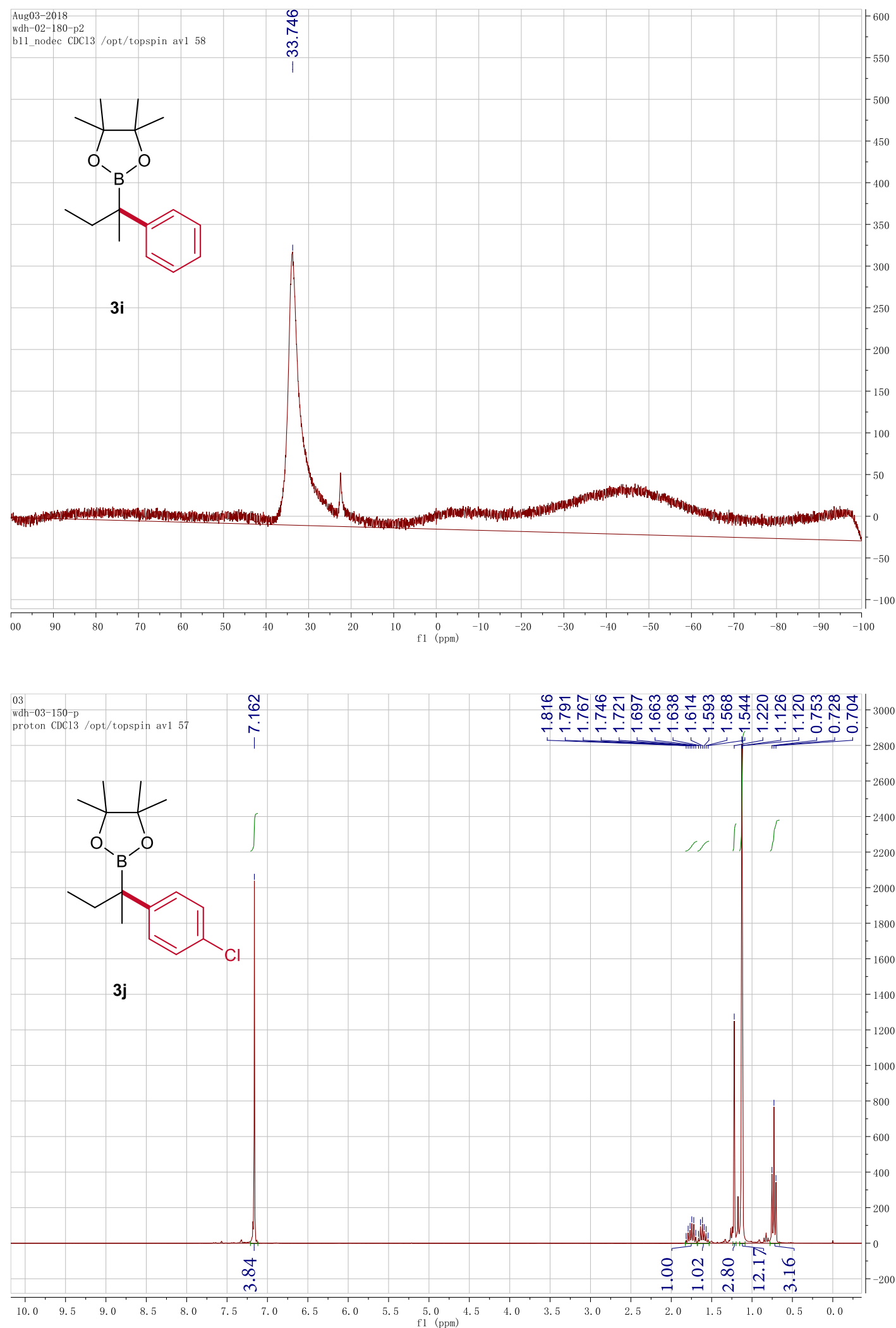

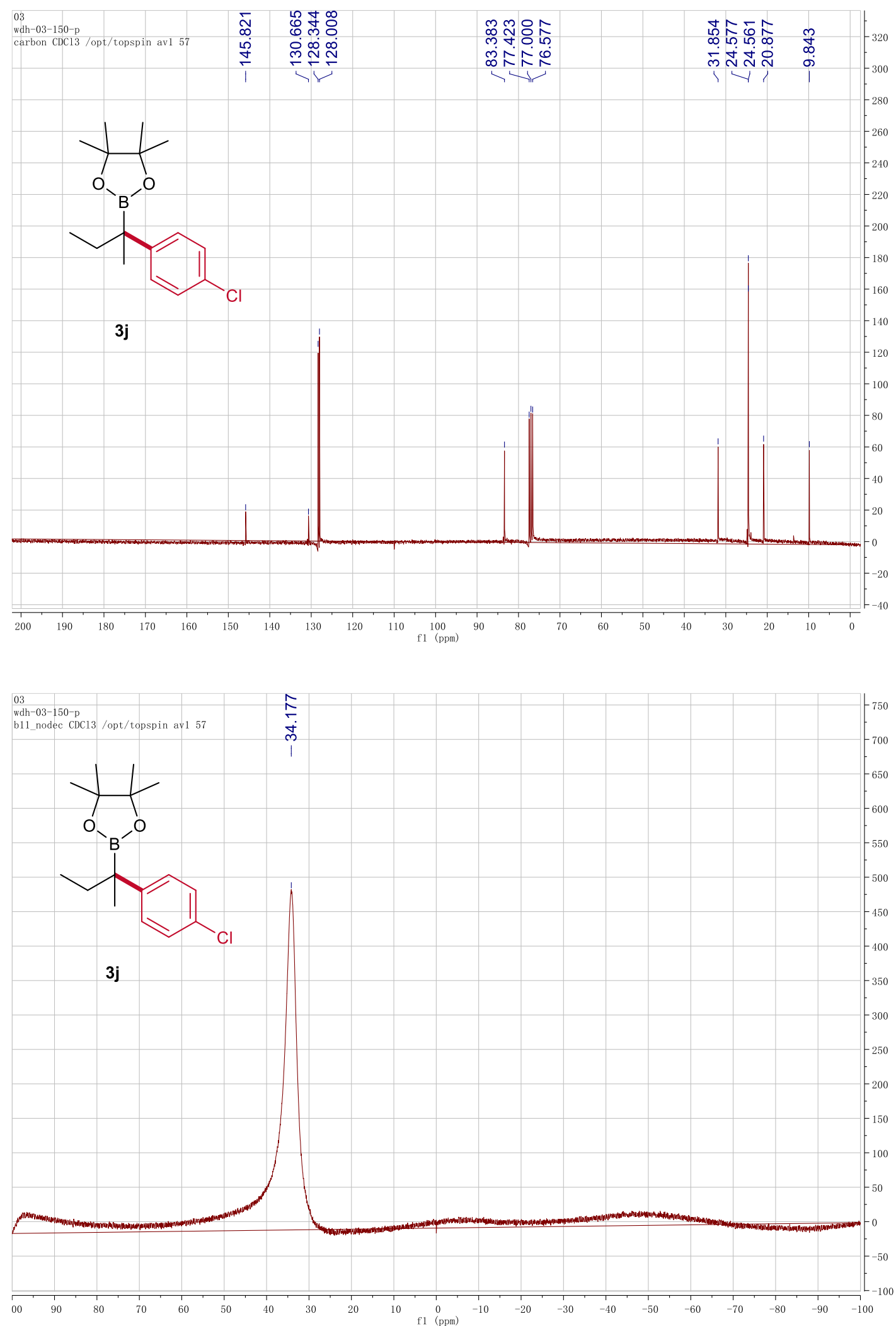

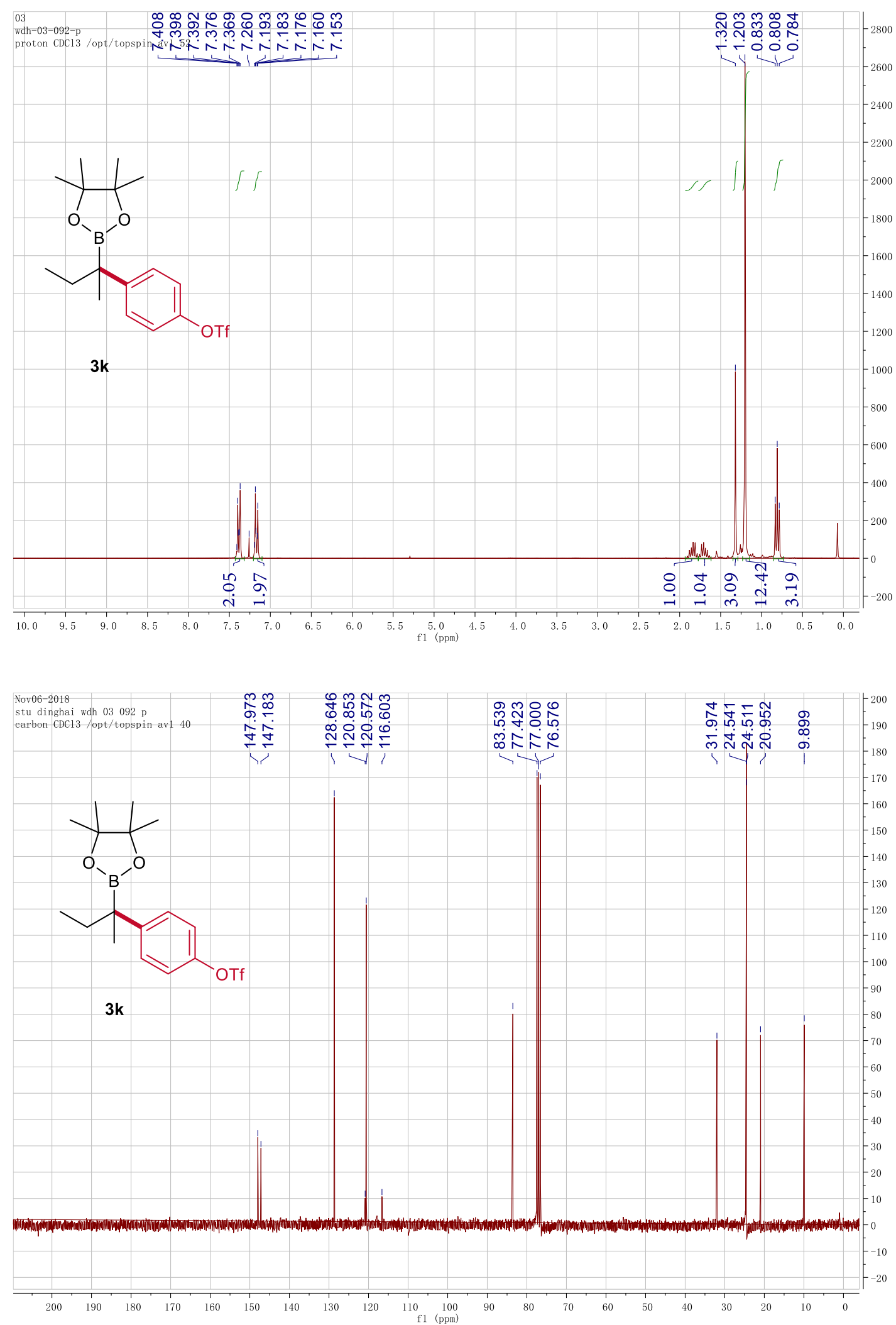

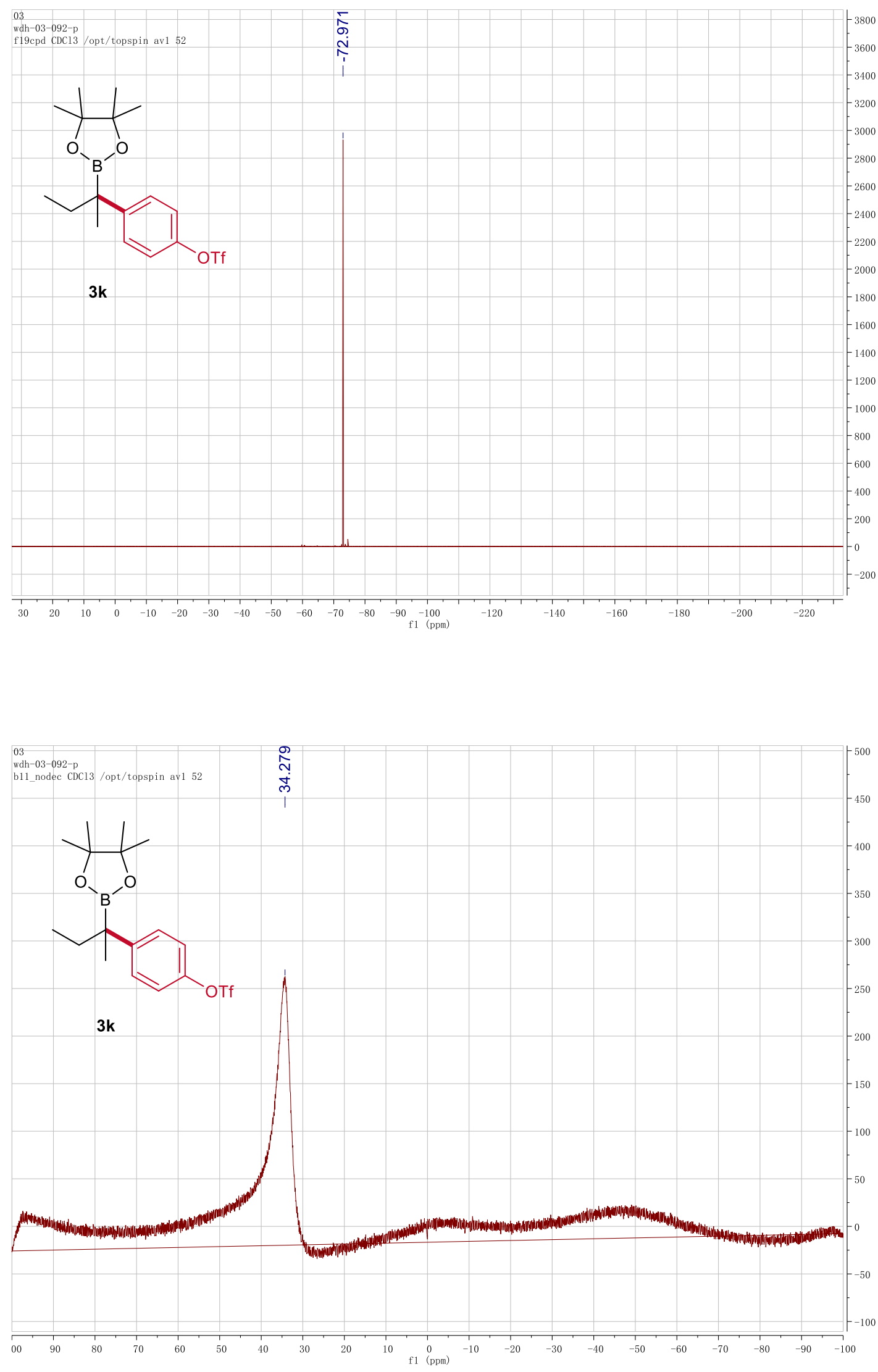

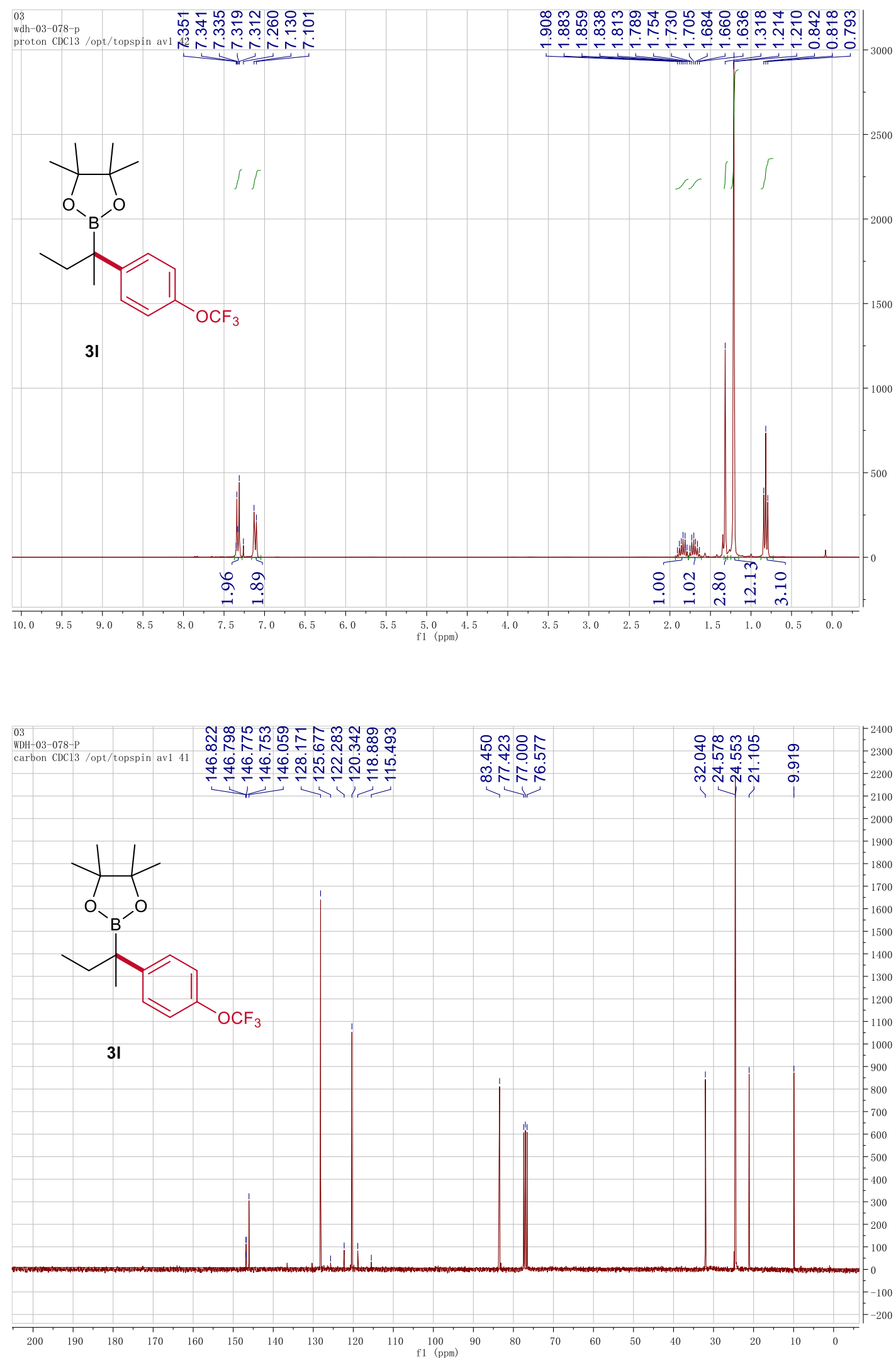

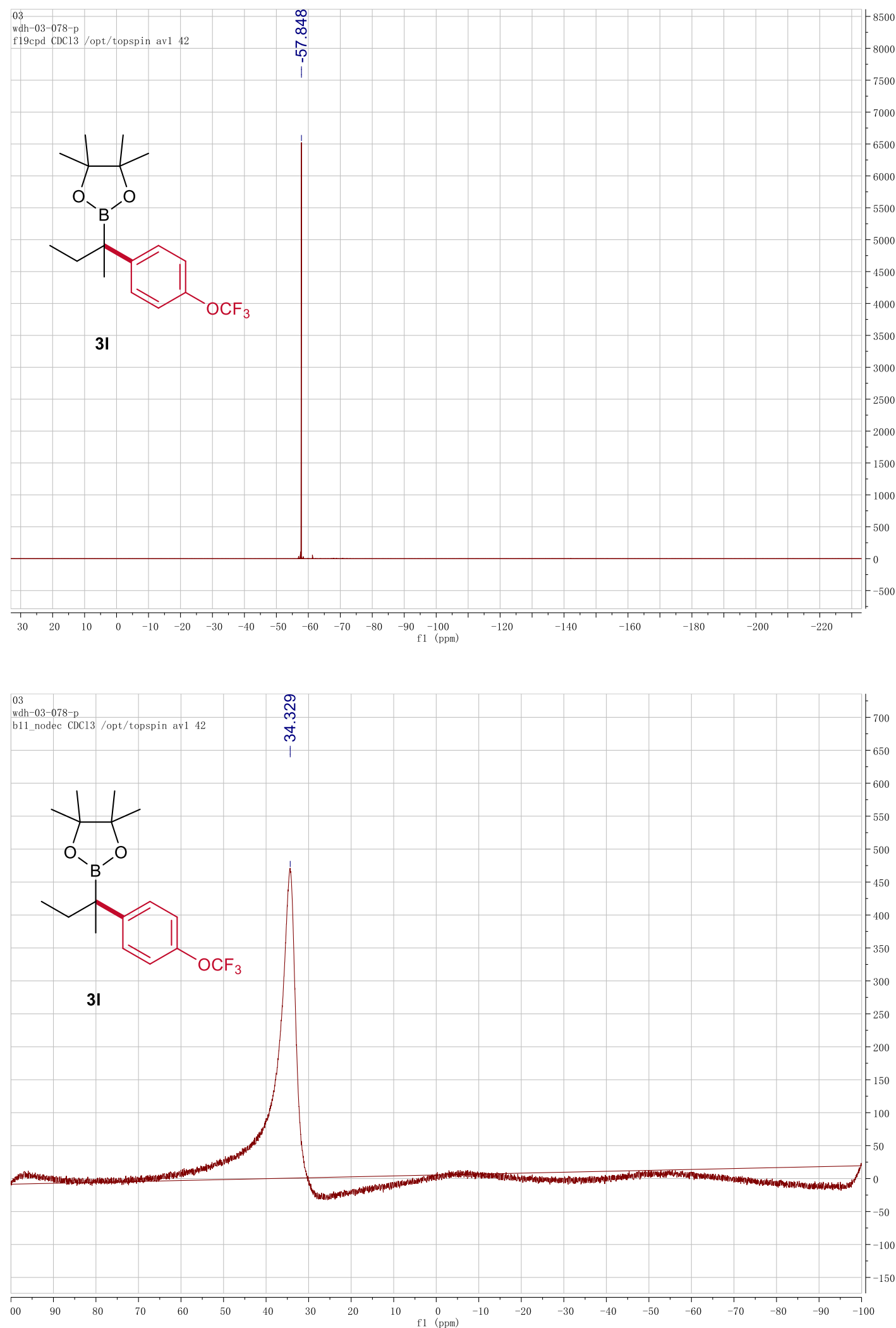

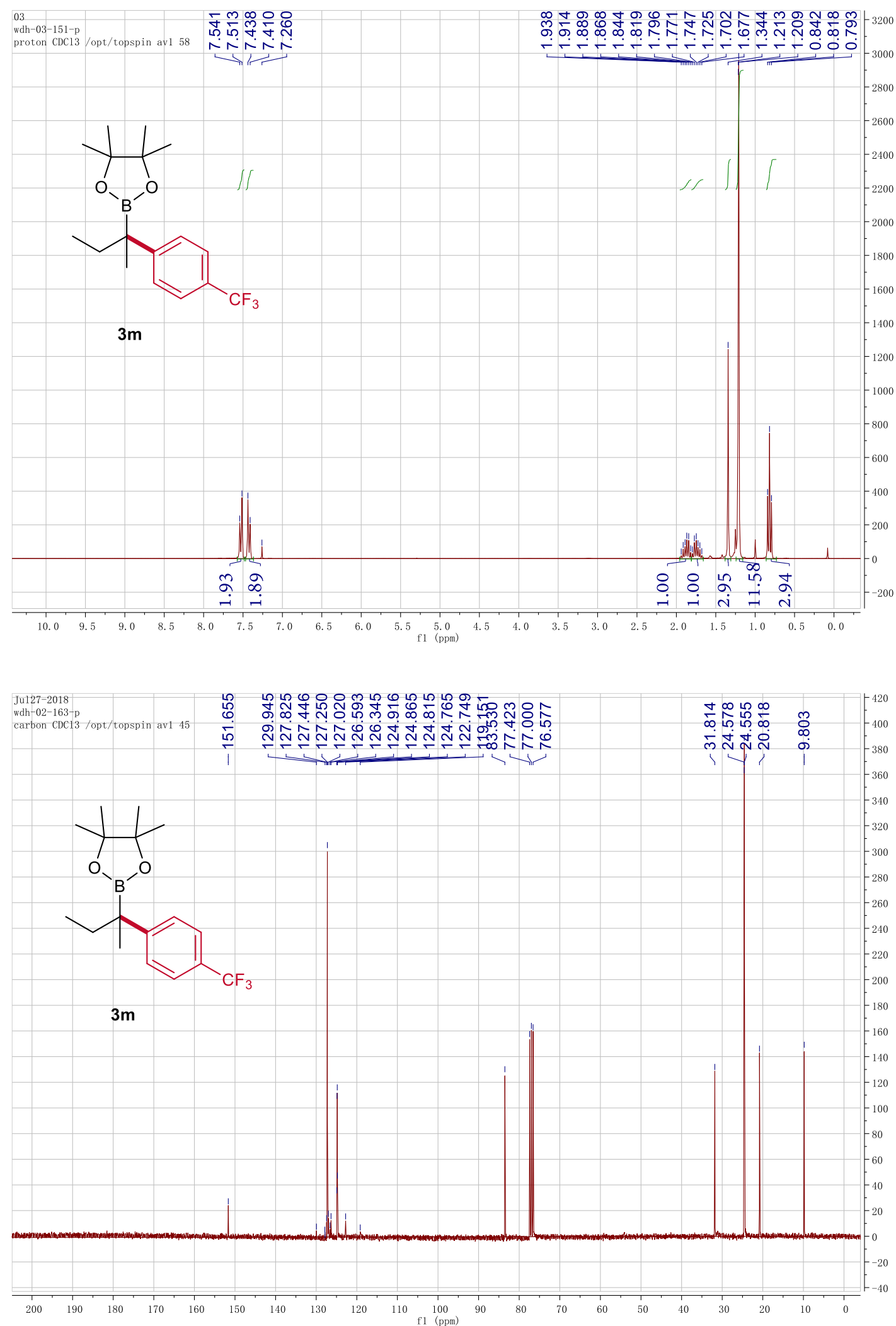

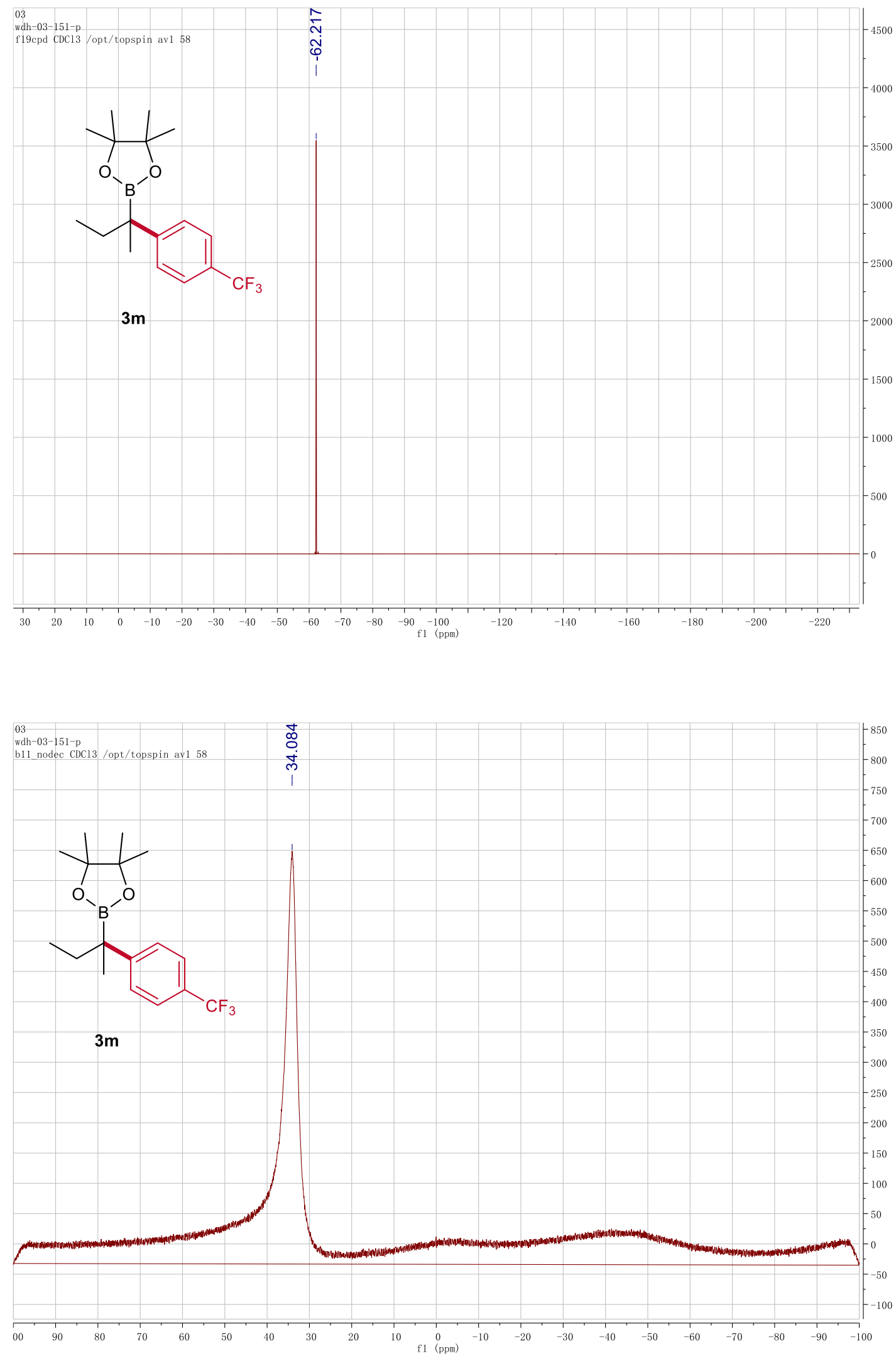

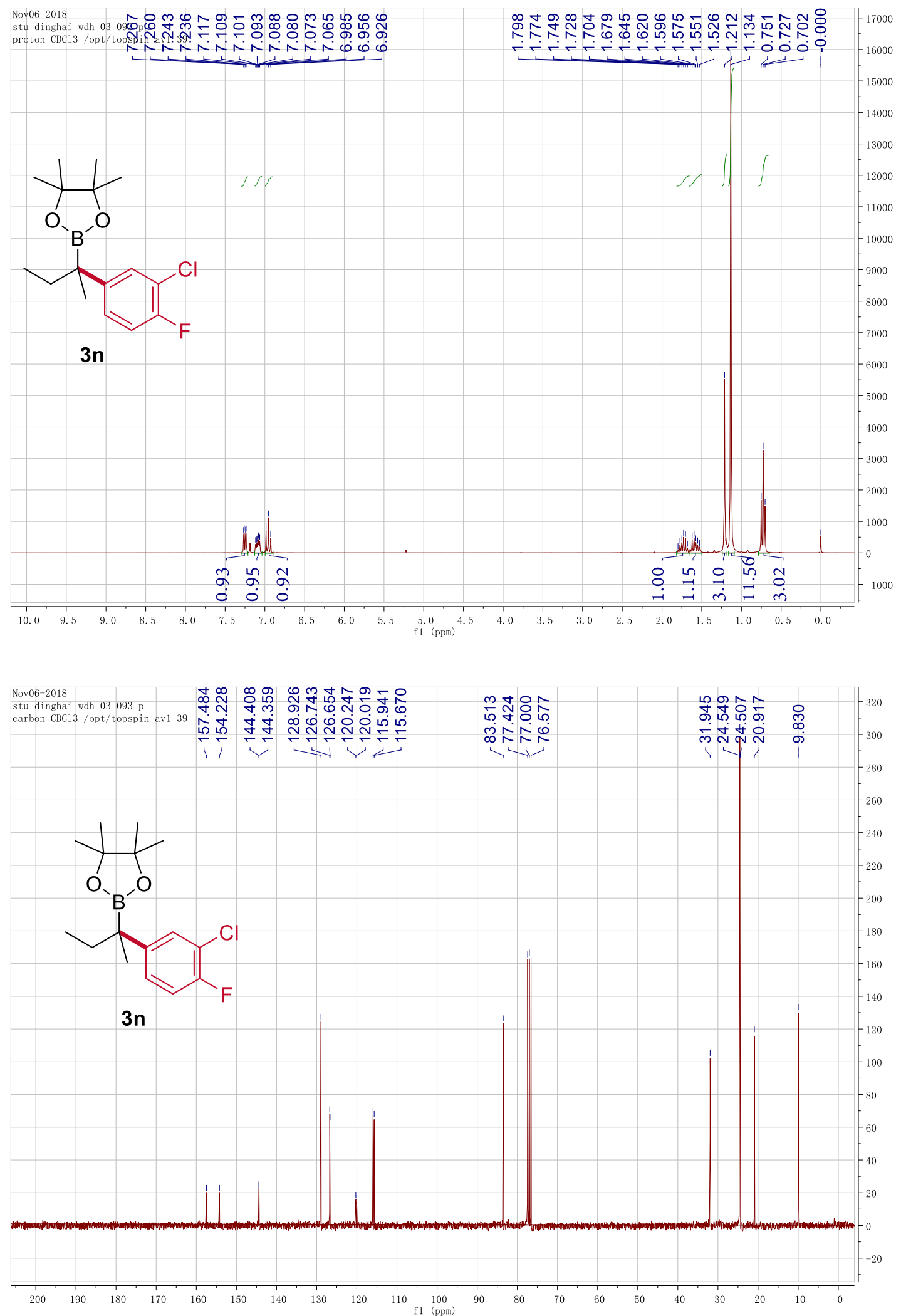


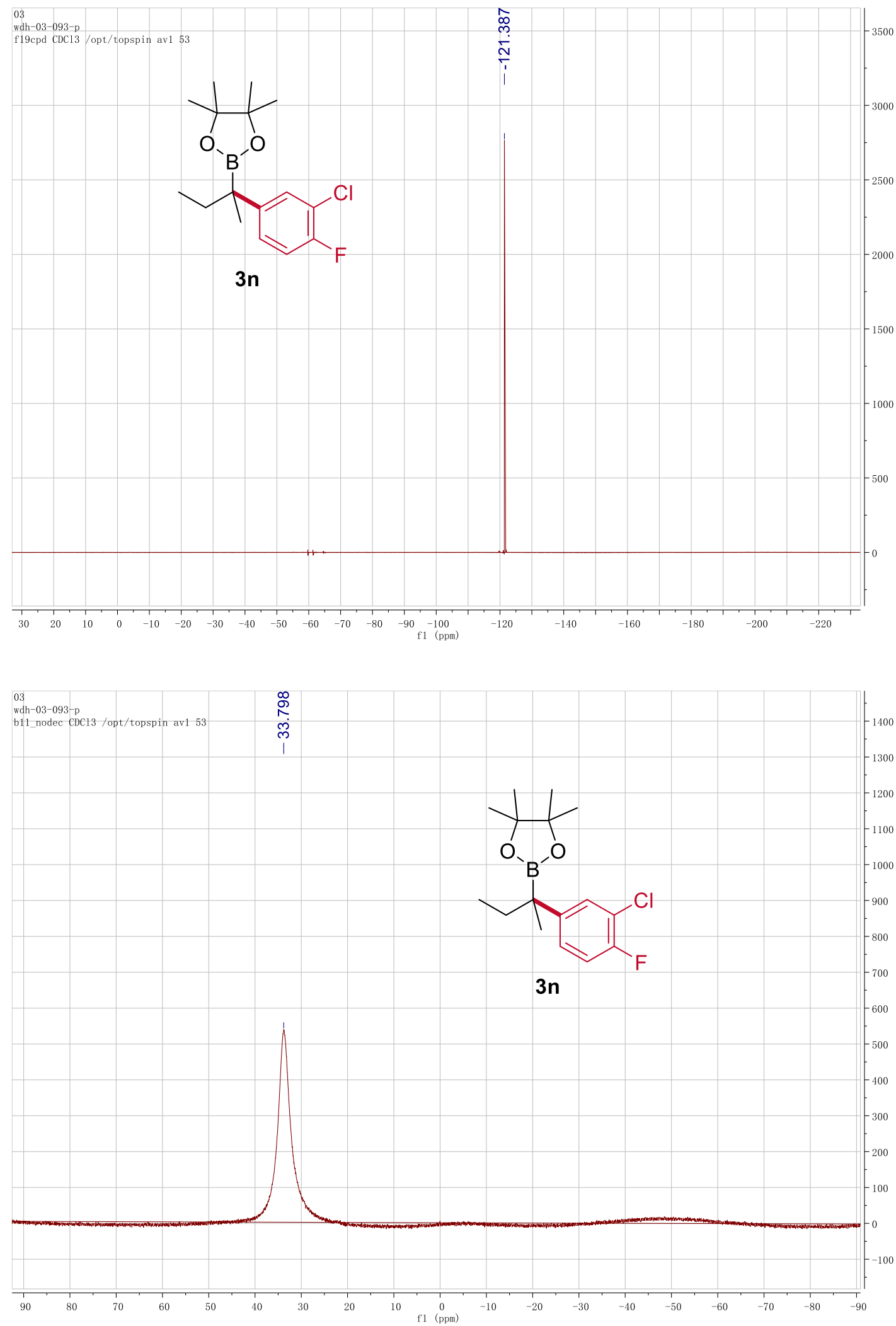



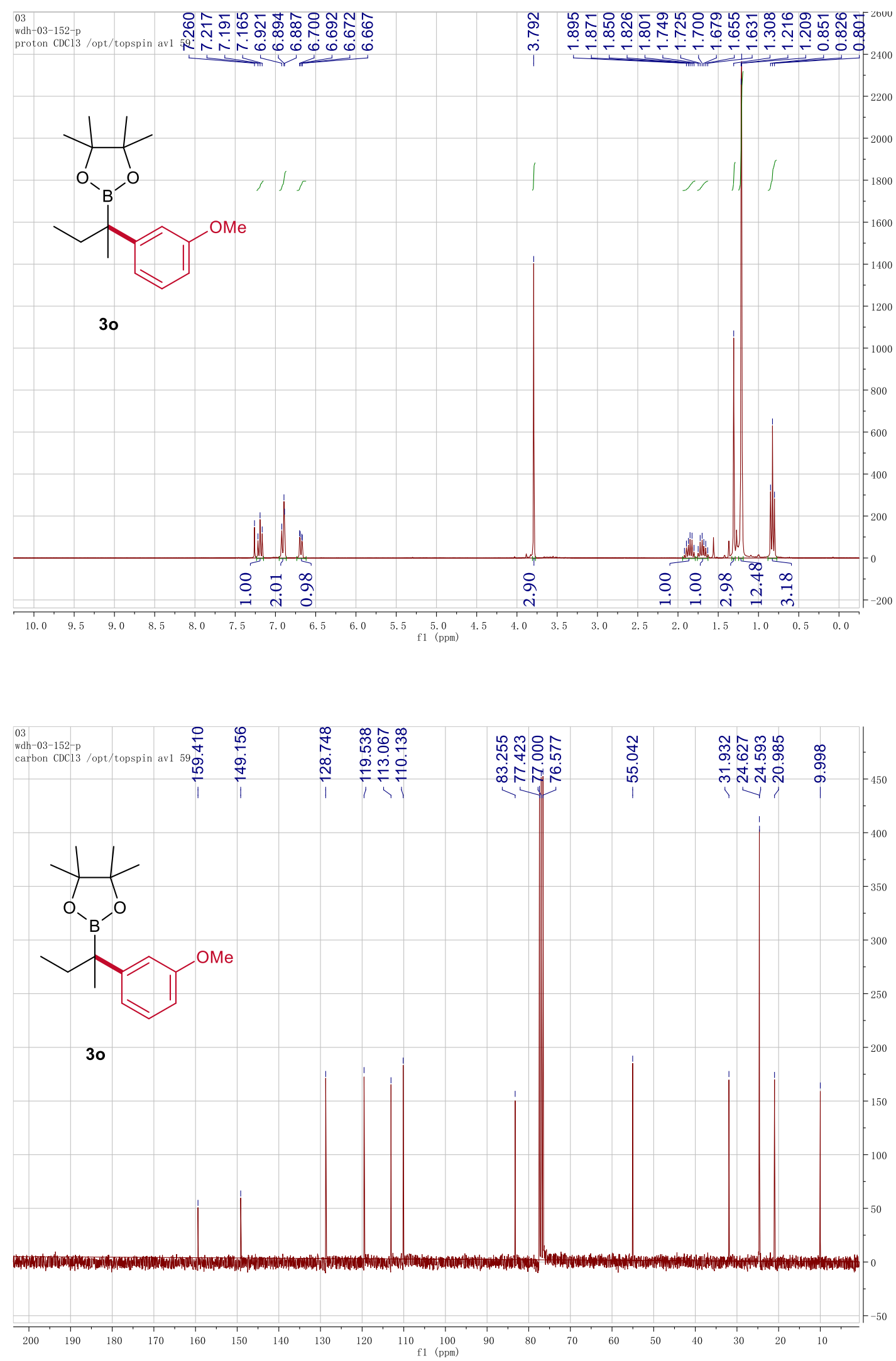

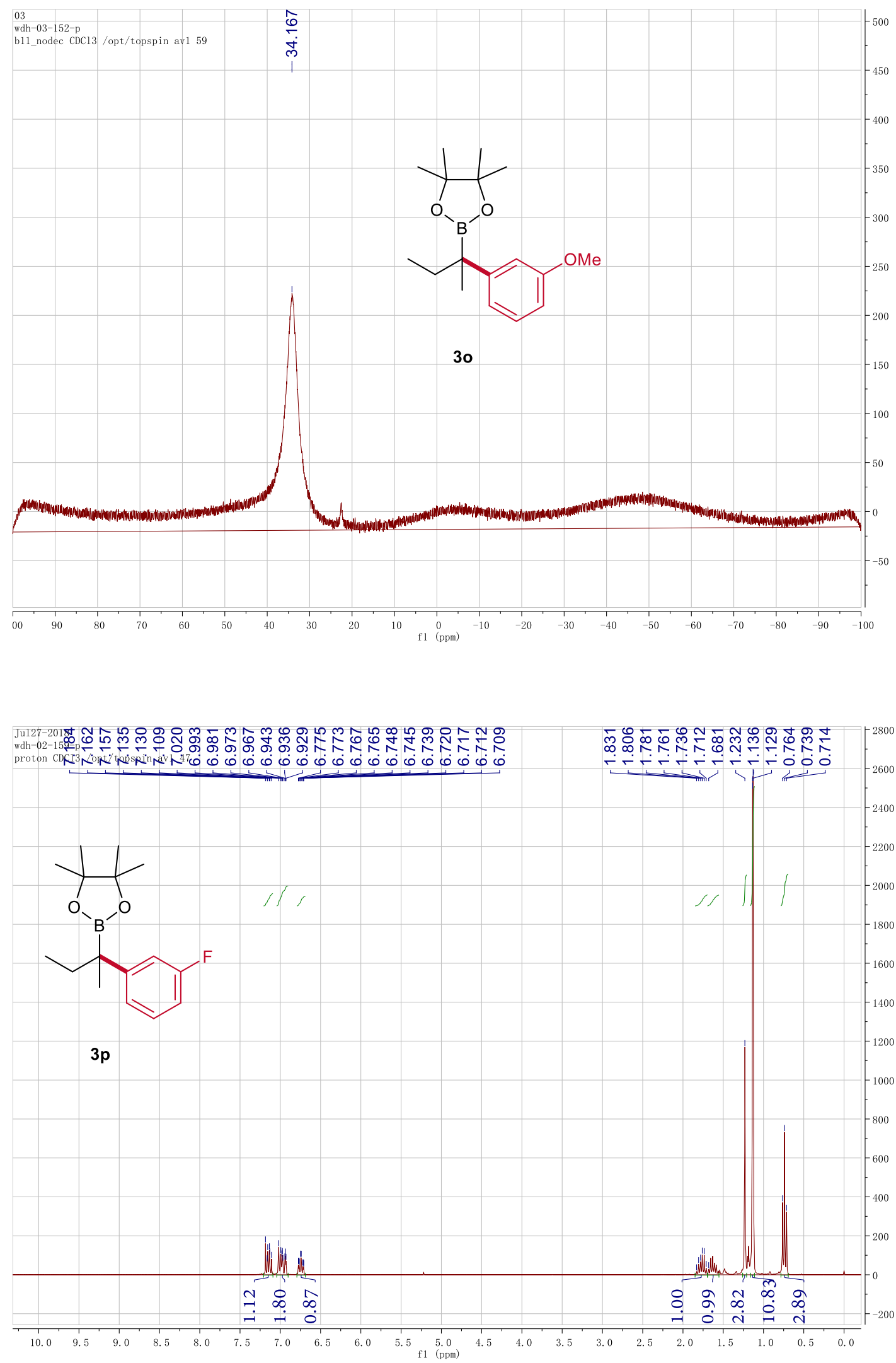

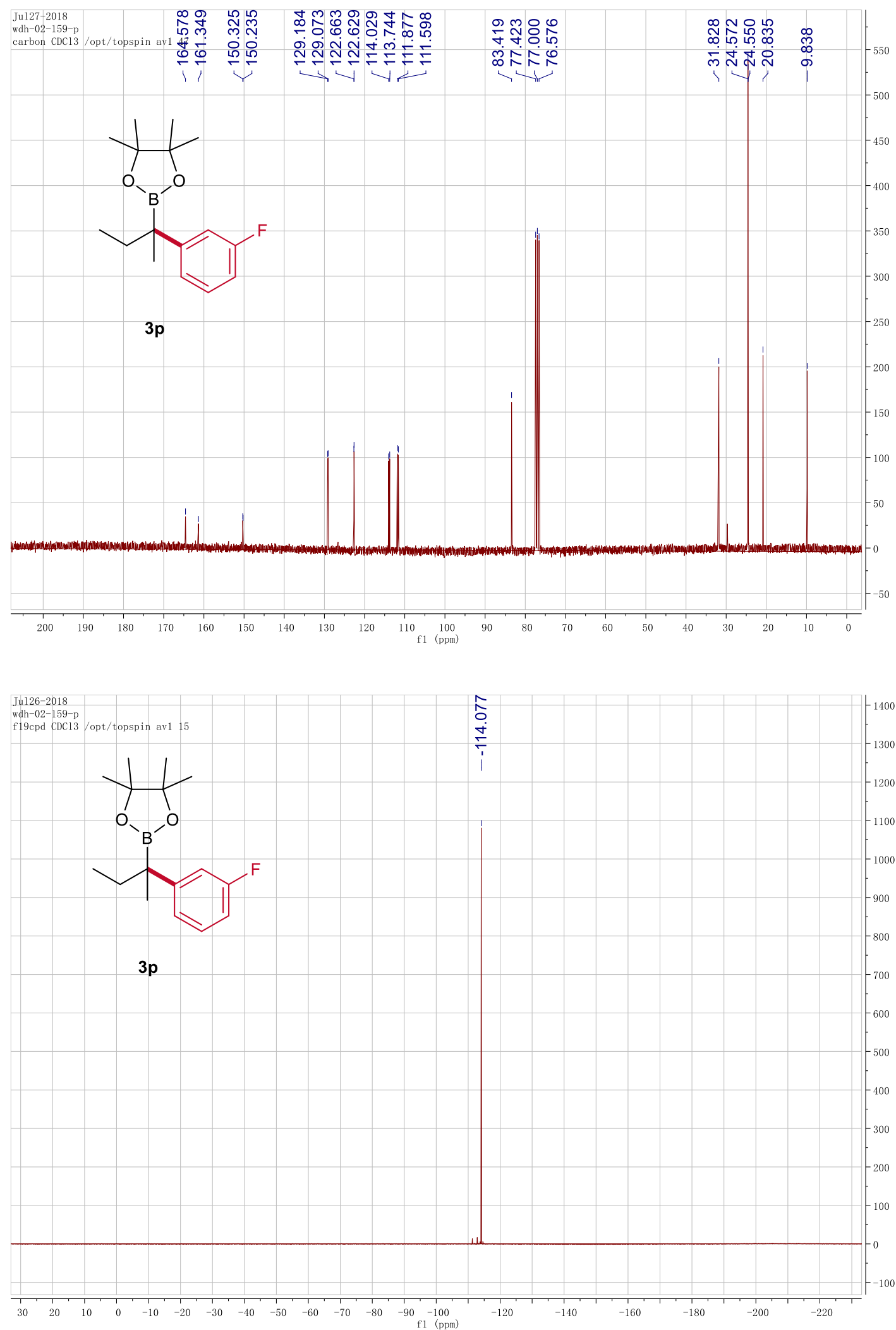

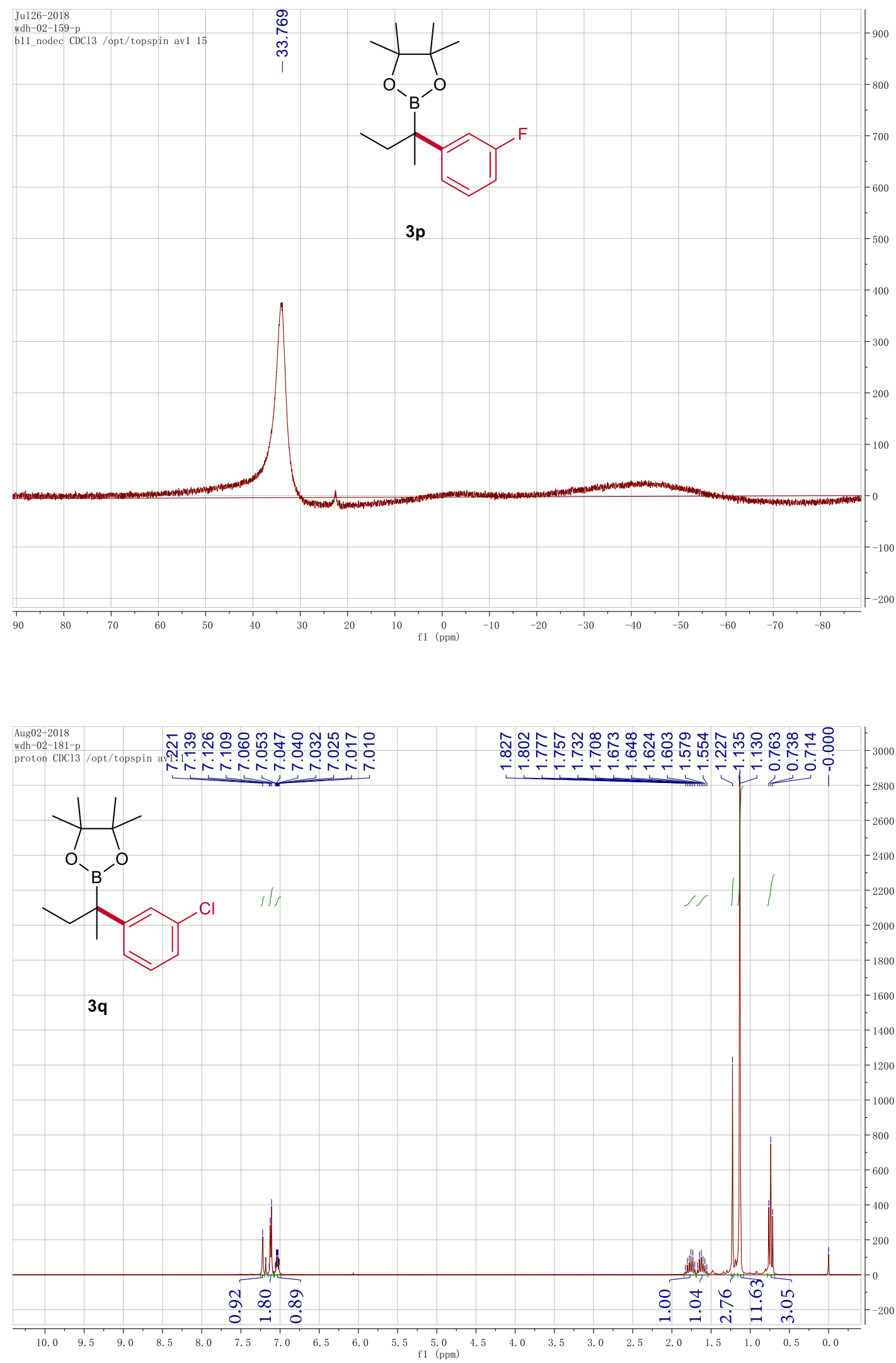

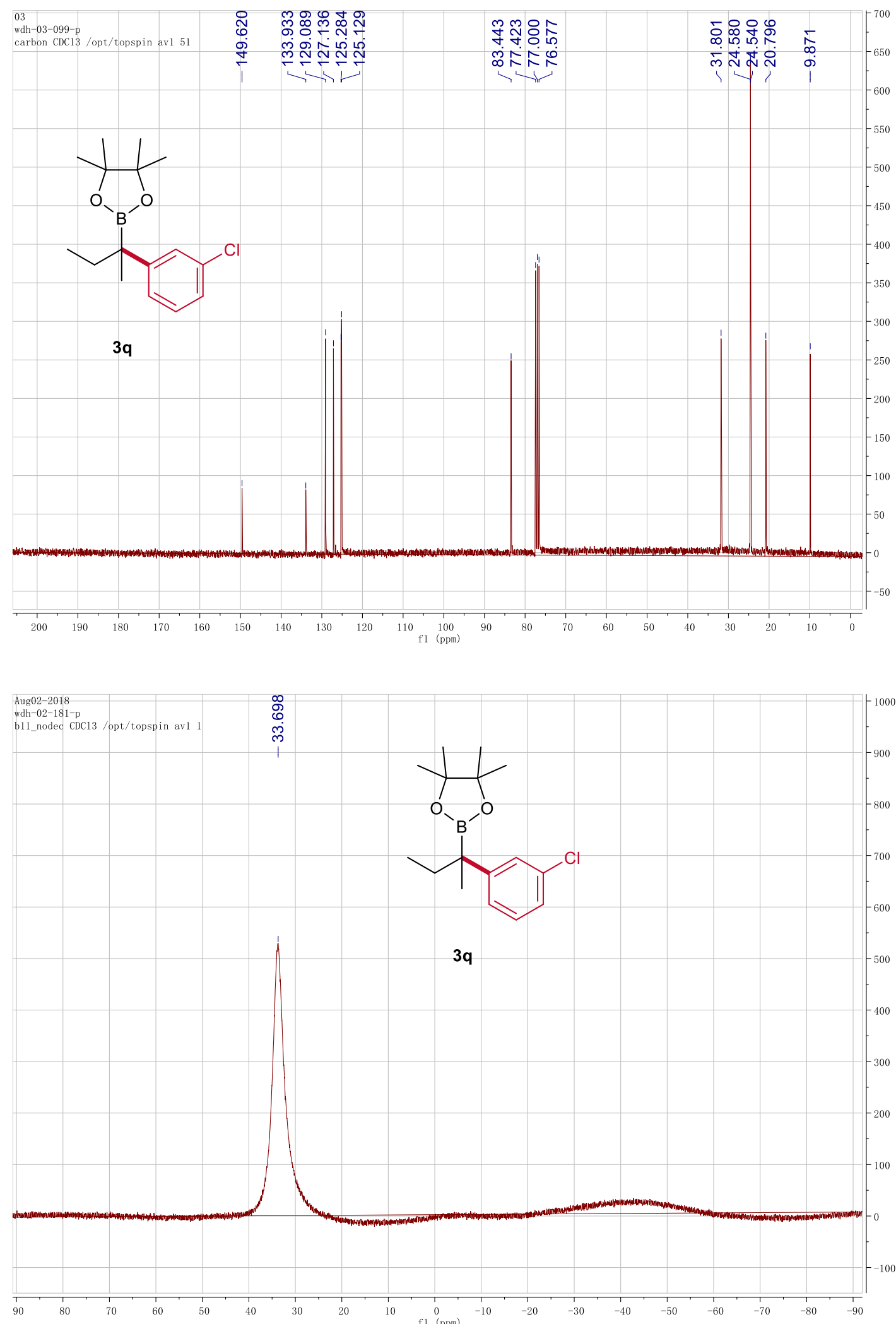


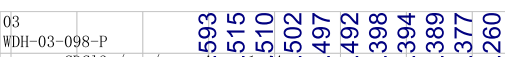

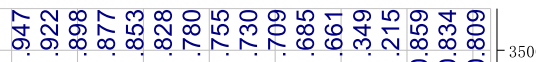

(1)

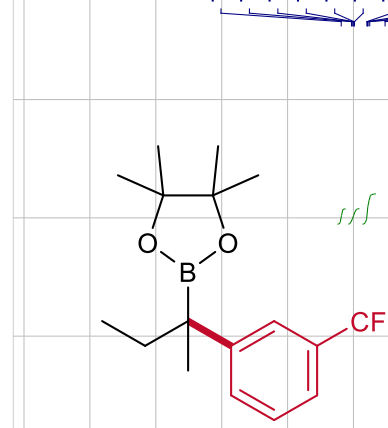

$3 r$
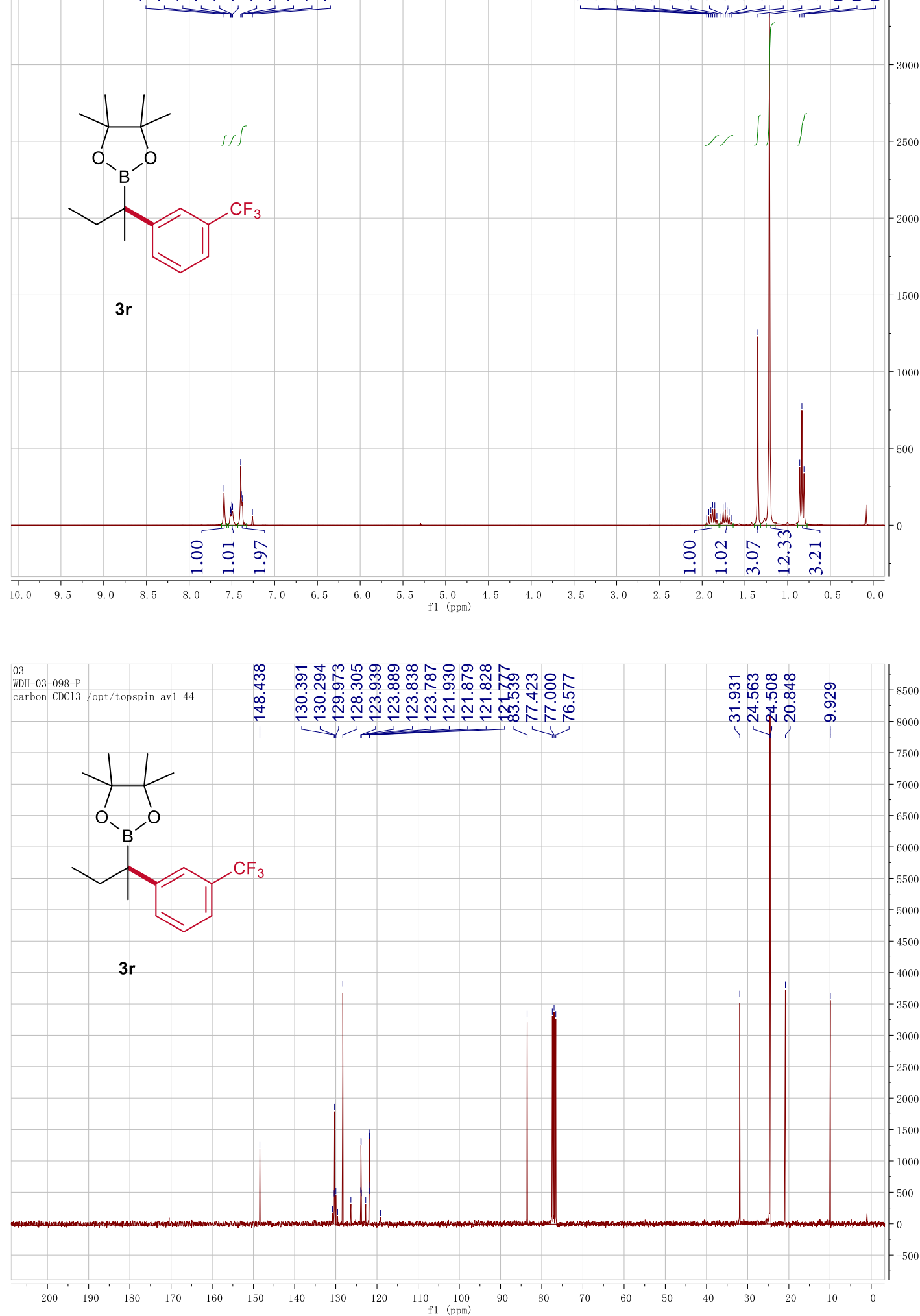

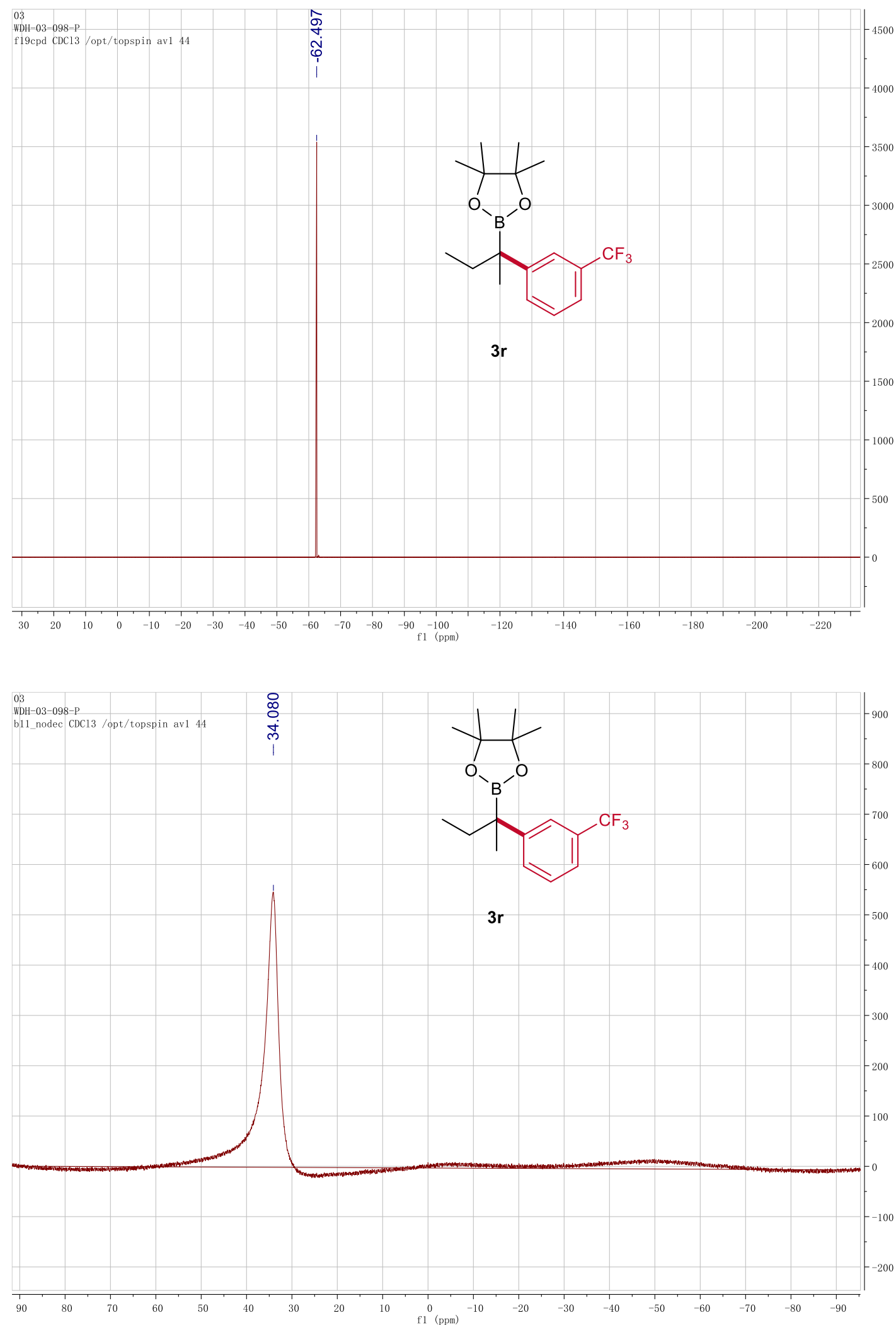

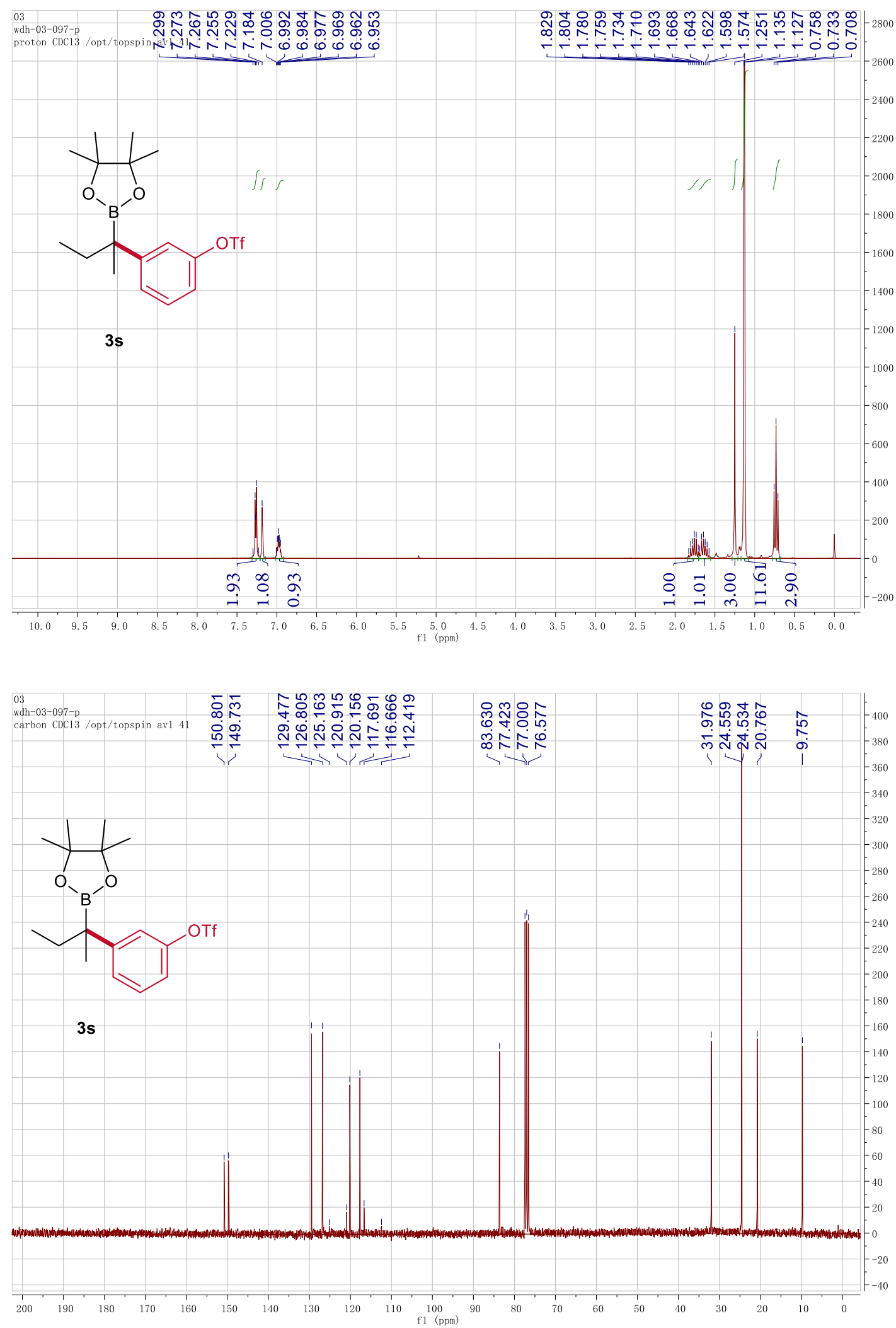

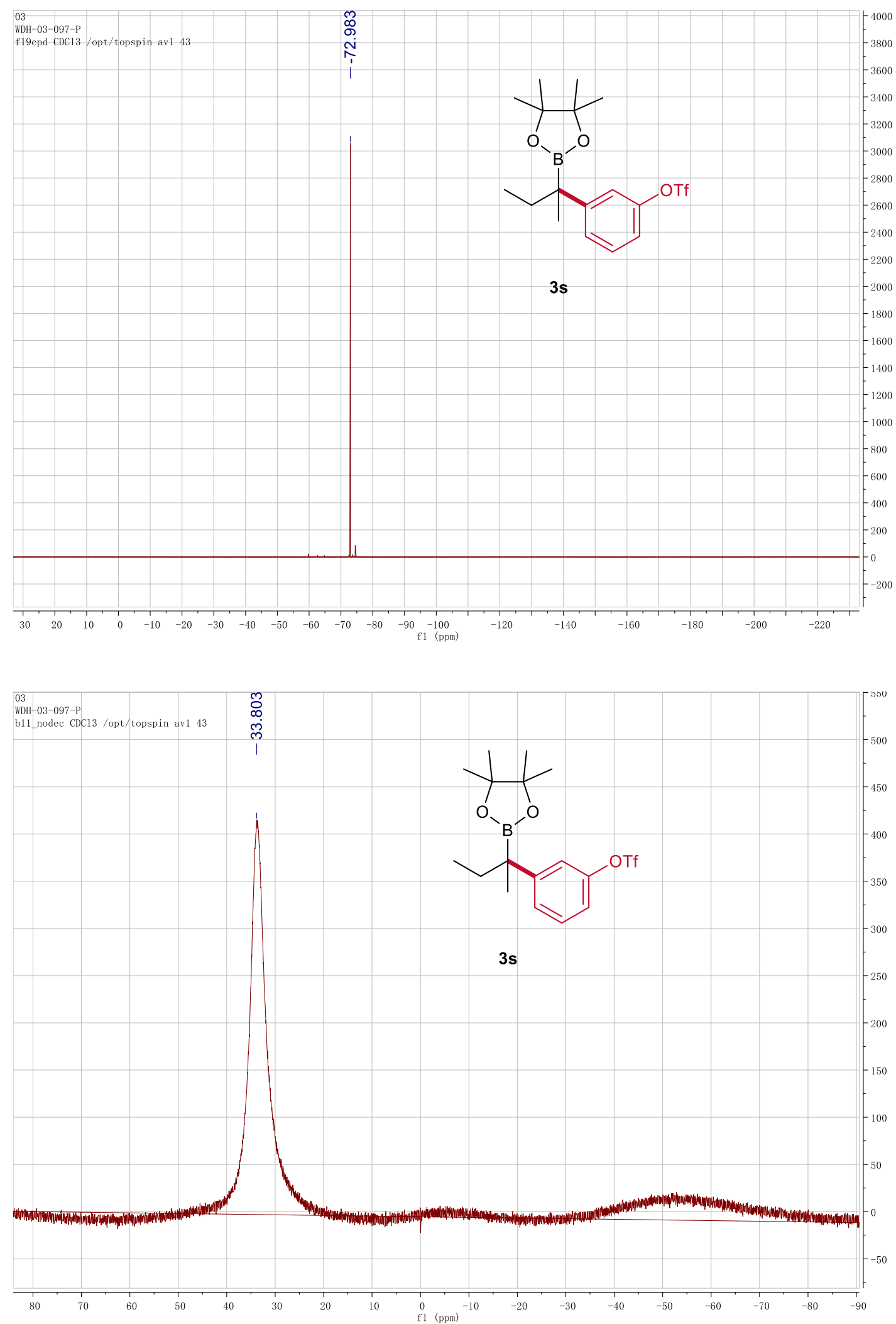

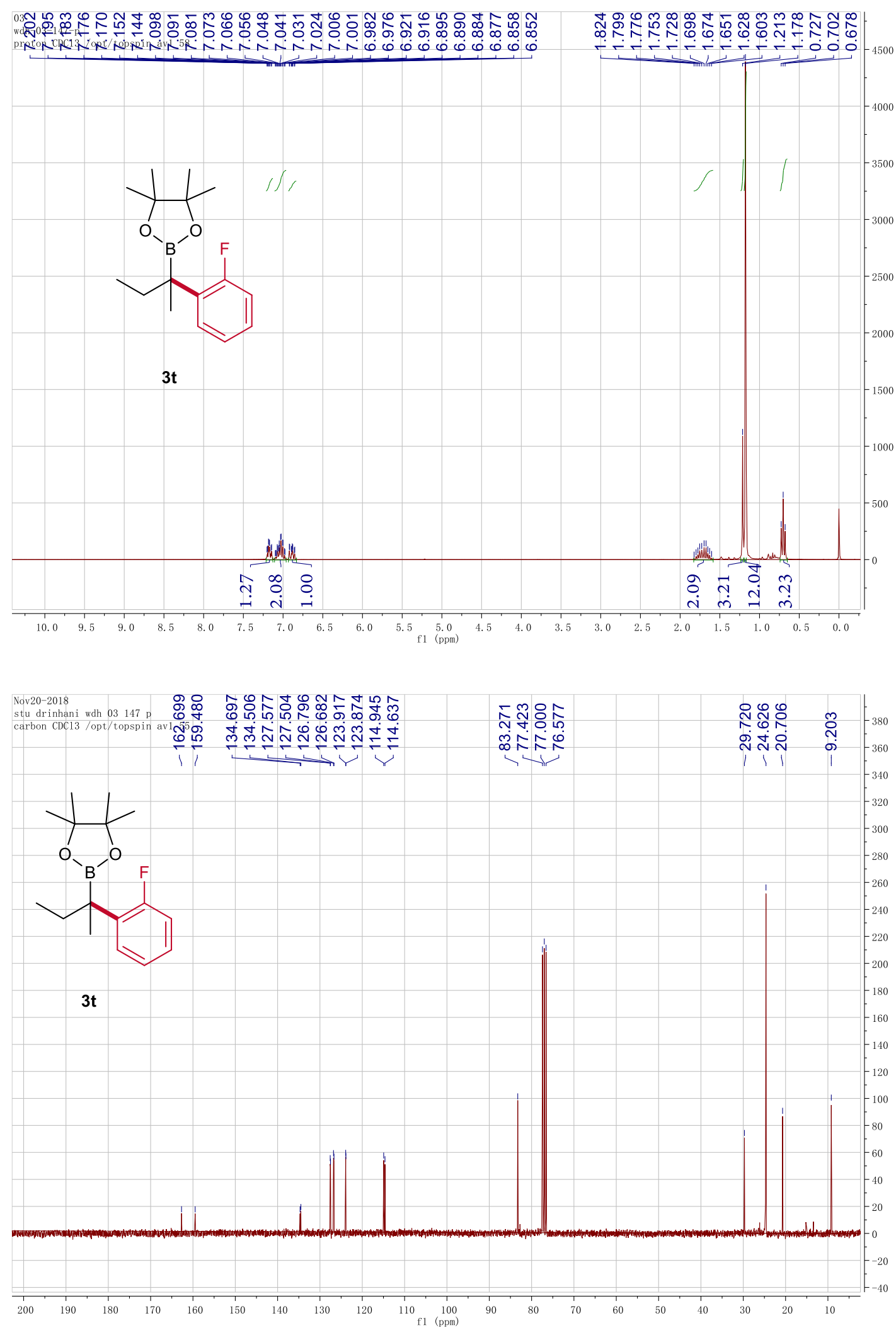

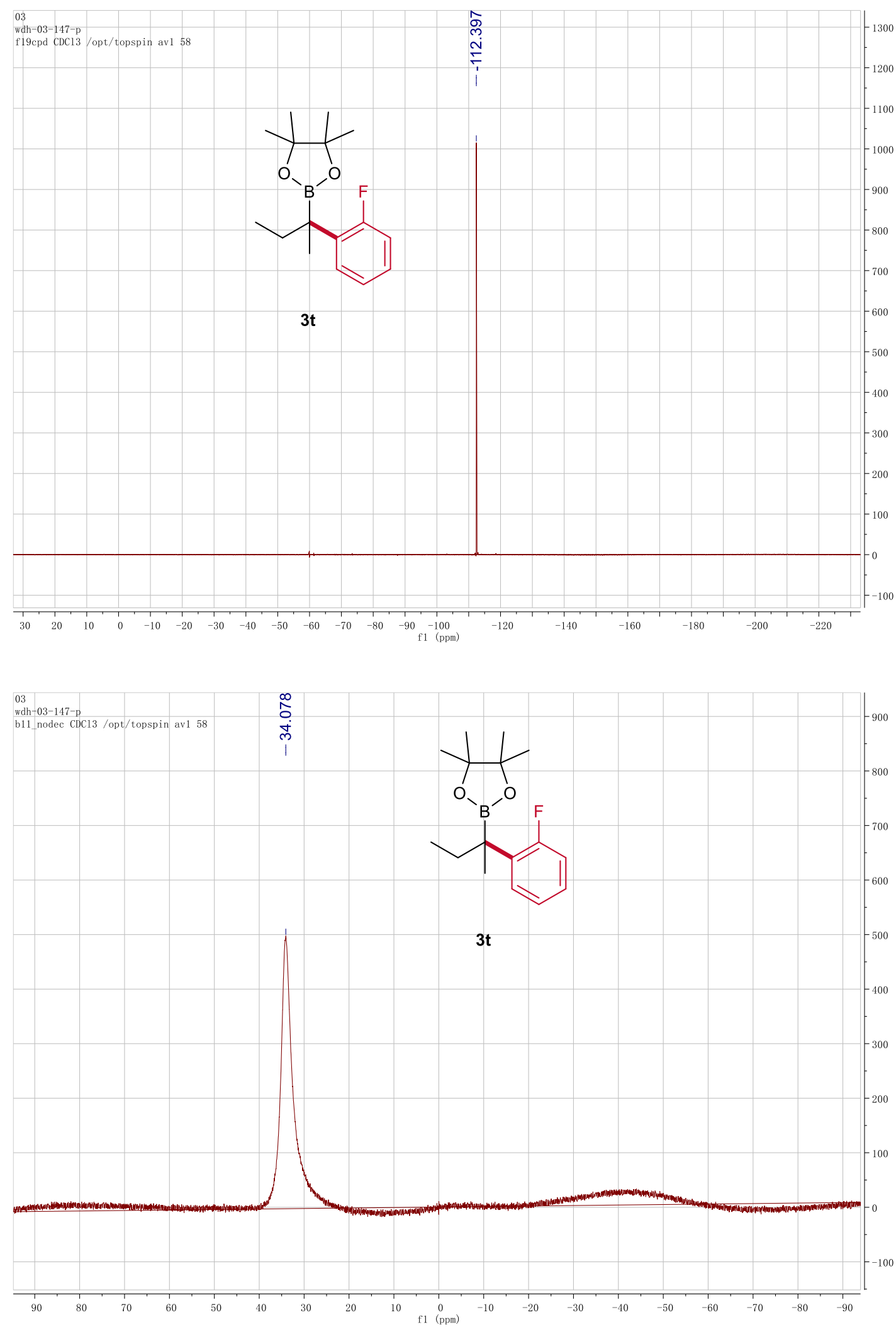

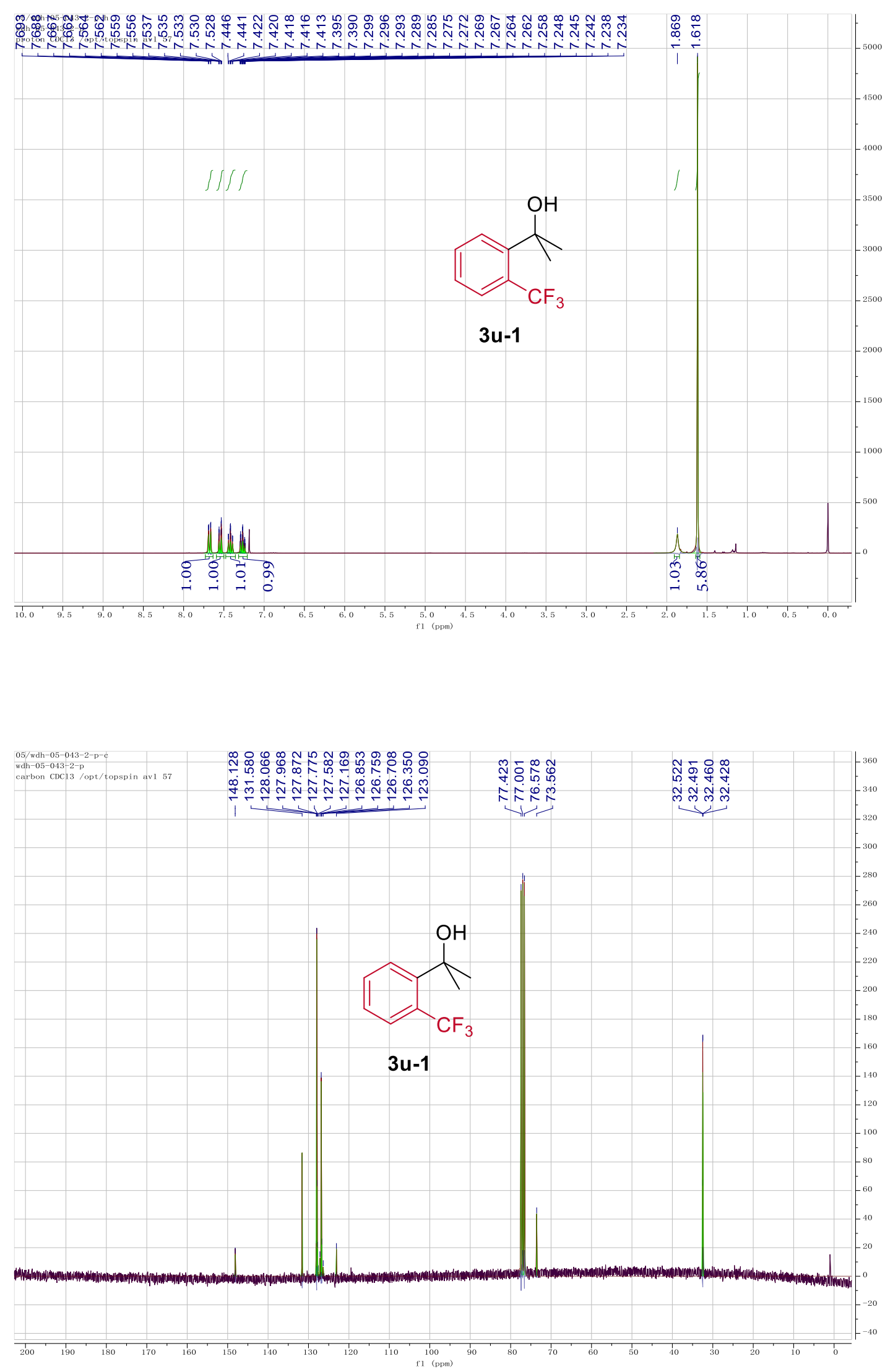

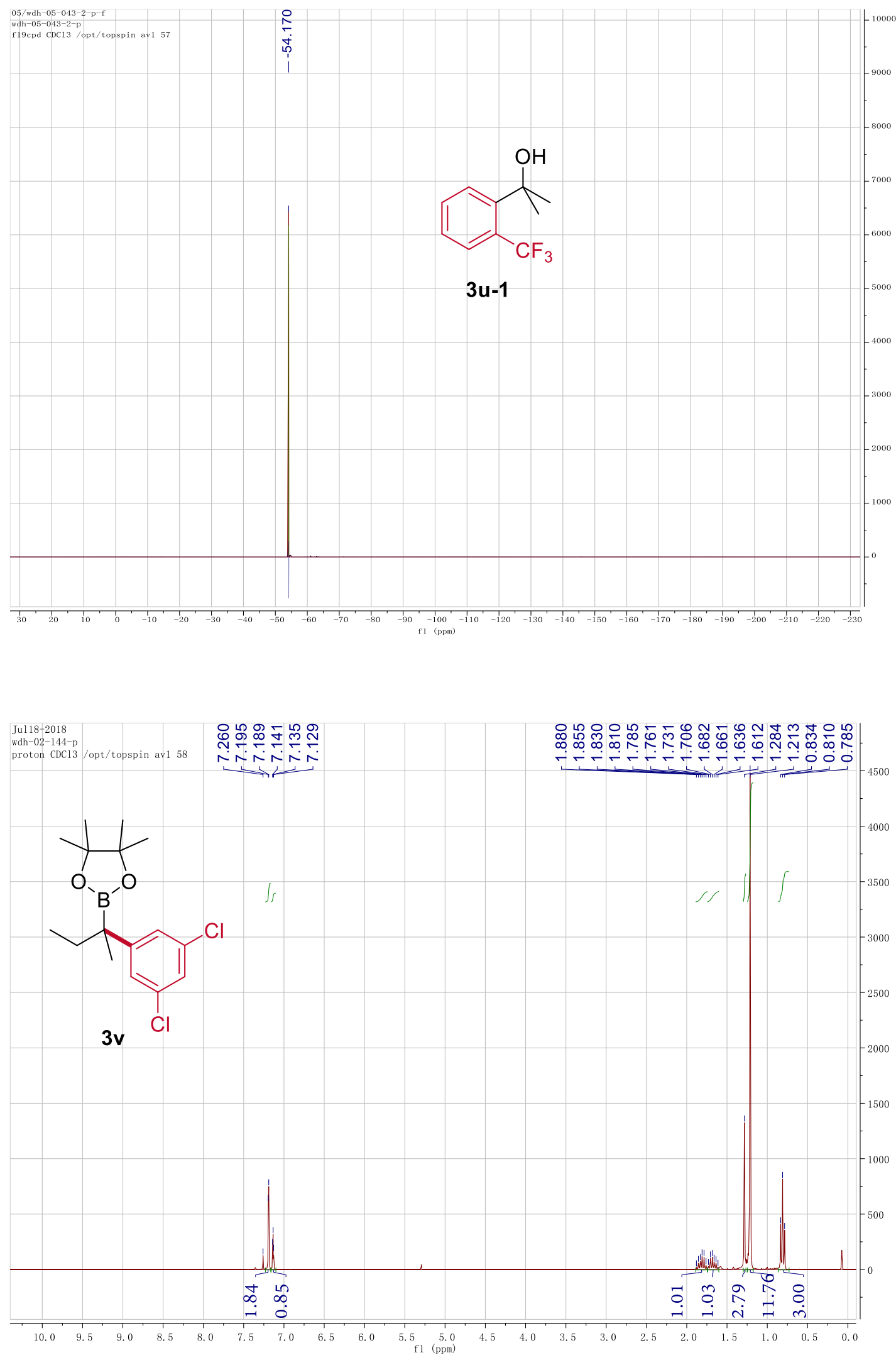

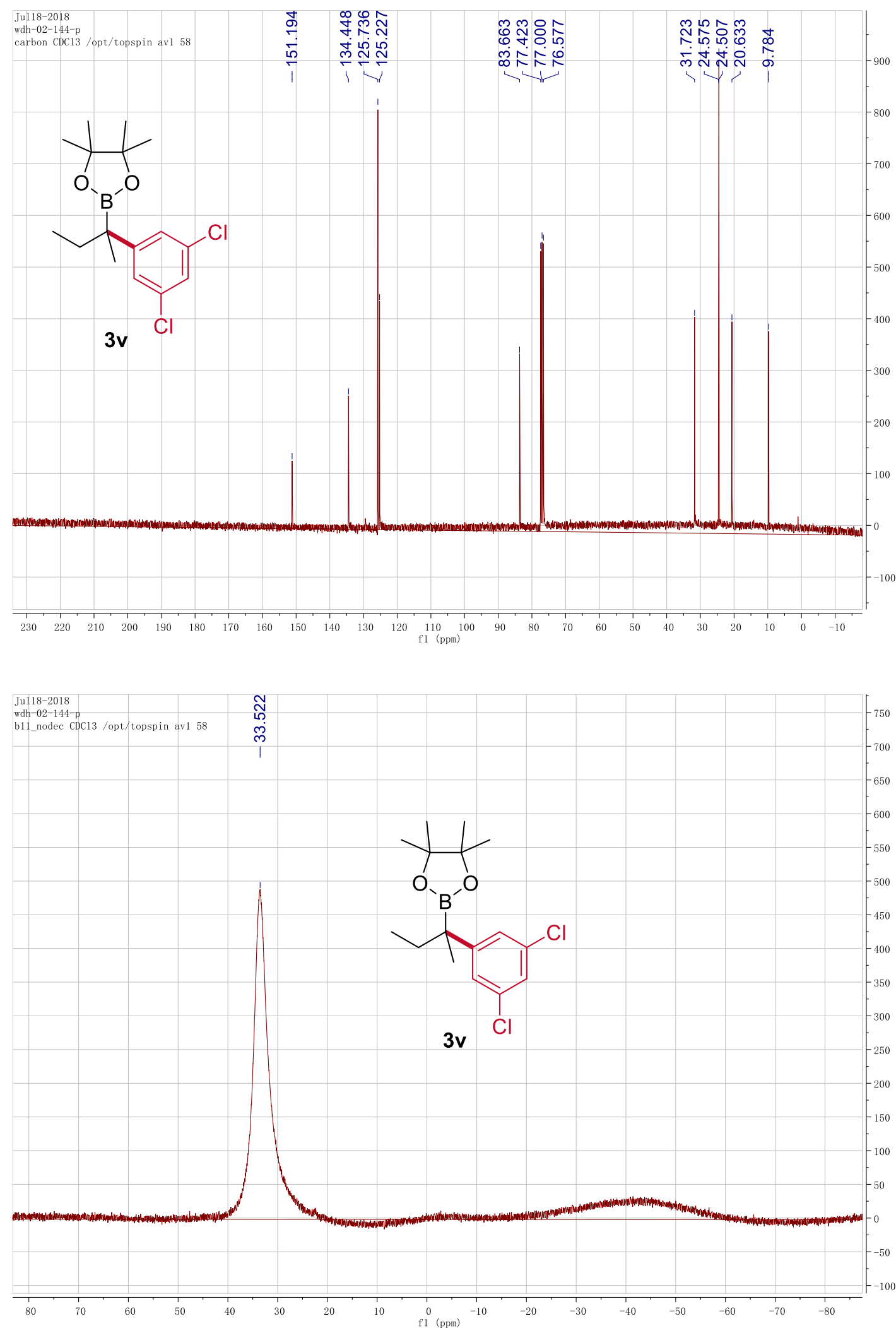

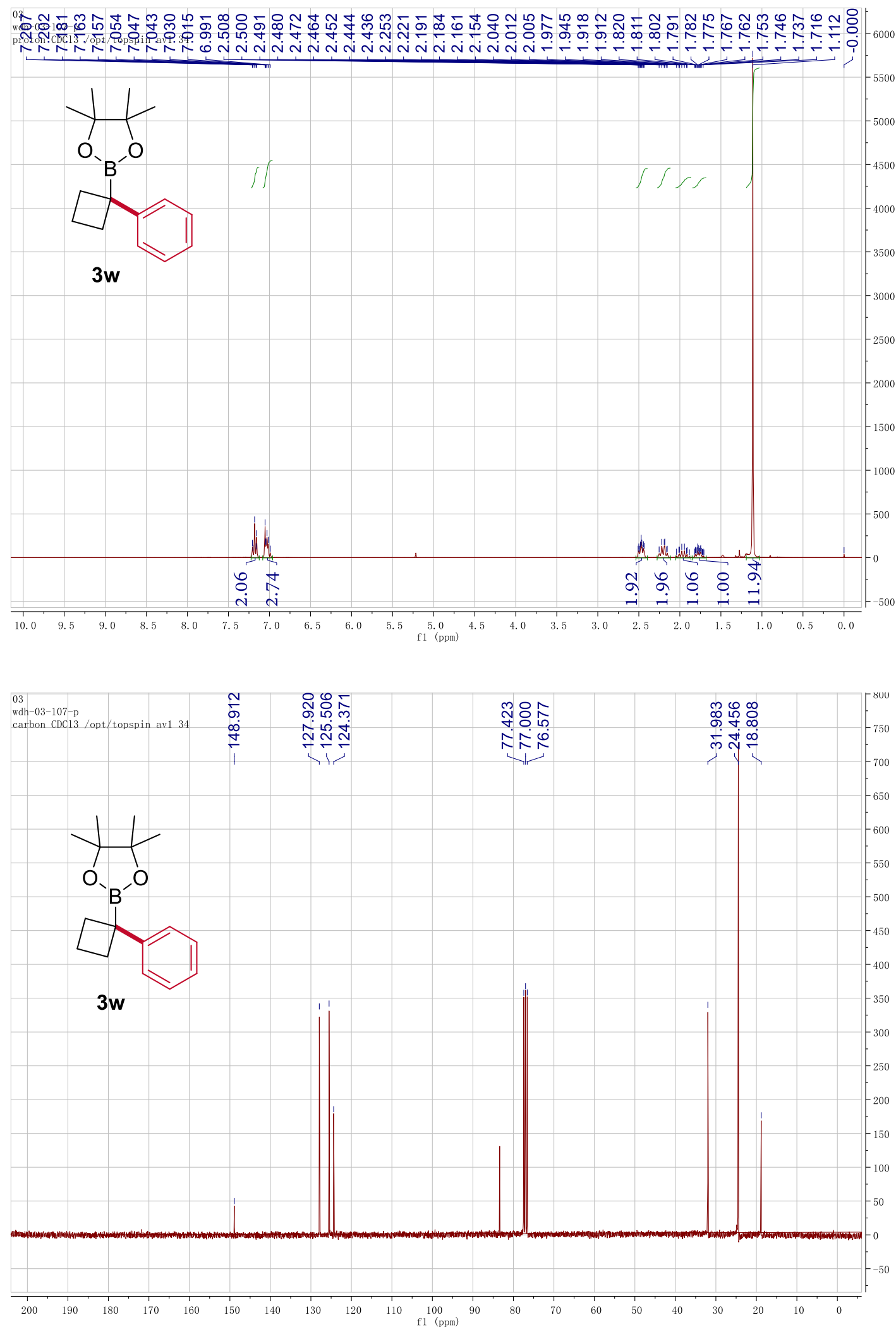

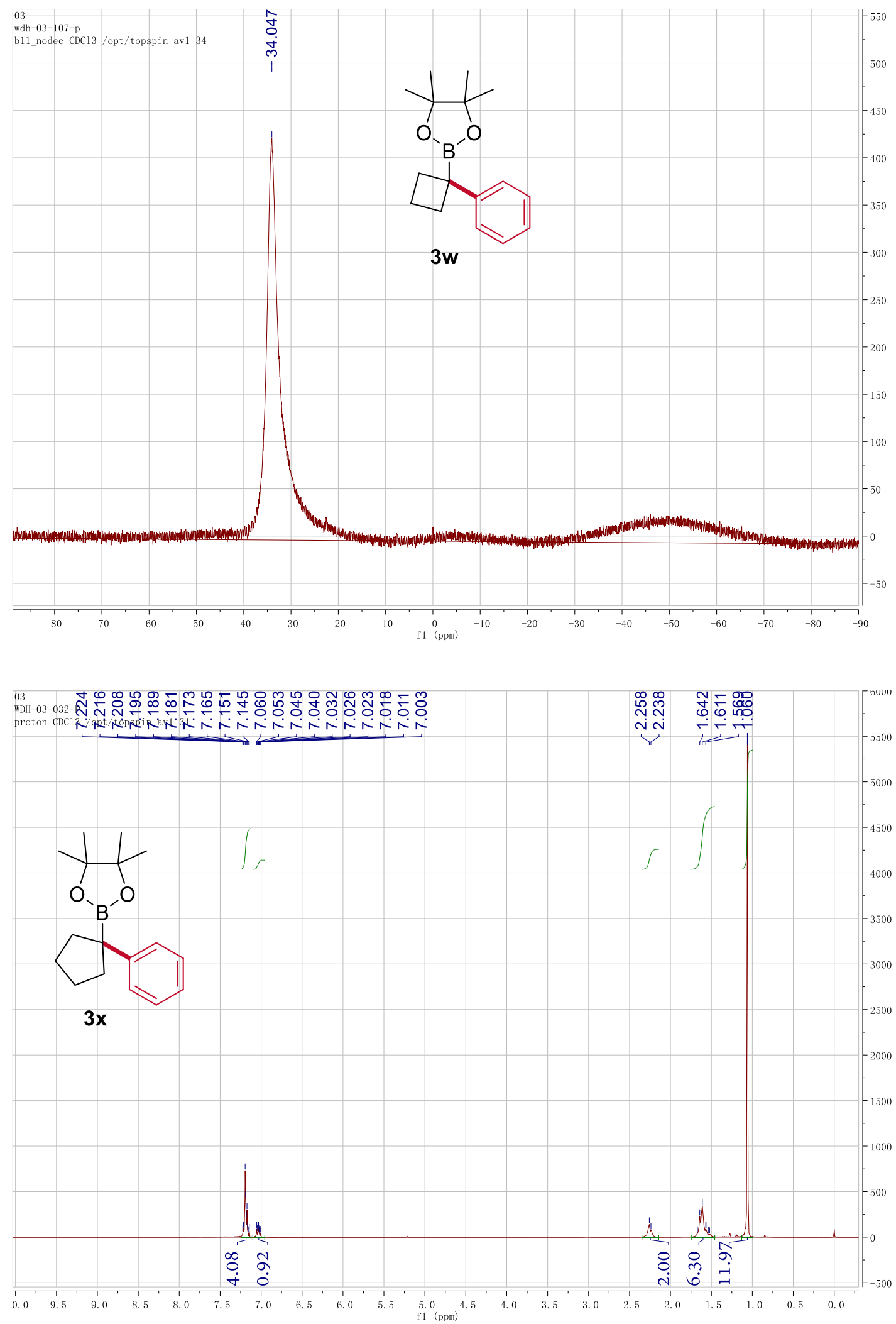

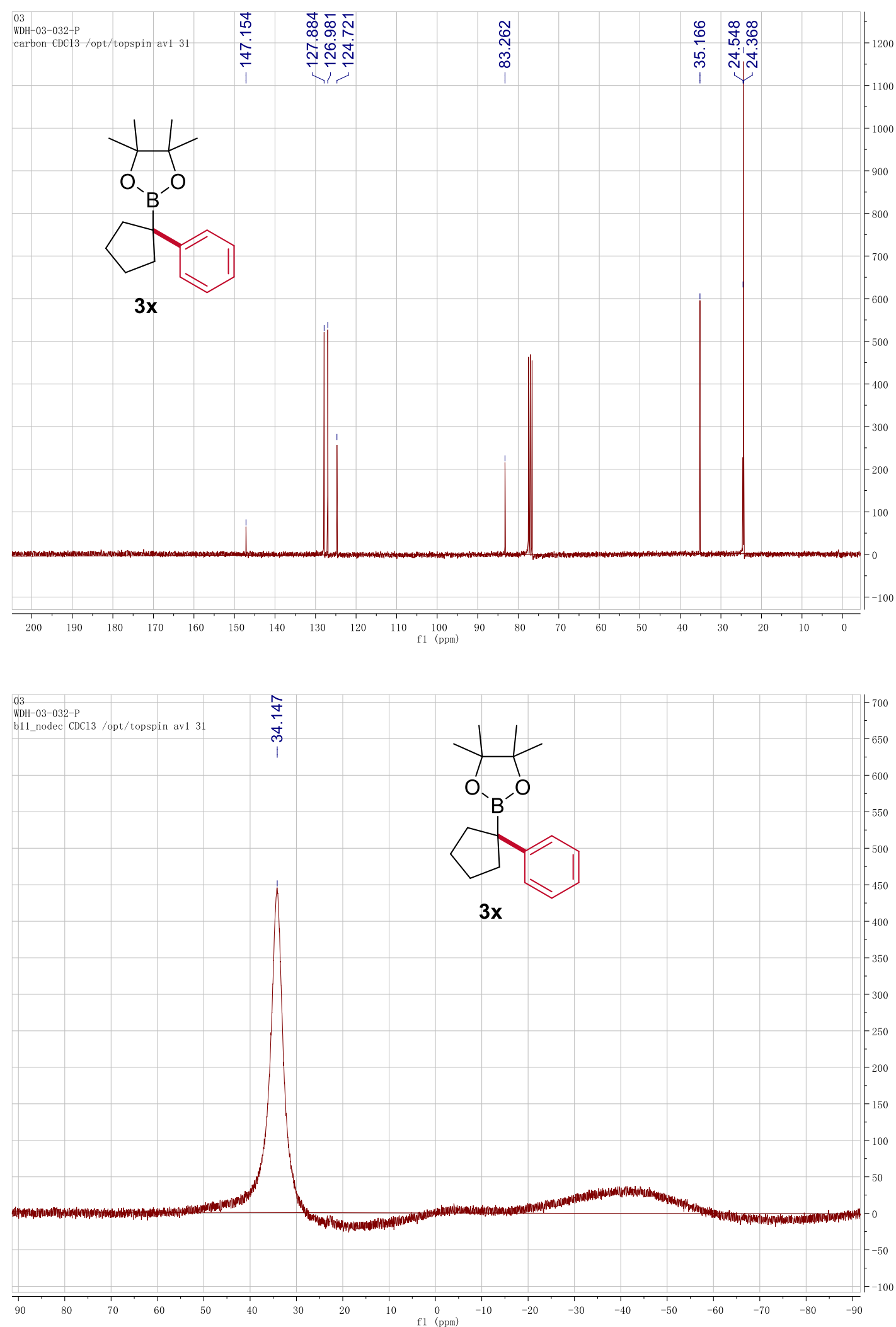

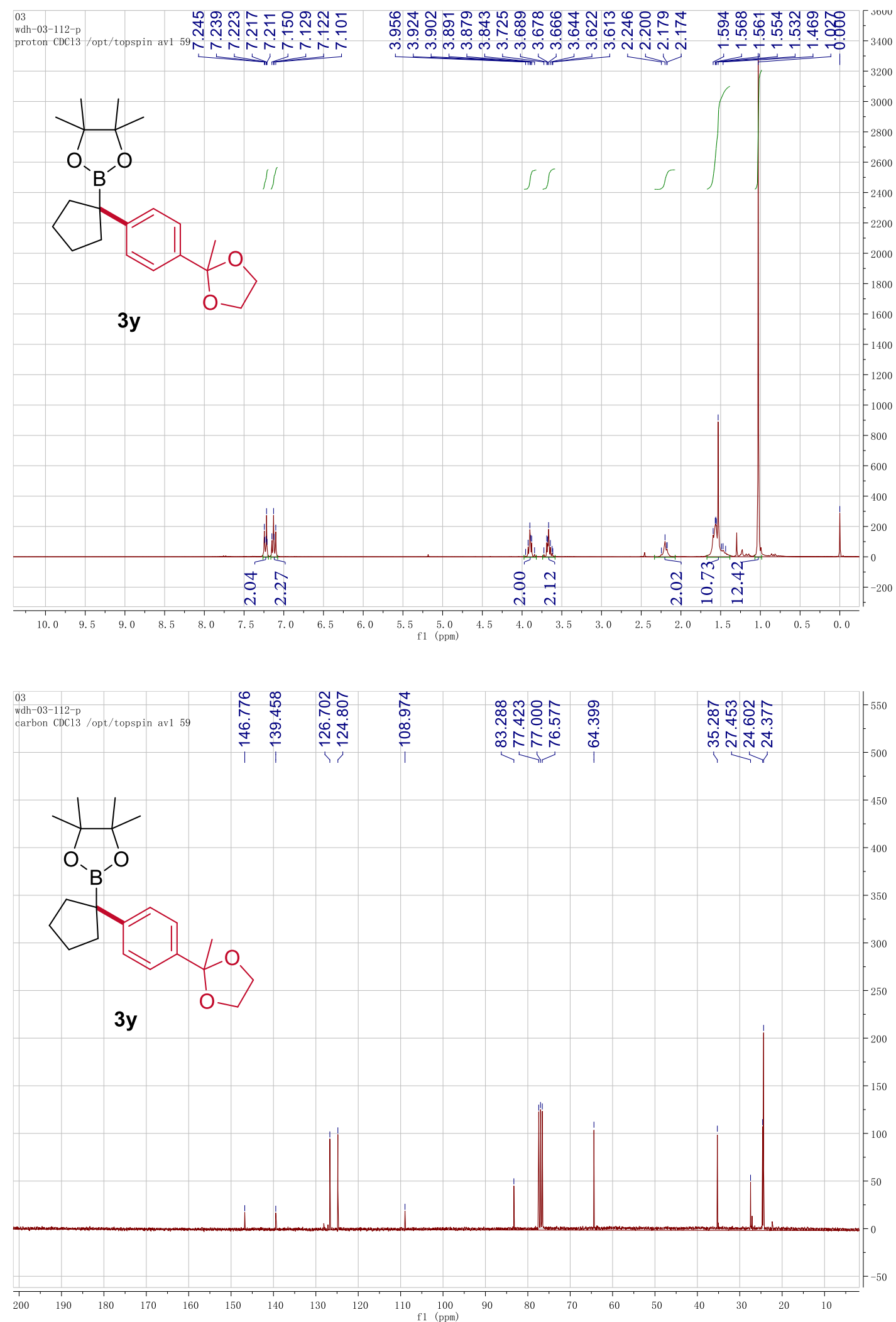

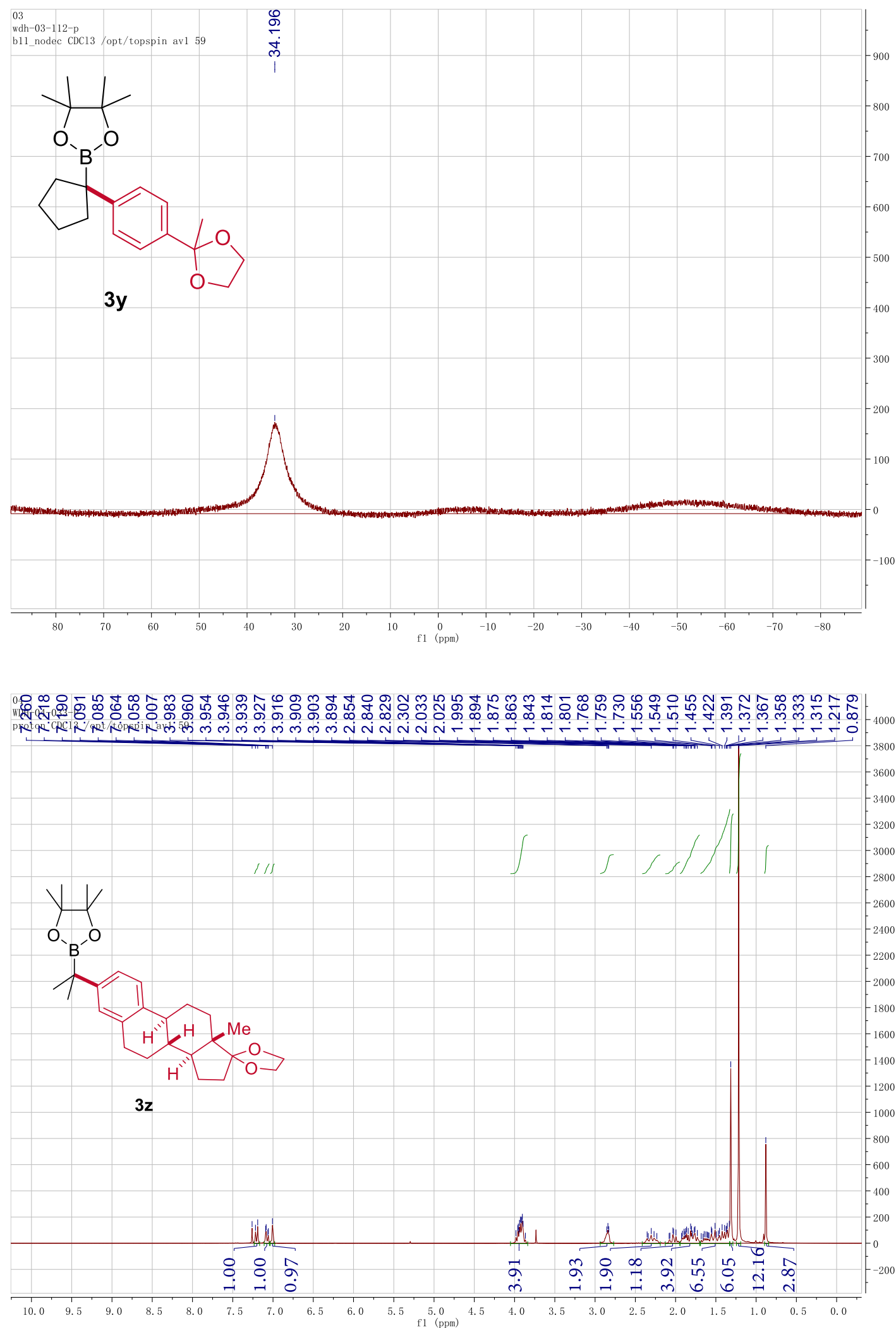

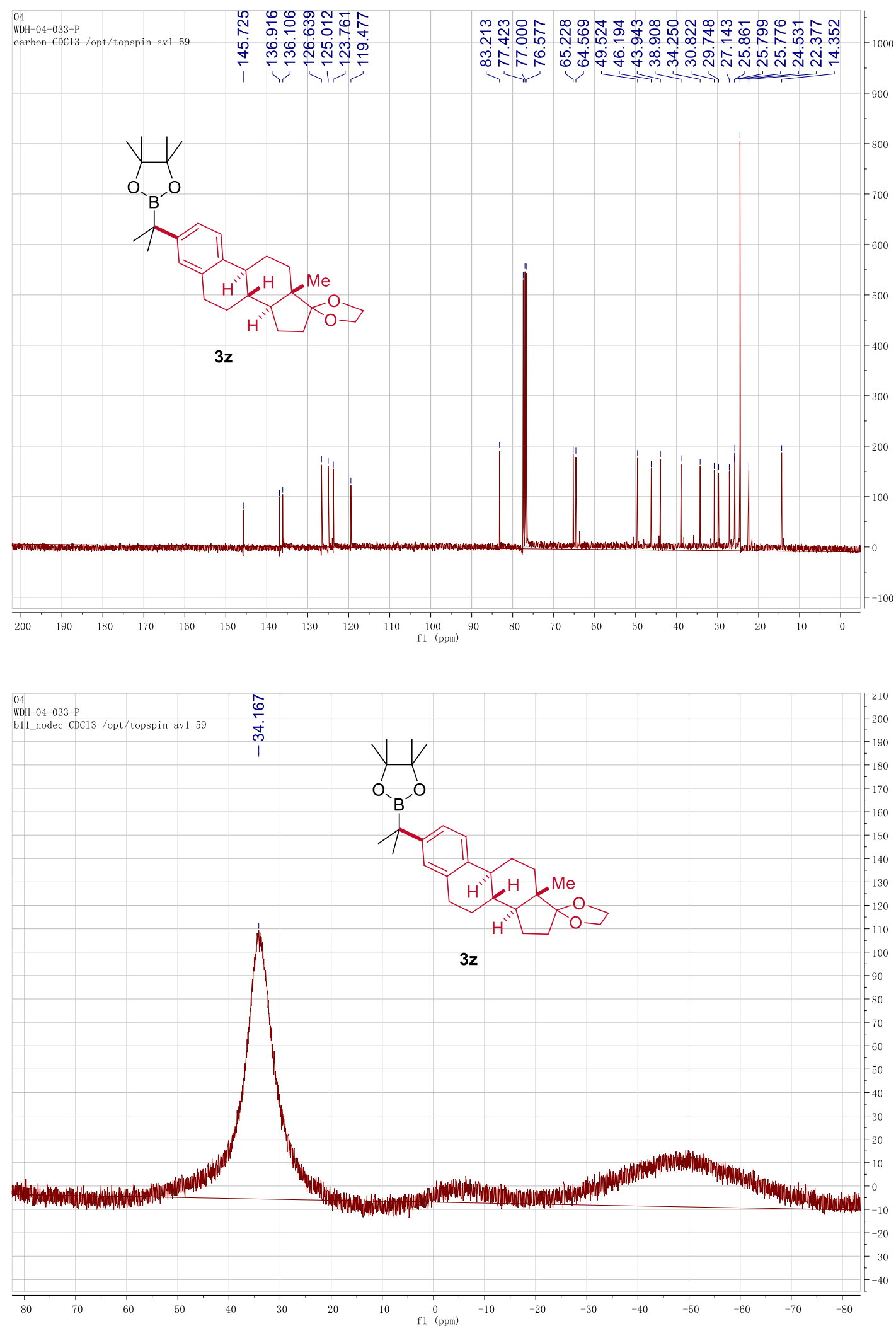

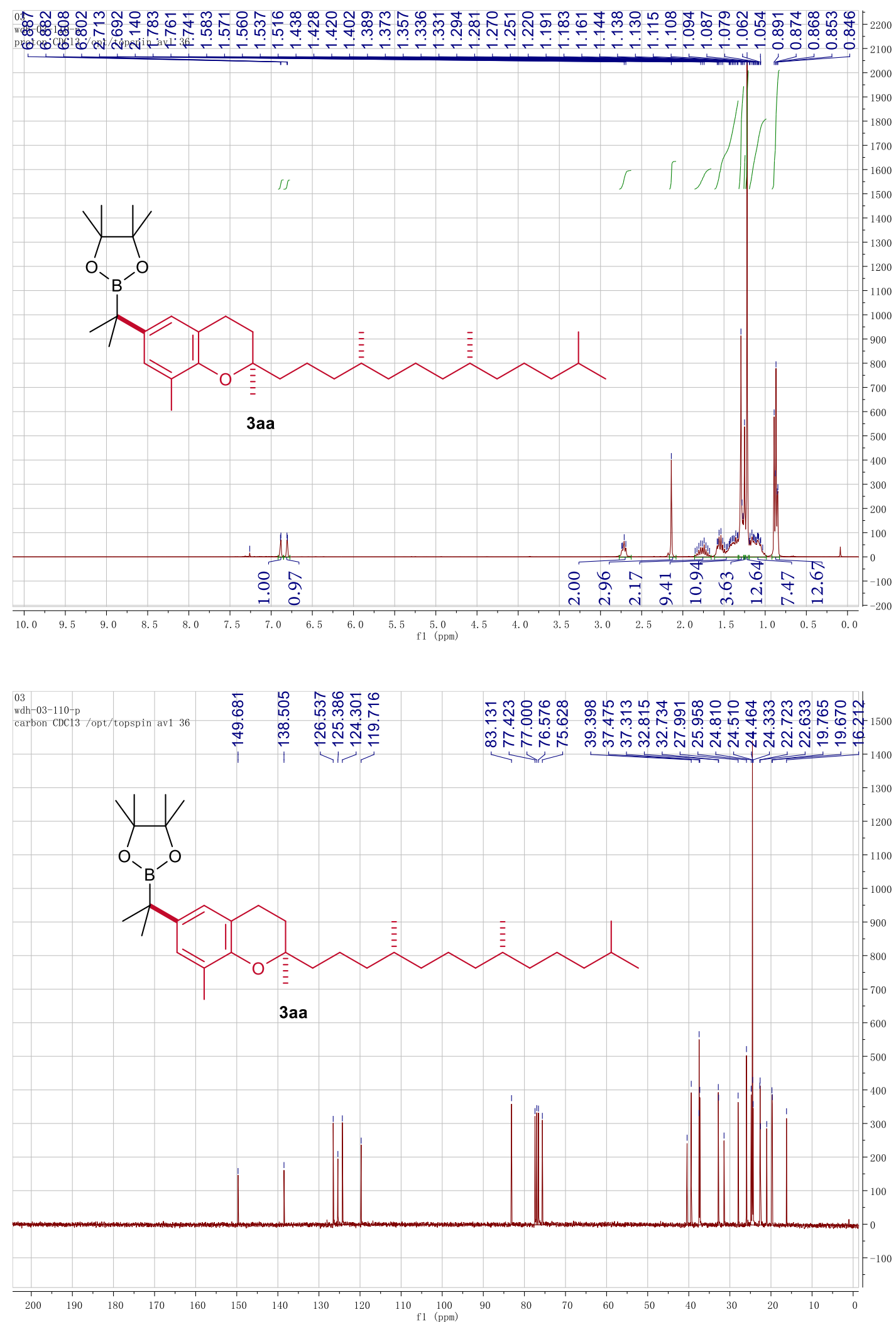

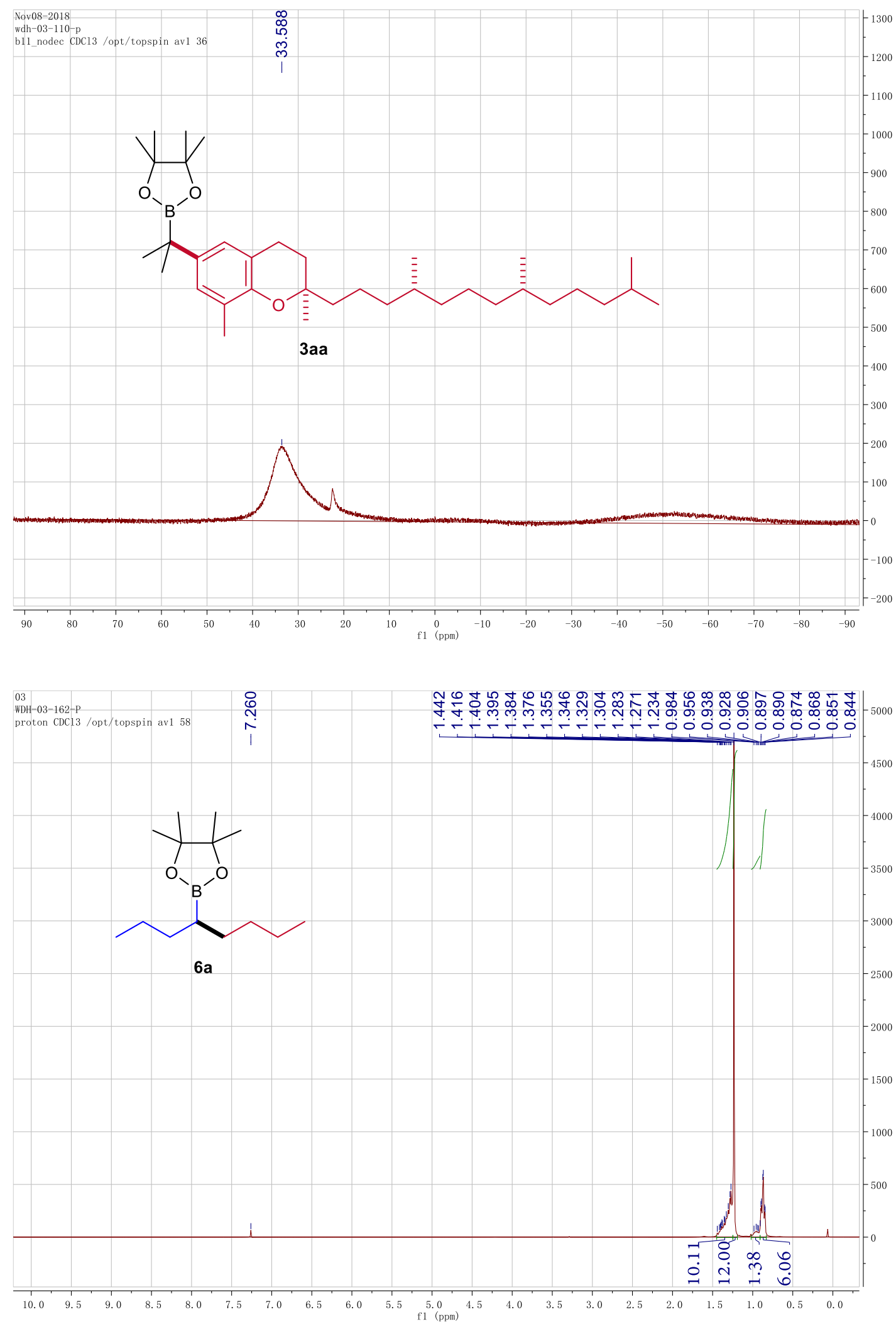

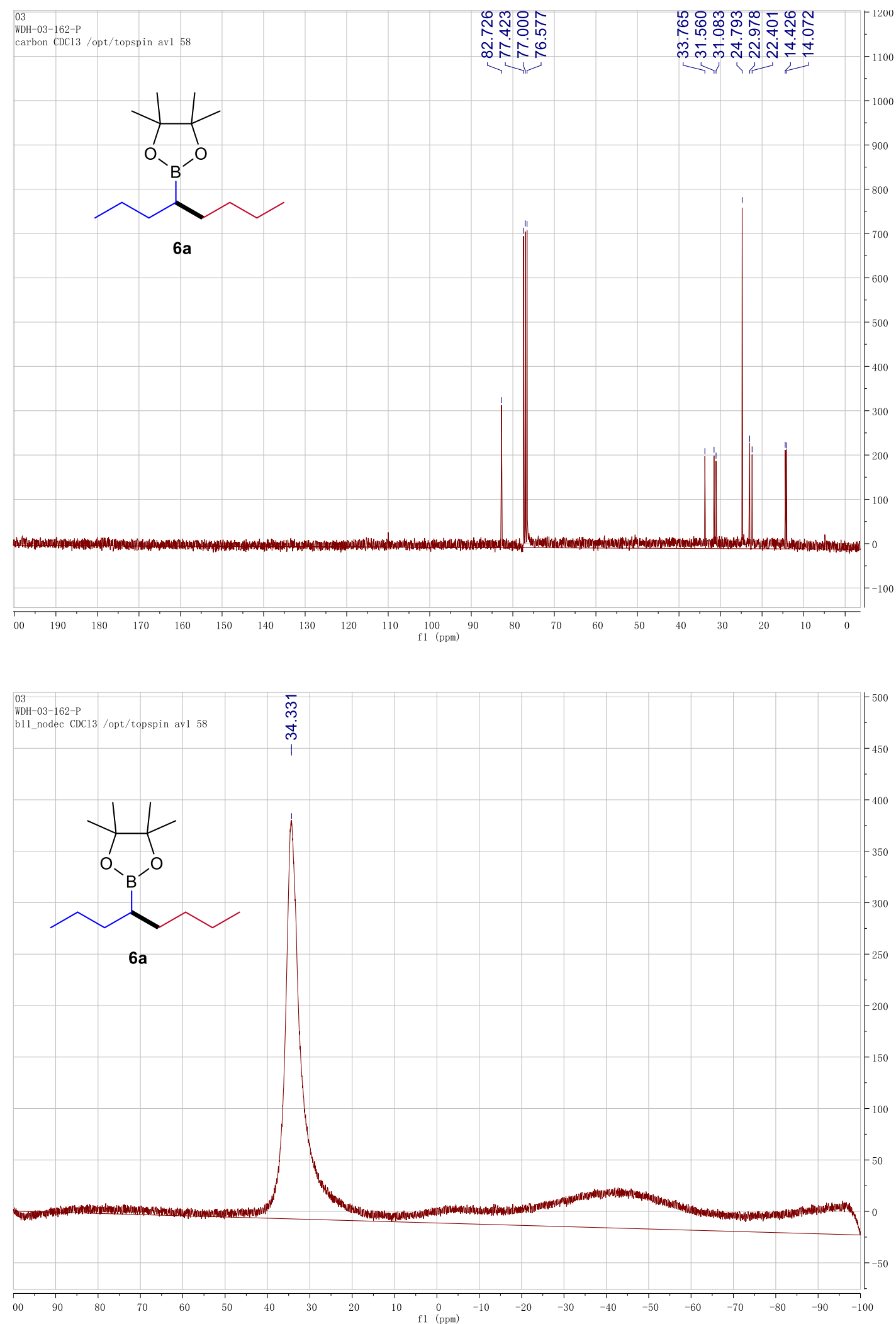

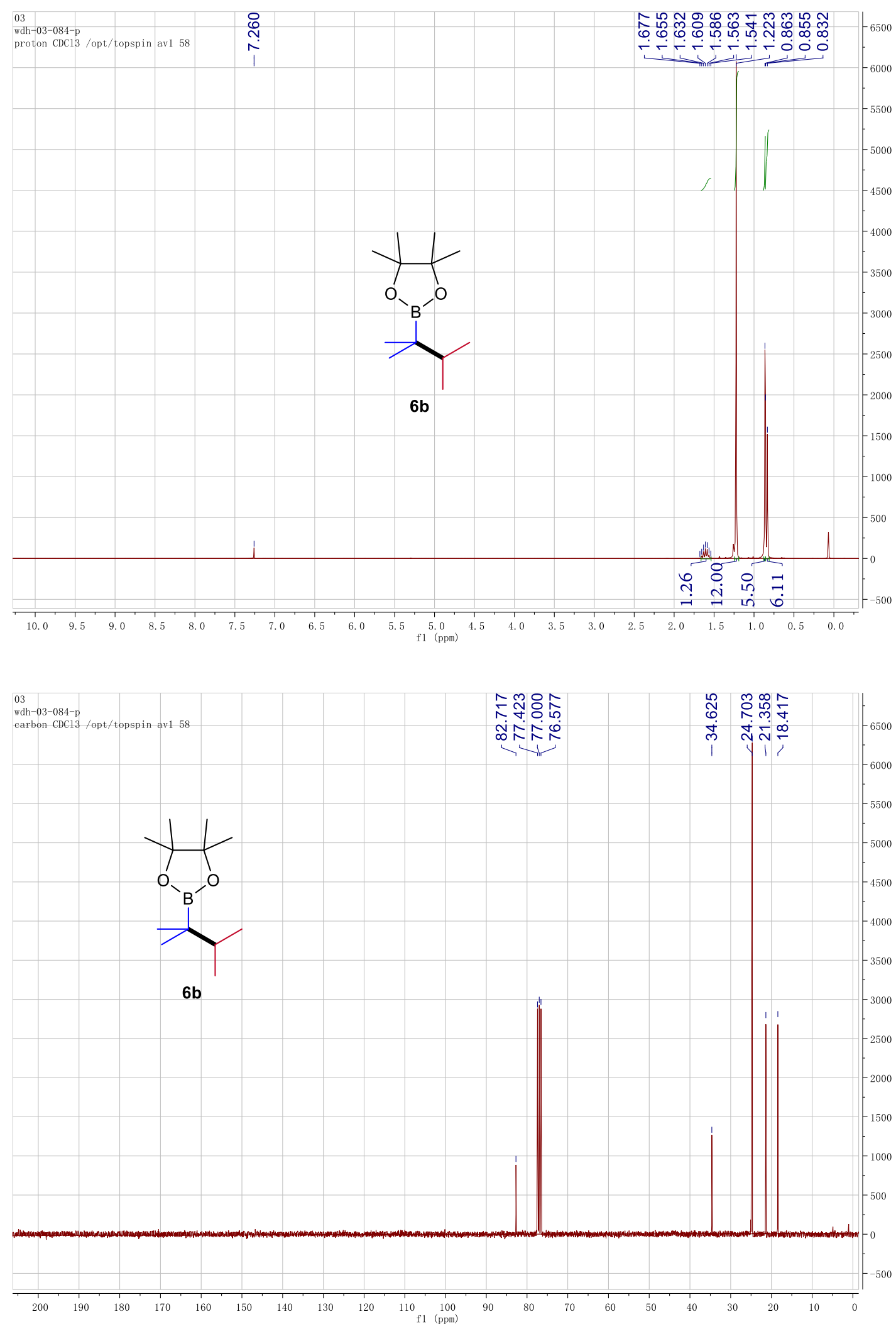

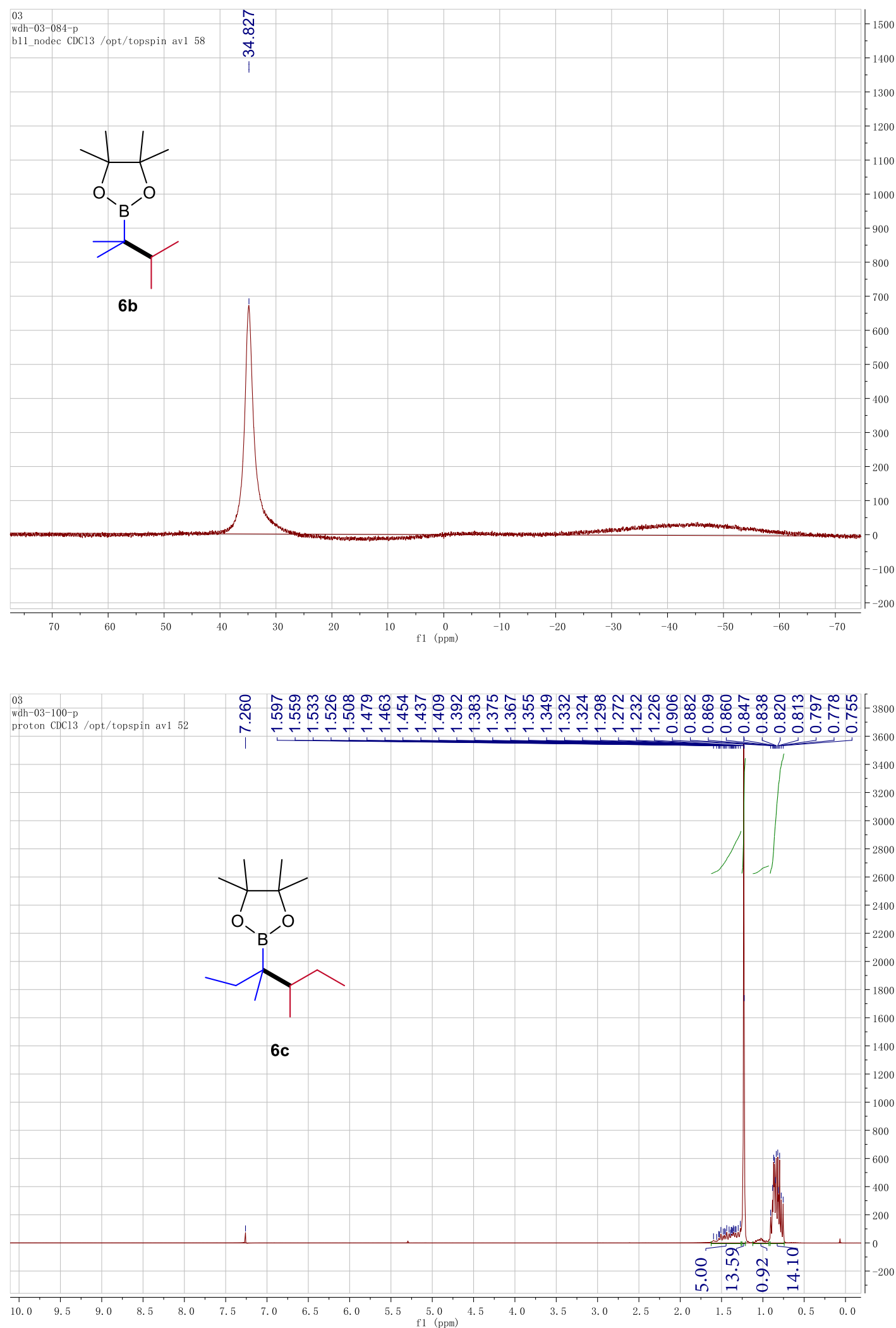

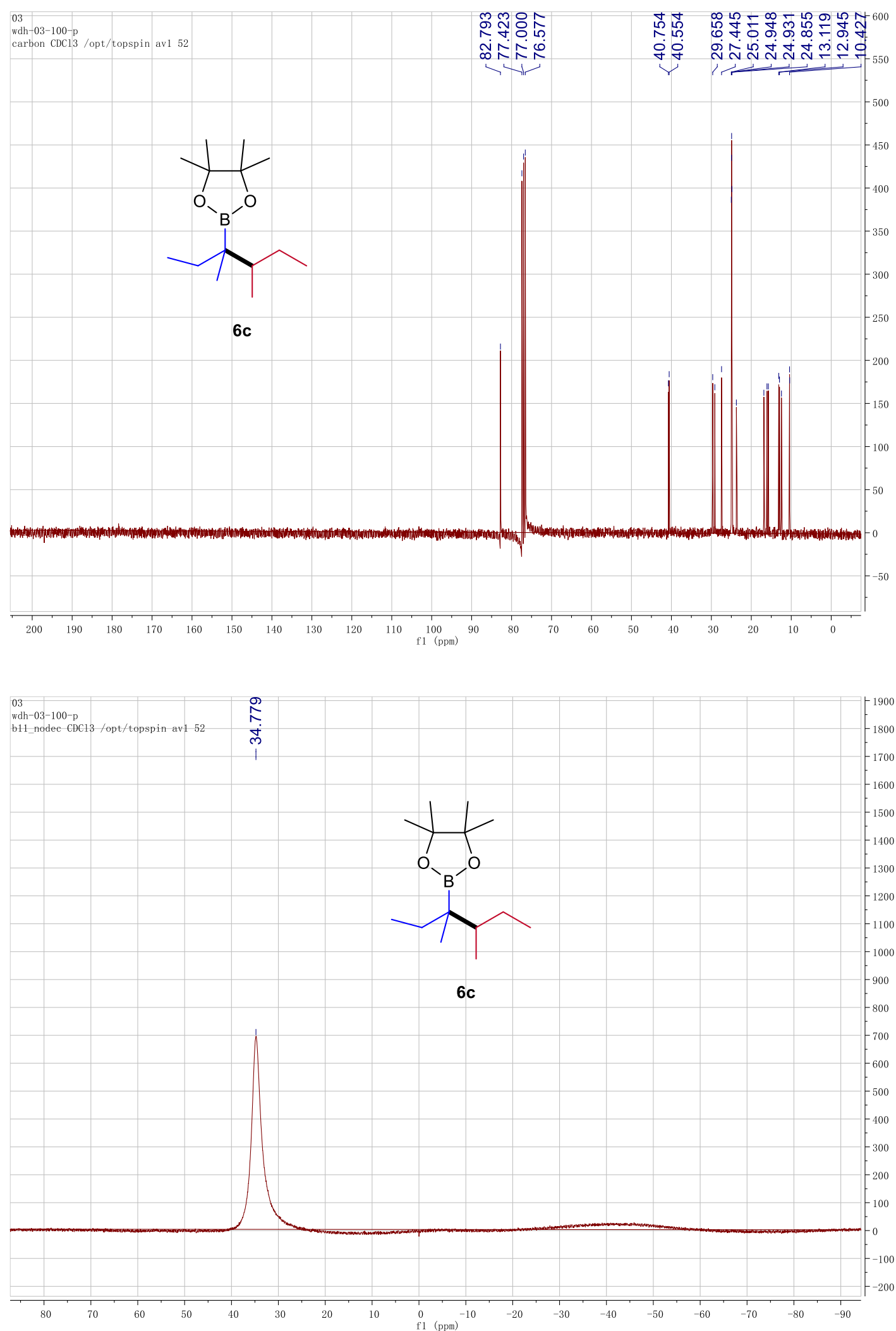

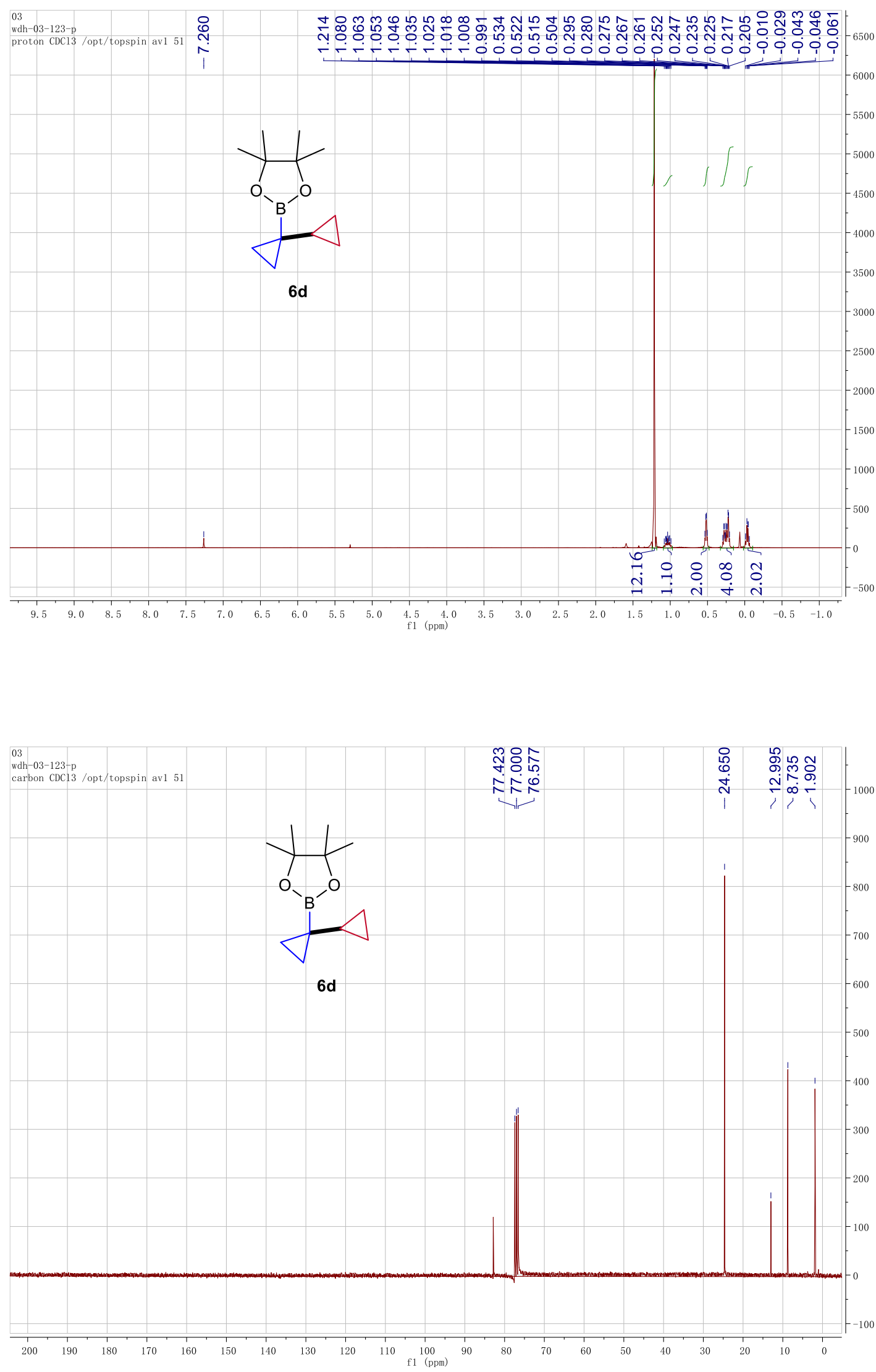

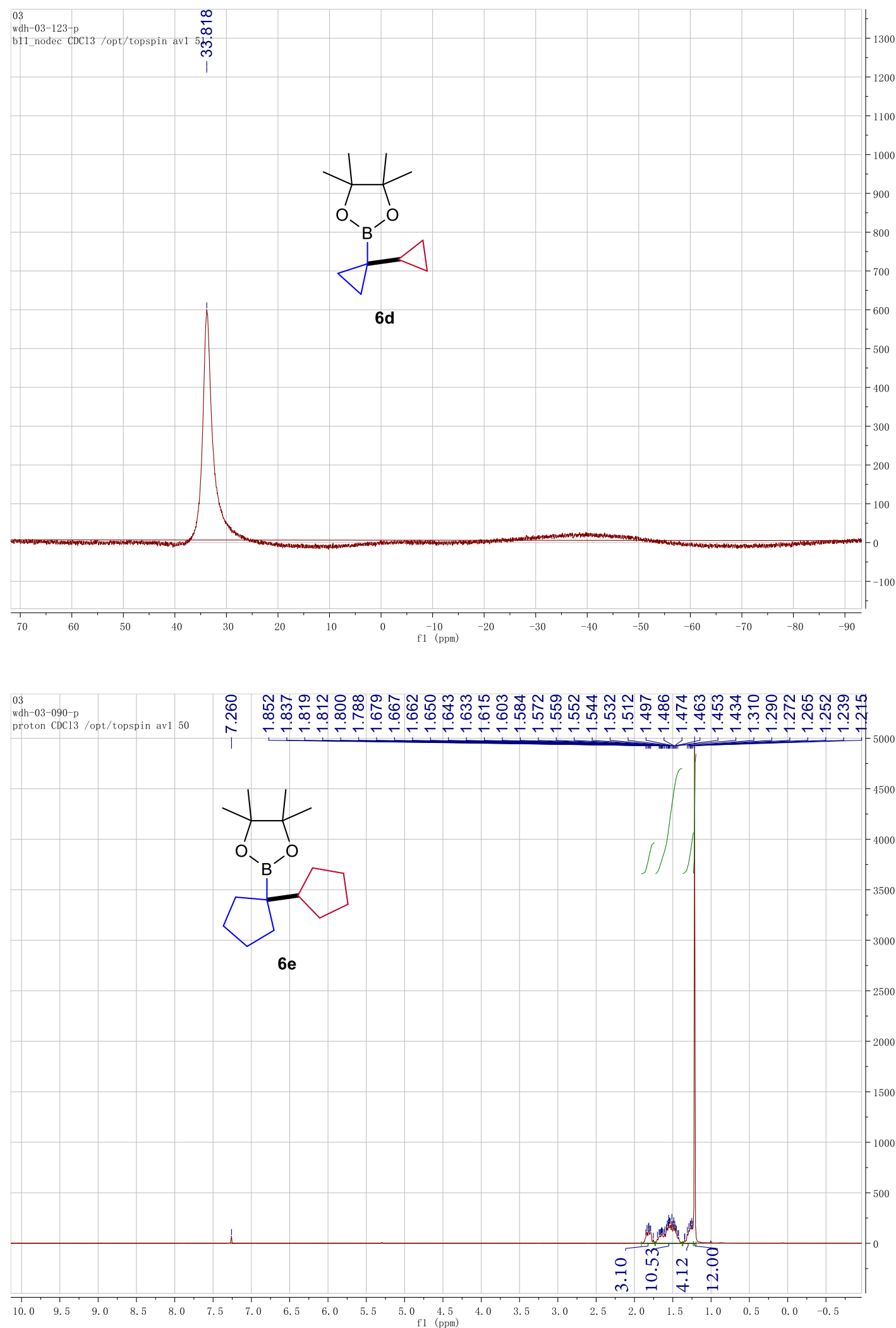


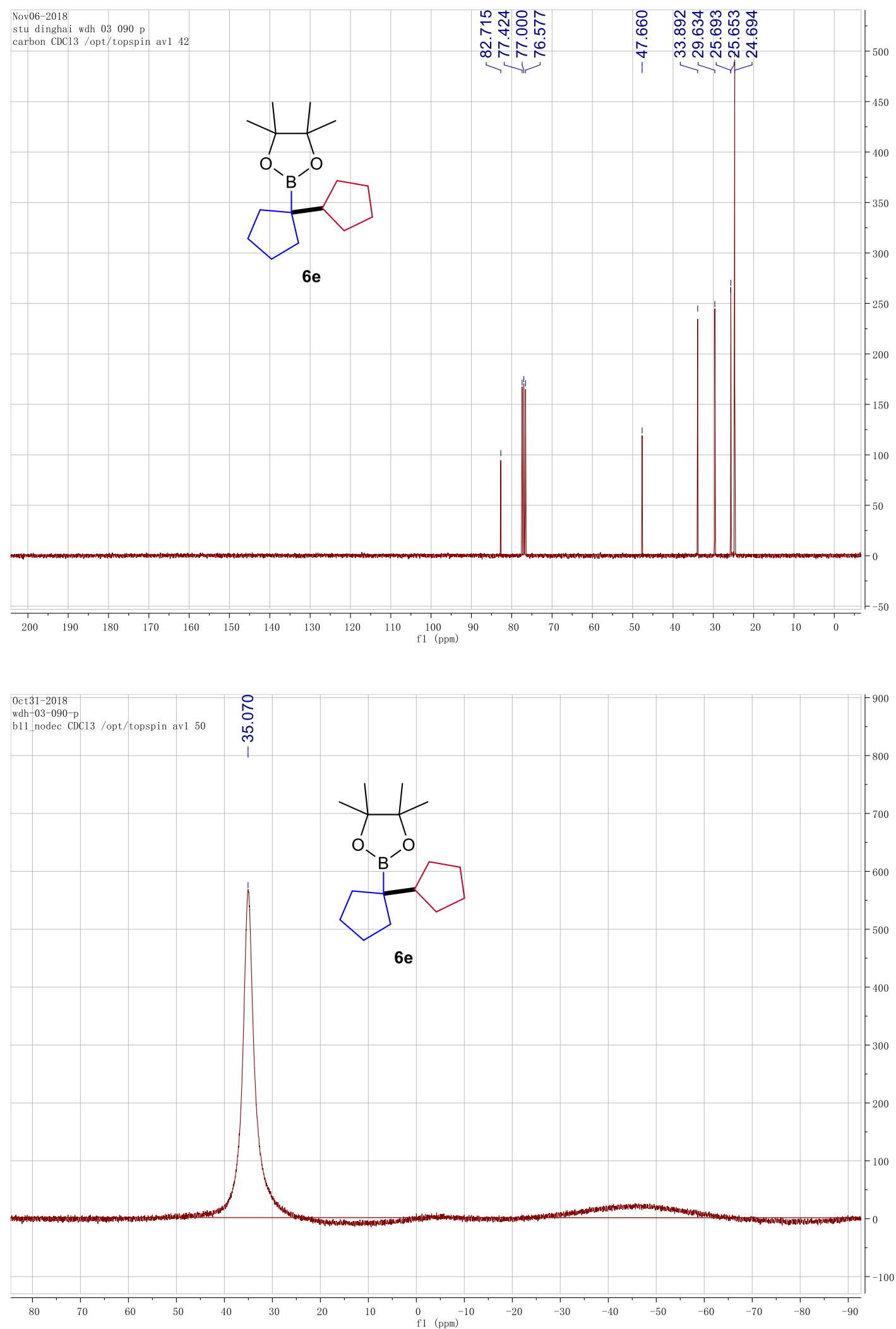



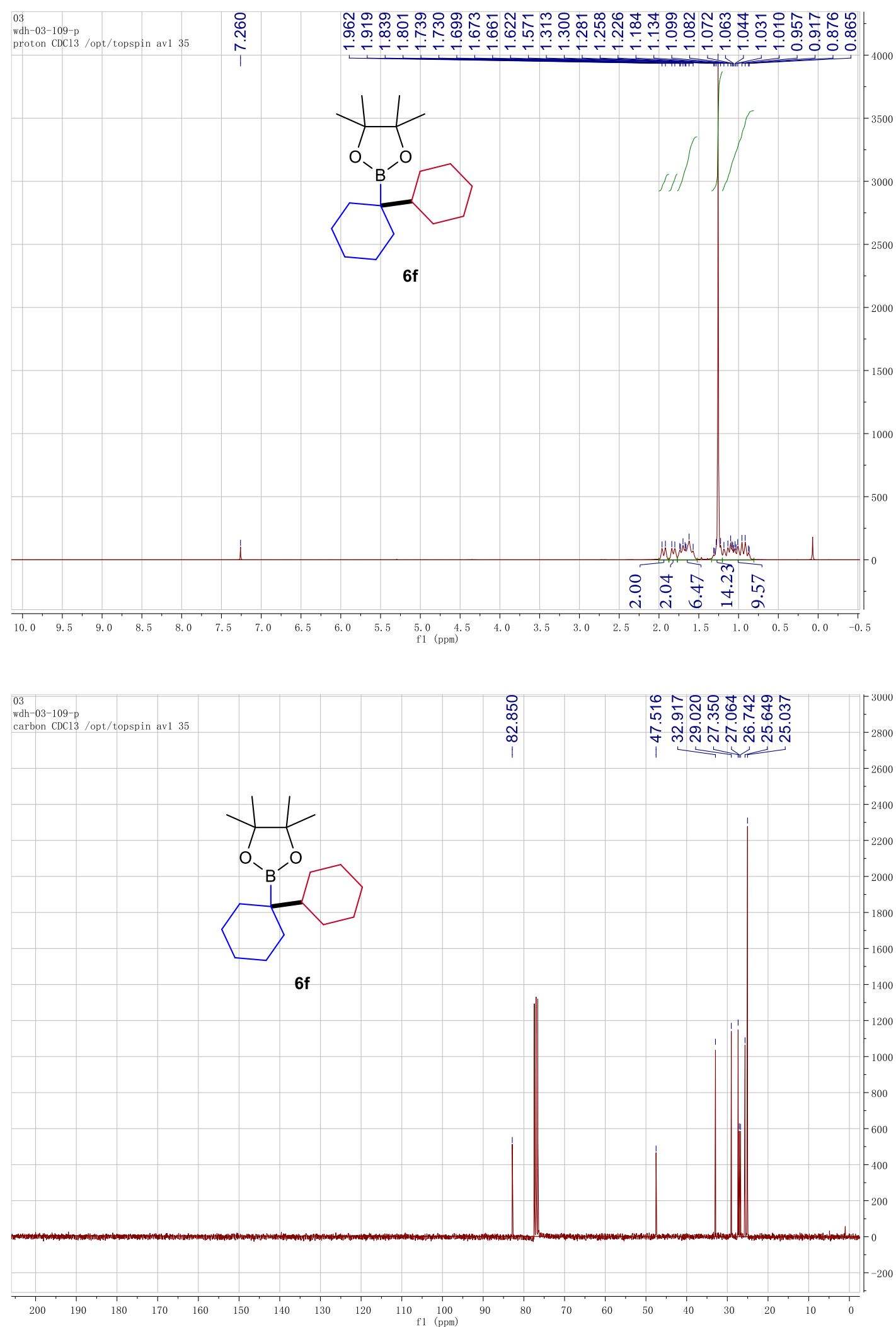

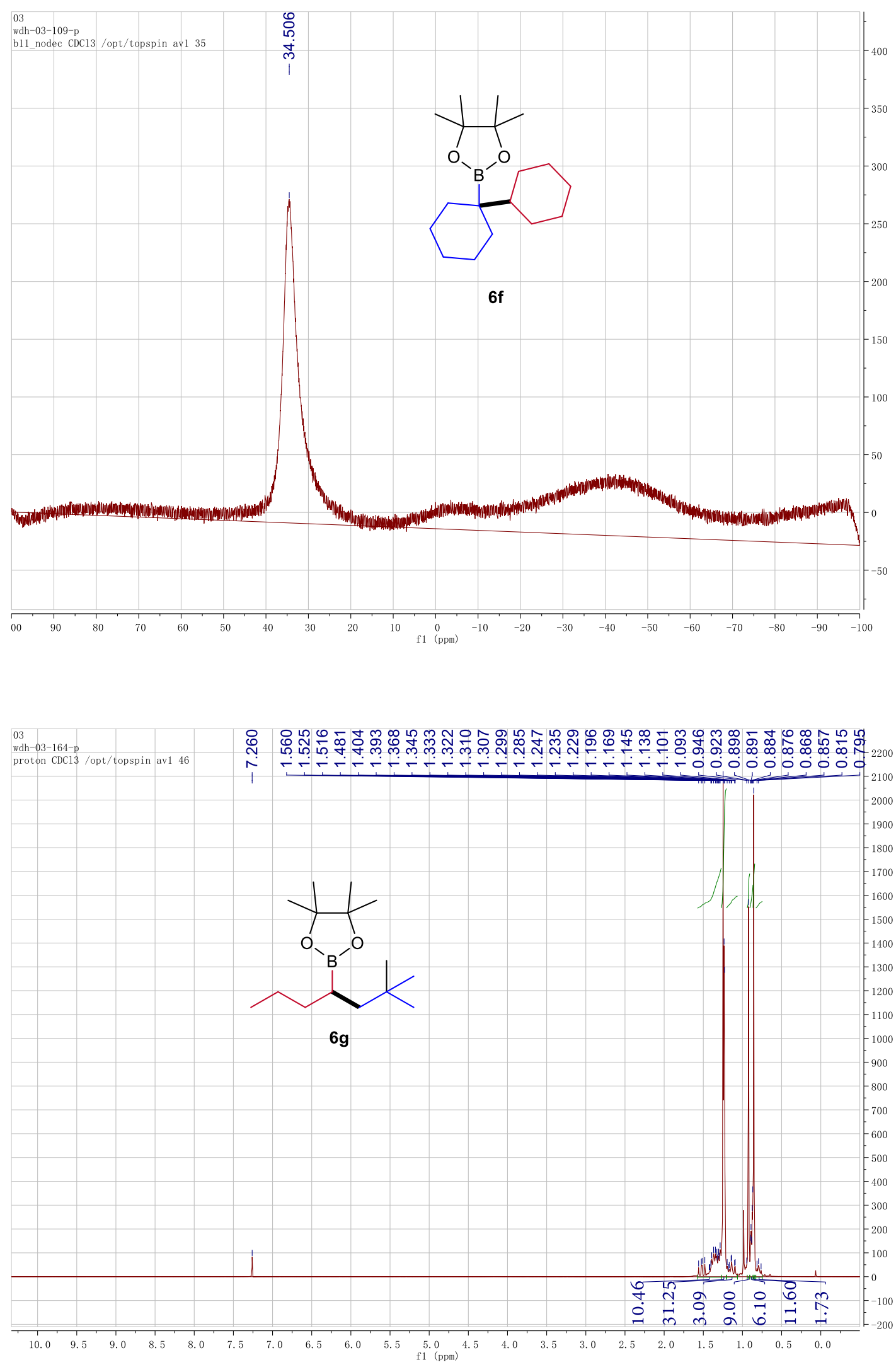

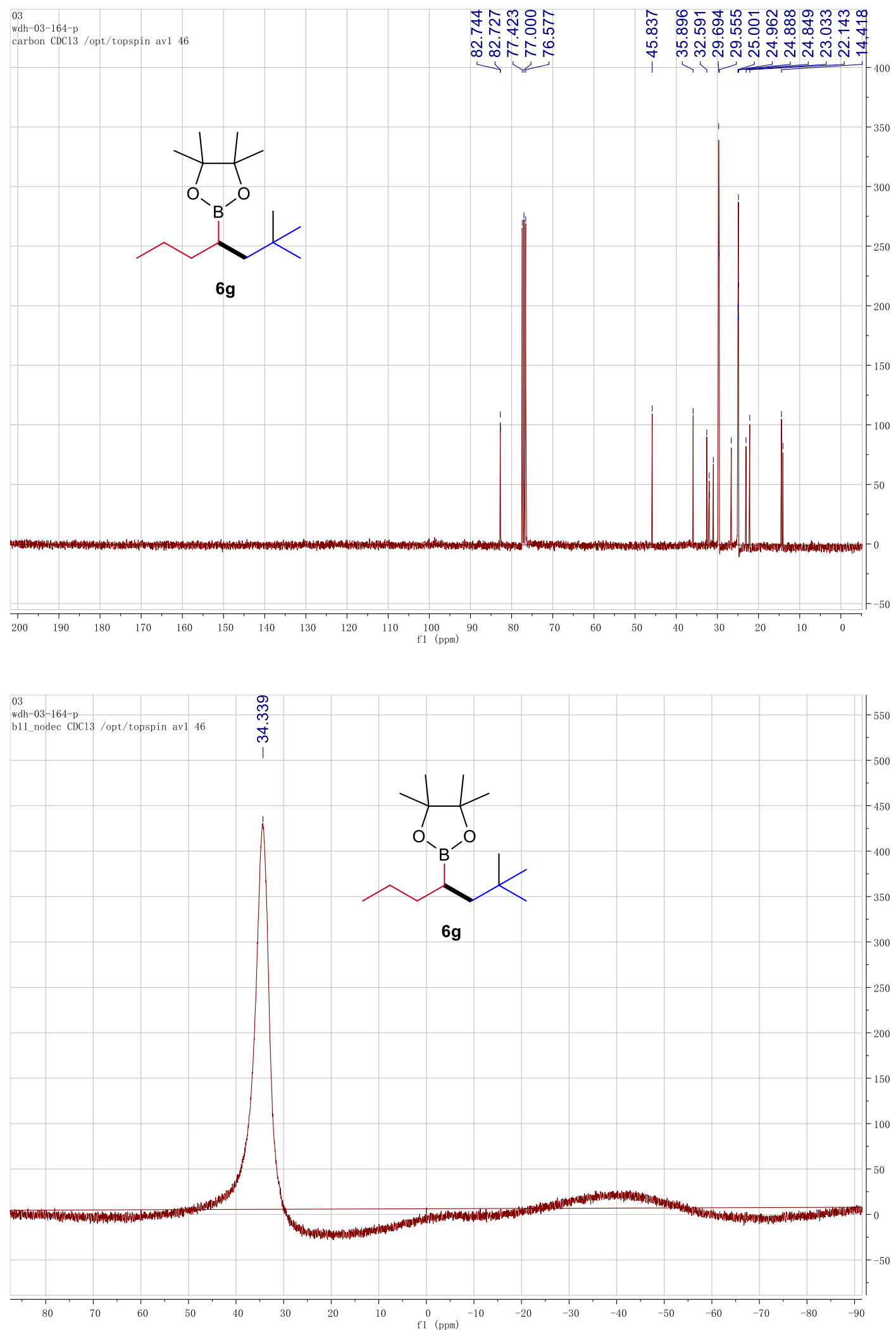

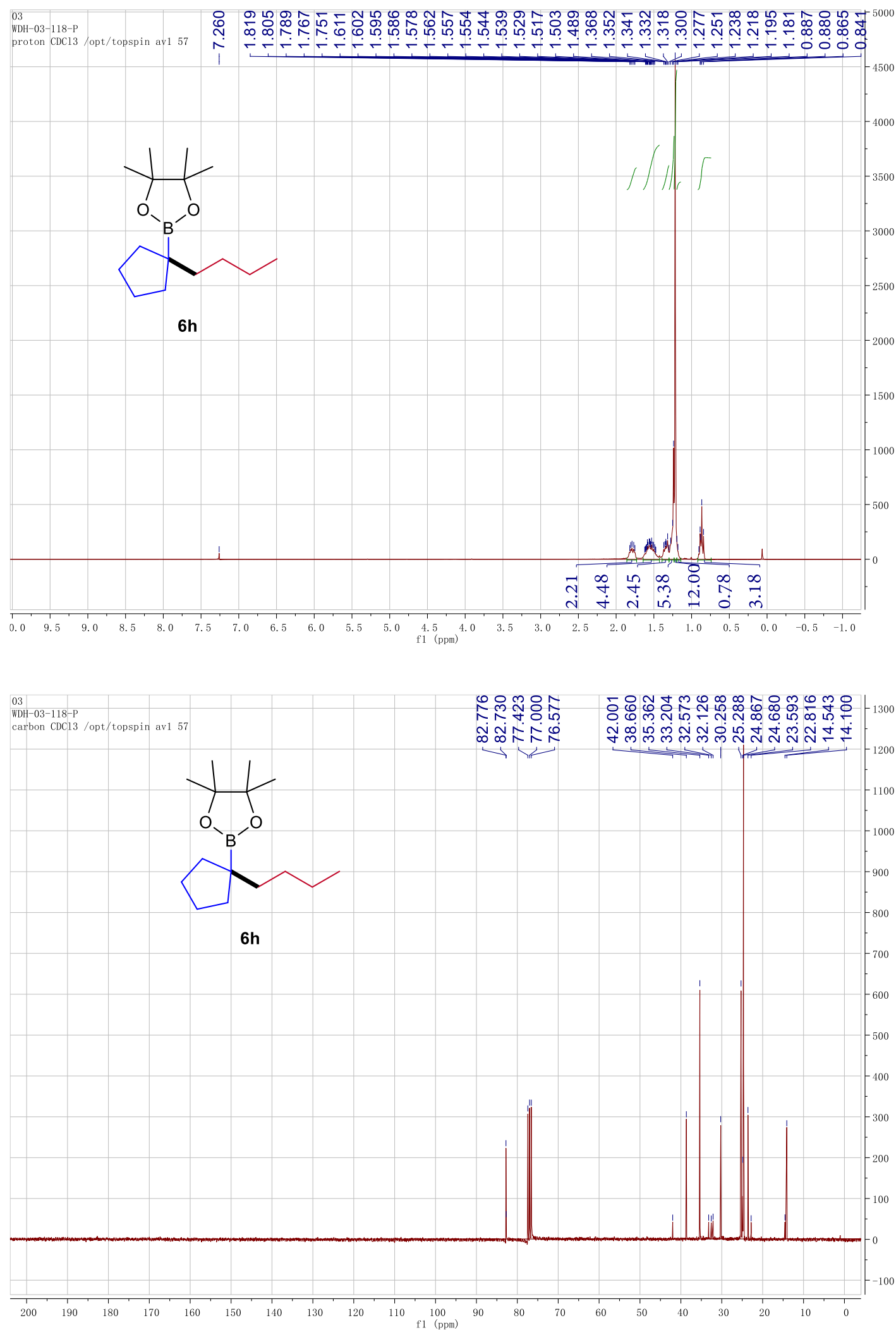

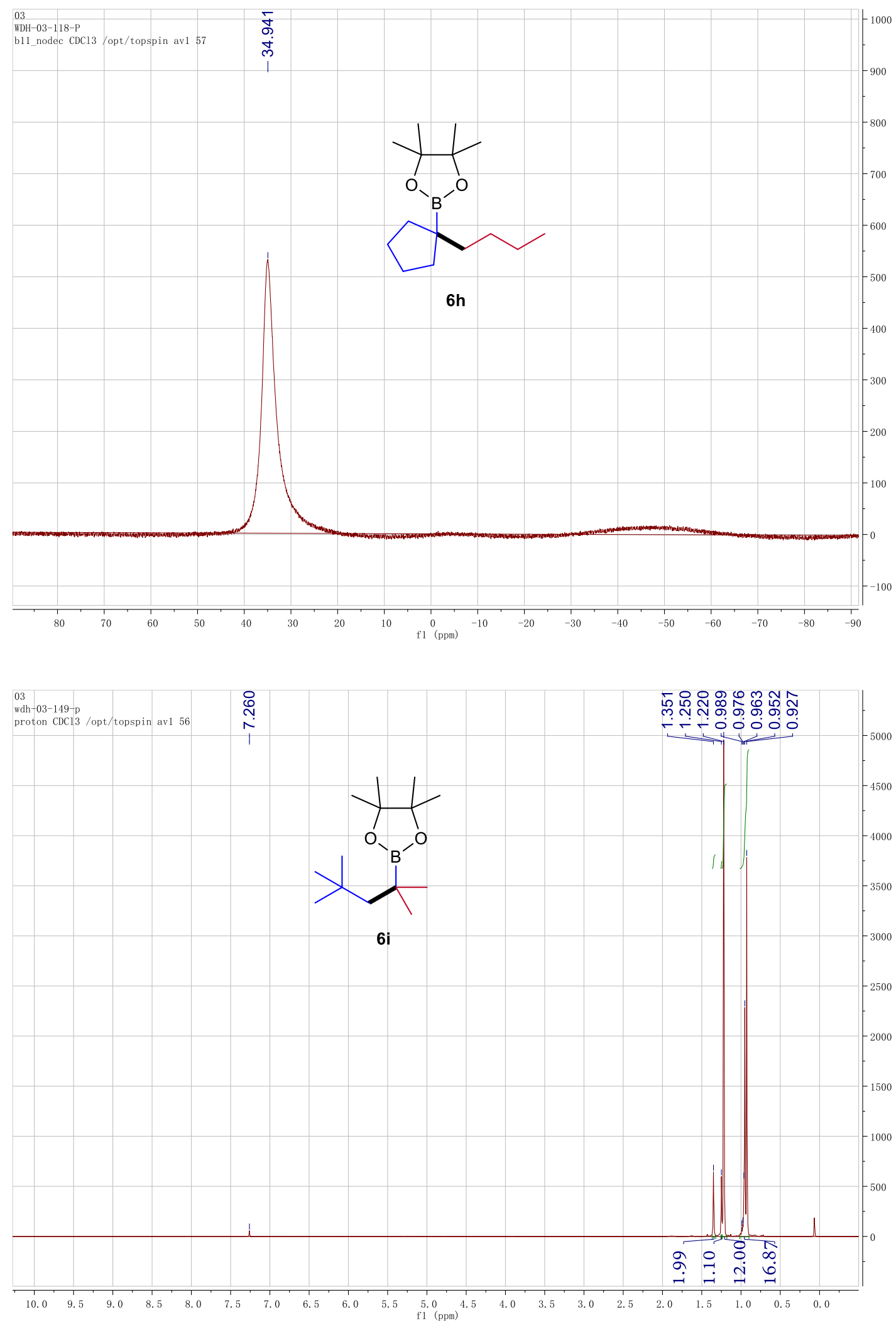

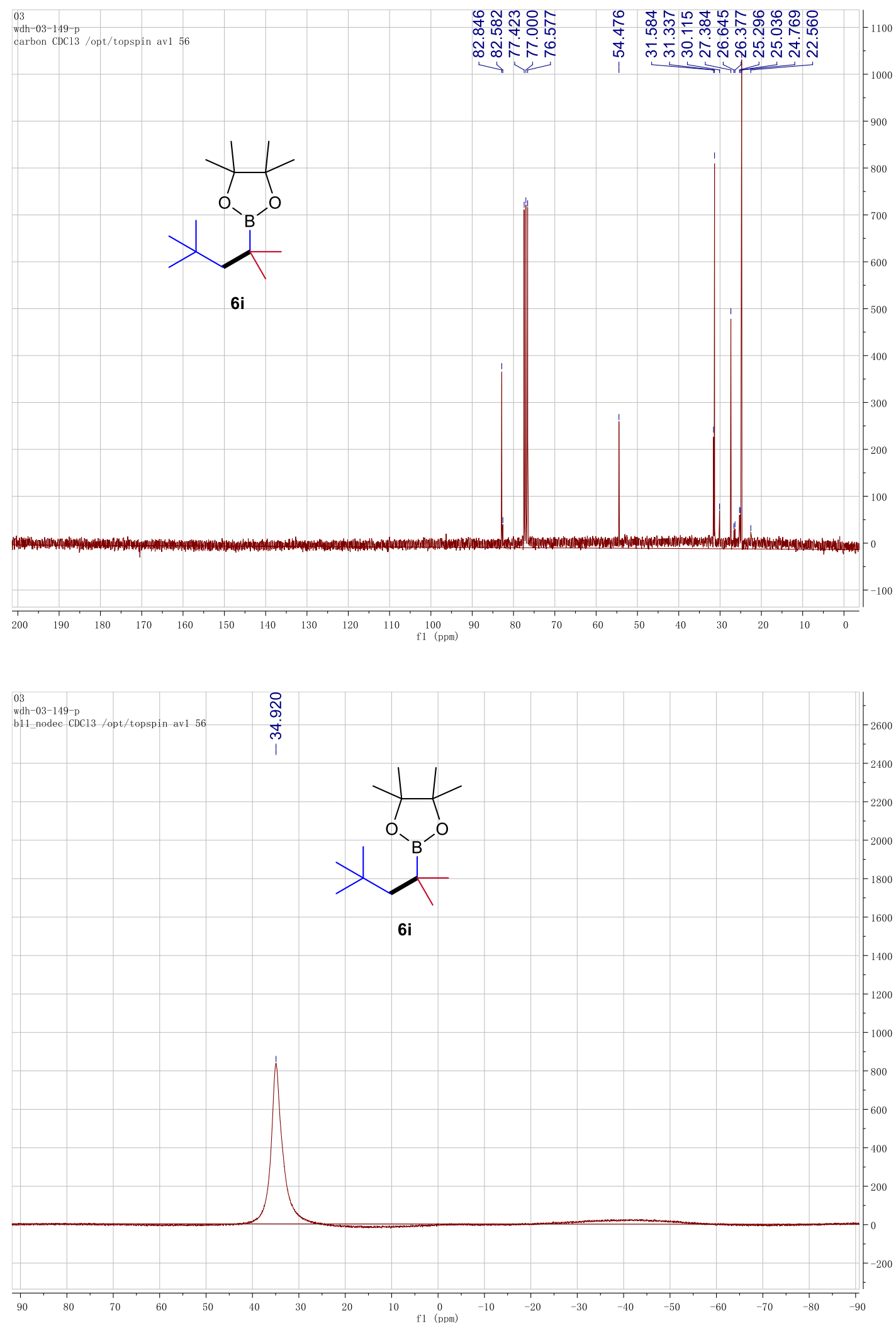

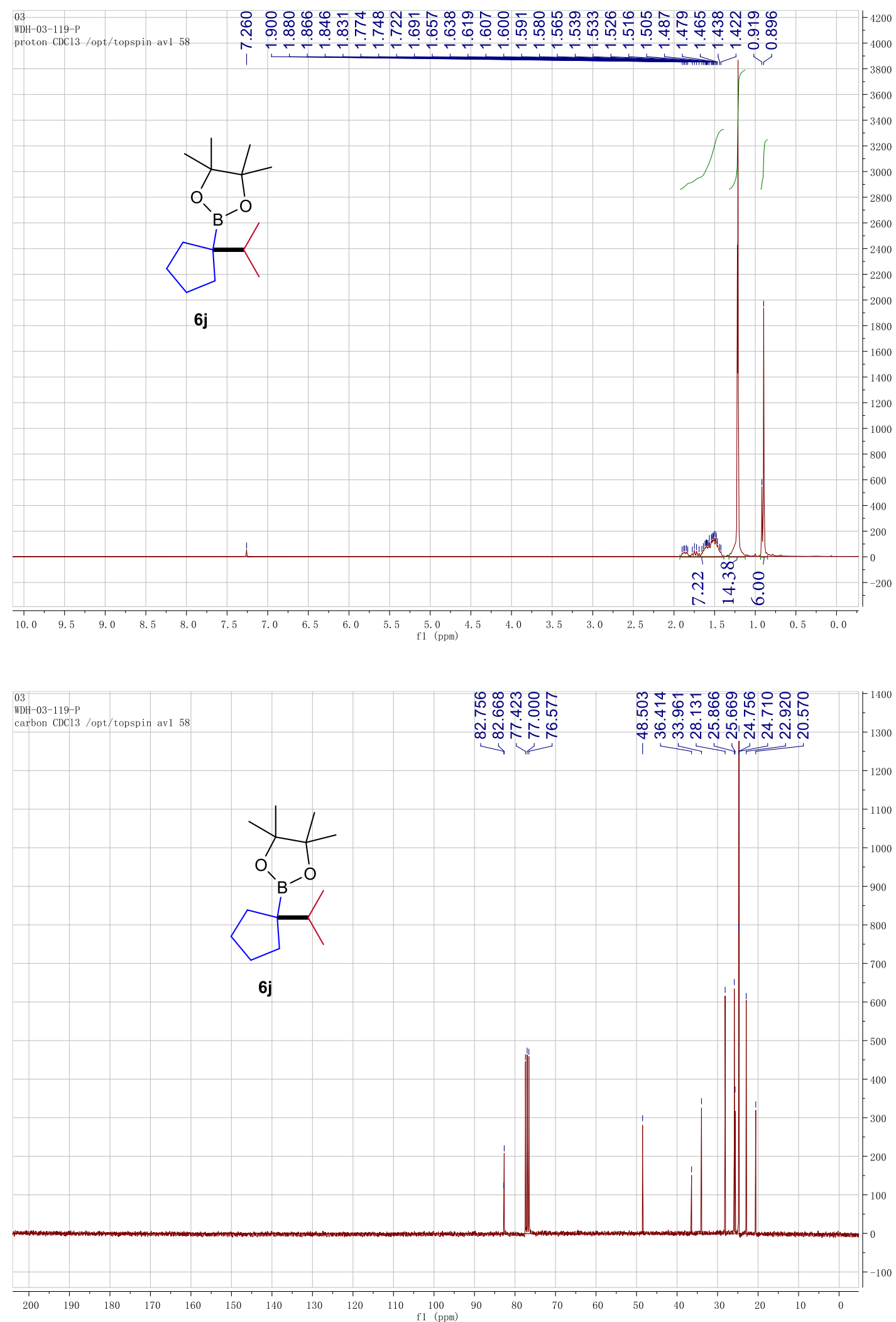

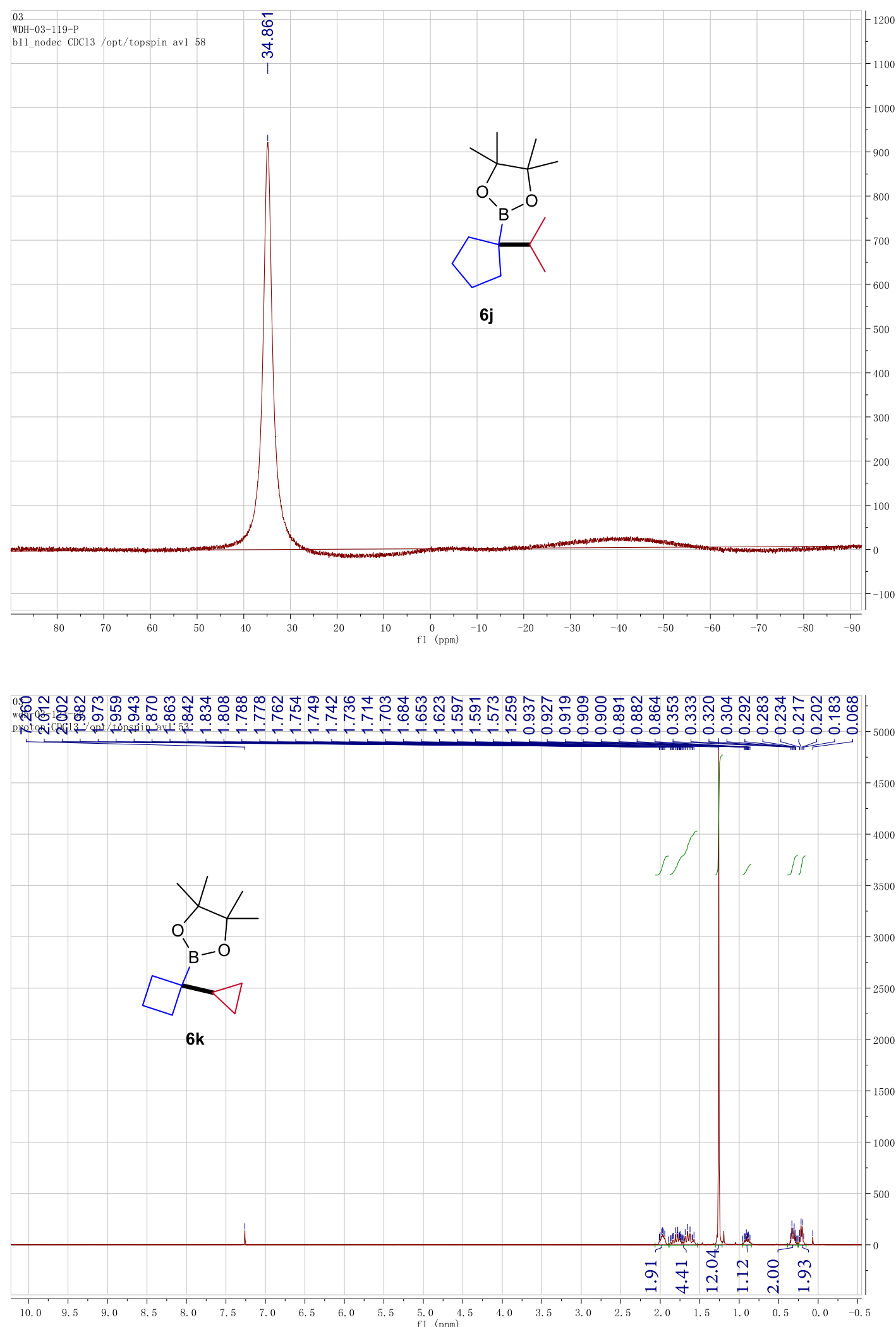

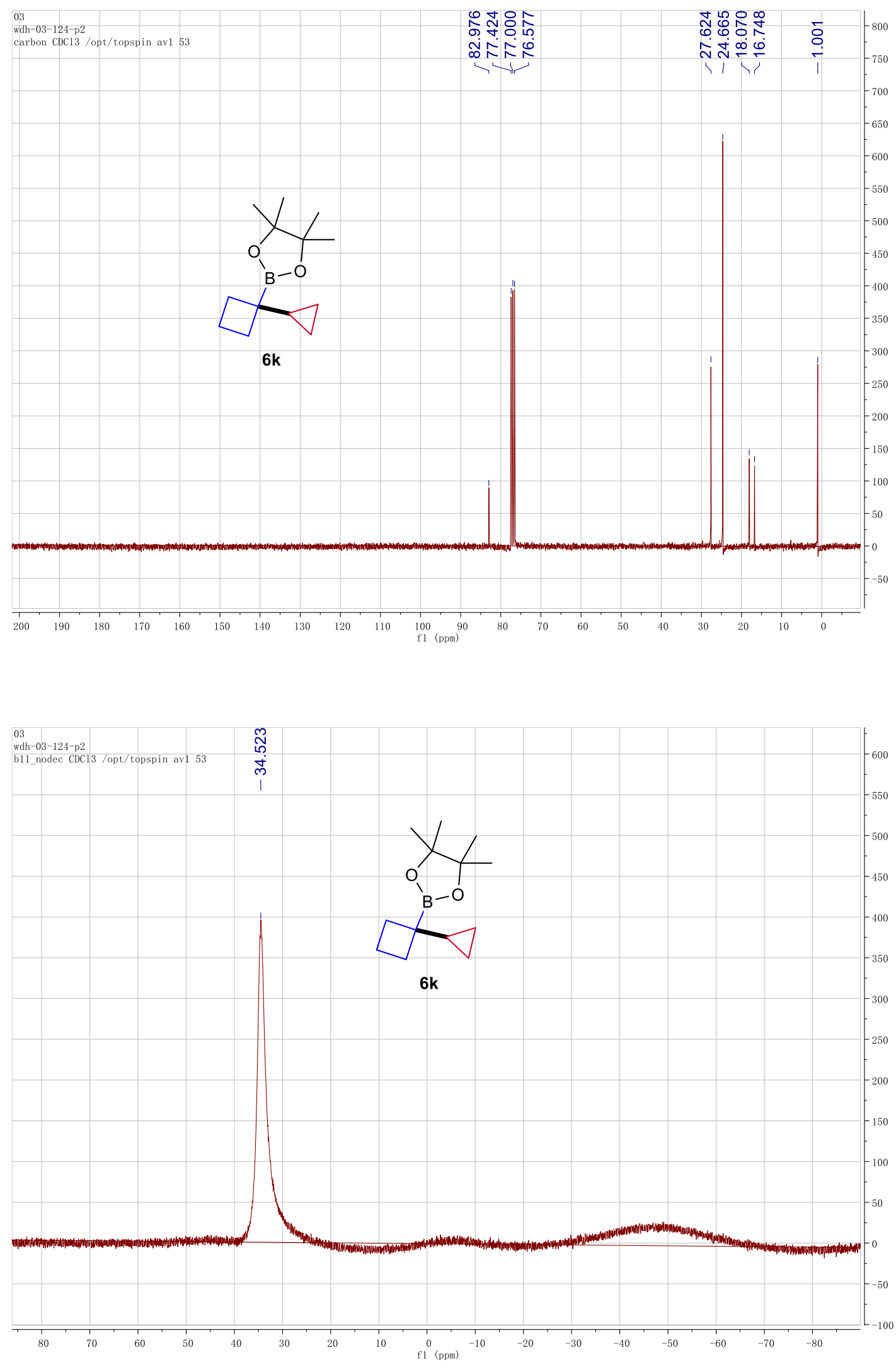

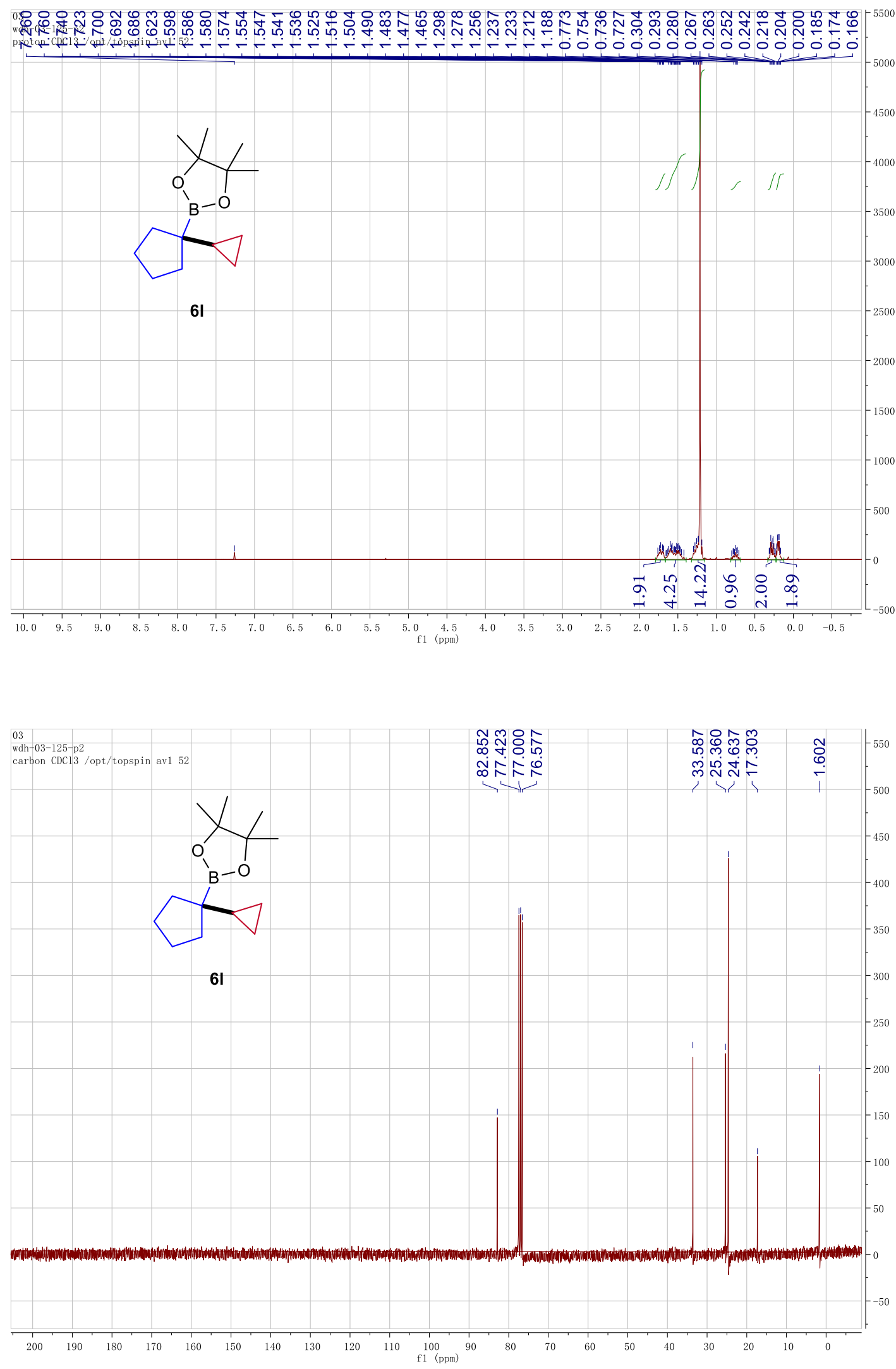

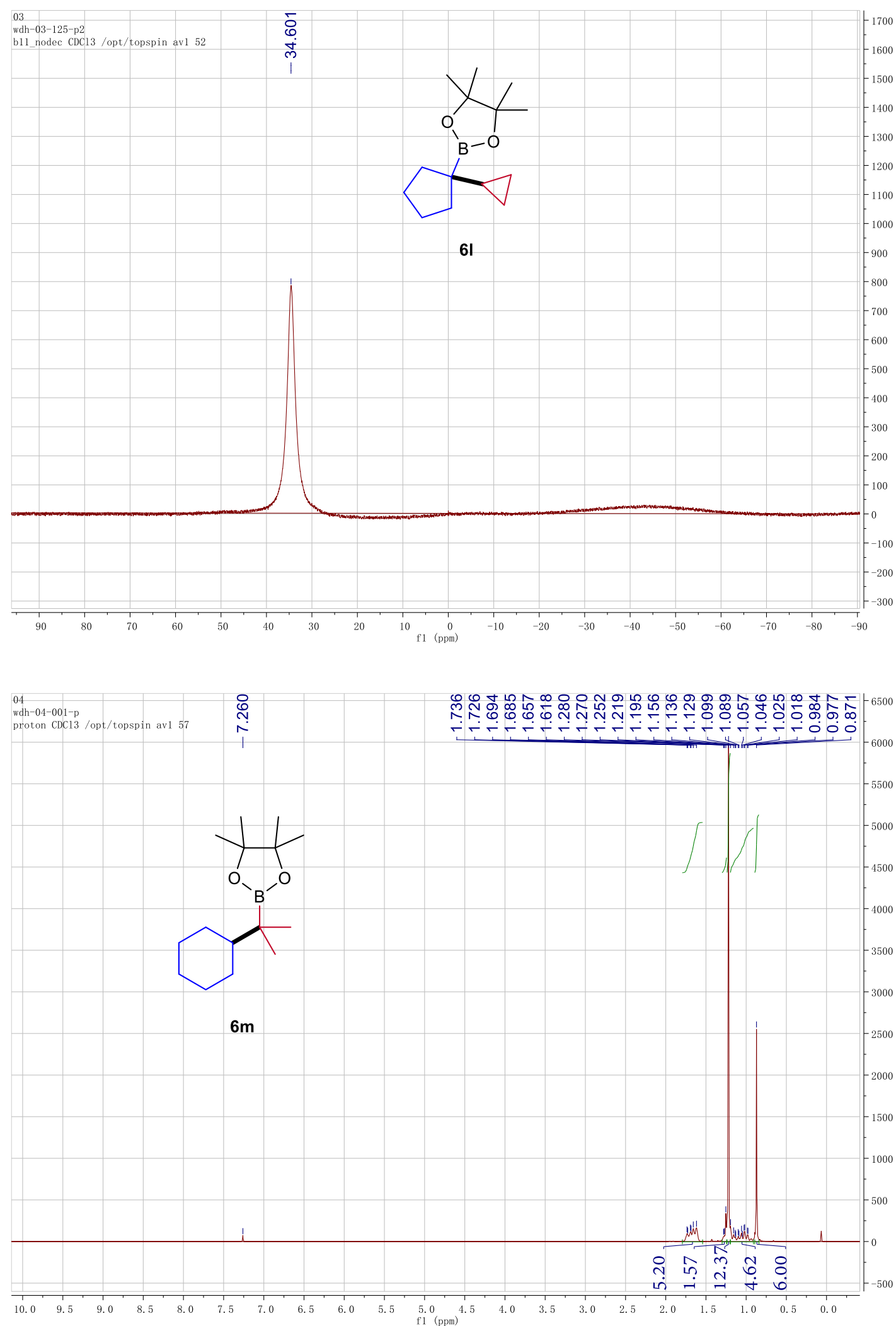

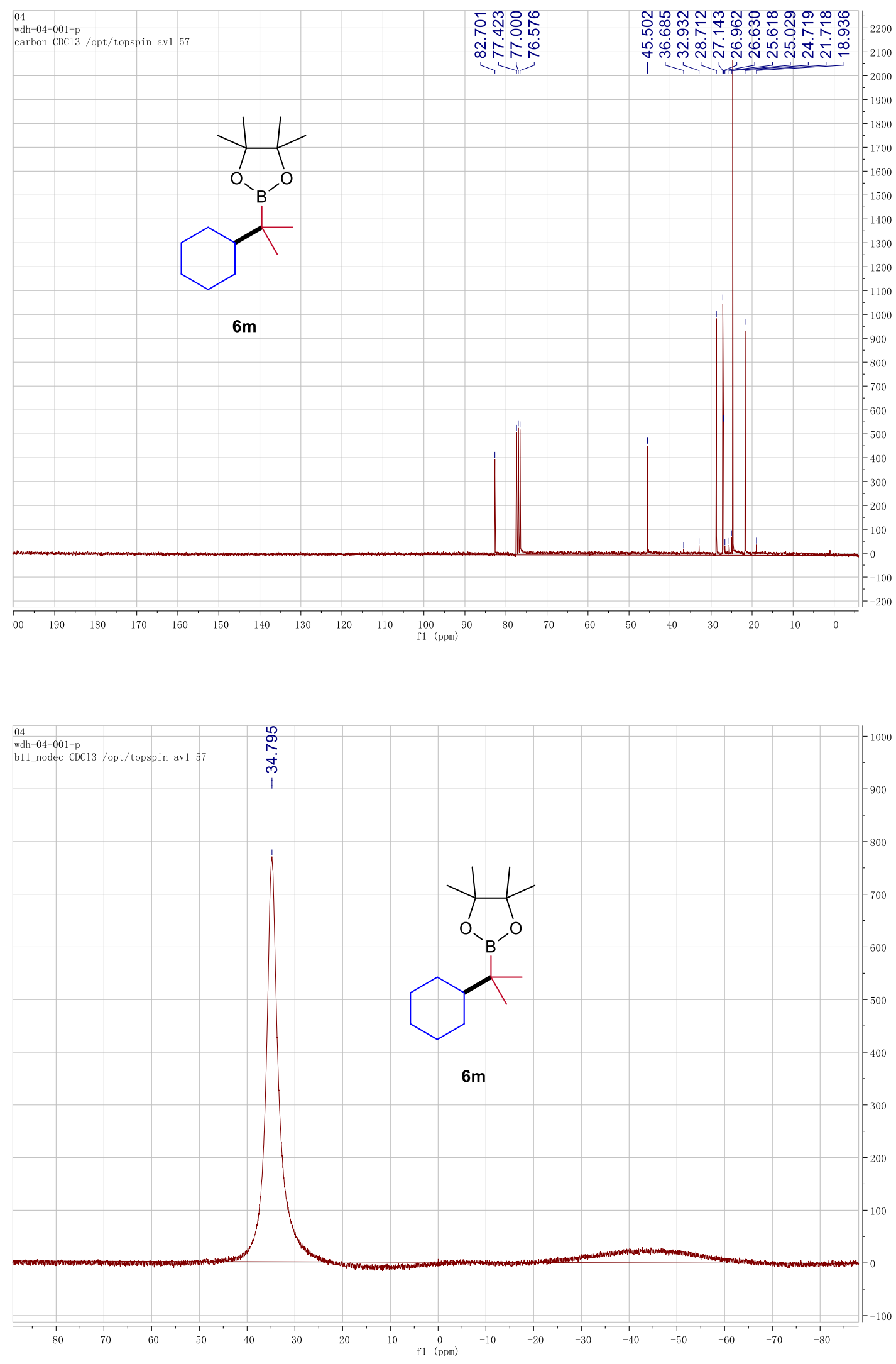

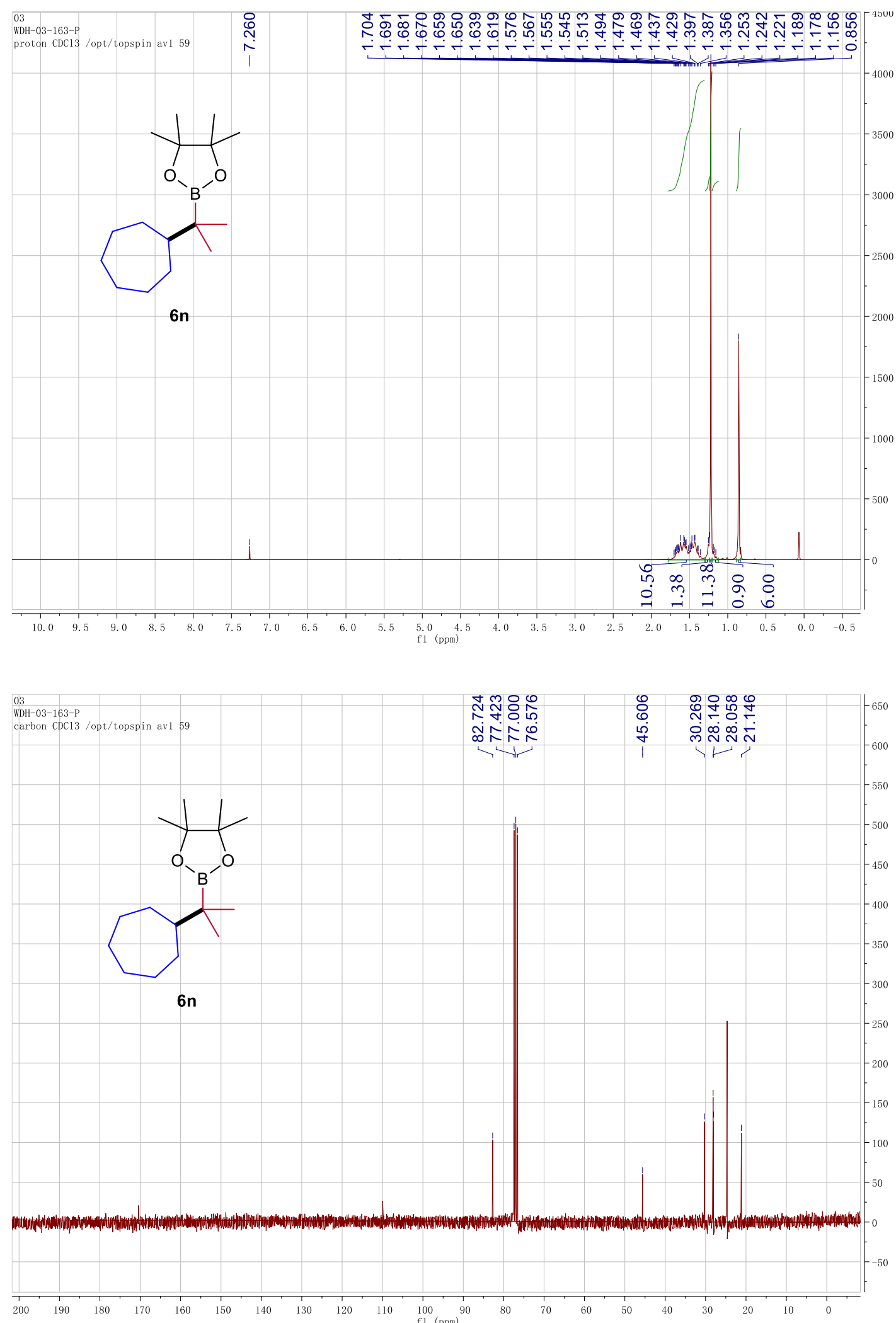

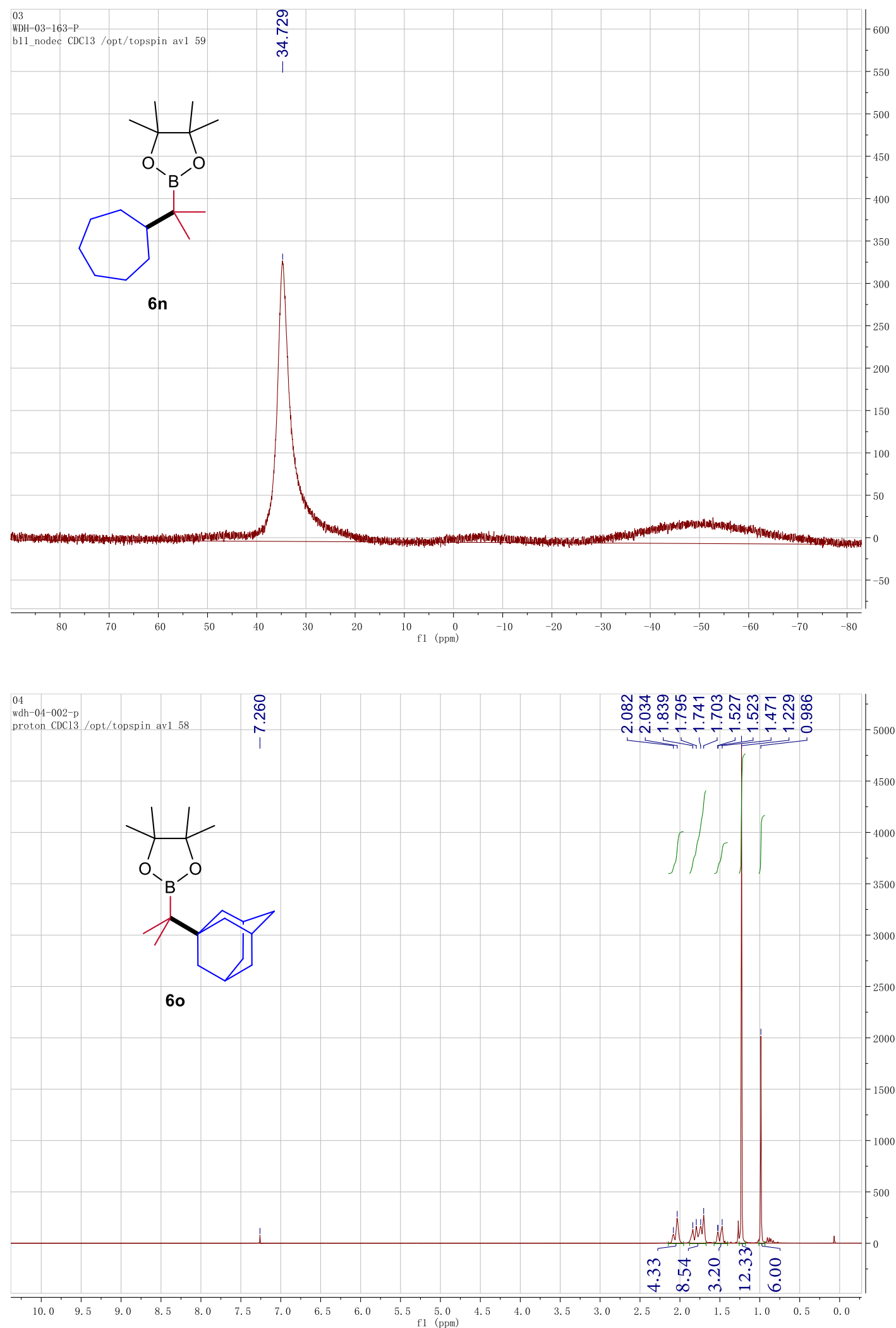

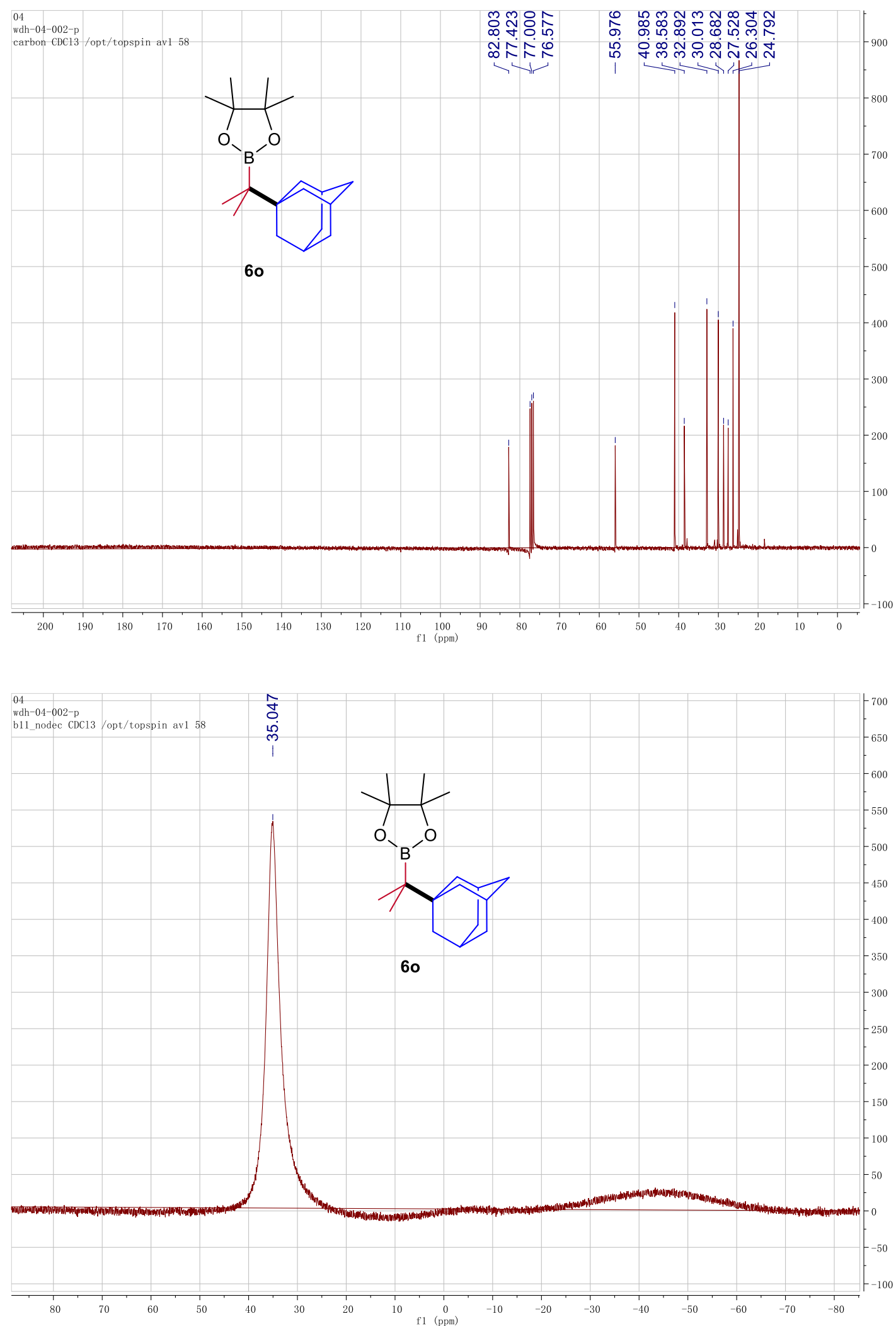

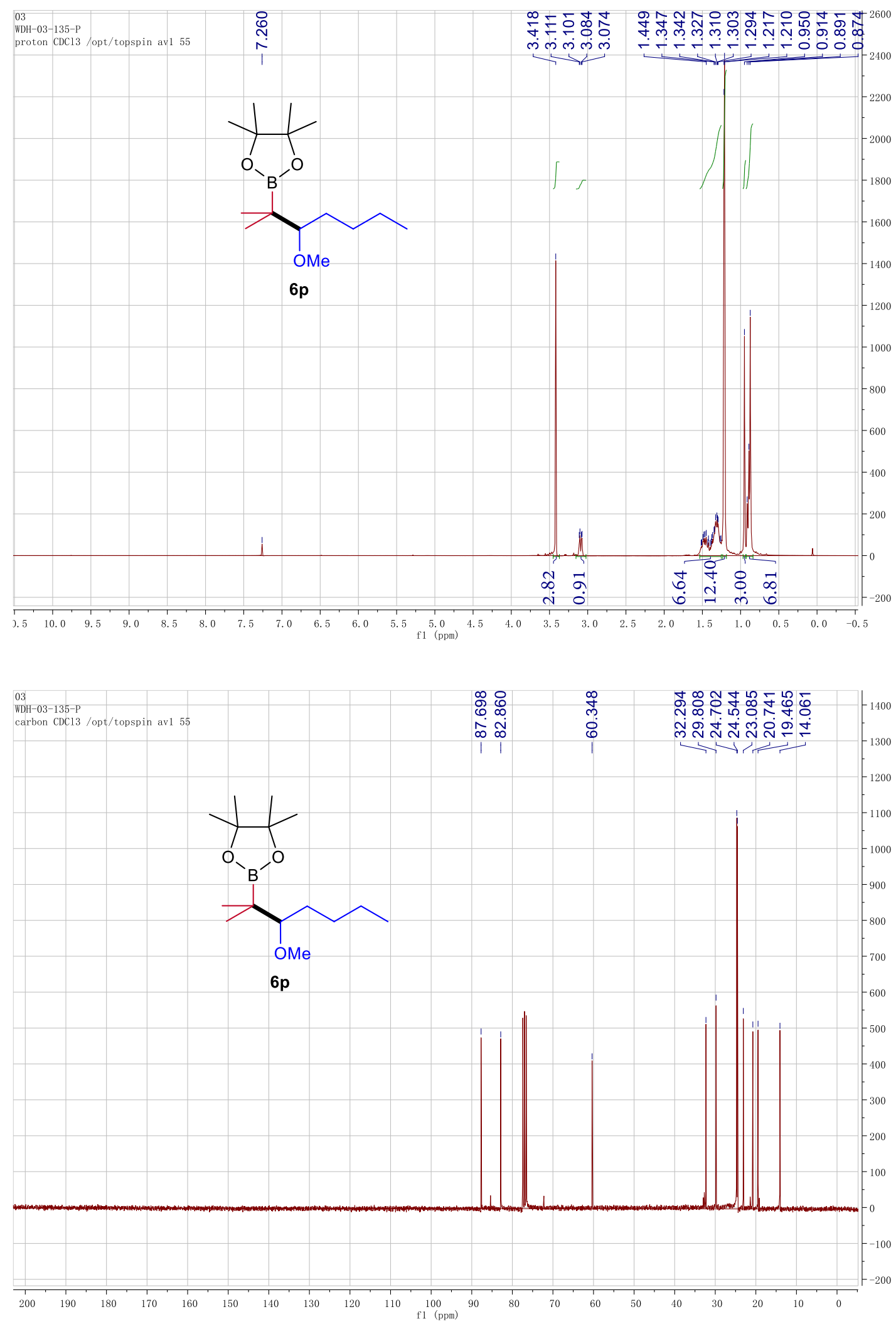

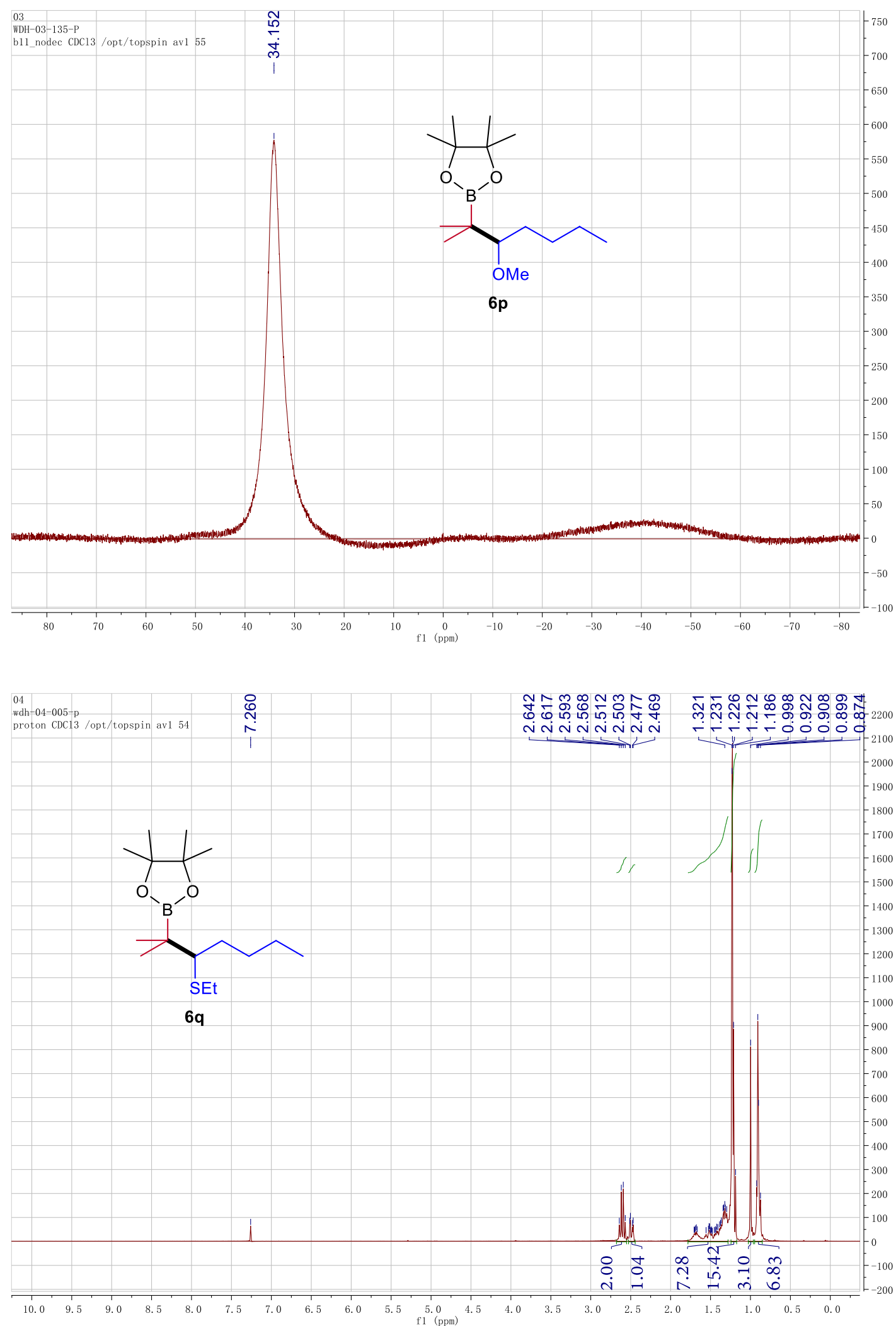

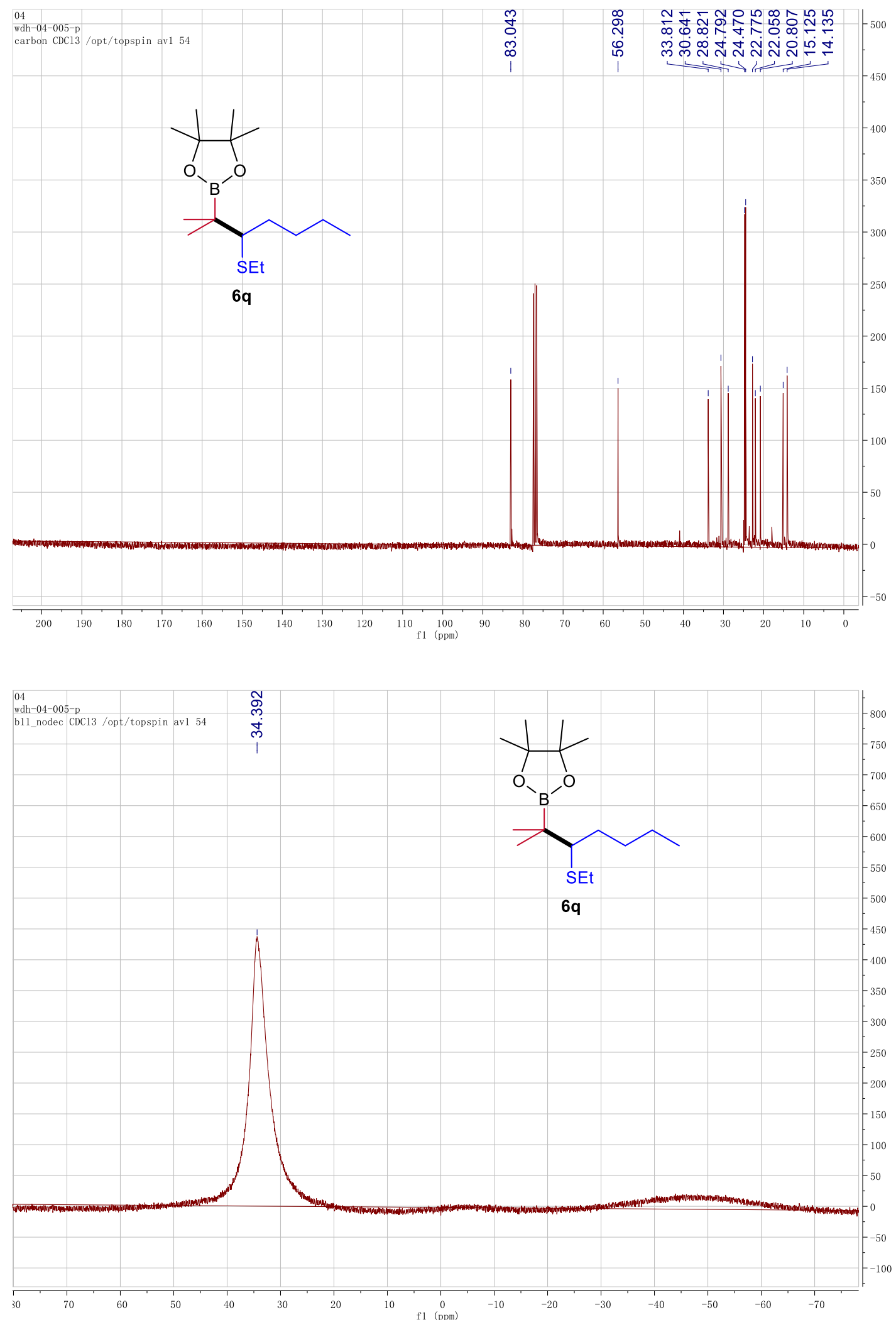

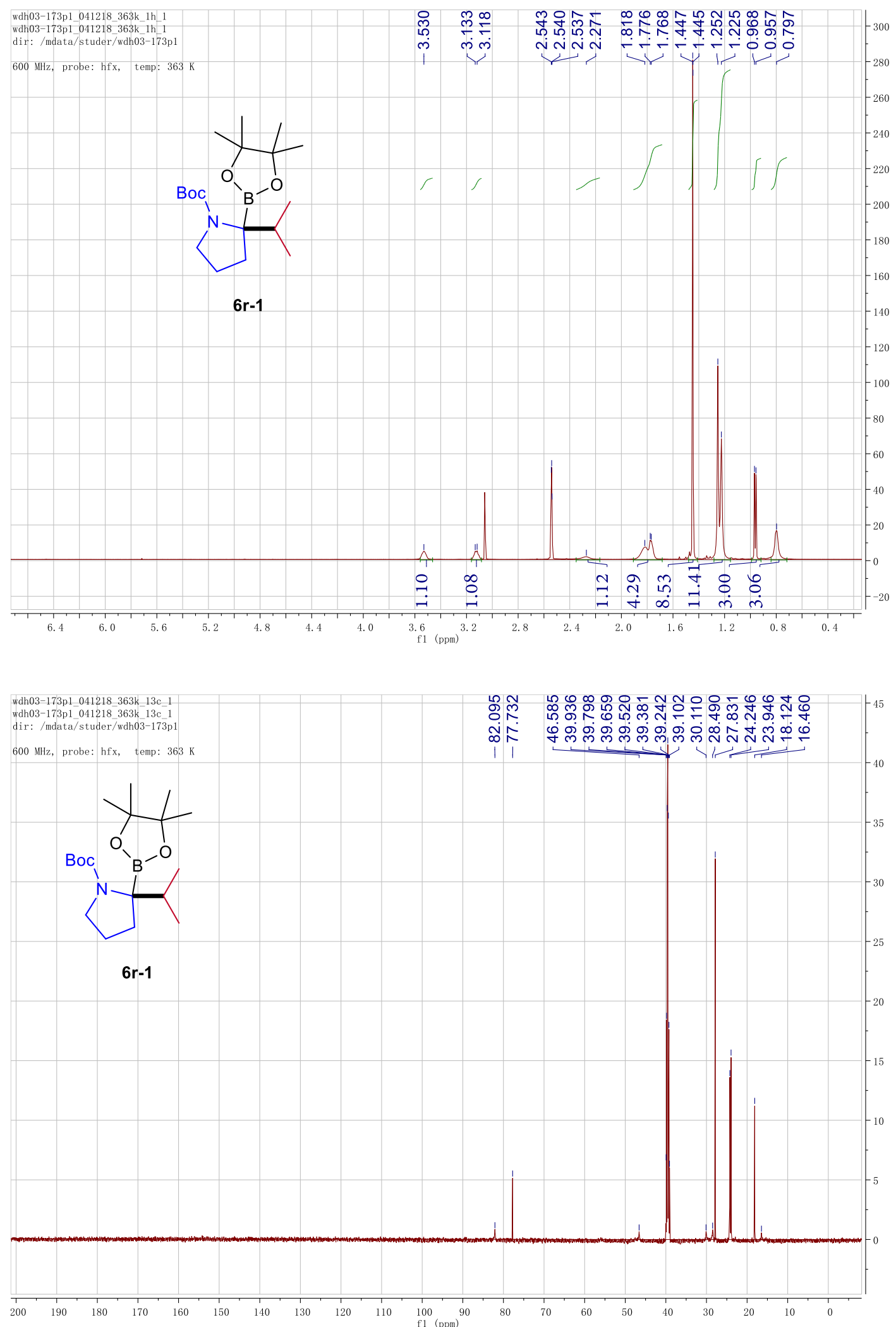

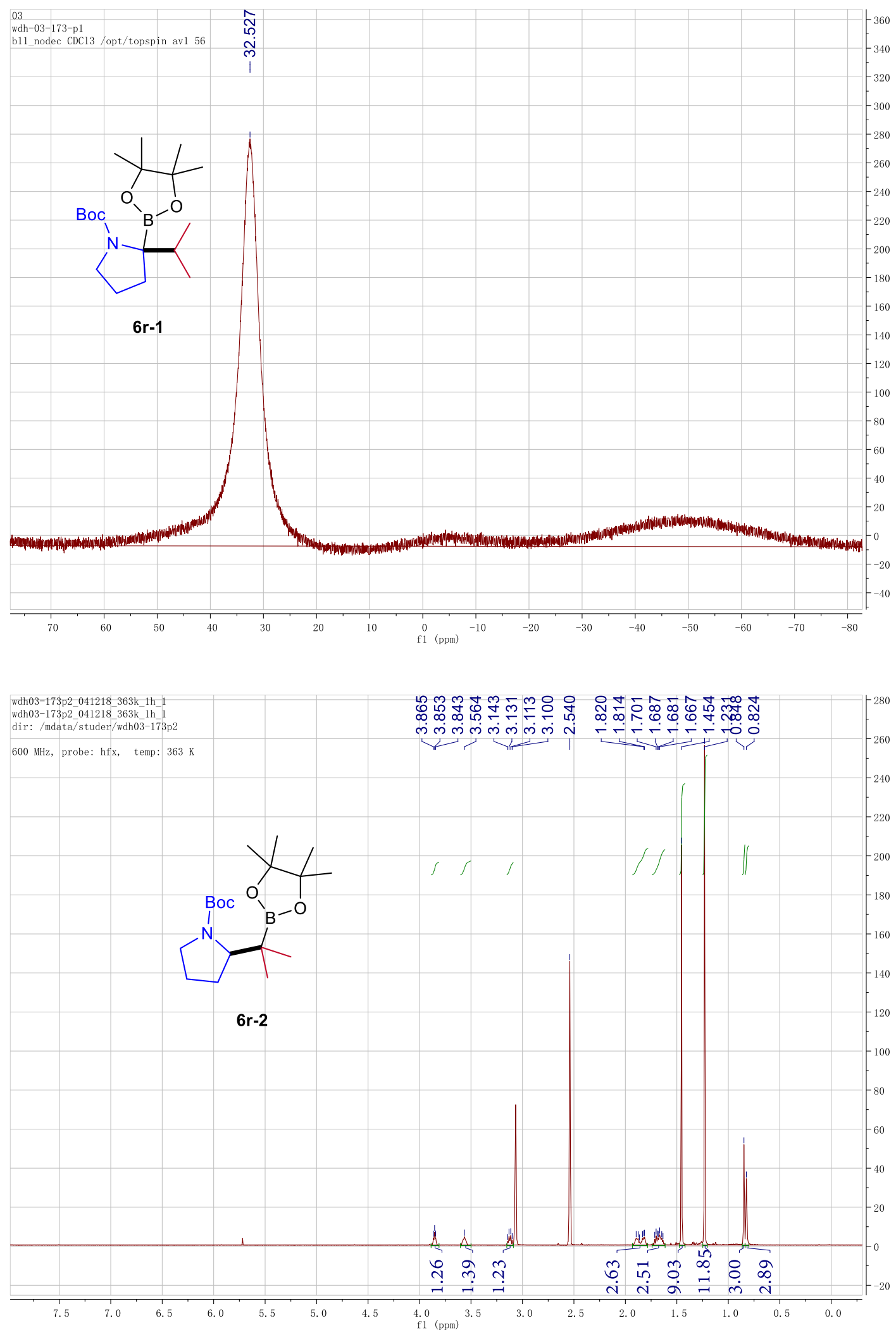

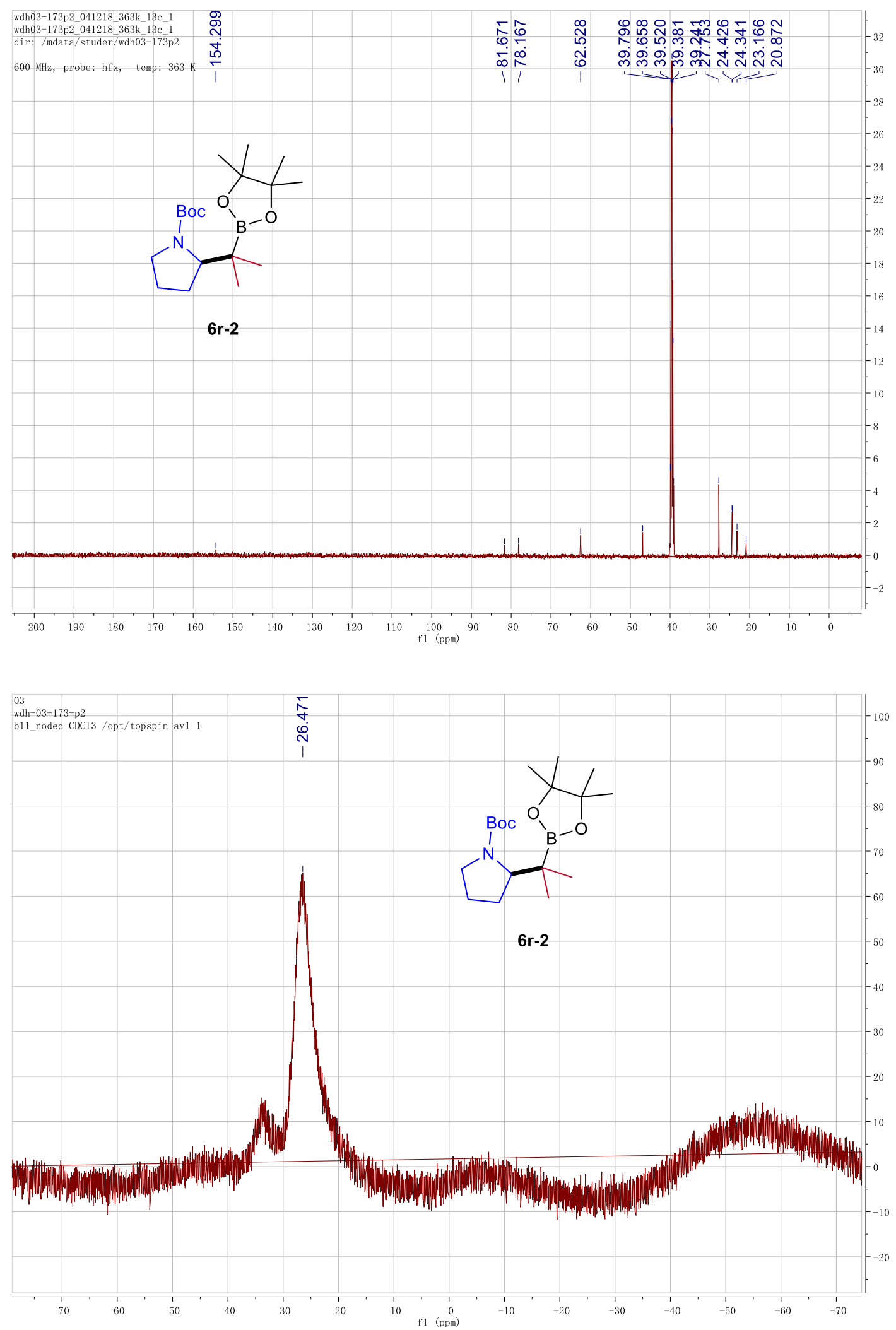

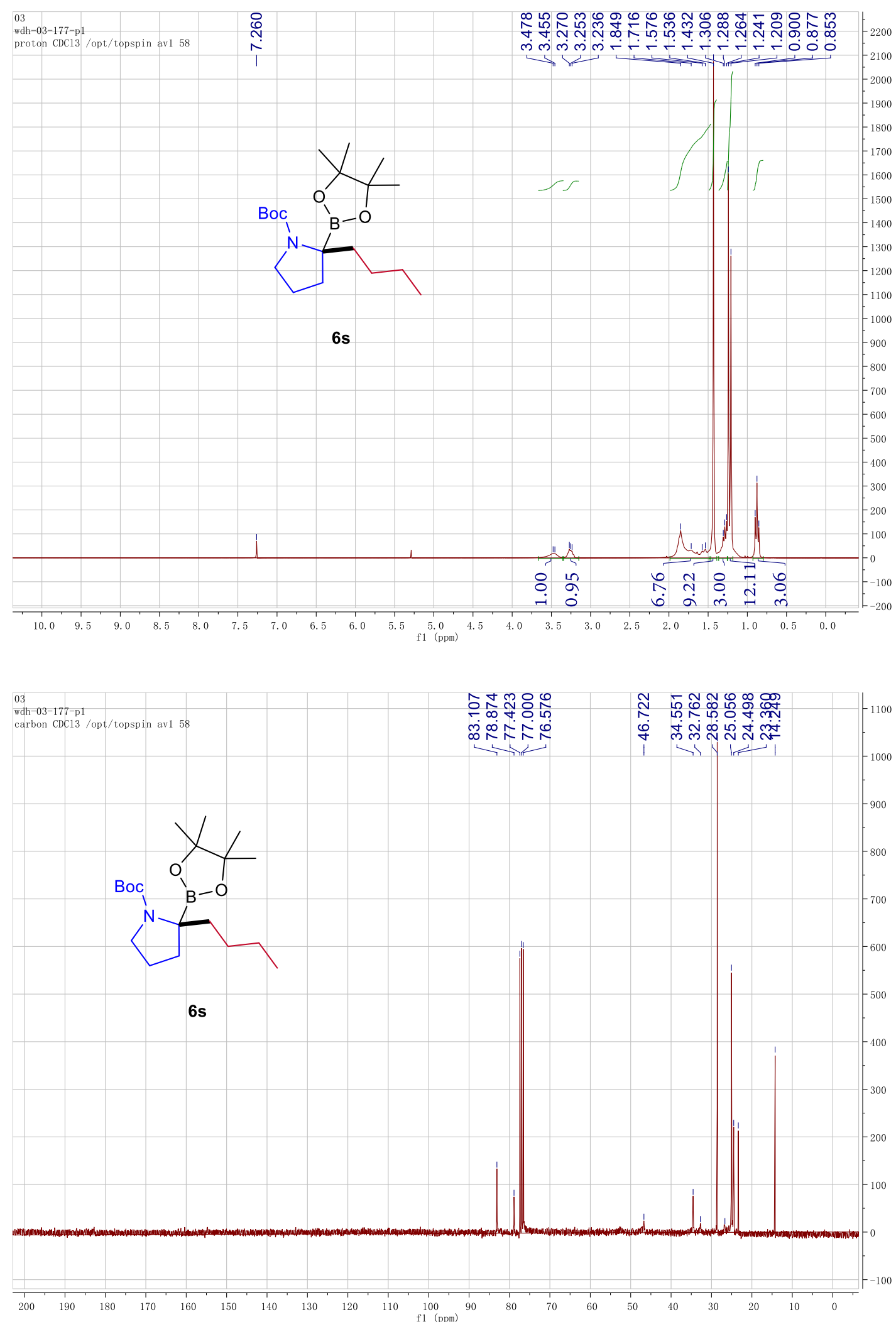

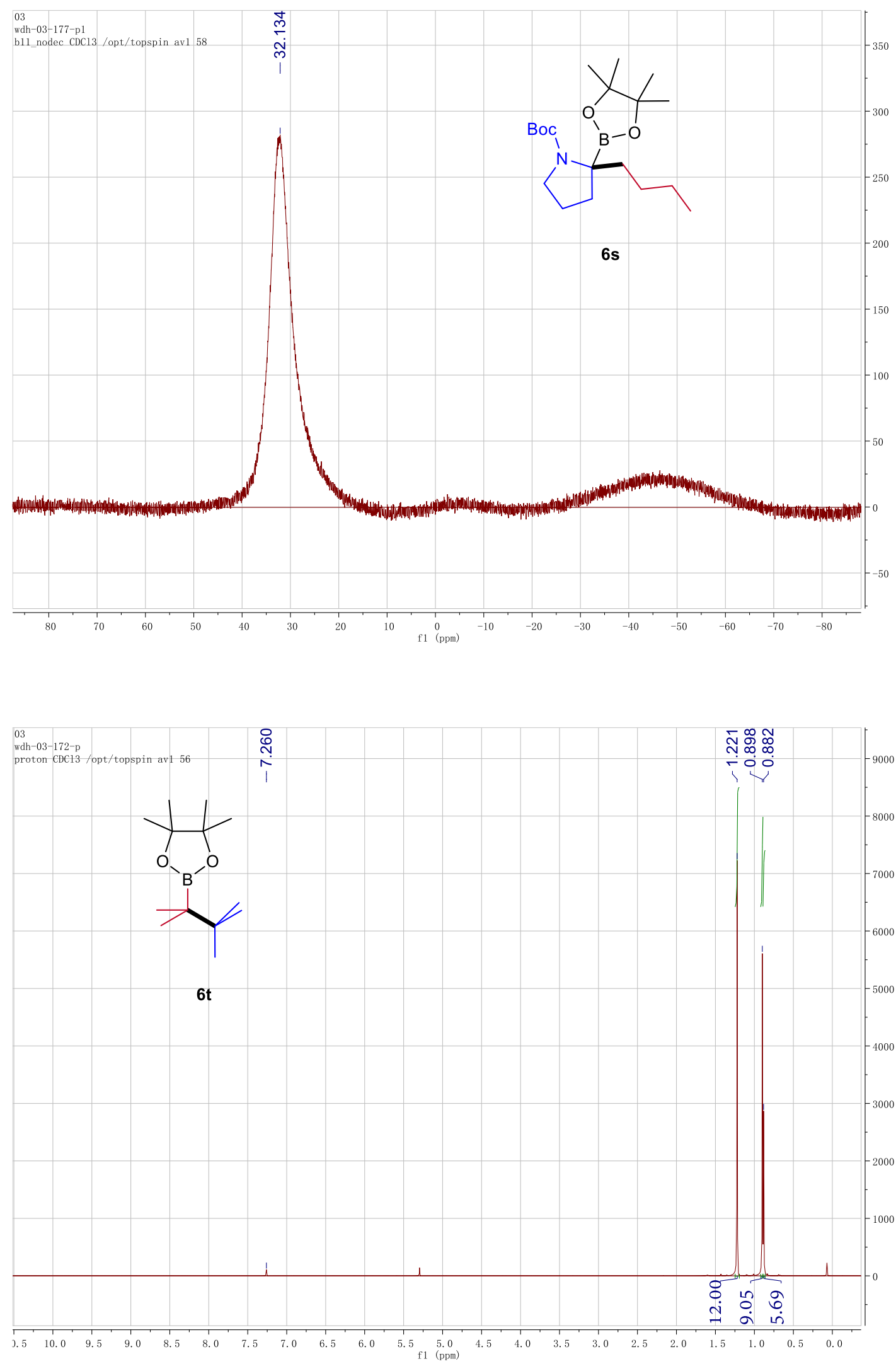

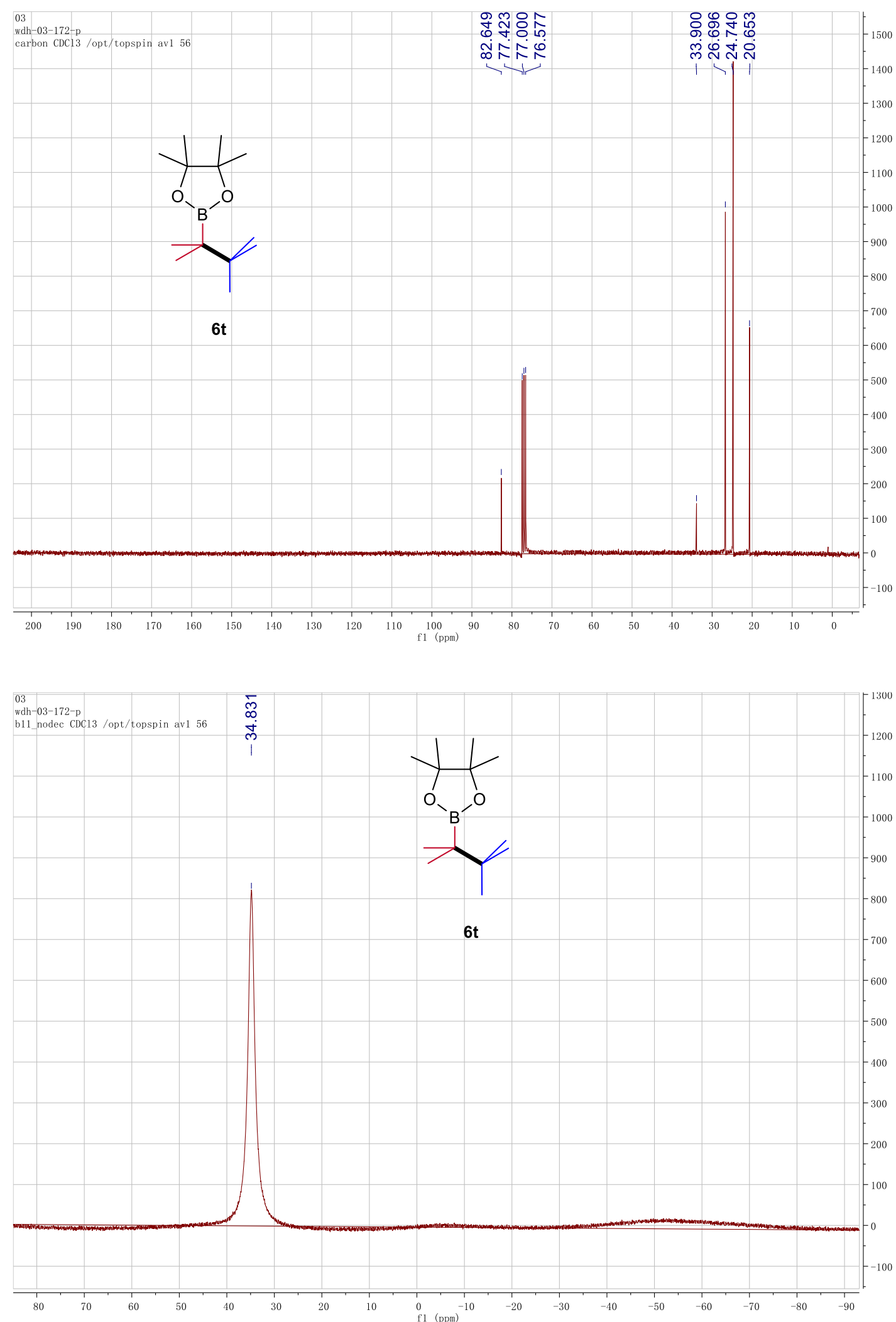

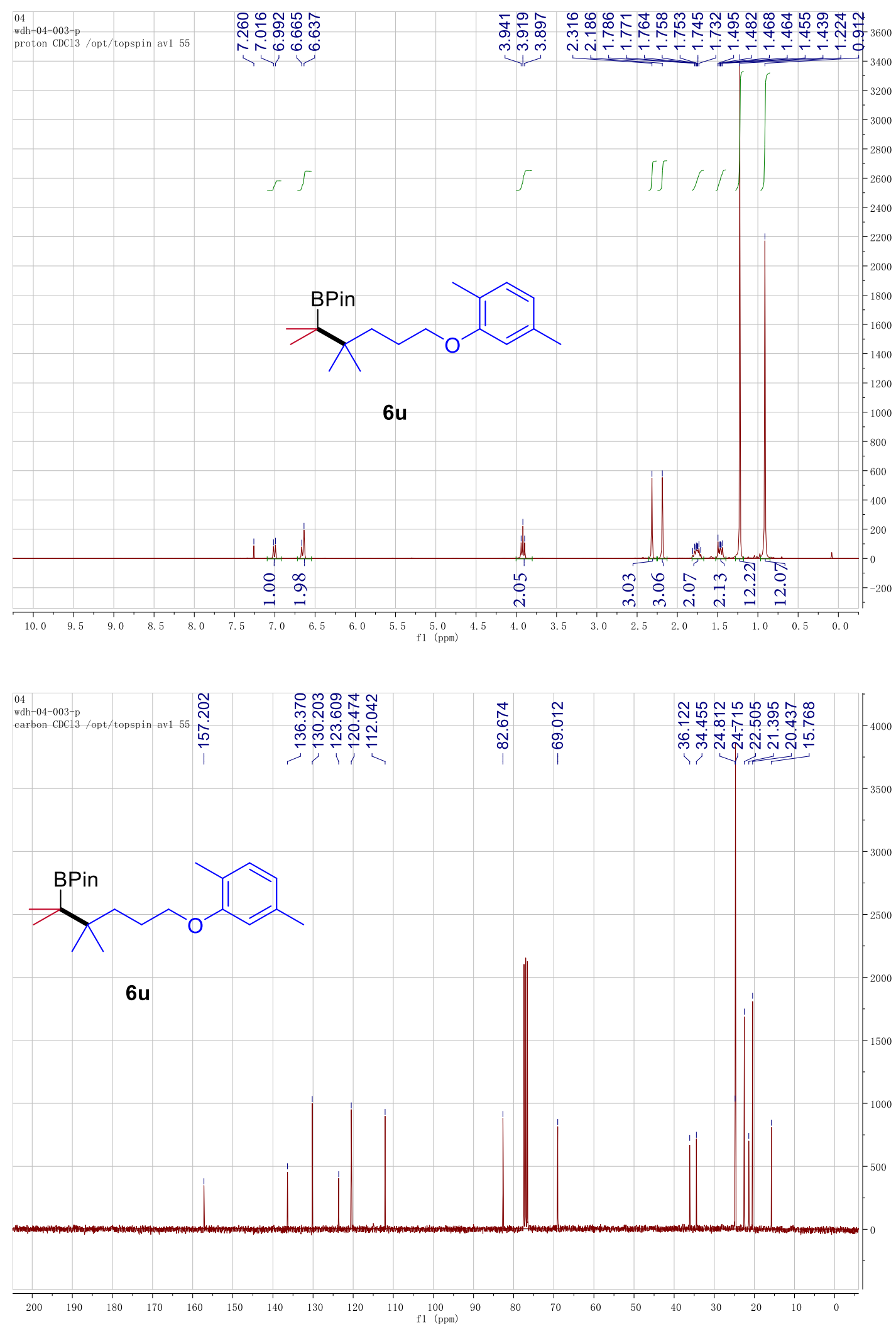


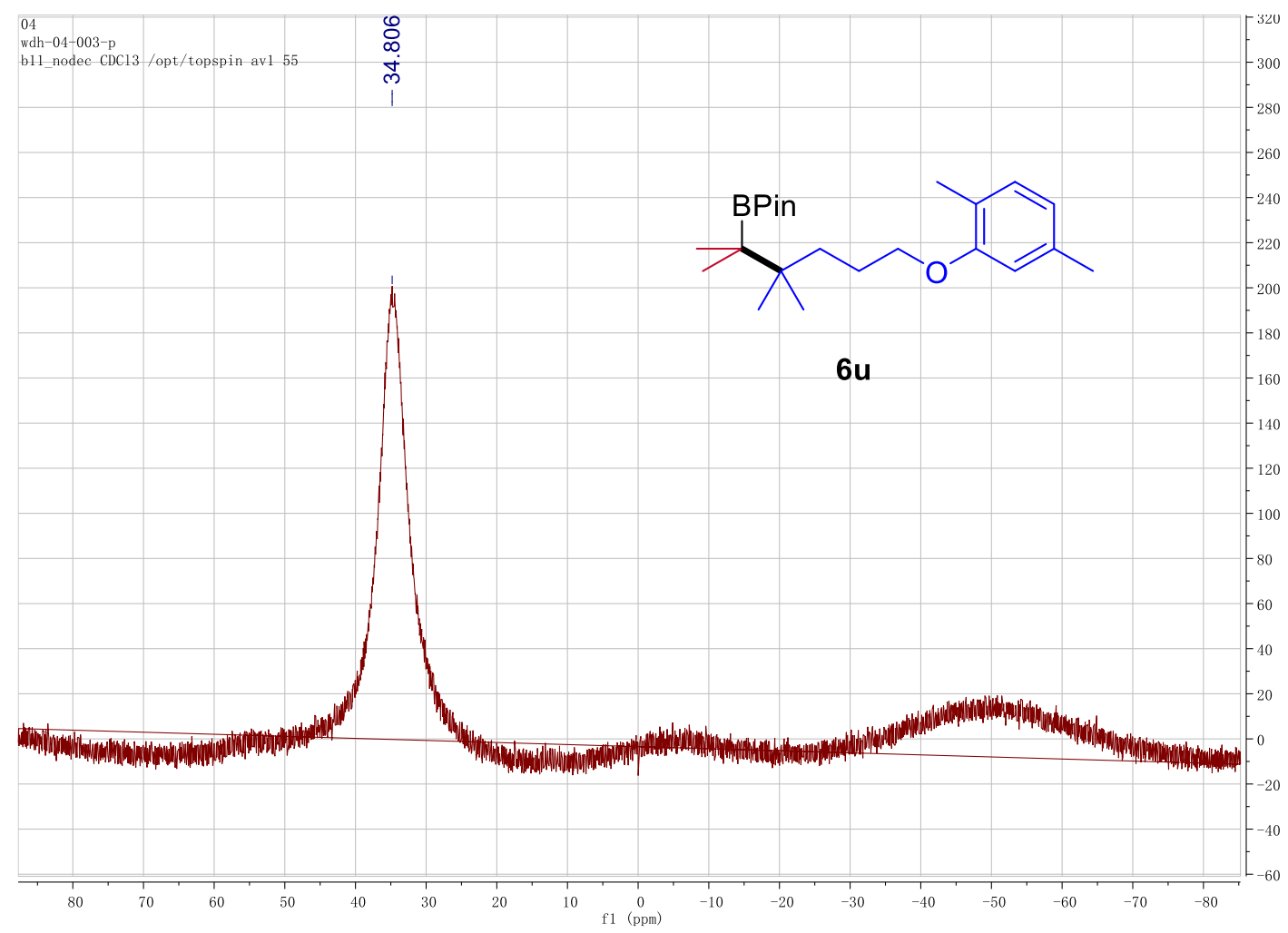

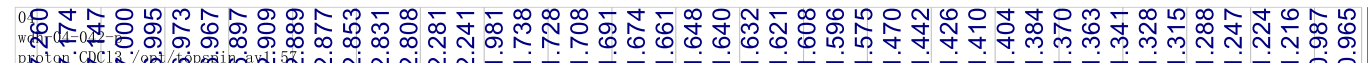

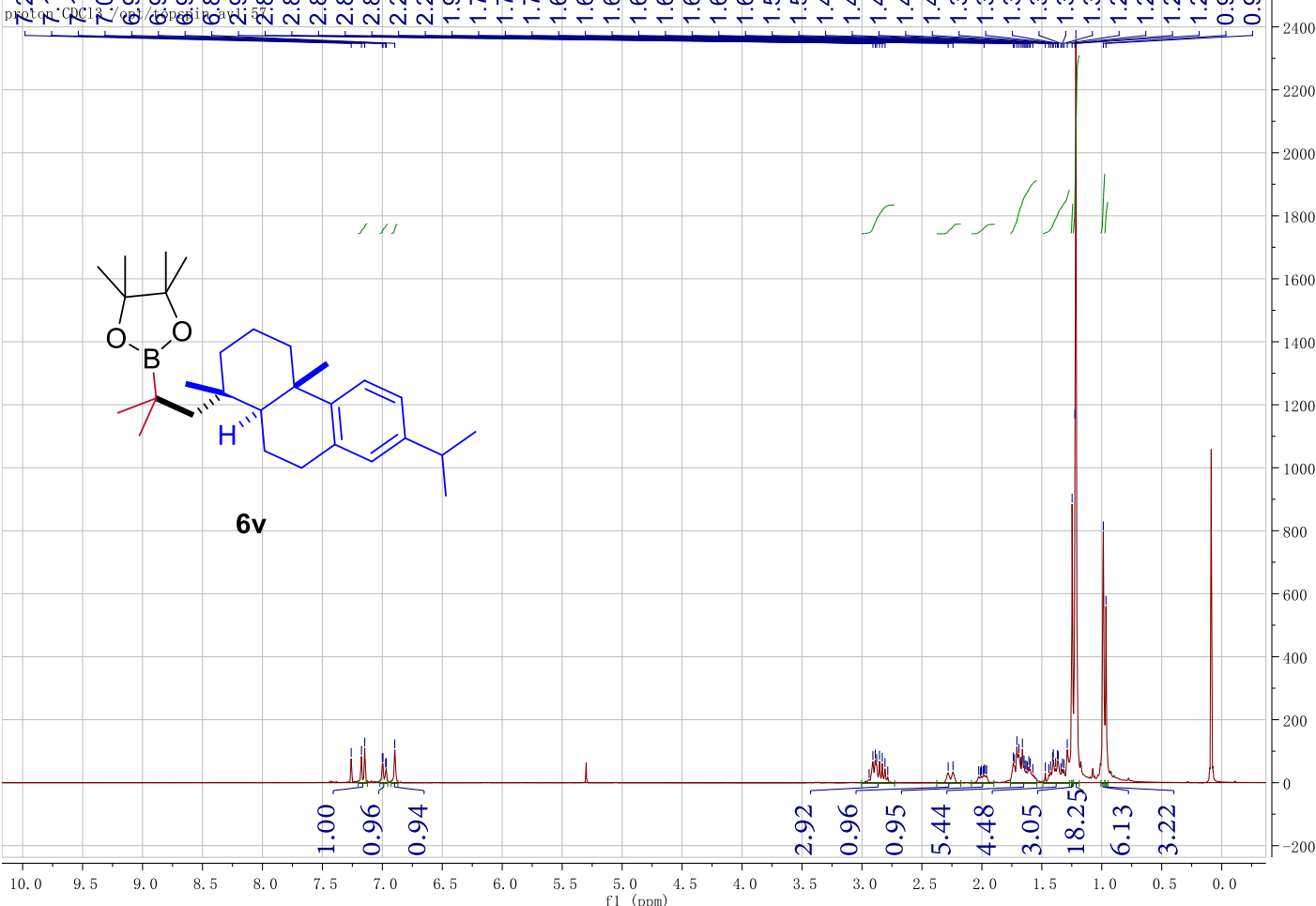



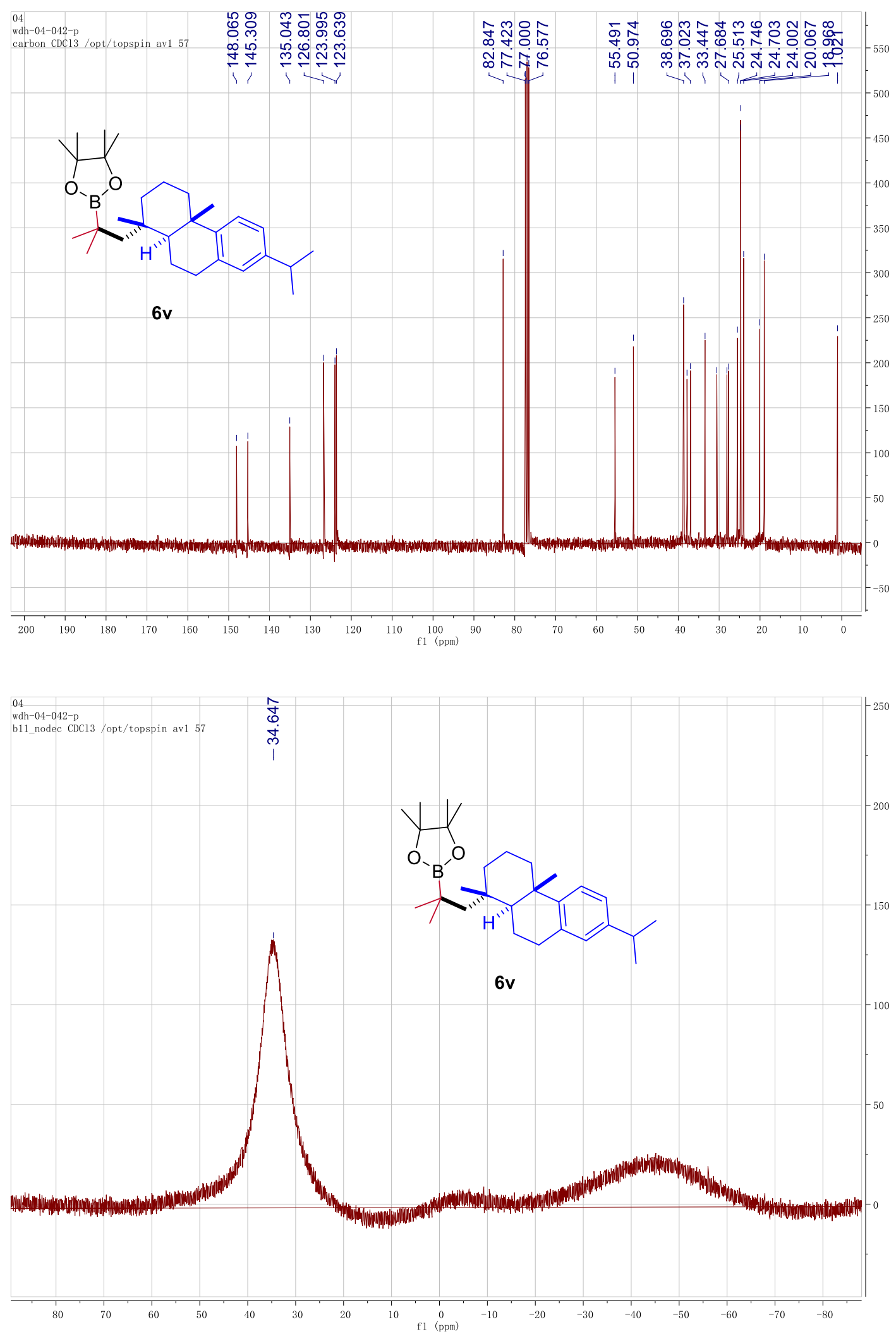

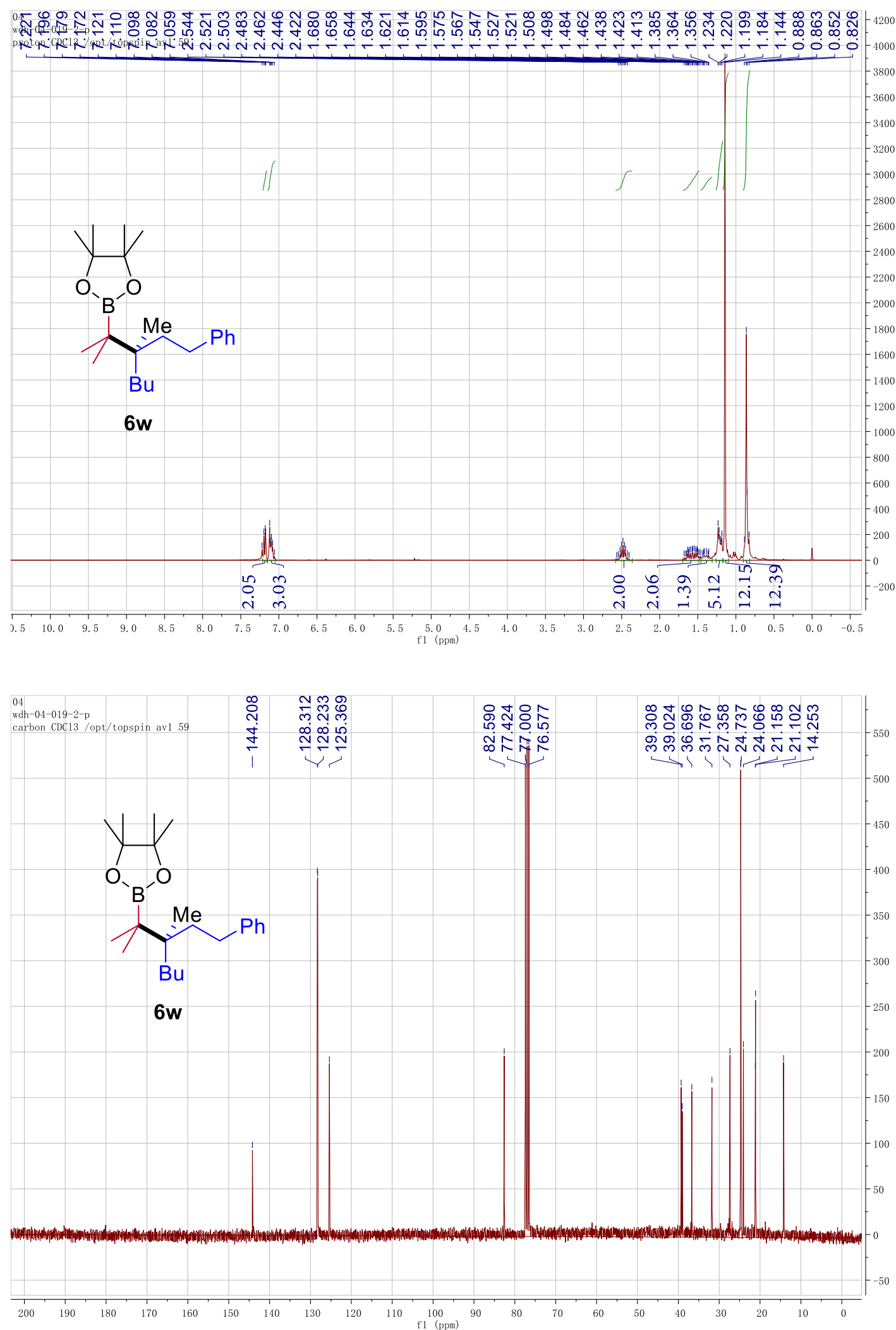

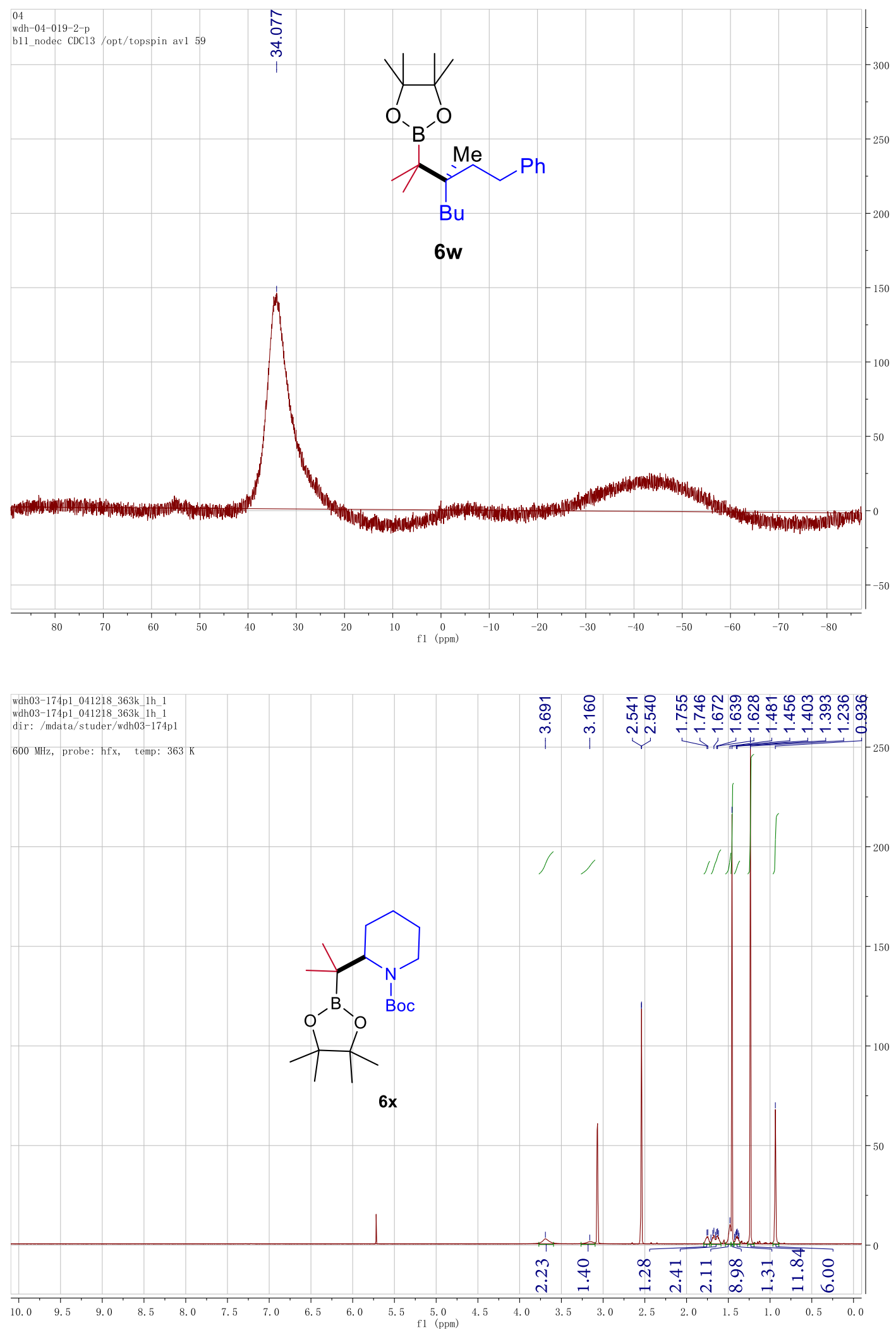

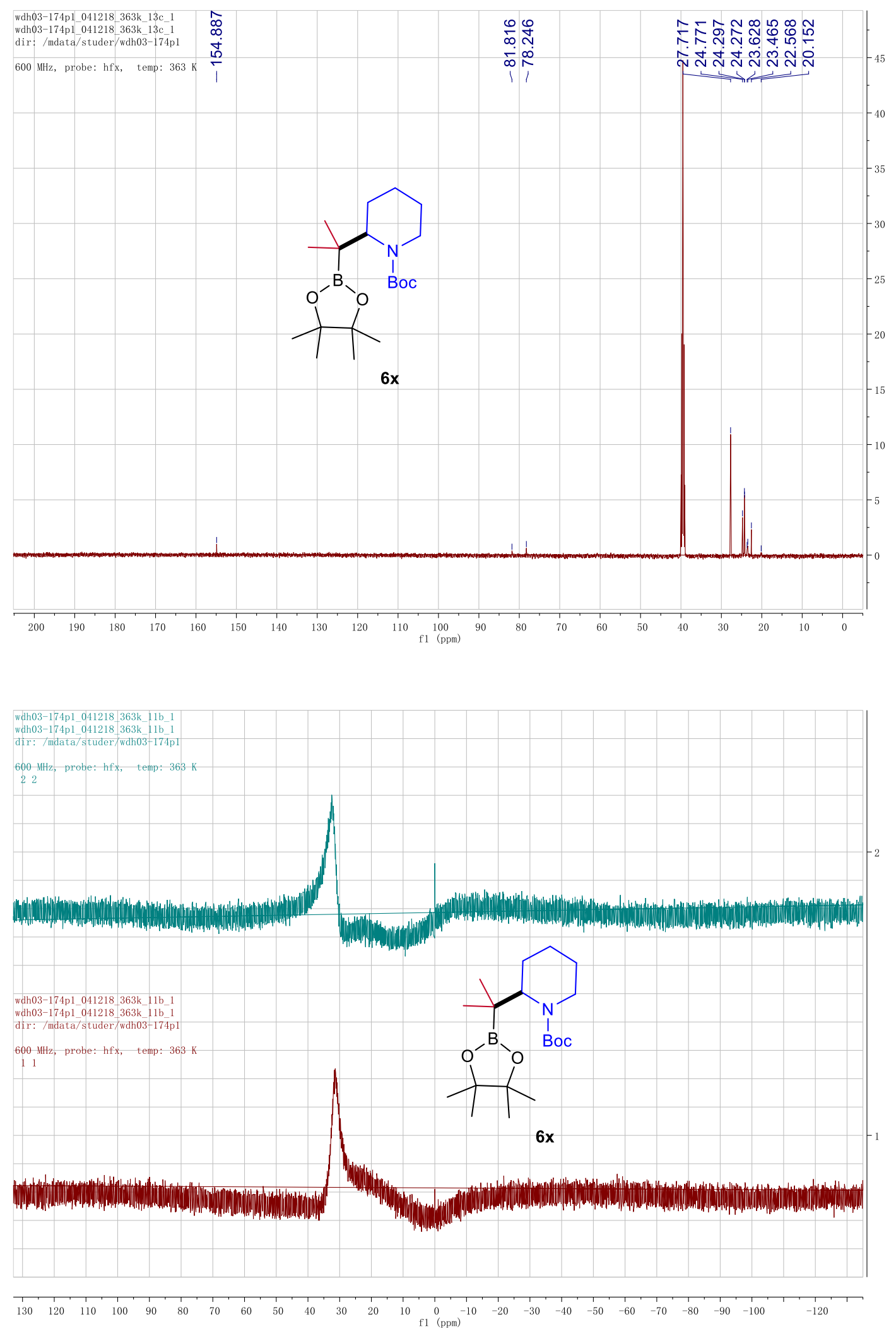

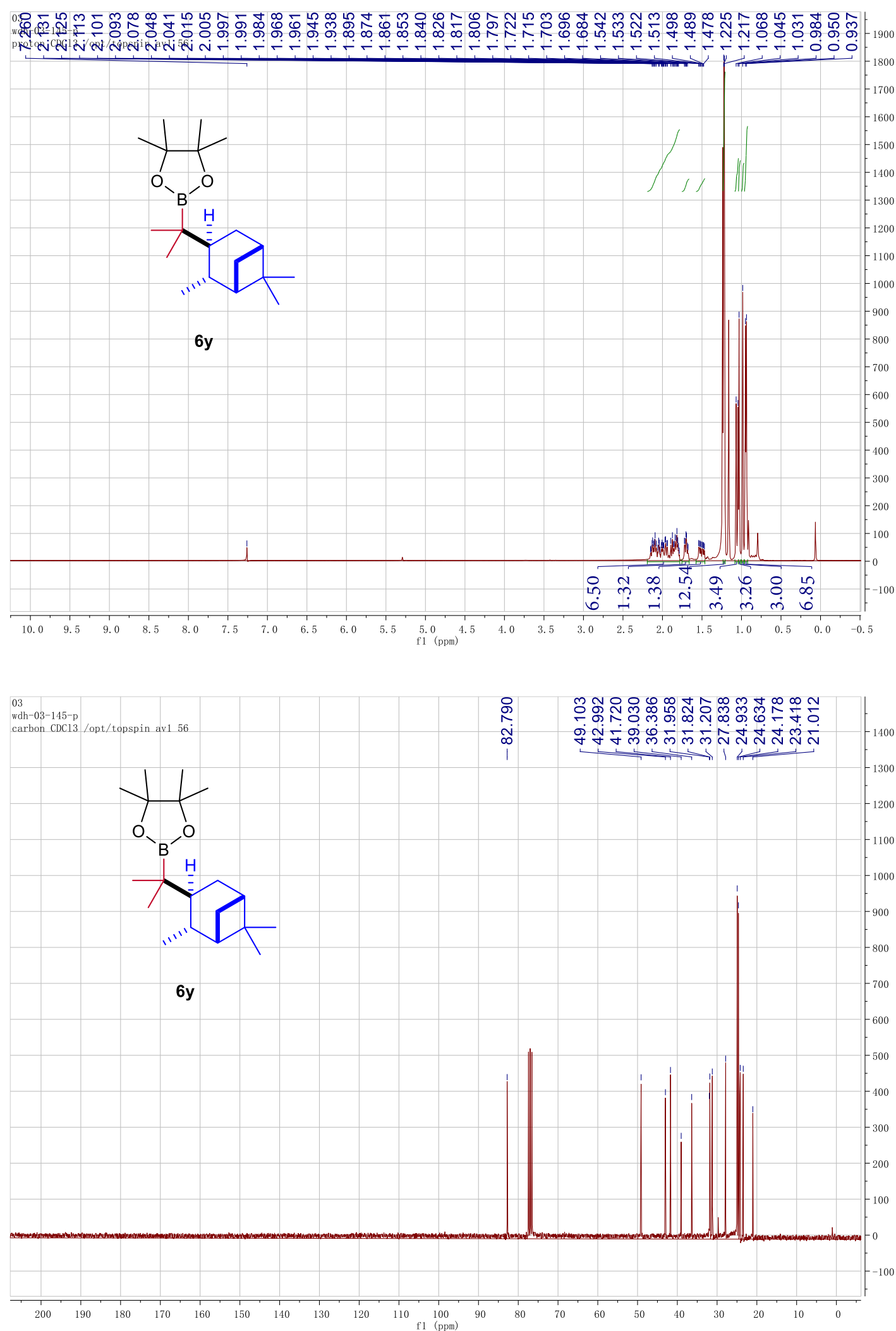

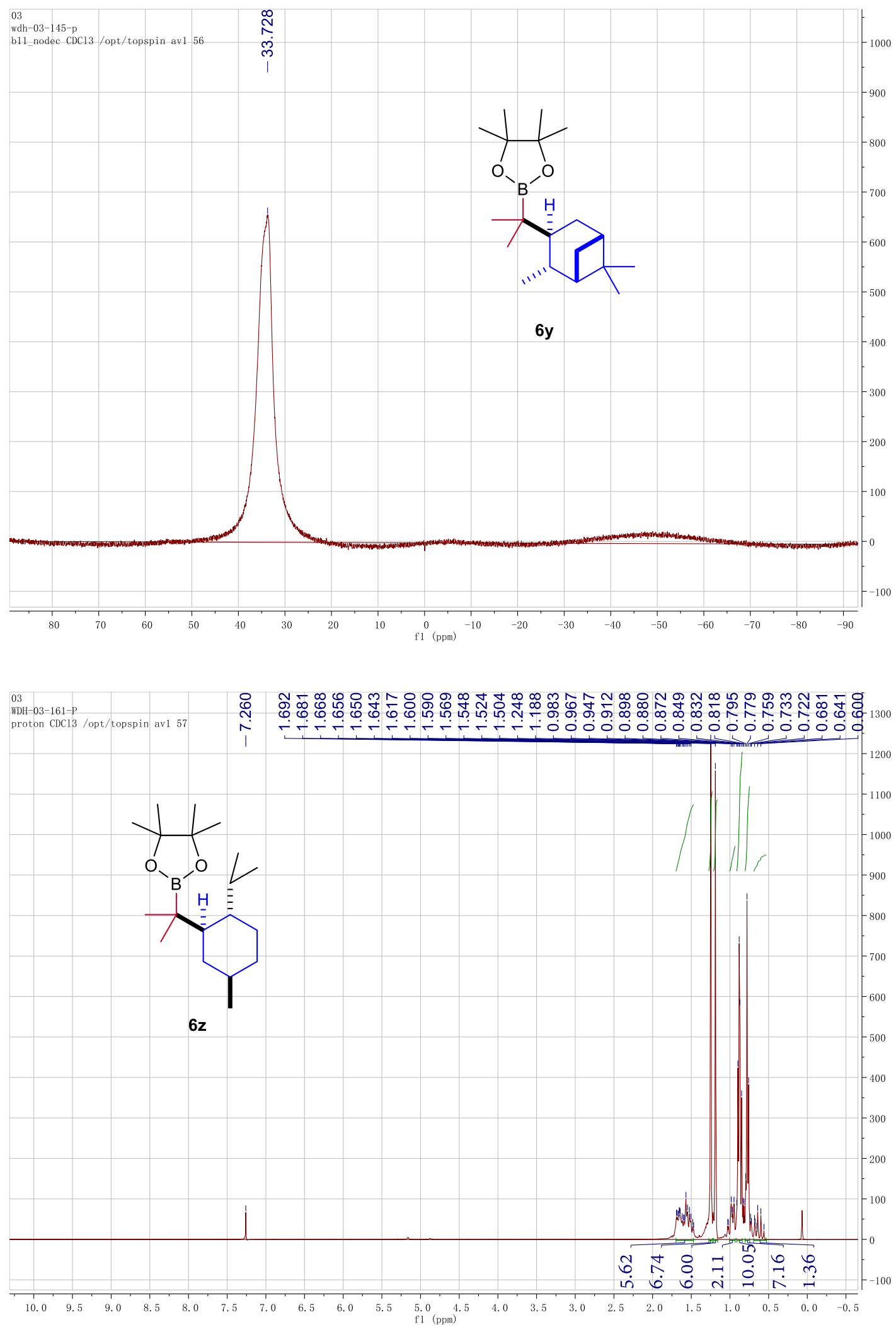

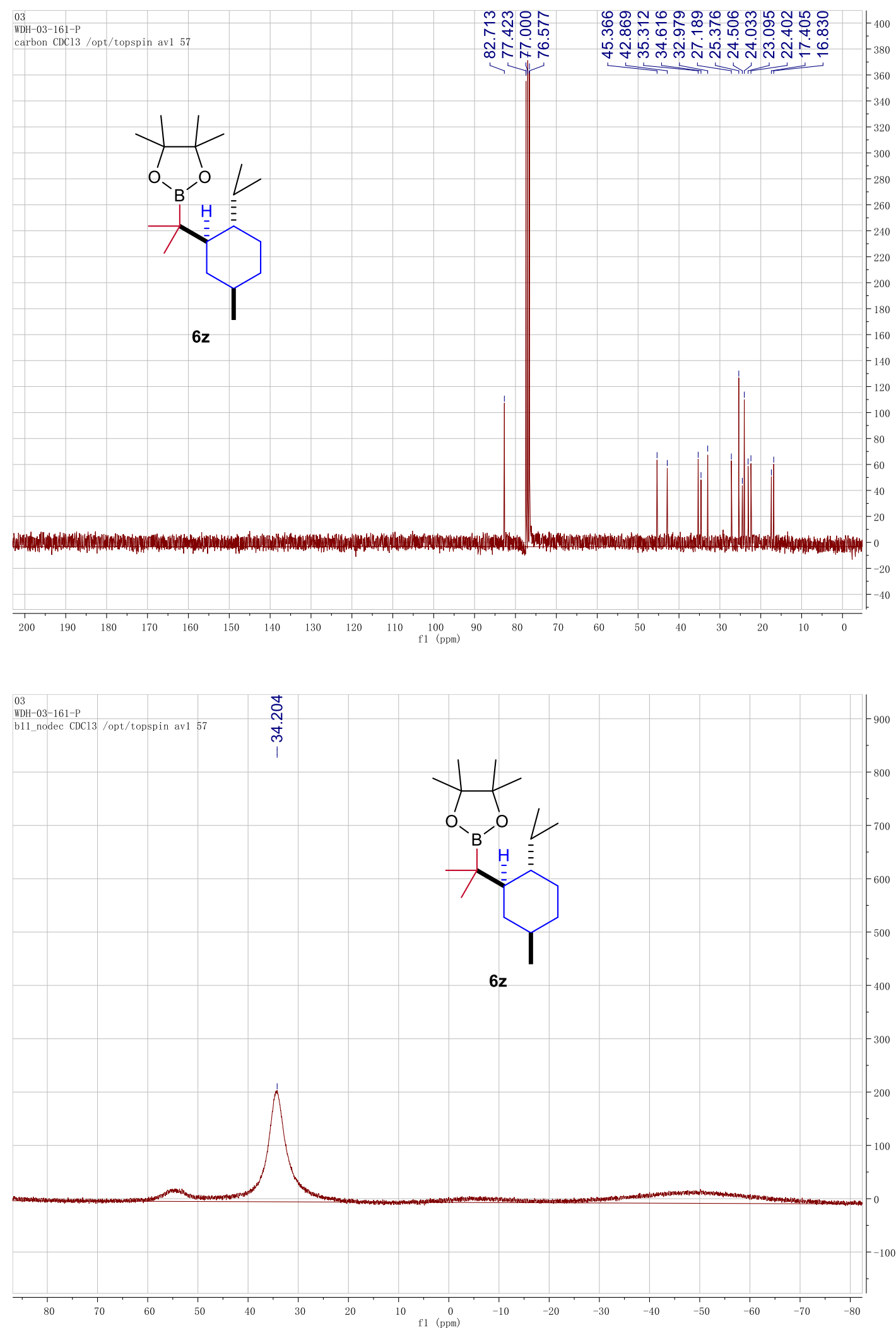

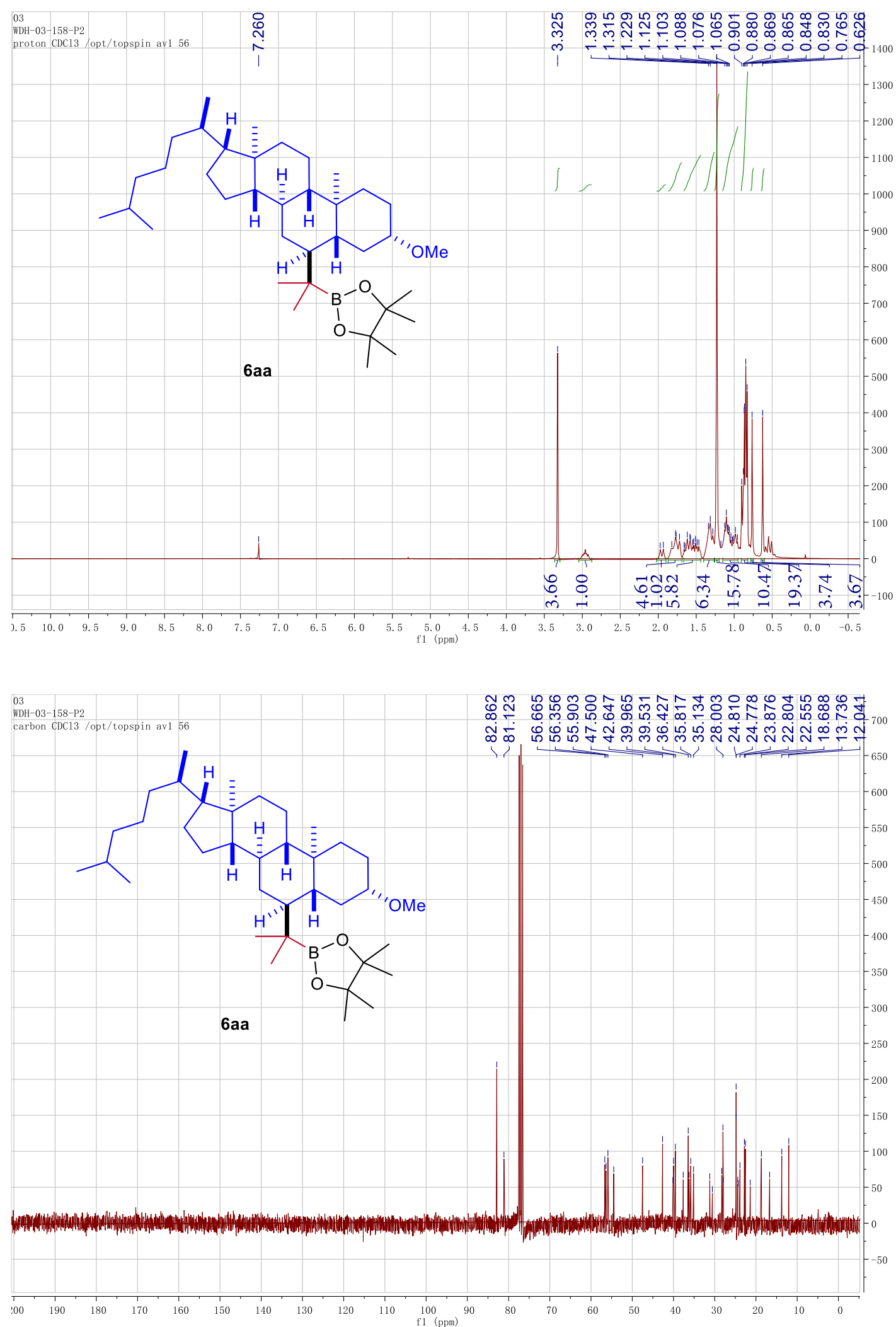

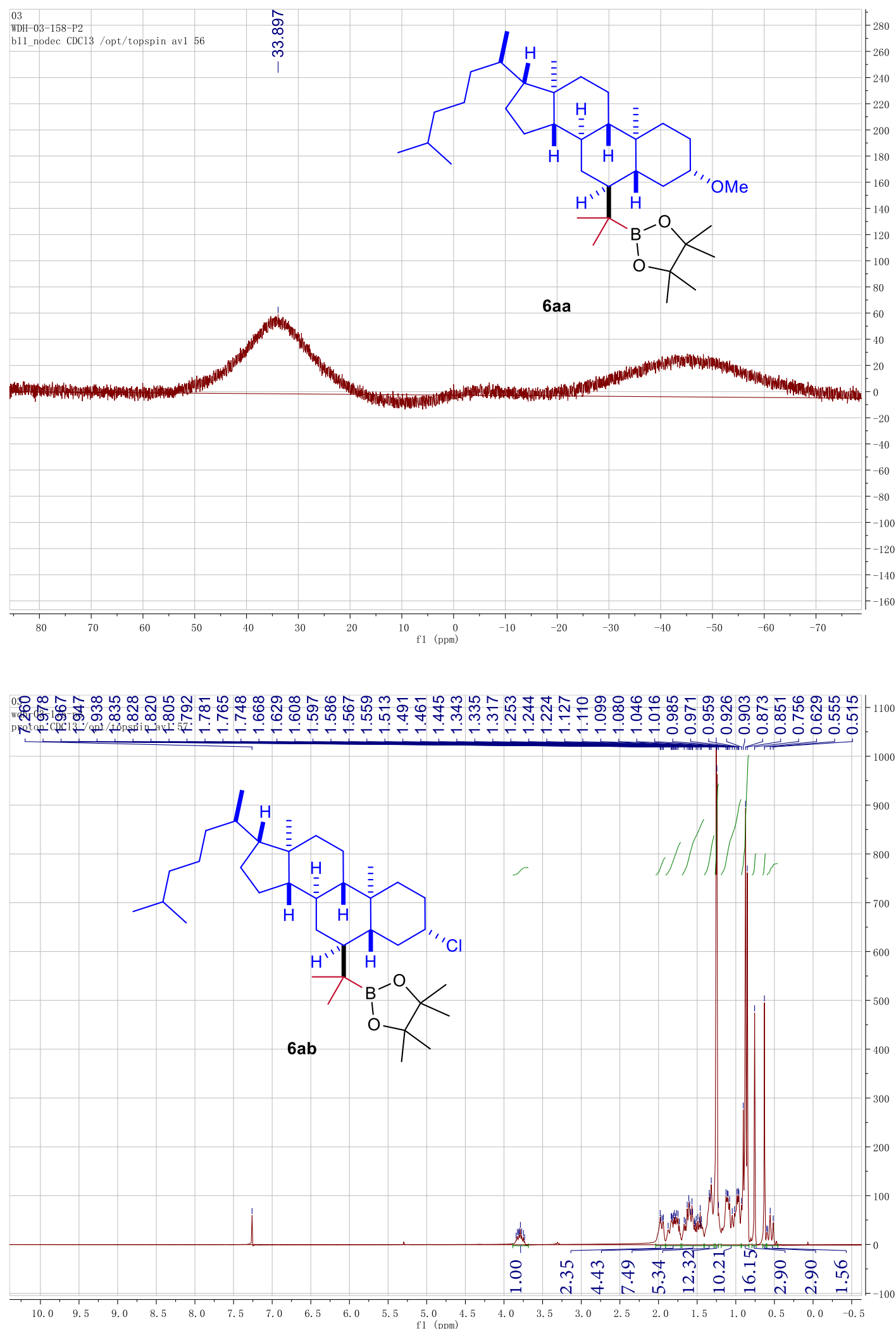

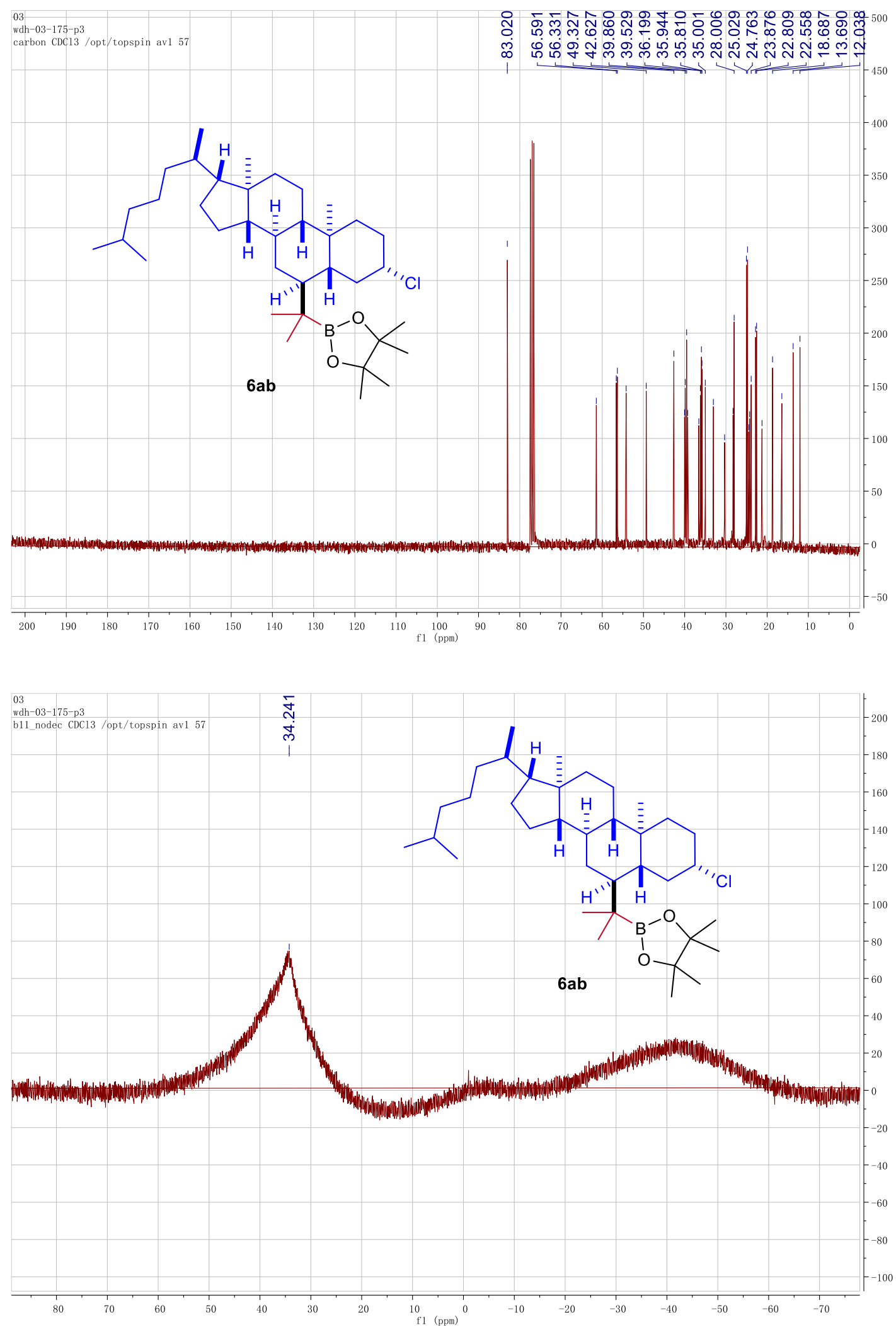